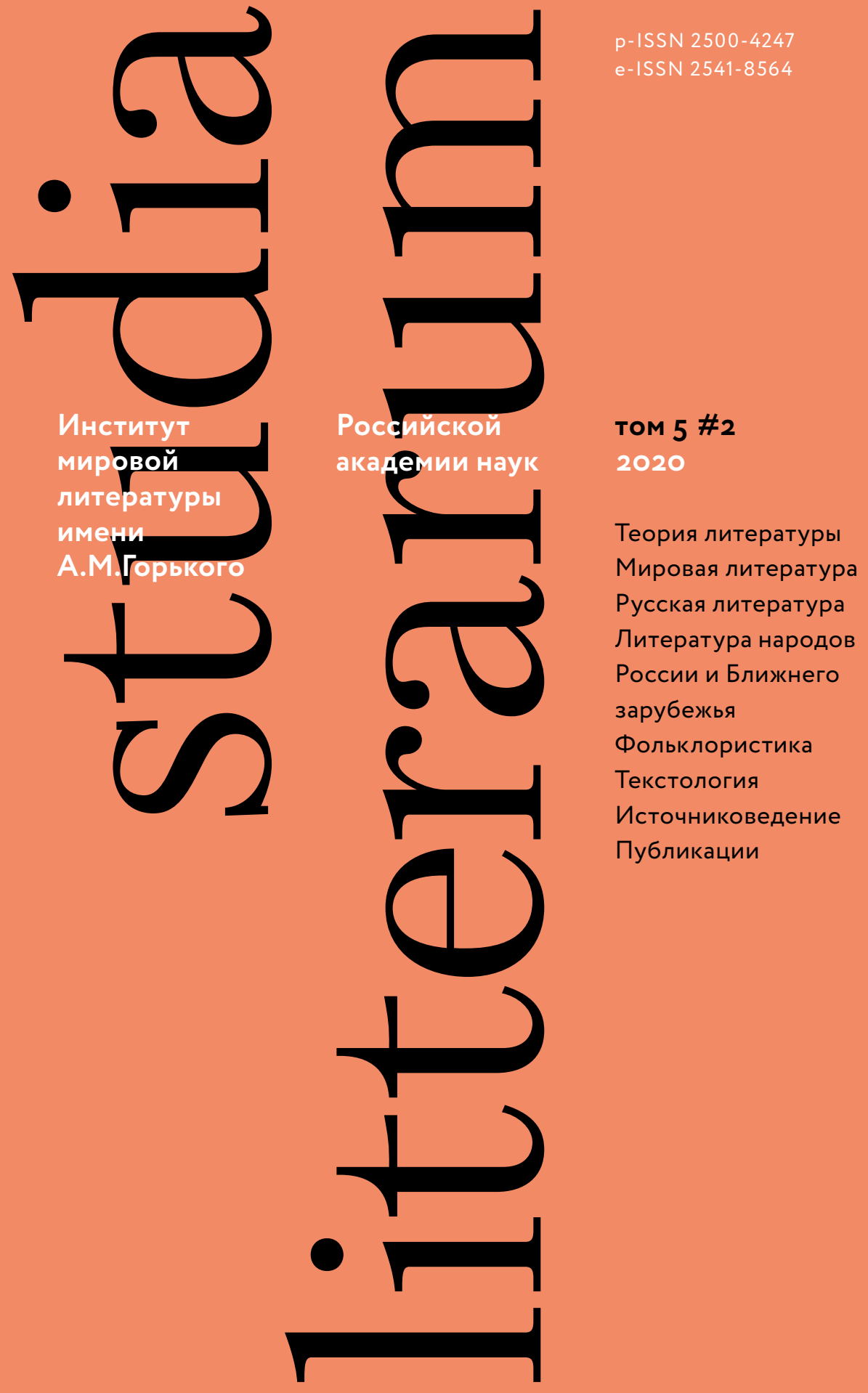


Федеральное

государственное

бюджетное

учреждение

науки

Институт

Российской

Tом 5 \#2

мировой

академии наук

2020

литературы

имени

А.М. Горького

Москва

Studia Litterarum

Литературные исследования

Научный журнал

Издается с 2016 года 
Studia Litterarum:

Науч. журн. - 2020.

-T. 5, № 2. - M.:

ИМЛИ РАН, 2020.

$-480 \mathrm{c}$.

Academic journal. - 2020 . - Vol. 5, no 2. - Moscow, IWL RAS Publ., 2020. $-480 \mathrm{p}$.

Включен

в Перечень рецензируемых научных изданий ВАК РФ

Indexed:

Scopus, WoS (ESCI)
Журнал

зарегистрирован

в Федеральной службе

по надзору

в сфере связи и массовых

коммуникаций

Свидетельство

о регистрации

ПИ № ФС $77-66625$

от 27 июля 2016 г.

Подписной индекс

по каталогу «Роспечать»

80538

ISSN 2500-4247 (Print)

ISSN 254I-8564 (Online)

Адрес редакиии:

І2І069 г. Москва,

ул. Поварская, д. 25 а

Телефон:

+7 (495) 690-50-30

E-mail: stud-lit@mail.ru

www.studlit.ru
The journal

is registered

at the Federal Service

for Supervision

of Media and

Mass Communications

Registration Certificate

PE № FS $77-66625$,

July 27, 2016

Subscription index

in the catalogue "Rospechat"

80538

ISSN 2500-4247 (Print)

ISSN 254I-8564 (Online)

Address of the Editorial

Department:

Povarskaya 25 a,

I2I069 Moscow

Phone:

+7 (495) 690-50-30

E-mail: stud-lit@mail.ru

www.studlit.ru 
Federal State

Budget

Institution

of Science

A.M. Gorky

of the Russian

vol 5 \#2

Institute

Academy

2020

of World

of Sciences

Literature

Moscow

Studia Litterarum

Literary Studies

Academic journal

Published since 2016 
Главный редактор

А.Б. Куделин (ИМЛИ РАН, Москва, Россия)

Заместитель главного редактора

О.А. Туфанова (ИМЛИ РАН, Москва, Россия)

Ответственный секретарь

М.В. Каплун (ИМЛИ РАН, Москва, Россия)

Редакторы

А.В. Голубков, А.П. Уракова (ИМЛИ РАН, Москва, Россия)

\section{МЕЖДУНАРОДНЫЙ РЕДАКЦИОННЫЙ СОВЕТ}

Д.П. Бак (Государственный литературный музей, Москва, Россия), Т.М. Горяева (Российский государственный архив литературы и искусства, Москва, Россия), Р. Джулиани (Университет Ла Сапиенца, Рим, Италия), Л.И. Ливак (Торонтский Университет, Торонто, Канада), Э. Лэрд (Университет Браун, Провиденс, США), Д. Ота (Кумамото Гакуэн Университет, Куматото, Япония), Ф.Б. Поляков (Институт славистики Венского университета, Вена, Австрия), Р.М. Распопович (Исторический институт Университета Черногории, Подгорица, Черногория), Д. Рицци (Университет Ка Фоскари, Венеция, Италия), И.В. Силантьев (Институт филологии СО РАН, Новосибирск, Россия), Г. Тиханов (Лондонский университет королевы Марии, Лондон, Великобритания), Л.С. Флейшман (Стэнфордский университет, Стэнфорд, США), М. Цимборска-Лебода (Университет Марии Кюри-Склодовской в Люблине, Люблин, Польша)

\section{РЕДАКЦИОННАЯ КОЛЛЕГИЯ}

В.Р. Аминева (Казанский федеральный университет, Казань, Россия), М.Л. Андреев (ИМЛИ РАН, Москва, Россия), С. Гардзонио (Пизанский университет, Пиза, Италия), Б.Ф. Егоров (Санкт-Петербургский институт истории РАН, Санкт-Петербург, Россия), Ж.-Ф. Жаккар (Женевский университет, Женева, Швейцария), В.Л. Кляус (ИМЛИ РАН, Москва, Россия), Н.В. Корниенко (ИМЛИ РАН, Москва, Россия), О.А. Коростелев (ИМЛИ РАН, Москва, Россия), А.Ф. Кофман (ИМЛИ РАН, Москва, Россия), А.В. Лавров (Институт русской литературы (Пушкинский Дом) РАН, Санкт-Петербург, Россия), Д.С. Московская (ИМЛИ РАН, Москва, Россия), В.В. Полонский (ИМЛИ РАН, Москва, Россия), В.Г. Родионов (Чувашский государственный университет им. И.Н. Ульянова, Чебоксары, Россия, Чувашская Республика), А.Ф. Строев (Университет Новая Сорбонна Париж 3, Париж, Франция), К.К. Султанов (ИМЛИ РАН, Москва, Россия), А.Л. Топорков (ИМЛИ РАН, Москва, Россия), О.Б. Христофорова (Российский государственный гуманитарный университет, Москва, Россия), М. Шруба (Рурский университет, Бохум, Германия)

Адрес редакции: І21069 г. Москва, ул. Поварская, д. 25 а

Телефон: +7 (495) 690-50-30

E-mail: stud-lit@mail.ru

Сайт: www.studlit.ru 
Editor-in-Chief

Alexander B. Kudelin (A.M. Gorky Institute of World Literature of the Russian Academy of Sciences, Moscow, Russia)

Deputy Editor-in-Chief

Olga A.Tufanova (A.M. Gorky Institute of World Literature of the Russian Academy

of Sciences, Moscow, Russia)

Managing Editor

Marianna V. Kaplun (A.M. Gorky Institute of World Literature of the Russian Academy of Sciences, Moscow, Russia)

Editors Andrei V. Golubkov (A.M. Gorky Institute of World Literature of the Russian Academy of Sciences, Moscow, Russia), Alexandra P. Urakova (A.M. Gorky Institute of World Literature of the Russian Academy of Sciences, Moscow, Russia)

\section{INTERNATIONAL EDITORIAL COUNCIL}

Dmitry P. Bak (State Literary Museum, Moscow, Russia), Tatiana M. Goryaeva (Russian State Archive of Literature and Art, Moscow, Russia), Rita Giuliani (Sapienza University, Rome, Italy), Leonid I. Livak (University of Toronto, Toronto, Canada), Andrew Laird (Brown University, Providence, USA), Jotaro Ohta (Kumamoto Gakuen University, Kumamoto, Japan), Fedor B. Poljakov (Institute for Slavistics, University of Vienna, Vienna, Austria), Radoslav M. Raspopovic (University of Montenegro, Historical Institute of the University of Montenegro, Podgorica, Montenegro), Daniela Rizzi (Ca' Foscari University, Venice, Italy), Igor V. Silantiev (Institute of Philology of Siberian Branch of the Russian Academy of Sciences, Novosibirsk, Russia), Galin Tihanov (Queen Mary University of London, London, Great Britain), Lazar S. Fleishman (Stanford University, Stanford, USA), Maria Cymborska-Leboda (Maria Curie-Skłodowska University in Lublin, Lublin, Poland)

\section{EDITORIAL BOARD}

Venera R. Amineva (Kazan Federal University, Kazan, Russia), Mikhail L. Andreev (A.M. Gorky Institute of World Literature of the Russian Academy of Sciences, Moscow, Russia), Stefano Garzonio (University of Pisa, Pisa, Italy), Boris F. Egorov (Saint Petersburg Institute of History of the Russian Academy of Sciences, Saint Petersburg, Russia), Jean-Philippe Jaccard (University of Geneva, Geneva, Switzerland), Vladimir L. Klyaus (A.M. Gorky Institute of World Literature of the Russian Academy of Sciences, Moscow, Russia), Natalya V. Kornienko (A.M. Gorky Institute of World Literature of the Russian Academy of Sciences, Moscow, Russia), Oleg A. Korostelev (A.M. Gorky Institute of World Literature of the Russian Academy of Sciences, Moscow, Russia), Andrey F. Kofman (A.M. Gorky Institute of World Literature of the Russian Academy of Sciences, Moscow, Russia), Alexander V. Lavrov (Institute of Russian Literature (Pushkinsky Dom) of the Russian Academy of Sciences, Saint Petersburg, Russia), Darya S. Moskovskaya (A.M. Gorky Institute of World Literature of the Russian Academy of Sciences, Moscow, Russia), Vadim V. Polonsky (A.M. Gorky Institute of World Literature of the Russian Academy of Sciences, Moscow, Russia), Vitalii G. Rodionov (I.N. Ulianov Chuvash State University, Cheboksary, Russia, Chuvash Republic), Alexander F. Stroev (New Sorbonne University - Paris 3, Paris, France), Kazbek K. Sultanov (A.M. Gorky Institute of World Literature of the Russian Academy of Sciences, Moscow, Russia), Andrey L. Toporkov (A.M. Gorky Institute of World Literature of the Russian Academy of Sciences, Moscow, Russia), Olga B. Khristoforova (Russian State University for the Humanities, Moscow, Russia), Manfred Schruba (Ruhr University, Bochum, Germany) 
Теория литературы

IO Махов А.Е. Категория правдоподобия

в литературной теории французского классицизма

34 Козлов А.Е. «Право на биографию»

и литературные воспоминания второй половины XIX в.

56 Андреев М.Л. Гольдони в переводе семейства Амфитеатровых

Мировая литература

68 Балаховская А.С. Агиографический нарратив и его интерпретации (на материале агиографии Иоанна Златоуста)

88 Топорова А.В. «Свое» и «чужое» в итальянских описаниях паломничеств в Святую Землю (XIV-XV вв.)

IO2 Игнатьева (Оганисьян) М.Ю. Петербург Париж - Геттинген - Мадрид: сюжет из истории Истории испанской литературы

I24 Kunešová K. Littérature de jeunesse connaît-elle des frontières? (entre tradition et transposition en littérature tchèque destinés)

I46 Шарыпина Т.А., Казакова П.Д. Russischdeutscher Literaturtransfer der 3oer-4oer Jahre des 20. Jahrhunderts (S. Tretjakow, F. Wolf, B. Brecht)

I62 Голубцова А.В. От К.Э. Гадды до неоавангарда: эволюция художественного эксперимента

I72 Попова А.В. Художественный образ Даниила Хармса в творчестве Аглаи Ветерани

I86 Чугунов Д.А. Особенности репрезентации прошлого в прозе Бернхарда Шлинка

Русская литература

$2 \mathrm{O}$ Щербаков В.И. Проблема героя времени в диалоге Тургенева и Писарева

220 Гриневич О.А. Трансформация постриторической модели «усадебного текста» в поэзии А.А. Фета 
234 Плотникова А.Г. Пьеса М. Горького «На дне» в мировом кинематографе

252 Cioni P. «La vita di Klim Samgin» e il romanzo dell' «uomo senza qualità»

270 Марков А.В. «Карнавал» Шумана в поэзии Дмитрия Кленовского

Литература народов России и Ближнего зарубежья 286 Барабаш Ю.Я. Этнокультурное пограничье: концептуальный, типологический и ситуативный аспекты (Чужое-Иное-Свое). Статья вторая: Харьков. Донбасс - этно- и лингвокультурное пограничье

322 Киримов Т.Н. Структура и семантика поэтических заглавий Дж. Керменчикли

Фольклористика

336 Агапкина Т.А. Благоверная цзарица хитра была мудра: об одной синонимической паре в русском фольклоре

390 Налепин А.Л. «Кодзики» и фольклористические разыскания А.А. Вановского при изучении генезиса мифологических сущностей в архаических мифах творения Древней Японии

4I2 Хаджиева T.M. The Religious-mythological characters and motifs in the Nart epic Balkars and Karachai

424 Цыбикова Б.-Х.Б. Сюжетно-композиционное своеобразие бурятских сказок (полевые материалы 2018 г.)

Текстология. Источниковедение. Публикации

438 Купченко Т.А. Пунктуация как способ создания редакции текста.

На примере поэмы В. Маяковского «150 о0о ооО» 
Contents

Literary Theory

IO Alexander E. Makhov. The Category of Verisimilitude in the Literary Theory of French Classicism

34 Alexey E. Kozlov. "The Right to Biography" and Literary Memories of the $19^{\text {th }}$ Century

56 Mikhail L. Andreev. Goldoni in the Translation of Amfiteatrov's Family

World Literature

68 Alexandra S. Balakhovskaya. Hagiographic Narrative and its Interpretations

88 Anna V. Toporova. The "Strange" and the "Familiar" in Italian Descriptions of Pilgrimages to the Holy Land $\left(\mathrm{I} 4^{\text {th }}-\mathrm{I} 5^{\text {th }}\right.$ Centuries)

IO2 Maria Iu. Ignatieva (Oganissian). Petersburg Paris - Göttingen - Madrid: a Story from the History of the History of Spanish Literature

I24 Kveta Kunesova. Juvenile Literature, Does It Know Any Frontiers? (Between Tradition and Transposition in Czech Literature for Young Readers)

I46 Tatiana A. Sharypina, Polina D. Kazakova. Russian-German Literary Transfer of the I930s-40S (S. Tretyakov, F. Wolf, and B. Brecht)

I62 Anastasia V. Golubtsova. Literary Experiment from C.E. Gadda to Neo-Avant-Garde: Continuity and Transformation

I72 Anna V. Popova. The Image of Daniil Kharms in The Works of Aglaya Veteranyi

I86 Dmitry A. Chugunov. Representation of the Past in Bernhard Schlink's Fiction

Russian Literature

$2 \mathrm{O} 2$ Viktor I. Shcherbakov. The Problem of the Hero of His Time in the Dialogue between Turgenev and Pisarev

220 Olga A. Grinevich. Post-Rhetorical Model of the "Estate Text" and Its Transformation in Fet's Poetry 
234 Anastasia G. Plotnikova. M. Gorky's Drama The Lower Depths in the World Cinema

252 Paola Cioni. Life of Klim Samgin as a Novel about the "A Man without Qualities"

270 Alexander V. Markov. Schumann's Carnival in the Poetry of Dmitry Klenovsky

Literature of the Peoples of Russia and Neighboring Countries 286 Yuri Ya. Barabash. Ethno-cultural Boerderline: Conceptual, Typological, and Circumstantial Aspects (Alien - Other - One's own). Second article: Kharkov. Donbass - Ethno-Linguistic and Cultural Borderland

322 Tair N. Kirimov. The Structure and Semantics of Poetic Titles by D. Kermencikli

Folklore Studies

336 Tatyana A. Agapkina. Blagovernaia Tsaritsa Khitra Byla Mudra: on One Synonymous Pair in the Russian Folklore

390 Alexey L. Nalepin. "Kojiki" and A.A. Vanovsky on the Genesis of Mythological Entities in the Archaic Myths of the Ancient Japan

4I2 Tanzily M. Khadzhieva. Religious and Mythological Characters and Motifs in the Nart Epic Balkars and Karachai

424 Badma-Khanda B. Tsybikova. The Specificity of the Plot and Structure of the Buryat Fairy Tales (2018 field materials)

Textology. Materials

438 Tatiana A. Kupchenko. Authorial Punctuation Signs as the Markers of the Meaning. On the Example of Mayakovsky's 150 ooo ooo 
УДК 82

ББК $83+83.3(4 \Phi$ ра $) 5$

\section{КАТЕГОРИЯ ПРАВДОПОДОБИЯ \\ В ЛИТЕРАТУРНОЙ ТЕОРИИ ФРАНЦУЗСКОГО КЛАССИЦИЗМА}

DOI: I0.22455/2500-4247-2020-5-2-10-33

Аннотация: В статье дан анализ категории правдоподобия (vraisemblance), занимающей центральное место в поэтологической системе французского классицизма. Используя уже давно существующую (как в поэтике, так и в риторике), но периферийную категорию, поэтологи классицизма впервые превратили принцип правдоподобия в доминанту поэтологической системы: принцип распространяется на все крупные жанры и на основные составляющие поэтического материала - события, ситуации, поступки, характеры. Дефиниции правдоподобия в текстах французских теоретиков можно свести к трем основным идеям: правдоподобие представляет собой I) некую универсальную модель, противопоставленную единичному, случайному, беспорядочному; 2) «должное» - то, что «должно быть»; 3) то, что согласуется с общим мнением. Все три определения предполагают различение правдоподобия и «правды» как таковой; однако это различение может принимать разные конфигурации. Правдоподобие может полностью замещать правду; может включать в себя правду, если эта правда правдоподобна; может смешиваться с правдой. Два первых определения связывают правдоподобие с принципом подражания, а третье - с принципом убеждения, что позволяет говорить о двух аспектах правдоподобия, миметическом и риторическом (рецептивном). Соотнесение правдоподобия с «мнениями» реципиентов в конечном итоге привело к рождению представления о его национально-исторической относительности: на смену идее единственно возможного правдоподобия, совпадающего с «мнением» современной французской публики, пришло представление о правомерности различных инокультурных «мнений» о правдоподобном.

ключевые слова: классицизм, правдоподобие, правда, декорум, подражание, убеждение.

Информация об авторе: Александр Евгеньевич Махов - доктор филологических наук, ведущий научный сотрудник, Институт мировой литературы им. А.М. Горького Российской академии наук, ул. Поварская, д. 25 а, І2Іо69 г. Москва, Россия. ORCID ID: 0000-0002-I675-5542

E-mail: makhov636@yandex.ru

Для цитирования: Махов А.Е. Категория правдоподобия в литературной теории французского классицизма // Studia Litterarum. 2020. Т. 5, № 2. С. Iо-33. DOI: I0.22455/2500-4247-2020-5-2-10-33 


\title{
THE CATEGORY OF VERISIMILITUDE IN THE LITERARY THEORY OF FRENCH CLASSICISM
}

This is an open access article

distributed under the Creative

Commons Attribution 4.0

International (CC BY 4.0)

\author{
(C) 2020. A.E. Makhov \\ A.M. Gorky Institute of World Literature \\ of the Russian Academy of Sciences, Moscow, Russia \\ Received: January 28, 2020 \\ Date of publication: June 25, 2020
}

\begin{abstract}
The article provides an analysis of the category of verisimilitude (vraisemblance) that occupies a central place in the poetological system of French classicism. This category has already existed for a long time (both in poetics and rhetoric) as a peripheral one; theorists of classicism for the first time have turned the principle of verisimilitude into the dominant notion of the poetological system: this principle was applied to all major genres and to the main components of the poetic material - events, situations, actions, and characters. The definitions of verisimilitude in the texts of French theorists can be reduced to three main ideas: verisimilitude is I) a certain universal pattern opposed to all that is singular, accidental and irregular; 2) something that "should be"; 3) something that is consistent with the general opinion. All the three definitions imply a distinction between verisimilitude and "truth"; however, this distinction may take different configurations. The verisimilitude can completely substitute the truth; it may include truth if that truth is believable; it may be mixed with truth. The first two definitions connect verisimilitude with the principle of imitation, and the third one - with the principle of persuasion; therefore, we can talk about two aspects of verisimilitude, mimetic and rhetorical (receptive). The correlation of the verisimilitude with the "opinions" of the recipients ultimately led to the notion of its national and historical relativity: the idea of the only possible verisimilitude that coincides with the opinion of the modern French public was replaced by the idea of the validity of various foreign opinions on verisimilitude.
\end{abstract}

Keywords: classicism, verisimilitude, truth, decorum, imitation, persuasion.

Information about the author: Alexander E. Makhov, DSc in Philology, Leading Researcher, A.M. Gorky Institute of World Literature of the Russian Academy of Sciences, Povarskaya St. 25 a, I2I069 Moscow, Russia. ORCID ID: 0000-0002-I675-5542

E-mail: makhov636@yandex.ru

For citation: Makhov A.E. The Category of Verisimilitude in the Literary Theory of French Classicism. Studia Litterarum, 2020, vol. 5, no 2, pp. IO-33. (In Russ.) DOI: IO.22455/2500-4247-2020-5-2-IO-33 
Правдоподобие (vraisemblance) - центральная категория поэтики французского классицизма, которая определяет и надлежащее отношение произведения к реальности, и способность произведения надлежащим образом воздействовать на реципиента. В категории правдоподобия французским теоретикам удалось соединить миметический и рецептивный аспекты своей поэтики; в миметическом аспекте правдоподобие соотносится с «правдой» (vrai, verité), а в рецептивном - с, казалось бы, совсем далеким риторическим понятием декорума, «благопристойного» (bienséant) как соответствующего «общему мнению». Как удалось правдоподобию обрести такую двойственность? Для ответа на этот вопрос необходимо предпринять анализ, который выходил бы за рамки свода высказываний о правдоподобии, уже существующего в отечественном литературоведении [3].

\section{Истоки классицистического учения о правдоподобии}

Категория правдоподобия не была изобретена поэтологами классицизма: она существовала уже в античности, как в поэтологическом, так и в риторическом контексте. Основным источником была «Поэтика» Аристотеля с ее категорией вероятного (віко́s), которая дополняется категорией необходимого: перелом в трагедии происходит «по вероятности или необходимости» (I45га, I3-I4); поэт должен говорить о возможном «в силу вероятности или необходимости» (I45га, 35-36; перевод М.Л. Гаспарова). Предпочтение правдоподобного реальному, столь важное для классицистической доктрины, также восходит к Аристотелю, предлагающему поэту предпочесть невозможное, но правдоподобное $(\mathrm{I} 460 \mathrm{a}, 26)$ или невозможное, но убедительное (I46Ib, го) - возможному, но неубедительному. Им- 
плицитно присутствующее в этом предписании понятие убеждения свидетельствует о том, что уже Аристотель принимает во внимание риторический аспект правдоподобия (правдоподобно то, что принимается на веру реципиентом). Однако еще яснее этот аспект будет выражен в римской риторике, в частности, в «Риторике к Гереннию», помещающей правдоподобие в число трех необходимых для «narratio» качеств: повествование должно быть «кратким, ясным, правдоподобным (ut brevis, ut dilucida, ut veri similis sit)»; повествовать нужно в соответствии с тем, «чего требуют характер (mos), мнение, природа» - т. е. согласно общепринятым представлениям; если не выполнить это требование, сама «истина (veritas)» «не сможет вызвать доверия» (I, I4). Римская риторика здесь близко подходит к классицистическому пониманию правдоподобного как соответствующего общему мнению. Идея такого соответствия могла вычитываться и из совета Горация либо измышлять, либо «следовать преданию (famam sequere)» («Поэтическое искусство», II9). Горацианская «fama» в средневековых комментариях была истолкована именно как «мнение людей». Так, анонимный accessus XII в. к «Поэтическому искусству» утверждает, что, согласно Горацию, поэт, как и художник, «должен подражать природе вещей как она предстает в реальности или во мнении людей (debet imitari naturam rerum vel in veritate vel ita ut est in opinione hominum)»; кентавр не существует, но поэт может его изображать так, как он существует во мнении (sicut habet fabulosa opinio hominum). Поэт, вводя фантастическое (ficticia), не должен отступать от «общего представления» о нем (цит. по: [25, p. I04-I05]). Используя уже существующий концепт правдоподобия, поэтологи классицизма впервые выдвигают его в центр поэтологической системы. Если для Аристотеля «понятие правдоподобия было второстепенным» и требовалось лишь для того, чтобы «легитимировать некоторые невозможные в реальности сюжеты» [7, p. 20I], то в поэтике классицизма концепт, примененный сначала к драме, затем распространяется на все крупные жанры и на основные составляющие произведения: правдоподобием должны обладать события, ситуации, поступки, характеры, нравы.

\section{Три основных определения правдоподобия}

Многочисленные дефиниции правдоподобия в текстах теоретиков можно свести к трем основным тезисам, каждый из которых определя- 
ет его путем противопоставления: правдоподобие I) некая универсальная «идея» («модель», «образец»), противопоставленная единичному, случайному, беспорядочному; 2) должное (то, что «должно быть»), в отличие от существующего в реальности, но лишенного «обязательности»; 3) то, что согласуется с общим мнением, в противоположность тому, что не может быть принято на веру. Различие между этими определениями не становится предметом рефлексии теоретиков, которые воспринимают их как единый аргументативный комплекс, не содержащий противоречий. Но мы рассмотрим эти тезисы по отдельности.

Правдоподобие как универсальная идея-модель. Так понимаемое правдоподобие противопоставляется несовершенной «правде» реальности; оно соответствует сущностному, а правда - акцидентальному: «Правда почти всегда несовершенна (défectueuse), из-за смешения отдельных качеств, которые ее составляют. Всё, что рождается в мире, родившись, удаляется от совершенства своей идеи. Подлинники и модели надо искать в правдоподобии и в универсальных первопричинах вещей...» [30, p. 4I]. Неоплатонический тон такого рода рассуждений (правдоподобие связывается с миром чистых идей, противостоящим материальному и единичному), отмечавшийся исследователями [26, р. 30о], особенно ясно выражен у Пьера Ле Муана, призывающего поэта оставить материальную реальность, подняться «над частным» и «искать свои подлинники в универсальном»; правда в материальном мире «изуродована и несовершенна», пусть же поэт обратится «К Возможности (Possibilité), которая совершенно чиста; пусть он изучает, копирует, изображает правдоподобное, которое целокупно и совершенно (entiere et parfaicte)» [23, p. Io].

В таком понимании оппозиция «правда - правдоподобие» коррелирует с противопоставлением поэзии и истории, намеченным уже в «Поэтике» Аристотеля («поэзия больше говорит об общем, история - о единичном», I45Ib, 4-5) и актуализированным теоретиками классицизма: «Искусство, намереваясь передать универсальную идею вещей, очищает (épure) их от недостатков и неправильностей, которые история, в силу строгости своих законов, вынуждена терпеть» [14, p. 366]. Очищение, о котором говорит Шаплен, в другом его тексте определено как отвлечение (abstraction) свойства от конкретного лица, которому оно принадлежит; воспринимая поэтическое произведение, пишет Шаплен, я вижу не «бла- 
гочестивого Энея и гневного Ахилла», но «благочестие с его следствиями и гнев с его результатами» [І2, p. 86-87]. Таким образом, у Шаплена «процесс абстрагирования привязан не только к творческим операциям поэта, но и к реакциям аудитории или читателя» [26, p. 30I]; реципиент вносит свой вклад в создание эффекта правдоподобия, понятого как обобщенное / идеальное. В том же тексте Шаплен противопоставляет поэзию истории по иному, нежели у Аристотеля, критерию: в предметы поэзии легче поверить, чем в факты истории, поскольку поэзия «сама по себе (de soi-même) вызывает веру», в то время как история «заключает в себе лишь голую истинy (la vérité nue), не вызывающую веры без помощи и поддержки другой [истины]» [г2, р. 88]. Комментируя это высказывание, М.-Н. Казальс справедливо замечает: «Истина в поэзии возникает из одной лишь рецепции, а не из гипотетической связи с реальностью» [9, р. 24]. С рецептивной точки зрения обосновывает превосходство поэзии над историей и Андре Дасье, переводчик и комментатор «Поэтики» Аристотеля: факты истории, в силу их частного характера, могут применить к себе лишь немногие («из тысячи людей найдется лишь один, кому они могут соответствовать»), в то время как «общие предметы (les choses generales)», о которых говорит поэзия, применимы ко всем. Это превосходство Дасье осмысляет в моральном плане: поэзия именно потому «более нравственна и назидательна», чем история, что «общие предметы превосходят частные» [І7, p. I37].

Правдоподобие как должное. Аристотель предлагает поэту на выбор три модуса подражания (в его отношении к реальности): поэт должен подражать «или тому, как было и есть; или тому, как говорится и кажется; или тому, как должно быть» («Поэтика». I46ob, го). Сосуществование (в той или иной степени) этих модусов изредка допускается и в литературных суждениях эпохи классицизма - например, в сравнении Корнеля и Расина у Жана де Лабрюйера, утверждавшего (в «Характерах»), что Корнель «рисует людей такими, какими они должны быть», а Расин - «такими, какие они есть». Однако общая тенденция состояла в том, что из трех возможностей, предложенных Аристотелем, выбиралась третья: поэт изображает то, «как должно быть»; это долженствование в свою очередь связывалось с правдоподобием. Такая конструкция ясно очерчена уже в «Предисловии к “Адонису” Шаплена: поэт говорит лишь о том, «что должно быть (се qui doit être)», а то, что должно быть, «всегда правдоподобно». В том же тексте оп- 
позиция «реальное - должное» связывается с противопоставлением истории, предмет которой - «вещи как они есть (les choses comme elles sont)», и поэзии, которая показывает, какими они «должны быть» [ı2, p. 86-87]. Рапен, утверждая необходимость правдоподобия в поэзии, также связывает его с долженствованием, противопоставляя правдоподобие - правде (verité): «Правда делает вещи лишь такими, каковы они есть, а правдоподобие делает их такими, какими они должны быть (doivent estre)» [30, p. 4I]. Франсуа д’Обиньяк применяет тезис о «должном» (в его связи с правдоподобием и в противопоставлении истории) к театру: «На сцене все изображается не таким, каким является в действительности, но таким, каким должно быть... Историк должен просто рассказывать о том, что произошло <...>, театр же должен воссоздавать происшедшее в виде и правдоподобном и приятном» [2, с. 334].

«Должное» как истинный предмет поэзии соединяет в себе два значения, которые, вслед за П. Гарнье, можно определить как «логическое и моральное» [I8, p. 5I]. Классицистическое «devoir» обозначает не только то, что «более возможно», но и то, что «морально более правильно» [27, р. 270]. Так, согласно «Мнению Французской академии о “Сиде” Корнеля, поведение Химены по отношению к Родриго «неправдоподобно» не только потому, что благонравная девушка не могла согласиться (пусть и молчаливо) с возможностью выйти замуж за убийцу своего отца (нарушение морального долженствования), но и потому, что это поведение представляет собой «неправильность», возможную в реальности, но нетерпимую в поэзии (нарушение разумного устройства мира, т. е. логического долженствования). Идея логического долженствования ясно выражена Шапленом в «Предисловии к переводу “Адониса” : «В историях [т. е. в исторических текстах. A.M.] происшествия и события <...> не упорядочены (non réglés), будучи зависимы от случая (fortune), который в равной степени приносит благополучие как дурным, так и добродетельным людям и неразборчиво губит как тех, так и других»; в поэзии же «последовательность действий» должна вытекать «из добродетели или порока, природа которых состоит в том, чтобы вознаградить или погубить тех, кто будут им следовать» [ı2, p. 86]. Моральная правильность (наказание дурных и вознаграждение добродетельных) представляется Шаплену следствием естественной логики событий, «правильная» причинная связь которых должна приводить именно к 
такому итогу. Философской основой такого воззрения на поэзию является вера в разумное устройство мира, омрачаемое, однако, вторжениями случая («fortune» в терминологии Шаплена вызывает ассоциацию с Фортуной из «Утешения Философией» Боэция, противостоящей Провидению как основе разумного Божественного мироустройства); эти вторжения случая-«Фортуны» поэзия должна исключить из своего мира. В широком поэтологическом контексте предписания Шаплена можно рассматривать как отдаленный ответ на сетования Платона, полагавшего, что поэты «превратно судят о людях», изображая несправедливых людей счастливыми, а справедливых - несчастными («Государство», кн. 3, 392а; перевод А.Н. Егунова); вслед за Платоном Шаплен предлагает запретить подобного рода «суждения», видя в них не только аморальность, но и противоречие естественному и разумному порядку событий, «разрыв каузальной связи» [18, p. 5I], а тем самым и неправдоподобие.

Логический (каузальный) и моральный аспекты правдоподобия, понимаемого как долженствование, самими теоретиками классицизма не различались. Осуждая как «неправдоподобные» поступки, аналогичные вышеупомянутому поведению Химены, теоретики имели в виду «одновременно и то, что эти поступки противоречат нравственным принципам, и то, что они противоречат всякому разумному предвидению...» [I, с. 30I]. Таким образом, «каузальность и моральность составляли единое целое: порочный герой попадал в несчастье потому, что дурные поступки, которые он совершал, логически не могли иметь иного исхода» [18, p. 54]. Причина подобного неразличения - в имплицитном, a priori принимаемом представлении о разумности мироустройства, охватывающего своей каузальной цепью и моральный мир, в котором пороки и добродетели имеют логически неизбежные следствия. Эта логика морали, собственно, и составляет главный предмет правдоподобного изображения.

Правдоподобие как соответствие общему мнению. Третье понимание правдоподобия также восходит к одному из намеченных Аристотелем вышеупомянутых модусов подражания: поэт может подражать тому, «как говорится и кажется» («Поэтика». I460b, го; в переводе С. Хэллиуэлла «тому, что люди говорят и думают»). О других возможных источниках такого понимания («Риторика к Гереннию», «Поэтическое искусство» Горация) было сказано выше. Теоретики классицизма связывают подражание 
«существующему во мнении» с концептом правдоподобия, давая последнему еще одно определение: «Правдоподобно всё то, что согласуется с мнением публики (conforme à l'opinion du public)» [30, p. 39]. При этом вставал вопрос, кто, собственно, является носителем этого общего мнения, т. е. кого следует понимать под «публикой», о которой говорит Рапен. Шаплен, уточняя понятие публики, поясняет, что имеет в виду государственных людей, высшее дворянство и всех «honnêtes gens» [13, p. 456], т. е. людей галантных, благовоспитанных. Вместе с тем в число «honnêtes gens», создающих «мнение публики», порой не включаются «ученые». Уже Г.И. Фосс в своей латинской поэтике отмечает, что мнения собственно «ученых» недостаточно для правдоподобия. «Правдоподобно (verisimile) не только то, что видится таковым для ученых <...>, но также и то, что народ (vulgus) полагает таковым. Для поэта достаточно, что народ имеет такое мнение (quod vulgus sic opinatur)» [37, vol. I, p. I40]. Р. Ле Боссю превращает различение мнения ученых и мнения «народа» в оппозицию, приписывая ее Аристотелю, который якобы «полагал, что поэт, когда фабула этого требовала, должен был в меньшей степени сохранять истины истории и сообразовываться со знаниями ученых (savants), чем соответствовать тому, что в глазах народа (peuple) могло сойти за правдоподобное» [22, p. 252]. Правдоподобие в этом суждении противопоставлено и исторической истине, и мнению ученых; в выпаде против последних А. Женетьо видит характерное для эпохи «подозрительное отношение ко всякому педантизму» [І9, p. 290].

\section{Миметический и риторический (рецептивный) аспекты правдоподобия}

Нельзя не заметить, что первые два определения правдоподобия принципиально отличаются от третьего: первые соотносят произведение с реальностью, будь то реальность материальная или высшая реальность идей; последнее - соотносит его же с неким гипотетическим набором воззрений на реальность. В первых двух определениях мы имеем отношение «дискурс - реальность», в третьем - отношение «дискурс - другой дискурс» [І8, p. 50], каковым можно признать упоминаемое Рапеном и другими теоретиками «мнение публики». Соответственно различаются и цели правдоподобного изображения: в первых двух случаях оно должно приблизить произведение к подлинной (должной) реальности, очищенной 
от случайностей; в третьем - привести «дискурс» реципиента (т. е. совокупность его «мнений») в согласие с дискурсом произведения. Это означает, что два первых определения связывают правдоподобие с принципом подражания, а третий - с принципом убеждения, что позволяет, вслед за Дж. Морган, определить эти два аспекта правдоподобия как миметический и риторический [26, p. 303], или рецептивный. Самими теоретиками они не различались, о чем особенно красноречиво свидетельствует их неотрефлектированное сосуществование у Рапена, который связывает правдоподобие и с «универсальными первопричинами вещей» (миметический аспект), и с «мнением публики» (риторический аспект). Это неразличение объясняется тем, что миметическое правдоподобие в конечном итоге рассматривается как одно из средств убеждения публики и достижения определенного морального воздействия; мимесис подчинен более общей риторической задаче. Классицистическое понимание мимесиса отличается от традиционного аристотелевского подчинением мимесиса риторической функции. Другое отличие состоит в том, что мимесис трактуется как иллюзия, воспринимаемая реципиентом в качестве подлинной реальности; акт мимесиса, в осознании которого для Аристотеля и состояло удовольствие от поэзии, в классицистической теории (по крайней мере применительно к драме) не должен осознаваться. Такое понимание правдоподобия ясно сформулировано Шапленом в «Письме о правиле двадцати четырех часов»: подражание в драматических произведения должно представлять вещи «как истинные и как присутствующие (comme vrais et comme présents)»; правдоподобие изображения должно заставить зрителя чувствовать себя «присутствующим при подлинном событии (à une véritable événement)» и «лишить зрителей любой возможности рефлексировать о том, что они видят, и сомневаться в его реальности» [I5, p. II5-II6]. Художественным воплощением данного способа восприятия стала пьеса Пьера Корнеля «Комическая иллюзия»: ее герой, наблюдая за действом, которое показывает ему маг Алькандр, верит, что видит происходящее в реальности; лишь в конце ему открывается, что он был зрителем театрального спектакля.

Миметическая иллюзия в конечном итоге оказывается средством возбуждения чувств реципиента, которое в свою очередь служит улучшению нравов. Связь между «правилом» правдоподобия и возбуждением чувств как целью поэта постулирует Жорж де Скюдери: «Среди всех правил, о ко- 
торых я говорю, самое важное <...> - правило правдоподобия. Без него нас не захватит этот приятный обман (agreable tromperie), который делает так, что нам кажется, что мы сочувствуем удачам и неудачам этих воображаемых героев. Поэт, который ставит своей целью возбуждать чувства (esmouvoir les passions) зрителя посредством чувств персонажей <...>, никогда не сможет этого достичь <..>, если то, что он хочет запечатлеть в душе, не будет правдоподобным» [34, p. 74-75]. Такое возбуждение чувств, однако, невозможно без соответствия изображаемого «обычным мнениям и воззрениям людей (l'opinion et le sentiment ordinaire des hommes)» [4, p. 76]. Здесь учение о правдоподобии переключается в риторический план: в требовании возбуждать чувства нельзя не узнать риторическое movere, а в условии соответствия изображаемого мнениям реципиента - принцип delectare / conciliare, состоящий в необходимости расположить к себе слушателей. Соблюдение вышеупомянутых миметических «правил» и риторическая консолидация с «мнениями» реципиента вызывают у последнего состояние доверия к изображаемому; доверие позволяет ему испытывать сильные чувства; возбуждаемые произведением чувства приводят к улучшению «нравов». Эта логическая цепочка ясно прослеживается в следующем рассуждении Шаплена: «Там где отсутствует доверие, отсутствуют также внимание и благорасположение (affection); но там, где совсем нет благорасположения, не может быть чувства и, соответственно, очищения (purgation) или улучшения нравов людей, которое является целью поэзии» [г2, р. 85].

\section{Правдоподобие и правда}

Три вышеназванные определения в той или иной степени предполагают противопоставление правдоподобия «правде» как таковой; однако степень этой противопоставленности может быть различной. Правдоподобие в поэзии может вообще исключать правду; может включать в себя правду, если эта правда правдоподобна; может, наконец, «смешиваться» с правдой (в последнем случае они трактуются как взаимодополняющие начала). Таким образом, теоретические манипуляции этими двумя понятиями допускают и строго разделительную стратегию, и стратегию в той или иной степени консолидирующую.

Строго разделительная стратегия, видимо, встречается редко и только в отдельных высказываниях, пример которого находим у Шаплена: он 
одобрительно пишет о древних поэтах, которые, осознав, что реальность, зависимая от случайности, «вредит своими неожиданными и неясными событиями их столь похвальному замыслу, все как один изгнали правду со своего Парнаса»; «правдоподобие <...>, а не правда служит инструментом поэту, чтобы направить человека к добродетели» [ı2, p. 87]. Это суждение строго разделительно - но Шаплен тут же смягчает его оговорками: правда, согласующаяся со «справедливостью и разумом» и правдоподобная, допустима в поэзии. Мы, таким образом, приходим ко второй стратегии, которую следует признать наиболее распространенной: в поэзии допустима правдоподобная правда. В этой стратегии есть и момент разделения (неправдоподобная правда исключается из поэзии), и консолидации (подобающая правда включается в сферу правдоподобного). Последняя, чисто консолидирующая стратегия, самая «либеральная» по отношению к правде, основана не на включении, но скорее на соединении, смешении: рекомендуется смешивать правдивое с правдоподобным; правда не растворяется в правдоподобном, но воспринимается как самостоятельное начало. Суждения такого рода фактически варьируют совет Горация - смешивать правду и ложь (истинный поэт «veris falsa remiscet», «Поэтическое искусство», I5I); о влиянии Горация свидетельствует и тот факт, что вместо понятия «правдоподобие» часто используется слово «fiction», «вымысел» (при этом предполагается, что он правдоподобен). Так, Мадлен де Скюдери полагает, что основа романной фабулы, соединяющей «исторический фундамент»с вымыслом, - «ложь, смешанная с истиной (le mensonge mêlé avec la verité) [35, p. I69]; это почти точный перевод совета Горация. Сходная мысль появляется даже у Корнеля, утверждавшего автономную ценность исторической правды, даже неправдоподобной: однако в «Кратком изложении мученичества св. Полиевкта» он говорит об «изобретательном переплетении вымыслов с правдой (tissure des fictions avec la vérité), в котором состоит самая прекрасная тайна поэзии» [г6, р. 323]; речь идет о деталях и изобретенных эпизодах (épisodes d'invention), которые можно вставлять в основную исторически точную сюжетную канву. Принцип смешения правды и вымысла имел большее значение для практической поэтики классицизма: драматурги действительно дополняли исторически точный сюжет изобретенными деталями или слегка модифицировали его в соответствии с «мнением публики»; романисты могли придерживаться обратной стратегии - ис- 
пользовали реальную историю и ее героев как фон, на котором разыгрывается вымышленная история с вымышленными основными персонажами («Принцесса Клевская» Мари-Мадлен де Лафайет).

\section{Области применения принципа правдоподобия}

Два основных предмета поэтического мимесиса, по Аристотелю, события, складывающиеся в фабулу, и характеры; склад событий для поэзии важнее, чем характеры. Поэтологи классицизма применяют принцип подражания и к событиям, и ко всем составляющим характера (природный «нрав», социальное положение, пол и т. п.). Самые существенные из запретов, налагаемых на события, - моральные: запрет на изображение торжествующего зла, а также привлекательного порока: «опасны» авторы, которые изображают «порок приятным» [6, p. І2г]. Однако даются запреты и на события, слишком неправдоподобные с точки зрения реальности. Так, «действие Самсона, который сокрушил филистимлян ослиной челюстью, действие героическое; но оно не может быть предметом эпической поэмы, потому что, хотя оно и истинно, оно неправдоподобно и потому слишком чудесно (merveilleuse), чтобы быть предложено для подражания» [29, p. II7]. При этом чудесное как таковое не исключалось из сферы правдоподобного, основание для чего находилось отчасти у Аристотеля, допустившего в трагедии «удивительное» («Поэтика», I45га, I-Іо), отчасти же в разработанном самими поэтологами (Кастельветро, а вслед за ним Шапленом, Менардьером, д’Обиньяком) различении правдоподобия обычного и необычного, т. е. включающего в себя события, которые нарушают естественный и ожидаемый ход вещей (см.: [26, p. 296]). В итоге чудесное рассматривается либо как составная часть правдоподобного, либо как необходимое дополнение к нему. Первый ход мысли находим у д’Обиньяка: «...театральное правдоподобие <...> охватывает и чудесное, благодаря чему события становятся особенно возвышенными» [2, p. 338]; второй - у Расина, нашедшего в драматургии П. Корнеля «счастливое» согласие «правдоподобного и чудесного (le vraisemblable et le merveilleux)» [28, p. 345]. Более подробно идея необходимого сочетания в сюжете правдоподобных и чудесных событий развита Рапеном: «Фабула (fable), чтобы быть совершенной, должна <...> иметь два качества: она должна быть чудесной и она должна быть правдоподобной. Достойной восхищения она становится благодаря второму». Чудесное само 
по себе не может нравиться без правдоподобия, но «одно лишь правдоподобие слишком мрачно и вяло (trop sombre et trop languissante) для поэзии, а одно лишь чудесное слишком необыкновенно (trop extraordinaire)». Heобходимо их соединение - ведь публика «получает удовольствие от чудесного, только если в него можно поверить» [30, p. 38-39]. В первом издании «Размышлений...» Рапен приводит и пример события, в котором удачно совмещаются правдоподобие и чудесное: Эней в двенадцатой книге «Энеиды» якобы поднимает скалу, которую не могли бы сдвинуть и десять мужчин, «это чудо становится правдоподобным благодаря помощи богов, которые принимают сторону Энея против Турна» [3I, p. 53]. Однако Рапен осуждает за неправдоподобие того же Вергилия, когда он «заставляет вырасти на дереве золотую ветвь» (в шестой книге «Энеиды»); массово осуждаются за злоупотребление чудесным итальянские и испанские поэты, особенно Ариосто, чудеса которого подобна «пустым фантазиям больного» [3о, p. 40] суждение об Ариосто явно перефразирует горацианское сравнение бессвязной книги со «снами больного» («Поэтическое искусство», 6-7).

При обсуждении жанра романа представление о правдоподобии событий принимает более приземленный характер. Так, Ж.Б.А. де Валинкур в анонимно опубликованной критике романа «Принцесса Клевская» Мари-Мадлен де Лафайет выражает недоумение, зачем автору понадобилось заставить герцога Немура целую ночь бродить в лесу: «Любой другой, нежели герой романа, за эти более чем восемь часов схватил бы простуду» [36, p. 47]. Н. Кремер справедливо отмечает сдвиг в представлениях о правдоподобном, который происходит при переносе внимания поэтологов и критиков от высоких жанров к жанру романа: правдоподобное теперь определяется не нормой, соответствующей «превосходству или образцовости поведения», но опытом жизни в реальном мире [20, p. 9].

Во многих случаях неправдоподобие события / поступка выводится из неправдоподобия характера. Так обстоит дело и с поведением Химены (она поступает неправдоподобно, потому что ее характер невыдержан), и с осуждаемым многими критиками и читателями признанием принцессы Клевской своему мужу в любви к другому мужчине. «Признание госпожи де Клев сумасбродно, оно могло бы быть высказано лишь в подлинной истории», но не в романе; «женщина редко говорит своему мужу, что в нее ктото влюблен, но никогда - что она любит другого, а не его...» [8, p. 6I7]. 
Делая правдоподобие событий производным от правдоподобия характеров (или во всяком случае тесно связывая то и другое), классицисты отступают от Аристотеля, для которого, напротив, характеры производны от действий («затрагиваются [лишь] через посредство действий») и, более того, вообще необязательны - действие возможно и без характеров («Поэтика». I450a, I5-30). При этом классицистская поэтика учла, конечно, краткое рассуждение Аристотеля о характерах, которые должны обладать четырьмя качествами: быть «хорошими», «сообразными», «похожими», «последовательными» («Поэтика». I454a, I5-30). Эти требования уже Шапленом в предисловии к «Адонису» сведены к двум: хорошее и сообразное объединены в понятии соответствия (convenance), ибо «хорошее» есть в то же время «соответствующее»; похожее и последовательное - в понятии равенства (égalité), т. е. выдержанности характера: он на протяжении всего произведения должен проявлять качества, которые были ему приписаны в начале. Ла Менардьер в «Поэтике» посвящает целую главу пороку «неравенства чувств (Les sentimens inégaux)», т. е. их невыдержанности, отмечая его и у современных драматургов, изображающих одних и тех же людей «то робкими, то весьма решительными», то скромными, то высокомерными и т. п. [2I, р. 286], и у античных классиков. Рапен находит невыдержанным характер Эдипа у Софокла, который «делает Эдипа слишком слабым в изгнании», что кажется неправдоподобным, поскольку до его опалы Софокл наделил его «твердым характером» [30, р. 43]. Проблема «неравенства», т. е. невыдержанности характера стояла и в центре полемики о «неправдоподобном» поведении Химены в «Сиде». Более разработанным в теоретическом плане оказался критерий соответствия, сообразности характера. Здесь одним из источников классицистской доктрины стал Гораций, гораздо подробнее, чем Аристотель, обосновавший принцип соответствия характера его возрасту, полу, этнической принадлежности, социальному положению («Поэтическое искусство», І05-I27). По сути, Гораций применяет к характеру риторический принцип декорума, и классицисты в этом следуют за ним. Однако решение подчинить изображение человека в его индивидуальности принципу этих внешних по своей сути соответствий не всегда давалось просто, о чем свидетельствует следующее рассуждение Рапена. Он утверждает, что для точного изображения нравов поэт должен «изучать человеческое сердце, дабы уметь различать все его движения», - речь, каза- 
лось бы, идет о необходимости психологической интроспекции, позволяющей воссоздать индивидуальность персонажа. Впрочем, далее выясняется, что такая интроспекция невозможна: «человеческое сердце - бездна такой глубины, которой не может достичь никакой лот; это непроницаемая тайна», попытки проникнуть в него бесполезны. Есть, однако, компромиссный выход из этого тупика: «Можно по крайней мере говорить о нравах в соответствии с общим мнением (opinion publique): Аякса нужно делать диким, каким его сделал Софокл, Поликсену и Ифигению благородными, какими их сделал Еврипид»; далее Рапен совсем уже традиционно переходит к требованиям соответствия характеров возрасту и полу [3о, p. 43-44].

Подойдя вплотную к принципу психологизма, Рапен, как видим, несколько неожиданно признает его невозможность и отступает к горацианскому декоруму. Зато последний разработан теоретиками классицизма чрезвычайно подробно, с массой примеров, отсутствовавших у Горация. Набор правдоподобных (соответствующих декоруму) «соответствий» в изображении тех или иных типов дает Шаплен в «Мнении Французской академии о “Сиде”», а затем и Рапен. Каждый персонаж должен быть изображен «в собственном характере: слуга - с низменными чувствами и склонностью к раболепию; государь - с щедрым сердцем <...>; солдат - диким, наглым; женщина - легкомысленной, пугливой, ветреной; старик - скупым, осторожным, недоверчивым». Применяя этот критерий к классической литературе, Рапен высоко ставит Теренция, «герои которого никогда не выходили за пределы своих характеров» [30, p. 42], но остается недоволен Гомером, изображавшим богов как «героев комедии» [29, р. Іі8]. Как обычно, резкую критику вызывают итальянские поэты: «Анджелика у Ариосто слишком нескромна, Армида у Тассо слишком страстна; эти два поэта отняли у женщин их характер, который состоит в стыдливости. Ринальдо у одного вял и женственен, Орландо у другого слишком нежен и страстен: эти слабости (foiblesses) не подобают героям...» [3о, p. 43-44]. В вопросе о запрете «слабостей» полного согласия не было: полемичным в отношении Рапена выглядит требование Буало оставить «великим сердцам» «какое-либо слабости», например, Ахиллу - его слезы обиды [6, р. гог]; «слабость» легитимирует и Расин, когда в предисловии к «Федре» заявляет, что счел нужным наделить Ипполита «слабостью» - любовным чувством к Арикии, а в первом предисловии к «Андромахе» выразил мнение, что герои трагедии 
должны обладать «добродетелью, способной на слабость (une vertu capable de faiblesse)».

Понятно, что принцип правдоподобного соответствия тех или иных свойств характерам функционирует лишь на уровне типов, но не индивидуальностей. Обойдя проблему индивидуальности, поэтика классицизма, однако, открыла чрезвычайное многообразие типов, система которых с наибольшей подробностью разработана в «Поэтике» И. Ла Менардьера. В главе, посвященной «нравам», развернута обширная типология характеров, дифференцированных по полу, национальности, социальному положению и т. п.; каждому «характеру» (т. е., в сущности, типу) дана дефиниция, состоящая в наборе качеств: король должен быть смелым, мудрым, щедрым; тиран - жестоким, коварным, скупым; королева - целомудренной, величественной, спокойной; канцлер - компетентным (sçavant), серьезным, pacсудительным. Целая страница посвящена национальным типам: французы должны изображаться «смелыми, галантными (courtois), нескромными, щедрыми, ловкими, опрометчивыми, пылкими, непостоянными, расточительными, не слишком трудолюбивыми, учтивыми, легкомысленными в своих любовных связях, нетерпеливыми и дерзкими»; в том же духе - с непредсказуемым чередованием позитивных и негативных качеств - даются предписания по изображению испанцев, англичан, немцев, персов, греков, египтян, мавров, фракийцев и скифов. Парадоксальным кажется соединение качеств, которые Ла Менардьер приписывает полам (предполагается, видимо, что разные качества надо использовать в разных ситуациях): мужчин следует представлять «твердыми, суровыми, великодушными, меланхоличными (chagrins), решительными, скупыми, мудрыми, честолюбивыми, спокойными, верными и трудолюбивыми»; женщин - «скрытными, нежными, слабыми, утонченными, скромными, стыдливыми, галантными, возвышенными в своих мыслях, внезапными в своих желаниях, бурными в своих страстях» и т. п. [2I, p. І20-I24]. Соответствие, сообразность характера в конечном итоге трактуются как его приличие, благопристойность (bienséance); можно согласиться с утверждением А. Женетьо: «будучи применено к нравам <...>, правдоподобие становится приличием» [19, p. 30I]. Это значит, что, трактуя вопрос о характерах, теория правдоподобия фактически вливается в теорию литературного декорума. 


\section{Рождение представления о национально-исторической относительности правдоподобия}

Понимаемое как универсальное и/или должное, правдоподобие мыслилось как абсолютная, вневременная величина; однако при его соотнесении с «мнением публики» неминуемо возникал вопрос, какая, собственно, публика имеется в виду. О социальном определении этой публики говорилось выше; однако вопрос мог ставиться и в историческом измерении. Ответ был очевиден: правдоподобно то, что воспринимается таковым современной публикой: «Всякий писатель, изобретающий фабулу, предмет которой составляют человеческие действия, должен изображать своих героев и их действия лишь в соответствии с нравами и верованиями своего времени» [г, р. 2І8].

Но далее историческая рефлексия приводила к противопоставлению вкусов современной и «древней» публики. Д’Обиньяк отмечает такое различие в области драмы: демократы-афиняне, воспринимавшие царей как тиранов, с удовольствием наблюдали на сцене их несчастья, что невозможно для современных французов, которые любят своих государей [2, p. 335-336]. На историческом различии представлений о правдоподобии д’Обиньяк основывает и свою критику «Царя Эдипа»: действие этой трагедии кажется еще менее вероятным (moins croyable), потому что Софокл строит его «на страхе перед неким предсказанием, которое должно потрясти лишь простодушных» (вместо того чтобы развивать интересно намеченные в начале характеры); но теперь «умы нуждаются в более основательной пище; и если античность сносила эти химерические изобретения (inventions chimériques), то наш век хочет обманываться (être trompé) более приятно и такими событиями, которые заслуживают больше доверия» [5, p. Іо9]. На сходных основаниях Андре Марешаль осуждает «Медею» Сенеки, где заглавная героиня уносится на воздушной колеснице, запряженной драконами: ныне «наши верования не могут допустить ничего подобного, они побуждают искать другие способы и другие пути к тому правдоподобию, которое отвечает умонастроениям (humeurs) наших французов и обычаям времени» [24, p. 22I].

Следующий шаг исторической рефлексии состоит в пробуждении интереса к тому «чужому» правдоподобию, которое объявлялось неприемлемым для современного француза. Буало призывает изучать «нравы эпох, 
стран», замечая, что «климаты часто порождают различные расположения духа (humeurs)» [6, p. Iог]. Возникает противостоящая основной классицистской доктрине идея, что правдоподобие состоит не в соответствии современным «мнениям», но в исторически точном воспроизведении той или иной эпохи и ее нравов. Ш. де Сент-Эвремон именно за историческую точность одобряет Корнеля; Расин, напротив, вызывает критику за то, что индийца Поруса в «Александре Великом» он приблизил к «нашему умонастроению» до такой степени, что Порус «кажется родившимся среди нас». Общий вывод таков: «Те, кто хотят изображать какого-либо героя старых времен, должны войти в дух народа, которому он принадлежал, в эпоху, в которую он жил» [32, р. 90, 88]. Однако и сам Расин в первом предисловии к «Баязету» заявляет о своем намерении «ничего не менять ни в нравах, ни в обычаях народа»; речь в данном случае идет о турках. О приверженности исторической точности говорят и авторы романов - Жорж де Скюдери в предисловии к «турецкому» роману «Ибрагим» заявляет, что следовал в нем «нравам, обычаям, законам, верованиям и наклонностям народа»; «я хотел, чтобы основания моего романа были историческими» [33, vol. I, p. 79].

Перенесение принципа правдоподобия в историко-культурное измерение (правдоподобно исторически точное) неизбежно вытекало из развития самой классицистической доктрины: выдвижение современных, «наших» мнений как критерия правдоподобия предполагало осознание их отличия от исторически и культурно чужих мнений; однако само существование этих чужих мнений, будучи осознанным, не могло не вызвать к ним интереса. Этот интерес в свою очередь породил требование исторической точности, которое подрывало классицистическое учение о правдоподобии: на смену идее единственно возможного правдоподобия, в перспективе которого «реальность XVII века должна была предстать как универсальная и вечная» [18, р. 69], приходило представление о множестве исторически и эстетически относительных «правдоподобий». Классицизм, в своем логическом развитии приходя к самоотрицанию, открывал путь к эстетическому релятивизму в духе Гердера и романтиков. 


\section{Список литературы}

I Женетm Ж. Правдоподобие и мотивация / пер. И. Иткина // Женетт Ж. Фигуры: в 2 т. М.: Изд-во им. Сабашниковых, І998. Т. г. С. 299-32г. д’Обиньяк Ф. Практика театра / пер. М.С. Гринберга // Литературные манифесты западноевропейских классицистов. М.: Изд-во МГУ, г980. С. 320-36о. Пахсарьян Н.T. Понятие «правдоподобие» во французской поэтике // Литературоведческий журнал. 2008. № 23. С. 77-83.

4 d'Aubignac F. La Pratique du Théâtre. Alger: Carbonel, I927. XXX, 440 p.

5 d'Aubignac F. Troisième dissertation // Oedipe / Corneille et Voltaire. Saint-Étienne: Université de Saint-Étienne, 2004. P. 99-I28.

6 Boileau N. Ars poétique // Boileau. CEuvres. T. I-2. Paris: Garnier - Flammarion, I969. T. 2. P. 87-II5.

$7 \quad$ Bray R. La formation de la doctrine classique en France. Paris: Nizet, I95I. 389 p.

8 Bussy-Rabutin. Lettre du 26 juin I678 à Mme de Sévigné // Sévigné M. Correspondance. 3 vol. Paris, I972-I978. Vol. 2. P. 6I7.

Casals M. $-N$. La vérité comme indice dans trois poétiques du premier XVIIe siècle: Jean Vauquelin de La Fresnaye, Pierre de Deimier, Jean Chapelain // XVIIe siècle. Année 200I/I. № 2IO. P. I9-33.

IO Chapelain J. Dialogue de la lecture des vieux romans // Chapelain J. Opuscules critiques. Paris: Droz, I936. P. 205-24I.

II Chapelain J. Discours de la poésie représentative // Chapelain J. Opuscules critiques. Paris: Droz, I936. P. I27-I3I.

I2 Chapelain J. La Préface à l'Adonis // Chapelain J. Opuscules critiques. Paris: Droz, I936. P. 7I-III.

I3 Chapelain J. La Pucelle - livres XIII à XXIV - Préface // Chapelain J. Opuscules critiques. Genève: Droz, 2007. P. 454-470.

I4 Chapelain J. Les Sentiments de l'Académie française sur la tragi-comédie du Cid // La Querelle du Cid. Paris: Welter, I898. P. 355-4I7.

I5 Chapelain J. Lettre sur la régle des vingt quatre heures // Chapelain J. Opuscules critiques. Paris: Droz, I936. P. II5-I2I.

I6 Corneille P. Abrégé du martyre de saint Polyeucte // Corneille P. Euvres complètes. T. I. Paris: Firmin Didot, I837. P. 323-324.

I7 Dacier A. La Poetique D’Aristote. Amsterdam: Gallet, I692. 527 p.

I8 Garnier P. La notion de vraisemblance chez les théoriciens français du Classicisme // Annales de Bretagne et des pays de l'Ouest. I976. T. 83, № I. P. 45-70.

I9 Génetiot A. Le classicisme. Paris: Quadrige, 2005. 475 p.

20 Kremer $N$. Vraisemblance et reconnaissance de la fiction. Pour une redéfinition de la vraisemblance dans le cadre d'une poétique romanesque // Fabula / Les colloques, Fictions classiques. Article publié le 29 avril 2006. URL: http://www.fabula.org/ colloques/documentı28.php (page consultée le o4 août 20I9). 
La Mesnardière H. J. Pilet de. La Poëtique. Paris: Sommaville, I640. 467 p. Le Bossu R. Traité du poème épique. 6 éd. La Haye: Scheurleer, I7I4. T. I. 490 p. Le Moyne P. Dissertation du poëme heroique // Le Moyne P. Oeuvres poetiques. Paris: Billaine, I67I. P. I-236.

4 Marechal A. Préface à La Généreuse allemande // Temps des préfaces: le débat théâtral en France de Hardy à la querelle du Cid. Paris: Klincksieck, I996. P. 218-225.

5 Mehtonen $P$. Old concepts and new poetics. Historia, argumentum, and fabula in the twelfth- and early thirteenth-century latin poetics of fiction. Dissertation. Helsinki: Societas Scientiarum Fennica, 1996. I73 p.

6 Morgan J. The Meanings of Vraisemblance in French Classical Theory // The Modern Language Review. 1986. Vol. 8I, № 2. P. 293-304.

7 Phillips $H$. «Vraisemblance» and Moral Instruction in Seventeenth-Century Dramatic Theory // The Modern Language Review. I978. Vol. 73, № 2. P. 267-277.

8 Racine J. Discours de réception à l'Académie française de Th. Corneille // Racine J. Euvres complètes. Paris: Fortic, I826. P. 565-568.

9 Rapin R. La comparaison d'Homère et de Virgile // Rapin R. Les œuvres. Amsterdam: Mortier, I709. T. I. P. 97-I78.

Rapin $R$. Les réflexions sur la poétique de ce temps. Genève: Droz, I970. XXXVI, 204 p.

I Rapin R. Réflexions sur la Poétique d'Aristote. Paris: Muguet, I674. 257 p.

2 Saint-Evremond Ch. de. Dissertation sur le Grand Alexandre // Saint-Evremond Ch. de. Euvres en prose. 4 vol. Paris: Didier, I962-I969. Vol. 2. P. 84-IO2.

33 Scudéry G. de. Ibrahim ou L'illustre Bassa. Fasano: Schena; Paris: Presses de l'Université Paris - Sorbonne, 2003. Vol. I-2. I224 p.

34 Scudéry G. de. Observations sur le Cid // La Querelle du Cid. Paris: Welter, I898. P. 7I-III.

35 Scudéry $M$. de. De la manière d'inventer une fable // Scudéry $M$. de. «De l'air galant» et autres Conversations (I653-I684). Paris: Champion, I998. P. I6I-I80.

36 Valincour J.B.H. de. Lettres à Madame la Marquise ${ }^{* * *}$ sur le sujet de la Princesse de Clèves. Paris: S. Mabre-Cramoisy, I678. 37I p.

Vossius G.J. Poeticarum institutionum libri tres. Leiden: Brill, 20IO. 2 vol. XII, VII, $2 \mathrm{I} 89 \mathrm{p}$. 


\section{References}

I Zhenett Zh. Pravdopodobie i motivatsiia [Verisimilitude and motivation], transl. by I. Itkin. In: Zhenett Zh. Figury: $v 2 t$. [Figures: in 2 vols.]. Moscow, Izd-vo im. Sabashnikovykh Publ., I998, vol. I, pp. 299-32I. (In Russ.) d'Obin'iak F. Praktika teatra [Practice of the theatre], transl. by M.S. Grinberg. Literaturnye manifesty zapadnoevropeiskikh klassitsistov [Literary manifests of West European classicists]. Moscow, Izdatel'stvo Moskovskogo gosudarstvennogo universiteta Publ., I980, pp. 320-360. (In Russ.)

3 Pakhsar'ian N.T. Poniatie "pravdopodobie" vo frantsuzskoi poetike [The category of verisimilitude in French poetics]. Literaturovedcheskii zhurnal, 2008, no 23, pp. 77-83. (In Russ.) d'Aubignac F. La Pratique du Théâtre. Alger, Carbonel, I927. XXX, 440 p. (In French) d'Aubignac F. Troisième dissertation. Oedipe / Corneille et Voltaire. Saint-Étienne, Université de Saint-Étienne, 2004. P. 99-I28. (In French) Boileau N. Ars poétique. Boileau. Euvres. T. I-2. Paris, Garnier - Flammarion, I969. T. 2. P. 87-II5. (In French) Bray R. La formation de la doctrine classique en France. Paris, Nizet, I95I. 389 p.

8 Bussy-Rabutin. Lettre du 26 juin I678 à Mme de Sévigné. Sévigné M. Correspondance. 3 vol. Paris, I972-I978. Vol. 2. P. 6I7. (In French) Casals M.-N. La vérité comme indice dans trois poétiques du premier XVIIe siècle: Jean Vauquelin de La Fresnaye, Pierre de Deimier, Jean Chapelain. XVIIe siècle. Année 200I/I. N 210. P. I9-33. (In French) Chapelain J. Dialogue de la lecture des vieux romans. Chapelain J. Opuscules critiques. Paris, Droz, 1936. P. 205-24I. (In French) Chapelain J. Discours de la poésie représentative. Chapelain J. Opuscules critiques. Paris, Droz, I936. P. I27-I3I. (In French)

I2 Chapelain J. La Préface à l'Adonis. Chapelain J. Opuscules critiques. Paris, Droz, I936. P. 7I-III. (In French)

I3 Chapelain J. La Pucelle - livres XIII à XXIV - Préface. Chapelain J. Opuscules critiques. Genève, Droz, 2007. P. 454-470. (In French)

I4 Chapelain J. Les Sentiments de l'Académie française sur la tragi-comédie du Cid. La Querelle du Cid. Paris, Welter, I898. P. 355-4I7. (In French)

I5 Chapelain J. Lettre sur la régle des vingt quatre heures. Chapelain J. Opuscules critiques. Paris, Droz, I936. P. II5-I2I. (In French)

I6 Corneille P. Abrégé du martyre de saint Polyeucte. Corneille P. Euvres complètes. T. I. Paris, Firmin Didot, I837. P. 323-324. (In French)

I7 Dacier A. La Poetique D’Aristote. Amsterdam, Gallet, I692. 527 p. (In French) 
I8 Garnier P. La notion de vraisemblance chez les théoriciens français du Classicisme. Annales de Bretagne et des pays de l'Ouest. I976. T. 83, № I. P. 45-70. (In French)

I9 Génetiot A. Le classicisme. Paris, Quadrige, 2005. 475 p. (In French)

20 Kremer N. Vraisemblance et reconnaissance de la fiction. Pour une redéfinition de la vraisemblance dans le cadre d'une poétique romanesque. Fabula, Les colloques, Fictions classiques. Article publié le 29 avril 2006. Available at: http: //www.fabula.org/ colloques/documentı28.php (page consultée le 04 août 20I9) (In French)

2 I La Mesnardière H.J. Pilet de. La Poëtique. Paris, Sommaville, I640. 467 p. (In French)

22 Le Bossu R. Traité du poème épique. 6 éd. La Haye, Scheurleer, I7I4. T. I. 490 p. (In French)

23 Le Moyne P. Dissertation du poëme heroique. Le Moyne P. Oeuvres poetiques. Paris, Billaine, I67I. P. I-236. (In French)

24 Marechal A. Préface à La Généreuse allemande. Temps des préfaces: le débat théâtral en France de Hardy à la querelle du Cid. Paris, Klincksieck, 1996.

P. 218-225. (In French)

25 Mehtonen P. Old concepts and new poetics. Historia, argumentum, and fabula in the twelfth-and early thirteenth-century latin poetics of fiction. Dissertation. Helsinki, Societas Scientiarum Fennica, I996. I73 p. (In English)

26 Morgan J. The Meanings of Vraisemblance in French Classical Theory. The Modern Language Review. I986. Vol. 81, № 2. P. 293-304. (In English)

27 Phillips H. "Vraisemblance" and Moral Instruction in Seventeenth-Century Dramatic Theory. The Modern Language Review. I978. Vol. 73, № 2. P. 267-277. (In English)

28 Racine J. Discours de réception à l'Académie française de Th. Corneille. Racine J. CEuvres complètes. Paris, Fortic, I826. P. 565-568. (In French)

29 Rapin R. La comparaison d'Homère et de Virgile. Rapin R. Les œuvres. Amsterdam, Mortier, I709. T. I. P. 97-I78. (In French)

30 Rapin R. Les réflexions sur la poétique de ce temps. Genève, Droz, I970. XXXVI, 204 p. (In French)

3I Rapin R. Réflexions sur la Poétique d’Aristote. Paris, Muguet, I674. 257 p. (In French)

32 Saint-Evremond Ch. de. Dissertation sur le Grand Alexandre. Saint-Evremond Ch. de. Euvres en prose. 4 vol. Paris, Didier, I962-I969. Vol. 2. P. 84-IO2. (In French)

33 Scudéry G. de. Ibrahim ou L'illustre Bassa. Fasano, Schena; Paris, Presses de l'Université Paris - Sorbonne, 2003. Vol. I-2. I224 p. (In French)

34 Scudéry G. de. Observations sur le Cid. La Querelle du Cid. Paris, Welter, I898. P. 7I-III. (In French) 
35 Scudéry M. de. De la manière d'inventer une fable. Scudéry M. de. "De l'air galant" et autres Conversations (I653-I684). Paris, Champion, I998. P. I6I-I80. (In French)

36 Valincour J.B.H. de. Lettres à Madame la Marquise *** sur le sujet de la Princesse de Clèves. Paris, S. Mabre-Cramoisy, I678. 37I p. (In French)

37 Vossius G.J. Poeticarum institutionum libri tres. Leiden, Brill, 20IO. 2 vol. XII, VII, 2I89 p. (In French) 
УДК 82 I.I6I.I +82.0

ББК $83+83.3(2 \mathrm{Poc}=\mathrm{Pyc}) 52$

\section{«ПРАВО НА БИОГРАФИЮ» \\ И ЛИТЕРАТУРНЫЕ ВОСПОМИНАНИЯ ВТОРОЙ ПОЛОВИНЫ XIX В.:}

\author{
(C) 2020 г. А.Е. Козлов \\ Тартуский университет, \\ Тарту, Эстония \\ Дата поступления статьи: 2г августа 2019 г. \\ Дата публикации: 25 июня 2020 г.
}

DOI: IO.22455/2500-4247-2020-5-2-34-55

Исследование поддержано EU Regional Development Fund (Research topic: Literature Reputation of Mass-Fiction Writer: Nikolai Aksharumov Case)

Аннотация: Рассматриваются категории «право на биографию в истории» и «право на биографию в истории литературы», устанавливаются типологические связи между описанием литературного быта и спецификой жанра литературных воспоминаний. В начале статьи исследуется несколько взаимосвязанных сюжетов, выстраивающихся вокруг критики журнала «Отечественные записки». Анализируются способы «пересобирания» истории литературы в синхронии (статьи о Ф.В. Растопчине и О.И. Сенковском), актуализация оппозиций «право на бессмертие» и «право на забвение». Основная часть статьи посвящена феномену литературных воспоминаний и принципам отбора исторических фигур. Часто в самом этом отборе (выбор публициста или мемуариста, о чем писать и о чем умолчать) заключены значимые ресурсы для автокомментария. Рассматривая литературные воспоминания на нарративном уровне, вне их фактографии, автор выявляет модели литературного быта как авантюры (Булгарин, Панаев, Антонович, Успенский), литературного быта как бытия (Тургенев, Григорьев, Григорович) и литературы как памяти (Анненков).

Ключевые слова: литературные воспоминания, биография писателя, рефлексия и нарратив, автокомментарий, механизмы канонизации.

Информация об авторе: Алексей Евгеньевич Козлов - докторант кафедры русской литературы, Тартуский университет, ул. Lossi, д. 3, 5 IоO3 г. Тарту, Эстония. ORCID ID: 0000-0003-0016-9546

E-mail: alexeykozlov54@gmail.com

Для цитирования: Козлов А.Е. «Право на биографию» и литературные воспоминания второй половины XIX в. // Studia Litterarum. 2020. T. 5, № 2. С. 34-55. DOI: I0.22455/2500-4247-2020-5-2-34-55

* $\quad$ Автор благодарит профессора кафедры русской литературы Тартуского университета Любовь Николаевну Киселёву за деятельные советы и критику черновых версий статьи. 


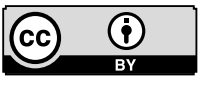

This is an open access article distributed under the Creative Commons Attribution 4.0 International (CC BY 4.0)

\section{"THE RIGHT TO BIOGRAPHY" AND LITERARY MEMORIES OF THE $19^{\text {th }}$ CENTURY}

\author{
(C) 2020. A.E. Kozlov \\ University of Tartu, Tartu, Estonia \\ Received: August 2I, 2019 \\ Date of publication: June 25, 2020
}

Acknowledgements: The research is supported by the EU Regional Development Fund (Research topic: Literature Reputation of Mass-Fiction Writer: Nikolai Aksharumov Case).

Abstract: The article bears on the classic articles by Lotman, Bakhtin, and Tomashevsky and contemporary works by Mestergazi, Kalugin, Djachuk and others. It focuses on the study of two categories: "the right to biography in history" and "the right to biography in the history of literature." Dialogue among writers, journalists, and scholars in the $19^{\text {th }}$ century demonstrates that these categories were understood differently, especially this concerns the limits of the mentioned "rights." At the beginning of the article, I examine several interrelated stories that line up around the journal Otechestvennye zapiski. The essay analyzes methods of local and global influence on the history of literature in articles (articles about Feodor Rastopchin and Osip Senkovsky) and critical reviews (about Ivan Panaev). These materials actualize the opposition between "the right to immortality" (Turgenev) and "the right to oblivion" (Panaev). The main part of the article focuses on the phenomenon of literary memories and the principles of selection of historical figures. Considering the specific ways of organizing a biographical narrative, one can identify basic models of literary life, from adventure (Bulgarin, Panayev, Antonovich, Uspensky) to memory and being (Turgenev, Annenkov) and literature as memory (Annenkov). In conclusion, I argue that the corpus of literary memories is aimed at building a certain hierarchy, or a system of names. In other words, not being themselves part of the literary canon, these texts play a role in its formation contributing to the "legend about literature that it invents about itself" (Lotman).

Keywords: literary memories, writer's biography, reflection and narrative, auto-commentary, canonization.

Information about the author: Alexey E. Kozlov, Doctoral Student, University of Tartu, 3 Lossi St., 51003 Tartu, Estonia. ORCID ID: 0000-0003-00I6-9546

E-mail: alexeykozlov54@gmail.com

For citation: Kozlov A.E. "The Right to Biography" and Literary Memories of the $19^{\text {th }}$ Century. Studia Litterarum, 2020, vol. 5, no 2, pp. 34-55. (In Russ.)

DOI: Io.22455/2500-4247-2020-5-2-34-55 
Анализируя опыт жизнеописания в широкой хронологической перспективе, Ю.М. Лотман писал о том, что «каждый тип культуры вырабатывает свои модели людей без биографии и людей с биографией. Здесь очевидна связь с тем, что каждая культура создает в своей идеальной модели тип человека, чье поведение полностью предопределено системой культурных кодов, и человека, обладающего определенной свободой выбора своей модели поведения» [Іо, с. 780]. Этот тезис, во многом продолжающий концепцию Б.В. Томашевского, обозначенную в его программной статье «Писатель и биография» [15; г3], позволяет включить в исследовательское поле не только тексты, чья жанровая природа соответствует научной или популярной биографии, но и периферийные жанры, в которых функционируют биографические нарративы. Такие нарративы, или конструкции [І7; I4; 6], запечатлевая в себе сюжеты из жизни реальных людей (и неизбежно их трансформируя), имеют довольно сходные траектории бытования в культуре. Знаменательно, что биографические нарративы, вне зависимости от их первичной среды: устной речи (легенды и анекдоты), толстого журнала и иллюстрированного еженедельника (фельетон, биографический очерк, некролог), отдельного издания (предисловие к собранию сочинений, материалы к биографии), - проникают не только в беллетризованные повествовательные тексты, но и с течением времени транслируются на страницах школьных учебников. Во всех случаях особую роль играют принципы и методы выбора фигуры, способы ее репрезентации и реконструкция окружения или сообщества. Некоторые из этих методов и принципов, стихийно или намеренно используемых журналистами и беллетристами XIX в., мы попытаемся продемонстрировать на материалах настоящей статьи. 
С точки зрения романтической эстетики, которой наследует практически весь XIX в., писателем с биографией должна быть неординарная личность, чей жизненный путь представляет собой отступление от общепринятой нормы. Более того, само это отступление корректирует впоследствии представление о нормальном. Отчасти эта тенденция нашла отражение в программных статьях и манифестах Т. Карлейля и Б. Дизраэли, проводивших общую мысль о героях и героическом в повседневной жизни. При этом, наряду с героем в исторической плоскости, на первый план выступают писатели и художники. Противоположный романтическому, позитивистский взгляд, представленный в первую очередь работами И. Тэна, предполагает, что практически любая личность, принадлежащая среде и оставившая свой след в истории, имеет право на биографию [5; гі].

В середине І850-х гг. в русском культурном пространстве не только определяется круг фигур, «достойных биографии» [г], но и многократно уточняется вопрос, «на какую именно биографию имеет право этот конкретный человек?» [6]. Именно в этот период усиливается рефлексия о прошлом и осмысляются границы периода литературы, позже названного Золотым веком: «После славы быть Пушкиным или Гоголем прочнейшая известность - быть историком таких людей»․ㅡㄴ. Показательно, что в течение I850-х гг. печатаются собрания сочинений Пушкина и Державина (предваряемые материалами к биографии поэтов), биография и неизданные произведения Гоголя.

Прослеживая историю становления биографического очерка в журнале «Русский вестник», Д. Калугин останавливается на трех фигурах: Т.Н. Грановском, П.Н. Кудрявцеве и Н.В. Станкевиче. Первые две биографии объединяет то, что эти общественные деятели - и во многом либералы - оставили свой след в истории науки: оба были преподавателями. В этом отношении и тот, и другой имели право на биографию, и здесь, скорее, возникал вопрос о границах ее открытия и сокрытия. Совсем иная история - Станкевич. Как мы помним, Станкевич не оставил значительных литературных сочинений, его личность важна не с точки зрения истории литературы как истории текстов, а истории литературы как истории идей.

I Чернышевский Н.Г. Очерки гоголевского периода русской литературы // Чернышевский Н.Г. Собр. соч.: в г5 т. М.: Гослитиздат, г948. Т. 3: Статьи. Эстетические отношения искусства к действительности. С. 780. 
Исследуя эту ситуацию, Калугин замечает: «..к 50-м годам формируется новый тип биографии человека без литературной истории. Важнее оказываются его мысли и концепции, без которых сложно представить направление многих кружков 40-х годов XIX века» [6, с. 30I].

Подобный процесс происходил и в других толстых журналах, в частности, в «Отечественных записках». Так, Н. Тихонравов, пытаясь реабилитировать в глазах читателя Ф.В. Растопчина как литератора, писал о значении «мелочных деятелей» русской литературы:

Наша критика не раз поднимала вопрос о том, есть ли у нас литература, достойная иметь свою историю? Сомнение может теперь показаться странным; но лет двадцать назад оно волновало литературный мир наш и отчасти остается в своей силе и теперь - не для ученой критики, а для некоторой части публики. Это пренебрежение отечественною литературою происходило и происходит от поверхностного знакомства с нею или от совершенного незнания ее. Много виновата в том и безотчетная вера в предание, которое возводило в число литературных гениев самые обыкновенные бездарности и часто забывало живые стремления даровитых писателей или обширные начинания энергических личностей. Возвеличив Хераскова как гениального поэта, это на слово принятое предание немного позволяло ждать от писателей, которые не были им замечены. Разумеется, подобный взгляд на нашу литературу мог твердо держаться только до тех пор, пока наука ограничивалась эстетическою оценкою писателей, признанных классиками, и только на них обращала внимание ${ }^{2}$.

Спустя пять лет С.С. Дудышкин подобным образом рассуждал и о О.И. Сенковском. Тезисы критика строились на «странном сближении» двух литераторов «прошлого» - Сенковского и Жуковского:

Сенковский, может быть, пережил себя самого, свою славу, и забывчивое общество забыло заплатить последнюю дань таланту? Но... не в пример говорим и не для сравнения... никто больше Жуковского не переживал своей славы, однако ж, когда гроб этого поэта, напоминавшего нам начало I9 века,

2 Тихонравов Н. Граф Ф.В. Растопчин и литература в І8г2-м году // Отечественные записки. 1854. Т. 95. С. 2. 
был привезен в Петербург, все поторопились отдать должную дань заслугам первого нашего романтика. Сенковский никогда не переживал сам себя так, как Жуковский, Сенковский произвел такой же восторг в своих поклонниках объявлением в I857 году, за несколько месяцев до смерти, каким были проникнуты его обожатели при чтении «Большого выхода у Сатаны» в I832 году; при чтении «Листков», фельетонных и политических в I856 году. Жуковский жаловался на равнодушие публики к его переводу «Одиссеи» и жалел, что не был жив единственный его ценитель и ученик - Пушкин; Жуковский был для одного времени, для одного направления литературы, Сенковский - для всякого. Следовательно, Сенковский не пережил своей известности - и между тем был забыт³.

Парадокс Сенковского состоял, с точки зрения автора статьи, в его «современности» и «своевременности». Однако за этими качествами стояли дилетантизм и несменяемая маска фельетониста.

Дудышкин снова возвращается к сравнениям - на этот раз он обращается к известному анекдоту об отставке Ломоносова от Академии.

Нет никакого сомнения, что Сенковский перефразировал не на словах, а в своей двадцатипятилетней жизни, как литератор и журналист, ответ Ломоносова и думал, что можно не Сенковского отставить от русской литературы, а русскую литературу от Сенковского. Но І830-І855 годы не были уже I730-I755, и русская литература была не академией ${ }^{4}$.

С точки зрения критика, Сенковский достоин упоминания как ученый-ориенталист, глубоко образованный и талантливый человек («Сенковский замечателен по своим способностям»). Однако литературное поприще, «вредное» по своей сути, определило судьбу его имени: Брамбеус поглотил Сенковского. Такой вывод подкреплялся в статье Дудышкина сильным риторическим обобщением.

3 Дудышкин С. Сенковский - дилетант русской словесности // Отечественные записки. I859. T. I22. C. 452.

4 Там же. С. 453. 
Литературе нет дела до того, какие у вас и у меня способности; она не меряет таланта на аршин, но зато справедливо взвешивает, кто и сколько внесет в нее жизни, правды, дела. Вы можете гордиться вашим талантом передо мной, но литература не уважает ни вашей гордости собственным достоинством, ни унижения: она, как жизнь, требует, чтобы ей служили и большие, и малые, и талантливые, и бесталанные. Только по делам она отводит места, и другой табели о рангах еще никто не создавал в литературе5.

В обоих случаях мы наблюдаем не только попытку ревизии культурного пространства (взгляд на Растопчина через Хераскова, сравнение Сенковского с Ломоносовым и Жуковским), но и своеобразную индукцию - от частного «случая» к некоторым общим, универсальным законам. Очевидно, что право на имя в истории и право на имя в литературе перестают быть тождественными, поскольку определяются разными критериями.

Эту закономерность можно проследить, обратившись к некрологическим статьям об ушедших из жизни современниках. Так, уже в конце I850-х гг., претендуя на особенное право называться журналом, где Белинский напечатал свои главные обзоры, «Отечественные записки» приветствовали издание первого собрания сочинений критика:

Первый том его сочинений, разбросанных по журналам, собран и издан. Появившись в Петербурге, этот том в то же мгновение и исчез. Мы полагаем, что нужно уже делать второе издание, хотя журналы не успели объявить и о первом. Вот лучшая похвала русской публике, которую привыкли обвинять во многом, а между прочим и в хладнокровии к именам, дорогим для русской литературы ${ }^{6}$.

Впоследствии по тому же принципу редакция «Отечественных записок» (А.А. Краевский и С.С. Дудышкин) поддержала и сочинения Н.А. Добролюбова. Не менее теплого отзыва удостоился и ушедший из жизни А.В. Дружинин (оцененный в большей мере не как писатель, а как человек). В то же время совсем иначе редакция действовала, обращаясь к И.И. Панаеву и Н.Г. Чернышевскому. Если автор «Эстетических отноше-

5 Там же.

6 Сочинения В. Белинского // Отечественные записки. І859. Т. І24. С. 29. 
ний...» был заклеймен как новый Брамбеус, а его критические статьи названы брамбеусовщиной (инвективы продолжились и после гражданской казни), то И. Панаев был провозглашен создателем литературы скандалов. При этом в вину беллетристу вменялось как раз его неумение написать достойное произведение: будучи современником «великих», Панаев не сумел создать нового:

Если помните, Иван Иванович, ваша деятельность началась в блестящее время, когда Гоголь писал «Мертвые души», когда Лермонтов помещал в журналах отдельные главы «Героя нашего времени», когда Белинский, переехавший из Москвы в Петербург, начал трудиться в том же журнале, в котором и вы начали печатать ваши повести; вы выступили в славное время - и друзья литературы в то время надеялись, что и вы сделаете для нее хоть каплю добра. Если я не забыл, то вы недавно напечатали даже в вашем журнале переписку с Белинским... Вы были поставлены хорошо. Перед вами лежала широкая дорога наблюдательности, которую только что открыл Гоголь, дорога прекрасная - дорогая изучения русской жизни в более выдающихся типах ее. В сорок первом году явился ваш «Онагр», за которым последовал растолстевший от деревенской жизни «Акетон». Потом явилась «Тля», и за нею вся тяжкая - им же нет числа и до сего дня. С первого шага вашего и до настоящего времени вы верны себе; все ваши литературные приемы остались у вас, и нового вы не приобрели ничего 7 .

Фельетонист Панаев, собирающий с точки зрения критика, слухи, новости, сплетни, тем самым терял свое право на имя в литературе. Репутации Панаева не способствовали и его воспоминания, воспринятые современниками по тому же ведомству. Буквально, похоронив Панаева в этой рецензии, критика журнала Краевского больше не упоминала его до самой смерти (исключение составляет обращение к Чернышевскому, где его статьи сравнивались с мемуарами Панаева). Сообщение о смерти беллетриста было дано подчеркнуто нейтрально, но составляло значимый контраст, в сравнении с другими некрологическими статьями журнала.

7 Литература скандалов. Три тома сочинений Ив. Панаева // Отечественные записки. I860. T. 132. C. 3 I. 
В ночь с г8 на I9 февраля скоропостижно умер Иван Иванович Панаев, один из редакторов «Современника», известный литератор, писавший под псевдонимом Нового поэта ${ }^{8}$.

Конечно, в подобной манере, зачастую нарушающей этические правила, во многом заключалась специфика коммуникации обозревателей журналов, истоки которой можно увидеть в диалогах «Трутня» и «Живописца» (повторяющих Spectator), а параллели - в западноевропейских изданиях типа «Pounch» и «Journal Pour Rire». Тем не менее, несмотря на игровой характер такой коммуникации, в функциональном плане она была направлена на ту же задачу - «собирания» и «пере-собирания» истории литературы через историю образующих ее имен. В этом процессе ключевую роль сыграли так называемые литературные воспоминания, образующие корпус мемуарных и квази-мемуарных текстов в русской литературе второй половины XIX в., созданных писателями или людьми, так или иначе причастными к литературе.

В настоящей статье нас не будет интересовать фактография этих воспоминаний - усилиями комментаторов и текстологов XX в. установлены многочисленные неточности - речь может идти как о нарочитых искажениях хроники событий, так и о многочисленных «аберрациях памяти». Наиболее подробно этот феномен объясняется в работах Л.Я. Гинзбург: «В мемуарах спорное и недостоверное объясняется не только несовершенной работой памяти или умышленными умолчаниями и искажениями. Некий фермент “недостоверности” заложен в самом существе жанра. Совпасть полностью у разных мемуаристов может только чистая информация (имена, даты и т. п.); за этим пределом начинается уже выбор, оценка, точка зрения. Никакой разговор, если он сразу же не был записан, не может быть воспроизведен в своей словесной конкретности. Никакое событие внешнего мира не может быть известно мемуаристу во всей полноте мыслей, переживаний, побуждений его участников - он может о них только догадываться. Так угол зрения перестраивает материал, а воображение неудержимо стремит-

8 Смесь // Отечественные записки. І862. Т. І4о. С. 72. Противоположную тактику выбрало «Время». Несмотря на жесткий отзыв о «Литературных воспоминаниях», некролог, атрибутируемый Достоевскому, содержал положительную оценку деятельности Панаева и заканчивался словами: «Знавшие его близко искренне пожалеют об утрате человека, публика - об утрате талантливого писателя» (Некролог. Иван Иванович Панаев // Время. I862. № 2. C. 95 ). 
ся восполнить его пробелы - подправить, динамизировать, договорить» [2, с. II]. В этих «достраиваемых» до факта конструкциях нередко угадывается интенция пишущего, связанная с его задачей сократить дистанцию между уходящим в историю прошлым и настоящим, утвердив место своего имени среди других имен [4].

Обратимся к «Воспоминаниям» Ф.В. Булгарина (г847), где недостоверность повествования и ее обнажение становится одним из распространенных приемов:

Николай Иванович Греч, излагая свое мнение о первых двух частях моих Воспоминаний (см. «Северную Пчелу» I846 г. № I47-й) назвал рассказ мой импровизациею. Это самая верная характеристика моих Воспоминаний. Решившись издать в свете отрывки из виденного, слышанного и испытанного в жизни, с тою единственно целью, чтоб представить хотя краткий, но верный очерк чудной эпохи, в которую мне привелось жить, я бросаю на бумагу мои воспоминания, точно так, как бы я рассказывал о былом, в кругу приятелей, без всяких приготовлений и требований. Может быть, иное и было не так, как я рассказываю, но по составленному мною плану это вовсе не мешает делу, потому что, желая представить верный очерк прошлого времени, я говорю так, как мы думали тогда, как верили тогда, и представляю предметы с той точки зрения, с которой тогда на них смотрели. Это именно и должно составлять главное достоинство моих Воспоминаний, если они имеют какое-либо достоинство9.

Характерным здесь является своеобразный «перевод» письменного текста в ранг устной речи. Изменение коммуникативной ситуации в данном случае предполагает снятие ответственности за сказанное слово («иное и было не так, как я рассказываю, но по составленному мною плану это вовсе не мешает делу»). Вместо распространенной метафоры памяти Булгарин обращается к образу дружеской беседы, имеющей свои принципы и границы бытования.

Тем не менее в большинстве воспоминаний мемуаристы исходят из установки на истинность. Более того, свидетельства писателя позиционируются как неотъемлемая часть истории литературы. Так, начиная свои «Литературные и театральные воспоминания», С.Т. Аксаков писал:

9 Воспоминания Фаддея Булгарина: Отрывки из виденного, слышанного и испытанного в жизни. СПб.: Изд-е М.Д. Ольхина, г847. Ч. 3. Без пагинации. 
Благодаря трудам наших библиографов и биографов, трудам, принимаемым читающею публикою с видимым участием, мы имеем теперь довольно важных сведений о писателях второстепенных, которые начинали приходить у нас в забвение, потому что они имели достоинства, относительные к своему времени. Кроме того, что все такие биографические сведения и разыскания любопытны, полезны и даже необходимы, как материал для истории нашей литературы, - в этом внимании, в этих знаках уважения к памяти второстепенных писателей выражается чувство благодарности, чувство справедливости к людям, более или менее даровитым, но не отмеченным таким ярким талантом, который, оставя блестящий след за собою, долго не приходит в забвение между потомками ${ }^{\mathrm{Io}}$.

Сохраняя интонацию дневниково-интимного повествования, Аксаков в то же время воспринимает себя «летописцем эпохи». Тем не менее этот летописец полностью включен в культурную и литературную жизнь. Как писал в своей рецензии Н.А. Добролюбов, «В предисловии к воспоминаниям своим С.Т. Аксаков говорит, что издает их как материал для истории литературы и как знак уважения и благодарности к людям, более или менее даровитым, но не отмеченным таким ярким талантом, который, оставя блестящий след за собою, долго не приходит в забвение между потомками. Намерение очень похвальное; но скажите, бога ради, о многоученые библиографы, неужто вы сумеете извлечь что-нибудь для истории литературы, - например, хоть из рассказов о том, как С.Т. Аксаков с Писаревым, Шаховским и Кокошкиным рыб удили на Седринском озере?» ${ }^{\text {I. }}$ В этой полемике нашло отражение видение истории глазами «новых людей»: не случайно разночинцы, ровесники Добролюбова, в первые десятилетия литературной деятельности либо вообще отказываются от воспоминаний, либо (как Антонович, Успенский и Жуковский) намеренно их скандализируют ${ }^{12}$. В обоих рассмотренных случаях наблюдается предельное сокращение дистанции между рассказчиком и собственно событием рассказывания

Іо Аксаков С.Т. Литературные и театральные воспоминания // Разные сочинения С.Т. Аксакова. М.: Тип. Л. Степановой, I858. С. 3-4.

II Разные сочинения Аксакова // Современник. 1859. № 2. Отд. III. С. 240.

I2 Оставляемый за скобками настоящей статьи иной, героический тип воспоминаний, в которых гражданская деятельность становится презумпцией права на литературное имя, получит свое развитие в последнюю треть ХІХ в. 
[2]. Так, возвращаясь к литературным воспоминаниям И. Панаева, остановимся на рецензии «Времени»:

Литература не есть выдумка, мечта, проект: она есть факт. Следовательно, ее возможно любить не одною платоническою, но действительною, живою любовью. Чтобы почувствовать к ней такую любовь, нужно именно взять ее в ее действительности, в ее жизненной, фактической стороне, нужно вникнуть в ее историю. Наша родина, как известно, сторона печальная. <..> Что мы построили, что создали? Где наши памятники, где наша живая история? Какие досадно темные и неопределенные ответы мы должны давать на эти вопросы! Но есть у нас один ответ ясный и вполне определенный: у нас уже есть литература; жизнь пробилась в ней светлою, текучею струею ${ }^{\mathrm{I}}$.

Очевидно, что в данном фрагменте литература становится синонимом культурной жизни страны.

Внутренняя история литературы интересна для читателей прямо как средство приблизиться к их недоступному идеалу, сколько-нибудь захватить в руки блестящие образы, которые носятся перед ними. Из этой истории читатель научается несколько выше ценить себя и иногда несколько ниже ценить писателей. Во всяком случае оба полюса, разорванные идеальными помыслами, сближаются. Читатель с радостью узнает, что писатели были люди, во многом похожие на него самого; в то же время перед ним яснее и правильнее обозначаются идеалы, имевшие до тех пор слишком общие, слишком яркие и сливающиеся формы ${ }^{\mathrm{I}}$.

Тем не менее, несмотря на очевидную программу, выстраиваемую в данной статье, в действительности она никогда не была выполнена. Упреки рецензента в адрес И. Панаева, служащего читательскому интересу весьма дурно и показавшего своими воспоминаниями, какими пустяками занимались литераторы в прежнее время, каких пустых людей превозносили и как творили многое неприличное, могут быть распространены на целый корпус

I3 Литературные воспоминания И. Панаева // Время. І861. № І2. С. І6о. Единой атрибуции статьи нет: ее авторство приписывается как Ф.М. Достоевскому, так и Н.Н. Страхову.

I4 Там же. 
подобных текстов. В то же время в литературных воспоминаниях, как в кривом зеркале, отражаются некоторые узнаваемые (хотя и искаженные) черты литературного быта.

Как мы видели выше, Иван Панаев создавал свои мемуары в двусмысленной ситуации. С одной стороны, его литературная слава как беллетриста и Нового поэта устоялась к 6о-м гг. XIX в. С другой стороны, в литературной борьбе г86о-х гг. Панаев предстает скорее человеком прошлого десятилетия: он уже «не подавал никаких надежд», и от него, в сущности, не ждали новых талантливых текстов. Вероятно, по этой причине его «Литературные воспоминания» становятся способом некоторой реабилитации в собственных глазах и глазах читателей. Вместо того чтобы «возвышать» литературную среду, как это сделал С.Т. Аксаков, Панаев, напротив, «обытовляет» ее. Не случайно в его «Воспоминаниях» Значительная роль отведена салонам и званым обедам (приемы у Н.В. Кукольника, Ф.П. Толстого, В.Ф. Одоевского).

Весь литературный вечер прошел в том, что хозяин дома, Глинка, Дельвиг и Кречетов подстрекали Колмакова и Огинского на разные нелепые выходки и подтрунивали над ними. Колмаков и Огинский забавляли и развлекали общество и бессознательно играли роль шутов ${ }^{15}$.

<...> На этих середах впоследствии (это уже было в начале сороковых годов) собиралось иногда человек до восьмидесяти. Тут не были исключительно любители искусства и поклонники литературы, художники и литераторы, а всякого рода весельчаки, военные и штатские, пожилые и молодые даже игроки, аферисты и спекулаторы. Вся эта разнохарактерная ватага бестолково толпилась и шумела, бродя из комнаты в комнату. Хозяин дома кочевал среди этой толпы и останавливался на минуту перед своими гостями с каким-нибудь любезным словом. О святыне искусства не было и поминуㅎ․

По этим фрагментам нетрудно определить, что в центре внимания Панаева преимущественно внелитературный быт. Для «Литературных воспоминаний» Панаева характерна прерывистость и неровность повествовательной интонации. Мемуарист постоянно отходит от хроники событий,

15 Панаев И.И. Литературные воспоминания. М.: Правда, I988. С. 33.

I6 Там же. C. I47. 
умалчивая и «вымарывая» из памяти многие значимые эпизоды. Знаменательно, что «Литературные воспоминания» Панаева свидетельствуют о своего рода «неустоявшейся идентичности» их автора. Панаев выступает скорее не в роли биографа, а репортера-карикатуриста, запечатлевающего персонажей в тот момент, когда герои сюжета не знают об этом, не позируют и не следят за своей речью.

Отчасти эта техника напоминает о жанре фельетона: обращаясь преимущественно к курьезным ситуациям, заимствуя стили своих современников (монологи Аксаковых представляют пересказ их журнальных статей), возвращаясь к пародиям и парафразам (Гоголь в роли Хлестакова, общество у Аксаковых в роли чиновников города N), Панаев-повествователь искажает «сохранившиеся в памяти» события. Из-за этого стирается литературная роль самого Панаева: человек, пожимающий руки А. Дельвига, Н. Кукольника, К. Аксакова, В. Белинского, оказывается, в некотором смысле, лишен собственного лица. Иными словами, наделяя «правом на биографию» практически всех героев воспоминаний, Панаев редуцирует свое личностное переживание и участие в литературе. Своеобразное доведение до абсурда этой линии мы находим в «Литературных воспоминаниях» Н.В. Успенского: Успенский обвиняет Н.А. Некрасова в недобросовестности (беллетрист получил гооо руб., а должен был - по собственным расчетам - получить 6ооо), рассказывает о том, как он - писатель-разночинец - чуть было не стал помещиком, купив землю у И.С. Тургенева, тиражирует бытовавший в литературных кругах анекдот о том, что Ф.М. Достоевский был высечен в Омском остроге. Разумеется, во всех случаях интенция Успенского очевидна: скандализировать знаковые имена литературного процесса (как некогда Жуковский и Антонович), в то же время показав свою роль в этой истории.

Противоположность такому типу описания составляют воспоминания И.С. Тургенева. Тургенев создал свои «Литературные и житейские воспоминания» в I869 г. - к этому времени не только сформировалась его репутация образцового стилиста русской литературы, но и неоднократно высказывалась мысль о гибели таланта писателя [г; г2; г6]. «Нигилистические издания» записали его в круг тенденциозных беллетристов, поставив в один ряд с Авдеевым и Хвощинской. Воспоминания Тургенева - своеобразная рефлексия о собственном месте в литературной истории, подкрепленная умело сгруппированными портретами и сценами. 
Заметим, что в сильную позицию - в начало текста - поставлена история его вхождения в литературу.

Около пасхи I843 года в Петербурге произошло событие и само по себе крайне незначительное и давным-давно поглощенное всеобщим забвением. А именно: появилась небольшая поэма некоего Т.Л., под названием «Параша». Этот Т.Л. был я; этою поэмой я вступил на литературное поприще. C тех пор прошло почти двадцать пять лет, и вот по поводу нового издания моих сочинений мне захотелось побеседовать с читателем и передать ему хотя частицу тех воспоминаний, которые накопились у меня в течение четверти века... ${ }^{17}$

Думается, не будет преувеличением утверждение о том, что в технике изображения литературных портретов Тургенев учитывал уроки «Portraits contemporains» Ш. Сент-Бёва. Рассказывая о себе в литературе, Тургенев дает стилистически точные зарисовки литературного мира.

Grande aevi spatium! Не обещаю читателю ничего очень нового, ничего «пикантного»; предуведомляю его также, что многое должно будет остаться невысказанным или недосказанным. <...> Потому я решаюсь ограничиться несколькими отрывками, несколькими отдельными главами из моих воспоминаний; внутреннее единство, я надеюсь, скажется в них; но от наружного единства, от последовательности рассказа отказываюсь заранее. Считаю, однако, нужным сообщить предварительно несколько данных, касающихся лично до меня и определяющих исходную точку моей деятельности ${ }^{\mathrm{I} 8}$.

Тон записок Тургенева полемичен по отношению к воспоминаниям И. Панаева, а образ самого Панаева имеет отчетливо негативные коннотации. Будучи современниками, людьми одной эпохи, и - до конца I850-х гг. - писателями одного круга, Тургенев и Панаев фиксируют сходные события из своей памяти.

I7 Тургенев И.С. Литературные и житейские воспоминания // Тургенев И.С. Собр. соч.: в 30 т. М.: Наука, І983. Т. ІІ. С. 7.

I8 Там же. 
Так, например, оба мемуариста передают встречу с Пушкиным кумиром их поколения, - используя технику «беглого взгляда». Если у Панаева встреча с Пушкиным завершается циничным анекдотом, в котором Сваррацкий, «лицо без биографии», приравнивается к Пушкину из-за совпадения дат смерти, то Тургенев, говоря о Пушкине, не нарушает дистанции, обращаясь к лирической интонации шестой главы «Евгения Онегина» ${ }^{19}$ (вспомним совет Тургенева Анненкову закончить биографию Пушкина словами Жуковского).

Бедный Сваррацкий! упоминая об нем, я не могу удержаться, чтобы не рассказать о последних минутах его жизни. Он получил Анну на шею и вслед затем взял отпуск, чтобы блеснуть этим знаком отличия на родине, но простудился и слег в постелю. Доктор департамента Спасский, лечивший его, заехал к нему от раненого и умиравшего Пушкина. Сваррацкому было плохо. Он приподнялся на постели, схватил руку доктора и произнес, бросая грустный взгляд на Анну, лежавшую на столике у его постели:

- Скажите мне, есть ли какая-нибудь надежда, доктор? Могу ли я выздороветь?

- Никакой, - отвечал Спасский, - да что ж такое? все мы умрем, батюшка. Вон и Пушкин умирает... Слышите ли, Пушкин?! Так уж нам с вами можно умереть.

Сваррацкий со стоном опустил голову на подушку и умер в один день и почти в один час с Пушкиным. Спасский по этому случаю заметил:

- Вишь, счастливец! Умереть в один час с таким человеком, как Пушкин. Это не всякому удастся ${ }^{20}$.
Несколько дней спустя я видел его лежавшим в гробу - и невольно повторял про себя:

Недвижим он лежал... И странен

Был томный мир его чела....

Но возвращаюсь к рассказу

I9 Здесь уместно вспомнить совет И.С. Тургенева в письме Анненкову: «Я понимаю, как Вам должно быть тяжело так дописывать биографию Пушкина - но что же делать? Истинная биография исторического человека у нас еще не скоро возможна, не говоря уже с точки зрения цензуры, но даже с точки зрения так называемых приличий. Я бы на Вашем месте кончил eе ex abrupto - поместил бы, пожалуй, рассказ Жуковского о смерти Пушкина, и только. Лучше отбить статуе ноги, чем сделать крошечные не по росту. А сколько я мог судить, торс у Вас выйдет отличный» (Тургенев И.С. Письма // Тургенев И.С. Собр. соч. и писем: в 30 т. М.: Наука, 1983. Т. 25. С. 7).

20 Панаев И.И. Литературные воспоминания. С. 50.

2I Тургенев И.С. Литературные и житейские воспоминания. С. І2. 
Следует отметить, что в создаваемой Тургеневым галерее литературных портретов упоминание о Панаеве имеет отчетливо негативные коннотации.

В последних числах февраля месяца следующего I852 года я находился на одном утреннем заседании вскоре потом погибшего общества посещения бедных - в зале Дворянского собрания - и вдруг заметил И.И. Панаева, который с судорожной поспешностью перебегал от одного лица к другому, очевидно, сообщая каждому из них неожиданное и невеселое известие, ибо у каждого лицо тотчас выражало удивление и печаль. Панаев, наконец, подбежал и ко мне - и с легкой улыбочкой, равнодушным тоном промолвив: «А ты знаешь, Гоголь помер в Москве. Как же, как же... Все бумаги сжег - да помер», - помчался далее. Нет никакого сомнения, что как литератор Панаев внутренне скорбел о подобной утрате - притом же и сердце он имел доброе, - но удовольствие быть первым человеком, сообщающим другому огорашивающую новость (равнодушный тон употреблялся для большего форсу), - это удовольствие, эта радость заглушали в нем всякое другое чувство 22 .

Нет возможности верифицировать этот факт ${ }^{23}$, однако в самом способе сообщения прочитывается хорошо просчитанный ход: анекдот о Сваррацком и Пушкине, сочиненный Панаевым, проецируется на Панаева и Гоголя. За счет этого «Литературные и житейские воспоминания» приобретают ярко выраженный полемический оттенок.

Начиная свой рассказ о себе, Тургенев сочетает план личного повествования и условной исторической хроники. Именно Т.Л. публикует «Парашу», именно он избирает кумиров пушкинской эпохи, именно он становится автором статьи о Гоголе. Каждый жест автора «Воспоминаний» не случаен, поскольку утверждает его в литературе. Как Сент-Бев, создающий историю через критику, Тургенев включил повествование о личностях, имеющих биографию, в то же время не забывая о своем праве ее иметь.

22 Тургенев И.С. Литературные и житейские воспоминания. С. 62-63.

23 Ср. с воспоминаниями А.Г. Достоевской о «предупредительности» Д.В. Григоровича во время агонии и смерти Достоевского. 
Противоположность «редуцирующим» воспоминаниям И. Панаева и «центрирующим» мемуарам И.С. Тургенева составляют очерки П.В. Анненкова. Литературные воспоминания критика и публициста складывались как сумма статей, опубликованных в разное время. Среди них наиболее ярким является «Замечательное десятилетие...» (г88о), составляющее «летопись духовной жизни эпохи по охвату фактов, событий и лиц, по освещению множества проблем и вопросов, занимавших литературные “партии” сороковых годов» [9].

Центральным героем воспоминаний Анненкова становится Белинский, однако эта фигура рассматривается на фоне исканий целого поколения. В центре внимания биографа - интеллектуальный переворот в сознании В.Г. Белинского, олицетворяющего собой «замечательное десятилетие» эпохи. Не случайно фигура Белинского дана на фоне его современников оппонентов-славянофилов (С.Т. Аксаков и К.С. Аксаков), политических деятелей (Маркс, Прудон), писателей-эмигрантов (А.И. Герцен, М. Бакунин). Современник и собеседник Гоголя, Анненков умело переключает план от «личного» повествования к «безличному»; условно находясь в определенной временной эпохе, он тем не менее находит точку «вненаходимости» прошлое, в котором история литературы неразрывно сплелась с историей идей. В таком способе описания можно увидеть индуктивный опыт - через частное выразить общее.

Особое внимание биограф останавливает на письме Белинского к Гоголю, говоря о последнем годе жизни критика.

Белинский явился мне в эти дни долгих бесед и каждочасного обмена мыслей совершенно в новом свете. Страстная его натура, как ни была уже надорвана мучительным недугом, еще далеко не походила на потухший вулкан. Огонь все тлился у Белинского под корой наружного спокойствия и пробегал иногда по всему организму его. Правда, Белинский начинал уже бояться самого себя, бояться тех еще не порабощенных сил, которые в нем жили и могли при случае, вырвавшись наружу, уничтожить зараз все плоды прилежного лечения. Он принимал меры против своей впечатлительности. Сколько раз случалось мне видеть, как Белинский, молча и с болезненным выражением на лице, опрокидывался на спинку дивана или кресла, когда полученное им ощущение сильно въедалось в его душу, а он считал нужным оторваться или 
освободиться от него. Минуты эти походили на особый вид душевного страдания, присоединенного к физическому, и не скоро проходили: мучительное выражение довольно долго не покидало его лица после них ${ }^{24}$.

Так, говоря о литературном мире, Анненков практически не упоминает об особенностях быта. Более того, в интеллектуальном напряжении эпохи жизнь критика приобретает не меньшую, а, вероятно, большую ценность, чем жизнь писателя.

Подводя итог, отметим: биографические нарративы о писателях конструируют не только образ исторического прошлого, но и образ литературы. Особую роль в «пограничных жанрах», существующих между журналистикой и беллетристикой, играет отбор фигур. Часто в самом этом отборе (выбор публициста или мемуариста, о чем писать и о чем умолчать) заключены мощные ресурсы для характеристики автора произведения. Так появляются модели литературного быта как авантюры (Булгарин, Панаев, Антонович, Успенский), литературного быта как бытия (Тургенев, Григорьев, Григорович) и литературы как памяти (Анненков). Быть свидетелями жизни и восхождения классиков для авторов этих текстов зачастую синонимично быть в литературе.

Приведенные примеры показывают, что литературные воспоминания направлены не только и не столько на реконструкцию литературного быта, но и на выстраивание некоторой иерархии, или системы имен [7; 8]. Иными словами, не являясь частью литературного канона, эти тексты сыграли свою роль в его формировании, в оформлении той «легенды о литературе, которую она творит о самой себе» [Іо].

В целом же биография писателя - открытая структура, заполняемая историческими, личностными, фикциональными и прочими нарративами. Их производство и воспроизводство становится одной из дискурсивных практик по созданию и воссозданию мифа о культуре, сохранению фигур и их репутаций в культурном сознании. 


\section{Список литературы}

I Батюто А.И. Тургенев - романист. Л.: Наука, I972. 390 с.

2 Бахтин М.M. Вопросы литературы и эстетики. М.: Худож. лит., I975. 504 с.

3 Гинзбург Л.Я. О психологической прозе. О литературном герое. М.: Азбука-Атикус, 2016. 704 с.

4 Дячук Т.В. Концепт «писатель» в литературных воспоминаниях второй половины XIX - начала XX веков: дис. ... канд. филол. наук. СПб., 2005. 208 с.

5 Зенкин С. Теория литературы. Проблемы и результаты. М.: Новое литературное обозрение, 2018. 368 с.

6 Калугин Д. Проза жизни: русские биографии XVIII-XIX вв. СПб.: Изд-во Европейского ун-та в Санкт-Петербурге, 2015. 264 c.

7 Киселева Л.Н. Проблема включения второстепенных писателей в литературный канон (на примере А.А. Шаховского) // Известия Российской академии наук. Серия литературы и языка. 20I9. № I. С. 27-33.

8 Козлов А.Е. Литературоведение. Биография писателя. М.: Юрайт, 2ОI9. I22 c.

9 Кулешов В.И. П.В. Анненков - мемуарист // Анненков П.В. Литературные воспоминания. М.: Правда, І989. С. 6-37.

Лотман Ю.М. Литературная биография в историко-культурном контексте (К типологическому соотношению текста и личности автора) // Лотман Ю.М. О русской литературе. Статьи и исследования: история русской прозы, теория литературы. СПб.: Искусство, 2002. С. 804-8I7. Макеев М. Николай Некрасов: Поэт и предприниматель: (Очерки о взаимодействии литературы и экономики). М.: МАКС Пресс, 2009. 236 с.

I2 Маркович В.М. Человек в романах И.С. Тургенева. Л.: Изд-во ЛГУ, І975. I54 с.

I3 Местергази Е.Г. Теоретические аспекты изучения биографии писателя (В.С. Печерин). М.: Флинта Наука, 2007. г6о с.

I Рейтблат А.И. Писать поперек: Статьи по биографике, социологии и истории литературы. М.: Новое литературное обозрение, 20I4. 400 с.

I5 Томашевский Б.В. Литература и биография // Книга и революция. I923. № 4 (28). C. 6-24.

I6 Фомина Е. Национальная характерология в прозе И.С. Тургенева: дис. ... д-ра филос. наук. Тарту, 20I4. I49 с.

I7 White H. The Content of the Form: Narrative, Discourse and Historical Representation. UP, I987. $264 \mathrm{p}$. 


\section{References}

Batiuto A.I. Turgenev - Romanist [Turgenev as a novelist]. Leningrad, Nauka Publ., I972. 390 p. (In Russ.)

Bakhtin M.M. Formy vremeni i khronotopa $v$ romane. Ocherki po istoricheskoi poetike [Forms of time and chronotope in the novel. Essays on historical poetics]. Moscow, Khudozhestvennaia literatura Publ., I975. 504 p. (In Russ.)

Ginzburg L. O psikhologicheskoi proze. O literaturnom geroe [On psychological prose. On the literary character]. Moscow, Azbuka-Atikus Publ., 20I6. 704 p. (In Russ.)

Diachuk T.V. Kontsept "pisatel”" v literaturnykh vospominaniiakh vtoroi poloviny $X I X$ - nachala XX vekov [The concept of the "writer" in the literary memoirs of the $2^{\text {nd }}$ half of the $\mathrm{I}^{\text {th }}-$ early $2 \mathrm{O}^{\text {th }}$ centuries: $\mathrm{PhD}$ dissertation]. St. Petersburg, 2005. 208 p. (In Russ.)

Zenkin S. Teoriia literatury. Problemy i rezul'taty [Theory of literature. Problems and outcomes]. Moscow, Novoe literaturnoe obozrenie Publ., 20I8. 368 p. (In Russ.)

Kalugin D. Proza zhizni: russkie biografii XVIII-XIX vv [The prose of life: Russian biographies of the $18^{\text {th }}-19^{\text {th }}$ centuries]. St. Petersburg, Izdatel'stvo Evropeiskogo universiteta v Sankt-Peterburge Publ., 20I5. 264 p. (In Russ.)

Kiseleva L.N. Problema vkliucheniia vtorostepennykh pisatelei v literaturnyi kanon (na primere A.A. Shakhovskogo) [On the intricacies of including secondary writers in the literary canon (the case of A. Shakhovskoy)]. Izvestiia Rossiiskoi akademii nauk. Seriia literatury i iazyka, 20I9, no I, pp. 27-33. (In Russ.)

Kozlov A.E. Literaturovedenie. Biografiia pisatelia [Literary Studies. Auhor's biography]. Moscow, Iurait Publ., 2019. I22 p. (In Russian)

Kuleshov V.I. P.V. Annenkov - memuarist [Annenkov as a memoirist]. In: Annenkov P.V. Literaturnye vospominaniia [Memoirs of Annenkov]. Moscow, Pravda Publ., I989, pp. 6-37. (In Russ.)

Lotman Ju.M. O russkoi literature. Stat'i i issledovaniia: istoriia russkoi prozy, teoriia literatury [About Russian Literature. Articles and research: history of Russian prose, theory of literature]. St. Petersburg, Iskusstvo Publ., I997, pp. 804-8I7. (In Russ.)

i ekonomiki) [Poet and businesman: Essays on the interaction of literature and economics)]. Moscow, MAKS Press Publ., 2009. 236 p. (In Russ.)

I2 Markovich V. M. Chelovek v romanakh I. S. Turgeneva [Human in the novels of I. S. Turgenev]. Leningrad, Izdatel'stvo Leningradskogo gosudarstvennogo universiteta Publ., I975. I54 p. (In Russ.)

Mestergazi E.G. Teoreticheskie aspekty izucheniia biografii pisatelia (V.S. Pecherin) [Theoretical aspects of studying author's biography (V.S. Pecheorin)]. Moscow, Flinta Nauka Publ., 2007. I6o p. (In Russian) 
I4 Reitblat A.I. Pisat' poperek: Stat'i po biografike, sotsiologii i istorii literatury [Writing across: Articles about biography, sociology, and the history of literature]. Moscow, Novoe literaturnoe obozrenie Publ., 20I4. 400 p. (In Russ.)

I5 Tomashevsky B.V. Literatura i biografiia [Literature and biography]. In: Kniga $i$ revoliutsiia [Book and revolution], I923, no 4 (28), pp 6-24. (In Russ.)

I6 Fomina E. Natsional'naia kharakterologiia v proze I.S. Turgeneva [National characterology in the Prose of I.S. Turgenev: PhD dissertation]. Tartu, 20I4. I49 p. (In Russ.)

I7 White H. The Content of the Form: Narrative, Discourse and Historical Representation. Baltimore: Johns Hopkins UP, I987. 264 p. (In English) 
УДК $82-2$

ББК $83+83 \cdot 3(4$ Ита)

\section{ГОЛЬДОНИ В ПЕРЕВОДЕ СЕМЕЙСТВА АМФИТЕАТРОВЫХ}

(C) 2020 г. М.Л. Андреев

Институт мировой литературы

им. А.М. Горького Российской академии наук;

Школа актуальных гуманитарных исследований

РАНХиГС, Москва; НИУ Высшая школа экономи-

ки, Москва, Россия

Дата поступления статьи: І9 февраля 2020 г. Дата публикации: 25 июня 2020 г.

DOI: IO.22455/2500-4247-2020-5-2-56-67

Аннотация: В пьесах Гольдони, переведенных на русский язык супругами Амфитеатровыми и составивших первое его собрание в России, демонстрируются два подхода к переводам. В пьесах, не утративших репертуарный потенциал, переводчики отходят от оригинала достаточно далеко, позволяя себе десятками опускать фразы, группы фраз и целые реплики.

В переводе «Комического театра», инсценированного драматического манифеста Гольдони, педантически следуют за оригиналом, не только не допуская никаких пропусков, но и придерживаясь лексического и синтаксического буквализма. Программа переводческой вольности и программа переводческой точности, как правило, выступают в истории перевода в качестве альтернативных. В сборнике Гольдони они даны как два равновозможных способа передачи иноязычного текста, что представляется явлением редким, если не уникальным.

Ключевые слова: Карло Гольдони, А.В. Амфитеатров, И.В. Амфитеатрова, перевод вольный, перевод точный.

Информация об авторе: Михаил Леонидович Андреев - член-корреспондент РАН, доктор филологических наук, главный научный сотрудник, Институт мировой литературы им. А.М. Горького Российской академии наук, ул. Поварская, д. 25 а, І2І069 г. Москва, Россия; ведущий научный сотрудник, Школа актуальных гуманитарных исследований РАНХиГС, пр. Вернадского, д. 82, II957I г. Москва, Россия; ведущий научный сотрудник, Институт гуманитарных историкотеоретических исследований НИУ Высшая школа экономики, ул. Старая Басманная, д. 2I/4, I05066 г. Москва, Россия. ORCID ID: о0оо-о0о2-5I70-7634

E-mail: mikhailandreevi@gmail.com

Для цитирования: Андреев М.Л. Гольдони в переводе семейства Амфитеатровых // Studia Litterarum. 2020. T. 5, № 2. С. 56-67. DOI: 10.22455/2500-4247-2020-5-2-56-67 


\section{GOLDONI IN THE TRANSLATION OF AMFITEATROV'S FAMILY}

This is an open access article distributed under the Creative Commons Attribution 4.0 International (CC BY 4.0)
(C) 202O. M.L. Andreev

A.M. Gorky Institute of World Literature

of the Russian Academy of Sciences, Moscow, Russia;

School of the Advanced Studies in the Humanities, Presidential Academy of National Economy and Public Administration, Moscow, Russia;

National Research University Higher School of

Economics, Moscow, Russia

Received: February 19, 2020

Date of publication: June 25, 2020

Abstract: Translations of Goldoni's plays into Russian by A.V. and A.I. Amfiteatrov, a married couple who compiled Goldoni's first collection in Russia, illustrate two basic approaches to translating fiction. In the plays that have not lost their repertoire potential, the translators depart from the original far enough, omitting dozens of phrases and whole replicas. The translation of The Comic Theater, a staged dramatic manifesto of Goldoni, pedantically follows the original, not only not allowing any omissions but also adhering to lexical and syntactical literalism. As a rule, free translation and accurate translation alternate as two models or templates in the history of translation. In the mentioned Goldoni's collection, two alternative translations present themselves as two equal modes of transmitting a text into the foreign language which seems to be a rare, if not a unique phenomenon.

Keywords: Carlo Goldoni, A.V. Amfiteatrov, I.V. Amfiteatrova, free translation, accurate translation.

Information about the author: Mikhail L. Andreev, Corresponding Member of RAS, DSc in Philology, Corresponding Member of RAS, Director of Research, A.M. Gorky Institute of World Literature of the Russian Academy of Sciences, Povarskaya 25 a, I21069 Moscow, Russia; Leading Resercher, School of the Advanced Studies in the Humanities, Presidential Academy of National Economy and Public Administration, prospekt Vernadskogo 82, II957I Moscow, Russia; Leading Researcher, Poletayev Institute for Theoretical and Historical Studies in the Humanities, National Research University Higher School of Economics, Staraia Basmannaya 2I/4, L, I05066 Moscow, Russia. ORCID ID: 0000-0002-5170-7634

E-mail: mikhailandreevi@gmail.com

For citation: Andreev M.L. Goldoni in the Translation of Amfiteatrov's Family.

Studia Litterarum, 2020, vol. 5, no 2, pp. 56-67. (In Russ.)

DOI: Io.22455/2500-4247-2020-5-2-56-67 
Первое собрание сочинений Гольдони в России вышло в 1922 г. Это двухтомник, включающий переводы пяти пьес с примечаниями и большой, в сто страниц «критико-биографический очерк» о Гольдони. «Комический театр» (Il Teatro comico), «Бабьи сплетни» (I Pettegolezzi delle donne), «Любопытные» (Le Donne curiose), «Семья антиквария» (La Famiglia dell'antiquario) на русский язык ранее не переводились, «Лгун» (Il Bugiardo) дважды переводился в XVIII в. (под названием «Лжец»). Издание вышло под редакцией А.Л. Волынского, автор статьи - А.В. Амфитеатров, переводы подписаны двумя фамилиями - А.В. и И.В. Амфитеатровых.

Александр Валентинович Амфитеатров - известный и популярный в свое время романист, драматург, журналист, литературный, театральный и музыкальный критик. Иллария Владимировна Амфитеатрова - его вторая жена, актриса и оперная певица (выступала под псевдонимом Райская). Как осуществлялась их совместная работа над переводами, установить пока не удалось. Новейшая энциклопедия «Русское присутствие в Италии в первой половине XX века» сообщает, что Амфитеатрова перевела на русский язык «сама или с помощью мужа почти все произведения Карло Гольдони» [6, с. 5I], но это представляется весьма сомнительным: никакие ее переводы, кроме тех, что опубликованы в двухтомнике, неизвестны, нет о них сведений в том числе и в архиве MXT (с Художественным театром, как сообщает то же издание, Амфитеатрова была тесно связана). «Почти все произведения Гольдони», если даже ограничиться его любимым жанром, это больше ста комедий. Вряд ли такое возможно и вряд ли такая титаническая работа могла не оставить никаких следов. 
Необходимым для перевода инструментарием обладали оба. Оба вращались в театральной среде, оба владели пером, оба знали итальянский язык. А.В. Амфитеатров в г88о-х гг. учился в Милане пению, в І890-х был итальянским корреспондентом «Нового времени», в I904 г. эмигрировал и также жил в основном в Италии. Вернулся в Россию только в г9І6 г. И.В. Амфитеатрова сопровождала мужа и во время первой эмиграции, и во время второй, послереволюционной, в ту же Италию, с г922 г. до конца жизни. Вскоре после отъезда из России она опубликовала по-итальянски свою книгу «В когтях Советов». Не удивительно, что в их переводах почти нет смысловых ошибок (у А.Н. Островского, к примеру, в его переводе «Кофейной» Гольдони несколько десятков случаев прямого непонимания оригинала), те же, которые все-таки встречаются, можно объяснить почти неизбежным у любого переводчика lapsus oculi: скажем, в переводе «Комического театра» pulizia (чистота) спутана с polizia (полиция), и призыв к соблюдению правил гигиенического приличия превратился в апелляцию к силам правопорядка.

Весьма квалифицированно написана и статья, открывающая издание, при том, что А.В. Амфитеатров не был профессиональным историком литературы, - это по сути первое развернутое исследование творчества Гольдони в России, и оно находится вполне на уровне литературоведческой оснащенности того времени. Некоторые вопросы вызывает отбор пьес для перевода. Конечно, Гольдони сто лет назад еще не приобрел репутацию бесспорного классика, в особенности за пределами Италии ${ }^{1}$, и гольдониевский канон в то время несколько отличался от современного (в частности, в него не входила так называемая «дачная трилогия»), но все же и тогда не вызывало сомнений, что наибольшая плотность шедевров приходится на конец I750 - начало І76о гг. (и они на русский язык не были переведены). В «Избранные сочинения» включены только комедии периода театра Сант-Анджело (т. е. до I753 г.), ни одна из отобранных составителями пьес никогда в канон не входила.

Понятен выбор «Комического театра» - это выведенный на сцену драматургический манифест, с изложением основных принципов прово-

I $\quad$ И А.В. Амфитеатров это отмечает: «Ее недавно Гольдони <...> был понятен и интересен только специалистам. Но наша современность, вновь заинтересованная Италией <...>, опять изучает ее... Гольдони в числе таких открытий» [5, с. 1о6-Іо7]. 
димой Гольдони реформы. Менее понятен выбор других пьес: хотя провальных среди них нет, но для Гольдони это в целом средний уровень, приличный, но средний. В статье А.В. Амфитеатрова совершенно справедливо отмечено, что «комедии Гольдони, помимо своих чисто литературных достоинств, являются еще и неисчерпаемым источником для истории быта» [5, с. II]. Однако и в этом отношении данные четыре пьесы ничем не выделяются (кроме, может быть, «Бабьих сплетен»), у Гольдони есть произведения, куда более яркие в плане изображения быта. Некоторым объединяющим фактором можно считать не слишком лестную роль, отведенную здесь слабому полу: в «Семействе антиквария» разлад в семью вносит жена антиквара-любителя, помешанная на своей родовитости и третирующая невестку, взятую из купечества; в «Бабьих сплетнях» компания кумушек чуть не разрушает помолвку героини из-за своей страсти молоть попусту языком; в «Любопытных» женщины измучены желанием узнать, чем занимаются их мужья и женихи, собираясь в мужской компании, и одна из них, нареченная невеста, готова разорвать со своим женихом, если ее любопытство не найдет удовлетворения. «Лгун» из данного ряда выпадает, к тому же это одна из немногих гольдониевских пьес, построенная на рецепции и переработке иноязычного источника, одноименной комедии Корнеля (у которого в свою очередь имелся такой же источник - «Сомнительная правда» Аларкона). Не случайно в последующих собраниях сочинений (их было в советское время еще три) из отобранных Амфитеатровым комедий воспроизводилась только одна, «Семья антиквария». А.Н. Островский выбрал «Кофейную» из тех пьес, что содержались в единственном сборнике Гольдони, находившемся в его библиотеке [3, c. I4, 72]. Но у А.В. Амфитеатрова, почти постоянно жившего в Италии, таких ограничений быть не могло (или могло? Все-таки после революции он пять лет безвыездно прожил в России).

Перевод «Комического театра» на фоне других вошедших в двухтомник переводов заметно выделяется: может быть, это говорит о перемене ролей у переводчиков, а может быть, о смене переводческой стратегии. Попробуем это показать, сравнив «Комический театр» с «Лгуном». Вместо «Лгуна» можно было бы взять любую иную комедию, но эти две естественным образом друг к другу притягиваются: «Комический театр» открывает так называемый «сезон шестнадцати комедий» (I750-I75I), «Лгун» в этот 
сезон входит (входят и «Бабьи сплетни», но «Лгун стоит по хронологии ближе, всего через две пьесы).

«Комический театр» переведен точно, «Лгун» - с многочисленными лакунами. В «Комическом театре» пропущена одна реплика (и, видимо, опять же по недосмотру), в «Лгуне» в первом действии есть четырнадцать мест с пропуском целых реплик, во втором - сорок семь, в третьем - двадцать два. Опущенная реплика может быть одна, но чаще всего выбрасывается несколько, вплоть до семи. В третьем акте исчезла даже целая сцена. Изымаются и отдельные фразы из реплик, и группы фраз. Вот примеры пропуска реплик (пропущенные выделены курсивом).

Пропуск одной реплики $(1,6)$ :

БРИГЕЛЛА. Вот оно как: всю ночь занимаемся серенадой, а чуть развиднеется - опять вон из дома. По всему видать, любовь лишает вас сна.

ФЛОРИНДО. Я не мог заснуть от радости, что так удалась моя серенада.

Пропуск 2 реплик $(1,9)$ :

ЛЕЛИО. А где вы живете?

ОТТАВИО. Вот в этой гостинице.

ЛЕЛИО. (Черт возъми!). Я живу в этой же гостинице, но ни вчера, ни прошлой ночью вас тут не видел.

ОТТАВИО. Я обедал в другом месте, а потом играл всю ночь.

ЛЕЛИО. Столько времени вы тут живете и не знаете этих двух синьор?

Пропуск трех реплик $(1,6)$ :

ФЛОРИНДО. Сегодня первый день ярмарки, мне хотелось бы, чтобы кружева были у нее уже до обеда.

БРИГЕЛЛА. Но как вам удалось скопить эти десять изехинов?

ФЛОРИНДО. Из содержания, что мне каждый месяи, посылает из Болоньи мой отец, и из тех гонорариев, что мне достаются, когда я хожу к больным, заменяя моего наставника.

БРИГЕЛЛА. Собираете по крохам, и все бросаете в один миг.

Флориндо. Ступай, Бригелла. 
Пропуск четырех реплик $(2,9)$ :

ДОКТОР. Кто же этот лгун?

ОТТАВИО. Лелио Бизоньози.

ДОКТОР. Сын синьора Панталоне?

ОТТАВИО. Он самый.

ДОКТОР. Он в Венещии?

ОТТАВИО. Вчера приехал, к моему несчастью.

ДОКТОР. И где он? В доме своего отиа?

ОТТАВИО. Полагаю, что нет. Это юноша развязный, любить жить на свободе.

ДОКТОР. Но как же он, негодяй эдакий, мог наболтать такие вещи?

Пропуск шести реплик (2, I2):

ЛЕЛИО. Меня заставили жениться, а в наказание присудили мне двадцать тысяч скуди приданого...

ПАНТАЛОНЕ. Сын мой, ты ужасно рисковал, но раз все так хорошо закончилось, возблагодари небо и в будущем веди себя более благоразумно. Пистолеты, пистолеты! Откуда взялись эти пистолеты? Здесь такого не водится.

ЛЕЛИО. Впредь больше никогда не буду брать с собой огнестрельного оружия.

ПАНТАЛОНЕ. Но почему не сказать об этом браке твоему дяде?

ЛЕЛИО. Когда все это случилось, я тяжело заболел.

ПАНТАЛОНЕ. Почему не написал мне?

ЛЕЛИО. Я хотел все рассказать сам.

ПАНТАЛОНЕ. А почему ты не взял с собой жену в Венецию?

Пропуск семи реплик $(3,5)$ :

ЛЕЛИО (в сторону). Это письмо стоит того проклятого сонета!

ПАНТАЛОНЕ. «Если вы намеревались меня обмануть, знайте, что я сумею прибегнуть к правосудию».

ЛЕЛИО. Какая-то несчастная брошенная женщина.

ПАНТАЛОНЕ. По всему видно, что этот Лелио Бизоньози тот еще негодяй.

ЛЕЛИО. Печально, что он грязнит мое имя. 
ПАНТАЛОНЕ. Вы ведь человек честный...

ЛЕЛИО. И тем горжусь.

ПАНТАЛОНЕ. Посмотрим, что в конце. «Если вы меня не вызовите $\kappa$ себе и не женитесь на мне, я обрашусь к влиятельному лииу с тем, итобы он написал синьору Панталоне, вашему отиу..». Вон оно что. Синьору Панталоне?

\section{ЛЕЛИО. Вот так штука! И имя отца совпадает!}

Ничего необычного в такого рода изъятиях нет, тот же Островский не менее решительно резал Гольдони, выбрасывая все, что противоречило его театральным вкусам и театральным вкусам его времени: реплики в сторону, ламентации, морализацию, сентенциозность. Персонажи «Лгуна» не предаются ламентациям и не вдаются в сентенциозность, и Амфитеатровы убирают из своего перевода излишние, на их взгляд, детали, повторы, разъяснения, отступления и с особенной охотой - отдельные фиоритуры из многоэтажного вранья заглавного героя. В общем, все, что замедляет ход разговора и притормаживает ход действия. (Например, в оригинале: «Ломбардия это также Милан, Бергамо, Брешия, Верона, Мантуя, Модена и множество других городов»; в переводе: «Да ведь в Ломбардии много городов», перечисление городов опущено). Идеологию такого рода переводческой стратегии можно найти в высказывании Амфитеатрова, сделанном, правда, не в связи с переводом, а по поводу его собственных пьес и пьес вообще:

Если бы я чувствовал себя драматургом par excellence, то - либо вовсе не издавал бы своих пьес, ограничиваясь печатанием их в количестве, потребном для специально-театрального, промышленного, так сказать, сбыта, либо, наоборот, печатал бы их сразу в двух редакциях: вот как эта пьеса должна идти на сцене, а вот - прочтите все, что я, автор, хотел в ней сказать, развить, оттенить... В книге вы с удовольствием и с благодарностью к автору читаете лирическую тираду, объясняющую вам тот или другой характер, но на сцене весьма благоразумно выбрасываемую, ибо она «не сценична», «тормозит действие», то есть, попросту говоря, наводит на слушателя тоску. Не думайте, господа, что это бывает только с фальшивыми лирическими местами, с дурными философскими диалогами и т. п. Нет, длинная отвлеченность, которую вы с наслаждением воспринимаете в чтении, всегда скучна, провоз- 
глашаемая со сцены. Обыкновенно, знатоки называют подобное обращение с классиками варварством. Но публика за него благодарна [І, с. I7-I8]2.

Перевод «Лгуна» делался так, как будто предназначался для «специально-театрального сбыта» - и он действительно был сыгран, в ленинградском театре «Народного дома» (журнал «Рабочий и театр» откликнулся на эту постановку статьей с красноречивым названием «“Лгун” рабочему не нужен»). Перевод «Комического театра» делался с тем, чтобы показать все, что автор хотел «сказать, развить, оттенить». Театральных перспектив у него по понятным причинам не было и быть не могло: «Комический театр» на современной сцене вообразить невозможно (надо сказать, что и на венецианской премьере он был представлен лишь дважды и затем возвращался на сцену в исключительных случаях и в целях, надо полагать, мемориальных). Зато читателю, интересующемуся Гольдони и вообще историей театра, эта пьеса Гольдони нужна вся, со всеми мельчайшими оттенками мысли, со всеми подробностями театрального быта.

Отсюда, от двух различных установок, идет различие не только в отношении полноты или неполноты перевода, но и в отношении его стилистики.

Архаизации нет ни в той, ни в другой комедии, но после Гнедича этот стилистический регистр не использовался. Модернизации тоже нет, в «Лгуне» можно встретить «журналиста» и «миллионера», что даже нельзя считать модернизацией. В «Комическом театре» имеется калькирование терминов, что почти неизбежно при установке на точность, хотя удачным этот прием признать трудно: i loro concetti (барочные метафоры) переданы словом «концепции», commedia a soggetto (комедия импровизации) стала «комедией сюжета» (что, конечно, никуда не годится), virtuosa di musica «музыкальной виртуозкой». Есть пример обратного свойства, но, может быть, переводчики просто не опознали термин: lazzi pericolosi (lazzo - caмодостаточный комический трюк в комедии дель арте) переводятся как «непозволительные движения».

2 В статье, предпосланной собранию сочинений, А.В. Амфитеатров ссылается на авторитет самого Гольдони, который «предупреждал своих переводчиков, что не советует им передавать его пьесы слишком близко к оригиналу <...>, а лучше рекомендует приспособлять их к быту и говору своего народа» [5, с. 98]. 
В «Лгуне» переводчики не избегают некоторой поверхностной русификации (барин, извозчик, барышня). «Папенька» и «доченька» (вместо signor padre и mia signora figlia) - это, конечно, не русизмы, но тоже работают на адаптацию текста. В «Комическом театре» есть только «барин» (но это еще вопрос, воспринимался ли «барин» в то время как русификация), а в принципе именно в «Комическом театре» А.В. Амфитеатров против русификации высказался вполне определенно, заявив в примечании, что «в подлиннике “Это бы мне вскочило в копеечку, как и следовало бы перевести, если бы русизм “копеечки” здесь не резал уха» [5, с г54]. Высказывание вполне содержательное, хотя звучит странно: откуда в подлиннике взяться копеечке? (В подлиннике: mi tornerebbe un bel conto, «мне это дорого обошлось бы», Амфитеатровы переводят: «Этак бы вы хорошо сели мне на шею»).

Зато в «Комическом театре» на порядок больше буквализмов; здесь также, надо полагать, дает о себе знать установка на точность. «Остальные дамы еще не удостоили» (queste signore donne non favoriscono), «уносит вонь свою подальше от дома» (porta la puzza lontano da casa), «совершить акт моего долга» (eserciti un atto del mio dovere), «совершить по вашему адресу акт моего уважения» (eserciti seco gli atti del mio rispetto), «держать актеров связанными писанным авторским текстом» (tenere i commedianti legati al premeditato), «теперь труппа совершенно закончена» (ora la compagnia è veramente compiuta), «не развлекайтесь ни глазами, ни мыслью» (non vi distraete cogl'occhi e colla mente), «маски обычно тяготятся говорить написанное» (le maschere ordinariamente patiscono a dire il premeditato), «если серьезные роли выступали с несколько длинным диалогом» (se le parti serie avevano un dialogo un poco lungo), «завязка достаточно изобиловала случайностями и новизной» (l'intreccio sia mediocremente fecondo d'accidenti, e di novità), «мораль была пересыпана шутками» (la morale mescolata coi Sali) и т. п.

Возможно, конечно, что «Лгуна» переводила супруга (а супруг редактировал), тогда как «Комический театр» переводил супруг (а редактировала супруга), или наоборот. Возможно, но маловероятно. Значительно вероятнее, что здесь проявились две переводческие стратегии. «Лгун» переведен так, как испокон века перекладывались на русский язык иностранные произведения (и пьесы особенно), адаптируя их если не к своему языку и нравам, то к знакомым сценическим обыкновениям. Установка на адапта- 
цию заявляет о себе в «Лгуне» относительно скромно, в основном сокращениями, но вполне определенно. За установкой на точность, проявившейся в «Комическом театре», стоит традиция, куда менее прочная: в прозе это только «Декамерон» А.Н. Веселовского (ср.: [2]). Но уже в десятые годы В.Я. Брюсов начинает вырабатывать программу буквализма и практически ее осуществлять - переводами армянских поэтов, «Энеиды» и «Фауста». Затем из этой программы вырастет целая переводческая школа. Амфитеатровых в переводе «Комического театра» можно считать одними из ее первых адептов - это любопытно, но не более. Значительно любопытнее, что памятник точного перевода соседствует в их Гольдони с памятником вольного перевода. Брюсов также пришел от абсолютной вольности к абсолютной точности, но пришел за четверть века, отказавшись от своей начальной программы [4]. Здесь же вольность и точность - не абсолютные, но вполне уверенно обозначенные - представлены как два равновозможных способа передачи иноязычного текста. Примеров такой методологической толерантности, пожалуй, и не сыскать.

\section{Список литературы}

I Амфитеатров А.В. Маски Мельпомены. М.: А.Д. Друтман, І9Іо. 280 с.

2 Андреев М.Л. Два русских «Декамерона» // Шаги / Steps. 20I9. Т. 5, № 3. C. $38-50$.

3 Буданова И.Б., Жилякова Э.М. А.Н. Островский - переводчик итальянских драматургов. Томск: Изд-во Томского ун-та, 2018. 233 с.

4 Гаспаров М.Л. Брюсов - переводчик. Путь к перепутью // Гаспаров М.Л. Избранные труды. М.: Языки русской культуры, І997. Т. 2: О стихах. С. І2І-І29.

5 Гольдони К. Избранные сочинения / под ред. А.Л. Волынского. Пг.: Госиздат, г922. T. I. 322 c.

6 Русское присутствие в Италии в первой половине XX века. Энциклопедия / сост. А. д’Амелия, Д. Рицци. М.: РОССПЭН, 2019. 863 с. 


\section{References}

I Amfiteatrov A.V. Maski Mel'pomeny [Melpomene's masks]. Moscow, A.D. Drutman Publ., I9IO. 280 p. (In Russ.)

2 Andreev M.L. Dva russkikh "Dekamerona” [Two Russian Decamerons]. Shagi / Steps, 2019, vol. 5, no 3, pp. 38-50. (In Russ.)

3 Budanova I.B., Zhiliakova E.M. A.N. Ostrovskii - perevodchik ital'ianskikh dramaturgov [A.N. Ostrovsky - translator of the Italian playwrights]. Tomsk, Izdatel'stvo Tomskogo universiteta Publ., 20I8. 233 p. (In Russ.)

4 Gasparov M.L. Briusov - perevodchik. Put' k pereput'iu [Bryusov as a translator. Towards the crossroads]. In: Gasparov M.L. Izbrannye Trudy [Collected Works]. Moscow, Iazyki russkoi kul'tury Publ., I997, vol. 2: O stikhakh [On the poems], pp. I2I-I29. (In Russ.)

5 Gol'doni K. Izbrannye sochineniia [Selected works], ed. by A.L. Volynsky. Petrograd, Gosizdat Publ., I922. Vol. I. 322 p. (In Russ.)

6 Russkoe prisutstvie v Italii v pervoi polovine XX veka. Entsiklopediia [The Russian presence in Italy in the first half of the $2 \mathrm{O}^{\text {th }}$ century. Encyclopedia], comp. by A. d'Ameliia, D. Ritstsi. Moscow, ROSSPEN Publ., 20I9. 863 p. (In Russ.) 
УДК 82I.I4

ББК 83.3(о)

\section{АГИОГРАФИЧЕСКИЙ НАРРАТИВ И ЕГО ИНТЕРПРЕТАЦИИ \\ (на материале агиографии Иоанна Златоуста)}

\author{
(C) 2020 г. А.С. Балаховская \\ Институт мировой литературы \\ им. А.М. Горького Российской академии наук, \\ Москва, Россия \\ Дата поступления статьи: го июня 2019 г. \\ Дата публикации: 25 июня 2020 г.
}

DOI: I0.22455/2500-4247-2020-5-2-68-87

Аннотация: В статье на материале агиографии епископа константинопольского Иоанна Златоуста рассматривается процесс формирования агиографической версии биографии святого и ее интерпретации в последующей традиции. Житие, будучи литературным произведением, созданным в контексте церковного культа, выражает актуальную церковную идеологию и реагирует на злободневные проблемы церковной жизни. В «Житии» Псевдо-Георгия Александрийского отражена одна из них - противостояние духовной власти императорскому произволу в Византии. Иоанн Златоуст и императрица Евдоксия представлены здесь как символические фигуры, знаменующие это противостояние.

С другой стороны, они соотносятся с библейскими образами пророка Илии и царицы Иезавели, которые становятся их типологическими прообразами. «Житие» Псевдо-Георгия является литературной моделью, которая легла в основу последующей агиографической традиции, в состав которой входят два «Похвальных слова Иоанну Златоусту, созданных Иоанном Дамаскиным и императором Львом VI Мудрым. В этих произведениях содержится интерпретация и дальнейшее развитие темы противостояния духовной и светской властей.

Ключевые слова: Византия, агиография, нарратив, интерпретация, агиографическая традиция, похвальное слово.

Информация об авторе: Александра Сергеевна Балаховская - доктор филологических наук, ведущий научный сотрудник, Институт мировой литературы им. А.М. Горького Российской академии наук, ул. Поварская, д. 25 а, І2Іо69 г. Москва, Россия.

E-mail: a.balakhovskaya@gmail.com

Для цитирования: Балаховская А.С. Агиографический нарратив и его интерпретации (на материале агиографии Иоанна Златоуста) // Studia Litterarum. 2020. T. 5, № 2. C. $68-87$. DOI: I0.22455/2500-4247-2020-5-2-68-87 


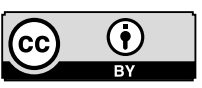

This is an open access article distributed under the Creative Commons Attribution 4.0 International (CC BY 4.0)

\section{HAGIOGRAPHIC NARRATIVE AND ITS INTERPRETATIONS}

(C) 2020. A.S. Balakhovskaya

A.M. Gorky Institute of World Literature

of the Russian Academy of Sciences, Moscow, Russia

Received: June IO, 2019

Date of publication: June 25, 2020

Abstract: The article based on the hagiography of the bishop of Constantinople St. John Chrysostom studies a development process of the hagiographical version of the saint's biography and its interpretation in the hagiographical tradition. The life of the saint, a literary work created in the context of a church cult, expresses the actual church ideology and is the answer to the current problems of the church life. The Life written by Pseudo-George of Alexandria reflects one of them - the intervention of secular authorities in the affairs of the Church in Byzantium. St. John Chrysostom and Empress Eudoxia are represented here as symbolic figures marking this opposition. On the other hand, they are correlated with the biblical images of the prophet Elijah and Queen Jezebel - their typological prototypes. The Life of Pseudo-George is a literary model that formed the basis of the subsequent hagiographical tradition, part of which are two encomiums, written by St. John of Damascus and Emperor Leo VI the Wise. In these works, we find the interpretation and further development of the theme of contradiction between spiritual and secular powers.

Keywords: Byzantium, hagiography, narrative, interpretation, hagiographic tradition, encomium.

Information about the author: Alexandra S. Balakhovskaya, DSc in Philology, Leading Research Fellow, A.M. Gorky Institute of World Literature of the Russian Academy of Sciences, Povarskaya 25 a, I2I069 Moscow, Russia.

E-mail: a.balakhovskaya@gmail.com

For citation: Balakhovskay A.S. Hagiographic Narrative and its Interpretations. Studia Litterarum, 2020, vol. 5, no 2, pp. 68-87. (In Russ.) DOI: Io.22455/2500-4247-2020-5-2-68-87 
Богатая агиографическая традиция епископа константинопольского Иоанна Златоуста (ок. 349-407) [г], истоки которой восходят к первой половине $\mathrm{V}$ в., основана на одной-единственной версии жития святого, появившейся в середине VII в. Что представляла собой эта версия, под влиянием каких факторов она возникла, почему она утвердилась как единственная и какую интерпретацию получила в более поздних агиографических памятниках ответом на этот вопрос является настоящая статья.

Житие, с которого начинается собственно агиографическая традиция Иоанна Златоуста, приписывается Георгию, патриарху Александрийскому (62I-63I) [I4, p. 69-285], но представляет собой псевдоэпиграф. По предположению К. Баура, его автором был неизвестный иеромонах, а местом создания была одна из итальянских провинций [9].

В основе жития, время составления которого колеблется между серединой VII и началом VIII вв., лежит несколько источников. В их числе - «Диалог о житии блаженного Иоанна, епископа константинопольского, Златоуста» епископа Палладия Еленопольского [23], VI книга «Церковной истории» Сократа Схоластика [25], фрагменты из V книги «Церковной истории» Феодорита Кирского [24, vol. 82, col. II97-I277], слова «О священстве» самого Иоанна Златоуста [24, vol. 48, col. 624-625], а также народные легенды об Иоанне Златоусте, которые частично циркулировали в устной форме, а частично были преданы записям, по свидетельству самого составителя «Жития» [14, p. 72] (Псевдо-Георгия, как он именуется в научной литературе).

Несмотря на то что «Житие» Псевдо-Георгия представляет собой не оригинальный авторский текст, а компиляцию различных источников, можно говорить о целостности этого произведения, поскольку агиограф 
искусно согласовывает заимствуемые им фрагменты и выстраивает из них единый сюжет.

История жизни и деятельности Иоанна Златоуста хорошо известна. Ее стержнем является противостояние епископа и его оппонентов, в итоге которого он потерпел поражение, был осужден, сослан и скончался в ссылке. В первой половине V в. существовали три основные версии этого противостояния: Палладия Еленопольского, Псевдо-Мартирия Антиохийского [2I] и Сократа Схоластика.

Палладий Еленопольский - автор апологетического произведения, в котором опровергаются обвинения, выдвинутые против Иоанна Златоуста, и создается его образ как идеального пастыря. Палладий видит корень конфликта епископа с его оппонентами в недовольстве клира и мирян, не следовавших во всей строгости нормам христианской жизни ${ }^{\mathrm{I}}$, церковными преобразованиями, начатыми в столице Иоанном Златоустом. Вражда против епископа, возникшая в среде тех, кто был недоволен его церковной политикой, и привела к созыву собора, который его осудил. Таким образом, основной пафос произведения Палладия Еленопольского - противостояние подлинного христианства, которое проповедовал Иоанн Златоуст, и христианства формального, олицетворением которого, по мнению Палладия, были некоторые епископы и часть высокопоставленных мирян.

Сократ Схоластик, который весьма сдержанно относился к константинопольскому предстоятелю², считал, что причина враждебного отношения к Иоанну Златоусту кроется в его нетерпимости, ригоризме, отсутствии гибкости, благодаря чему он и восстановил против себя клир и власть имущих, что способствовало его низложению и ссылке.

Псевдо-Мартирий Антиохийский, неизвестный константинопольский пресвитер и сторонник Иоанна Златоуста [22], предложил иную трактовку противоборства Иоанна Златоуста и его врагов. Он выдвинул на первый план социальное служение епископа, его заботу об обездоленных: нищих и прокаженных. Одну из основных причин его низложения он видит

I B «Диалоге» Палладия Еленопольского нашла отражение церковная ситуация начала константиновской эпохи, когда после окончания гонений к Церкви обратились вчерашние язычники, не имея внутренней решимости отказаться от прежней жизни, что сказалось на общем уровне христианской нравственности.

2 Причиной сдержанного отношения Сократа к Иоанну Златоусту являются, по мнению М. Варллаффа, новатианские симпатии историка [26, р. 369]. 
во вражде к Златоусту богатых землевладельцев, которые, боясь соседства с прокаженными, воспротивились строительству больницы, предпринятому Иоанном на земельном участке, примыкавшем к их владениям, и сделались активными участниками созыва собора, на котором он был низложен.

Подобное разнообразие версий, существовавшее в первой половине V в., к середине VII в. было унифицировано и сведено к одной-единственной версии, которая представлена в «Житии» Псевдо-Георгия Александрийского. Она сводится к тому, что святой епископ, защитник обездоленных и обиженных, не боялся открыто говорить правду власть предержащим и вступил в противостояние со сребролюбивой и жестокой императрицей, не переносящей его обличений и стремящейся его погубить. Впоследствии эта версия варьировалась во всех житиях константинопольского предстоятеля и вплоть до нашего времени продолжает влиять на трактовку как истории Иоанна Златоуста, так и его образа. В чем же заключается причина ее возникновения и столь большой ее популярности?

Агиография - это литература культа. По словам В.М. Лурье, она существует только там, где есть культ, и говорит о святом на символическом языке культа [5, с. 52]. Сам же агиограф как автор позиционирует себя в качестве участника формирования и функционирования культа святого [I7, p. 63-93].

Церковный культ Иоанна Златоуста складывался постепенно. Официальное признание его как церковного авторитета произошло на IV вселенском соборе в Халкидоне в 45I г. С этого времени популярность Иоанна Златоуста продолжала возрастать, и значимость его творений стала постепенно выходить на первый план. VI-IX вв. были ознаменованы окончательным утверждением неоспоримого авторитета Златоуста в вопросах вероучения. К нему апеллировали все православные полемисты от Максима Исповедника до Никифора, патриарха константинопольского. В конце X - начале XI вв. авторитет Златоуста как учителя Церкви утвердился окончательно, был установлен день празднования памяти трех вселенских святителей: Василия Великого, Григория Богослова и Иоанна Златоуста [Іо, р. 5-26].

В строгом смысле слова ни «Диалог» Палладия, ни «Надгробное слово» Псевдо-Мартирия не были агиографическими произведениями. Они отражали только самое начало зарождения культа Златоуста, имевшее место лишь в среде его сторонников, и создавались, главным образом, как 
сочинения апологетические и полемические. В отличие от них, «Житие» Псевдо-Георгия Александрийского было первым произведением агиографии, созданным в честь Иоанна Златоуста, выражающим его уже существующий и развивающийся церковный культ.

В контексте культа святого агиографический памятник является ответом на злободневные вопросы церковной жизни. Как пишет В.М. Лурье, «отзываясь на “злобу дня”, агиография может превращать святых <...> в символы той церковной идеологии <...>, борьба за которую ведется в данный момент» [5, с. 50]. В агиографическом произведении святой становится символической фигурой [I5], которая подчас имеет мало общего с его реальным образом. Такой символической фигурой оказывается в «Житии» Псевдо-Георгия и Иоанн Златоуст. В чем же заключается ее символизм?

Обратимся к версии истории низложения епископа, представленной в «Житии» Псевдо-Георгия. Она нашла свое воплощение в сюжетной линии, изображающей конфликт между Иоанном Златоустом и императрицей Евдоксией. Согласно «Житию» Псевдо-Георгия, императрица была сребролюбива, и Иоанн Златоуст постоянно изобличал ее за этот порок, что вызывало ее негодование. В «Житии» содержится несколько эпизодов, в которых епископ вступает с императрицей в прямое противостояние. Один из них посвящен защите Златоустом патриция Феодориха, чье богатство под предлогом займа для государственных нужд вознамерилась присвоить себе императрица [I4, p. I48-I5I]. Другой эпизод посвящен рассказу о вдове Каллитропе, обманутой военачальником Павлакием, хитростью выманившим у нее пятьсот золотых. Когда вдова обратилась за помощью к императрице, та взыскала с Павлакия всю сумму, но почти полностью присвоила ее себе, вернув вдове лишь тридцать шесть монет. После этого вдова идет с жалобой к епископу, который, не добившись правды у императрицы, заключает Павлакия под стражу, пока он не вернет деньги [І4, p. I67-г7І].

Финальным эпизодом этой сюжетной линии является легенда о винограднике вдовы Феогноста [I4, p. г9г-г96], в которой просматриваются многие элементы библейского рассказа о винограднике Навуфея (3 Цар. 2I)³.

3 Вопрос о достоверности повествования о винограднике вдовы Феогноста вплоть до нашего времени вызывает споры среди исследователей. Значительная их часть, например, Дж. Келли [І6, p. І68-І7І], Р. Брэндле [2, с. ІІ8-ІІо], склоняются в пользу версии подлинности конфликта Иоанна Златоуста и императрицы Евдоксии из-за присвоенной императрицей собственности и полагают, что этот факт впоследствии был отождествлен с библейской 
Некий сенатор Феогност был несправедливо оклеветан, сослан и умер по дороге в ссылку. Все его имущество, за исключением одного виноградника, оставленного его вдове, было конфисковано. В сезон сбора винограда императрица Евдоксия, осматривая свои владения, зашла в виноградник вдовы, находившийся по соседству, где она сорвала и съела гроздь винограда. Согласно житийному рассказу, в то время существовал закон, в котором постановлялось, что если царственная особа войдет в какое-либо имение и вкусит от произросшего там плода, то это имение становится ее собственностью. На этом основании императрица и решила отнять у вдовы виноградник, последнее достояние, которое у нее осталось. Заступаясь за вдову, Иоанн Златоуст обратился к императрице с просьбой вернуть виноградник, но та отказалась. Тогда епископ обличил ее, сравнив с нечестивой библейской царицей Иезавелью. Императрица изгоняет его из дворца, а он, в свою очередь, не допускает ее на церковную службу в день Воздвижения Креста Господня. После этих событий судьба Иоанна Златоуста была решена, поскольку императрица твердо вознамерилась добиться его низложения.

Почему же предложенная Псевдо-Георгием версия низложения Иоанна Златоуста стала столь востребованной и единственной? Содержащееся в ней изображение напряженного противостояния между епископом и императрицей наводит на мысль, что ответ на этот вопрос кроется в проблеме взаимоотношений духовной и светской властей в Византии.

В византийском законодательстве был недвусмысленно сформулирован принцип разграничения духовной и светской властей, о чем говорится в преамбуле к VI новелле Юстиниана. «Величайшими у людей дарами Божиими, данными свыше по человеколюбию, являются священство и царство. Первое служит делам божественным, второе начальствует и наблюдает над делами человеческими; и то, и другое происходит от одного начала и гармонично обустраивает жизнь человеческую. Ибо если первое будет совершенно безукоризненным и удостоится у Бога благорасположения, а второе будет по справедливости и подобающим образом обустраивать порученное от него государство, то наступит некое доброе согласие, которое обеспечит все какие ни есть блага роду человеческому» [6]. 
С другой стороны, абсолютизм императорской власти неминуемо давал о себе знать. Например, в CXXXIII новелле того же Юстиниана, посвященной нормам монашеской жизни, содержится утверждение, противоречащее сказанному в преамбуле к VI новелле: «...для царской власти, получившей от Бога общее начальствование над всеми людьми, нет ничего недоступного для исследования» [І2, р. 666].

По словам А.П. Доброклонского, «мысль об абсолютизме императора должна была иметь очень большую силу и напряженность, чтобы проникнуть в законодательство при явном противоречии с его основными положениями. И действительность показывает, что для многих императоров это был живой нерв, двигавший их политикой. Отсюда, как часто они преступали границы своей компетенции и власти в отношении к Церкви!» [3, с. 69].

Действительно, история свидетельствует о том, что императоры часто вмешивались в церковную жизнь вопреки тому, что было прописано в законодательстве. Они имели влияние на избрание епископов, особенно константинопольских патриархов, сами возводили их на кафедры, перемещали с кафедр, интригами принуждали к отречению, без суда низлагали, оскорбляли их достоинство [3, с. 70-7I].

Тема противостояния духовной власти императорскому абсолютизму и произволу звучит в «Житии» Псевдо-Георгия. Знаменателен конец главы, посвященной истории Павлакия и Каллитропы. Императрица через своих посланников обращается к Златоусту с призывом не вмешиваться в государственные дела, сосредоточившись на делах церковных: «Прекрати, наконец, вмешиваться в те вопросы, которые относятся к компетенции царей, удались от таковых затей; подобным же образом и императрица удаляется от церковных дел, предоставив тебе управление ими. <...> Избери то, что подобает, руководя церковными делами и не ввергая себя в дела общественные и государственные. Ибо я не потерплю, если ты будешь так поступать» [I4, p. I7I].

Златоуст в ответ возражает, что его проповедь не является вмешательством в государственные дела, он лишь выполняет то, что заповедано в Священном Писании и обличает только саму страсть сребролюбия, а не конкретного человека: «Пусть она знает, что я обличаю и порицаю не ее, а ее дела, ибо всякий делающий грех, есть раб греха (Ин. 8: 34), согласно тому, чему учит апостол» [14, p. I72]. 
Посланные, вернувшись к императрице после ответа Иоанна, возвещают ей: «Сегодня мы слышали слова человека вообще не опасающегося ни смерти от меча, ни потопления в море, но почитающего все ничем и имеющего лишь одну заботу: обличать и порицать тех, кто живет не так, как подобает. И вообще он непобедим» [І4, p. І72].

Обличения императрицы в сребролюбии не рассматриваются в этом фрагменте «Жития» как превышение Златоустом своей власти. Напротив, констатируется, что он делает лишь то, что должен делать в силу своего пастырского долга. В противоположность действиям Златоуста, сребролюбие императрицы, ее покушения на чужую собственность в житии признаются неправомерными и осуждаются. Златоуст представлен здесь как бесстрашный и непобедимый борец, который вплоть до смерти готов противостоять властному произволу.

Таким образом, основной пафос версии низложения Иоанна Златоуста в «Житии» Псевдо-Георгия сводится к обличению беззакония и произвола императрицы, которому противопоставлено бесстрашие и дерзновение праведного епископа.

Можно сделать предположение, что именно этот пафос оказался востребованным в агиографической традиции Иоанна Златоуста, принявшей единственную версию противостояния епископа и его оппонентов, версию, выражающую идеологию сопротивления Церкви властному абсолютизму и произволу, а сам Иоанн Златоуст в контексте этой версии становится символической фигурой, знаменующей эту идеологию. Символической фигурой становится также и императрица Евдоксия, чей образ указывает на царское беззаконие.

Знаменательно, что в «Житии» Псевдо-Георгия два эти образа епископа и императрицы - ассоциируются с библейскими образами пророка Илии и царицы Иезавели. Псевдо-Георгий не первый вводит в свое произведение эту ассоциацию. Впервые она появляется в «Надгробном слове» Псевдо-Мартирия Антиохийского. Однако есть существенная разница между использованием ее Псевдо-Мартирием и Псевдо-Георгием.

У Псевдо-Мартирия уподобление Иоанна Златоуста пророку Илии, с одной стороны, и императрицы Евдоксии царице Иезавели, с другой, представляет собой риторический прием сравнения (би́үкрıбı) [2I, р. 45, 74, I39]. Появление в «Надгробном слове» подобного сравнения можно объяснить тем, что Иоанн Златоуст в кругу своих сторонников ассоциировался 
с пророком Илией, поскольку по аналогии с ним считался заступником за слабых и обиженных, в первую очередь за прокаженных, строительством больницы для которых он занимался [2I, p. 90-93], а императрица Евдоксия уподоблялась Иезавели, поскольку она, как следует из текста «Надгробного слова», поддержала землевладельцев, бывших противниками строительства больницы [2г, р. 94-95].

В отличие от «Надгробного слова», в «Житии» Псевдо-Георгия имеет место не просто сравнение Иоанна Златоуста и императрицы Евдоксии с пророком Илией и Иезавелью. В легенде о винограднике вдовы Феогноста словно оживает и совершается вновь само библейское событие, участниками которого являются пророк Илия и царица Иезавель.

Видение и изображение мира через библейское повествование характерно для произведений агиографии. Подобное наблюдение сделано Д. Крюгером в его исследовании, посвященном проблемам авторства на христианском Востоке [I7]. Проанализировав «Историю боголюбцев» Феодорита Кирского, ученый обратил внимание на то, что Феодорит находит в библейских текстах прообразы описываемых им святых подвижников, и это дает ему возможность смотреть на их жизнь сквозь призму Священного Писания [I7, p. I5-32]. Таким образом, священная история не закончилась, она имеет продолжение в жизни святых ${ }^{4}$, а сам агиограф оказывается в одном ряду с библейскими авторами [I7, p. 27-32].

Мысль о том, что создание библейских книг и составление жизнеописаний святых - явления одного порядка, что святые продолжают дело библейских царей и пророков, а сами создатели их житий - богодухновенных авторов Священного Писания, просматривается и во вступлении к «Житию» Псевдо-Георгия.

«Великий среди пророков Моисей описал происхождение сотворенного Богом мира с самого начала, будучи тайноводим Им, не созерцая чувственными очами ничего из того, что было создано. Затем, после этого сочинения, он написал и другую книгу, исход своего народа из Египта и освобождение от

4 На преемство между агиографической литературой и библейскими текстами указывает и В.М. Лурье. В частности, он замечает: «Вполне возможно, что новые святые будут изображаться как заключительные звенья одной цепи, иногда очень длинной, святых прошлого: например, князь Владимир - новый Константин, но Константин - новый апостол и даже новый Мессия. Таким образом, связь с актуальным для какого-то времени и места пониманием христианства все равно оказывается проекцией на Новый Завет» [5, с. 68]. 
рабства фараону <...>, затем по порядку - три оставшиеся книги иудейского закона вплоть до его завершения. После него в свою очередь другие передали в хронологическом порядке о том, что произошло при Иисусе сыне Навине и судьях израильского народа и о войнах Израиля с другими племенами. После этого иные записали то, что произошло при их царях <...>. После же того ветхозаветного Писания явилось, словно весна, славное пришествие Господа Бога нашего и Спасителя Иисуса Христа, источив аромат всякого духовного благоухания, изгнав всякий мрак нечестия, а лучше сказать, неведения и просветив мысли верующих в Него через обнародование писаний Его божественных евангелистов и апостолов. Просияло же несметное множество и святых мучеников за истину, и монахов, и богоносных мужей, чьи добродетели, житие и подвиги описали иные усерднейшие мужи во славу Божию, для памяти и ревности об их житии» [I4, p. 70-7I].

Итак, если с точки зрения Псевдо-Георгия, деяния христианских святых являются продолжением деяний библейских персонажей, то и история Иоанна Златоуста видится им как продолжение библейской истории, а сам Златоуст и императрица Евдоксия становятся новым Илией и новой Иезавелью, имея свои прообразы в персонажах Ветхого Завета.

Стало быть, в «Житии» Псевдо-Георгия имеет место совмещение двух характерных для агиографического повествования явлений: идеологизации повествования и его типологизации. Идеология противостояния святого епископа императорскому абсолютизму и произволу облекается в форму типологии, символическая фигура Иоанна Златоуста начинает рассматриваться в контексте образа пророка Илии, который воспринимается, прежде всего, как борец с Иезавелью.

Таким образом, элементы библейского повествования о винограднике Навуфея, включенные в нарратив «Жития» Псевдо-Георгия, несут интертекстуальную нагрузку. Иоанн Златоуст и императрица Евдоксия выступают в роли нового пророка Илии и новой Иезавели, и византийские реалии оказываются вписанными в контекст библейского повествования. Если основой противостояния пророка Илии и царицы Иезавели была борьба за чистоту единобожия, и пророк Илия обличал Иезавель за служение Ваалу, то противостояние Иоанна Златоуста как нового Илии императрице как новой Иезавели объясняется правом епископа обличать незаконные действия императорской власти. 
Именно этот символический образ Иоанна Златоуста и именно эта трактовка его противостояния с оппонентами оказываются востребованными более поздней агиографией, и в «Житии» Псевдо-Георгия мы видим ту сформировавшуюся литературную модель, которая легла в основу последующей агиографической традиции, в состав которой входят несколько биографий, энкомиев и слов на перенесение мощей, относящихся к VIII-X вв. и

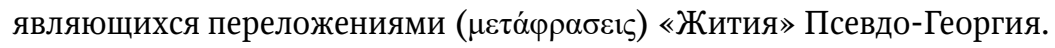

Практика переложения текстов получила широкое распространение в Византии. Переложение агиографического произведения не предполагало, в целом, изменения его содержания. Как правило, вносились исправления в его стиль, сокращения или, наоборот, оно восполнялось дополнительными сведениями, менялась его литературная форма[І9].

К числу переложений «Жития» Псевдо-Георгия относятся два похвальных слова Иоанну Златоусту - Иоанна Дамаскина и императора Льва VI. В основе каждого из них лежит произведение Псевдо-Георгия, и в каждом оно нашло свою особую интерпретацию.

«Похвальное слово св. Иоанну Златоусту» Иоанна Дамаскина (676-749) [24, vol. 96, col. 76I-78I] - одно из ранних произведений, созданных на основе «Жития» Псевдо-Георгия5. Оно датируется первой половиной VIII в., будучи произнесено в день празднования перенесения мощей святителя из Коман в Константинополь, по всей видимости, перед монашеской аудиторией, поскольку в нем особое внимание уделяется аскетическому подвигу Иоанна Златоуста [ІІ, р. 65].

Как жанровая форма «Похвальное слово» представляет собой христианский энкомий, который своими корнями уходит в эпоху Античности. Энкомии составлялись в честь знаменитых людей, императоров, полководцев в согласии со строгими правилами, описанными в различных руководствах по риторике, одним из которых является трактат Менандра «О торже-

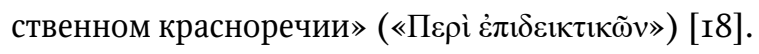

В эпоху Константина Великого (272-337) на основе античного энкомия возник новый жанр христианской литературы - энкомий христианскому мученику, который постепенно подвергся изменениям: со временем похвальные слова стали слагаться и в честь епископов, и в честь монахов,

5 О том, что Иоанн Дамаскин был знаком с «Житием» Псевдо-Георгия, свидетельствует тот факт, что он упоминает его в трактате «Об образах» [24, vol. 96, col. I277]. 
и в честь девственниц [г3, p. г88]. Таковым является «Похвальное слово Иоанну Златоусту» Иоанна Дамаскина, которое продолжает традиции христианского энкомия.

$\mathrm{B}$ «Похвальном слове» Иоанна Дамаскина нашли отражение две тенденции. С одной стороны, в нем прослеживается влияние античной риторики, с другой - эта традиция видоизменяется и переосмысливается [II, p. 66-83], и в этом отношении Иоанн Дамаскин уходит от классических образцов похвального слова гораздо дальше, нежели авторы христианских энкомиев V в.

$\mathrm{B}$ «Похвальном слове» появляются мотивы, не знакомые классическому энкомию. По сути дела похвальное слово Иоанну Златоусту превращается не в похвалу святому, а в похвалу Богу [ІІ, р. 78-79]. Панегирист, используя образ Златоуста как повод, рассуждает об истинах православной веры, излагает учение о единстве двух природ во Христе, говорит о необходимости веры в божественный Промысл и на примере жизни Иоанна Златоуста демонстрирует конкретные проявления действия Промысла в мире.

Однако в «Похвальном слове» имеют место не только абстрактные рассуждения о вере и добродетели. Свои мысли об этих предметах Иоанн Дамаскин иллюстрирует конкретными примерами из жизни святого, используя при этом повествовательную канву «Жития» Псевдо-Георгия и заимствуя из него символику образа константинопольского епископа, которая получает в его произведении дальнейшую разработку.

Иоанн Дамаскин обращается к биографии Иоанна Златоуста в пятой и восьмой частях «Похвального слова». В пятой части он говорит о приходе Иоанна в Церковь, о его жизни под руководством Мелетия Антиохийского, о принятии от его рук таинства крещения, о поставлении во чтецы, об отречении от мира и монашеской жизни, а в восьмой - о его последних годах: о низложении, ссылке, кончине и о перенесении его мощей в Константинополь.

Правда, здесь следует сделать оговорку. В рассказе о церковной и монашеской жизни Иоанна Златоуста Иоанн Дамаскин, по всей видимости, следует не тексту «Жития» Псевдо-Георгия Александрийского, а тексту его источника - «Диалога о житии Иоанна Златоуста» Палладия Еленопольского, из которого Псевдо-Георгий черпал свои буквальные текстуальные 
заимствования. Во всяком случае в тексте Иоанна Дамаскина имеется больше соответствий тексту Палладия, нежели тексту Псевдо-Георгия ${ }^{6}$.

Таким образом, Иоанну Дамаскину были известны оба текста: и «Диалог» и «Житие». Однако при выборе концепции образа Иоанна Златоуста и его символики он следует «Житию» Псевдо-Георгия, а не «Диалогу» Палладия, и этот выбор подчеркивает, что трактовка истории Иоанна Златоуста, предложенная Псевдо-Георгием, прочно утвердилась уже во времена Иоанна Дамаскина.

Тема противостояния святого епископа произволу императорской власти, которая лишь намечена в «Житии» Псевдо-Георгия, получает дальнейшее развитие в «Похвальном слове». «Власть, - говорит Иоанн Дамаскин, основанная на законе, является царством, а полагающая для себя основанием беззаконие, справедливо именуется тиранией» [24, vol. 96, col. 777A-B].

Исходя из этого тезиса, он обращается с обличениями к императрице. «Что делаешь ты, о беззаконная женщина? Облаченная в порфировое платье, будучи выставлена как страж закона, ты попираешь закон? О, неизреченная мудрость сказавшего: Не давайте святыни псам и не бросайте жемчуга вашего перед свиньями! (Мф. 7: 6). Ибо она, поправ святой божественный закон, разумеется, драгоценную жемчужину, измучив, сокрушила бедную вдову, похитив средства для ее каждожневной жизни» [24, vol. 96, col. 776D-777A].

С другой стороны, в «Похвальном слове» еще более отчетливо, чем в «Житии» Псевдо-Георгия, выражены типологические параллели между ветхозаветными событиями и историей Иоанна Златоуста. Его оппонентов Иоанн Дамаскин прямо называет «собирающимися то в одном, то в другом доме и торопящимися захватить виноградник Навуфея», самого епископа он непосредственно именует пророком Илией: «...но снова Святой Дух воздвигает Илию, чтобы он пребывал среди праведных душ», а императрицу - Иезавелью: «Иезавель вновь восстает против пророка» [24, vol. 96, col. 776B-C; 777C].

6 Например, Иоанн Дамаскин, говоря о крещении Иоанна Златоуста Мелетием Антио-

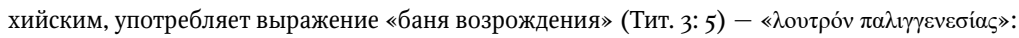

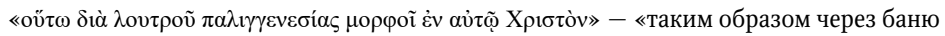
возрождения он (Мелетий. - А.Б.) изображает в нем Христа». [24, vol. 96, col. 769 В]. Это же

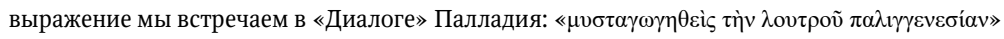
(«будучи посвящен в таинство бани возрождения») [23, р. Іо8]. В тексте «Жития» ПсевдоГеоргия это выражение отсутствует. 
Таким образом, для Иоанна Дамаскина Иоанн Златоуст является новым пророком Илией, и библейская история воплощается в словесной ткани «Похвального слова». Так же, как и в «Житии» Псевдо-Георгия, ветхозаветные образы в произведении Иоанна Дамаскина, будучи идеологическими символами, несут в себе интертекстуальную нагрузку, будучи переосмыслены в контексте современных автору церковных реалий.

Подобная концепция образа Иоанна Златоуста находит свое отражение и развитие в другом «Похвальном слове» святому, принадлежащем императору Льву VI Мудрому (886-9I2). Лев VI получил блестящее образование под руководством патриарха Фотия, обладал литературным талантом и был одним из немногих византийских императоров, сочинявших гомилии и публично произносивших их в церкви. Свой литературный дар он поставил на службу пропаганде своего понимания имперской идеи, заключавшейся в том, что император, получивший власть от Бога, несет на себе ответственность за духовное руководство народом $[7$, p. 72-8o]. Существует предположение, что Лев начал проповедовать в церкви также и потому, что в силу молодости своего брата, патриарха Стефана7, стремился заменять его [7, р. 40-48].

«Похвальное слово» Иоанну Златоусту является самой ранней гомилией императора Льва. Оно было составлено им не позже ноября 882 г., когда ему было всего шестнадцать лет, и он был соправителем своего отца Василия I [7, p. 67-68]; во вступлении к «Похвальному слову» недвусмысленно указано, что он принялся за эту работу по указанию своего отца:

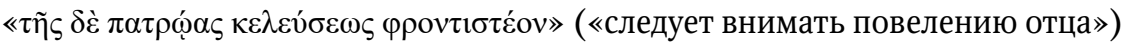
[24, vol. I07, col. 228D].

Юный возраст автора «Похвального слова» определил литературную специфику этого сочинения. «Похвальное слово» Иоанну Златоусту Льва VI, в отличие от «Похвального слова» Иоанна Дамаскина, по своему характеру больше соответствует жанру биографии, нежели энкомия. Оно представляет собой сокращенный риторизированный пересказ «Жития» Псевдо-Георгия, предназначенный для чтения вслух в церковной аудитории. «Похвальное слово» производит впечатление сочинения не вполне зрелого, и создается впечатление, что Лев VI боялся отклониться от сво-

7 Стефан, патриарх константинопольский (886-893). Будучи братом Льва VI, был поставлен патриархом в шестнадцатилетнем возрасте вместо смещенного патриарха Фотия. Стефан умер через шесть лет после занятия патриаршей кафедры [4, с. 29]. 
его образца, остерегаясь продемонстрировать литературную неопытность [7, p. I24-I26].

Тема противостояния епископа произволу императорской власти нашла отражение в произведении Льва Мудрого, но в несколько ином аспекте, нежели в «Похвальном слове» Иоанна Дамаскина. Несмотря на небольшой литературный опыт автора, в его сочинении присутствует интересная типологическая интерпретация эпизода, который в «Житии» Псевдо-Георгия изложен схематично, однако логически связан с повествованием о винограднике вдовы Феогноста. Речь идет о слове Иоанна Златоуста на тему восемнадцатой главы Третьей книги Царств, которое тот произнес после того, как узнал, что по наущению императрицы Евдоксии против него собирается собор во главе с Феофилом Александрийским.

В библейском отрывке, который, согласно «Житию» Псевдо-Георгия, лег в основу проповеди Иоанна Златоуста, говорится о состязании перед лицом израильского народа пророка Илии с языческими пророками, которым покровительствовали царь Ахав и его жена Иезавель. Языческие пророки не смогли через призыв к Ваалу низвести на жертву огонь, после же того, как пророк Илия воззвал к Богу Израилеву, огонь, ниспавший с неба, пожрал жертву (3 Цар. г8: 20-39).

Рассказывая об обстоятельствах, вынудивших Иоанна Златоуста произнести эту проповедь, и о самой проповеди, Лев Мудрый называет Иоанна «Илией нашего времени», связывая тем самым личность древнего пророка с личностью пророка нового - Иоанна Златоуста. Но он идет дальше, ассоциируя Иоанна не только с пророком Илией, но и с другими ветхозаветными праведниками: «Илия нашего времени и великая труба Церкви, Златоуст, узнав об этом, воспользовавшись трубой слова и не отступив перед противодействием нападавших, словно какой-то новый Моисей, или Финеес, или Иисус, или тот страшный и вооруженный божественной силой архистратиг и, извлекши меч, поражает дерзость противников, проповедуя и говоря: Собрались против меня священники неправедные, питающиеся от стола Иезавели (3 Цар. І8: І9)» [24, vol. Iо7, col. 272D-273A].

Таким образом, Иоанн Златоуст, с одной стороны, ставится в один ряд с библейскими пророками и праведниками и наделяется той духовной силой, которой обладали они. Но, с другой стороны, в контексте «Похвального слова» библейская реальность приобретает иной пафос. Слова «не- 
праведные священники, питающиеся от стола Иезавели», относятся к жрецам Ваала, которые находились на содержании царицы Иезавели. Однако в проповеди Иоанна Златоуста они обращены к епископам, собравшимся по воле императрицы Евдоксии на незаконный собор. Следовательно, языческие жрецы отождествляются с епископами, которые поддерживают беззаконные действия императорской власти, и тем самым это беззаконие отождествляется с языческим нечестием.

Итак, образ Иоанна Златоуста в «Житии» Псевдо-Георгия сложился под воздействием двух факторов, определяющих особенности агиографического нарратива: идеологического символизма и типологического подхода к изображению святых, что находит свое продолжение и развитие в похвальных словах Иоанна Дамаскина и Льва Мудрого.

В «Похвальном слове» Иоанна Дамаскина идеология противостояния епископа произволу императорской власти выражена более рельефно, нежели в «Житии» Псевдо-Геогрия. Определяя, что такое тирания и царство, Иоанн Дамаскин дает своеобразный комментарий к тексту Псевдо-Георгия и раскрывает глубину правды, которая, с его точки зрения, была заключена в действиях Иоанна Златоуста по отношению к императрице.

Типологические параллели между ветхозаветными и житийными образами, намеченные в «Житии» Псевдо-Георгия, становятся у Иоанна Дамаскина более четкими, нежели в «Житии» Псевдо-Георгия; углубление типологического видения образа Иоанна Златоуста, по сравнению с «Житием» Псевдо-Георгия, имеет место и в «Похвальном слове» императора Льва VI, который дает интересную типологическую интерпретацию рассказа Псевдо-Георгия о проповеди Златоуста на тему библейского эпизода из Третьей книги Царств, лишь намеченную в «Житии» Псевдо-Георгия.

\section{Список литературы}

I Балаховская А.С. Иоанн Златоуст в византийской агиографической традиции (V-Х вв.). М.: Тезаурус, 2013. 300 с.

2 Брендле Р. Иоанн Златоуст. Проповедник, епископ, мученик: [пер. с нем.] М.: Библейско-богословский ин-т св. апостола Андрея, 2006. 222 с. Доброклонский А.П. Преп. Феодор Студит, исповедник и игумен студийский. Одесса: «Экономическая» тип., І9І3. Ч. г: Его эпоха, жизнь и деятельность. ХХ, $972, \mathrm{XC}$, Iо c. 
Лебедев А.П. Очерки внутренней истории Византийско-восточной церкви. СПб.: Алетейя, І998. 320 с.

5 Лурье В.М. Введение в критическую агиографию. СПб.: Ахіо̄ma, 2009. 239 с.

6 Максимович К.А. Церковные новеллы св. императора Юстиниана I (527-565 гг.) в современном руссом переводе: Из опыта работы над проектом // Вестник ПСТГУ І: Богословие. Философия. 2007. Вып. І7. С. 27-44. Antonopoulou Th. The Homilies of the Emperor Leo VI. Leiden; New York: Brill, I997.310 c.

The Ashgate Research Companion to Byzantine Hagiography. Farnham: Ashgate Publishing Limited, 20Ir. Vol. I: Periods and Places / Ed. by S. Ephthyamidis. 464 p. Baur Ch. "Georgius Alexandrinus" // Byzantinische Zeitshrift. I927. Vol. 27. P. I-I6. Baur Ch. Jean Chrysostome et ses oeuvres dans l'histoire littéraire: Recuiel de travaux publiés par les membres des conférences d'histoire et de philologie, I8 fascicule. Bureaux du Recueil: Louvain, I907.312 p.

Brottier L. Figures de l'évêque idéale. Jean Chrysostome. Panégyrique de Saint Mélèce; Jean Damascène. Panégyrique de Saint Jean Chrysostome. Paris: Les Belles Lettres, 2004. 2IO p.

I2 Corpus Juris Civilis / R. Schoell, G. Kroll. Berlin, I895. Vol. 3: Novellae. 8I3 p.

I3 Delehaye H. Les passions des martyrs et les genres littéraires. Bruxelles: Bureaux de la Société des Bollandistes, I92I. 452 p.

I4 Douze récits byzantins sur saint Jean Chrysostome / Publiés par François Halkin. Bruxelles: Société des Bollandistes, I977.562 p. Esbroeck M., van. Le saint comme symbole // The Byzantine Saint / Ed. by S. Hackel. St. Vladimir's Seminary Press: Crestwood, New York, 200I. P. I28-I40. Kelly J.N.D. Golden Mouth. The Story of John Chrysostom: Ascetic, Preacher, Bishop. London: Duckworth, I996. X, 3II p.

Krueger D. Writing and Holiness. The Practice of Autorship in the Early Christian East. Philadelphia: University of Pensilvania Press, 2004. 302 p.

Menander Rhetor / Ed. with translation and commentary by D.A. Russell and N.G. Wilson. Oxford: At the Clarendon Press, I98I. 390 p.

Metaphrasis. Redactions and Audiences in Middle Byzantine Hagiography / Ed. by Christian Høgel. Oslo: The Research Council of Norway, I996. 82 p. Ommeslaehge F., van. Jean Chrysostome en conflit avec l'impératrice Eudoxie: Le dossier et origines d'une légende // Analecta Bollandiana. I979. T. 97. P. I3I-I59. Ommeslaeghe, F., van. De lijkrede voor Johannes Chrysostomus toegeschreven aan Martyrius van Antiochie. Tekstuitgave met Commentaar Hoofdstukken uit de Historische Kritiek: PhD Dissertation. Louvain, I974. IX, 322 p. Martyrius d'Antioche (BHG 87I) // Studia Patristica. I975. Vol. I2. P. 478-483. 
23 Palladios. Dialogue sur la Vie de Jean Chrysostome. T. I / introduction, texte critique, traduction et notes par A-M. Malingrey et Ph. Leclercq / Sources Chrétiennes, 34I. Paris: Les éditions du Cerf, I988. 45I p.

24 Patrologiae Graecae Cursus Completus: in I6I vols / Ed. J.-P. Migne. Paris: Fratres Garnier editores, I857-I866.

25 Socratis Scholastici Ecclesiastica Historia with the Latin translation of Valesius: in 3 vols / Ed. R. Hussey. Vol. 2. Oxford: E typographeo academico, I853. 887 p.

26 Wallraff $M$. Le conflit de Jean Chrysostome avec la cour chez les historiens ecclésiastique grecs // L'historiographie de l'église des premiers siècles: Actes du Colloque de Tours, sept. 2000. Paris: Beauchesne, 200I. P. 666.

\section{References}

I Balakhovskaia A.S. Ioann Zlatoust v vizantiiskoi agiograficheskoi traditsii (V-X vv.) [St. John Chrysostom in the Byzantine hagiographic tradition (V-X cc.)]. Moscow, Tezaurus Publ., 2013. 300 p. (In Russ.)

2 Brendle R. Ioann Zlatoust. Propovednik, episkop, muchenik [St. John Chrysostom. Preacher, bishop, martyr]: [transl. from German]. Moscow, Bibleisko-bogoslovskii institut sv. apostola Andreia Publ., 2006. 222 p. (In Russ.)

3 Dobroklonskii A.P. Prep. Feodor Studit, ispovednik i igumen studiiskii [St. Theodore the Studite, confessor and abbot of the Studios Monastery]. Odessa, "Ekonomicheskaia" tipografiia Publ., I9I3. Part I: Ego epokha, zhizn' i deiatel'nost' [His epoch, life and work]. XX, 972, XC, Io p. (In Russ.)

4 Lebedev A.P. Ocherki vnutrennei istorii Vizantiisko-vostochnoi tserkvi [Essays on the internal history of the Byzantine-Eastern Church]. St. Petersburg, Aleteiia Publ., 1998. 320 p. (In Russ.)

5 Lur'e V.M. Vvedenie v kriticheskuiu agiografiu [Introduction to the critical hagiography]. St. Petersburg, Axiōma Publ., 2009. 239 p. (In Russ.)

6 Maksimovich K.A. Tserkovnye novelly sv. imperatora Iustiniana I (527-565 gg.) v sovremennom russkom perevode: Iz opyta raboty nad proektom [Church novels of St. Emperor Justinian I (527-565) in the modern Russian translation: From the experience of working on the project]. Vestnik PSTGU I: Bogoslovie. Filosofiia, 2007, no I7, pp. 27-44. (In Russ.)

7 Antonopoulou Th. The Homilies of the Emperor Leo VI. Brill, I997. 3Io p. (In English)

8 The Ashgate Research Companion to Byzantine Hagiography. Farnham, Ashgate Publishing Limited, 20II. Vol. r: Periods and Places. Ed. by S. Ephthyamidis. 464 p. (In English)

9 Baur Ch. "Georgius Alexandrinus. Byzantinische Zeitshrift. I927. Vol. 27. S. I-I6. (In German)

Io Baur Ch. Jean Chrysostome et ses oeuvres dans l'histoire littéraire: Recuiel de travaux publiés par les membres des conférences d'histoire et de philologie, I8 fascicule. Louvain, Paris, I907.312 p. (In French) 
Brottier L. Figures de l'évêque idéale. Jean Chrysostome. Panégyrique de Saint Mélèce; Jean Damascène. Panégyrique de Saint Jean Chrysostome. Paris, Les Belles Lettres, 2004. 2Io p. (In French)

Corpus Juris Civilis, R. Schoell, G. Kroll. Berlin, I895. Vol. 3: Novellae. 8I3 p. (In Latin and Ancient Greek)

Delehaye H. Les passions des martyrs et les genres littéraires. Bruxelles, Bureaux de la Société des Bollandistes, I92I. 452 p. (In French)

Douze récits byzantins sur saint Jean Chrysostome, Publiés par François Halkin. Bruxelles, Société des Bollandistes, 1977. 562 p. (In Ancient Greek)

Esbroeck M., van. Le saint comme symbole. Byzantine Saint, Ed. by S. Hackel. London, I98I. P. I28-I40. (In French)

Kelly J.N.D. Golden Mouth. The Story of John Chrysostom: Ascetic, Preacher, Bishop. London, Duckworth, I996. X, 3II p. (In English)

Krueger D. Writing and Holiness. The Practice of Autorship in the Early Christian East. Philadelphia, University of Pensilvania Press, 2004. 302 p. (In English)

Menander Rhetor, ed. with translation and commentary by D.A. Russell and N.G. Wilson. Oxford, At the Clarendon Press, I98I. 390 p. (In English and Ancient Greek)

Metaphrasis. Redactions and Audiences in Middle Byzantine Hagiography, Ed. by Christian Høgel. Oslo, The Research Council of Norway, I996. 82 p. (In English) Ommeslaehge F., van. Jean Chrysostome en conflit avec l'impératrice Eudoxie: Le dossier et origines d'une legend. Analecta Bollandiana. I979. T. 97. P. I3I-I59. (In French)

Ommeslaeghe, F., van. De lijkrede voor Johannes Chrysostomus toegeschreven aan Martyrius van Antiochie. Tekstuitgave met Commentaar Hoofdstukken uit de Historische Kritiek: PhD Dissertation. Louvain, I974. IX, 322 p. (In Flemish and Ancient Greek) Ommeslaeghe, F., van. La valeur historique de la Vie de S. Jean Chrysostome attribuée à Martyrius d'Antioche (BHG 87I). Studia Patristica, I975, vol. I2, pp. 478-483. (In French)

23 Palladios. Dialogue sur la Vie de Jean Chrysostome. T. I, introduction, texte critique, traduction et notes par A-M. Malingrey et Ph. Leclercq, Sources Chrétiennes, 34I. Paris, Les éditions du Cerf, I988. 45I p. (In French and Ancient Geek)

Patrologiae Graecae Cursus Completus: in I6I vols., ed. J.-P. Migne. Paris, Fratres Garnier editores, I857-I866. (In Latin and Ancient Greek)

5 Socratis Scholastici Ecclesiastica Historia with the Latin translation of Valesius: in 3 vols., ed. R. Hussey. Oxford, E typographeo academico, I853. Vol. 2. 887 p. (In Latin and Ancient Greek) Wallraff M. Le conflit de Jean Chrysostome avec la cour chez les historiens ecclésiastique grecs. L'historiographie de l'église des premiers siècles: Actes du Colloque de Tours, sept. 200o. Paris, Beauchesne, 200I. P. 666. (In French) 
УДК 82I.I3І.І

ББК $83.3(4$ Ита 4

\section{«СВОЕ» И «ЧУЖОЕ» В ИТАЛЬЯНСКИХ ОПИСАНИЯХ ПАЛОМНИЧЕСТВ В СВЯТУЮ ЗЕМЛЮ (XIV-XV ВВ.)}

\author{
(C) 2020 г. А.В. Топорова \\ Институт мировой литературы \\ им. А.М. Горького Российской академии наук; \\ Российский государственный гуманитарный уни- \\ верситет, Москва, Россия \\ Дата поступления статьи: 25 февраля 2019 г. \\ Дата публикации: 25 июня 2020 г.
}

DOI: IO.22455/2500-4247-2020-5-2-88-IOI

Аннотация: C середины XIV в. паломничества приобретают в Италии массовый характер, наблюдается значительное расширение социальной среды, к которой принадлежат паломники. Многие из них вели дневники своего путешествия. В путешествиях замкнутый мир средневекового человека расширяется, устоявшаяся картина мира меняется, в нее вторгается множество новой информации, которую надо осмыслить и поместить в найденное для нее место, и часто надежным методом такой классификации становится сопоставление нового со своим. Поэтому паломники обращают внимание, прежде всего, на то, что отличается от привычных для них вещей, что они воспринимают как диковинное, непонятное, чудесное. Здесь нередко описания приближаются к жанру mirabilia. В изображении неизвестного мира и его реалий можно отметить две противоположные тенденции: с одной стороны, неприятие и страх; с другой - интерес и желание узнать побольше. Подход к новому у каждого автора свой: кто-то видит в любом непривычном для него явлении чудо и описывает его, не стесняясь добавлять «живописные» и обычно неправдоподобные детали от себя; а кто-то придерживается «реалистической» манеры изображения и не украшает свой рассказ дополнительными вымышленными деталями. С течением времени доля и модальность таких описаний меняется: если в Средние века акцент ставился на изображение мест Священной истории и духовном назидании, то в XV в. он начинает смещаться в сторону развлечения читателя.

Ключевые слова: литература о путешествиях, средневековые паломничества, дневники паломничества, жанр mirabilia, Никколо да Поджибонси «Заморская книга».

Информация об авторе: Анна Владимировна Топорова - доктор филологических наук, ведущий научный сотрудник, Институт мировой литературы им. А.М. Горького Российской академии наук, ул. Поварская, д. 25 а, І2Іо69 г. Москва, Россия; профессор, Российский государственный гуманитарный университет, ул. Чаянова, д. І5, І25047 г. Москва, Россия.

E-mail: anna.toporova@gmail.com

Для цитирования: Топорова А.В. «Свое» и «чужое» в итальянских описаниях паломничеств в Святую землю (XIV-XV вв.) // Studia Litterarum. 2020. T. 5, № 2. C. 88-IOI. DOI: IO.22455/2500-4247-2020-5-2-88-IOI 


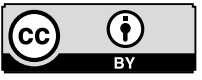

This is an open access article distributed under the Creative Commons Attribution 4.0 International (CC BY 4.0)

\title{
THE "STRANGE" AND THE "FAMILIAR" IN ITALIAN DESCRIPTIONS OF PILGRIMAGES TO THE HOLY LAND $\left(14^{\text {TH }}-15^{\text {TH }}\right.$ CENTURIES)
}

\author{
(C) 2020. A.V. Toporova \\ A.M. Gorky Institute of World Literature \\ of the Russian Academy of Sciences, Moscow, Russia; \\ Russian State University for the Humanities, Moscow, \\ Russia \\ Received: February 25, 2019 \\ Date of publication: June 25, 2020
}

\begin{abstract}
Starting from the mid- $14^{\text {th }}$ century, pilgrimage became a popular activity in Italy, the social status of the individuals participating in this activity suddenly became more varied. Many of the pilgrims kept diaries of their journeys - a genre that became very popular. Thanks to these journeys, the closed world of the medieval man began to expand, and his traditional worldview changed, incorporating a lot of new information. This information had to be understood and classified, and often a reliable method of classification was comparison of the new and the familiar. For this reason, pilgrims paid attention, first and foremost, to things that differed from what they were used to and that they perceived as strange, incomprehensible, and miraculous. Here their descriptions often approached the genre of the mirabilia. One can identify two opposite trends in these depictions of a new world and its realities: rejection and fear, on the one hand, and interest and curiosity on the other. Each author takes a different approach to new information: some considered every unfamiliar phenomenon to be a miracle and described it in corresponding terms, often adding "picturesque" and usually farfetched details along the way. Others adopted a "realistic" and quasi-scholarly style of description, refraining from embellishing their accounts with invented details. The relative share and modality of such descriptions changed over time: whereas emphasis was placed in the Middle Ages on depicting places from the Bible and on spiritual edification, pilgrims' diaries became increasingly bent on entertaining readers.
\end{abstract}

Keywords: descriptions of journeys, medieval pilgrimage, the pilgrims' diaries, the genre of mirabilia, Niccolò da Poggibonsi "Libro d'Oltramare".

Information about the author: Anna V. Toporova, DSc in Philology, Leading Research Fellow, A.M. Gorky Institute of World Literature of the Russian Academy of Sciences, Povarskaya 25 a, I2I069 Moscow, Russia; Professor, Russian State University for the Humanities, Chayanova I5, I25047 Moscow, Russia.

E-mail: anna.toporova@gmail.com

For citation: Toporova A.V. The "Strange" and the "Familiar" in Italian Descriptions of Pilgrimages to the Holy Land ( $4^{\text {th }}-\mathrm{I} 5^{\text {th }}$ Centuries). Studia Litterarum, 202O, vol. 5, no 2, pp. 88-IOI. (In Russ.) DOI: IO.22455/2500-4247-2020-5-2-88-IOI 
Паломничества в святые места предпринимались уже в первые века нашей эры, а с IV в., когда христианство было признано государственной религией и гонения на христиан прекратились, их количество значительно возросло. Преимущественным местом паломничеств была Святая Земля - Иерусалим, Вифлеем, Иордан, а также Синай, Александрия, Каир.

Почти сразу появляются путеводители или описания святых мест, содержащие как религиозные сведения, так и практические советы. Одним из самых ранних (IV в.) образцов является краткий путеводитель из Бордо в Иерусалим («Itinerarium Burdigalense»). К этому же времени относится описание блаж. Иеронимом его странствия по Палестине в «Надгробном слове блаженной Павле». В VI в. появляются сочинения «О положении Святой Земли» («De situ terrae sanctae») Феодосия, «Путешествия Эгерии», анонимный «Иерусалимский бревиарий» («Breviarius de Hierosolyma»), в VII в. - «O святых местах» («De locis sanctis») Беды Достопочтенного, труд, пользовавшийся большим успехом на протяжении веков и послуживший источником многочисленных заимствований; в IX в. Теодорих пишет трактат под таким же названием, а Петр Дьякон составляет «Путеводитель святых мест» («Itinerarium de locis sanctis») [1; 3; 5; 7].

В Италии паломничества по святым местам активизируются начиная с XII в. В это время они становятся несколько более безопасными в связи с прекращением арабских набегов и утверждением эпохи крестовых походов (вспомним, что первый Крестовый поход завершился в го99 г. взятием Иерусалима). Тогда же утверждается практика индульгенций - полного прощения грехов на определенный срок в случае посещения святых мест (составляются длинные списки святынь с указанием, на сколько лет дается отпущение 
грехов). В ІІ40 г. Раньери даль Борго из состоятельной купеческой семьи, переживший обращение после бурной юности, оставляет свое имущество сестре и отправляется в Святую Землю, где проводит тринадцать лет. Известно, что к нему приходили за советами и наставлениями итальянские паломники. Однако первые тексты, описывающие паломничества, относятся к XIV в.: то ли более ранние свидетельства не сохранились, то ли насущная потребность в них возникла именно в это время, когда паломничества стали массовыми.

Если до этого их предпринимали в основном монахи, клирики, духовные лица, то с середины XIV в. наблюдается значительное расширение социальной среды, к которой принадлежат паломники. В паломничества отправляются и миряне, купцы, политики, придворные, дипломаты, ремесленники; люди образованные и не очень; состоятельные и среднего достатка [I5]. Что касается их возраста, то он тоже варьируется; чаще всего паломники - это зрелые люди, но еще полные физических сил, однако есть случаи, когда паломничества совершались под конец жизни, в преклонном возрасте (Лионардо Фрескобальди, Микеле да Фильине). «Антропологический тип» паломника ${ }^{\mathrm{B}}$ встречался в Италии повсюду, жители самых разных итальянских городов оставили воспоминания о своих странствиях.

Перечислим основные тексты, на которые будем ссылаться, и их авторов. В г346-г350 гг. францисканец Никколо да Поджибонси посещает Святую Землю и составляет описание своего путешествия - «Заморская книга» («Libro d'Oltramare»). Это первое подробное описание Святой Земли, рассчитанное на будущих паломников, написанное на итальянском языке.

В I384 г. на Святую Землю отправляется группа флорентийцев, трое из которых оставят описания этого путешествия. Лионардо Фрескобальди, автор «Путешествия в Святую Землю» («Viaggio in Terrasanta»), происходил из знатного рода, представители которого занимались торговлей, банковским делом и политикой (принадлежали к партии гвельфов). Сам Лионардо в юности неоднократно участвовал в сражениях, а позже исполнял ряд должностей в Коммуне - входил в Совет двадцати, был подеста в Кастелло, участвовал в дипломатических миссиях. Симоне Сиголи, составивший «Путешествие на гору Синай» («Viaggio al monte Sinai»), также был из гвельфской благородной семьи. Джорджо Гуччи, написавший «Путеше-

I J. Дзандзи говорит о паломнике как об антропологическом типе средневекового человека [I6, p. 9г]. 
ствие по святым местам» («Viaggio ai luoghi santi»), имел простонародное происхождение; однако известно, что в г 379 г. он был избран одним из приоров, а пятью годами позже был послом в Риме.

В I4I3 г. на Святую Землю отправляется необычная шумная придворная компания из Феррары, включающая в себя около пятидесяти человек. Возглавляет ее герцог Феррарский Николо III д‘Эсте, незаконнорожденный сын Альберто V д‘Эсте и Изотты Альбарезани, военный, политик, дипломат. Вести дневник путешествия он поручил своему канцлеру Лукино даль Кампо, его труд озаглавлен «Путешествие герцога Николо д‘Эсте к Гробу Господню» («Viaggio del marchese Nicolò D’Este al Santo Sepolcro»). Как мы увидим, это яркий, хотя и не единственный пример «придворного» паломничества.

В I43I г. сиенский клирик Мариано да Сиена описывает свое последнее паломничество в Святую Землю - «Путешествие, совершенное ко Гробу Господню» («Viaggio fatto al Santo Sepolcro»). В І474 г. банкир, служивший в лондонском филиале банка Медичи, а затем вступивший в доминиканский орден и ставший настоятелем монастыря Сан-Марко, из известного флорентийского рода, Алессандро Ринуччини описывает свой паломнический опыт в «Святейшем паломничестве ко Гробу Господню» («Sanctissimo viaggio del Sancto Sepolcro»). В І48о г. чиновник, возглавлявший канцелярию миланского герцога Галеаццо Мария Сфорцы, Санто Браска отправляется в Святую Землю и описывает свое путешествие («Viaggio in Terrasanta»). В I489-I490 гг. священник из окрестностей Флоренции Микеле да Фильине посещает Иерусалим и Египет и рассказывает об этом в своем дневнике.

Этот список можно было бы существенно расширить и продолжить, но и приведенного перечисления основных дневников паломничества достаточно для вывода о том, что жанр этот пользовался огромной популярностью. Его можно считать разновидностью описаний путешествий, путевых заметок. Впрочем, по форме своей он был неоднородным. Это могли быть путеводители (итинерарии), в которых подробно описывается маршрут паломничества, дается краткая характеристика места, указывается, где какие молитвы и богослужебные тексты надо читать, какие индульгенции можно получить; или описания святых мест (descriptions), на фоне событий Священной истории и с подробным перечнем культурных достопримечательностей; или собственно дневник, в котором события паломничества записывались хронологически, по дням. Четкой границы между этими разновидностями не было. 
В этих текстах нередко описываются «чудеса», связанные с определенным местом - как религиозного характера, так и «естественного» (растения, звери), или «социального» - диковинные обычаи, манера одеваться, готовить пищу и т. п. Они восходят к распространенному средневековому жанру mirabilia, представляющему собой нечто среднее между энциклопедическими жанрами, суммами (ср. также бестиарии, флорилегии, лапидарии), и собственно путевыми записками, изобилующими интересными, реальными или вымышленными, сведениями [2]. Примечательно, что Ле Гофф в этимологии слова mirabilia указывает на визуальный аспект (miror, mirari) [8, p. I7-39], т. е. имеется в виду нечто необычное, увиденное собственными глазами и зафиксированное в тексте. В качестве прообраза этого жанра можно рассматривать «Собрание достопримечательностей» Юлия Солина.

Хотя для паломнических сочинений познавательный аспект не был главным, но человеческая любознательность, радостное удивление при виде нового и непривычного, разумеется, не могли не прорваться наружу. Поэтому описание местного населения и его обычаев, а также флоры и фауны посещаемых стран является непременным топосом дневников паломничества ${ }^{2}$, тем более что жанр дневника предполагает присутствие личных впечатлений от увиденного, даже если эти впечатления не имеют прямого отношения к «религиозной» линии повествования. В путешествиях замкнутый мир средневекового человека расширяется, устоявшаяся картина мира меняется, в нее вторгается множество новой информации, которую надо осмыслить и поместить в найденное для нее место, и, конечно, надежным методом такой классификации является сопоставление нового со своим. Паломники обращают внимание, прежде всего, на то, что отличается от привычных для них вещей, что они воспринимают как диковинное, непонятное, чудесное. В изображении неизвестного мира и его реалий можно отметить две противоположные тенденции: с одной стороны, неприятие и страх; с другой - интерес и желание узнать побольше. Надо сказать, что подход к новому у каждого свой: кто-то видит в любом непривычном для него явлении чудо и описывает его соответствующим образом, не стесняясь добавлять «живописные» и обыч-

\footnotetext{
2 Отметим, что даже в таком строгом жанре, как хроники крестовых походов, описание «чужого мира» присутствовало в немалых подробностях. Это рассматривалось как одна из особенностей исторического дискурса, призванного передать «культурную и временную специфику». См.: [14].
} 
но неправдоподобные детали от себя; а кто-то придерживается «реалистической», если не сказать, научной, манеры изображения и не украшает свой рассказ дополнительными вымышленными деталями.

Никколо да Поджибонси придерживается второй манеры письма. Он любознателен, наблюдателен и информативен в своих описаниях. Ему все интересно, и он стремится передать увиденное читателю полно и точно, ничего не упустив и не исказив. Морские рыбы, верблюды в пустыне, красиво расписанный храм в Лидде, «дикие арабы», финики, способы молиться у евреев, греков и грузин и многое другое, чему он оказывается свидетелем и наблюдателем, заносит он в свой дневник. Интересует его и архитектура; так, он обращает внимание на красоту отдельных деталей Иерусалимского храма: «Le porti sono ad arco, volte e lavorate con belle colonne di porfido verde e rosso e bianco. In su l'arco della detta porta che s'apre si è una figura di santa Maria col figliuolo in braccio, ed è opera musaica, ma ora la maggior parte è guastata; e ll limitario di sopra la porta, sotto la figura, si è di marmo bianco, ed ècci intagliato come Cristo risuscitò Lazzaro» [II, p. 43] («Двери сделаны в виде арки, они сводчатые и украшены красивыми колоннами из зеленого, красного и белого порфира. Над аркой этой открывающейся двери находится фигура Девы Марии с младенцем на руках, это мозаика, но сейчас большая ее часть повреждена; а портал над дверью, под фигурой, из белого мрамора, и там вырезано, как Христос воскресил Лазаря»). Нельзя сказать, что увиденное не производит на него впечатления (ср. его неоднократно повторяющуюся ремарку «сhе pare una meraviglia a vedere» - «что воспринимается как чудо»), но он не дает излишней эмоциональности и восторженности потеснить собственно «информативный» аспект. Примечательно, что там, где он не понимает, что происходит или что говорят, он обращается за разъяснениями к окружающим, а не дает собственных интерпретаций. Так, описывая религиозную процессию в Вербное воскресение (гл. XXXVI), он упоминает о двух огромных оливах, наверху которых находились какие-то люди, что-то громко кричавшие, обращаясь к епископу. Поджибонси просит находившегося рядом переводчика объяснить ему эту сцену; тот отвечает, что выкрикивают «по-эфиопски», а он переводчик c «еврейского и сарацинского» [II, p. 55]. Этот, казалось бы, незначительный эпизод весьма важен для понимания метода работы Поджибонси. Описывая изобилие и разнообразие Дамаска, диковинные привычки его населения, которое не готовит еду дома, а все покупает на улицах и площадях (кстати, об 
этой особенности пишут многие) и ест день и ночь, как если бы у людей были «железные желудки», красивые мечети, розовую воду и прочие интересные вещи, Поджибонси замечает в заключение, что многое из увиденного он опускает, поскольку опасается, что ему не поверят и поднимут на смех.

Поджибонси тяготеет к энциклопедическому стилю: его интересуют география, зоология, ботаника, искусство (архитектура, живопись, мозаика), этнография (быт, обычаи), геммология. Даже когда он явно поражен и восхищен увиденным, как в случае со слоном, он пытается дать «научное» описание - внешний вид, строение тела, привычки. Не менее поражают его жираф, дикая коза, бабуин и некоторые другие животные, названия которых он не может привести, так как рядом не было переводчика.

У Фрескобальди и Сиголи преобладает интерес к изображению нового, непривычного. Мусульманский мир представлен в их дневниках значительно ярче, чем христианский. Фрескобальди с живым интересом и воодушевлением, в деталях и с чувством, представляет читателю мир Александрии: внешний вид его жителей, их одежды, вооружение, дома. Особенно ярко изображен дворец султана: «In capo di questa scala si è una porta d'una gran sala, dove tutti fummo fatti scalzare <...>. Dalla parte di sopra si era a sedere in su drappi di seta colle gambe incrociate questo re, e li suoi baroni gli erano ritti innanzi, ed era bene insino al terzo della sala pieno lo spazzo di bellissimi drappi e tappeti» [II, p. I76] («Наверху лестницы дверь, ведущая в огромную залу, и там нас заставили снять обувь <...>. Сверху на шелковых тканях восседал, скрестив ноги, их царь, а его бароны стояли вокруг; и до трети залы пространство было заполнено тканями и коврами»). Описывает Фрескобальди и обычаи, в частности, способ хоронить умерших; мечети, религиозные обряды. Примечательно, что и местное население, через переводчика, расспрашивало паломника о жизни в его стране, о которой оно имело уже некоторые представления и знания; в частности, о существовании в этот период Папы и антипапы. Особый всплеск эмоций вызывают экзотические плоды (финики, кедровые орехи, арбузы и прочие), изобилие, разнообразие и удивительный вкус которых поражает автора; а также животные, и в первую очередь крокодил. Ему вторит Сиголи, плененный «райскими яблоками», грушами, сливами, арбузами, растущими в Александрии, необыкновенно дешевым мясом, курами и рыбой, продающимися на городских базарах. Каждому из наименований он посвящает отдельный абзац. Он сообщает также о местных 
обычаях (например, сидеть на ковре, скрестив ноги), об отношениях мужа и жены, об одежде сарацин, о мусульманском посте; восторженно и в мельчайших деталях описывает товары, которые можно купить в лавках Дамаска. Тот же подход характерен и для Гуччи; одна из глав его сочинения (VI) носит такое название - «Повествует о невиданных вещах и чудесах Вавилонии и Каира» («Racconta delle cose mirabili e maravigliose di Bambilonia e del Cairo»). Среди чудес Гуччи упоминает обилие людей и верблюдов, богатство султана, количество умерших во время эпидемии чумы, а также бальзамовое дерево, о котором подробно писал и Санто Браска.

Другие авторы менее красноречивы в изображении Востока, но и они передают то, что их поразило, что отличается от привычного им мира. Описание Санто Браски все построено на сравнении увиденного с родными ему местами и реалиями: по размеру Иерусалим такой же, как Павия; а крыши его домов не покатые, как «наши», а плоские, и музыкальные инструменты очень отличаются от «наших», равно как и одежда местного населения [6, р. 67-68]. Каир нельзя сравнить по богатству ни с Миланом, ни с Венецией [6, р. І42]. Описания Браски порой носят почти этнографический характер, он обращает внимание на мельчайшие детали мужской и женской одежды, подробно рассказывает об устройстве жилищ, о товарах и лавках. у Мариано да Сиена встречаются лишь отдельные краткие замечания о природе, местных жителях и их обычаях (так, его поразила работорговля). Главное для него - религиозный аспект его путешествия, все остальное остается, как правило, за кадром. Микеле да Фильине несколько более подробен, но в целом тоже пишет немного и без особых деталей: об опасном рифе, о почтовых голубях в Александрии, о работорговле, о способе приготовления пищи, о бальзамовом дереве, арбузе, крокодиле, о восточном базаре. Увиденный им красивый сад он сравнивает по размеру с одной из площадей Флоренции. Как и многие другие авторы дневников паломничества, он перечисляет разные группы христиан. Тот же обычный набор «диковинных» вещей находим мы и у Ринуччини. Для него тоже мерилом всего являются родные реалии - так, Гору искушений он сопоставляет с тосканскими Апеннинами. Для Лукино характерен не столько интерес к достопримечательностям, сколько желание подчеркнуть роскошь путешествия; именно так изображается турецкая баня с розовой водой в королевском дворце на Кипре или акробатические упражнения турка там же. 
Описание мусульманских городов и обычаев почти всегда содержит в себе оценочные коннотации как в отношении конкретных особенностей жизни и поведения мусульман, так и в связи с мусульманской верой в целом. Чаще всего это отношение отрицательное, и вызвано оно не различием вероисповедания, а теми неприятностями, которые паломники претерпевали от мусульман на Святой Земле, - нападения, грабежи, ругань, обман. Как пишет Ринуччини: «...questa canaglia non si fanno conscienza alchuna di rubare i pellegrini et fare loro ogni altro male» [ı3, p. 68] («...эти канальи без малейшего зазрения совести грабят паломников и чинят им всякие прочие неприятности»). А Микеле да Фильине вспоминает, как в окрестностях Александрии араб напал на венецианца, повалил его на землю, бил ногами и палками, а затем посадил в темницу на цепь; все это «из-за ничего» («per non neente» [Iо, p. 65]), из-за какого-то спора, возникшего на корабле. В ответ паломники презрительно и насмешливо говорят о том, что мусульмане едят, сидя на земле, не готовят сами пищу, а покупают ее на базаре, облизывают губы, как собаки (вообще, сравнение с собаками - одно из самых распространенных). Но бывает, что и религиозные обряды и верования становятся объектом критики. Так, Сиголи эмоционально и не без преувеличений изображает молитвенную практику мусульман: «...e vanno intorno a questo ballatoio tre volte, gridando ad altissime voci ch'egli è nona, raccontando ancora della disonesta vita di Macometto e de' suoi cattivi compagni, i quali dicono che furono suoi apostoli. Appresso gridano: "Fate la tale cosa", ch'é sarebbe disonesto a scrivere com'eglino dicono scolpitamente: "Crescete e moltiplicate”, sicché la legge di Maometto cresca e moltiplichi. E così fanno per lo simile modo quando viene l'ora di vespro, salvo che eglino stanno in sul campanile tre cotanti a gridare, raccontando cose disonestissime di lussuria le quali fece Maometto in questo mondo, e così comandando che ciascuno si sforzi di fare; e per questo modo bestialmente vivono» [ıг, p. 225] («...и так они делают три круга по галерее, громко выкрикивая, что настал девятый час, а также рассказывая о бесчестной жизни Магомета и его дурных товарищей, про которых они говорят, что те были его апостолами. Потом они кричат: “Сделайте то-то”, так что и писать стыдно, как отчетливо они выговаривают: “Плодитесь и размножайтесь”, дабы закон Магомета возрастал и распространялся. И подобным образом поступают они, когда наступает время вечерней службы, разве что в это время три человека кричат на колокольне, 
рассказывая о бесчестнейших прелюбодействах, которые совершал Магомет в этой жизни, повелевая тем самым каждому стремиться к тому же; так по-скотски живут они»). А Браска отмечает, что мусульманская вера с уважением относится к «нашему Спасителю», но над Гробом Господним, Голгофой и христианским таинством смерти насмехается [6, p. 70-7I].

Вместе с тем есть и положительные отзывы. Поджибонси рассказывает, как гид-араб, похищенный бедуинами в Синайской пустыни, вернулся через два дня к испуганным и потерянным паломникам. Роберто да Сансеверино вспоминает приятного арабского юношу, который показал паломникам дорогу и подарил им козленка. Микеле да Фильине пишет о приветливом арабе, который, как выяснилось из беседы, бывал во Флоренции.

Особую категорию мусульман составляют христиане-отступники, которые обычно служат переводчиками (turcimanni) у паломников. Отношение к ним тоже весьма различное: Поджибонси решительно осуждает их, говорит об их алчности, об их вечной погибели. Фрескобальди, скорее, сочувствует такому переводчику, родом из Венеции, и советует ему вернуться на родину и вновь принять христианство. Микеле да Фильине хоть и упоминает одного такого отступника, попытавшегося его обмануть, но от оценки воздерживается.

Различен и стиль описания у разных авторов. Поджибонси в целом «бесстрастен», но некоторые моменты путешествия он изображает с глубоким чувством (страха - во время бури, изумления - при виде Иерусалима, разных достопримечательностей, а также непривычных животных и растений или плодов, тихой и глубокой радости религиозных переживаний); при этом он всегда помнит о тех, кто прочитает его дневник. Перечисляя разные группы христиан, он высказывает и собственное мнение: «...хотя мы и не считаем, что это истинные христиане» («...benché noi non crediamo che sieno veri cristiani» [II, p. Iı6]). А описывая козу, не может удержаться от удивления, что она оседлана («Or chi crederebbe che la capra portasse sella, е anche il freno e la poselle, a modo di cavallo?» [ı, p. II8] - «Кто бы подумал, что на козу надели седло, а также уздечку и чересседельник, как на лошадь?»). Приблизительно то же можно сказать о стиле Санто Браски: он стремится к «объективности», пишет ровно и спокойно, но в повествовании о разных приключениях, случившихся с ним, появляются личные нотки. 
А когда чему-то удивляется Симоне Сиголи, то его стиль становится очень эмоциональным и даже почти разговорным: «...delle più belle cose del mondo vi si trovano e de' più nobili e ricchi lavorii, per tale che $<\ldots>$ se tu avessi i denari nell'osso della gamba, senza fallo te la romperesti per comprare di queste cose, perocché tu non sapresti immaginare colla mente quella ragione di cosa che quivi non si trovi, e sia fatta come si vuole» [II, p. 239] («...там находятся самые прекрасные вещи в мире и самые благородные и богатые изделия, такие, что <...> если бы у тебя деньги находились внутри кости ноги, ты несомненно сломал бы ее, чтобы купить их, потому что ты даже не можешь вообразить в уме, какие только вещи там можно найти и как они сделаны»).

Подводя итоги, можно сказать, что при всем разнообразии - жанровом, содержательном, стилистическом - сочинений такого рода интерес к материальным свидетельствам о евангельских событиях и к контексту путешествия присутствует всегда. «Мир сей» в той или иной мере вторгается в текст дневника паломничества. Если в ранних текстах главное внимание уделяется изображению мест Священной истории и духовному назиданию, то в XV в. акцент начинает смещаться в сторону развлечения читателя. Любознательность становится основным стимулом паломничества и, соответственно, влияет на модальность его описания. Рассказ об увиденных странах, людях и их обычаях, фиксация любопытных происшествий, случившихся с автором, порой затмевают собственно религиозный аспект³. «Чужое» становится более интересным и, порой, более ценным, чем «свое».

\section{Список литературы}

I Добиаш-Рождественская О.А. Западноевропейские паломничества в Средние века. СПб.: Акционер и Ко, 2006. I42 с.

2 Муштанова О.Ю. Представления о чудесном в культуре средневекового Запада и их воплощение в жанре mirabilia // Филологические науки в МГИМО. М.: Изд-во МГИМО-Университет, 2012. № 48 (63). С. І86-г93.

3 Ненарокова M.P. Чудеса Востока глазами средневековых европейских путешественников // Культурологический журнал. 20I4. № 3. C. I. URL: http://www.crjournal.ru/rus/journals/28I.html\&j_id=2о (дата обращения: oI.02.20I9).

3 О процессе секуляризации религиозной литературы на пороге Возрождения см.: [4, c. $16 \mathrm{I}-169]$. 


\section{References}

I $292 \mathrm{p}$.

Топорова А.В. Религиозная жизнь средневековой Италии в зеркале литературы. М.; СПб.: Центр гуманитарных инициатив, 2018. І9г с. Шупляк С.П. Западноевропейские средневековые паломничества. Минск: Бду, 2013. $219 \mathrm{C}$.

Brasca S. Viaggio in Terrasanta di Santo Brasca, I480; con l'Itinerario di Gabriele Capodilista, I458 / A cura di A.L. Momigliano Lepschy. Milano: Loganesi, I966. 30 I p. Cherubini G. I pellerini // Viaggiare nel Medioevo / A cura di S. Gensini. Roma: Pacini, 2000. P. 537-566.

Le GoffJ. L'imaginaire medieval. P.: Gallimard, I985. XXI, 352 p.

Mariano da Siena. Viaggio fatto al Santo Sepolcro, I43I. In appendice: Viaggio di Gaspare di Bartolomeo / A cura di P. Pirillo. Ospedaletto: Pacini, I99I. I75 p.

Montesano M. Da Figline a Gerusalemme: viaggio del prete Michele in Egitto e in Terrasanta (I489-I490).Con il testo originale del viaggio di ser Michele. Roma: Viella, 20IO. 187 p.

Pellegrini scrittori: viaggiatori toscani del Trecento in Terrasanta / A cura di A. Lanza e M. Troncarelli. Firenze: Ponte alle Grazie, I990. 342 p.

Richard J. Il santo viaggio: pellegrini e viaggiatori nel Medioevo. Sesto San Giovanni: Jouvence, 20I4. II9 p.

Rinuccini A. Sanctissimo peregrinaggio del Sancto Sepolcro, I474. In appendice: itinerario di Pierantonio Buondelmonti, I468 / A cura di A. Calamai. Pisa: Pacini, I993.

4 Skottiki K. «Was gibt es Grösseres als die Reise nach Jerusalem?» Die lateinischchristliche Geschichtsschreibung des Mittelalters am Beispiel der Kreuzungschronik (um iıIo n.Chr.) des Robert von Reims // Wozu Geschichte? Historisches Denken in vormodernen historiographischen Texten. Ein transkultureller Vergleich / Hg. Von S. Conermann (Bonner Asienstudien I8). Berlin: EB-Verlag, 20I7. S. 67-IIO.

5 Sumption J. Monaci, santuari, pellegrini: la religone nel Medioevo. Roma: Editori riuniti, I999. $397 \mathrm{p}$.

Zanzi L. Metamorfosi dei pellegrinaggi dall'età medioevale all'età moderna // Medioevo in cammino: l'Europa dei pellegrini. Atti del Convegno internazionale di studi. Orta San Giulio, 2-7 settembre 1987. Orta San Giulio, I989. 430 p.

Dobiash-Rozhdestvenskaia O.A. Zapadnoevropeiskie palomnichestva v Srednie veka [Western European pilgrimages in the Middle Ages]. St. Petersburg, Akcioner i Ko Publ., 2006. I42 p. (In Russ.)

Mushtanova O.Iu. Predstavleniia o chudesnom v kul'ture srednevekovogo Zapada i ikh voploshchenie $\mathrm{v}$ zhanre mirabilia [Ideas of the miraculous in the culture of the medieval West and their embodiment in the genre of mirabilia]. Filologicheskie nauki v MGIMO 
[Philological disciplines in MGIMO]. Moscow, Izdatel'stvo MGIMO-Universitet Publ., 20I2, no 48 (63), pp. I86-I93. (In Russ.)

Nenarokova M.R. Chudesa Vostoka glazami srednevekovykh evropeiskikh puteshestvennikov [Miracles of the East as seen by the Medieval European travelers]. Kul'turologicheskii zhurnal, 20I4, no 3, p. I. Available at: http://www.cr-journal.ru/ rus/journals/28I.html\&j_id=20 (accessed or February 20I9). (In Russ.) Toporova A.V. Religioznaia zhizn' srednevekovoi Italii v zerkale literatury [Religious life in medieval Italy as reflected in literature]. Moscow, St. Petersburg, Centr gumanitarnyh iniciativ Publ., 2018. I9I p. (In Russ.) Shupliak S.P. Zapadnoevropeiskie srednevekovye palomnichestva [Western European medieval pilgrimages]. Minsk, BDU Publ., 20I3. 219 p. (In Russ.) Brasca S. Viaggio in Terrasanta di Santo Brasca, I480; con l'Itinerario di Gabriele Capodilista, I458, a cura di A. L. Momigliano Lepschy. Milano, Loganesi, I966. 30 I p. (In Italian)

Cherubini G. I pellerini. Viaggiare nel Medioevo, a cura di S. Gensini. Roma, Pacini, 2000. P. 537-566. (In Italian)

8 Le Goff J. L'imaginaire medieval. P., Gallimard, I985. XXI, 352 p. (In French)

9 Mariano da Siena. Viaggio fatto al Santo Sepolcro, I43I. In appendice: Viaggio di Gaspare di Bartolomeo, a cura di P. Pirillo. Ospedaletto, Pacini, I99I. I75 p. (In Italian) Montesano M. Da Figline a Gerusalemme: viaggio del prete Michele in Egitto e in Terrasanta (I489-I490). Con il testo originale del viaggio di ser Michele. Roma, Viella, 20Io. I87 p. (In Italian)

II Pellegrini scrittori: viaggiatori toscani del Trecento in Terrasanta, a cura di A. Lanza e M. Troncarelli. Firenze, Ponte alle Grazie, I990. 342 p. (In Italian) Richard J. Il santo viaggio: pellegrini e viaggiatori nel Medioevo. Sesto San Giovanni, Jouvence, 20I4. II9 p. (In Italian)

I3 Rinuccini A. Sanctissimo peregrinaggio del Sancto Sepolcro, I474. In appendice: itinerario di Pierantonio Buondelmonti, I468, a cura di A. Calamai. Pisa, Pacini, I993. 292 p. (In Italian)

I4 Skottiki K. "Was gibt es Grösseres als die Reise nach Jerusalem?” Die lateinisch-christliche Geschichtsschreibung des Mittelalters am Beispiel der Kreuzungschronik (um IIIO n.Chr.) des Robert von Reims. Wozu Geschichte? Historisches Denken in vormodernen historiographischen Texten. Ein transkultureller Vergleich. Hg. Von S. Conermann (Bonner Asienstudien I8). Berlin, EB-Verlag, 20I7. S. 67-IIO. (In German) Sumption J. Monaci, santuari, pellegrini: la religone nel Medioevo. Roma, Editori riuniti, I999. 397 p. (In Italian)

I6 Zanzi L. Metamorfosi dei pellegrinaggi dall'età medioevale all'età moderna. Medioevo in cammino: l'Europa dei pellegrini. Atti del Convegno internazionale di studi: Orta San Giulio, 2-7 settembre 1987. Orta San Giulio, 1989. 430 p. (In Italian) 
УДК 82 I.I34.2 + 821.I6I.I ББК $83.3(4$ Исп)

\section{ПЕТЕРБУРГ - ПАРИЖ - ГЕТТИНГЕН - МАДРИД: СЮЖЕТ ИЗ ИСТОРИИ ИСТОРИИ ИСПАНСКОЙ ЛИТЕРАТУРЫ}

\author{
(C) 2020 г. М.Ю. Игнатьева (Оганисьян) \\ Государственная школа иностранных языков \\ Драссанес, Барселона, Испания \\ Дата поступления статьи: І5 июня 2019 г. \\ Дата публикации: 25 июня 2020 г.
}

DOI: IO.22455/2500-4247-2020-5-2-IO2-I23

Аннотация: В статье рассматривается один из малоизвестных сюжетов истории Истории испанской литературы: от первых попыток описания и систематизации в XVIII в. до появления обзоров испанской литературы на страницах русских журналов в 2о-е гг. XIX в. В задачи исследования входит реконструкция основных этапов истории испанской литературы этого периода и их особенностей. Перипетии родившейся в лоне Просвещения истории испанской литературы показывают, как постепенно эта история открывала глаза на самое себя, часто благодаря иностранным переводчикам и комментаторам. Автор восстанавливает историю возникновения испанской темы в русской литературе (от Карамзина до Булгарина). Затем исследуются источники булгаринского «Взгляда на Историю Испанской Литературы» (первый обзор истории испанской литературы на русском языке): от Сисмонди до Бутервека и Дитце. Таким образом, автор приходит к отправной точке истории испанской литературы сочинению просветителя Х.Л. Веласкеса, «Истории испанской поэзии» (I754). Особое внимание уделено «Запискам по Истории Поэзии и Испанских Поэтов» Мартина Сармьенто (I745) и «Поэтике» Игнасио де Лусана (I737) как двум догматизирующим и мифологизирующим взглядам на роль литературы в истории нации.

Ключевые слова: история испанской литературы, Булгарин, Сисмонди, Дитце, Веласкес, Лусан, Сармьенто.

Информация об авторе: Мария Юльевна Игнатьева (Оганисьян) - кандидат филологических наук, доцент, преподаватель русского языка, Барселонская Государственная Школа Языков Драссанес, EOIBD, av. Drassanes, I4. Barcelona 08005 Еspaña; НИУ ВШЭ, Департамент общей и прикладной филологии, Старая Басманная ул., д. 2I/4, I05066 г. Москва, Россия. ORCID ID: о0оо-о0оI-97I43582

E-mail: maria.ignatieva@gmail.com

Для цитирования: Игнатьева (Оганисьян) М.Ю. Петербург - Париж - Геттинген Мадрид: сюжет из истории Истории испанской литературы // Studia Litterarum. 202O. T. 5, № 2. C. IO2-I23. DOI: IO.22455/2500-4247-202O-5-2-IO2-I23 


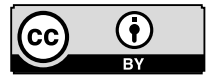

This is an open access article distributed under the Creative Commons Attribution 4.0 International (CC BY 4.0)

\section{PETERSBURG - PARIS - GÖTTINGEN - MADRID: A STORY FROM THE HISTORY OF THE HISTORY OF SPANISH LITERATURE}

\author{
(C) 2020. M.Iu. Ignatieva (Oganissian) \\ Escola Oficial d'Idiomes de Barcelona (Drassanes), \\ Spain \\ Received: June I5, 2019 \\ Date of publication: June 25, 2020
}

\begin{abstract}
The article discusses one of the little-known plots of the history of the History of Spanish literature: from the first attempts to describe and systematize it in the $18^{\text {th }}$ century until it appeared in the pages of Russian journals in the I820s. The objectives of the study include the reconstruction of the main stages of the history of Spanish literature of this period and description of their features. The ups and downs of the history of Spanish literature born in the age of Enlightenment show how it gradually became famous thanks to foreign translators and commentators. The author restores the history of the emergence of the Spanish theme in Russian literature (from Karamzin to Bulgarin), followed up by the analysis of the sources of Bulgarin's "A Look at the History of Spanish Literature" (the first review of the history of Spanish literature in Russian), from Sismondi to Bouterwek and Ditze. Thus, the author comes to the starting point of the history of Spanish literature - the composition of the enlightener J.L. Velazquez, “Orígenes de la poesía española” (I754). Particular attention is paid to the "Memorias para la historia de la poesia y poetas españoles" by Matin Sarmiento (I745) and "La Poetica” by Ignacio de Luzan (I737) seen as two dogmatizing and mythologizing views on the role of literature in the history of the nation.
\end{abstract}

Keywords: history of Spanish literature, Bulgarin, Sismondi, Dieze, Velásquez, Luzán, Sarmiento.

Information about the author: Maria Iu. Ignatieva (Oganissian), PhD in Philology, Associate Professor, Russian Language at the State School of Idioms Drassanes, EOIBD, av. Drassanes, I4. Barcelona o8005 España; National Research Institute Higher School of Economics, Old Basmannaya St. 2I/4, I05066 Moscow, Russia. ORCID ID: oOoo-oooI-97I4-3582

E-mail: maria.ignatieva@gmail.com

For citation: Ignatieva (Oganissian) M.Iu. Petersburg - Paris - Göttingen - Madrid: a Story from the History of the History of Spanish Literature. Studia Litterarum, 2020, vol. 5, no 2, pp. IO2-I23. (In Russ.) DOI: IO.22455/250O-4247-2O2O-5-2-IO2-I23 


\section{В сумерках бенедиктинской кельи. Мартин Сармьенто}

Истоки истории испанской литературы стали предметом специальных исследований испанских ученых в конце XX - начале XXI вв. (см., например: [I8; 2I; 23]) Ниже мы постараемся описать основную траекторию первого периода этой истории (XVIII - первая треть XIX вв.), дополнив ее сюжетную линию русским материалом. В нашу задачу входит реконструкция основных этапов истории испанской литературы этого периода и выявление их особенностей: создание корпуса авторитетных источников испанской литературы, переводов и переложений главных текстов этого корпуса, а также их рецепции в России.

B I74I г. папский нунций в Мадриде Сильвио Валенти Гонзага имел беседу с бенедиктинцем Мартином Сармьенто о поэзии. Удивленный широтой эрудиции своего собеседника, нунций попросил его записать все, что тому было известно об испанских поэтах прежних времен. Сармьенто за четыре года выполнил поручение и отправил свое сочинение Гонзаге, который к тому времени вернулся в Рим уже в сане кардинала. В послании, сопровождавшем рукопись, автор предуведомлял своего адресата: «Записки на пятидесяти листах, которые я посылаю Вашему превосходительству, доходят только до времени Католических королей. Хотя они и названы “Записки по Истории Поэзии и Испанских Поэтов”, это неоправданно многообещающий заголовок, я не стер его только потому, что не хотел множить черновики. Так что под нынешним названием предполагается другое: “Черновые записки”. Так как я не выхожу из своей кельи и ни с кем не общаюсь на темы, связанные с литературой, я вынужден был довольствоваться тем 
немногим, что у меня было под рукой, и досадовать на себя за свою неловкость. В напечатанных книгах имеется мало новых сведений, при том, что в архивах и библиотеках Испании хранится множество рукописных сборников песен и романсеро, и там можно найти многих древних испанских поэтов и испанские стихи, которые, пылясь в углах, воюют с древоточцами и молью» [25, с. XXIII].

Сармьенто (I695-I772) предупреждал, что пишет всего лишь «записки»: «..не для истории, но лишь для высказывания некоторых догадок» [25, c. I6]. Недаром его сочинение было опубликовано только в 1775 г., три года спустя после смерти автора. Этот текст, созданный в келье, тем примечательнее, что именно здесь впервые упоминается и первый известный по имени испанский писатель - Гонсало де Берсео, такой же монастырский сочинитель, как и сам Сармьенто ${ }^{\text {. }}$

Так начиналась «история испанской литературы», одну из множества сюжетных линий которой мы и попытаемся прочертить в этой статье, речь пойдет о той части литературы, которую в XVIII в. было принято называть «поэзией» ${ }^{2}$. «Следует отграничить понятие “поэзии” от “красноречия”, пишет Родригес Айон. - Поэзией, то есть сочинениями в стихах, занималась Поэтика, в то время как сочинениями в прозе, красноречием, занималась Риторика. <...> Противоречие между реальностью и теорией привело к тому, что веками литературой считалось только написанное в стихах, но не в прозе. <...> К поэзии относились лирические стихи, эпические поэмы, комедии и трагедии, представлявшие собой драматическую поэзию» [23, c. 324].

В сумерках бенедиктинской кельи под пером брата Мартина мысли, сведения, чувства и чаяния смешивались в единый текст, жанр которого сам он определил в тон освещению - «черновик». На другом конце нашей сюжетной линии - ярко озаренный балкон, с которого незнакомка в мантилье улыбается русскому поэту. Начнем же с конца, чтобы постепенно вернуться к Сармьенто, чтобы с бо́льшим вниманием и, возможно, сочувствием прочитать несколько фрагментов из его сочинения.

I См. о Берсео нашу статью: [6].

2 Тогда понятие «литература» охватывало различные виды знаний: искусства, науки, эрудицию. 


\section{История одной мантильи.}

\section{Ф.В. Булгарин - первый русский испанист?}

Скинь мантилью, ангел милый,

И явись как яркой день!

(А.С. Пушкин, «Ночной зефир», І824)

Незнакомка - испанская поэзия - не сразу явилась вниманию русского читателя как яркой день. Под мантильей скрывались то француженки, то немки, пытавшиеся говорить по-русски с испанским акцентом. История появления этого акцента начинается в І789 г., в Веймаре. Двадцатитрехлетний Карамзин шагает по вечернему Веймару, останавливается рядом с домом, где живет Гёте, а тот как раз выглянул в окно. Карамзин загляделся на Гёте: «...остановился и рассматривал его с минуту: важное греческое лицо!» На следующий день Карамзин спешит представиться Гёте, но поэт уехал в Йену. Впрочем, в городе «есть еще и другие известные писатели: Бертух, Боде и проч. Бертух перевел с гишпанского “Дон-Кишота” и выдавал “Магазин гишпанской и португальской литературы”; а Боде славится переводом Стернова “Путешествия” и “Тристрама Шанди” [8, с. 77].

Упомянутый Фридрих Юстин Бертух (I747-I822) перевел на немецкий и напечатал еще в I780 г. в своем журнале, посвященном испанской литературе, романс о графе Гвариносе, который Карамзин и перевел на русский язык, вероятно, во время своего путешествия³. Первые два стиха этой «Древней гишпанской исторической песни», как назвал ее русский переводчик, распевает хлебопашец в девятой главе второй части «Дон Кихота». Возможно, отсюда и возник интерес Бертуха, переведшего роман, к этому романсу.

Текст в обоих переводах, немецком и русском, состоит из I52 стихов - против г7о стихов в оригинале. Бертух перевел романс по возможности рифмованным стихом, что соответствует оригиналу, в котором четные стихи связаны ассонансной рифмой. Карамзин полностью отказался от рифмы.

Худо, худо, ах, французы,

В Ронцевале было вам!

3 Интересно, что оба они - Карамзин и Бертух - изобрели для своих языков и слово «промышленность». 
Карл Великий там лишился

Лучших рыцарей своих.

$$
\text { [9, с. 22-23] }
$$

Сюжет романса таков: рыцарь Карла Великого по имени Гваринос оказался в плену у мавританского короля Марлотеса. Последний предложил пленнику принять ислам, а взамен получить руку его дочери и всю Аравию. Гваринос отказался и за это был брошен в темницу. В день святого Иоанна Марлотес устроил праздничный турнир. Никто из собственных рыцарей короля не мог попасть в цель, повешенную слишком высоко. Гваринос уговорил короля позволить ему участвовать в состязании. Семь лет он просидел в темнице, доспехи его покрылись ржавчиной, конь все годы возил известь (у Бертуха - известь и камни, у Карамзина - песок), и все же он сумел копьем поразить цель, а затем, одолев разъяренных его победой мавров, улетел чудесным образом в родную Францию, где его приняли со всякими почестями.

Карамзинский перевод задал своеобразный генетический код, определивший на десятилетия вперед образ и бытие одной из главных испанских тем в русской поэзии. Назовем этот код рыцарским: испанец - это воин-монах, стойко преодолевающий вражеские искушения и гонения, «бенефициар» прижизненных или посмертных чудес ${ }^{4}$. Но не только смысловой код передал Карамзин. «Следует отметить, - пишет Ю.М. Лотман, - что именно Карамзин выработал русскую ритмическую систему для передачи формы испанского романса средствами русской поэзии. Ее в дальнейшем использовал Пушкин (ср. “На Испанию родную... ”)» [І3, с. 380].

Упомянутые Ю.М. Лотманом стихи Пушкина (сокращенный перевод начала английской поэмы Р. Саути «Родрик, последний из готов») подобны трехчастному вееру, раскрывающему полный рисунок испанской темы: мужественный воин становится аскетом, а затем, сподобившись чудесного видения, возвращается в мир, чтобы там побеждать врагов и обрести покой в душе. Так, первым русским «испанским» стихотворением стал романс о

4 Ср. «С другой стороны, переводу этого романса, сделанному Карамзиным с немецкого перевода и впервые опубликованному в Москве в I792 г., суждена была долгая популярность не только в литературе; положенный на музыку, он исполнялся на театральных сценах и проник в народную среду, что свидетельствует о широкой известности, которой он пользовался в течение нескольких десятилетий» [г, с. І89]. 
графе Гвариносе, переведенный Н.М. Карамзиным с немецкого стихотворного перевода Ф.Ю. Бертуха.

Увлечение Испанией 5 пришло в Россию из Франции, где в 2о-е гг. XIX столетия испаномания, по словам А.Д. Михайлова, захватила широкие литературные круги: «Причины этих увлечений понятны. Для многих романтиков Испания была наиболее близкой страной, пронизанной экзотикой, тем местом, где Европа смыкалась с красочным, загадочным арабским Востоком» [14, с. 27].

Не случайно именно в І824 г. Пушкин написал свое первое «испанское» стихотворение: годом раньше в «Сыне Отечества» появились «Воспоминания об Испании» [3], а в г82г - «Взгляд на Историю Испанской Литературы», принадлежавшие перу Фаддея Бенедиктовича Булгарина [2], которого и следует, по всей видимости, считать первым русским историком испанской литературы ${ }^{6}$.

Булгарин и сам был героем испанского плутовского романа, пикаро, Ласарильо, гениально разыгравшим все слабые и нелепые карты, которые ему подкидывала фортуна. Исследователь наследия Ф.В. Булгарина А.И. Рейтблат пишет: «Биография Булгарина поражает причудливыми извивами и поворотами. Для Булгарина жанр плутовского романа, к которому он не раз обращался в своем творчестве, не только литературная традиция; он сам, подобно плуту-пикаро, прошел “огонь, воду и медные трубы”, с легкостью перемещался в географическом (Польша - Россия Германия - Франция - Испания) и социальном (офицер-кавалерист - за-

5 Перевод Карамзина предшествовал грядущей испаномании. «В европейской литературе конца XVIII в. пора увлечения испанскими романсами еще не наступила» [І2, c. Iо4]. Эта пора наступит спустя тридцать лет, подобно тому как «российское испанофильство» проснется во время гражданской войны в XX в. (ср.: [г2, с. Iо9]). Так же и в 2о-е гг. XIX в. peволюция в Испании, «либеральное трехлетие» 1820-I823 гг., послужит политическим фоном эстетическому увлечению пиренейским колоритом.

6 В эти годы Пушкин относился к Булгарину с уважением, примером чему может служить следующее письмо, написанное поэтом Булгарину в феврале 1824 г.: «С искренней благодарностью получил я I-й № “Северного архива”, полагая, что тем обязан самому почтенному издателю, с тем же чувством видел я снисходительный ваш отзыв о татарской моей поэме. Вы принадлежите к малому числу тех литераторов, коих порицания или похвалы могут быть и должны быть уважаемы. Вы очень меня обяжете, если поместите в своих листках здесь прилагаемые две пьесы. Они были с ошибками напечатаны в “Полярной звезде”, отчего в них и нет никакого смысла. Это в людях беда не большая, но стихи не люди. Свидетельствую вам искреннее почтение. Пушкин. Одесса. г февраля г824 г.» [15, т. 9, 79]. 
ключенный - стряпчий - литератор - издатель) пространстве, общался с представителями самых разных социальных слоев и приобрел в результате богатейший и многообразнейший жизненный опыт. Сближает его с героем плутовского романа и тот факт, что при внешней инициативности он всегда стремился не переделать окружающую среду, а приспособиться к ней, действовать в зависимости от обстоятельств» [16, с. 13].

Будучи офицером наполеоновской армии, Булгарин побывал в Испании и оставил «Воспоминания об Испании» - «офицерский рассказ для друзей моих» [3: Предисловие]. Это сочинение, как хорошо показала Л.Н. Киселева, подчинялось конкретным стратегическим задачам: Иисторический контекст для публикации был <...> выбран осмысленно. Либерально мыслящую часть русского общества, сочувствующую испанской революции начала І820-х гг., должен был привлечь сам объект, а также описание героического сопротивления испанцев завоевателям, картины народной войны, параллели с Отечественной войной I8I2 г. С другой стороны, сочувственный рассказ Булгарина о судьбе испанских Бурбонов вполне укладывался в официальную реакцию русского правительства на те же испанские события начала І820-х годов» [1о, с. 93].

Тем не менее, несмотря на стратегичность акцентов и компилятивный характер многих страниц, все же есть в «Воспоминаниях» собственные, живые описания Испании. Заметки Булгарина интересны не только фактами и меткими наблюдениями, но и тем образом Испании, который создает автор и который, несомненно, повлиял и на последующую рецепцию Испании в русской литературе. Булгарин восторженно описывает картины южной природы: «Северный житель, по самому красноречивому описанию, не будет иметь о нем слабого даже понятия. <..> Миртовые, померанцевые и лимонные рощи, оливковые деревья, тысячи разнородных трав и цветов наполняют воздух сладостным благоуханием» [3, с. II].

Будто в противовес дивной природе, жители и города вызывают у нашего автора брезгливую гримасу: «Как в одежде, так и в домах они (испанцы. - М.И.) весьма неопрятны; у самых богачей домы весьма посредственно меблированы и без всякого вкуса. <... Бедные гидальгосы и простой народ, по большей части, спят на соломе. В деревенских трактирах нет ни столов, ни стульев: сидят, едят и спят на полу» [3, с. 6]. 
В том, что касается благочестия, испанские бедняки чрезвычайно набожны, а дворянство предано вольнодумству: «Церквей и монастырей невероятное множество. В одном Мадрите считается оных 6оо. Богатство храмов чрезвычайное. <...> Народ чрезвычайно набожен; но большая часть дворянства только из благопристойности следует общим обыкновениям. Зловредное вольнодумство посеяло уже там горькие семена свои, и между дворянами находится множество последователей философии XVIII в.» [3, c. 6-7].

Булгарин отмечает и рыцарский характер испанской поэзии: «Баллада есть народная собственность Испании: содержание сих стихотворений всегда рыцарское и сверхъестественное, и как француз несет с собою в поход рапиры, испанский солдат несет гитару» [3, с. 8].

Эти булгаринские описания и сейчас читаются с интересом. Можно вообразить, что во времена, когда об Испании знали больше со слов французов, а по-русски припоминали в первую очередь карамзинское «Худо, худо, ах, французы, // В Ронцевале было вам!»7, «Воспоминания» создавали в русском культурном поле ту испанскую нишу, в которой так живо и естественно в I830 г. пушкинская Лаура выйдет на балкон, чтобы отмахнуться от сурового дона Карлоса и уже издалека, с юга, поглядеть на Париж: «А далеко, на севере - в Париже...».

В процитированных фрагментах из первых, вводных, воспоминаний Булгарина имплицитно содержатся черты основных жанров испанской литературы предшествующих эпох: рыцарский роман, плутовской роман, трагикомедия, романсеро. Пока же Булгарин издает «Взгляд на Историю Испанской Литературы»: «Со времени упадка народной славы и могущества Испании, то есть от конца царствования Карла V, ученая Европа вовсе не занималась Испанскою Литературою. Едва ли несколько Романов и Баллад, переведенных на иностранные языки, извещали о ея существовании. Наконец, в наше время Немцы первые расторгли завесу, сокрывавшую от глаз литераторов красоты Испанской Словесности, и ученою критикою освежив увядающие лавры великих мужей, возбудили желание в любителях изящного обратить внимание на их творения. Шлегель, Дице и Бутер-

7 Разумеется, следует учитывать рецепцию «Дон Кихота» и новелл Сервантеса, знакомого русской читающей публике по французским переводам, а также по переводам на русский, появившимся в XVIII в. См.: [II]. 
век, славные Эстетики Германские, познакомили своих единоземцев с произведениями пылкого воображения благословенной Гесперии, а Сисмонд Сисмонди, шествуя по их следам, издал на Французском языке сочинение: О Литературе южных стран Европы» [2, с. 289-290].

Упомянутое Булгариным сочинение Сисмонди и послужило ему основой для журнальной статьи. Жан Шарль Леонар Симонд де Сисмонди (I773-I842), швейцарский историк и экономист, написал, на основе прочитанного им в Женеве курса, четырехтомный обзор южноевропейских литератур, «Литературу южной Европы» $\left(\right.$ г8г3) ${ }^{8}$.

Булгарин очень близко следует за Сисмонди, его пересказ часто граничит с переводом. Так, Булгарин пишет: «Язык Испанский богатый и звучный превосходит все одноплеменные языки важностию, протяжностию в произношении и каким-то торжественным тоном, с коим Испанцы произносят выражения самые обыкновенныя. Со всем тем, по свидетельству ученых Критиков, он не столько возделан и утвержден правилами, как языки других просвещенных народов, и потому не имеет надлежащей точности и гибкости; высокопарность же его часто приближается к надутости» [2, c. 29I-29I].

А вот текст Сисмонди: «Испанский язык более звучный, чем другие языки, слова в нем произносятся очень четко и с придыханием, в нем есть нечто более торжественное, твердое, внушительное; с другой стороны, поскольку философы и ораторы пользовались им меньше, чем итальянским, ему недостает гибкости и точности, и в своей величественности он не всегда ясен, а его высокопарность не лишена надутости» [26, с. I04-I05].

Булгарин целиком основывается на сочинении Сисмонди, при этом невольно придавая его тексту ту самую испанскую «высокопарность» и «надутость», над которой иронизировали оба автора. Позднее, в г823 г., в пылу полемики Булгарин проговорится. Обвиняя А.Ф. Воейкова, издавшего в «Собрании Образцовых Русских сочинений и переводов», в частности, сведения о «Истории иностранных Словесностей» (выражение Булгарина), в недобросовестном изучении имеющейся литературы, Булгарин объявля-

8 Известно, что Пушкин в марте г825 г. просил брата прислать ему это сочинение, но в І82I г., вероятнее всего, поэт держал в руках журнал со статьей Булгарина. См. письмо Л.С. Пушкину: «Душа моя, горчицы, рому, что-нибудь в уксусе - да книг: Conversations de Byron, Mémoires de Fouché, “Талию”, “Старину”, да Sismondi (littérature), да Schlegel (dramaturgie), если есть у St. FlorentI)» [15, т. 9, с. I28]. 
ет, что сам он ею не пользовался, т. е. сам немецких историков не читал: «Между сими Историями ${ }^{9}$ нет никакой общей связи: каждая написана по особому расположению; источники Автора были притом самые недостаточные. Он не хотел заглянуть в сочинения Бутервека или Эйхгорна, которые доставили бы ему богатые и достоверные материялы, но брал где что попадалось <...>. История Литературы Испанской также большею частью заимствована из статьи, которую я наскоро извлек из Сисмонди» [4, с. 6].

Однако стоит серьезно отнестись и к булгаринскому пересказу Сисмонди (сорок страниц бойкого, а главное, первого повествования об испанской литературе на русском языке), и к его критике Историй, изданных Воейковым. Булгаринские сочинения послужили романтизации Испании. «В Испании Амур не чужестранец» - так начинается сонет А. Дельвига, написанный при посылке книги испанских воспоминаний Булгарина (I823). Испанский амур «и к нам, всесильный не суров, // и к северу мы зрим его вниманье», он «всю тебя одел в очарованье!» Булгарин «одел в очарованье» испанскую литературу, поглядев на нее глазами русского, прочитавшего швейцарца. А тот, в свою очередь, пересказал «ученых немцев». Подобно тому, как Карамзин перевел с немецкого испанский романс и создал первое «русское испанское стихотворение», так же и в истории испанской литературы пути ведут в Германию.

\section{«Славные эстетики германские»: Бутервек и Дитце}

В Германии в середине XVIII в. наблюдается антифранцузская реакция, «которая заставила ученых и литераторов обратиться к другим европейским литературам, главным образом к английской и испанской» [23, c. 322]. В самом начале XIX в. И.Г. Гердер издает свою обработку романсов о Сиде (г8ог), а А.В. Шлегель публикует свои переводы пьес Кальдерона (г803-I804) ${ }^{\text {Iо }}$. Гений Кальдерона стал известен Шлегелю благодаря «Истории испанской литературы» (I8о4) Фридриха Бутервека (г766-г828) и предварявшим ее лекциям в Геттингене ${ }^{\text {I. }}$ «Трудно представить себе, - пи-

9 Они были написаны профессором И.Е. Срезневским.

го Шлегель перевел «Поклонение кресту», «Любовь, величайшее колдовство», «Лента и цветок», «Стойкий принц» и «Мантибльский мост».

II Имя Бутервека вновь приводит на память Карамзина: в I792 г. тот опубликовал в своем «Московском журнале» перевод статьи Бутервека «Аполлон». Как пишет Н.К. Гаврюшин, «Карамзин остановил выбор на этой статье не случайно: он почувствовал в ней пафос 
шет Роджер Полин, автор биографии Шлегеля, - сколькими познаниями Шлегель обязан Фридриху Бутервеку, своему современнику, с которым он пересекался в Геттингене <...>. Когда позднее Шлегелю понадобилось изложить историю испанской драмы, он обратился к Бутервеку и иже с ним (хотя и не всегда признавал это)» [ 22, с. 48-49].

Труд Бутервека был переведен на несколько языков, и лишь в последнюю очередь - на испанский ${ }^{\text {I2 }}$. Сам Бутервек, в свою очередь, был обязан интересом к испанской литературе Иоганну Андреасу Дитце (I729-I785): тот перевел и дополнил собственными комментариями первую систематическую историю испанской поэзии, которую написал Луис Хосе Веласкес (1722-I772). Речь о ней, следуя логике нашего рассказа - от будущего к прошлому - пойдет в следующей главе. А пока несколько слов о заслугах Дитце перед историей испанской литературы. Дитце опубликовал в I769 г. «Историю испанской поэзии, переведенную с испанского, с комментариями». Он дополнил текст Веласкеса новыми данными, важными биографическими сведениями и библиографическими ссылками.

Дитце собрал в Геттингене превосходную библиотеку испанской литературы, именно здесь зарождалась немецкая испанистика, сочетавшая в испанском идеале просветительскую жажду знаний и романтическую риторику. Ленский «с душою прямо геттингенской» пародирует этот идеал: туманная немецкая ученость и вполне испанская «восторженная речь и кудри черные до плеч». То же соединение холодной академичности

родственной души и увидел эстетическую программу, которую сам был готов разделить» [5, с. І40]. Идеализирующее поэзию отношение, как мы увидим, стало нитью, связывавшей первых историков испанской литературы с теми, кто последовал за ними в России в XIX в. Интересно, что в Лицее Пушкин слушал лекции профессора Георгиевского, возможно, увлеченного эстетическими идеями Бутервека. Вот запись из лицейского дневника Пушкина (I8I5): «Вчера не тушили свечек; зато пели куплеты на голос: “Бери себе повесу”. Запишу, сколько могу упомнить:

\section{На Георгиевского}

Предположив - и дальше

На грацию намек.

Ну-с - Августин бого́слов.

Профессор Бутервек» [15, т. 8, с. гі].

I2 Авторы предисловия к испанскому изданию сетовали: «Поистине позорно для нас, что эта История Испанской Литературы уже тому немало лет как была переведена на другие языки культурной Европы, в то время как в Испании она была известна лишь по нескольким экземплярам французского перевода» [I9, IV]. 
и теплого сочувствия к персонажам истории литературы отличает комментарии Дитце ${ }^{\mathrm{I} 3}$.

Ранее мы обратили внимание на привязанность Сисмонди и Шлегеля к Кальдерону. Именно в оценке испанской драматургии, составившей ее последующую славу, «ученые немцы» оказались проницательнее своих испанских предшественников. Дитце исправляет, дополняет и извиняет строгие суждения о драматургии Лопе де Вега и Кальдерона, высказанные неоклассицистами - Веласкесом и авторами, которых обильно цитирует последний: Насарре (г689-I75I) и Монтиано (г697-I764). Интересно, что немцы открыли Кальдерона, отталкиваясь от сведений, полученных у его недоброжелателей. Как справедливо пишет Санчес, нападки на Лопе или Гонгору были «частью стратегии по распространению их сочинений, а эта стратегия у эрудита Лусана была фирменным знаком» $[24$, с. 72$]$.

\section{История - поэтика: Веласкес и Лусан}

Интерес к собственной национальной истории, включая историю литературы, развился именно в эпоху Просвещения. «Сознание своего отличия, - пишет Алварес Барриентос, - стимулировало, вместе с понятием историцизма и прогресса, появление национального и патриотического чувства, столь характерного для лучших людей XVIII в. Хотя слово “патриот” задокументировано еще в XVII веке, именно в восемнадцатом оно приобретает значение компромисса с политической национальной идеей» [I8, c. IO2].

Научный прогресс сопровождался финансовой поддержкой со стороны правящей династии, стремившейся отметить этот прогресс декором национального достоинства, а также одновременно повести его в сторону большей независимости от других держав, включая Римский престол. Одним из таких проектов стало создание, по заказу короля Фернандо VI, «Общей истории нации», порученное Л.Х. Веласкесу, автору первой систематической истории испанской литературы.

I3 Ср. «Биографии, добавленные Дитцем к тексту Веласкеса, восхищают широтой и надежностью документации; имеют они и другое, не менее важное значение: помимо холодных познавательных фактов, чувствуется внимание к человеческим внутренним движениям и чертам характера, которые можно извлечь из фактов» [2I, с. 3Іо]. 
Луис Хосе Веласкес, маркиз де Вальдефлорес, стоит в ряду испанских ученых и эрудитов XVIII в.; он был наравне с известными деятелями испанского Просвещения - Агустином Монтиано, Бласом Антонио Насарре и Игнасио де Лусаном (I702-I754) - членом Академии хорошего вкуса (I749-I75I). Это его «История испанской поэзии» оказалась в руках у Дитце, который и перевел ее, и дополнил новыми сведениями и более объективными оценками. Перечислим главные заслуги автора «Истории испанской поэзии»:

I) это первое описание истории испанской литературы по эпохам и стилям: от варваров до современников;

2) Веласкес первым ввел в оборот термин «Золотой век» по отношению к эпохе второй половины XVI - первой половины XVII вв.;

3) здесь впервые были определены понятия консептизма и культеранизма, ставшие опорными в большинстве учебников по испанской литературе.

Буквальный перевод названия труда Веласкеса (Orígenes de la poesía castellana) звучит так: «Происхождение (источники) кастильской поэзии». Слово orígenes указывало на одну из задач как просветительского, так и политического проекта: помимо поиска национальных корней, о котором говорилось выше, это слово, как указывает Родригес Айон, несло «резонанс престижа» [23, с. 35]: авторитетный труд просветителя Грегорио Майанса назывался Orígenes de la llengua española («Происхождение испанского языка»). Этот же термин появляется в целом ряде последующих трудов, вплоть до Orígenes de la novela («История романа») Менендеса Пелайо и Orígenes del español («История испанского языка») Менендеса Пидаля. Лишь тогда, когда были сформированы основы испанской литературной историографии, благодаря в первую очередь трудам двух последних упомянутых ученых, «источники» уступили место «истории». Несмотря на то что Веласкес пишет именно историю (не случайно Дитце, переводя его труд, в заголовке указывает Geschichte («история»), тем не менее его описание озарено факелом первопроходца: даже рассказывая о современниках, Веласкес не упускает из виду того, что́ является подлинным (оригинальным), заслуживающим внимания. В этом смысле его труд тесно соприкасался с поэтикой и носил прескриптивный характер. 
В этой статье мы не станем подробно рассматривать сочинение Веласкеса ${ }^{\mathrm{I}}$, а отправимся дальше вглубь XVIII в., где испанские просветители обсуждают правила хорошего вкуса в литературе.

Это интересный случай, когда теория запаздывает и не успевает осознать величие практических завоеваний. Историки и теоретики были движимы идеалом канона и правил, хорошего вкуса и совершенства формы. Пушкинский Сальери учил Моцарта жить, но не объяснял ему, как следует писать музыку. Здесь же «ремесленники совершенства» воспринимали весь Золотой век испанского барокко как оплошность, ошибку, падение (decadencia).

В I737 г. доминиканец Игнасио Лусан издал знаменитую «Поэтику», «первый испанский манифест неоклассицизма» ${ }^{15}$. В этом манифесте Лусан сетует: «Разумеется, если бы какой-нибудь Лопе де Вега, Педро Кальдерон, Солис или им подобные прибавили к своим большим природным дарованиям образование и мастерство, то появились бы у нас в Испании комедии такие, что прочие нации стали бы восхищаться и завидовать, а между тем сейчас их сочинения, по большей части, служат предметом критики и осмеяния» $[20$, с. 5$]$.

В качестве «отцов испанских муз» Лусан называет маркиза де Сантильяна, Хуана Боскана, Диего де Мендоса, Гутьерре де Сетина и Гарсиласо де ла Вега (последнего он величает «принцем испанской лирики») и скорбит о «вырождении», последовавшем за этой плеядой. «Я бы погрешил против правды, если бы умолчал о том, кто именно первым ввел эти несчастные перемены: Лопе де Вега Карпио и Луис де Гонгора!» [20, с. I8]. «Лопе де Вега изобрел какую-то свою новую систему, или искусство комедии, противу правил лучших мастеров, и чернь, гоняющаяся за своей излюбленной приманкой - новизной, приучила свой слух, свою речь и аплодисменты ко всему неправильному и экстравагантному» [20, с. I8].

Так же строго Лусан судит и Кальдерона, не прощая ему своенравной игры с неприкасаемыми концептами ${ }^{16}$. Новая, собственно испанская, не

I4 Наша статья «Первая история испанской литературы: Луис Хосе Веласкес, маркиз де Вальдефлорес» выйдет в специальной монографии ИМЛИ, посвященной истории Истории литературы.

I5 «Не будучи явлением оригинальным, “Поэтика” Лусана интересна как первый манифест классицизма в Испании» [17, с. 282].

I6 Вот образец его критики. Любовь, говорит Лусан, принято сравнивать с огнем, «а безудержная фантазия многих поэтов вывела из этой метафоры тысячу ребяческих софизмов 
итальянизированная поэзия сдвинула тектонические пласты классической лирики, обнаружив не столько возможности изобретательной фантазии (как считал Лусан), но и новые способы владения речью для понимания нового мира. Лусан остается в прошлом, и сам это чувствует. «Я верю, что иные почитатели упомянутых авторов и их образов не одобрят моей цензуры и, пожалуй, еще и назовут дерзостью то, что для меня всего лишь - любовь к истине; и, не рассудив моих резонов, осудят мои слова лишь потому, что они противоречат мнениям тех, о ком они заботятся, и славе поэтов, которых считали до сих пор безупречными» [20, с. I76-I77].

«Невежественной черни, полной страстей» противопоставляет Лусан «суд бесстрастных ученых». Лусан, так противившийся соединению фантазии и реальности, утверждает свою истину на умышленной твердыне неоклассицистской фантазии: «Подлинная поэзия покоится на правде и состоит из подлинных совершенств, а не из разладов и призрачных иллюзий. Человеческому разумению, воспитанному для того, чтобы познать правду, если только оно не развращено и не испорчено, никогда ложное не покажется прекрасным» [20, с. I78].

Первая систематическая история испанской литературы - сочинение маркиза де Вальдерфлореса - возникла в кругу неоклассицистов, и это не случайно: истории литературы предшествовала поэтика, в которой была описана и классифицирована, с точки зрения хорошего вкуса, современная историку литература (напоминаем, что речь идет исключительно о текстах, написанных в стихах).

и тысячу ложных и пустых понятий. Любовь, говорит один из этих поэтов, есть огонь, а плач - вода; воде свойственно гасить огонь, так почему же мои слезы не гасят мой любовный огонь? Таков образ (concepto) в одной строфе Кальдерона:

Ardo y lloro sin sosigo,

llorando y ardiendo tanto,

que ni al fuego apaga el llanto,

no al llanto consume el fuego.

(«Горю и плачу неустанно, // так плача и горя, // что ни огонь не осушает плача, // ни плач не угашает огонь».)

Ясно же, что настоящий огонь гасится водой, но не воображаемый огонь любви», и Лусан то ли дело Тассо в “Аминте”, где

De llanto se alimenta el inhumano

Cupido, y aún no queda jamás sacio («Бесчеловечный Купидон насыщается плачем, и никогда не может насытиться»)» [20, p. 175].

То есть настоящий плач может питать, не насыщая, воображаемого Купидона, но воображаемый огонь никак не может иметь дело с настоящими слезами. 


\section{Возвращение к началу: Сармьенто}

Сармьенто создавал ночной текст, где любовь к Поэзии, родившейся в раю, сияла сильнее дневного света. «Ты, ночь, меня водила нежнее, чем рассвет», - писал Иоанн Креста (I542-I59I), поэт, оставшийся вне поля внимания первых историков испанской литературы: и потому, что был малоизвестен вне кругов ордена кармелитов, и потому, что не вписывался ни в неоклассицистские, ни в барочные рамки.

Спустя семь лет после издания Лусановой поэтики Сармьенто посылает свой текст кардиналу Гонзаге. У двух образованнейших людей своего времени - Сармьенто и Лусана - были разные задачи. Лусан - законодатель вкусов, он с особой заносчивой уверенностью в своем даже не праве, а долге публикует «Поэтику», стремясь воздействовать на литераторов и публику. Сармьенто - скромный историк, монах, пишущий по послушанию для памяти и будущих исследователей. Но у обоих мы встречаем характерное для человека Просвещения отношение к культуре как к некоему идолу: свет правильного знания просвещает ум и сердце. Мимо обоих проходит гениальность «беспорядочного», «беззаконного» Золотого века. Все золото для них - в прошлом. Вот почему и Веласкес, маркиз де Вадьдефлорес, придумавший термин «Золотой век», ошибается, применяя его: Лопе и Кальдерону он предпочитает трагедии Монтиано «Виргиния» и «Атаульфо», написанные по всем канонам классической трагедии, одаривая их высшей похвалой: он называет их «самыми правильными» [27, с. I02]. Уже следующее поколение историков испанской литературы, в лице Дитце и Бутервека, будет расставлять новые акценты, корректирующие иерархию писательских имен.

Мартину Сармьенто так же, как и Лусану и Веласкесу, была свойственна идеализация поэзии. Его записки - личное послание архиерею, в котором проникновенно и доверительно звучат его признания в любви к Поэзии (Сармьенто пишет это слово только с прописной).

Будучи первым историком, Сармьенто и сам обращается к первому поэту на земле. Им, по его убеждению, был прародитель Адам: «Ясно, что если Адам и написал какое-нибудь стихотворение, то оно воспевало его Творца» [25, с. II]. Здесь у Сармьенто точная интуиция о генетической связи лирики с гимнографией (см.: [7]). Если Лусан апеллировал к Гомеру [2о, $\mathrm{Al}$ Lector], то Сармьенто размышляет об Адаме и его поэтическом языке, 
пережившем потоп. «Я убежден, что в наши дни не сохранилось ни одного из тех первоначальных языков, которые появились в результате вавилонского смешения. Но делаю исключение для еврейского языка Писания, поскольку легко поверить, что в его исключительной сохранности есть нечто таинственное, тем более что именно на этом языке говорили Адам и люди до потопа. Точно так же бессмысленно было бы пытаться узнать, каким был первый язык Испании, на котором говорили ее жители. Я считаю только, что этот язык должен был быть связан с еврейским» [25, с. 36].

Неоклассицист Лусан категоричен, Сармьенто догматичен, и у обоих бьется сердце от райских звуков рифмованной речи. «Поэзия, - торжественно уверяет Сармьенто, - древнее прозы. Это означает не то, что люди сначала говорили стихами, а потом прозой, а то, что из оставшегося письменного наследия написанное стихами древнее того, что написано прозой. А все оттого, что речь и пение намного предшествует письменности» [25, c. 54-55].

Первые испанские историки литературы знали: Поэзия родилась в раю. Поэтому так важны ее дальнейшие приключения, успехи и падения, что она, по Горацию, цивилизует мир («О поэтическом искусстве», стихи 39I-404). Один из сюжетов этих приключений, рассказанный в нашей статье, можно было бы представить схематически цепочкой имен (теперь уже в хронологическом порядке - от прошлого к будущему): Лусан - Сармьенто - Веласкес - Дитце - Бутервек - Сисмонди - Булгарин. Первые Историки литературы остались в тени ее творцов. Однако, как мы видели, благодаря историкам поэзии, литературные сочинения пересекали границы времени и пространства и становились источником вдохновения для новых поэтов. 


\section{Список литературы}

Алексеев М.П. К литературной истории баллады «Граф Гваринос» // Алексеев М.П. Русская культура и романский мир. Л.: Наука, Ленингр. отд-ние, I985. C. 249-257. Булгарин Ф.В. Взгляд на Историю Испанской Литературы // Сын отечества. СПб., I82I, № 4O. C. 289-305, № 4I. С. 3-2I.

3 Булгарин Ф.В. Воспоминания об Испании. СПб: В тип. Н. Греча, I823. I86 с., IV.

4 Булгарин Ф.В. Ответ на антикритику, помещенную г. Воейковым в N 66 Рускаго инвалида касательно Образцовых сочинений, изданных гг. Воейковым же и Срезневским // Сын отечества. СПб., І823. № І 3. С. 3-33.

5 Гаврюшин Н.К. Мистический неоэллинизм и идеал «эстетической Церкви». Ф. Бутервек и Ф. Гельдерлин // Вопросы философии. 2005. № 3. С. I40-I48. Игнатьева (Оганисъян) М.Ю. «Жил на свете клирик бедный»: долг и упование Гонсало де Берсео // Знание. Понимание. Умение. 2016. № 4. С. 260-267. Игнатьева (Оганисьян) М.Ю. Гимнографические принципы испанской духовной поэзии Высокого средневековья // МедиаАльманах. 2017. Вып. 5. С. І52-І62. Карамзин Н.М. Письма русского путешественника. Л.: Наука, І984. 720 с. Карамзин Н.М. Полное собрание стихотворений. М.; Л.: Сов. писатель, г966. 423 с.

Iо Киселева Л.Н. Фаддей Булгарин о наполеоновских войнах: К вопросу о прагматике мемуарного текста // «Цепь непрерывного предания...»: Сб. памяти А.Г. Тартаковского. М.: РГГУ, 2004. С. 9I-IO4. Корконосенко К.С. Перевод с испанского в XVIII веке: «Прекрасная цыганка» Сервантеса // Русская литература. 2004. № 4. С. II8-I24. Корконосенко К.С. Испанская литература в русской печати (XVIII - I920-е годы) // Вестник РГНФ. 2009. № I(54). С. IO2-IIO. Лотман Ю.М. Комментарии к стихам Карамзина // Карамзин Н.М. Полное собрание стихотворений. М.; Л.: Сов. писатель, г966. С. 37І-403.

I4 Михайлов А.Д. Сервантес и Мериме // От Франсуа Вийона до Марселя Пруста. Страницы истории французской литературы Нового времени (XVI-XIX в.).

М.: Языки славянских культур, 20Iо. Т. II. С. 365-394.

I5 Пушкин А.С. Полное собрание сочинений: в го т. Изд. 2-е. М.: Изд-во АН СССР, I957-I958.

I6 Рейтблат А.И. Фаддей Венедиктович Булгарин: идеолог, журналист, консультант секретной полиции. Статьи и материалы. М.: НЛО, 20I6. 920 с. Тертерян И.А. Классицистическая «Поэтика» Лусана: [Испанская литература] // История всемирной литературы: в 8 т. М.: Изд-во АН СССР, І983-І994. Т. 5 (I988). C. 282-283.

I8 Álvarez Barrientos Joaquín. Nación e Historia literaria a mediados del siglo XVIII en España // Historia de la literatura, Zaragoza, Prensas Universitarias de Zaragoza, Universidad de Zaragoza, 2004. P. IOI-II4. 
I9 Bouterwek Friedrich. Historia de la literatura española. Madrid: Imp. de Eusebio Aguado, I829. P. XVI, 276.

20 Luzán Ignacio de. La Poética ó Reglas de la poesía en general, y de sus principales especies. Zaragoza: Francisco Revilla, I737.503 p.

2I Meregalli Franco. De José Luis Velázquez a Johann Andreas Dieze // Coloquio internacional sobre el teatro español de siglo XVIII, I988. P. 303-3I4.

22 Paulin Roger. The Life of August Wilhelm Schlegel, Cosmopolitan of Art and Poetry. Openbook publishers, 20I6. Available at: https://www.openbookpublishers.com/reader/25\#page/6/mode/2up (Accessed 20 November 20I8).

23 Rodríguez Ayllón Jesús Alejandro. Un hito en el nacimiento de la Historia de la literatura española: los Orígenes de la poesía castellana (I754) de Luis José Velázquez, Málaga, Fundación Unicaja, 20Io. 43I p.

24 Sánchez Lailla, Luis. La Poética de Luzán // La luz de la razón: literatura y cultura del siglo XVIII: a la memoria de Ernest Lluch / coord. por Aurora Egido Martínez, José Enrique Laplana Gil. Zaragoza: Prensas Universitarias de Zaragoza, Universidad de Zaragoza 20IO. P. 7I-96.

25 Sarmiento Martín. Memorias para la historia de la poesia y poetas españoles. En: Obras posthumas del P.M.Fr. Martín Sarmiento benedictino: tomo primero, Monasterio de San Martín (Madrid), I775. XXVII, 430 p.

26 Sismondi Simonde de. La Litterature du Midi de l'Europe, t. 3, Paris: Chez Treutel et Würtz libraires, I829.560 p.

27 Velázquez de Velasco Luis José (marqués de Valdeflores). Orígenes de la poesía castellana. Malaga: Por los herederos de F. Martinez de Aguilar, I797. I45 p.

\section{References}

I Alekseev M.P. K literaturnoi istorii ballady "Graf Gvarinos” [On the literary history of the ballad]. In: Russkaia kul'tura i romanskii mir [Russian culture and the Romanesque world]. Leningrad, Nauka Publ., I985, pp. 249-257. (In Russ.)

2 Bulgarin F.V. Vzgliad na Istoriiu Ispanskoi Literatury [A look at the history of Spanish Literature]. Syn otechestva, I82I, no 40, pp. 289-305, no 4I, pp. 3-2I. (In Russ.)

3 Bulgarin F.V. Vospominaniia ob Ispanii [Memories of Spain]. St. Petersburg, N. Grech Publ., I823. I86, IV p. (In Russ.)

4 Bulgarin F.V. Otvet na antikritiku, pomeshchennuiu g. Voeikovym v N 66 Ruskago invalida kasatel'no Obraztsovykh sochinenii, izdannykh gg. Voeikovym zhe i Sreznevskim [The Answer to the anti-criticism placed by Mr. Voeikov in N 66 of the Russky Invalid regarding exemplary compositions published by Voeikov and Sreznevskim]. Syn otechestva, I823, no I3, pp. 3-33. (In Russ.) 
Gavriushin N.K. Misticheskii neoellinizm i ideal "esteticheskoi Tserkvi”. F. Bouterwek i F. Hölderlin [Mystical neo-Hellenism and the ideal of the "aesthetic Church". F. Butervek and F. Gölderlin]. Voprosy filosofii, 2005, no 3, pp. I4O-I48. (In Russ.) Ignat'eva (Oganissian) M.Iu. "Zhil na svete klirik bednyi”: dolg i upovanie Gonzalo de Berceo [Once upon a time there lived a poor cleric: debt and aspiration of Gonzalo de Berceo]. Znanie. Ponimanie. Umenie, 20I6, no 4, pp. 260-267. (In Russ.) Ignat'eva (Oganissian) M.Iu. Gimnograficheskie printsipy ispanskoi dukhovnoi poezii Vysokogo srednevekov'ia [Hymnographic principles of Spanish spiritual poetry of the High Middle Ages]. MediaAl'manakh, 20I7, no 5, pp. I52-I62. (In Russ.) Karamzin N.M. Pis'ma russkogo puteshestvennika [Letters of a Russian traveler]. Leningrad, Nauka Publ., I987. 720 p. (In Russ.) Karamzin N.M. Polnoe sobranie stikhotvorenii [Complete collection of poems]. Moscow, Leningrad, Sovetskii pisatel' Publ., I966. 423 p. (In Russ.) Kiseleva L.N. Faddei Bulgarin o napoleonovskikh voinakh: K voprosu o pragmatike memuarnogo teksta [Faddey Bulgarin on Napoleonic wars: On the issue of the pragmatics of the memoir]. In: “Tsep' nepreryvnogo predaniia...”: Sb. pamiati A.G. Tartakovskogo ["The chain of continuous tradition ...": Col. in memory of A.G. Tartakovsky]. Moscow, RGGU Publ., 2004, pp. 9I-IO4. (In Russ.) Korkonosenko K.S. Perevod s ispanskogo v XVIII veke: "Prekrasnaia tsyganka" Cervantes'a [Translations from Spanish in the $18^{\text {th }}$ century: "Beautiful Gypsy" by Cervantes]. Russkaia literatura, 2004, no 4, pp. II8-I24. (In Russ.) Korkonosenko K.S. Ispanskaia literatura v russkoi pechati (XVIII - I920-e gody [Spanish literature in the Russian press ( $\mathrm{I} 8^{\text {th }}$ century - the I920s)]. Vestnik Rossiiskogo gumanitarnogo nauchnogo fonda, 2009, no I (54), pp. IO2-IIO. (In Russ.) Lotman Iu.M. Kommentarii k stikham Karamzina [Comments on the poems by Karamzin]. In: Karamzin N.M. Polnoe sobranie stikhotvorenii [Complete collection of poems]. Leningrad, Sovetskii pisatel', I966, pp. 37I-403. (In Russ.) Mikhailov A.D. Cervantes i Mérimée [Cervantes and Mérimée]. In: Ot François Villon'a do Marcel'ia Proust'a. Stranitsy istorii frantsuzskoi literatury Novogo vremeni (XVI-XIX veka) [From Francois Villon to Marcel Proust. Pages of the history of French literature of the New time ( $\left(6^{\text {th }}-19^{\text {th }}\right.$ centuries)]. Moscow, Iazyki slavianskikh kul'tur Publ., 20Io, vol. II, pp. 365-394. (In Russ.) Pushkin A.S. Polnoe sobranie sochinenii: $v$ ro t. [Complete works: in Io vols.], $2^{\text {nd }}$ ed. Moscow, Nauka Publ., I957-I958. (In Russ.) Rejtblat A.I. Faddei Venediktovich Bulgarin: ideolog, zhurnalist, konsul'tant sekretnoi politsii. Stat'i i materialy [Faddey Venediktovich Bulgarin: ideologist, journalist, and advisor of the secret police. Articles and materials]. Moscow, Novoe literaturnoe obozrenie Publ., 2016. 920 p. (In Russ.)

Terterian I.A. Klassitsisticheskaia “Poetika” Luzan’a [The Classicist poetics of Luzán]. In: Ispanskaia literatura. Istoriia vsemirnoi literatury: $v 8 t$. [Spanish Literature. History 
of world literature: in 8 vols.] Moscow, Nauka Publ., I983-I994. Vol. 5, I988, pp. 282-283. (In Russ.)

I8 Álvarez Barrientos, Joaquín. Nación e Historia literaria a mediados del siglo XVIII en España. Historia de la literatura. Zaragoza, Prensas Universitarias de Zaragoza, Universidad de Zaragoza, 2004, pp. IOI-II4. (In Spanish)

I9 Bouterwek Friedrich. Historia de la literatura española, Madrid, Imp. de Eusebio Aguado, I829, pp. XVI, 276. (In Spanish)

20 Luzán Ignacio de. La Poética ó Reglas de la poesía en general, y de sus principales especies. Zaragoza, Francisco Revilla, I737. 503 p. (In Spanish)

2I Meregalli Franco. De José Luis Velázquez a Johann Andreas Dieze. Coloquio internacional sobre el teatro español de siglo XVIII, I988, pp. 303-3I4. (In Spanish)

22 Paulin Roger. The Life of August Wilhelm Schlegel, Cosmopolitan of Art and Poetry. Openbook publishers, 20I6. Available at:

https://www.openbookpublishers.com/reader/25\#page/6/mode/2up (Accessed 20 November 20I8). (In English)

23 Rodríguez Ayllón Jesús Alejandro. Un hito en el nacimiento de la Historia de la literatura española: los Orígenes de la poesía castellana (I754) de Luis José Velázquez. Málaga, Fundación Unicaja Publ., 20Io. 43I p. (In Spanish)

24 Sánchez Laílla, Luis. La Poética de Luzán. La luz de la razón: literatura y cultura del siglo XVIII: a la memoria de Ernest Lluch, coord. por Aurora Egido Martínez, José Enrique Laplana Gil. Zaragoza, Institución “Fernando el Católico” (C.S.I.C.), 20Io, pp. 7I-96. (In Spanish)

25 Sarmiento Martín. Memorias para la historia de la poesia y poetas españoles. Obras posthumas del P.M.Fr. Martín Sarmiento benedictino. Madrid, Monasterio de San Martín, I775. Vol. I. XXVII, 430 p. (In Spanish)

26 Sismondi Simonde de. La Litterature du Midi de l'Europe. Paris, Chez Treutel et Würtz libraires, I829. Vol. 3. 560 p. (In French)

27 Velázquez de Velasco Luis José (marqués de Valdeflores). Orígenes de la poesía castellana. Malaga. Por los herederos de F. Martinez de Aguilar Publ., I797. I45 p. (In Spanish) 


\section{LITTÉRATURE DE JEUNESSE CONNAÎT- ELLE DES FRONTIĖRES? (ENTRE TRADITION ET TRANSPOSITION \\ EN LITTÉRATURE TCHĖQUE DESTINÉS AUX JEUNES LECTEURS)}

This is an open access article distributed under the Creative Commons Attribution 4.0 International (CC BY 4.0)

(C) 2020. K. Kunešová

Université Hradec Kralove, République tchèque

Envoyé le: I9 juin 2019, Hradec Kralove

Publié le: 25 juin 2020

Résumé: L'article traite de l'histoire de la littérature d'enfants et de jeunesse tchèque et sa tradition dans un contexte national mais aussi européen en citant les auteurs étrangers (français, allemands, russes, anglais, américains ou autres) et leurs œuvres qui ont marqué la scène littéraire tchèque grâce aux traductions. La redécouverte du folklore tchèque au XIX ${ }^{\mathrm{e}}$ siècle coïncide avec le renouveau de la culture nationale et la restitution de la langue qui se reflètent notamment dans les contes et dans la poésie. Le développement de la littérature pour les enfants et la jeunesse est lié avec les traductions où le nom de Jules Verne est incontournable au XIX ${ }^{\mathrm{e}}$ siècle ainsi qu'au $\mathrm{XX}^{\mathrm{e}}$ siècle celui d'Antoine de Saint-Exupéry dont Le petit prince a connu des éditions multiples. La seconde partie de l'étude est consacrée à la littérature contemporaine d'enfants et de jeunesse en comparant la situation sur le marché du livre en France à celui en République tchèque. L'analyse se concentre sur deux romans pour la jeunesse qui présentent les jeunes personnages obligés de faire face aux crises et de résoudre des problèmes d'une maladie chez des gens qu'ils aiment (Céline Lavignette Ammoun et Ivona Březinová). La conclusion, basée sur les sondages parmi les enfants et les jeunes ainsi que sur la critique littéraire, démontre que ni la thématique, ni l'approche des auteurs ou les preférences des lecteurs dans les deux pays ne diffèrent considérablement car la littérature de jeunesse ne connaît pas de frontières en privilégiant aujourd'hui l'imaginaire fantastique et ludique. Ce qui est pourtant caractéristique pour la littérature contemporaine de jeunesse, c'est son ouverture aux thèmes autrefois tabouisés et sa recherche des rapports entre l'identité et l'altérité.

Mots clés: Littérature de jeunesse, littérature française, littérature tchèque, traductions, thématique d'enfants et de jeunesse, livre, roman, conte, traduction.

Information sur l'auteur: Kveta Kunešová, docteur ès lettres, Professeur, Département de langue et littérature françaises, Faculté de Pedagogie, Université Hradec Kralove, Rokitanského 62; 50003 Hradec Králové, République tchèque.

E-mail: Kvetuse.Kunesova@uhk.cz

Pour la citation: Kunešová K. Littérature de jeunesse connaît-elle des frontières? (Entre tradition en littérature tchèque destinés aux jeunes lecteurs). Studia Litterarum, 2020, vol. 5, no 2, pp. I24-I45. (In French) DOI: IO.22455/2500-4247-202O-5-2-I24-I45 


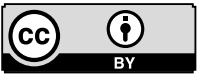

This is an open access article distributed under the Creative Commons Attribution 4.0 International (CC BY 4.0)
JUVENILE LITERATURE, DOES IT KNOW ANY FRONTIERS? (BETWEEN TRADITION AND TRANSPOSITION IN CZECH LITERATURE FOR YOUNG READERS)

(C) 2020. K. Kunesova University Hradec Kralove, Hradec Králové, Czech Republic Received: June I9, 2019 Date of publication: June 25, 2020

Abstract: This article deals with the history of Czech children's and juvenile literature and its tradition in both national and European contexts. It examines foreign authors (French, German, Russian, English, American, and some others) and their works translated into Czech that played a significant role in the Czech literary scene. The rediscovery of Czech folklore in the $I^{\text {th }}$ century coincides with the revival of the national culture and restitution of the language as reflected in fiction and poetry. The development of literature for children and youth owes much to translations. In the I $9^{\text {th }}$ century, Jules Verne was the must read for children and so was Antoine de SaintExupery in the $20^{\text {th }}$; his Little Prince has undergone multiple editions. The second part of the study examines contemporary children's and juvenile literature by comparing the situation on the book market in France with that in Czech Republic. The analysis focuses on two novels for young people that present young characters who have to cope with different crises and help ill people they love (Céline Lavignette-Ammoun and Ivona Březinová). The essay's conclusion, based on the polls among children and young people as well as on literary criticism, shows that neither the theme nor the approach of the authors or the preferences of the readers in the two countries considerably differ. This is due to the fact that juvenile literature knows no borders as it gives preference to the interplay of fantasy and imagination. What characterizes contemporary juvenile literature, however, is its openness to the hitherto tabooed themes as well as its interest in the relation between the sameness and the otherness.

Keywords: children's literature, French literature, Czech literature, translations, topics for children and youth, book, novel, story, translation.

Information about the author: Kveta Kunesova, $\mathrm{PhD}$ in Philology, Professor, Departement of the French language and literature, Faculty of Pedagogy, University Hradec Kralove, Rokitanského 62; 50003 Hradec Králové, Czech Republic.

E-mail: Kvetuse.Kunesova@uhk.cz

For citation: Kunesova K. Juvenile Literature, Does It Know Any Frontiers? (Between Tradition and Transposition in Czech Literature for Young Readers). Studia Litterarum, 2020, vol. 5, no 2, pp. I24-I45. (In French) DOI: IO.22455/2500-4247-2020-5-2-I24-I45 
УДК 82I.I62.3

ББК 83.3(4Чех)
«ЛИТЕРАТУРА ДЛЯ ЮНОШЕСТВА:

ЗНАЕТ ЛИ ОНА ГРАНИЦЫ?

(ЧЕШСКАЯ ЛИТЕРАТУРА

ДЛЯ ЮНЫХ ЧИТАТЕЛЕЙ МЕЖДУ

ТРАДИЦИЕЙ И ПЕРЕХОДОМ)

(C) 2020 г. К. Кунешова

Университет Градеи-Кралове,

Градеи-Кралове, Чешская республика

Дата поступления статьи: І9 июня 2019 г.

Дата публикации: 25 июня 2020 г.

DOI: IO.22455/2500-4247-2020-5-2-I24-I45

Аннотация: Статья посвящена истории чешской литературы для детей и юношества и выработанным ею традициям в национальном и европейском контекстах. Рассмотрены произведения иностранных авторов (французских, немецких, русских, английских, американских и пр.), сыгравшие благодаря переводам заметную роль в чешской словесности. Повторное открытие чешского фольклора в XIX в. совпадает с возрождением национальной культуры и языка, что нашло свое отражение, в частности, в сказках и поэзии. Развитие литературы для детей и юношества в Чехии многим обязано переводам (в XIX в. лидирующее положение в них занимал Жюль Верн, в ХХ в. - Антуан де Сент-Экзюпери). Вторая часть исследования посвящена современной литературе для детей и юношества, сравнительному анализу положения дел на книжном рынке во Франции и в Чешской Республике. Особое внимание уделено двум романам для молодежи, герои которых оказываются перед необходимостью преодоления кризисных ситуаций и оказания помощи больным людям, которых они любят (Селин Лавинетт-Аммон и Ивона Бржезинова). В заключительной части статьи, показано, что выбор и трактовка темы, а также читательские предпочтения в двух указанных странах существенно не отличаются, поскольку современная литература для детей и юношества не ведает границ и неизменно отдает предпочтение игре фантазии и воображения. Особенностью именно современной молодежной литературы можно считать ее обращение к ранее табуированным темам и поиск взаимоотношений между идентичностью и инаковостью.

Ключевые слова: литература для детей и юношества, французская литература, чешская литература, переводы, детская и молодежная тема, роман, сказка, перевод.

Информация об авторе: Квета Кунешова - доктор филологических наук, профессор, департамент французского языка и литературы, Педагогический институт, Университет Градец-Кралове, Рокатанскего, 62, Градец-Кралове, 50003, Чешская республика.

E-mail: Kvetuse.Kunesova@uhk.cz

Для цитирования: Кунешова К. «Литература для юношества: знает ли она границы? (Чешская литература для юных читателей между традицией и переходом) // Studia Litterarum. 2020. T. 5, № 2. C. I24-I45. DOI: IO.22455/2500-4247-2020-5-2-I24-I45 
Le titre de notre réflexion relève de la tâche envisagée comme objectif de la recherche concernant la littérature de jeunesse tchèque: esquisser tout d'abord son histoire sans laquelle il est impossible de comprendre son état contemporain, d'où la première phase, la tradition. Selon l'acception générale, il s'agit d'un ensemble de phénomènes culturels transmis sur un long espace de temps. Ensuite, nous nous penchons sur la notion de transposition qui concerne «l'action de faire passer quelque chose, fait d'être transposé dans un autre domaine en l'adaptant à des conditions nouvelles, à un contexte différent» [5]. Dans le présent cas, nous essayons de démontrer la transposition de nouveaux genres et de nouvelles thématiques en littérature tchèque pour enfants et adolescents. Les tendances du monde littéraire globalisé sont bien perceptibles sur la scène littéraire tchèque malgré la tradition.

En République tchèque, la production littéraire pour le jeune public représente actuellement environ 2000 livres par an [I7]. Il existe plusieurs prix littéraires dont le plus prestigieux, «Magnesia Litera», est attribué chaque année et comprend également une catégorie jeunesse. Le réseau des bibliothèques municipales et locales est traditionnellement très dense depuis la fondation de la Première république tchécoslovaque.

Le problème qui se pose, comme dans tous les pays européens, concerne la lecture, car le livre comme tel est éclipsé et marginalisé par les nouveaux médias. Selon les sondages tchèques, il apparaît que le nombre de lecteurs réguliers atteint ces dernières années à peu près 52 pour cent de la population, dont la plupart sont des jeunes filles. Les manifestations culturelles ciblées sur la littérature etla lecture, organisées au niveau national telle que La nuit avec Andersen par exemple, ou les expositions comme La journée du livre, sont suivies par des événements à caractère régional. 
Présenter la situation de la littérature pour enfants et de jeunesse en République tchèque est un projet ambitieux. Les résultats des analyses et des réflexions qui portent sur les thèmes développés par cette littérature au seuil du $\mathrm{XXI}^{\mathrm{e}}$ siècle essaient d'établir certains parallèles ou certaines différences vis-à-vis de la littérature pour enfants et de jeunesse en France. Avant de décrire l'état des lieux actuel, il me semblait indispensable d'esquisser un panorama historique qui montrerait l'évolution de ce secteur de littérature en lien avec les spécificités culturelles tchèques.

Afin de pouvoir étudier la problématique nous avons analysé un corpus très vaste dont les références bibliographiques dépasseraient le cadre de cette étude. Les titres présentés dans la bibliographie se limitent aux plus importants. Sur le plan méthodologique, nous sommes guidés par les ouvrages théoriques majeurs, tant tchèques, comme les écrits de Svatava Urbanová [I8], que français (les monographies de Christian Chelebourg et Francis Marcoin [3] ou celle d'Isabelle Nières-Chevrel [I6]).

\section{Les débuts de la littérature tchèque pour enfants et de jeunesse}

Dans les pays dits tchèques, c'est-à-dire en Bohême et en Moravie, qui faisaient partie de l'Empire austro-hongrois pendant près de trois cents ans, entre 1620 et 1918 , la littérature de jeunesse a vu sa naissance, comme ailleurs en Europe, dans la première moitié du XIX ${ }^{\mathrm{e}}$ siècle.

La volonté de réunir le folklore tchèque, notamment des contes de fées à vocation pédagogique, se mariait bien avec les efforts des nationalistes tchèques dont le but était précisément la valorisation et la renaissance de la langue et de la culture nationales.

Les conteurs tchèques s'inspiraient pour la plupart des contes des frères Grimm en imitant et transposant certains thèmes folkoriques aux récits de ces derniers. Toutefois l'art du conte qu'on trouve dans les œuvres des conteurs tchèques reflète purement le milieu tchèque et la culture nationale: les thématiques des frères Grimm étaient enrichies et élargies par les légendes traditionnelles que les auteurs tchèques essayaient de trouver dans des villages où la production orale en langue tchèque était encore vivante malgré la germanisation du territoire due à la domination des Habsbourgs. Les écrivains qui s'engageaient dans le mouvement du renouveau de la culture autochtone sont considérés comme des auteurs classiques de la littérature tchèque car leurs œuvres étaient destinées tant aux 
enfants qu'aux adultes: Karel Jaromír Erben (I8II-I870) ou Božena Němcová (I820-I862), méritent ici d'être cités.

En ce qui concerne les autres genres, on observera que les Tchèques traduisaient et lisaient avec enthousiasme les séries de romans de Jules Verne: en effet, un éditeur pragois, Jos. R. Vilímek, avait eu la lucidité de signer un contrat avec Pierre-Jules Hetzel concernant les romans verniens, ce qui lui a permis de publier la majeure partie de sa production en traduction tchèque entre I87I et I949 [9, p. I65]. Si l'histoire des traductions de l'œuvre de Jules Verne dans les pays tchèques surprend par son envergure, elle ne commence cependant que sept ans après la première édition française de Cinq semaines au ballon chez Hetzel: celui qui a fait découvrir le roman aux Tchèques a été le célèbre poète Jan Neruda. Âgé alors de I9, ans Neruda avait acheté ce livre à Paris comme curiosité littéraire [6]. La première traduction de Verne en tchèque, à laquelle Neruda avait également contribué, celle du Voyage dans la Lune [6] est parue dans la maison d'éditions «Matice lidu» («Association du peuple») en I870.

C'est la maison d'éditions Jos. R. Vilímek ${ }^{\mathrm{I}}$ qui a considérablement marqué le marché de livres dans nos pays dans la période I87I-I949. Etant donné qu'au milieu des années I880 les éditeurs pragois n'étaient plus attirés par Jules Verne, Vilímek a pris, selon les témoignages de ses archives, une décision ambiguë [7]: publier l'œuvre de Jules Verne dans son ensemble et avec les illustrations d'origine. Il s'agissait en fait d'une décision révolutionnaire parce que les illustrations étaient rares dans les livres tchèques publiés à l'époque. Le premier livre de Verne publié chez Vilímek était Deux ans de vacances en I889, d'abord en cahiers et plus tard, sous la forme d'un livre. Il est à noter que les raisons de la publication sous forme de cahier étaient purement économiques, le livre étant considéré objet de luxe. En I890 Vilímek demande à Hetzel les droits exclusifs en matière d'édition de l'œuvre de Verne pour son projet de publication. Le contrat a été signé en I89I après de longues négociations (il existe une correspondance, menée en français, entre les deux éditeurs). Vilímek a été obligé de publier un certain nombre de nouveautés qui sortaient chaque année. Initialement, il a été prévu que Vilímek publierait l’intégralité des illustrations françaises; plus tard une réduction a été négociée pour ne

I Josef Richard Vilímek aîné (I835-I9II), fondateur de la maison d'éditions Jos. R. Vilímek a commencé à publier en I858. Josef Richard Vilímek fils (I860-I938) a succédé à son père en I886. 
reprendre que la moitié des illustrations. Malgré l'enthousiasme de Vilímek, la critique littéraire officielle tchèque, à l'instar de celle en France, n'acceptait pas Verne en tant qu'auteur digne d'intérêt. Néanmoins, au cours des années de collaboration entre Vilímek et Hetzel, la maison d'éditions Jos. R. Vilímek a réussi à produire 64 publications de 44 titres de Jules Verne dans trois éditions verniennes différentes. Les illustrations de Benett ont trouvé un prolongement fort heureux dans celles de Zdeněk Burian². Enfin, entre I889-I949, la maison d'éditions Jos. R. Vilímek a fait paraître 900 mille exemplaires de livres de Jules Verne, illustrés de gravures de Benett ou plus tard, par les gouaches et dessins à la plume de Zdeněk Burian. Outre Jos. R. Vilímek, il y avait d'autres maisons d'éditions qui publiaient les livres de Verne: Bedřich Kočí (Maison d'éditions, fondée en I893 à Pilsen, en I899 à Prague), Alois Hynek (Maison d'éditions fondée en I869 à Prague) et Edouard Beaufort (Maison d'éditions fondée en I884 à Prague). «Malgré la renommée et la position de Vilímek sur le marché du livre, l'on se rend compte du fait que certains romans de Verne ont été publiés pour la première fois par une autre maison d'éditions, comme par exemple: Les enfants du capitaine Grant (1865), I ${ }^{\text {ère }}$ édition, traduit par R.S., Prague, A. Lauermann, I883; $2^{\mathrm{e}}$ édition, traduit par Václav Beneš, Prague, Jos. R. Vilímek, I899. Le Tour du monde en quatre-vingts jours (1872), I ère édition, traduit par J. Tichý, Prague, A. Lauermann, I884; $2^{\mathrm{e}}$ édition, traduit par B. Klika, Prague, Jos. R. Vilímek, I899. L'île mystérieuse(I874-1875), $\mathrm{I}^{\text {ère }}$ édition, traduit par František Brábek, Prague, J. Otto, I878; $2^{\mathrm{e}}$ édition, traduit par Antonín Koudelka, Prague, Jos. R. Vilímek,I896/97.

Après le Coup d'État de I948, la situation politique et économique du pays avait changé: la nationalisation a apporté la fin de la plupart des maisons d'édition, d'autres ont été créées. SNDK - Maison d'édition nationale de livres pour enfants, fondée en 1949, à partir de 1969 connue sous le nom d' «Albatros», a publié 29 livres de Jules Verne dans l'édition «Podivuhodné cesty» («Voyages extraordinaires»), 4 livres dans l'édition «Karavana» («Caravane»), I958-I968, 9 livres dans l'édition «Karavana - sešity» («Cahiers de La Caravane »), I969-I989. La maison d'édition “Návrat” («Retour»), fondée en I99I à Brno, a publié plus de 77 œuvres de Jules Verne, pour la plupart avec les illustrations originales.

2 Zdeněk Burian (1905-198I), peintre et illustrateur tchèque, collabore avec l'éditeur Vilímek à partir de 1927 . 
Il est important d'ajouter que Jules Verne a largement inspiré les cinéastes tchèques, notamment Karel Zeman dont le film L'invention diabolique (1956-1957) a développé et actualisé les idées pacifistes de Verne au moment de la guerre froide.

Dans le domaine de la littérature de jeunesse, aucun autre auteur français n'a atteint autant de retentissement que Jules Verne, et ceci malgré leur gloire et notoriété. Les Fables de La Fontaine, traduites pour la première fois en I873 par Bedřich Peška et publiées par Ed. Grégr à Prague, ont connu quatorze éditions. La première traduction des Contes de Charles Perrault date de I9II. D'autres éditions ont suivi au cours du siècle, et en I972, une publication bilingue (française-tchèque) a vu le jour, rééditée deux fois plus tard. Les contes de Perrault et de Mme d'Aulnoy ont été publiés dans un même volume pour la première fois en I990, tandis que l'édition des contes de Mme d'Aulnoy uniquement a tardé jusqu'en 20II. Les traductions des contes séparés précèdent ces publications, bien que leur apparition dans les pays tchèques semble toutefois relativement tardive, en I9I83 ${ }^{3}$, due sans aucun doute aux préférences des éditeurs tchèques qui se trouvaient sous l'influence des œuvres des frères Grimm. Le même décalage temporel entre la parution de l'original et celle de la traduction en tchèque est perceptible en considérant plusieurs autres titres mondialement connus, entre autres Les malheurs de Sophie de Mme de Ségur dont la traduction effectuée par la comtesse Nora Kinsky n’a parue qu'en I909 à Prague, dans Nakladatelské družstvo Máje.

La première moitié du $\mathrm{XX}^{\mathrm{e}}$ siècle a vu des traductions des littératures européennes dont les auteurs se sont inscrits dans la mémoire des lecteurs tchèques: Carlo Collodi avec Pinocchio, Rudyard Kipling avec Mowgli, A.A. Milne avec Winnie l'ourson, Wilhelm Hauff, Erich Kästner etc. Les traducteurs tchèques choisissaient souvent des œuvres étrangères qui racontaient des histoires qui se passaient dans la nature sauvage ou des aventures liées à l'exploration des territoires inconnus. Les jeunes appréciaient tout autant les auteurs européens qu'américains, tels que K. May, R.L. Stevenson, L. Carrol, M. Twain, J. London, E.T. Seton, ou H. Sienkiewicz pour ne citer qu'eux. Les auteurs russes ont été toujours traduits et publiés avec succès. Dans le domaine de la littérature de jeunesse, c'est le nom d'Alexandre Kouprine, auteur traduit depuis la fin du XIX siècle, qui s'est

3 La biche au bois, Pacov, Přemysl Plaček, I9I8, traduit par V. F. Suk; L'Oiseau bleu, Prague, Artia, I97I, traduit par Jan Vladislav. 
inscrit dans le contexte tchèque ${ }^{4}$, dont le livre intitulé Les contes pour la jeunesse a paru en $1925^{5}$.

L’année I9I8 signifie non seulement la fin de la Grande guerre, mais aussi pour les Tchèques un changement politique considérable: la fondation de la République tchécoslovaque, dont la devise ne différait pas de celle de la France, incluant en plus un patriotisme fervent. Les grandes idées du fondateur de la Première République tchécoslovaque, Tomas Garrigue Masaryk (professeur de philosophie renommé et premier Président de la République), qu'il a réussi à communiquer à ses compatriotes, ont suscité chez eux un vif intérêt pour la communauté et la construction d'un état national moderne et démocratique.

Les principes de cette philosophie (idéaliste et pratique en même temps) se reflètent logiquement dans l'éducation nationale et dans la littérature jeunesse qui est imprégnée de l'enthousiasme et de la volonté de construire une société stable avec un esprit de symbiose harmonieuse. Non seulement le travail bien fait y est glorifié, mais c'est aussi le sens de la communication et le respect de l'autre qui sont prônés, par exemple dans la série d'allégorie animale Ferda, la Fourmi, étant donné que l'espèce en question représente une organisation remarquable, basée sur la discipline et la répartition detâches. A l'occasion de la première édition de Ferda, la Fourmi en France en mars 20I7, le Centre tchèque à Paris et le Musée national de Brno (République tchèque) ont organisé une exposition sur l'auteur, Ondřej Sekora, en janvier - février 20I7.

L'anthropomorphisme est une approche habituelle, excellemment analysée dans les fameuses éditions de la série Père Castor en France par Michel Defourny (Roman des bêtes). A l'époque où Paul Faucher et sa femme Lida Durdikova (d'origine tchèque) publiaient leurs œuvres inoubliables, c'est-à-dire dans les années 1920 et I930, en Tchécoslovaquie paraissaient Histoires de Chien et Chat (1929) de Josef Čapek. Josef Čapek (1887-1945), peintre, illustrateur et écrivain tchèque, frère de Karel Čapek (1890-1938), écrivain, journaliste et philosophe. Histoires de chien et de chat se sont inscrits dans la mémoire des enfants non seulement tchèques mais grâce aux traductions elles parlent aussi aux enfants français). De la même popularité se réjouit Dasenka ou la vie d'un chiot (1933),

4 Les contes. Prague, Jos. R. Vilímek, i8.. (non daté). Le duel, traduit par F. Mézl, Prague, Jos. R. Vilímek, I907.

5 Traduit et publié par František Zpěvák, Prague, I925. 
écrit par son frère Karel Čapek, auteur mondialement connu pour ses romans et pièces de théâtre. Il est à noter que grâce à la renommée de Karel Čapek, il existe des traductions françaises de la majorité de ses œuvres. Dasenka ou plutôt Dachenka en traduction française a paru en 2013 dans les «Editions de Poche». Les idées portées par l'éthique des scouts ont trouvé également un sol propice dans les livres destinés aux jeunes Tchèques. L'auteur de romans d'aventure pour garçons, Jaroslav Foglar, est devenu célèbre chez les jeunes lecteurs de plusieurs générations car ses personnages incarnent parfaitement les valeurs mises en avant par la société de cette Première République tchécoslovaque: la vérité, le courage et la solidarité qui s'opposent au mensonge et à la lâcheté. Même dans les récits pour les jeunes filles, on retrouve des personnages qui sont dotés d'une autonomie remarquable et d'un grand courage individuel. Au cours de cette période, le conte de fées moderne s'inspire des modèles précédents et ne cesse de figurer parmi les genres les plus populaires chez les jeunes lecteurs tchèques. Après la Seconde guerre mondiale, le conte de fées perd son caractère mythique et fatal en donnant préférence à la métaphore et au ludique. La Seconde guerre mondiale et la période communiste ont mis fin aux espoirs et à l'idéalisme de la Première république tchécoslovaque. Pendant quatre décennies, l'esprit officiel dominant la littérature était lié à l'idéologie totalitaire. La littérature de jeunesse s'est montrée néanmoins un champ de résistance. Grâce à ce domaine, les poètes, les écrivains et les illustrateurs ont pu «sortir du monde de la lutte de classes» et entrer dans un univers de leur imagination, qui permettait maintes fois d'exprimer leurs pensées politiques cachées.

\section{Traductions sous le régime totalitaire}

Après la Seconde guerre mondiale, les traductions du russe culminent en présentant l'héroïsme des soldats soviétiques et en inoculant aux enfants et aux jeunes des idées communistes. Parmi les auteurs qui méritent néanmoins d'être cités, il y a Nicolay Nossov dont les livres sont devenus populaires dans les années I950. Les histoires de Neznaika et ses amis ont enthousiasmé plusieurs générations d'enfants par la vivacité de la narration des aventures qui ressemblent à celles des héros de Jules Verne ou de Cyrano de Bergerac par les motifs thématiques de voyages à la Cité du Soleil (peut-être un reflet de la Cité radieuse signée par Le Corbusier en I947?) et dans la Lune. Les traductions les plus souvent publiées sont dues à Milan Korejs (à partir de I950) et Marie Štastná (à partir de I976) [r]. 
La modernité de Nossov s'oppose aux publications multiples des œuvres classiques de la littérature russe, les fables d'Ivan Krylov et notamment les contes populaires dont le fonds thématique original rivalise avec les corpus de Charles Perrault et des frères Grimm.

Cependant, sous le régime totalitaire qui commence en I948, il y avait également des échos des autres littératures européennes. Paraissent ainsi des traductions des auteurs tels qu'Astrid Lindgren dont les œuvres commencent à divertir les jeunes Tchèques à partir de la fin des années I950.

Le bestseller par excellence, c'est la traduction du Petit Prince d'Antoine de Saint-Exupéry qui date de I959. Depuis, on compte 53 éditions de ce conte (en traductions différentes), devenu la lecture favorite de plusieurs générations.

\section{Les années 1960}

Dans les années I960, on peut voir partout en Europe une montée de nouvelles idées où la culture de l'après-guerre atteint son sommet en plusieurs sens, ce que l'on appelle parfois un âge d'or. Le régime totalitaire en Tchécoslovaquie connaît une période de «dégel», une ouverture dont le résultat est une vague de créativité dans tous les domaines culturels.

Le nom qui mérite d'être cité est celui de Miloš Macourek (I9262002), poète, dramaturge, écrivain, scénariste et cinéaste tchèque, qui s'est fait remarquer comme auteur de livres pour enfants, mais aussi en tant que scénariste de films qui sont destinés tant aux jeunes qu'aux adultes. Ses lecteurs ainsi que ses spectateurs admiraient son sens de l'humour et son ironie. Ses œuvres font ressortir une critique cachée des absurdités de la vie tchèque sous le régime totalitaire [8, p. 49-57]. Macourek collaborait avec l'illustrateur Adolf Born qui accompagnait ses récits de dessins en couleurs ${ }^{6}$. Les lecteurs de ses contes étaient majoritairement les enfants de ceux qui lisaient les histoires de la fourmi Ferda. Macourek savait surprendre, éveiller la curiosité et faire réfléchir:

«L'œuvre de Macourek porte des marques de l'influence exercée par l'œuvre de Jacques Prévert qui lui servait de modèle et dont il traduisait les vers. Il s'efforçait de trouver une vision authentique des choses et une expression simple et compréhensible tant en poésie qu'en prose» $[15 ; 4]$.

6 Adolf Born, né en I930, est peintre, graphiste et dessinateur tchèque.Il a illustré, entre autres, des traductions tchèques des romans de Jules Verne et d'Alexandre Dumas père. 
La création de Macourek (et également d'autres artistes) démontre à quel point la littérature et toute la culture tchèque étaient liées aux valeurs européennes déjà avant I989. Les traductions de la littérature française servaient d'inspiration: Le petit Nicolas de René Goscinny a remporté un grand succès en I970 pour être réédité et imité par les auteurs tchèques. La traduction de Chantefables et chantefleurs de Robert Desnos (I97I) a influencé les auteurs qui se plaisaient à jouer avec la langue. Dans les manuels de français de l'époque, les vers de Robert Desnos ou de Jacques Prévert ne manquaient pas, justement à cause de leur caractère ludique. Ceux de Paul Eluard et de Louis Aragon étaient lus par les élèves tchèques pour leur message antifasciste et pacifiste, les idées que le régime soutenait officiellement. Il est par exemple à noter que Le journal d'Anne Frank a été traduit en tchèque dès 1956 et lu avec beaucoup d'intérêt et compassion.

Un autre exemple est cependant en opposition avec cet idéal: Le cheval de guerre, roman au message pacifiste de l'auteur britannique Michael Morpurgo, publié en 1982, qui n'a été traduit en tchèque qu'en 20II. Le Hobbit de J.R.R. Tolkien, écrit en I937, a, quant à lui, été publié en traduction tchèque avec un retard de quarante ans, seulement en 1979. La guerre des boutons (I9I2) de Louis Pergaud est paru en tchèque et slovaque en I968, résultat de la situation politique libérale, ainsi que Les contes rouges du chat perché (1934) de Marcel Aymé qui ont vu le jour en tchèque en 1965. Les livres destinés aux enfants et à la jeunesse, pleins de poésie et d'harmonie, dus à l'écrivain russe Victor Goliavkine, par exemple Notre père ${ }^{7}$, ont été traduits dans les années I960-I980.

\section{La Révolution de velours et la littérature de jeunesse}

L’année I989 a complètement changé la situation. Les traductions des œuvres étrangères pour la jeunesse se sont multipliées et la thématique de la production tchèque s'est diversifiée. Les modèles et les influences des genres les plus populaires ont transformé la production littéraire destinée aux enfants et à la jeunesse. Les maisons d'édition tchèques différaient selon leurs objectifs: on proclamait un renouveau d'une part, c'est-à-dire un retour à la tradition nationale, mais d'autre part, il existait également une forte tendance à absorber toutes les nouveautés de la littérature mondiale pour les enfants et

7 Prague, Albatros, I975, traduit par Alena Nováková. 
la jeunesse. Les maisons d'éditions pour la jeunesse devenaient ainsi de plus en plus nombreuses ${ }^{8}$.

Au début des années I990, la société et toute la culture, y compris la littérature d'enfants et de jeunesse, se retrouvent à un carrefour. Cette époque se caractérise par un certain chaos, vu le nombre de maisons d'éditions qui émergent et dont la production mène des fois à une perte d'orientation et, malheureusement, également souvent à une disparition des valeurs. On est témoin d'un processus de libéralisation qui apporte de nouveaux médias, liés à la mode du visuel, ou à de nouveaux genres reflétant le goût du mystère et de l'action.

La littérature de jeunesse, en traduisant les différents aspects de la société de consommation, traite de nouveaux thèmes, ceux qui étaient tabous dans la société tchèque antérieure à la Révolution de velours. Les lecteurs présupposés, enfants ou adolescents tchèques, sont exposés à un envahissement de traductions.

Dans les années 1990, on assiste à la réédition des auteurs classiques de la littérature tchèque. On retrouve aussi des auteurs interdits, qui n'ont pas pu être publiés au cours de la période entre I948 et I968 ou I970-I989 parce que leurs œuvres, imprégnées par la religion ou glorifiant la Première république tchécoslovaque, la période de l'entre-deux-guerres, étaient considérées idéologiquement nuisibles pour le régime totalitaire (bien que certaines aient été publiées clandestinement, comme par exemple les livres de Ivan Klíma ou Eda Kriseová).

Dans les pays tchèques, le conte est un genre privilégié dans le cadre de la littérature pour enfants. Les contes classiques réédités, les maisons d'édition ont enrichi le spectre du genre par les contes d'auteurs rénommés. Non seulement les mythes, les légendes et les contes d'origine étrangère sont publiés et réédités, mais on voit également apparaître par exemple des variations sur les histoires traditionnelles du peuple Rom (Hana Doskocilova) ou des contes et légendes qui s’inspirent de la culture d'Israël ou de celle des Juifs pragois (Leo Pavlát).

\section{La littérature de jeunesse au XXI ${ }^{\mathrm{e}}$ siècle}

En ce qui concerne la production littéraire contemporaine pour enfants et pour la jeunesse, on peut constater la même chose que pour les belles lettres

8 Actuellement en fonction: Albatros, Baobab, Meander, BB-Art, Amulet, Hynek, Havran. 
en général: les différences entre les genres s'effacent ainsi que les frontières entre les catégories d'âge d'enfants auxquelles les œuvres récemment écrites sont destinées. La tradition n'a pas pu sauver la littérature: de nouvelles approches sont apparues, qui reflètent la réalité du jour et qui répondent aux besoins de l'enfant qui se retrouve au seuil du XXI ${ }^{\mathrm{e}}$ siècle [i2].

Le genre favori parmi les lecteurs de $7-8$ ans est un récit prosaïque dont les thèmes relèvent de la vie actuelle. Le contexte social se reflète dans les œuvres d'auteurs dont la plupart sont des femmes: Horelová, Stýblová, Doskočilová, Zinnerová. Les thèmes récurrents dans leurs ouvrages concernent l'environnement et les questions sociales, que ce soit des oppositions d'âge, de nationalité, de culture ou de santé.

La thématique relative aux problèmes existentiels graves apparaît aussi dans les livres destinés aux enfants, en République tchèque comme en France. Si l'on considère par exemple le livre de Brigitte Labbé Maman a une maladie grave ${ }^{9}$ ou les séries sur Max et Lili de Dominique Saint Mars et Serge Bloch, on peut y trouver des problèmes d'adultes exposés devant les plus jeunes lecteurs (Le cousin de Max et Lili se drogue, La copine de Lili a une maladie grave ${ }^{\mathrm{\top}}$ ).

Pareillement, dans le livre Le cadeau pour Monique (2000), son auteur tchèque, Hana Pražáková, introduit de façon très délicate le thème de la mort, regardé du point de vue d'une petite fille de cinq ans qui est témoin du deuil de sa copine. Les lecteurs tchèques du même âge sont considérés comme aptes à comprendre le message de l'œuvre. Dans l'histoire intitulée Anne et Annette (20I5) de Martina Špinková, la mort est présentée comme la fin nécessaire et logique de la vie. Annette comprend, sans être choquée, le décès de sa grand-mère Anne, avec qui elle a vécu beaucoup de moments joyeux. En train de mourir, sa grand-mère est entourée de toute la famille.

Aujourd'hui, les livres destinés aux adolescents ne connaissent pas de tabous en exposant ouvertement tous les sujets. Iva Procházková, auteure tchèque, décrit des situations pénibles dans lesquelles le protagoniste peut se retrouver (maladie, solitude, abandon, famille déréglée, déracinement, catastrophe). L'identité des héros se manifeste au moment de la crise qui mène à la reconnaissance de soi-même et à l'auto-réflexion. Dans son écriture, Iva Procházková combine le monde réel avec celui de l'imaginaire en introduisant des éléments

9 Toulouse, Milan jeunesse, 2007.

IO Paris, Calligram, 2004. 
magiques dans une narration réaliste. Karolína, l'histoire d'une jeune fille de seize ans (1999) est un roman pour les adolescents qui raconte la vie de Karolína, qui espère être danseuse puisqu'elle adore le ballet. Après un accident, elle ne peut plus penser à une carrière de ballerine, obligée d'accepter la vie telle qu'elle est. Les rapports entre les personnages subissent des transformations causées par le handicap de l'un d'entre eux. Dans ses romans, Iva Procházková montre également des conflits entre les enfants et les adultes, ou bien des conflits entre les enfants abandonnés ou handicapés et ceux qui empêchent l'intégration de ces derniers dans la société, étant eux-mêmes sains et privilégiés.

C'est dans un autre roman tchèque, Le foyer pour les Martiens (I998), qu'une autre auteure, Martina Drjiverová, dévoile des rapports compliqués entre les personnages dont la cause est une maladie qui crée un décalage entre les gens sains et un enfant atteint du syndrome de Down. Celui-ci est comparé au personnage principal de la fameuse histoire d'E.T. l'extraterreste, d'où le titre. Léthique matérialiste de la société de consommation se heurte à celle qui est basée sur les valeurs que l'on peut retrouver dans les rapports envers l'autre.

En 20Io, en France, paraît le roman de Céline Lavignette-Ammoun intitule Amour, Patates et Rock' n' roll [ıо]. L'auteure raconte l'histoire de Julia, adolescente de quatorze ans. Comme toutes les filles de son âge, Julia a une meilleure amie, Bérénice, à qui elle confie qu'elle est amoureuse d'Yvan, le plus beau garçon de son collège, et qu'elle déteste Jessica, la fille la plus populaire auprès des élèves. Julia a un secret car son frère jumeau, Julien, est autiste. Elle a honte de cela à tel point qu'elle invente une histoire où Julien est son cousin, un chanteur de rock anglais. Julien ne va pas à l'école, il est dans un institut spécialisé. L'auteure de Amour, Patates et Rock' n' roll centre son histoire sur Julia. Au début, elle cache l'existence de son frère, elle est embarrassée mais finalement, elle s'efforce à accepter sa maladie. Elle comprend que la différence doit exister et ose assumer son rôle de sœur d'un autiste.

En littérature tchèque, un parallèle se prête: c'est le roman d'Ivona Březinová Crie doucement, mon frère, paru en 20I6, destiné également aux adolescents. Lehéros s'appelle Jérémy. Il a une sœur qui s'occupe de lui en aidant leur mère parce que Jérémy est un garçon autiste. Il est différent des autres et pose beaucoup de problèmes à ses proches. Or, la famille refuse l'idée de se débarrasser de lui et de le mettre dans un centre spécialisé pour les malades de l'autisme. La 
sœur de Jérémy, à l'instar de Julia du roman précédent, se pose des questions sur son statut et son rapport vis-à-vis du frère malade: «Je me demande des fois comment la vie serait si maman n'avait d'autre enfant que moi-même. Je crois que je serais différente. Je serais peut-être plus folle, plus difficile, je sortirais beaucoup, toujours au Facebook ou devant un miroir en me coiffant et en disant que je n'ai pas assez de fringues, mais maman a aussi mon frère et elle a besoin de mon aide. Une idée m'est venue plusieurs fois que maman est plutôt comme ma sœur. Des fois je pense qu'elle est impossible. Vraiment. Si elle ne m'avait pas derrière, elle s'écroulerait peut-être. Elle abandonnerait peut-être. Mais je ne le lui dirais pas directement. Non plus à personne d'autre. Je peux le dire comme ça, à moimême» [2, p. 95].

Tout comme Julia dans Amour, Patates et Rock' n' roll, la protagoniste de ce roman tchèque accepte la situation et son destin ainsi que celui de son frère.

Les parallèles qui apparaissent dans les deux littératures, française et tchèque, prouvent l'existence des mêmes questions, et par conséquent des mêmes attitudes vis-à-vis des problèmes des sociétés européennes; la littérature tchèque reflète les enjeux sociologiques qui ne diffèrent pas beaucoup de ceux qui inspirent les auteurs en France ou ailleurs en Europe.

Le trait important de la prose des années I990, c'est l'intervention des thèmes fantastiques dans le monde réel - dans la vie quotidienne des enfants d'aujourd'hui. Cette tendance a pris ses racines déjà au cours de la décennie précedente et est liée à la remise au goût du jour du genre fantasy (Ende, Tolkien, Lindgren). Les thèmes fantastiques qu'on trouve dans leurs livres sont des résultats de l'approche totalement subjective de l'auteur, la réalité étant corrigée par l'irrationalité magique et mystique. Sur ce plan-là, la littérature tchèque s'est montrée un bon disciple car, à côté des traductions de livres de fantasy étrangers, les auteurs tchèques en produisent avec succès. Ils ont su adapter ce type de récit qui représente une évasion totale pour un enfant ou un adolescent. Néanmoins, les auteurs classiques du genre sont des étrangers que la littérature tchèque essaie d'imiter.

\section{Traductions du français au début du nouveau millénaire}

Tandis que la traduction de Harry Potter de J. K. Rowling n’a pas tardé les premiers tomes de la série ont été publiés en République tchèque dès $200 \mathrm{I}$, certaines œuvres francophones sont parvenues aux lecteurs tchèques relative- 
ment tard, malgré leurs qualités. Les livres de Daniel Pennac influencent les jeunes et ainsi les grands lecteurs tchèques depuis 1993 en remportant beaucoup de succès, notamment Cabot-Caboche (1982) dont la traduction date seulement de 20II tandis que Tobie Lollness de Timothée de Fombelle a été traduit presque immédiatement après sa publication en France (2006-2007), c'est-àdire entre 2007 et 2009. Nicolas de Crécy est connu depuis 200I. Son Salvatore (2005) a été traduit récemment, en 20I7. Les traducteurs tchèques essaient de «payer leurs dettes» vis-à-vis de la littérature française en traduisant des livres presque historiques comme Babar (I93I) de Jean de Brunhoff, publié en tchèque en $201 \mathrm{I}$.

En 20I3 paraît en République tchèque un ouvrage de Pavel Mandys (né en 1972), intitule $2 x$ IOI livres-les meilleurs livres d'enfants et de jeunesse et les livres effectuant la plus grande influence sur le jeune public tchèque [13. Ce chercheur tchèque a essayé d'établir un aperçu des œuvres littéraires qui ont posé les fondations du monde de la littérature de jeunesse de plusieurs générations de Tchèques. 2 x Ior livres propose une sélection selon l'âge: enfants et adolescents. Dans la partie historique, nous avons mentionné la plupart des titres que l'ouvrage de Mandys propose et tous les noms qui sont relatifs à la littérature française.

Or, nous avons souhaité avoir un panorama actuel concernant les préférences et prédilections de jeunes lecteurs tchèques. En nous appuyant sur plusieurs sources bibliographique et électroniques, nous pouvons analyser la thématique et le message des œuvres qui sont parues récemment en République tchèque, comparées aux choix de livres ayant du succès en France.

\section{Les choix recommandés}

La première sélection est une tranche de la production tchèque des dernières décennies que représentent les livres qui sont proposés par les spécialistes de littérature de jeunesse tchèque, pour la plupart les universitaires, et qui, selon les commentaires, ont réussi également auprès des enfants et des jeunes [II].

La sélection distingue les catégories habituelles d'âge: 3-6 ans, 6-II ans, II-I4 ans, I4-I6 ans. La littérature pour les plus petits se limite en majorité aux auteurs tchèques, souvent poètes célèbres en réédition, y compris des épisodes de La petit taupe de Zdeněk Miler. La seule exception concerne le livre Les Aristochats par Walt Disney. 
La deuxième catégorie de livres, destinés au enfants de 6 à II ans, est également fidèle à la production tchèque. La poésie représente approximativement 50 pour cent du total. Il s'agit des écrivains ayant acquis une véritable renommée, ce qui est valable tant pour les auteurs tchèques que pour les traductions (Crompton, Gaarder, Jansson, Lindgren Paterson).

La troisième tranche d'âge (II-I4 ans), selon l'avis des spécialistes, contient des œuvres à thématique variée, représentées en majorité par les traductions (Brezina, Crompton, Fombelle, Gaarder, Jansson, Lindgren, Paterson, Talbot, Terakowska, Selcznick), y compris les livres historiques. La production tchèque ne représente que 20 pour cent, dont les textes se caractérisent fréquemment des enjeux linguistiques et poétiques. Les drames de la vie réelle figurent également parmi les livres les plus populaires.

La dernière catégorie d'âge (I4-I6 ans) favorise les traductions d'ouvrages de fantasy (Almond, Bradley, Rowling, Selznick, Tolkien), ou les histoires d'amour (Prochazkova, Lanczova). La littérature classique est représentée par Shakespeare (Roméo et Juliette), à côté duquel on retrouve l'auteur tchèque K.J. Erben. Comme dans la catégorie précédente, la production tchèque n'occupe que 20 pour cent des œuvres les plus appréciées, tandis que dans les traductions figurent également des auteurs américains.

\section{Les sondages parmi les jeunes}

Les statistiques tchèques relatives à l'intérêt des jeunes lecteurs prouvent l'équilibre entre la production tchèque et les traductions des langues européennes. La répartition est approximativement de cinquante pour cent. Les auteurs étrangers célèbres ne manquent pas. Parmi les dix meilleurs livres selon l'opinion des enfants, on trouve deux auteurs autrichiens (T. Brezina et G. Smetanig), trois auteurs britanniques (J.K. Rowling, R. Gordon et W. Awdry), un auteur américain (S. Meyer). Les auteurs tchèques sont représentés notamment par des femmes: I. Březinová, A. Ježková, M. Burdová, D. Krolupperová, H. Lamková et une auteure slovaque (G. Futová). En ce qui concerne le genre, dans cette sélection la fantasy occupe la première place. Et à l'exception de M. Burdová, ce sont des œuvres d'auteurs étrangers. La production tchèque appréciée par les jeunes touche le monde des enfants, des animaux ou l'histoire.

En France, les bestsellers en littérature de jeunesse selon les statistiques de 2OIo sont des œuvres de fantasy pour la plupart, dont les auteurs sont connus en 
République tchèque: Stephenie Meyer, J.K. Rowling, Roald Dahl. Outre la domination de la fantasy, c'est aussi celle des auteurs américains (Mary Pope Osborne, Alyson Noël, Rick Riordan, Lisa Jane Smith, Kami Garcia, Stewart et Weisman). Le même genre est représenté par la Française Sophie Audoin-Mamikonian et Anne Robillard, auteure québécoise. A leurs côtés figurent néanmoins Le petit prince d'Antoine de Saint-Exupéry, favori éternel des sélections mondiales, et Vendredi ou la vie sauvage de Michel Tournier.

La production littéraire pour enfants en France est incomparable avec celle en République tchèque, tant par ses dimensions que par sa diversité et variété. Sans trop aller dans les détails, il est indéniable que le goût des lecteurs français est différent: la fantasy est privilégiée, les thèmes multiculturels et ceux de l'altérité abondent.

D’autre part, il est évident que la littérature tchèque du XXI ${ }^{e}$ siècle a adopté et développé les mêmes thèmes que toutes les littérature européennes. Si l'on compare, les thèmes et les motifs qui apparaissent le plus souvent dans les livres pour enfants et pour la jeunesse en France, d'après des sondages, sont les suivants: identité-différence, séparation-solitude, amour-amitié. Il est possible de constater que les auteurs tchèques présentent les mêmes questions à leurs lecteurs. En ce qui concerne les genres, les préférences données ci-dessus se confirment: en France, la priorité est donnée aux romans d'aventure ou fantastiques et aux romans dits sociaux. La science-fiction et le genre historique se trouvent en deuxième position.

Les nominations récentes aux Prix littéraires tchèques montrent la thématique diverse qui apparaît dans la production des livres pour les enfants, ainsi que le goût hétérogène de ses consommateurs: à partir des contes de fées, des fables, à travers les livres de science-fiction ou fantasy, on peut trouver des récits basés sur des innovations formelles, linguistiques (néologismes) et stylistiques (emploi de formes poétiques inhabituelles) aussi bien que thématiques (par exemple Un apprentissage ludique par Tereza Vostradovská - Prix Magnesia Litera 20I7).

Les choses s'imposent: l'ordinateur omniprésent dans la vie des enfants d'aujourd'hui ouvre le monde virtuel qui entoure l'enfant des technologies de science-fiction (par exemple Les prisonniers du soleil d'argent, nominé pour le Prix Magnesia Litera 20I7, dont l'auteur est Milos Kratochvíl ${ }^{\mathrm{II}}$ ); la vie réelle,

II Prague, Triton, 20I5. 
telle qu'elle est montrée dans certains livres, est altérée de plus en plus par des êtres surnaturels ou des choses, par exemple des objets inanimés qui deviennent animés (nous pouvons citer ici la personnification des Fautes et erreurs dans le livre éponyme de Tomáš Končinský et Barbora Klárová - Prix Magnesia Litera 20I6). Cette tendance prend source peut-être déjà dans l'œuvre d'Andersen et récemment dans le monde magique des livres anglo-saxons pour enfants car, traditionnellement, l'anthropomorphisme concernait presque toujours des animaux ou des végétaux dans la littérature tchèque.

\section{Conclusion}

Si nous essayons de comparer, en conclusion, la situation dans le domaine de la production littéraire destinée aux enfants et à la jeunesse en France et en République tchèque au tournant des siècles, on se rend compte de nombreuses différences: la quantité de titres publiés chaque année en France est incomparable à notre production, y compris les traductions. La tradition de livres pour enfants n'a pas subi de ruptures comme dans notre pays. Dans une perspective globale, toute la politique culturelle et la tradition de la vie littéraire française ont d'autres aspects. Finalement, il faut prendre en considération le goût des lecteurs (et les ambitions des écrivains) qui déterminent en effet la situation sur le marché du livre. Malgré toutes ces différences, il est possible de constater que la littérature tchèque d'aujourd'hui reflète les mêmes problèmes que les autres littératures européennes avec lesquelles elle partage également des approches et des solutions.

En République tchèque, l'Europe s'impose par l'intermédiaire des livres pour la jeunesse qui paraissent depuis les années I990: tout d'abord grâce à la traduction de L'histoire de l'Europe pour enfants de Jacques Le Goff en 1997, puis grâce à deux auteures tchèques, R. Fučiková et D. Krolupperová qui ont publié L'histoire de l'Europe: voyage en images en 20II. Le même but est poursuivi par un ouvrage plus récent, L'histoire peinte de l'Europe de V. Haškovec et O. Muller, datant de 2018.

Or, les livres tchèques sont également traduits et appréciés par les jeunes lecteurs français ou francophones, comme la parution de Ferda la Fourmi d'Ondřej Sekora $^{\text {I2 }}$ que nous avons mentionnée ci-dessus. Cinq contes pas comme les autres, de Karel Čapek, sont parus chez MeMo en 20I7. En 2009, les «Editions MeMo»

I2 Malavida, 2OI7. 
ont publié les vers de Josef Brukner Tony casse-cou qui accompagnent les images de Josef Lada, célèbre peintre naïf tchèque; en 20I6, les éditions «La joie de lire» de Genève ont fait paraître le livre de Jiří Kahoun, intitulé L’hippopotame, l'ours, la tortue... et autres histoires, illustré par Miloslav Jágr.

Les traductions de ces livres sont une preuve que l'apport de la littérature tchèque dans le cadre des littératures européennes peut être identifiable. C'est une vision de l'enfance et de l'enfant et des approches spécifiques, qui se manifestent avec la poétisation, l'idéalisation de l'enfance ou le regard plein d'humour ou d'ironie qui peuvent enrichir le monde de la littérature de jeunesse. 


\section{References}

I Bibliographie nationale tchèque. Available at: https://aleph.nkp.cz (Accessed o2 June 20I9). (In Czech)

2 Březinová I. Ǩvi potichu, brácho. Praha, Albatros, 20I6. 208 p. (In Czech)

3 Chelebourg C., Marcoin F. La littérature de jeunesse. Paris, Armand Colin, 2007. I27 p. (In French)

4 Dictionnaire de la littérature tchèque. Available at: www.slovnikceskeliteratury.cz/ showContent.jsp?docId=I284 (Accessed 2I June 20I9). (In Czech)

5 Dictionnaire Larousse. Available at: https://www.larousse.fr/dictionnaires/francais/ transposition/79226 (Accessed 2I June 20I9). (In French)

6 Dušková J. Jules Verne. Ústí nad Orlicí, Okresní knihovna v Ústí nad Orlicí, I985. I4 p. (In Czech)

7 Horák V. Jules Verne v nakladatelstvíJos. R. Vilímek. Praha, Thyrsus, 2005. I7I p. (In Czech)

8 Kunešová K. Le bestiaire moderne: expressions imagées. Les enjeux du jeu (éd. K. Kunešová). Hradec Králové, Gaudeamus, 2015. P. 49-57. (In French)

9 Kunešová K. L'image et l'imaginaire: inspiration de Jules Verne. De l'image àl'imaginaire (éd. K. Kunešová). Hradec Králové, Gaudeamus, 20II. I93 p. (In French)

Io Lavignette-Ammoun C. Amour, Patates et Rock' n' roll. Paris, D'un monde à l'autre, 20IO. 225 p. (In French)

II Litérature pour les enfants et la jeunesse. Available at:www.ctesyrad.cz/nejctivejsi/literatura-pro-deti-mladez (Accessed o2 April 20I9). (In Czech)

Littérature pour les enfants tchèques. Available at: http://www.iliteratura.cz/ Clanek/IoI79/provaznik-jaroslav-literatura-pro-ceske-deti (Accessed o2 April 20I9). (In Czech)

I3 Mandys P. 2xIoI knih. Nejlepší a nejvlivnějši knihy pro děti a mládež. Praha, Albatros, 20I3, 430 p. (In Czech)

I4 Marché du livre. Available at: https://www.idboox.com/economie-du-livre/chiffrescles-du-marche-du-livre-jeunesse/ (Accessed 20 May 20I9). (In French)

I5 Miloš Macourek. Available at: www.spisovatele.cz/milos-macourek (Accessed 20 May 20I9). (In Czech)

I6 Nières-Chevrel I. Introduction à la littérature de jeunesse. Paris, Didier, 2009. 240 p. (In French)

I7 Statistiques des éditions. Available at: https://tvurce.eu/knihy/statistiky-vydavani-knihv-cestine-v-cr-od-roku-I993/ (Accessed o2 April 2019) (In Czech)

I8 Urbanová S. Meandry a metamorfózy dětské literatury. Olomouc, Votobia, 2003.363 p. (In Czech) 


\title{
RUSSISCH-DEUTSCHER
}

LITERATURTRANSFER DER 30ER-40ER

JAHRE DES 20. JAHRHUNDERTS

This is an open access article distributed under the Creative Commons Attribution 4.0 International (CC BY 4.0)

\author{
(S. TRETJAKOW, F. WOLF, B. BRECHT) \\ (C) 2020. T.A. Sharypina, P.D. Kazakowa \\ Lobachewskij-Forschungsuniversität Nishnij Nowgorod, \\ Nishnij Nowgorod, Russland \\ Datum der Artikelübergabe: I4. Juni 2019 \\ Veröffentlichungsdatum: 25. Juni 2020
}

Inhaltsangabe: Die Auswirkungen des Phänomens der Russischen Avantgarde im ersten Drittel des zwanzigsten Jahrhunderts auf die ethisch-ästhetischen Prinzipien und die Poetik des deutschen sozialistischen Dramas werden analysiert. Ein nationalistischer Mythos wird in Deutschland nach dem Ersten Weltkrieg aktiv gebildet, während die internationale Grundlage in der Literatur Russlands vorherrscht, was für B. Brecht, I. Becher, F. Wolf, E. Weinert konzeptionell attraktiv war. Der Artikel befasst sich mit der Analyse des Einflusses des Theaterstück-Artikels von S. Tretjakow «Brülle, China!» auf das Drama von F. Wolf und B. Brecht. Es wird festgestellt, dass B. Brecht («Der gute Mensch von Sezuan», I938-I94I) in den Traditionen des epischen Theaters versuchte, den Geist des Zuschauers zu wecken und ihm ein anschauliches Beispiel für die Handlung zu geben. Im Stück «Tai Young erwacht» (I93I) nutzt F. Wolf alle Möglichkeiten, um den Zuschauer emotional zu beeinflussen, versucht mit Hilfe der Katharsis, die Mitwirkung des Zuschauers auf der Bühne zu erreichen, und stützt sich auch auf die Traditionen von M. Gorki und A. Fadejew, indem er seine Heldin während des Werdens eines Charakters darstellt. Die Vielfältigkeit der Ansätze zur Aufstellung eines chinesischen Themas in Abhängigkeit von der politischen und ethisch-ästhetischen Ausrichtung der Autoren zeugen von der Produktivität kreativer russisch-deutscher Kulturkontakte.

Stichwort: B. Brecht, F. Wolf, S. Tretjakow, literarischer Transfer, optimistische Tragödie, Katharsis, sozialistische Dramaturgie.

Information zu den Autoren: Tatiana A. Sharypina, Doktor der Philologie, habit., Professor mit Lehrstuhl für ausländische Literatur an der Lobachewskij-Forschungsuniversität Nishnij Nowgorod. Bolshaya Pokrovskaya, 37, 603000 Nishnij Nowgorod, Russland. ORCID ID: 0000-0002-8585-8983

E-mail: swawa@yandex.ru

Polina D. Kazakowa, Kandidat der Philologie, Assistenzprofessor am Lehrstuhl für ausländische Linguistik an der Lobachewskij-Forschungsuniversität Nishnij Nowgorod. Bolshaya Pokrovskaya, 37, 603000 Nishnij Nowgorod, Russland.

E-mail: polina_iwliewa@mail.ru

Zum Zitieren: Sharypina T.A., Kazakowa P.D. Russisch-Deutscher Literaturtransfer Der zoer4oer Jahre Des 20. Jahrhunderts (S. Tretjakow, F. Wolf, B. Brecht). Studia Litterarum, 2020, vol. 5, no 2, pp. I46-I6I. (In German) DOI: IO.22455/2500-4247-2020-5-2-I46-I6I 


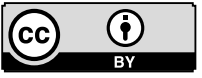

This is an open access article distributed under the Creative Commons Attribution 4.0 International (CC BY 4.0)

\section{RUSSIAN-GERMAN LITERARY TRANSFER OF THE 1930S-40S (S. TRETYAKOV, F. WOLF AND B. BRECHT)}

\author{
(C) 2020. T.A. Sharypina, P.D. Kazakova \\ Lobachevsky State University of Nizhni Novgorod, \\ Nizhni Novgorod, Russia \\ Received: June I4, 2019 \\ Date of publication: June 25, 2020
}

Abstract: The essay examines the influence of Russian literature upon ethical and aesthetic principles and poetics of German socialist drama. After the defeat in the WWI, Germany developed nationalist myths, whereas the international principle prevailed both in Russian literature and culture. The latter fact attracted B. Brecht, J. Becher, F. Wolf, and many others. The essay's aim is to demonstrate the influence of the playarticle Roar China! A Drama in Seven Scenes by S. Tretyakov on the German socialist drama. It is stated that Brecht (The Good Person of Szechwan, I938-I94I), considering the traditions of the epic theater, tried first of all to awaken the mind of the spectator and to give a clear example of action. In the play Tai Yang erwacht (I93I), F. Wolf used all available means of impact to influence the viewer emotionally, aiming to achieve the involvement of the audience into what was going on the stage by means of catharsis, and within the traditions of M. Gorky and A. Fadeyev depicted his heroine in the process of her character development. The versatility and the multidimensional nature of approaches to the development of the Chinese theme is the evidence of the productivity of artistic Russian-German cultural contacts.

Keywords: B. Brecht, F. Wolf, S. Tretyakov, literary transfer, optimistic tragedy, catharsis, socialist drama.

Information about the author: Tatiana A. Sharypina, DSc in Philology, Professor, Head of the Department of Foreign Literature, Lobachevsky State University of Nizhni Novgorod, Bolshaya Pokrovskaya St. 37, 603000 Nizhny Novgorod, Russia. ORCID ID: 0000-0002-8585-8983

E-mail: swawa@yandex.ru

Polina D. Kazakova, PhD in Philology, Assistant Professor of the Department of Foreign Linguistics, Lobachevsky State University of Nizhni Novgorod. Bolshaya Pokrovskaya St. 37, 603000 Nizhny Novgorod, Russia.

E-mail: polina_iwliewa@mail.ru

For citation: Sharypina T.A., Kazakova P.D. Russian-German Literary Transfer of the I930s-4Os (S. Tretyakov, F. Wolf, and B. Brecht). Studia Litterarum, 2020, vol. 5, no 2, pp. I46-I6I. (In German) DOI: I0.22455/2500-4247-2020-5-2-I46-I6I 
УДК 82I.II2.2 + 82I.I6I.I

ББК $83.3(4$ Гем $)+$

$83.3(2 \mathrm{Poc}=\mathrm{Pyc})$

\section{РУССКО-НЕМЕЦКИЙ ЛИТЕРАТУРНЫЙ TРАНСФЕР 30-Х-40-Х ГГ. ХХ В. \\ (С. ТРЕТЬЯКОВ, Ф. ВОЛЬФ, Б. БРЕХТ)}

(C) 2020 г. Т.А. Шарыпина, П.Д. Казакова

Национальный исследовательский Нижегородский государственный университет им. Н.И. Лобачевского, Нижний Новгород, Россия

Дата поступления статьи: г4 июня 2020 г.

Дата публикащии: 25 июня 2020 г.

DOI: I0.22455/2500-4247-2020-5-2-I46-I6I

Аннотация: Анализируется влияние феномена русского авангарда первой трети $\mathrm{XX}$ в. на этико-эстетические принципы и поэтику немецкой социалистической драматургии. В Германии после Первой мировой войны активно формируется националистический миф, тогда как в литературе России преобладало интернациональное начало, что было концептуально притягательно для Б. Брехта и Ф. Вольфа. Целью статьи является анализ влияния на драматургию Ф. Вольфа и Б. Брехта пьесы-статьи С. Третьякова «Рычи, Китай!». Констатируется, что Б. Брехт («Добрый человек из Сычуани», I938-І94I) в традициях эпического театра пытался пробудить разум зрителя и дать наглядный пример действия. В пьесе «Тай Янг пробуждается» (I93I) Ф. Вольф использует все способы эмоционального воздействия на зрителя, при помощи катарсиса старается добиться сопричастности зрителей происходящему на сцене, а также опирается на традиции М. Горького и А. Фадеева, изображая свою героиню в процессе становления характера. Многоплановость подходов к разработке китайской темы в зависимости от политической и этико-эстетической ориентации писателей свидетельствуют о продуктивности творческих российсконемецких культурных контактов.

Ключевые слова: Б. Брехт, Ф. Вольф, С. Третьяков, литературный трансфер, оптимистическая трагедия, катарсис, социалистическая драматургия.

Информация об авторах: Татьяна Александровна Шарыпина - доктор филологических наук, профессор, заведующий кафедрой зарубежной литературы, Национальный исследовательский Нижегородский государственный университет им. Н.И. Лобачевского, ул. Большая Покровская, д. 37, 603000 г. Нижний Новгород, Россия. ORCID ID: оооо-о0о2-8585-8983

E-mail: swawa@yandex.ru

Полина Дмитриевна Казакова - кандидат филологических наук, доцент кафедры зарубежной лингвистики, Национальный исследовательский Нижегородский государственный университет им. Н.И. Лобачевского, ул. Большая Покровская, д. 37, 603000 г. Нижний Новгород, Россия.

E-mail: polina_iwliewa@mail.ru

Для цитирования: Шарыпина Т.А., Казакова П.Д. Русско-немецкий литературный трансфер 30-х-40-х гг. ХХ в. (С. Третьяков, Ф. Вольф, Б. Брехт) // Studia Litterarum. 2020. T. 5, № 2. C. I46-I6I. DOI: IO.22455/2500-4247-2020-5-2-I46-I6I 
Der Prozess der russisch-deutschen literarischen und kulturellen Wechselbeziehungen und der des Transfers von philosophischen, ästhetischen, künstlerischen Ideen und Erscheinungen ist der Gegenstand intensiver Forschung sowohl in der deutschen als auch in der russischen Literaturwissenschaft seit Jahrzehnten [I8; 19; 20; 2I]. Es gibt jedoch immer noch Fragen, die in den wissenschaftlichen Arbeiten nicht genug ausreichend behandelt wurden, darunter auch das Problem des transnationalen Phänomens der Avantgarde im ersten Drittel des 20. Jahrhunderts. Die meisten deutschen Avantgarde-Künstler stammen aus der «Schule» des Expressionismus, in deren Manifesten eine internationale und zeitlose Beschaffenheit mehrmals betont wurde [9, S. 3IO-3II]. Nach dem Ersten Weltkrieg begann der germanisch-nationalistische Mythos in der soziokulturellen Atmosphäre Deutschlands zu bilden, während die internationale Grundlage in der Literatur und Kultur Sowjetrusslands vorherrschte, was für B. Brecht, I. Becher, F. Wolf, E. Weinert konzeptionell attraktiv war. Das internationale Fabel- und Themenspektrum war für deutsche sozialistisch orientierte Schriftsteller grundlegend. Friedrich Wolf, einer der bekanntesten Vertreter des deutschen sozialistischen Dramas des 20. Jahrhunderts, erklärte in seiner Rede auf dem Ersten Kongress der sowjetischen Schriftsteller, dass die Fragen der Existenz und Entwicklung der deutschen antifaschistischen Literatur nicht ausschließlich national sind, sondern sie sind von entscheidender Bedeutung für die Stärkung der fortschrittlichen Schriftsteller der ganzen Welt im Kampf gegen Faschismus. Sergei Tretjakow, ein brillanter Publizist, ein futuristischer Dichter (einer der Leiter der LEF-Gruppe), ein innovativer Dramatiker und Übersetzer, dessen Bemühungen im Vorkriegsjahrzehnt eine bedeutende Rolle bei der Stärkung der sowjetischen und deutschen sozialistisch orientierten Schriftsteller spielten, widmete diesem 
Thema eine eindrucksvolle pathetische Rede. S. Tretjakow erinnert sich unter anderem an seine Kontakte zu B. Brecht. Ein anschauliches Beispiel für den Kulturtransfer Russland-Deutschland ist die Verkörperung des Themas des rebellischen China.

Die Bedeutung der chinesischen Themen in der europäischen Literatur und Kultur in den späten zoer und frühen zoer-4oer Jahren des zwanzigsten Jahrhunderts wurde von den sozialen und politischen Prozessen geprägt, die dieses große Land auf dem Weg der Selbstbestimmung im Kampf um nationale Unabhängigkeit umfasst haben. Die aktuelle Situation des Kulturtransfers unterscheidet sich von der Aktivierung des Interesses an China in den zwanziger und vierziger Jahren des zwanzigsten Jahrhunderts. Um die Transformation der gegenseitigen Wahrnehmung in der Dynamik des literarischen Prozesses an der Wende des XX-XXI Jahrhunderts richtig zu verstehen, muss man den literarischen Transfer der 3oer-4oer Jahre gründlich untersuchen. Dieser Transfer «Russland - Deutschland - China» hatte nämlich meist eine schwierige Form. Somit entstanden zu dieser Zeit in Russland Gedichte über China von Wladimir Majakowski wie «Moskau China», «Finger weg von China!» und «Lies mal und ab nach Paris und China». Dazu gehören auch Gedichte von Demjan Bedny. In ihren Kunstwerken drückten die Schriftsteller ihr Mitgefühl für unterdrückte Menschen in China aus und prangerten die Militär Diktatur der Kuomintang an, die sich vom Westen mit Schätzen ihres Landes freikaufen wollte. In dieser Zeit erscheinen ferner eine Erzählung von Nikolai Tichonow über Sun YatSen, ein Gedicht von Saken Seifullin sowie seine Dokumentarfilme «Der große Flug» (1925) und «Schanghaier Tagebuch». Im Jahre I925 wurde das Ballett von Reinhold Gli re «Rote Mohnblume» inszeniert. Einen besonderen Einfluss auf europäische namentlich deutsches sozialistisches Drama übte Theaterstück Tretjakows «Brülle, China!» (I924) aus, das sich durch eine überaus markante Poetik auszeichnete. Es war das Ergebnis seines Aufenthalts in China und wurde im Meyerhold Theater von W. Fedorov unter Leitung von Meyerhold inszeniert. Später schrieb S. Tretjakow ein ergreifendes Gedicht «Brülle, China!», das ein «poetisches Gelübde darstellt. Ein Gelübde das zur Rache für die Demütigung eines großen Volkes aufruft» [5, S. 554-564]. Das Spiel fand großen Zuspruch und wurde im Jahre 1929 in Deutschland in Frankfurt am Main uraufgeführt. Die österreichische Tageszeitung «Arbeiter-Zeitung» hat das Spiel auf die gleiche Stufe mit «Panzerkreuzer Potemkin» von Sergei Eisenstein gestellt. 
Im Kontext der soziokulturellen Situation 30-40er und des allgemeinen Interesses der europäischen Kunst an der Kultur und der politischen Situation in China stellt die Vergleichsanalyse der ideologischen und künstlerischen Struktur der dramatischen Werken von F. Wolf («Tai Yang erwacht», I93I) und von B. Brecht «Der gute Mensch von Sezuan», (I938-I94I) ein riesiges Forschungsdesiderat dar. Die Vergleichsanalyse ermöglicht, die unterschiedlichen Herangehensweisen festzustellen, mit denen das chinesische Thema und der Hauptkonflikt der Werke verwirklicht werden, und das vor allem im Hinblick auf Zugehörigkeit zum politischen (F. Wolf) beziehungsweise epischen Theater (B. Brecht).

Künstlerisches Schaffen von Friedrich Wolf (Friedrich Wolf, I888-I953) nimmt zu Recht einen bedeutsamen Platz in der deutschen Literatur des zwanzigsten Jahrhunderts ein. Neben B. Brecht war F. Wolf der größte Dramatiker der sozialistischen Richtung der 30-40er Jahre, der zum Teil die Weiterentwicklung des nicht nur deutschen, sondern auch des gesamteuropäischen Theaters vorausbestimmt hat.

F. Wolf betritt die Weltbühne mit Stücken «Zyankali», I929 und «Professor Mamlock», I933; den Wendepunkt erfährt sein Schaffen aber bereits im Jahr 1923 mit dem Stück «Der Arme Konrad». Während der Arbeit an dem Stück «Der Arme Konrad» findet Wolf sein allgegenwärtiges Thema - das Thema des Volksaufstands, das mit den Motiven der Abfolge von revolutionären Ideen und denen der politischen Reife der Massen im Kampf um ihre Rechte aufs Engste verbunden ist. Dies wird zum zentralen Thema im Stück «Tai Yang erwacht». Solch ein Bühnenwerk Wolfs lässt sich als «optimistische Tragödie» bezeichnen, in deren Mittelpunkt die Einsichtskatharsis steht. Im Jahre 1926 veröffentlichte der Schriftsteller einen Programmartikel «Der Dichter und das Zeitgewissen». Den Dichter sieht Wolf als Zeitgewissen, der hart und unparteiisch das Zeitalter spiegelt. Sein ästhetisches Credo definiert Wolf als «Kunst ist Waffe», und begründet dieses theoretisch in der gleichnamigen Broschüre im Jahre I929. In seinen Beiträgen, Essays, Artikeln und Gedichten appelliert Wolf immer wieder an Künstler, auf aktuelle Ereignisse scharf zu reagieren. Eine unerschöpfliche Ideenquelle dafür seien die Hektik des Alltags, Streiks, Zeitungen, Statistiken und Tatsachen. Als überzeugter Internationalist ist Wolf auf der leidenschaftlichen Suche nach neuen Formen der Verkörperung vom politischen Material und neuen Wegen, auf den Zuschauer zu wirken. Dabei wäre zu betonen, dass Wolf es sich vornimmt, auf den Zuschauer emotional zu wirken und mithilfe der Katharsis den Zuschauer 
zum Miterleben zu bringen. Brecht hingegen hat es sich angelegen sein lassen, vor allem den Geist zu wecken und ein anschauliches Beispiel für die Aktion zu geben. F. Wolf versucht sich in verschiedenen Genres und Themen, wobei er seinen Sujets prinzipiell internationalen Charakter zugrunde legt. So widmet er ein Hörspiel mit dem Titel «Krassin rettet Italien» der Rettung der Nobile-Nordpolexpedition. Weiterhin spiegelt sich in Wolfs «Marsch auf Mossul» der Kampf des Westens um Bodenschätze des Nahen Ostens wider. I93I erscheint das Drama «Tai Yang erwacht», das von der für Wolf typischen aufrichtigen Utopie geprägt ist. Da der Dichter unentwegt bestrebt ist, den Weg der Einsicht und den der politischen Reife der Arbeiterbewegung im Kampf um ihre Rechte zu zeigen, mutet die Umwandlung des Protagonisten teilweise nicht authentisch, ja gekünstelt an. Thema und Problematik sowie stilistische Ausdruckskraft des Dramas «Tai Yang» stehen offensichtlich im Einklang mit Ideen und Bildern des Theaterstücks und gleichnamigen Dramas «Brülle, China!» von Tretjakow.

Die 1930, I947 und 195I veröffentlichten Spiele enthalten ein Vorwort, das über historische Ereignisse berichtete, z.B. über ausbeutende Kinderarbeit in Schanghai von über hunderttausend Kindern oder darüber, dass der Monatslohn von Weberinnen nur 9 Mexikanischer Dollar betrug, während das Existenzminimum für eine Familie bei 30 Dollar lag. F. Wolf deckt weitere erschreckende Tatsachen auf, dass die Hände der Weberinnen bei kleinsten Fehlern zur Strafe mit kochendem Wasser verbrüht wurden. All diese unbequemen Tatsachen kommen zum Ausdruck in Wolfs Spielen, was ihnen noch mehr Aussagekräftigkeit verleiht. Doch auch an dichterischer Bildhaftigkeit lässt sich das Vorwort es nicht ermangeln. Beispielsweise bezeichnet Wolf chinesische Demonstrationen und Meutereien als «ein Sichrecken halb schlummernden gefesselten Riesen» [23, S. 97], der sich nunmehr, also I947, auf die Beine gestellt hat. I95I stellte der Autor mit Stolz fest, dass «Tai Yang» der Vorbote des zum neuen Leben erwachten chinesischen Volks war.

Trotz des dokumentarischen Charakters des Bühnenwerks, der sich in Gesprächen oder Anmerkungen oder Diskussionen zeigt und vom Vorwort antizipiert wird, spielt sich die Handlung durchaus rasch ab. Das ist unter anderem der besonderen Gliederung des Spiels zu verdanken. Das Stück ist nicht in Akte, sondern in Bilder gegliedert; jedes Einzelne davon zeichnet sich durch hohe Dynamik aus. All dies sorgt für die Atmosphäre der Erwartung, des Anbruchs einer neuen Epoche und allgemeiner Veränderung. Um die notwendige Atmosphäre aufrecht- 
zuerhalten, führt F. Wolf darüber hinaus in seine Spiele eigenartige volkstümliche Lieder ein, die chinesische Volkslieder nachahmen sollen.

Eines, in dem sich um das Übel der Vorgänger handelt, eröffnet den Akt wie folgt: «Bambus flattert und Wolke schiebt, // Blutt rollt und Welle stiebt, // Alles schaukelt wie eine Affenherde... // Still liegt am Ahnenberg Yu-Chan // Die Erde // Man muss wissen, wo man hingehört» [23]. Dasselbe Ziel wird auch durch das Leitmotiv, das Lied über den Mangobaum, verfolgt. Dessen eingangs langsamer Rhythmus symbolisiert die unveränderbare, gleichmäßige Lebensordnung in China, die seit Jahrtausenden von Bestand ist. «Viele tausend Jahre steht der Mangobaum, // Tausend Menschen lagen in seinem Schatten, // Überhundert Geschlechtern // Rauscht der Mangobaum» [23]. Nähert sich das Stück seiner Mitte, ändert sich langsam der gleichmäßige Rhythmus: Zunächst einmal aus dem Munde eines Arbeiters Wan entwichen, ertönt das Lied schließlich als Kampflied des zum Aufstand bereiten chinesischen Volkes: «Einmal aber fährt ein Sturm in den Mangobaum, // Einer der Äste saust nieder,ward zum Speer, // Einer ins Feuer fiel, ward zur Jackel, // Einer zerschlug, ward der Schaft zum Gewehr, // Hundert Gewehre, tausend Gewehre, zehntausend Gewehre // Aus dem uraltem Mangobaum» [23, S. I86].

Derlei Technik findet übrigens in Hauptmanns Drama «Die Weber» Anwendung, das sich ebenfalls dem Aufstand des Volks widmet, das unter unmenschlichen Arbeitsbedingungen richtiggehend darbt und leidet. Hier lässt sich also eine gewisse Tradition erahnen. F. Wolf macht auch zum Leitmotiv das sich im Laufe des Stücks verwandelnde Lied. Das nationale Kolorit des Stücks hängt mit der Parabel über zwei Blumen zusammen, die auf einem blutroten Mohngefilde wachsen, das zwar den Menschen einen Opiumrausch verbürgt und den Alltag vergessen lässt, allerdings Kriege, Wahn und Zwist mit sich bringt, was vom Westen herbeigesehnt wird. Es steht mittlerweile fest, dass Schlafmohn nach China von Engländern eingeführt wurde. Das Rauschgift hielt Einzug ins Leben ärmerer Bevölkerung und berauschte bisweilen ganze Siedlungen [8]. Dem Mohn wird eine kleine weiße Baumwollpflanze gegenübergestellt, die im Herbst aufblüht und den Fleiß der Chinesen symbolisiert. Sie bietet ihnen Arbeit, Bekleidung und Nahrung; daraus wird Papier hergestellt, auf dem man die Wahrheit über das Leben eines Volks und Flugblätter schreiben kann. Die Protagonistin ist noch weit entfernt von der Offenbarung, doch die Parabel, die ihr Arbeiter Wan erzählt, flößt ihr Angst ein; Angst vor etwaigen Streikwellen und Demons- 
trationen, die zu Krawallen und Blutvergießen führen werden. Das Hauptthema dieses Stücks, wie auch vieler anderen Wolfs, ist das der Offenbarung und des Werdegangs des Charakters vom Protagonisten. Gegebenenfalls geht es um ein chinesisches Mädchen namens Tai Yang. Also kein Wunder, dass Wolf Alexander Fadejews Roman «Die Niederlage» besonders wertschätzte. Denn als Dramendichter fühlt sich Wolf besonders davon angesprochen, dass Fadejew den Durchbruch vom Lewinsons Partisanenverband als Werdegang des Charakters schildert [2, S. 35I]. Es vergeht eine Weile, bis Tai Yang eine Offenbarung erlebt. Zunächst einmal erfolgt mithin keine Offenbarung, als Tai Yangs zwölfjährige Schwester Ma als Strafe für einen zerrissenen Faden vom Fabrikherrn Tschu Fu missbraucht werden soll. Das Geschehen hält Tai Yang sogar für ein Glück für sie und ihre Familie. Doch der Zucker in der Zuckerdose, wie das ironisch in der Fabrik bezeichnet wird, erweist sich als ziemlich bitter: Genau auf Tschu Fus Befehl hin werden die Fabrikarbeiter misshandelt und genau seinetwegen verrät Tai Yang, wenn auch im Unwissen, ihren Geliebten Wan. Auf den ersten Blick scheint Tai Yang, ganz unversehens die Offenbarung zu erleben. Indessen wird der Zuschauer durch einzelne Züge und Anmerkungen an den Umbruch im Sinn und Geist der Figur herangeführt. Etwas geradliniger und weniger begründet ist die Offenbarung der Fabrikarbeiterinnen ausgefallen. Eine besondere Rolle im Stück kommt Bildern 7 und $8 \mathrm{zu}$, in denen sich Tai Yang dazu entschließt, Flugblätter in der Fabrik zu verteilen. Unerkennbar gekleidet, verteilt sie nicht nur die Flugblätter, sondern auch rote Tücher, die Solidarität mit den Streikenden symbolisieren. Daher kommt man nicht um die Gedanken herum an den Roman Maxim Gorkijs «Die Mutter», der von Wolf überaus begehrt wurde. In Wolfs Drama vermitteln keine Figuren einen gestelzten noch gekünstelten Eindruck. Sowohl Tai Yang, als auch die Fabrikarbeiterinnen sind nicht ideal: Erst zum Schluss des Stücks erlebt die zwölfjährige Ma die Offenbarung, die bislang überzeugt ist, dass ihre Schwester selbst an die Zuckerdose heranwollte; ihr älterer Bruder Tse ist Aufseher in der Fabrik, ihre Urgroßtante Tse-Tse verkauft Opium. Dagegen weist die Figur Tschu Fus durchaus positive Züge auf. Nur die Figuren der westlichen Missionare und der Rotes-Kreuz-Delegierten Miss Lund sind grotesk gehalten. Es ist bemerkenswert, dass genauso in Hauptmanns «Die Weber» das Stück an dem Höhepunkt abbricht, als die aufständischen Weber das Militär vertreiben. Damit schafft Hauptmann eine eigenartige Hymne für das meuternde Volk. Wolf beendet sein Stück ebenfalls symbolisch: Mit einem Lied über den Mangobaum, das 
Symbol Chinas, das Wanderern Rast und Ruhe bietet und aus dessen Zweigen die Aufständischen im Kampf um ihre Freiheit Waffen anfertigen.

Angesichts der politischen und kulturellen Situation der 1920-30er Jahre erfuhr das chinesische Thema damals großen Zulauf. Annähernd zu dieser Zeit arbeitet Wolfs dramaturgischer Rivale Bertolt Brecht an seinem Stück «Der gute Mensch von Sezuan», 1938-I94I. Desgleichen schildert das Stück einen steinigen Weg der Offenbarung der Protagonistin, die indes im Gegensatz zu Tai Yang nicht über den Scheideweg hinaus gelangt. Zur gleichen Zeit arbeitet Brecht schon seit Jahren an dem Prosabuch «Me-ti. Buch der Wendungen», das in chinesischer Manier verfasst ist und in bester Tradition von M. de Montaigne, J. Swift und F. Bacon. Der Titel stellt den verballhornten Eigennamen des altchinesischen Philosophen und Politikers Mozi und seines Werks «Buch der Wendungen». Die chinesisch stilisierten Versuche Brechts bestehen zwar aus fünf Bänden von Parabeln und Aphorismen, werfen aber die akutesten Probleme der 20-40er Jahre auf, darunter Aufarbeitung und Revision des Marxismus. Erst nach dem Tode Brechts wurde es möglich, das Buch herauszugeben. Für das Stück «Der gute Mensch von Sezuan» wählt Brecht eine sehr markante Form, die zum einen bedingt märchenhaft, zum anderen sinnlich-konkret ist. Den Anstoß dazu nahm er aus der Ballade «Der Gott und die Bajadere» von J.W. von Goethe. Wie so oft schon «verfremdet» Brecht ein bekanntes Sujet, indem er folgende Fragen zu Tage fördert: Ob die Bajadere die Vergebung Gottes überhaupt braucht und ob es wahrlich schwer ist, im Himmel gut zu sein, oder aber es wichtiger wäre, auf dieser Erde gut zu bleiben. Des Problems nimmt sich der Dramatiker dialektisch an, wobei eine paradoxale Gesellschaft geschildert wird, in der das Gute zum Bösen wird und nur dank des Bösen das Gute existieren kann. Dergleichen Probleme der Ethik beschäftigten den Schriftsteller seit je her. Als er seine früheren Werke kommentierte, behauptete er beispielshalber, dass es unmöglich ist, in einer konkreten Gesellschaft nach abstrakten ethischen Vorstellungen zu leben: «Freiheit, Güte, Gerechtigkeit, Geschmack und Großzügigkeit sind Produktionsfragen, sagte Me-ti zuversichtlich <...>. Unter sittlichem Verhalten kann ich nur ein produktives Verhalten verstehen. Die Produktionsverhältnisse sind die Quellen aller Sittlichkeit und Unsittlichkeit» [7, S. 84]. Aus «Dem Versuchsbuch» wird ersichtlich, dass der Autor mit den früheren Ideen Lenins vertraut war, die besagten, dass es im ganzen Marxismus kein Gran Ethik ist. Me-ti, Brechts Alter Ego, macht darauf aufmerksam, dass weder Ka-Meh (Karl Marx) noch Mie-en leh (Lenin) 
eine Sittenlehre vorschlägt. Doch auch hier ist Brechts Selbstständigkeit nicht zu übersehen. Man kommt nicht umhin, S.N. Semljanoj in dem Punkt zuzustimmen, dass Bertolt Brecht nach der Verkörperung seiner eigenen ethischen Utopie trachtete. Er träumt von dem Land, das von seinen Einwohnern keine besondere Tugendhaftigkeit verlangen und darum keine vorgeschriebene Ethik benötigen würde [6, S. 45-46].

Die chinesische, fast märchenhaft anmutende Entourage darf der Zuschauer aber nicht für bare Münze nehmen: Hier liegt ein Gesamtbild eines Staates vor, in dem das Gesetz der sozialen Ungerechtigkeit herrscht. Die kläglichen Bedingungen, unter denen eine junge, arme Prostituierte Shen Te dahinlebt, haften jedweder Gesellschaft der Unterdrückung an. Die Tatsache, dass die Handlung nach China verlagert wird, verleiht dem Stück einen überzeitlichen Charakter sowie «den Verfremdungseffekt». Der Begriff der Verfremdung hat mit dem der Entfremdung von Karl Marx nichts gemeinsam und entstammt dem literarischen Konzept der Verfremdung von Wiktor Schklowski, den Bertolt Brecht über Sergej Tretjakow kennengelernt hat. Die chinesische Entourage, wie sie in Brechts «Buch der Wendungen» und «Der gute Mensch von Sezuan» vorzufinden ist, ist somit keine Nachahmung noch Stilisierung, sondern eine Verfremdung, von der Brecht weiterhin in seinem nicht beendeten, ebenfalls in China spielenden Roman über TUI (Intellektuelle) Gebrauch macht. Man geht wohl nicht fehl in der Annahme, dass Brecht nicht nur das Sujet der Ballade von Goethe verfremdet, sondern er ruft auch die Folkloretradition eines wunderlichen Märchens ins Gedächtnis, wo ein gutes aber von bösen Menschen beleidigtes Waisenkind von der Glücksfee belohnt wird. Auf der Suche nach wenigstens einem guten Menschen führen die Götter einen regelrechten sozialen Versuch am Schicksal Shen Tes durch, in dem sie aber zu deren Unzufriedenheit durchfällt. Denn im Staat, wo die Ungerechtigkeit ungeheuer wuchert, gelten die Märchenregeln nicht länger. Für das Geld, das Shen Tes von den Göttern bekommt, eröffnet sie einen Tabakwarenladen und hilft allen Notleidenden. Doch ein paar Tage später wird ihr klar, dass sie böse werden soll, um weiter Gutes zu tun. So erblickt das Licht der Welt ihr Cousin, der böse und eigennütziger Shui Ta. Langsam leuchtet es Shen Te ein, dass sie nur dann überleben kann, wenn sie sich an den Prinzipen ihres Cousins hält und lediglich von Zeit zu Zeit auch gut ist. Wie paradoxal das auch immer bedeuten mag. Brecht hielt das für vollkommen inakzeptabel, wenn bei einigen Aufführungen die Hauptdarstellerinnen bestrebt waren, zwei diametral 
entgegengesetzte Figuren darzustellen, von der Besetzung mit zwei Schauspielerinnen ganz zu schweigen. Bei der Verkörperung zweier Wesen der Protagonistin ging es Brecht nämlich nicht nur um die Verfremdung, die auf der Bühne statthat; in „der gute Mensch von Sezuan“ wird nicht weniger die Widersprüchlichkeit der menschlichen Natur in den Vordergrund gerückt. Seinem Wesen nach ist der Mensch gut, doch seine Umstände und Umgebung sind dergestalt, dass das Wohltun nur Verfall mit sich bringt, das Übeltun dagegen Wohlstand. Nachdem die Götter festgellt hatten, dass Shen Te der gute Mensch ist, stiegen sie wieder zum Himmel auf. Das Problem des Guten und des Bösen blieb dabei im Grunde genommen ungelöst. Ganz absichtlich lässt Bertolt Brecht das Ende des Stücks offen. Der Zuschauer des epischen Theaters soll selbst daraus eine Schlussfolgerung ziehen. Das offene Ende lässt eine gewisse Mehrdeutigkeit zu. Das Stück «Der gute Mensch von Sezuan» ist eine der besten Errungenschaften der epischen Dramendichtung Bertolt Brechts. Brecht versucht also vor allem an den Verstand zu appellieren und ein anschauliches Beispiel fürs Handeln aufzuführen. Wolf demgegenüber ist bestrebt, auf die Emotionen der Zuschauer zu wirken und mithilfe der Katharsis ihre Mitbeteiligung am Bühnengeschehen zu erlangen. In seinem Stück über Chinesin Tai Yang schlägt Wolf alle Wege der emotionalen Einwirkung auf den Zuschauer ein, die ihm zur Verfügung stehen. Zusammenfassend lässt sich festhalten: Die Vielfalt und der mehrdimensionale Ansatz zur Formulierung und Entwicklung des chinesischen Themas, je nach politischer, ethischer und ästhetischer Orientierung des Dramatikers zeigen das Problemausmaß der deutschen sozialistischen Drama dieser Zeit, ebenso wie die Produktivität der deutsch-russischen Kulturkontakte. Der internationale universelle Schwerpunkt, der in der russischen Literatur der Berichtsperiode und insbesondere im Konzept der Russischen Avantgarde und ihrer besten Vertreter, wie Sergej Tretjakow, zum Ausdruck kam, erwies sich außerordentlich anziehend für die deutschen sozialistischen Schriftsteller B. Brecht, I. Becher, F. Wolf und andere, die aus der „Schule“ des Expressionismus stammten. S. Tretjakow erwies sich als Persönlichkeit und als Künstler, als so eine hervorragende und vielseitige Individualität, dass die kreativen Kontakte zu ihm der Entwicklung des deutschen sozialistischen Dramas und vor allem der Theateraktivitäten von Bertolt Brecht und Friedrich Wolf einen starken Impuls gaben. 


\section{Список литературы}

Брехт Б. Ме-ти. Книга перемен // Брехт Б. Собрание избранных сочинений. М.: «Логос-Альтера», «Ессе homo», 2004. Т. г: Проза. 224 с. Вольф Ф. Годы и люди. М.: Прогресс, 1988. 374 с.

3 Гирин Ю.Н. Картина мира эпохи авангарда. Авангард как системная целостность. М.: ИМЛИ РАН, 2013. 400 с.

4 Головчинер B.E. Сергей Третьяков - учитель Бертольта Брехта // Сибирский филологический журнал. 20I4. № 2. С. II7-I25.

5 Гомолицкая-Третьякова Т.С. О моем отце // Третьяков С.М. Страна-перекресток. Документальная проза. М.: Сов. писатель, І99І. С. 554-564.

6 Земляной С. Этика Бертольта Брехта // Этическая мысль. М.: ИФ РАН, 2004. Вып. 5. С. 37-53.

7 Ленин В.И. Полн. собр. соч. М.: «ЁЁ Медиа», І970. Т. г. С. 440-44I.

8 Опиумные войны Китая. URL: http://www.shaolin.ru/china/history/ı8о (дата обращения: II.06.2019).

9 Первый Всесоюзный съезд советских писателей I934. Стенографический отчёт. Москва: ГИХЛ, І934. 7І 8 с. «Рычи, Китай!» Сергея Третьякова // Педагогика школьная. URL: http://www. portalus.ru/modules/shkola/rus_readme.php?archive=006\&id=I296I3I495\&start from=\&subaction=showfull\&ucat (дата обращения: ІІ.о6.20I9). SovLitСовЛит: Третьяков С. Рычи Китай. URL: http://www.ruthenia.ru/sovlit/j/2952.html (дата обращения: II.06.20I9). Третьяков С.М. Дэн Ши-хуа. Люди одного костра. Страна-перекресток. М.: Сов. писатель, г962. 770 с. Шарыпина T.A. Концепция «документального эпоса» русского авангарда и становление театральной практики Бертольта Брехта // Ученые записки Петрозаводского государственного университета. 20I6. № 3 (I56). С. 67-74.

I4 Шумахер Э. Жизнь Брехта. М.: Радуга, І988. 352 с.

I5 Brecht Bertolt. Der gute Mensch von Sezuan. Suhrkamp Verlag: Frankfurt a.M., I964. I $44 \mathrm{~S}$.

I6 Brecht Bertolt. Me-ti. Buch der Wendungen. Aufbau-Verlag: Berlin, I975. 260 S.

I7 Bertolt Brecht. Werke. Große kommentierte Berliner und Frankfurter Ausgabe. Herausgegeben von Werner Hecht, Jan Knopf, Werner Mittenzwei, Klaus-Detlef Müller. Band 26. Berthold Brecht Journale I I9I3-I94I: Tagebücher I9I3-I922. Journale I938-I94I. Autobiographische Notizen I9I9-194I Aufbau-Verl.. Brel. und Weimar; Suhrkamp Verl. Frankfurt am Main, I994. S. 326-327.

I8 Brecht-Lexikon. Ana Kugli / Michael Opitz (Hrsg.). Stuttgart-Weimar, 2006. 289 S.

I9 Jarmatz K., Barck S., Diczel P. Exil in der UDSSR. Leipzig, I979. 662 S.

20 KnopfJ. Bertolt Brecht. Lebenskunst in finsteren Zeiten. München: Carl Hanser Verlag, 2012.560 S. 
2I Lehmann J. Russische Literatur in Deutschland. Ihre Rezeption durch deutschsprachige Schriftsteller und Kritiker vom I8. Jahrhundert bis zur Gegenwart / Verlag J. B. Metzler, Stuttgart, 20I5. $432 \mathrm{~S}$.

22 Sharypina T., Ivlieva P. Das chinesische Tema in der deutschen Dramaturgie der dreißiger bis vierziger Jahre des 20. Jahrhunderts (Friedrich Wolf, Bertolt Brecht)// Akten des XIII. Kongresses der Internationalen Vereinigung für Germanistik (IVG), Shanghai 20I5. Germanistik zwischen Tradition und Innovation. Band 9. Frankfurt am M. etc.: Peter Lang. (= Publikationen der Internationalen Vereinigung für Germanistik 28). S. I43-I47.

23 Wolf F. Dramen. Berlin: Aufbau-Verlag, I960. 432 S. 


\section{References}

Brekht B. Me-ti. Kniga peremen [Book of Changes]. In: Brekht B. Sobranie izbrannykh sochinenii [Collection of selected works]. Moscow, "Logos-Al'tera”, "Esse homo” Publ., 2004. Vol. I: Proza [Prose]. 224 p. (In Russ.)

$2 \quad$ Vol'f F. Gody i liudi [Years and people]. Moscow, Progress Publ., I988. 374 p. (In Russ.)

3 Girin Iu.N. Kartina mira epokhi avangarda. Avangard kak sistemnaia tselostnost [The worldview of the epoch. Avant-garde as a systematic integrity]. Moscow, IWL RAS Publ., 20I3. 400 p. (In Russ.)

4 Golovchiner V.E. Sergei Tret'iakov - uchitel` Bertol'ta Brekhta [Sergey Tretyakov Bertolt Brecht's teacher]. Sibirskii filologicheskii zhurnal, 20I4, no 2, pp. II7-I25. (In Russ.) Gomolitskaia-Tret'iakova T.S. O moem ottse [About my father]. In: Tret'iakov S.M. Strana-perekrestok. Dokumental'naia proza [Country-intersection. Documentary prose]. Moscow, Sovetskii pisatel' Publ., I99I, pp. 554-564. (In Russ.) Zemlianoi S. Etika Bertol'ta Brekhta [Bertolt Brecht's ethics]. In: Eticheskaia mysl' [Ethical thought]. Moscow, IF RAN Publ., 2004, issue 5, pp. 37-53. ( In Russ.) Lenin V.I. Polnoe sobranie sochinenii [Complete works]. Moscow, "EE Media” Publ., I970, vol. I, pp. 440-44I. (In Russ.)

8 Opiumnye voiny Kitaia [Opium Chinese wars]. Available at: http://www.shaolin.ru/ china/history/I80 (Accessed II June 20I9). (In Russ.)

9 Pervyi Vsesoiuznyi s"ezd sovetskikh pisatelei 1934. Stenograficheskii otchet [The first all-Union Congress of Soviet writers in I934. Verbatim record]. Moscow, GIKhL Publ., I934. 7I8 p. (In Russ.)

“Rychi, Kitai!” Sergeia Tret‘iakova [Roar, China! by Sergey Tretyakov]. Pedagogika shkol'naia [School pedagogy]. Available at: http://www.portalus.ru/modules/shkola/ rus_readme.php?archive $=006 \&$ id $=$ I296I3I495\&start_from $=\&$ subaction $=$ showfull\&ucat (Accessed II June 20I9). (In Russ.) SovLitSovLit: Tret'iakov S. Rychi Kitai [Roar, China!]. Available at: http://www.ruthenia.ru/sovlit/j/2952.html (Accessed II June 20I9). (In Russ.) Tret'iakov S.M. Den Shi-khua. Liudi odnogo kostra. Strana-perekrestok [Dan Shih Hua. People of one bonfire. Cross country]. Moscow, Sovetskii pisatel' Publ., I962. 770 p. (In Russ.) Sharypina T.A. Kontseptsiia “dokumental'nogo eposa” russkogo avangarda i stanovlenie teatral'noi praktiki Bertol'ta Brekhta [Conceptual ideas of "documentary epos" in Russian avant-garde and the development of Bertolt Brecht's theatrical practice]. Uchenye zapiski Petrozavodskogo gosudarstvennogo universiteta, 20I6, no 3 (I56), pp. 67-74. (In Russ.)

I4 Shumakher E. Zhizn` Brekhta [The life of Brecht]. Moscow, Raduga Publ., I988. 352 p. (In Russ.) 
I5 Brecht Bertolt. Der gute Mensch von Sezuan. Frankfurt a.M., Suhrkamp Verlag, I964. I44 S. (In German)

I6 Brecht Bertolt. Me-ti. Buch der Wendungen. Berlin, Aufbau-Verlag, I975. 260 S. (In German)

I7 Bertolt Brecht Werke. Große kommentierte Berliner und Frankfurter Ausgabe. Herausgegeben von Werner Hecht, Jan Knopf, Werner Mittenzwei, Klaus-Detlef Müller. Band 26. Berthold Brecht Journale I I9I3-I94I: Tagebücher I9I3-I922. Journale I938-I94I. Autobiographische Notizen I919-I94I Aufbau-Verl. Brel. und Weimar; Suhrkamp Verl. Frankfurt am Main 1994. S. 326-327. (In German)

I8 Brecht-Lexikon. Ana Kugli / Michael Opitz (Hrsg.). Stuttgart-Weimar, 2006. 289 S. (In German)

I9 Jarmatz K., Barck S., Diczel P. Exil in der UDSSR. Leipzig, I979. 662 S. (In German)

20 Knopf J. Bertolt Brecht. Lebenskunst in finsteren Zeiten. München, Carl Hanser Verlag, 20I2. 560 S. (In German)

2I Lehmann J. Russische Literatur in Deutschland. Ihre Rezeption durch deutschsprachige Schriftsteller und Kritiker vom I8. Jahrhundert bis zur Gegenwart. Stuttgart, Verlag J.B. Metzler, 20I5. 432 S. (In German)

22 Sharypina T., Ivlieva P. Das chinesische Tema in der deutschen Dramaturgie der dreißiger bis vierziger Jahre des 20. Jahrhunderts (Friedrich Wolf, Bertolt Brecht). Akten des XIII. Kongresses der Internationalen Vereinigung für Germanistik (IVG), Shanghai 2015. Germanistik zwischen Tradition und Innovation. Band 9. Frankfurt am M. etc.: Peter Lang. (= Publikationen der Internationalen Vereinigung für Germanistik 28). S. I43-I46. (In German)

23 Wolf F. Dramen. Berlin, Aufbau-Verlag, I960. 432 S. (In German) 
УДК 82I.I3І.І

ББК 83.3(4Ита)

\section{ОТ К.Э. ГАДДЫ ДО НЕОАВАНГАРДА: ЭВОЛЮЦИЯ ХУДОЖЕСТВЕННОГО ЭКСПЕРИМЕНТА}

\author{
(C) 2020 г. А.В. Голубцова \\ Институт мировой литературы \\ им. А.М. Горького Российской академии наук, \\ Москва, Россия \\ Дата поступления статьи: о8 апреля 2019 г. \\ Дата публикации: 25 июня 2020 г. \\ DOI: IO.22455/2500-4247-2020-5-2-I62-I7I
}

Статья написана при финансовой поддержке гранта РФФИ І7-04-ооо73-ОГН «Литературный процесс первой половины ХХ века в Европе и Америке: направления и школы»

Аннотация: В статье рассматривается влияние Карло Эмилио Гадды, одного из крупнейших итальянских писателей XX в., на итальянский неоавангард г96о-х гг. - экспериментальное литературное течение, которое ставит своей целью подрыв основ сложившегося общества (привычных мыслительных схем, расхожих убеждений и мифов) через разрушение традиционного языка. В романах «Познание боли» и «Пренеприятнейшее происшествие на улице Мерулана» Гадда создает оригинальный художественный язык - сложное переплетение языковых и стилистических кодов, интертекстуальных отсылок и цитат. Тексты Гадды становятся эстетическими ориентирами для представителей нового течения, в особенности для Л. Малербы и Дж. Манганелли. Это влияние прослеживается на всех уровнях, от идейного и тематического до формального, вплоть до заимствования конкретных приемов и техник работы с языком. Однако Гадда не разделяет программной антиидеологичности и разрушительного пафоса неоавангарда. Техники смешения и трансформации разнородных языковых и культурных кодов в его текстах используются как способ выявления скрытых связей между вещами, восстановления преемственности с традицией, познания реальности во всей ее сложности и полноте. Неоавангард же воспринимает язык Гадды как средство критики социума и культуры, развенчания мифов и идеологий, отвергая возможные реконструктивные смыслы художественного эксперимента.

ключевые слова: К.Э. Гадда, неоавангард, Л. Малерба, Дж. Манганелли, художественный эксперимент, интертекстуальность.

Информация об авторе: Анастасия Викторовна Голубцова - кандидат филологических наук, старший научный сотрудник, Институт мировой литературы им. А.М. Горького Российской академии наук, ул. Поварская, д. 25 а, І21069 г. Москва, Россия. ORCID ID: о0оо-0002-I286-7707

E-mail: anaı294@yandex.ru

Для цитирования: Голубцова А.В. От К.Э. Гадды до неоавангарда: эволюция художественного эксперимента // Studia Litterarum. 2020. Т. 5, № 2. С. I62-I7I. DOI: IO.22455/2500-4247-2020-5-2-I62-I7I 


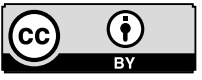

This is an open access article distributed under the Creative Commons Attribution 4.0 International (CC BY 4.0)

\section{LITERARY EXPERIMENT FROM C.E. GADDA TO NEO-AVANT-GARDE: CONTINUITY AND TRANSFORMATION}

\author{
(C) 2020. A.V. Golubtsova \\ A.M. Gorky Institute of World Literature \\ of the Russian Academy of Sciences, Moscow, Russia \\ Received: April o8, 2019 \\ Date of publication: June 25, 2020
}

Acknowledgements: The paper has been written with the support of the Russian Foundation for Basic Research (RFBR), project № I7-04-00073-OGN “Literary Process of the First Half of the $20^{\text {th }}$ Century in Europe and America: Movements and Schools”.

Abstract: The article examines the influence of Carlo Emilio Gadda, one of the greatest Italian $2 \mathrm{O}^{\text {th }}$ century authors, on the Italian Neo-Avant-Garde of the I96os, an experimental literary movement aimed at undermining the pillars of the established society (clichéd patterns, widespread beliefs, and myths) by destroying traditional language. In his novels The Experience of Pain and That Awful Mess on Via Merulana, Gadda invents his own peculiar "language," a complex combination of various linguistic and cultural codes, intertextual references and quotations. Gadda's texts fully published in the I950s-I960s, in the period of animated discussions around Neo-Avant-Garde theory and practice, become aesthetic models for the young authors, especially for Luigi Malerba and Giorgio Manganelli. Gadda's works influence Neo-Avant-Garde ideas, themes, and linguistic techniques, even though Gadda does not share Neo-AvantGarde's anti-ideological and destructive spirit. He mixes and transforms different codes seeking to reveal hidden connections between things, to reach back to the cultural tradition, and to convey reality in its fullness, while Neo-Avant-Garde perceives Gadda's language as a means of social and cultural criticism that allows to discredit myths and ideologies, and denies any possible reconstructive meanings of literary experimentation.

Keywords: C.E. Gadda, Neo-Avant-Garde, L. Malerba, G. Manganelli, experiment, intertextuality.

Information about the author: Anastasia V. Golubtsova, PhD in Philology, Senior Researcher, A.M. Gorky Institute of World Literature of the Russian Academy of Sciences, Povarskaya 25 a, I21069 Moscow, Russia. ORCID ID: 0000-0002-I286-7707

E-mail: anai294@yandex.ru

For citation: Golubtsova A.V. Literary Experiment from C.E. Gadda to Neo-Avant-Garde: Continuity and Transformation. Studia Litterarum, 2020, vol. 5, no 2, pp. I62-I7I. (In Russ.) DOI: I0.22455/2500-4247-2020-5-2-I62-I7I 
Самым ярким феноменом в литературе Италии г96о-х гг. становится итальянский неоавангард - направление, связанное с деятельностью так называемой «Группы 63» и ориентированное на радикальное обновление итальянской культуры через возрождение опыта исторического авангарда и освоение актуальных тенденций европейской мысли (структурализма и постструктурализма, семиотики, феноменологии, психоанализа). Писателей и критиков, входивших в «Группу 63», объединяла убежденность в том, что между идеологией и языком существует тесная связь, а изменение привычного языка в конечном счете должно неминуемо привести к изменению мышления - привычных мыслительных схем, расхожих убеждений и мифов. Стремясь к литературной и лингвистической «революции», неоавангард обращается к радикальным языковым экспериментам и создает особый, трудный для понимания художественный язык.

В том, что касается техник работы с языком, предтечей неоавангарда является Карло Эмилио Гадда (г893-1973), один из крупнейших и самых оригинальных итальянских писателей XX в., автор многочисленных рассказов, эссе и двух романов, принесших ему общеитальянскую известность: «Познание боли» (La cognizione del dolore, публиковался по главам в журнале «Letteratura» в I938-I94I гг., в I963 г. издан отдельной книгой) и «Пренеприятнейшее происшествие на улице Мерулана» (Quer pasticciaccio brutto de via Merulana, публиковался по главам в журнале «Letteratura», I946 г., в 1957 г. издан отдельной книгой).

Оба романа отличает крайне необычный язык - сложное переплетение диалектизмов, жаргонизмов, авторских неологизмов, иноязычных заимствований, архаизмов, научных терминов. Разнообразие языковых ко- 
дов сочетается с широким применением интертекстуальных техник: автор в изобилии вводит в текст явные и скрытые отсылки к другим литературным произведениям - в виде структурных параллелей, прямых или видоизмененных цитат, отдельных узнаваемых слов, оборотов, имен (в числе основных, хотя и не единственных претекстов - основополагающие для итальянской литературы «Энеида» Вергилия, «Божественная комедия» Данте и «Обрученные» Мандзони). В результате рождаются экспериментальные, трудные для понимания тексты, которые естественным образом становятся эстетическими ориентирами для неоавангарда. Публикация отдельной книгой «Пренеприятнейшего происшествия на улице Мерулана» в 1957 г. «делает имя Гадды известным широкой публике, обозначает его как литературное явление в культурной атмосфере, отмеченной закатом проблематики реализма и актуализацией теорий и перспектив, ориентированных на лингвистические искания и эксперименты» [3]. «Познание боли» выходит отдельной книгой в I963 г., в год образования «Группы 63», в период самых оживленных дискуссий вокруг теории и практики неоавангарда.

Сами неоавангардисты вполне осознают эту преемственность и ощущают глубинное родство с Гаддой. В своих теоретических выступлениях они неоднократно отмечают современность и даже революционность текстов Гадды, подчеркивая широту кругозора ${ }^{\mathrm{I}}$, открытость актуальным тенденциям европейской культуры и, возможно, главное - отсутствие морализаторства, отказ от идеологической ангажированности [7, р. 269]. Итальянский неоавангард воспринимает реальность как принципиально хаотичную и непознаваемую, а любая попытка ее интерпретации, т. е. наделения каким-либо определенным смыслом, неизбежно приводит лишь к образованию мифов и ложных идеологий. Один из основных теоретиков неоавангарда, А. Гульельми, в своем программном выступлении 3 октября г963 г. на первом съезде «Группы 63» в Палермо упоминает Гадду (наряду с Поллоком, Роб-Грийе, Селином и др.) в числе писателей, которые «сводят все ценности к нулевому уровню, подрывая всякую возможность значащей речи (discorso significativo) (что при нынешнем положении вещей означало бы “ложную речь” (discorso

I «Ни один из наших авторов не проявлял такого поразительного инстинкта сороки-воровки и не брал из самых внелитературных (или антилитературных) дисциплин столько блестящих идей и смутных фрагментов, чтобы <...> потом превратить их в осколки сверкающей литературы» [I, p. I9I]. 
falso)» [7, p. 269]. Главным способом создания такого рода литературы объявляется пастиш, понимаемый как смешение разных кодов и способов выражения, которые воспринимаются как равнозначные и, соответственно, предполагают принципиальный отказ от идеологий и ценностных систем. Именно это позволяет литературе уловить реальность в ее максимально объективном виде, за пределами любых навязанных извне интерпретаций. В этом смысле Гадда, как признанный мастер пастиша, воспринимается как предтеча неоавангарда. Арбазино в одном из своих эссе вводит в обиход удачную формулу «i nipotini dell'ingegnere» [2] - внуки инженера (как критики нередко именовали К.Э. Гадду, имевшего инженерное образование). Действительно, экспериментальные тексты Гадды, открывая новый этап в развитии итальянской литературы, оказывают непосредственное влияние на неоавангард - прежде всего в формальном плане, как образец техники письма.

В частности, обнаруживаются явные параллели между романом Гадды «Пренеприятнейшее происшествие на улице Мерулана», действие которого разворачивается в Риме эпохи фашизма, и текстами одного из ключевых участников «Группы 63» - Луиджи Малербы (1927-2008). Текст Гадды представляет собой своеобразную пародию на детектив, нарочито запутанную и лишенную логической развязки: изложение хода расследования двойного преступления - ограбления и убийства - прерывается многочисленными отступлениями, рассуждениями, описаниями, а имя убийцы остается не названным: читателю предоставляется возможность самому решить, кто из персонажей виновен, или же вовсе отказаться от попыток установить истину. Малерба также обращается к детективному сюжету в своих первых романах - «Змей» (Il Serpente, г966) и «Сальто-мортале» (Salto mortale, 1968) - и столь же последовательно разрушает традиционную схему детектива. В первом романе история о том, как герой знакомится с девушкой, а затем убивает ее, также разворачивается нелинейно, прерываясь отступлениями, побочными сюжетами, посторонними рассуждениями, а в конце и вовсе оказывается вымыслом, плодом воображения безумца. «Змей» - это своеобразный «детектив наоборот», где сомнения вызывает не личность убийцы, а сам факт убийства и существования жертвы. Второй роман тоже представляет собой детективную историю, рассказанную героем-безумцем, который ведет расследование убийства, собирает улики, опрашивает свидетелей, но не способен ни отличить реальность от 
вымысла, ни выстроить линейную последовательность событий. В итоге у читателя возникает подозрение, что сам герой является или убийцей, или жертвой, или и тем и другим одновременно ${ }^{2}$. Обращение к данному жанру отнюдь не случайно, поскольку детективный сюжет сам по себе ориентирован на восстановление порядка и выяснение истины и предполагает определенную картину мира - логичную, упорядоченную, разумно устроенную. Разрушая детективную схему, и Гадда, и Малерба тем самым указывают на хаотичность, непознаваемость, абсурдность окружающей реальности, где причинно-следственные связи нарушены, а истина либо недоступна, либо (в случае Малербы) и вовсе не существует.

И Гадда, и Малерба - прежде всего, в «Сальто-мортале», - обращаются к римской топонимике и ономастике, которая хранит в себе память о древней истории и культурной традиции. События «Пренеприятнейшего происшествия...» и «Сальто-мортале» разворачиваются в одной и той же местности к юго-востоку от Рима, связанной с мифом о прибытии Энея в Италию - в районе Павоны, Альбано (легендарной Альба-Лонги), Пратика-ди-Маре (древнего Лавиниума, якобы основанного Энеем). У Гадды ряд персонажей, представителей дна римского общества, носят имена героев Энеиды - Эней, Лавиния, Камилла, Асканий и т. п. У Малербы частью расследования (которое ведет старьевщик, также представитель низшего слоя общества) становится подчеркнуто прозаичный и даже грубый пересказ мифа об Энее и Дидоне. Результатом подобной работы с мифологическими аллюзиями становится резкий контраст между историческими и мифологическими аллюзиями и нарочито сниженной, неприглядной социальной реальностью.

На уровне языковых структур между текстами двух авторов также прослеживаются определенные параллели. Текст «Сальто-мортале» написан в технике потока сознания, но сознания шизофренического, раздробленного, разные части которого вступают между собой в диалог, что приводит к постоянной резкой смене точек зрения и лица, от которого ведется повествование. В результате фразы приобретают сложную, зачастую аграмматическую структуру: «Я шел посреди луга, там была высокая трава, лядвенец. <...> Лядвенец лучше клевера или люцерны, ради бога. Вперед

2 Подробнее о ранних романах этого автора см.: Голубцова А.В. «Ракурсы безумия в ранней прозе Луиджи Малербы // Вестник Московского государственного лингвистического университета. 20I4. Вып. 2I (707). С. 70-8I. 
иди вперед, Джузеппе. Хорошо иду вперед и вдруг почувствовал что-то под ногой» 3 [9, с. г6]. Подобные резкие переходы в изобилии встречаются и у Гадды, однако они маркированы не изменением лица глагола, а в первую очередь изменением манеры речи, например, появлением просторечий и диалектизмов: «Ее муж был состоятельным <...>. Но сама она была еще богаче. Ну да, в этом шикарном доме номер 2І9 жили одни богатеи (nun ce staveno che signori grossi): кое-кто из благородных (quarche famija der generone), а так все больше нувориши, каких еще не так давно звали акулами бизнеса. Да и сам-то дом в народе прозвали золотым. Потому что весь он по самую крышу был битком набит этим металлом» [5, p. 7]. Прослеживаются параллели и на других уровнях. Так, к излюбленным неоавангардным техникам относится семантическая деконструкция привычных языковых структур - например, фразеологизмов или даже отдельных слов, и одним из способов такой деконструкции являются избыточные пояснения, которые вводятся союзом «то есть» (сіоѐ). Они создают эффект остранения, актуализируя буквальное значение лексических единиц, привычно используемых в переносном смысле: «Это мне не очень-то нравится, то есть совсем не нравится» [9, p. I7]; «Видели, как он шел один по пляжу <...> так говорят, то есть так говорит одна женщина, жена мясника» [9, р. Іо7]. Это характерная особенность стиля неоавангардных романов Малербы, однако уточняющие обороты с «то есть» в подобной функции встречаются и в тексте Гадды: «общественное мнение, то есть коллективное безумие» [5, p. 8о]; «он словно прочистил (sembrò detergere) рукой глаза, то есть веки» [5, p. І88].

Другой, во многом автобиографический ${ }^{4}$ роман Гадды «Познание боли», ключевой темой которого становятся противоречивые, невротические отношения героя с матерью, оказывает непосредственное влияние на тексты такого значимого представителя неоавангарда, как Джорджо Манганелли (1922-1990). В г964 г., через год после книжной публикации «Познания боли», Манганелли пишет «Гиларотрагедию» (Hilarotragoedia) - экспериментальный текст, выстроенный как нарочито усложненный барочный трактат с обилием сносок, комментариев, примечаний, примечаний к примечаниям, посвященный так и не названной теме. По сути, текст Манганелли -

3 Пунктуация авторская.

4 Многочисленные указания на связь сюжета романа с обстоятельствами жизни автора см., например, в комментариях к изданию романа под ред. Э. Мандзотти [4]. 
это «пустая» структура, выстроенная вокруг несуществующего предмета с помощью отсутствующей логики, хотя в процессе чтения и создается иллюзия наличия логической связи. При всех структурных отличиях от «Познания боли», которое представляет собой относительно связное сюжетное повествование, между двумя текстами обнаруживается несомненное сходство.

Произведения объединены темой нездоровых, мучительных отношений с авторитарной, эмоционально холодной матерью и порожденного этими отношениями невроза. Для обоих авторов, глубоко увлеченных психоанализом ${ }^{5}$, художественное творчество становится своего рода психотерапией. Однако общая тема конфликта между матерью и сыном у каждого из них раскрывается в принципиально разном ключе. Гадда, исследуя истоки и развитие конфликта, прибегает к почти автобиографическому повествованию, в то время как Манганелли обращается к символам аналитической психологии - архетипу Великой Матери (в трактовке юнгианца Эриха Нойманна, автора работы «Великая мать» (г956) и концепции травматичного расставания с ней в процессе отделения сознания от бессознательного).

В стилистическом плане между текстами также обнаруживается заметное сходство. Манганелли и Гадду объединяет особое отношение к барокко и барочной стилистике. Гадда в тексте «Издатель извиняется за публикацию» (L'Editore chiede venia del recupero), задуманном как предисловие к «Познанию боли», пишет о барочности мира, которая отражается в структуре и языке его романа [4, p. 480-483]. Манганелли говорит об эпохе барокко как о периоде, который «насквозь пронизан радостью болтовни (gioia della chiacchiera), радостью <...> слов, играющих друг с другом» [ı2, p. Іоо], - именно это, по мысли автора, и составляет сущность истинной литературы. Барочный характер творчества Гадды и Манганелли давно стал общим местом в итальянской и мировой критике 6 . Ощущение «барочности» текстов Гадды и Манганелли поддерживается как сложной повествовательной структурой с обилием разнообразных отступлений, так и нарочитой усложненностью языка, сближа-

5 Гадда обращается к психоаналитической проблематике в своих литературоведческих, социологических и психологических эссе: «Эрос и Приап» (написан в 1944-I945 гг., опубл. в I967), «Эмилио и Нарцисс» (І949), «Психоанализ и литература» (I954) и др. Манганелли в І950-х гг. проходит курс психоанализа и активно использует психоаналитический инструментарий в своих художественных произведениях.

6 Сравнительный анализ концепций барокко у двух авторов см. в статье Ф. Милани «Гадда и Манганелли: сопоставление двух лингвистических вихрей» [II]. 
ющей художественный дискурс с научным (что свойственно барочной литературе). Тексты обоих авторов насыщены научными терминами из самых разных сфер - медицины, математики, инженерии, гуманитарных наук, а также латинизмами и архаизмами (например, грецизм «ittide», в бытовом контексте заменяющий нейтральный термин «рыба») [4, p. 86]. Оба автора прибегают к конструированию наукообразных неологизмов: «gutturaloide» (от «gutturale» - горловой) у Гадды [4, p. 386], «pitecoidante» (досл. «уподобляющийся обезьяне») у Манганелли [Іо, p. 22].

В обоих текстах активно используется парадоксальная барочная метафора-кончетто: «palpebre-mensole» («веки-кронштейны») у Гадды [4, p. 204], «epilessia di fazzoletti» («эпилепсия платков»< <при прощании>) у Манганелли [Іо, p. 48]. Характерной особенностью стиля обоих авторов является обилие «физиологических» метафор (образности, связанной с «телесным низом», пищеварением, выделением, разнообразными болезненными явлениями), нередко порождающих стилистические диссонансы - столкновение научных и книжных терминов с разговорной и диалектной лексикой: так, Гадда описывает желудок как «отчаянное амебоподобное, разминающее и пептонизирующее кусок мяса» (disperato ameboide a mantrugiare 7 e a peptonizzare l'ossobuco) [4, p. 346], в тексте Манганелли фигурирует «припухлость пищевода, сжигаемого божественной яростью изжоги» [Iо, p. 42]. В синтаксическом плане оба текста отличаются чрезвычайно сложным построением фраз с обилием придаточных предложений, вставных конструкций и длинных перечислительных рядов. В целом два текста настолько похожи стилистически и близки тематически, что, по воспоминаниям дочери Манганелли, Гадда с негодованием счел «Гиларотрагедию» пародией на «Познание боли» [II].

Влияние текстов Гадды на итальянский неоавангард прослеживается на всех уровнях - от идеологического и тематического до формального, вплоть до заимствования конкретных приемов и техник работы с языком. Однако при всей очевидной близости между творчеством Гадды и писателей-неоавангардистов существует принципиальное различие: программная антиидеологичность неоавангарда остается для Гадды глубоко чуждой8. Если

7 Тосканский диалектизм.

8 В своих эссе Гадда прямо указывает, что для него эстетика и поэтика тесно связаны с этикой и даже подчинены ей («Когда я напишу Поэтику, каждый, кто пожелает понять ее, должен будет отталкиваться от Этики; более того, Поэтика будет не более чем главой Этики» $[6])$. 
художественная практика неоавангарда обнажает внутреннюю ложность традиционного языка, несоответствие между планом выражения и планом содержания, то для Гадды лингвистический эксперимент служит не разрушительной, а конструктивной цели - установлению истины, выявлению подлинного, изначального смысла слова. Техники смешения и трансформации разнородных языковых кодов в его текстах используются как средство выявления скрытых связей между вещами, восстановления преемственности с культурной традицией, познания реальности во всей ее сложности и полноте. Неоавангард же переосмысляет гаддианский художественный язык в «разрушительном», десакрализующем ключе - как инструмент критики социума и культуры, развенчания мифов и идеологий, - программно отвергая возможные реконструктивные смыслы языкового эксперимента.

\section{References}

I Arbasino A. Genius loci, Sessanta posizioni. Milano, Feltrinelli, I97I. P. I85-I93. (In Italian)

2 Arbasino A. I nipotini dell'ingegnere. Sessanta posizioni. Milano, Feltrinelli, I97I. P. I93-210. (In Italian)

3 GADDA, Carlo Emilio. Dizionario Biografico degli Italiani. Volume 5I (I998). Available at: http://www.treccani.it/enciclopedia/carlo-emilio-gadda_(Dizionario-Biografico) (Accessed I3 January 20I9). (In Italian)

4 Gadda C.E. La cognizione del dolore, a cura di E. Manzotti. Torino, Einaudi, I987. 578 p. (In Italian)

5 Gadda C.E. Quer pasticciaccio brutto de Via Merulana. Milano, Garzanti, I997. 292 p. (In Italian)

6 Gadda C.E. Saggi, giornali, favole e altri scritti. Milano, Garzanti, I99I. Vol. I. I37I p. (In Italian)

7 Gruppo 63. Critica e teoria, a cura di R. Barilli, A. Guglielmi. Milano, Feltrinelli, I976. 395 p. (In Italian)

$8 \quad$ Malerba L. Il serpente. Milano, Bompiani, I990. 22I p. (In Italian)

$9 \quad$ Malerba L. Salto mortale. Milano, Bompiani, I968. 236 p. (In Italian)

Io Manganelli G. Hilarotragoedia. Milano, Feltrinelli, I964. I76 p. (In Italian)

II Milani F. Gadda e Manganelli: vortici linguistici a confronto. The Edinburgh Journal of Gadda Studies. № 7. Available at: https://www.gadda.ed.ac.uk/Pages/journal/issue7/ articles/milanimangao7.php (Accessed I3 January 20I9) (In Italian)

I2 Pulce G. Lettura d'autore: conversazioni di critica e di letteratura con Giorgio Manganelli, Pietro Citati e Alberto Arbasino. Roma, Bulzoni, I988. 210 p. (In Italian) 
УДК 82I.I6I.I+82I.II2.2 ББК $83.3(2 \mathrm{Poc}=\mathrm{Pyc}) 6+$ $83.3(4 \mathrm{Heм})$

\section{ХУДОЖЕСТВЕННЫЙ ОБРАЗ ДАНИИЛА ХАРМСА В ТВОРЧЕСТВЕ АГЛАИ BETEPAHИ}

\author{
(C) 2020 г. А.В. Попова \\ Российский государственный гуманитарный \\ университет, \\ Москва, Россия \\ Дата поступления статьи: о8 апреля 2019 г. \\ Дата публикации: 25 июня 2020 г.
}

DOI: IO.22455/2500-4247-2020-5-2-I72-I85

Аннотация: Исследование посвящено рецепции русского писателя Даниила Хармса в неоконченном романе «Осторожно кусачий куриный суп. Даниил Хармс в эмиграции» швейцарской писательницы литературы абсурда Аглаи Ветерани. Целью исследования является определение особенностей портрета Хармса в этом произведении. Рассматриваются биография и особенности литературного творчества Ветерани, с учетом которых производится интерпретация наиболее значимых сюжетообразующих эпизодов произведения для составления представления о месте образа Хармса и особенностях его трансформации. Результаты исследования показывают, что Ветерани смешивает биографические факты из своей жизни и жизни героинь других автобиографических романов и рассказов с фактами биографии настоящего Хармса, что приводит к некоторому отождествлению самого автора с главным героем. Большой интерес писательница проявляет к сведениям о смерти Хармса и его склонности к самоинсценированию и пытается их обыграть и гиперболизировать, а также анализирует и пародирует творчество Хармса. Так конструируется сложный образ, соединяющий в себе несколько ипостасей - самой писательницы, Хармса как эталонного писателя-абсурдиста с чертами трикстера, револьтирующего против законов логики и уворачивающегося от смерти любыми способами, включая перевоплощение в других людей или предметы. Устанавливается, что мотив смерти и бегства/отказа от смерти встречается в других произведениях Ветерани. Таким образом, Ветерани выражает нежелание верить в смерть, как в свою собственную, так и любимых ею людей.

Ключевые слова: Даниил Хармс, Аглая Ветерани, литература абсурда, рецепция.

Информация об авторе: Анна Владимировна Попова, аспирант, Российский государственный гуманитарный университет, Миусская пл., д. 6, І25993 г. Москва, Россия.

E-mail: annapopowa20I2@gmail.com

Для цитирования: Попова А.В. Художественный образ Даниила Хармса в творчестве Аглаи Ветерани // Studia Litterarum. 2020. T. 5, № 2. С. I72-I85.

DOI: I0.22455/2500-4247-2020-5-2-I72-I85 


\section{THE IMAGE OF DANIIL KHARMS IN THE WORKS OF AGLAJA VETERANYI}

This is an open access article distributed under the Creative Commons Attribution 4.0 International (CC BY 4.0)
(C) 2020. A.V. Popova

Russian State University for the Humanities, Moscow, Russia

Received: April 08, 2019

Date of publication: June 25, 2020

Abstract: The essay focuses on the reception of the Russian writer Daniil Kharms in the unfinished novel Attention, the Chicken Soup Bites! Daniil Kharms in Exile by the Swiss absurdist writer Aglaja Veteranyi. The purpose of the study is to highlight the features of the portrait of Kharms in this work. The essay examines Veteranyi's biography as well as the peculiarities of her style, making an emphasis on the most significant plotforming episodes of the novel that shed light on the place and specificity of Kharms' image. The results of the study show that Veteranyi mixes her own biographical facts and the life of the characters of other autobiographical novels and stories with the facts of Kharms' own biography which allows for some identification of the author with the main character. The writer shows exaggerated interest in the death of Kharms as well as in his histrionic capacities; she hyperbolizes both as well as analyzes and parodies Kharms' works. As a result, we have a complex image that combines several personalities - the novelist herself and Kharms as an exemplary absurdist writer with the features of a trickster, revolting against the laws of logic and trying to escape death by all means, also by transforming himself into other characters or objects. The motive of death and escape from / refusal of death is common to other fictional works by Veteranyi. This testifies to her unwillingness to believe in death, both in her own and of her loved ones.

Keywords: Daniil Kharms, Aglaja Veteranyi, literature of the absurd, reception.

Information about the author: Anna V. Popova, PhD student, Russian State University for the Humanities, Miusskaya 6, I25993 Moscow, Russia.

E-mail: annapopowa20ı2@gmail.com

For citation: Popova A.V. The Image of Daniil Kharms in tThe Works of Aglaja Veteranyi. Studia Litterarum, 2020, vol. 5, no 2, pp. I72-I85. (In Russ.)

DOI: $10.22455 / 2500-4247-2020-5-2-172-185$ 
Швейцарско-румынская писательница Аглая Ветерани (1962-2002) покончила с жизнью в ночь со 2 на 3 февраля 2002 г., в день через 6о лет после смерти Даниила Хармса (1905-1942) [3, с. 86]. Было ли это лишь совпадением или Аглая, которая уже долгое время находилась в тисках душевной болезни, преднамеренно выбрала день смерти любимого писателя - вопрос, ответ на который исследователь дать не может, однако значение Хармса для становления Ветерани как автора неоспоримо и подлежит подробному рассмотрению. Влияние Хармса на творчество Ветерани констатируется исследователями [5, с. II; 3, с. 84] и комментаторами ее текстов [6, с. І27], но по сей день нет исследования, посвященного проблеме значения Даниила Хармса в писательском пути Ветерани. Ее рецепция Хармса прослеживается при обнаружении заимствований: некоторые рассказы напоминают рассказы из цикла «Случаи», например, рассказ «Почему я не ангел» («Warum ich kein Engel bin») [II, c. 29] построен на основе рассказа «Вываливающиеся старухи» Хармса. В 1996 г. Даниил Хармс стал персонажем незаконченного романа Ветерани «Осторожно кусачий куриный суп. Даниил Хармс в эмиграции» («Vorsicht bissige Hühnersuppe. Daniil Charms im Exil» [sic]).

Если в имитирующей творчество Хармса малой прозе писательница не ссылается на своего любимого писателя, то в данном романе он даже становится главным действующим лицом. Здесь Ветерани составляет портрет любимого писателя на основе его текстов и известных ей подробностей о его жизни, раскрывает мотив смерти, который получил развитие в других ее произведениях. Поскольку роль фигуры Хармса в данном произведении ранее не рассматривалась исследователями, должно быть, ввиду того, что его текст был официально опубликован только в 2018 г., то в рамках дан- 
ной работы будут изложены лишь изначальные предположения о том, какие трансформации претерпел образ писателя в художественной рецепции Ветерани.

При изучении произведений Ветерани исследователи нередко прибегают к фактам ее биографии. Ее творчество автобиографично, а фантастическое органично вплетается в канву повествования о реальных событиях, малая и крупная проза перекликаются между собой благодаря тому, что в них используется единый биографический материал [5, с. 64].

Профессиональный путь Аглаи предопределило ее происхождение. Будущая писательница родилась в семье румынских циркачей. Когда Аглае было четыре года, она вместе с семьей бежала в Швейцарию от диктатуры Чаушеску. Подростком во время их длительного циркового тура по Европе, Африке и Южной Америке она выступала в качестве танцовщицы и певицы в различных варьете. Аглая не могла читать и писать ни на одном языке вплоть до возвращения в Швейцарию в 1978 г., когда она начала актерское образование и параллельно с этим - изучение немецкого языка, который впоследствии стал языком ее прозы и средством письменного самовыражения [4, с. 266].

На протяжении всей жизни Аглая находилась в поиске и попытках определения своей индивидуальной и культурно-национальной идентичности. В детстве она пережила насилие и агрессию со стороны отца, «мрачного клоуна», а также непрерывно испытывала страх, что во время акробатического номера матери может произойти несчастный случай. Все это писательница отразила в романах «Почему ребенка варят в мамалыге» («Warum das Kind in der Polenta kocht») (1999), «Полка последних вдохов» («Das Regal der letzten Atemzüge») (2002) и в рассказах, вошедших в сборник малой прозы «Об убранном море, арендованных носках и госпоже Масло» («Vom geräumten Meer, den gemieteten Socken und Frau Butter») (2004). Борьба с давлением культурно-языкового происхождения, которое в последнем романе воплощает мать [5, с. 5], с одной стороны, и с вызовами новой культурно-языковой среды в Швейцарии, с другой [5, с. 3], лежат и на пути самоидентификации героинь Аглаи.

Для корректной интерпретации творчества Ветерани необходимо учитывать, что она не в совершенстве владела немецким, поскольку начала учить его лишь в подростковом возрасте [4, с. 266], в силу чего тексты име- 
ют много лексических неточностей, синтаксис довольно прост, превалируют краткие, эллиптические и назывные предложения. Кроме того, стиль произведений Ветерани отличается инфантилизмом, повествование часто ведется из наивной детской перспективы [4, с. 272] и похоже на пересказ сновидений. Издатели сохраняли эти особенности при публикации, не давая пояснений и интерпретаций, осознавая, насколько важной для Аглаи была свобода от точности и определенности [7, с. І39-І40].

Несмотря на лаконичность и синтаксическую упрощенность, язык Ветерани характеризуется высокой метафористичностью. В метафорах Ветерани «соединяется невозможное, что дает свободу для поэтически сильно заряженного смыслового изобилия» ${ }^{\mathrm{I}}$ [3, с. 80]. И, пожалуй, самой главной отличительной чертой ее текстов была непримиримая борьба с логикой, абсурдность. Причем абсурд у Ветерани - инструмент и главный художественный принцип. По словам Йенса Нильсена, нелогичность (Unlogik) была для нее «топливом». «Она была для нее точным средством, которое она использовала целенаправленно, мне кажется, для подрыва определенности, которая была для нее чрезвычайно подозрительной. Так называемая истина, реальное и корректное тогда оставались на втором месте. Потому что нелогичное действовало внутривенно, как говорила она. Непосредственно» [7, с. 139].

В этом совпадают взгляды Хармса и Ветерани на создание текстов. Исследователь Дмитрий Викторович Токарев, производя сравнение творчества Сэмюэля Беккета и Хармса, установил, что, в отличие от центральных представителей западных театра и литературы абсурда Беккета и Эжена Ионеско, «для русского поэта осознание абсурда является лишь исходной точкой поисков путей его преодоления» [I, c. I7]. Отсутствие логики было для Аглаи тем же, чем была бессмыслица для Хармса, - отправной точкой поиска истины, способом чувствовать мир.

Рассматриваемый текст представляет собой нечто вроде биографической фикции - посмертного путешествия Хармса в Венецию, - где категория абсурда выступает в качестве связеобразующего принципа. Его жанровую специфику определить непросто: произведение сохранилось в виде фрагментов, сюжетная целостность отсутствует. Тем не менее изда-

I З Здесь и далее перевод с немецкого автора статьи - A.В. Поповой. 
тели, среди которых персоны, очно знакомые с биографией и творческим процессом Аглаи, опубликовали его в составе второго тома, «Кафе папа. Фрагменты» («Café Papa. Fragmente»), двухтомного издания дневниковых записей и фрагментов незавершенных произведений в 2018 г. и обозначили как «фрагмент романа» [9, с. I48].

Фрагмент не имеет единого сюжета, нет единства места, времени и действия. События врываются в повествование произвольно, нельзя выделить нити, проходящей через все повествование. Объединяющим элементом, не позволяющим повествованию окончательно распасться на отдельные мини-рассказы, служит время от времени появляющаяся фигура писателя Хармса. Описываются эпизоды из его полувымышленного прошлого и вымышленного настоящего за границей. Повсеместно, где бы автор ни предпринимал попытки реконструировать историю героя, он порывает с логикой и лишь спорадически вводит реальные данные, а если в канву повествования и вплетается событие, соответствующее действительности, то оно подвергается максимальной гиперболизации, либо в него проникает фантастический вымысел. Вспомним, что Хармс сам довел до гротеска историю своего появления на свет («Я родился в камыше. Как мышь...» [2, c. 35I]). Фрагменты, посвященные биографии Хармса, перемежаются с фрагментами о биографии Ветерани или героинь рассказов из сборника «Об убранном море...» [II, с. 50, 62, 64, 80].

Если в одном абзаце Ветерани приступает к рассказу о семье Хармса («Über seine Familie schreibt er...» [ıІ, с. 52] / «O своей семье он пишет следующее...» или «Über Charms Familienverhältnisse wissen wir viel» [ıг, c. 89] / «О семейных отношениях Хармса мы знаем много»), то в следующем же она приводит не относящиеся к Хармсу детали, тем самым обманывая ожидания читателя. Например:

Die Tochter mit der Hand im Bauch gleicht der Mutter [II, c. 52]. - Дочь с рукой в животе похожа на мать.

Im Nebenzimmer liegt eine entfernte Cousine auf dem Sofa und liest 23 Gramm Buch, 5 Gramm Krimi und I8 Gramm Sex [II, c. 53]. - В соседней комнате на диване лежит дальняя двоюродная сестра и читает 23 грамма книги, 5 граммов детектива и I8 граммов секса. 
Наличие подобного рода элементов наводит на мысль, что Ветерани в некоторой степени отождествляла себя с Хармсом. Подкрепить этот довод способно также то, что в фонде Ветерани среди черновиков и записных книжек можно найти небольшой листок бумаги, в котором она пишет, что ее настоящее имя не Аглая Ветерани, а Даниил Хармс².

Продолжением алогичности и смешения биографических фактов является анахроничность и расширение географических рамок. Так, Хармс воскресает из мертвых 3 и продолжает жить, но уже за границей, в Венеции, где в 1996 г. побывала Ветерани, но настоящий Хармс за свою короткую жизнь никогда не был:

Am Ende des 20. Jahrhunderts erlebt ein Autor seine Auferstehung. Nachdem der Dichter Daniil Charms, der Meister der Groteske, im russischen Gefängnis verhungert war, flüchtete er nach Venedig [ІІ, с. 50]. - В конце XX в. автор переживает свое воскресение из мертвых. После того как поэт Даниил Хармс, мастер гротеска, умер от голода в русской тюрьме, он бежал в Венецию.

Затем у окна в венецианском кафе «Флориан», которое, очевидно, посетила Ветерани во время своей поездки в Венецию, рождаются его новые рассказы [ІІ, с. 50].

Фальсифицируются не только биографические факты, но и творчество Хармса. Текст, обозначенный во фрагменте номером 2, представляет собой пародию на совокупные тексты писателя, отражающую представление писательницы о его прозе. В нем Ветерани как бы глазами Хармса подвергает сомнению физическую идентичность живого существа - курицы:

Ein Huhn kann auch ein Huhn sein. Jedenfalls kann ein Huhn auch was anderes sein. Das glaube ich [II, c. 5I]. - Курица, конечно, может быть курицей. В любом случае курица может быть чем-то еще. Я так считаю.

\footnotetext{
2 SLA-VET (Schweizerisches Literaturarchiv - Veteranyi): C-I-063.

3 Можно предположить, Хармс введен Ветерани в мотив библейского сюжета воскрешения из мертвых, потому что имя Даниил Хармс (в немецком написании «Daniil Charms») напоминает ей имя Иисус Христос («Jesus Christus»).
} 
Ветерани осознавала специфику текстов Хармса и в другом эпизоде признала, что понимать тексты Хармса непросто, поскольку они «selbst für den geübten Leser eine Zumutung sind» [ıг, c. 67] - «даже опытному читателю не по зубам», что, как мы можем догадываться, и привлекало ее в них как противницу логичного. В данной связи вызывает интерес следующая деталь - плод фантазии Ветерани: папа римский провозглашает Хармса святым и поручает ему перевод Библии [ІІ, с. 86-87], текст которого также «публикуется» в романе и состоит из одного предложения:

ALS GOTT DEN FADEN VERLOR BEGANN ER DIE WELT ZU ERSCHAFFEN [sic] [II, c. 88]. - «Когда Бог потерял нить, он начал творить мир».

Истинный процесс создания начинается тогда, когда изначальные связи теряются, когда творец соскальзывает с вектора логики. Такой взгляд на творческий процесс был характерен для Ветерани, она считала логику главным врагом творчества [7, с. I38-I4I].

Сведения о склонности Хармса к шутливым перевоплощениям, которую Аглая могла почерпнуть из биографических материалов, сопровождавших немецкоязычные издания, например, «Случаи. Сцены. Стихотворения. Проза» 1984 г. [8], побуждают ее на изобретение фантастических и гротескных видов перевоплощения:

[Charms] schlenderte durch die Gassen, bildete sich ein, eine Laterne zu sein, und begann zu leuchten, bis seine Haut fast wegschmolz. Vor der völligen Verbrennung konnte man ihn nur durch zwanghaftes Kühllagern retten [II, с. 98]. - [Хармс] бродил по улочкам, воображал, будто он - уличный фонарь, и начинал светить до тех пор, пока его кожа почти не расплавилась. От полного сгорания его смогли спасти только насильно охладив.

Переодевание Хармса в несуществующего брата Ивана Ивановича писательница объясняет его стремлением скрыться от смерти [II, с. 54].

Необходимо обратить внимание на то, что чувство присутствия смерти преследовало саму Ветерани с детства: опасная профессия матери и смерть любимой тети наложили отпечаток на сознание автора. Тема смер- 
ти неизменно интересовала ее на протяжении всей жизни. Незадолго до смерти Аглая совершила поездку на родину, во время которой увидела, как проходят похороны по румынскому обычаю, и написала об этом репортаж «Смешное кладбище» («Lustiger Friedhof») (200I) [9, с. I47].

Вообще смерть для лирических героев Ветерани, с которыми она часто отождествляет себя, - что-то, что можно избежать одним лишь усилием мысли, отказом от нее. В миниатюре «Дерево» («Der Baum») читаем:

Ich glaub nicht an den Tod sagt der Baum und sammelt seine Zähne wieder ein [Iо, c. 9I]. - «Я не верю в смерть», - говорит дерево и собирает свои зубы обратно.

Это может быть также побег в другую плоть или предмет. В рассказе «Забастовка» («Der Streik») старый человек говорит: «Лучше быть яблоком, чем умереть» - и производит против наступления смерти действия, эффективность которых кажется читателю сомнительной: он кладет себе на голову яблоко и садится посреди улицы за складной столик, написав на своем теле: «Прошу смерть меня не фотографировать. Кладбище закрыто по причине уклонения от смерти» [1о, с. 90].

Сведения о том, как умер Хармс, также произвели на нее интенсивное впечатление [II, c. 54-55]. Абсурдный способ избежать смерти описывается в рассматриваемом романе на примере Хармса. Герой пишет на асфальте «Hier Charms - betreten verboten!» [ІІ, с. 54] - «Здесь Хармс - вход воспрещен!»

Эта фраза отсылает к фразе «Hier Himmel» («Здесь небо»), которая была произнесена в одной из глав в «Осторожно...» [II, с. 92]. Глава была опубликована ранее в виде сноподобного рассказа «Дом» («Das Haus») [Іо, с. 94]. В рассказе так называемый урожденный иностранец («еin gebürtiger Ausländer») оставляет обувь в своем доме, а дом выбрасывает в реку. В поисках дома иностранец находит под водой старика с табличкой на шее «Здесь небо». Дом снова появляется, но в другом месте, и, «возможно, это был другой дом, потому что он не помнил обувь иностранца», затем этот дом теряет свою дверь [Іо, с. 94]. Опираясь на данные биографии автора, эту главу можно читать как аллегорию. Аглая была пришельцем в чужой стране, «урожденным иностранцем», но и на родине в Румынии она жила 
недолго, поэтому один дом в рассказе вполне может соответствовать родине, другой - Швейцарии, оставленная обувь может быть символом утраченного или не приобретенного из-за эмиграции чувства принадлежности к одной культуре, этносу. Небо Аглаи - это продолжение жизни, ее обратная сторона, спасение от несправедливости, переносимой ее лирическими героями в жизни, небо - это рай, заграница, убежище (Asyl). В небе все чисто, потому что оно - живот Бога [го, с. 82].

Как считает автор фрагмента, превращения и бегство Хармса - это, «предположительно, выражение его голода и отчаяния, потому что его попытки остаться в живых становились все гротескнее» [II, с. 54]. Кроме того, и побег в Венецию был вызван нежеланием умирать на родине:

Es ist also verständlich, dass Charms in Russland den Tod nicht aushielt und ins Ausland flüchtete [ı, с. 55]. - То есть понятно, что Хармс не вынес смерти в России и бежал за границу.

В конце романа же высказывается предположение, что Хармс все-таки оказался на небе:

Es wäre verfrüht zu behaupten, Charms sei in den Himmel geflüchtet [II, с. III]. - Было бы поспешным утверждать, что Хармс бежал на небо.

Данное высказывание, казалось бы, вступает в противоречие с завязкой: в начале фрагмента романа читатель узнает, что Хармс бежал от смерти в Венецию, в конце же автор высказывает допущение, что он бежал на небо. Однако противоречие легко разрешается, если допустить, что в знаковой системе произведения (и, возможно, творчества Ветерани в целом) существует метафорическая связь между заграницей физической, пространством, которое находится за пределами родины-государства, и «заграницей» метафизической - небом, пространством за пределами Земли. Образ Хармса, который сформировался у Ветерани в результате чтения его творчества и биографической информации, наделен теми свойствами, которые необходимы для осуществления этого прыжка в воображении автора. Этот образ - своего рода лабораторная болванка для проведения эксперимента, который заключается в возведении моста между реальностью и вожделен- 
ным местом, парадизом на Земле. Но в результате автор как будто бы отпускает ситуацию, позволяя нежелательному быть, герою отправиться на небо, т. е. умереть. Однако Ветерани, подобно тому, как поступал Хармс-писатель в своих коротких рассказах, не берется отвечать за достоверность приводимой информации и подрывает доверие читателя многочисленными переключениями, отказами от сказанного, так что и здесь мы не можем быть уверены, умер ли герой.

Для онирических миров прозы Ветерани характерна эта подвешенность, неразрешенность. Главная идея зачастую глубоко скрыта от посторонних глаз, как будто бы автор боится стать понятым, что равнозначно уязвимости. В данном произведении, как и повсеместно в творчестве Ветерани, в каждом высказывании слышится вымышленная цитата «Bitte missverstehen Sie mich richtig» - «Пожалуйста, правильно поймите меня неправильно», которую автор приписывает Хармсу [Іі, с. 68], и она вполне может послужить девизом автора.

Обобщая изложенное, можно сказать, что образ Даниила Хармса в художественной рецепции Аглаи Ветерани подвергся ряду трансформаций, которые выделили в гипертрофированном виде те черты, по которым Хармс, как писатель, запомнился Ветерани. Абсурдизация биографических фактов и их смешение с деталями из жизни персонажей других произведений, с которыми Ветерани зачастую персонифицирует себя, формируют альтернативный портрет Хармса с элементом отождествления с образом самого автора. Параллельно Ветерани раскрывает ее представление о механизмах творчества любимого писателя, что свидетельствует о том, что она провела его глубокий анализ. Не без внимания писательница оставляет и поведенческие особенности русского писателя. Его самоинсценирование с вхождением в роли вымышленных людей мотивировали Ветерани дать развитие мотиву смерти: как и герои многих ее произведений, герой Хармс пытается бежать от смерти путем перевоплощения. Вполне возможно, что данный прием обладает для автора своего рода высвобождающим эффектом: на примере любимого писателя Ветерани как бы демонстрирует внутреннее сопротивление смерти - как своей собственной, так и смерти близких и любимых людей, одним из которых, судя по величине значения, которое она для него отводит в своем творчестве, был писатель Хармс. 
Конечно, данными аспектами художественной обработки рецепция Хармса в творчестве Ветерани не исчерпывается, она имеет множество граней, многие из которых не очевидны, но могут обнаружиться при тщательной шлифовке - детальном анализе произведений писательницы. Представленное исследование имеет целью также дать толчок для дальнейшего изучения влияния Хармса на творческий мир Аглаи Ветерани и обратить внимание как филологов, так и всех интересующихся творчеством рассмотренных писателей и литературой абсурда на его плодотворность. 


\section{Список литературы}

I Tокарев Д.В. Феномен литературы абсурда во Франции и в России в XX в.

Сэмюэль Беккет и Даниил Хармс: дис. ... канд. филол. наук. Экс-ан-Прованс, 1998. 292 c.

2 Хармс Д. Малое собрание сочинений. СПб.: Азбука-классика, 2003. 864 с.

3 Baltag $I$. «Solange ich verletzlich bleibe, kann ich weiterschreiben». Die Schweizer Schriftstellerin mit rumänischen Wurzeln Aglaja Veteranyi // Philologica Jassyensia. 2009. № 2 (IO) (An V). S. 79-87. URL: http://www.diacronia.ro/ro/indexing/details/ A9I2/pdf (дата обращения: о5 апреля 20I9).

4 Esselborn K. Im Ungesicherten unterwegs: Aglaya Veteranyi // Jahrbuch Deutsch als Fremdsprache 37 (20II). S. 263-286.

5 Gieser L. Heimatlose Weltliteratur? Zum Werk von Aglaja Veteranyi // Germanica. 2006. № 38. S. $63-85$.

6 Morlang W. Nachwort // Vom geräumten Meer, den gemieteten Socken und Frau Butter / A. Veteranyi. München: Deutsche Verlags-Anstalt, 2004. S. I25-I33.

$7 \quad$ Nielsen J. Unlogik streng erlaubt edition spoken script. In: Vorsicht bissige Hühnersuppe. Daniil Charms im Exil edition spoken script / A. Veteranyi. Luzern: Der gesunde Menschenversand, 20I8. I38-142 S.

8 Rausch B. Ein biographisches Stichwort Haffmans // Fälle. Szenen, Gedichte, Prosa. D. Charms, Zürich, Haffmans Publ. 1984. S. 236-256.

9 Rothenbühler D. Editorischer Bericht edition spoken script // Vorsicht bissige Hühnersuppe. Daniil Charms im Exil edition spoken script. A. Veteranyi. Luzern: Der gesunde Menschenversand, 20I8. S. I46-I49. Veteranyi A. Vom geräumten Meer, den gemieteten Socken und Frau Butter / A. Veteranyi. München: Deutsche Verlags-Anstalt, 2004. I36 S. Veteranyi A. Vorsicht bissige Hühnersuppe. Daniil Charms im Exil edition spoken script. Luzern: Der gesunde Menschenversand, 20I8. 49-III S. 


\section{References}

I Tokarev D.V. Fenomen literatury absurda vo Frantsii $i v$ Rossii v XX v. Semiuel' Bekket $i$ Daniil Kharms [The Phenomenon of the absurd literature in France and in Russia in the $2 \mathrm{O}^{\text {th }}$ century: Samuel Beckett and Daniil Kharms: PhD dissertation] Aix-en-Provence, I998. 292 p. (In Russ.)

2 Kharms D. Maloe sobranie sochinenii [Small collected works]. St. Petersburg, Azbukaklassika Publ., 2003. 864 p. (In Russ.)

3 Baltag I. "Solange ich verletzlich bleibe, kann ich weiterschreiben”. Die Schweizer Schriftstellerin mit rumänischen Wurzeln Aglaja Veteranyi. Philologica Jassyensia, 2009. № 2 (IO) (An V). pp. 79-87. Available at: http://www.diacronia.ro/ro/indexing/ details/A9I2/pdf (Accessed o5 April 20I9). (In German)

4 Esselborn K. Im Ungesicherten unterwegs: Aglaya Veteranyi. Jahrbuch Deutsch als Fremdsprache 37 (20II), S. 263-286. (In German)

5 Gieser L. Heimatlose Weltliteratur? Zum Werk von Aglaja Veteranyi. Germanica. 2006. № 38. S. 63-85. (In German)

6 Morlang W. Nachwort. Vom geräumten Meer, den gemieteten Socken und Frau Butter, A. Veteranyi. München, Deutsche Verlags-Anstalt, 2004. S. I25-I33. (In German)

$7 \quad$ Nielsen J. Unlogik streng erlaubt edition spoken script. Vorsicht bissige Hühnersuppe. Daniil Charms im Exil edition spoken script, A. Veteranyi. Luzern, Der gesunde Menschenversand, 2018. S. 138-I42. (In German)

8 Rausch B. Ein biographisches Stichwort Haffmans. Fälle. Szenen, Gedichte, Prosa. D. Charms. Zürich, Haffmans, I984. S. 236-256. (In German)

9 Rothenbühler D. Editorischer Bericht edition spoken script. Vorsicht bissige Hühnersuppe. Daniil Charms im Exil edition spoken script. A. Veteranyi. Luzern, Der gesunde Menschenversand, 20I8. S. I46-I49. (In German) Veteranyi A. Vom geräumten Meer, den gemieteten Socken und Frau Butter. München, Deutsche Verlags-Anstalt, 2004. I36 S. (In German) Veteranyi A. Vorsicht bissige Hühnersuppe. Daniil Charms im Exil edition spoken script. A. Veteranyi. Luzern, Der gesunde Menschenversand, 20I8. S. 49-III. (In German) 
УДК 82I.II2.2

ББК $83.3(4$ Гем $) 7$

\section{ОСОБЕННОСТИ РЕПРЕЗЕНТАЦИИ ПРОШЛОГО В ПРОЗЕ БЕРНХАРДА ШЛИНКА}

\author{
(C) 2020 г. Д.А. Чугунов \\ Воронежский государственный университет, \\ Воронеж, Россия \\ Дата поступления статьи: 29 сентября 2019 г. \\ Дата публикации: 25 июня 2020 г.
}

DOI: I0.22455/2500-4247-2020-5-2-I86-2OI

Аннотация: В статье ставится цель определить место Бернхарда Шлинка в современной немецкой литературе. Несмотря на всемирный успех романа «Чтец», многие последующие произведения писателя подвергались серьезной критике. Главной причиной негативных суждений были стилистические особенности повествования и недостаточная глубина психологической проработки образов. Однако восприятие писателя как автора идейных романов позволяет понять действительную значимость его художественных опытов. Шлинк занимает позицию писателя-интеллектуала, подвергающего тщательному анализу привычные суждения о прошлом и настоящем. Особенностью его творческой манеры является постоянное прикосновение к ключевым пунктам современной немецкой концептосферы. Поле художественной литературы, к которому скрыто апеллирует Шлинк в своих размышлениях, обеспечивает его прозе наличие опорных точек, понятных большинству читателей. В этом отношении опора на узнаваемые сюжеты и образы, интеллектуальное общение с образованным читателем, угадывающим в том или ином случае продолжение известной и важной темы, обсуждение которой началось еще до Шлинка, - все это позволяет писателю систематизировать множество отдельных суждений об истории и обществе.

Ключевые слова: Бернхард Шлинк, литературный ландшафт, современная немецкая литература, осмысление прошлого, «Ольга».

Информация об авторе: Дмитрий Александрович Чугунов - доктор филологических наук, доцент, профессор кафедры истории и типологии русской и зарубежной литературы, ФГБОУ ВО «Воронежский государственный университет», пл. Ленина, д. Іо, 394018 г. Воронеж, Россия.

E-mail: dmtrchugunov@yandex.ru

Для цитирования: Чугунов Д.А. Особенности репрезентации прошлого в прозе Бернхарда Шлинка // Studia Litterarum. 2020. Т. 5, № 2. С. I86-20I. DOI: $10.22455 / 2500-4247-2020-5-2-186-201$ 


\section{REPRESENTATION OF THE PAST IN BERNHARD SCHLINK'S FICTION}

This is an open access article distributed under the Creative Commons Attribution 4.0 International (CC BY 4.0)
(C) 2020. D.A. Chugunov

Voronezh State University,

Voronezh, Russia

Received: September 29, 2019

Date of publication: June 25, 2020

Abstract: The article aims to determine the place of Bernhard Schlink in the modern German literature. Despite the worldwide success of his novel The Reader, many of the writer's subsequent writings were heavily criticized. The main objects of negative reviews were stylistic features of the narrative and insufficient depth of the characters' psychology. However, perception of the writer as the author of ideological novels allows us to understand the real significance of his artistic experiments. Schlink takes a position of the intellectual writer who carefully analyzes trivial judgments about the past and the present. In his work, he touches upon different key points of the modern German concept sphere. The field of fiction, to which Schlink covertly appeals in his thoughts, provides his fiction with the presence of reference points shared by most readers. In this regard, relying on recognizable stories and images, intellectual communication with an educated reader capable of recognizing widely discussed and important topics that Schlink picks up - all this allows the writer to systematize many separate judgments about history and society.

Keywords: Bernhard Schlink, literary landscape, modern German literature, understanding of the past, "Olga".

Information about the author: Dmitry A. Chugunov, DSc in Philology, Associate Professor, Professor Department of the History and Typology of Russian and Foreign Literature, Voronezh State University, Lenin Sq. I, 3940I8 Voronezh, Russia.

E-mail: dmtrchugunov@yandex.ru

For citation: Chugunov D.A. Representation of the Past in Bernhard Schlink's Fiction.

Studia Litterarum, 2020, vol. 5, no 2, pp. I86-20I. (In Russ.)

DOI: I0.22455/2500-4247-2020-5-2-I86-20I 
Оценивая место произведений Бернхарда Шлинка в современном литературном процессе Германии, мы сталкиваемся с двумя проблемными вопросами. Во-первых, в какой мере можно рассматривать Шлинка в качестве серьезного писателя? Во-вторых, насколько он самостоятелен в своих художественных поисках?

До того, как о Шлинке по-настоящему заговорили после шумной дискуссии, развернувшейся в г995 г. вокруг его романа «Чтец» (Der Vorleser), писатель запомнился читателям и критикам лишь тремя произведениями в детективном или полудетективном жанре, выбор которого легко объяснялся его профессией высококвалифицированного юриста ${ }^{\text {. }}$

Успех «Чтеца» был предопределен переменами в немецком общественном сознании в г990-е гг. Еще за восемь лет до его опубликования Шлинку удалось уловить общую тенденцию конца XX в. - стремление подвести некий итог размышлениям о прошлом. Подключившись, по сути, к знаменитому «спору историков» (середина г980-х гг.), Шлинк также продемонстрировал стремление «К полной палитре вместо черно-белой» [I5, с. 20] в изображении недавнего прошлого. В публицистическом эссе на тему «Право - вина - будущее» (1987) он затронул тему внутреннего конфликта поколения «детей», пытающихся одновременно и осудить преступления нацизма, и понять истоки поступков «отцов». Следует заметить, что здесь Шлинк выступал еще в роли юриста, но не писателя, термино-

I $\quad$ Б. Шлинк с 1987 по 2006 гг. был членом Конституционного суда земли Северный Рейн - Вестфалия. С 1982 г. по настоящее время он преподает государственное право в университетах Бонна (I982-I99I), Франкфурта-на-Майне (I99I-I992), Берлина (Ун-т им. Гумбольдта, с 1992 г.) 
логически сопоставляя коллективный контекст немецкой «вины» с субъективно ощущаемой виной, сталкивая узкое понимание вины в уголовном праве с определениями вины, основывающимися на нормах религии, морали и т. д. [23, с. I2]. Однако похожие размышления прозвучали и в «Чтеце», где Михаэль Берг педантично, с неотвратимой логичностью мучил себя вопросами: можно ли, например, ненавидеть нацизм как историческое явление, но при этом испытывать любовь к человеку, участвовавшему в нацистских злодеяниях? Можно ли ненавидеть свое прошлое, но при этом открывать в нем наличие счастливых страниц? Наконец, что вообще делать с неприятной исторической правдой ${ }^{2}$ Именно поэтому роман «Чтец» стал знаковым, войдя в один ряд с произведениями, вне всякого сомнения, обозначившими поворот в литературном процессе конца XX в., такими, как «Летучие собаки» (Flughunde, г995) Марселя Байера, «Комнатный фонтан» (Der Zimmerspringbrunnen, I995) Йенса Шпаршу, «Герои, как мы» (Helden wie wir, І995) Томаса Бруссига, «Faserland» (Faserland, г995) Кристиана Крахта, «Долгий разговор» (Ein weites Feld, г995) Гюнтера Грасса.

Однако показательно, что последующие произведения Шлинка не оценивались критикой столь же высоко. Так, уже роман «Возвращение» (Heimkehr, 2006) примечательно охарактеризовали как произведение, в котором «эмоции подавлены <...> историческим содержанием, юридическим дискурсом и философскими рассуждениями» [25], как попытку «большого литературного броска», которая так и осталась «попыткой» - из-за сюжетной расплывчатости и невозможности вместить сразу «всё» в довольно компактную жанровую форму [2о]. В адрес романа «Три дня» (Das Wochenende, 2008) прозвучали упреки в том, что персонажи в нем обрисованы «без какой-либо психологической тонкости», что они, «подобно деревянным шахматным фигурам, лишь скользят по полю дебатов» о политике [г3]. Роман «Женщина на лестнице» (Die Frau auf der Treppe, 20I4) назвали разочаровывающей и китчевой «мыльной оперой» [22]. Определенной традицией в критике стало и сравнение каждой новой книги Шлинка с «Чтецом» - не в

2 Михаэль Берг спрашивает: «Нам нельзя претендовать на понимание того, чего нельзя понять, нельзя пытаться с чем-то сравнивать то, что не поддается никаким сравнениям, нельзя задавать лишних вопросов, потому что спрашивающий, даже если он не подвергает пережитые ужасы сомнению, заставляет говорить о них вместо того, чтобы, содрогнувшись перед ними, оцепенеть в стыде, сознании своей вины и в немоте. Стало быть, мы должны цепенеть в стыде, сознании вины и немоте? До каких пор?» [8, с. II2]. 
пользу новых произведений. На этом фоне, пожалуй, лишь последний роман писателя - «Ольга» $(O \lg a, 2018)$ - удостоился серьезных похвал и был поставлен на одну с ступень с «Чтецом» как серьезное, панорамное представление национальной истории [19; 22].

При ответе на заданные в начале статьи вопросы в качестве определенной подсказки можно опереться на проницательное суждение рецензента «Нойе Цюрхер Цайтунг», заметившего: «Упорство, с которым Шлинк вплетает исторические темы в свои книги <..> заставляет заподозрить в нем автора идейных романов» [I7].

Именно это соображение позволяет расставить точки над «i». То, что часто вызывает порицание критиков, например, кажущаяся холодность, безэмоциональность повествования (см., например: [Іо; 16; 27]), при взгляде с другой стороны выглядит как достоинство: идейная проза юриста Шлинка «ясна, точна и отличается красивой элегантностью» [9]. Поэтому важно учитывать не только двойственную природу произведений Шлинка, сочетающую в себе глубину осмысляемых художником слова проблем с определенной юридической лаконичностью выражения, которая не допускает речевого карнавала $[\mathbf{1 7} ; 28]$. Ключевой оказывается роль, принятая на себя Шлинком, - роль писателя-интеллектуала.

В интереснейшей работе Даниэля Мората «Интеллектуалы и история интеллектуальности» (Intellektuelle und Intellektuellengeschichte, 20II) хорошо показано, что в немецкой традиции чаще всего именно писатели выступали в роли тех, кто инициировал общественные дискуссии, поляризовал общественное мнение. «Интеллектуалы особым образом являются экспонентами духа времени» (Exponenten des Zeitgeistes), - замечает Морат [2г]. В этом отношении романы Шлинка абсолютно созвучны глубинным переживаниям немецкого общества, они воспроизводят сильнейшие эмоциональные реакции на происходящее и случившееся³. Раскладывая происходящее по полочкам, подвергая тщательному анализу привычные суждения о прошлом и настоящем, писатель постоянно прикасается к различного рода ключевым пунктам современной немецкой концептосферы, он называет вещи, события или обстоятельства, которые у всех на слуху. Эти ключевые пункты или опорные точки, важные для понимания логики

3 Например, о «Чтеце» писали, что в нем Шлинк выразил «в экстремально усиленной форме мучительный опыт, с которым еще и сегодня сталкивается поколение “внуков”» [12]. 
Шлинка, действительно понятны большинству его читателей. Они представляют легко узнаваемый код, знакомый немцам с ранних лет. И поле художественной литературы служит здесь тем излюбленным пространством, в котором возможно соразмышление автора и читателя.

Уже в «Правосудии Зельба» (Selbs Justiz, I987), своем первом художественном опыте, Шлинк протянул смысловые нити сразу к трем известным произведениям немецкой послевоенной литературы, которые приобрели определенный символический смысл в общественном сознании. Так, например, его герой, беседуя с женщиной моложе себя, знающей о нацизме лишь стандартные тезисы из учебников, открывает ей глаза на то, что человеческое существование в те годы зачастую было вполне обыденным. По словам Зельба, многие совершенно не задумывались о происходившем вокруг них [7, с. I34]. Здесь можно усмотреть явное авторское знакомство с «Образами детства» (Kindheitsmuster, 1977) Кристы Вольф, которая едва ли не первой засвидетельствовала страшную истину: и во времена нацизма можно было вести нормальную жизнь. Жена же Зельба «была белокурой красавицей-нацисткой и оставалась ею, пока не раздобрела и не превратилась в достойный продукт германского экономического чуда» [7, с. 134]. И в этом абсолютно неконфликтном внутреннем превращении также угадывается аллюзия - на судьбу матери рассказчика из романа Г. Бёлля «Глазами клоуна» (Ansichten eines Clowns, I963), которая с восхитительной легкостью приноровилась к новым временам. Наконец, показательна сцена, в которой Зельб беседует с бывшим судьей Бойфером, в нацистские времена отправлявшим на казнь ученых-евреев. Судья ничуть не переживает по поводу содеянного, оправдывая себя исполнением долга: «Домке казнили, а Тибергу удалось скрыться. Этот малый потом далеко пошел. Был уважаемым человеком. Или он еще жив? Мы с ним как-то встретились <...>, пошутили о старых временах. Он понял, что мы все тогда выполняли свой долг» (курсив мой. - Д.Ч.) [7, с. 245]. О подобном самооправдании долгом шла речь и в известном романа Зигфрида Ленца «Урок немецкого» (Deutschstunde, 1968), включенном в школьную программу.

При этом подобные переклички никак не свидетельствуют о постмодернистской вторичности произведений Шлинка, характерной для литературы конца XX в. Серьезные романы Шлинка не вписываются в игровой канон постмодернизма с его амбивалентностью идей и суждений, с заменой 
автора на скриптора, а героев на симулякры, с равноценностью прекрасного и безобразного в повествовании и т. п. Однако чем тогда вызвана узнаваемость «чужих» сюжетов, образов, коллизий в прозе Шлинка?

Первое объяснение может носить психологический характер. Мы должны учитывать особенное внутреннее состояние автора, который вступает в большую литературу из другой сферы творческой деятельности. Нечто подобное проявлялось, например, в случае Теодора Фонтане. Он, известный на тот момент журналист и театральный критик, опубликовав первый роман - «Перед бурей» (Vor der Sturm, I878), был вынужден признать, что интрига в нем слаба, что нет соразмерности диалогов и действия, отсутствует драматизм описываемых событий. После этого Фонтане на протяжении нескольких лет тщательно изучал романы Тургенева, Бальзака, Теккерея, учась мастерству композиции и создания образов. Закономерным следствием этих штудий стали определенные переклички между названными авторами 4 .

О том, что Шлинк как автор абсолютно открыт для знакомства с чужим художественным опытом, свидетельствуют его гейдельбергские лекции (Gedanken über das Schreiben, 2оII). В них он, не отказываясь от самостоятельных решений, все же не раз задает себе вопрос: а как следует в том или ином случае писать об истории, о любви, об обществе? Возможны ли некие правила для писателя, некая художественная практика?

И подобные вопросы подводят нас ко второму объяснению. Шлинк с самого начала мыслит себя как автор, существующий в сложившемся художественном пространстве определенных идейных споров. Еще И. Тэн, увязывая художественное произведение с социальной жизнью, замечал в работе «О методе критики и об истории литературы», что «литературное произведение не есть простая игра воображения, самородный каприз, родившийся в горячей голове, но снимок с окружающих нравов и признак известного состояния умов» (цит. по: [г, с. Іо2]). Именно «известное состояние умов» определяет важнейшие лейтмотивы произведений Шлинка: вины, стыда, исторического возмездия. Так, Гюнтер Грасс сказал в нобелев-

4 Например, можно с уверенностью говорить о тургеневском влиянии, сказавшемся в выборе сюжетообразующей роли диалогов в «Поггенпулах» (Die Poggenpuhls, I896) Фонтане, о сведении в этом произведении к минимуму занимательной стороны фабулы и усилении социального и психологического элемента повествования, как в «Нови» Тургенева. 
ской речи: «Всякий раз нас снова настигало прошлое» [3, с. 329]. Однако и в большинстве произведений Шлинка тема прошлого выходит на первый план. Уже в «Правосудии Зельба» относительно невинные хитросплетения настоящего получают объяснение только благодаря погружению в темные события нацистского прошлого. То же самое происходит и в «Чтеце», и в «Возвращении». И даже повседневные любовные истории в «Летних обманах» (Sommerlügen, 2ого) вращаются вокруг лжи, к которой прибегают герои, чтобы спрятать свое прошлое. Бремя прошлого из поколения в поколение делается легче, однако Шлинк уверен (как и Грасс), что немцам придется еще долго нести его [II].

В упомянутых нами гейдельбергских лекциях Шлинк поставил перед своими слушателями вопрос о роли художественной литературы в передаче важных исторических событий. Его интересовало возможное соотношение документальности и художественности в повествовании. Как следует относиться к тем произведениям, в которых художественное начало вытесняет сами факты? Или если факты как таковые вообее не востребованы автором? Ведь даже «такие ужасные события, как Холокост, в художественном изложении теряют полную правду случившегося» [24, с. 85]. Продолжая его мысль, заметим: не ею ли вызвана узнаваемая стилистика шлинковского повествования, кажущегося многим излишне сдержанным, суховатым, холодным, но вместе с тем насыщенного вопросами к читателю, требующего от него не вчувствования в описываемое, но активного соразмышления?

При этом, ослабляя художественную сторону повествования в пользу его идейного наполнения, Шлинк - возможно бессознательно, как юрист, - компенсирует это апеллированием к тому, что уже известно, доказано (argumentum ad verecundiam), к сложившемуся литературному ландшафту, к тому, что уже однажды прозвучало в художественной литературе. Покажем это на нескольких примерах из романа «Ольга», который, по справедливому замечанию Б. Хайдеманн в газете «Винер Альгемайне Цайтунг», следует читать скорее как коллективную драму всего столетия, нежели как реальную судьбу одного человека [г8].

В «Ольге» обнаруживаются легко узнаваемые отсылки к произведениям классиков немецкой послевоенной литературы, например, к роману Генриха Бёлля «Бильярд в половине десятого». Так, герой Бёлля, размышляя о трагической слепоте немцев, не замечавших, как из вполне обыден- 
ных вещей вырастает чудовище будущей войны, вспоминает о детских годах своего погибшего сына: «Я слышал, как внизу мой четырехлетний сынишка повторял: “Хочу ружье, хочу ружье...” Мне бы следовало спуститься вниз и высечь его в присутствии моей гордой тещи, но я позволил ему петь, позволил играть с уланским кивером, который мальчику подарили дяди, позволил волочить за собой саблю, позволил выкрикивать: “Французу каюк! Англичанину каюк! Русскому каюк!” [2, с. 3ІІ]. Фигура ребенка, воодушевленного ложно понятыми патриотическими идеями, появляется и у Шлинка: «Война хороша для... детей. Младшие и слабые должны в играх представлять сербов и англичан, а остальные бросаются на них с криками: “Сербия, вот смерть твоя!” и “Боже, Англию накажи!” [6, с. 276].

Не менее прозрачная отсылка звучит в словах Ольги, высказывающей в конце жизни намерение взорвать памятник «железному» канцлеру: «Я взорву Бисмарка. С него всё и началось. Ты считаешь, что он сделал хорошее дело, - нет, это не правда. Может быть, люди задумаются об этом, когда он будет взорван» [6, с. 297]. Шлинк актуализирует в сознании читателя поступок Роберта Фемеля, взорвавшего в романе Бёлля аббатство Святого Антония. В обоих случаях эти поступки вызваны не практической необходимостью, а отчаянным протестом против лицемерного искажения истории, в которой за красивыми фразами теряется ценность человеческой жизни.

Метафоры, которые использует Шлинк в «Ольге», часто становятся узнаваемыми именно в литературном контексте. Так, однажды «у Ольги поднялась температура, она подумала, что подхватила грипп, прилегла, заснула, а наутро проснулась глухой» [6, с. ІІ3]. Шлинк пишет не о физической немощи, а об оглушении человека в крикливом мира, установившемся при нацистах, которые «везде понавешали репродукторов, из которых день-деньской гремели речи, лозунги, призывы, военные марши, от них некуда было деться» [6, с. II5]. Вспомним здесь, что известный роман Грасса «Под местным наркозом» в оригинале называется «Örtlich betäubt»: метафора глухоты, оглушения вынесена автором в название. Подобным же образом фраза Ольги «Германия стала мне чужой» [6, с. 29I] отчетливо проецируется на судьбы эмигрантов, не пожелавших после Второй мировой войны вернуться на родину, например, на судьбу Шреллы, описанную Бёллем в «Бильярде в половине десятого».

«Ольга» Шлинка построена как рассказ о судьбе человека, разворачивающийся на фоне масштабных исторических событий. Перед глазами 
читателя проходит немецкая история с кайзеровских времен и до современности. Подобная панорама требуется Шлинку для того, чтобы прийти к осознанию трагического обстоятельства: разрушительную идею о превосходстве над другими нациями в сознание немцев заложил вовсе не Гитлер, а не кто иной, как «железный канцлер» Бисмарк - всеми почитаемый объединитель германских государств. Ольга обвиняет Бисмарка в том, что именно он соблазнил немцев мечтами о великой Германии. С Бисмарка, по ее мнению, началось и формирование культа личности, той сильной фигуры, которая способна поднять немецкую нацию над другими.

Показательно, что эта мысль прозвучала в немецкой литературе задолго до Шлинка. Впервые о сильном влиянии Бисмарка на формирование идеологии Третьего Рейха написал в книге «Германская катастрофа» (Die deutsche Katastrophe, I946) Ф. Мейнеке. А в конце века Грасс в «Моем столетии» продемонстрировал, как связываются незримыми нитями разные моменты национальной истории. Так, его размышления в главе «1943» - о чудовищной эмоциональной невосприимчивости немцев эпохи националсоциализма суть не что иное, как продолжение размышлений, начатых в главе «1900» о том самом времени, когда в гражданах новорожденной Германской империи только закладывалось неразличение добра и зла, культуры и ее эрзаца. Однако Шлинк довел эту мысль до кристального совершенства, словно подытожив в художественной форме предшествующие поиски историков и социологов.

В поле зрения Шлинка находятся не только произведения «классиков» немецкой послевоенной литературы. Следует отметить присутствие в его тексте и той особенной, задиристой публицистичности, что сделалась характерной для литературного процесса после падения Берлинской стены. Так, в скепсисе Ольги, направленном против ритуальных действий федеральных властей, отголоском слышится грандиозный скандал, устроенный М. Вальзером II октября I998 г. Выступая по случаю вручения ему премии Немецкого союза книготорговли, Вальзер безапелляционно заявил: «Ни один нормальный человек не отрицает Освенцим... Но, когда каждый божий день средства массовой информации преподносят мне ужасы прошлого, я замечаю, что во мне что-то восстает против этой нескончаемой “презентации” нашего позора... И начинаю отворачивать голову... И анализирую... И вижу, что очень часто вовсе не память о жертвах и не ответственность 
перед историей являются подлинными мотивами. Наш позор превращают в разменную монету, вспомогательный инструмент, служащий достижению текущих целей. Пусть и самых благих...»5. После чего Вальзер назвал бетонирование в центре Берлина участка под Мемориал жертвам холокоста размером с два футбольных поля «кошмаром» и «монументализацией позора» [5]. Любопытно, что мнение Ольги в романе Шлинка совпадает с мнением Вальзера, не побоявшегося пойти против официальной позиции германских властей: «Думаю, она бы сказала, что здания администрации федерального канцлера, и здание бундестага, и Мемориал жертвам холокоста чересчур велики...» (курсив наш. - Д.Ч.) [6, с. І86].

Представляя «Ольгу» во время Лейпцигской книжной ярмарки, Шлинк признался в своей очарованности литературой позапрошлого столетия [26] Действительно, литературный XIX в. просвечивает сквозь художественную ткань «Ольги», как, например, в сюжетном совпадении с новеллой Теодора Шторма «Ганс и Гейнц Кирх» (Hans und Heinz Kirch, I883). В «Ольге» также возникает ситуация непонимания между «отцами» и «детьми», и также письмо отца сыну становится свидетельством «о тщете запоздалого раскаяния» [6, с. 223-224]. Обращение к XIX в. (и не только к нему) позволяет Шлинку, соединяющему в своих размышлениях разные времена и эпохи, выстраивать для читателя единый текст немецкой культуры. Подобно тому, как в романах Грасса мы являемся свидетелями возникновения так называемого «четвертого времени» (Vergegenkunft), совмещающего в себе осознание в настоящем катастрофических событий прошлого и их проецирование в будущее, так и у Шлинка прошлое и настоящее оказываются настолько «прорастающими» друг в друга, что невозможно понять одно без другого. Например, отсылка к стихотворению И.В. Гёте «Свидание и разлука» («Гёте пишет: “И все ж любить - какое счастье!”, способность любить он ставит превыше счастья быть любимым» [6, с. 285-286]) важна временем своего появления в тексте. Ольга вспоминает эти строки во время войны. Без учета этого обстоятельства особенный гуманистический смысл фразы едва ли будет уловлен читателем. Однако, напротив, при связывании строчки Гёте и трагических переживаний

\footnotetext{
5 Русский перевод цитируется по источнику: [5]. Текст оригинала: [14].

6 В критике уже обращалось внимание на многочисленные параллели между его романами и книгами В. Раабе, Г. Келлера, на схожий социально-психологический характер повествования Шлинка и Т. Фонтане и т. п.
} 
военных лет делается, например, возможным ассоциативный выход уже к известному рассказу В. Борхерта «Хлеб» (г946), в котором автор также представил победу любви над ненавистью в сердце человека.

Наконец, одним из важнейших в романе «Ольга» становится прикосновение к мифу о Ф. Гёльдерлине. Спасаясь от наступающих советских войск, Ольга символически приходит вместе с другими беженцами в некий город «на берегу Неккара. Он не был разрушен, и здесь, после многих городов с разбитыми, сожженными, рухнувшими домами, со сгоревшими деревьями на улицах, в садах и парках, с полями развалин, где над кучами щебня торчали печные трубы или церковная колокольня или виднелась крыша бункера, с подвалами, куда люди прятались, юркнув, точно крысы, Ольга почувствовала: вот и пришла» [6, с. ІІ8].

Гёльдерлин родился в Лауфене, стоящем на Неккаре, жил в детстве в Нюртингене - тоже на Неккаре. Долинам Неккара посвящены его стихотворные строки. И потому судьба Гёльдерлина, бесприютного скитальца, нигде, кроме Поэзии, не находящего приюта (о чем он и писал в «Песне судьбы Гипериона»), вдруг удивительным образом проецируется на судьбу самой Ольги и - шире - на судьбу огромного количества немцев в I945 г. А.В. Карельский однажды обратил внимание на гениальное высказывание Гёльдерлина: «Да не оправдывает себя никто тем, что его погубил мир! Человек сам губит себя! В любом случае!» [4, с. 399]. Именно здесь открывается символический смысл прихода Ольги в не названный в романе город на Неккаре: перед нами движение от высокой культуры прошлого к бесприютности настоящего, в котором немцы губят себя сами.

Таким образом, Бернхард Шлинк занимает особенное место в современной немецкой литературе. Он не стремится поразить читателя формальными изысками, как не старается превзойти других в литературной известности. Профессия юриста, от которой Шлинк не отказался в пользу профессии свободного писателя, обеспечивает ему достаточную самостоятельность, чтобы не зависеть от литературной моды. В силу этого он может позволить себе быть традиционным немецким автором в лучшем смысле этого слова интеллектуалом, ориентированным на размышление, ждущим такого же читателя-интеллектуала, предпочитающим повествование более глубокое по смыслу, нежели блестящее по форме. Различные литературные аллюзии, возникающие в его произведениях, играют при этом особенную роль. Опора на 
узнаваемые сюжеты и образы, интеллектуальное общение с образованным читателем, угадывающим в том или ином случае продолжение известной и важной темы, обсуждение которой началось еще до Шлинка, - все это позволяет ему систематизировать множество отдельных суждений об истории и обществе. Именно опора на яркие, во многом ключевые образы, сюжеты, конфликты из классических произведений немецкой литературы открывает читателю всю логичность и системность идейных исканий писателя.

\section{Список литературы}

I $\quad$ Академические школы в русском литературоведении. М.: Наука, I975. 5I5 c.

2 Бёлль Г. О себе самом. Где ты был, Адам? Рассказы. Бильярд в половине десятого. Глазами клоуна. Письмо моим сыновьям, или Четыре велосипеда.

М.: НФ «Пушкинская библиотека», ООО «Изд-во АСТ», 2004. 728 с.

3 Грасс Г. Продолжение следует... // Моё столетие. М.: ООО «Изд-во АСТ», $200 \mathrm{I}$. C. 320-333.

Карельский А.В. Метаморфозы Орфея: Беседы по истории западных литератур. Вып. 3: Немецкий Орфей. М.: Рос. гос. гуманит. ун-т, 2007. 608 с. Миримов А. А был ли спор? // citycat. 2002. URL: http://telegraf.citycat.ru/ Politic/9185962237906o.html (дата обращения: го.о8.2002).

6 Шлинк Б. Ольга. М.: Иностранка, Азбука-Аттикус, 2018. 304 с.

7 Шлинк Б. Правосудие Зельба. СПб.: Азбука, 201о. 320 с.

8 Шлинк Б. Чтец. М.: АСТ, 2004. 25I с.

9 Bernhard Schlink // Diogenes Verlag. https://www.diogenes.ch/leser/autoren/s/ bernhard-schlink.html (дата обращения: 20.10.20I9).

IO Cavelty G. Die Odyssee als Obsession // Neue Zürcher Zeitung. 2006. 22. April. URL: https://www.nzz.ch/articleDLKTE-I.26954 (дата обращения: 20.09.20I9).

II Connolly $K$. Bernhard Schlink: Deutschsein ist 'eine riesige Belastung' // The Guardian. 20I2. I7th sep. URL: https://www.theguardian.com/world/20I2/sep/I7/interviewmit-bernhard-schlink (дата обращения: I7.04.2019). Deißner D., Lindemann Th. Ist «Der Vorleser» ein großer Roman? // Die Welt. 20 o. I7. Oktober. URL: https://www.welt.de/kultur/articleI24I86I/Ist-Der-Vorleser-eingrosser-Roman.html (дата обращения: 20.09.2019).

I3 Dörting Th. Wochenend' und Bullenschwein // Spiegel Online. 2008. 28. Februar. URL: https://www.spiegel.de/kultur/literatur/schlinks-raf-roman-wochenend-undbullenschwein-a-537727.html (дата обращения: 22.Iо.20I8).

I4 Erfahrungen beim Verfassen einer Sonntagsrede : Friedenspreis des deutschen Buchhandels / Martin Walser. Laudatio: Sein Anteil / Frank Schirrmacher. Frankfurt am Main: Suhrkamp, I998. 50 S. 
I5 Forever in the shadow of Hitler? Original documents of Historikerstreit. New Jersey: Humanities Press, I993. 286 p.

I6 Greiner U. Einer, der etwas riskiert // Die Zeit. 20I4. II. September. URL: https:// www.zeit.de/20I4/35/bernhard-schlink-roman (дата обращения: 21.09.20I9).

I7 Güntner. Fabulierender Jurist mit klarer Prosa - Bernhard Schlink wird 70 // Neue Zürcher Zeitung. 20I4. 07. July. URL: http://www.nzz.ch/feuilleton/buecher/ fabulierender-jurist-mit-klarer-prosa-I.I8336895 (дата обращения: 22.Iо.20I9).

I8 Heidemann B. Bernhard Schlink erzält vom Drama eines Jahrhunderts // Wiener Allgemeine Zeitung. 20I8. Io. Jan. URL: https://www.waz.de/kultur/bernhardschlink-erzaehlt-vom-drama-eines-jahrhunderts-id2I3072235.html (дата обращения: 30.04.2019).

I9 Kürten J. Ein deutsches Jahrhundert: Bernhard Schlinks neuer Roman «Olga»// Deutsche Welle. 20I8. I2. Jan. URL: https://www.dw.com/de/ein-deutschesjahrhundert-bernhard-schlinks-neuer-roman-olga/a-42II4066 (дата обращения: 24.06.2019). Leopold A. Alles und nichts // Die Tageszeitung. 2006. 4. März. S. Ioo6. Morat D. Intellektuelle und Intellektuellengeschichte // Docupedia-Zeitgeschichte: Begriffe, Methoden und Debatten der zeithistorischen Forschung. 20II. 20. November. URL: https://docupedia.de/zg/Intellektuelle_und_Intellektuellengeschichte\#Der_ Begriff_des_Intellektuellen (дата обращения: І2.08.20I9).

22 Moritz R. Sinnliche Gewichtigkeit // Neue Zürcher Zeitung. 20I4. 7. Oktober. URL: https://www.nzz.ch/sinnliche-gewichtigkeit-I.I83983I7 (дата обращения: I2.II.2OI4).

23 Schlink B. Vergangenheitsschuld und gegenwärtiges Recht. Frankfurt am Main: Suhrkamp Taschenbuch Verlag, 2002. I56 S.

24 Schlink B. Gedanken über das Schreiben. Heidelberger Poetikvorlesungen. Zürich: Diogenes, 20II. $87 \mathrm{~S}$.

25 Schmitz M. Heimkehr als Utopie // Deutschlandfunk. 2006. 9. April. URL: https:// www.deutschlandfunk.de/heimkehr-als-utopie.700.de.html?dram:article_id=82670 (дата обращения: 20.09.2019).

26 Schriftsteller Schlink von I9. Jahrhundert fasziniert // t-online.de. 20I8. I5. März. URL: https://www.t-online.de/region/id_83397582/schriftsteller-schlink-von-I9jahrhundert-fasziniert.html (дата обращения: 26.09.2019).

27 Schulte Th. Oberlehrerhaft vorgetragene Trivialitäten. Bernhard Schlinks neuer Roman «Die Frau auf der Treppe» enttäuscht // Literaturkritik.de. 20I4. I. September. URL: https://literaturkritik.de/id/ı9526 (дата обращения: 21.09.20I9).

28 Wirtz Th. Immer nur lebenslänglich // Frankfurter Allgemeine Zeitung. 2000. I2. Februar. URL: https://www.faz.net/aktuell/feuilleton/buecher/rezensionen/ belletristik/rezension-belletristik-immer-nur-lebenslaenglich-II0380.html?printPaged Article=true\#pageIndex_2 (дата обращения: I7.03.20I7). 


\section{References}

Akademicheskie shkoly v russkom literaturovedenii [Academic schools in Russian literary criticism]. Moscow, Nauka Publ., I975. 515 p. (In Russ.)

Bell' G. O sebe samom. Gde ty byl, Adam? Rasskazy. Bil'iard v polovine desiatogo. Glazami klouna. Pis'mo moim synov'iam, ili Chetyre velosipeda [About myself. Where have you been, Adam? Stories. Billiards at half past nine. Through the eyes of a clown. Letter to my sons, or four bicycles]. Moscow, NF "Pushkinskaia biblioteka" Publ., OOO “Izdatel'stvo AST” Publ., 2004. 728 p. (In Russ.)

3 Grass G. Prodolzhenie sleduet... [To be continued]. Moe stoletie [My century]. Moscow, OOO “Izdatel'stvo AST” Publ., 200I, pp. 320-333. (In Russ.) Karel'skii A.V. Metamorfozy Orfeia: Besedy po istorii zapadnykh literatur. Vyp. 3: Nemetskii Orfei [Metamorphoses of Orpheus: Conversations on the history of Western Literature. Issue 3: German Orpheus]. Moscow, Russian State University for the Humanities Publ., 2007. 608 p. (In Russ.) Mirimov A. A byl li spor? [Was there a dispute?]. Citycat, 2002. Available at: http:// telegraf.citycat.ru/Politic/9I85962237906o.html (Accessed Io August 2002). (In Russ.)

Schlink B. Ol'ga [Ol'ga]. Moscow, Inostranka Publ., Azbuka-Attikus Publ., 20I8. 304 p. (In Russ.)

Schlink B. Pravosudie Zel'ba [Justice of Zelb]. St. Petersburg, Azbuka Publ., 2 oIo. 320 p. (In Russ.)

8 Schlink B. Chtets [Reader]. Moscow, AST Publ., 2004. 25I p. (In Russ.)

9 Bernhard Schlink. Diogenes Verlag. Available at: https://www.diogenes.ch/leser/ autoren/s/bernhard-schlink.html (Accessed 20 October 20I9). (In German) Cavelty G. Die Odyssee als Obsession. Neue Zürcher Zeitung. 2006. 22. April. Available at: https://www.nzz.ch/articleDLKTE-I.26954 (Accessed 20 September 20I9).

(In German)

II Connolly K. Bernhard Schlink: Deutschsein ist 'eine riesige Belastung'. The Guardian. 20I2. I7 September. Available at: https://www.theguardian.com/world/20I2/sep/I7/ interview-mit-bernhard-schlink (Accessed I7 April 20I9). (In German) Deißner D., Lindemann, Th. Ist “Der Vorleser” ein großer Roman? Die Welt. 20Io. I7. Oktober. Available at: https://www.welt.de/kultur/articleı24I86I/Ist-Der-Vorleserein-grosser-Roman.html (Accessed 20 September 20I9). (In German) Dörting Th. Wochenend' und Bullenschwein. Spiegel Online. 2008. 28. Februar. Available at: https://www.spiegel.de/kultur/literatur/schlinks-raf-roman-wochenendund-bullenschwein-a-537727.html (Accessed 22 October 2018). (In German)

I4 Erfahrungen beim Verfassen einer Sonntagsrede: Friedenspreis des deutschen Buchhandels, Martin Walser. Laudatio: Sein Anteil, Frank Schirrmacher. Frankfurt am Main, Suhrkamp, 1998. 50 S. (In German) Forever in the shadow of Hitler? Original documents of Historikerstreit. New Jersey, Humanities Press, I993. 286 p. (In German) 
I6

Greiner U. Einer, der etwas riskiert. Die Zeit. 20I4. II. September. Available at: https:// www.zeit.de/20I4/35/bernhard-schlink-roman (Accessed 2I September 20I9).

\section{(In German)}

Güntner. Fabulierender Jurist mit klarer Prosa - Bernhard Schlink wird 70. Neue Zürcher Zeitung. 20I4. o7 July. Available at: http://www.nzz.ch/feuilleton/buecher/ fabulierender-jurist-mit-klarer-prosa-I.I8336895 (Accessed 22 Oktober 20I9). (In German)

Heidemann B. Bernhard Schlink erzält vom Drama eines Jahrhunderts. Wiener Allgemeine Zeitung. 20I8. Io. Jan. Available at: https://www.waz.de/kultur/bernhardschlink-erzaehlt-vom-drama-eines-jahrhunderts-id2I3072235.html (Accessed 30 April 20I9). (In German)

Kürten J. Ein deutsches Jahrhundert: Bernhard Schlinks neuer Roman "Olga”. Deutsche Welle. 20I8. I2 Jan. Available at: https://www.dw.com/de/ein-deutsches-jahrhundertbernhard-schlinks-neuer-roman-olga/a-42II4066 (Accessed 24 Juny 20I9). (In German)

Leopold A. Alles und nichts. Die Tageszeitung. 2006. 4 March. P. Ioo6. (In German) Morat D. Intellektuelle und Intellektuellengeschichte. Docupedia-Zeitgeschichte: Begriffe, Methoden und Debatten der zeithistorischen Forschung. $201 \mathrm{I} .20$ November. Available at: https://docupedia.de/zg/Intellektuelle_und_ Intellektuellengeschichte\#Der_Begriff_des_Intellektuellen (Accessed I2 August 20I9). (In German)

22 Moritz R. Sinnliche Gewichtigkeit. Neue Zürcher Zeitung. 20I4. 7 Oktober. Available at: https://www.nzz.ch/sinnliche-gewichtigkeit-I.I83983I7 (Accessed I2 November 20I4). (In German)

3 Schlink B. Vergangenheitsschuld und gegenwärtiges Recht. Frankfurt am Main, Suhrkamp Taschenbuch, 2002. I56 p. (In German)

4 Schlink B. Gedanken über das Schreiben. Heidelberger Poetikvorlesungen. Zürich, Diogenes Publ., 20II. 87 p. (In German)

5 Schmitz M. Heimkehr als Utopie. Deutschlandfunk. 2006. 9. April. Available at: https:// www.deutschlandfunk.de/heimkehr-als-utopie.70o.de.html?dram:article_id=82670 (Accessed 20 September 20I9). (In German)

Schriftsteller Schlink von I9. Jahrhundert fasziniert. t-online.de. 20I8. I5 March. Available at: https://www.t-online.de/region/id_83397582/schriftsteller-schlink-vonI9-jahrhundert-fasziniert.html (Accessed 26 September 20I9). (In German)

27 Schulte Th. Oberlehrerhaft vorgetragene Trivialitäten. Bernhard Schlinks neuer Roman "Die Frau auf der Treppe” enttäuscht. Literaturkritik.de. 20I4. I September. Available at: https://literaturkritik.de/id/I9526 (Accessed 2I September 20I9). (In German) Wirtz Th. Immer nur lebenslänglich. Frankfurter Allgemeine Zeitung. 2000. I2 Februar. Available at: https://www.faz.net/aktuell/feuilleton/buecher/rezensionen/belletristik/ rezension-belletristik-immer-nur-lebenslaenglich-II0380.html?printPagedArticle=true \#pageIndex_2 (Accessed I7 March 20I7). (In German) 
УДК 82I.I6І.І

ББК $83.3(2 \mathrm{Poc}=\mathrm{Pyc}) 52$

\section{ПРОБЛЕМА ГЕРОЯ ВРЕМЕНИ В ДИАЛОГЕ ТУРГЕНЕВА И ПИСАРЕВА}

\author{
(C) 2020 г. В.И. Щербаков \\ Институт мировой литературы \\ им. А.М. Горького Российской академии наук, \\ Москва, Россия \\ Дата поступления статьи: ог сентября 2ог9 г. \\ Дата публикации: 25 июня 2020 г.
}

DOI: IO.22455/2500-4247-2020-5-2-202-219

Аннотация: Дмитрий Писарев вошел в историю литературы во многом благодаря конгениальной интерпретации романа «Отцы и дети» (I862). Его статьи «Базаров» (I862) и «Реалисты» (1864) убедили общество в том, что нигилисты действительно существуют и что они изображены писателем «совершенно верно» (Н.Н. Страхов). Эти же статьи прояснили саму идеологию нигилизма, представленную И.С. Тургеневым в утрированном виде. Однако Писарев «решительно» не принял следующий роман Тургенева - «Дым» (1867). Причины этого неприятия рассмотрены подробно. Исследованы творческие и личные взаимоотношения Тургенева и Писарева, дана характеристика их общественно-политических взглядов. Основная часть статьи является оригинальным комментарием к переписке Тургенева и Писарева I867 г., в которой речь идет о «Дыме». Особое внимание уделено проблеме главного героя «Дыма» и парадоксальному факту игнорирования критиком образа Потугина, которому Тургенев придавал большое значение. Диалог писателя и критика выявил принципиальные расхождения в их представлениях об эпохе І86о-х гг. и ее героях, а кроме того, обнаружил и недостаток взаимопонимания, проявившийся в своеобразном quiproquo.

Ключевые слова: Писарев, Тургенев, «Отцы и дети», «Дым», литературная критика, І86о-е гг., нигилизм, творческий диалог, quiproquo, квипрокво.

Информация об авторе: Виктор Игоревич Щербаков - кандидат филологических наук, старший научный сотрудник, Институт мировой литературы им. А.М. Горького Российской академии наук, ул. Поварская, д. 25 а, І21069 г. Москва, Россия.

E-mail: Visherıı@yandex.ru

Для цитирования: Щербаков В.И. Проблема героя времени в диалоге Тургенева и Писарева // Studia Litterarum. 2020. Т. 5, № 2. С. 202-219.

DOI: $10.22455 / 2500-4247-2020-5-2-202-219$ 


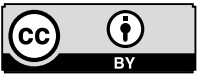

This is an open access article distributed under the Creative Commons Attribution 4.0 International (CC BY 4.0)

\section{THE PROBLEM OF THE HERO OF HIS TIME IN THE DIALOGUE BETWEEN TURGENEV AND PISAREV}

\author{
(C) 2020. V.I. Shcherbakov \\ A.M. Gorky Institute of World Literature \\ of the Russian Academy of Sciences, Moscow, Russia \\ Received: September OI, 20I9 \\ Date of publication: June 25, 2020
}

\begin{abstract}
Dmitry Pisarev entered the history of literature largely due to the congenial interpretation of the novel Fathers and Sons (I862). His articles "Bazarov" (I862) and "Realists" (I864) convinced the public that nihilists really existed and the novel offered their "absolutely true" representation (N.N. Strakhov). The same articles expained the ideology of nihilism presented by Turgenev in exaggerated form. However, Pisarev did not approve of Turgenev's next novel, The Smoke (I867). The article discusses in detail the reasons of Pisarev's negative review. It also sheds light on professional and personal relations of Turgenev and Pisarev as well as on political views of both. The main part of the article is an original commentary on the correspondence of Turgenev and Pisarev in I867 around The Smoke. Particular attention is paid to the problem of the main character of The Smoke and the paradoxical fact that the critic ignored the character of Potugin to whom Turgenev attached great importance. The dialogue between the writer and the critic revealed fundamental differences in their ideas about the I86os and its heroes, and also exposed a lack of understanding that manifested itself in their qui pro quo.
\end{abstract}

Keywords: Pisarev, Turgenev, Fathers and Sons, The Smoke, literary criticism, I86os, nihilism, creative dialogue, qui pro quo.

Information about the author: Viktor I. Shcherbakov, PhD in Philology, Senior Researcher, A.M. Gorky Institute of World Literature of the Russian Academy of Sciences, Povarskaya 25 a, I21069 Moscow, Russia.

E-mail: Visherııı@yandex.ru

For citation: Shcherbakov V.I. The Problem of the Hero of His Time in the Dialogue between Turgenev and Pisarev. Studia Litterarum, 2020, vol. 5, no 2, pp. 202-219. (In Russ.) DOI: $10.22455 / 2500-4247-2020-5-2-202-219$ 
I

Литературно-критическая деятельность Д.И. Писарева была сосредоточена на изучении «нового типа» в русской жизни и литературе. Он не признал нового человека в гончаровском Штольце («Обломов», I859) и не поддержал энтузиазма Н.А. Добролюбова в оценке тургеневского Инсарова («Накануне», I860), посчитав обе фигуры сочиненными. Зато нигилист Базаров оправдал надежды Писарева вполне, став его любимым литературным героем.

В статьях «Базаров» (г862) и «Реалисты» (1864) Писарев сделал Базарова знаменем своего поколения и вжился в образ настолько, что стал почти соавтором писателя. «Он в Базарове узнал себя и своих и добавил, чего недоставало в книге», - писал А.И. Герцен [5, т. 20, кн. І, с. 335]. Сам же Тургенев характеризовался Писаревым как «великий художник и честный гражданин России», сумевший разглядеть в Базарове тип сильный и перспективный [ІІ, т. 4, с. 20I].

При всех преувеличениях слишком субъективного анализа Писарев оказался много ближе к адекватному истолкованию романа, чем критик «Современника» М.А. Антонович, который одновременно с ним заявлял прямо обратное - что Базаров «не характер, не живая личность, а карикатура», и даже уверял, что «новое произведение г. Тургенева крайне неудовлетворительно в художественном отношении» («Асмодей нашего времени», г862) [I, с. 42, 36]. Разбор Антоновича был заведомо необъективен и транслировал точку зрения «отцов» русской демократии. Писарев же подчеркивал, что Базарова могут понять только молодые и «свежие» люди. Последнее слово он повторял часто: «Базарову некого любить, потому что 
вокруг него все мелко, плоско и дрябло, а сам он свеж, умен и крепок <...> теперешние молодые люди увлекаются и впадают в крайности, но в самых увлечениях сказываются свежая сила и неподкупный ум...» («Базаров») [II, T. 4, с. 2OI].

Н.Н. Страхов, выступивший тогда же арбитром в споре Антоновича и Писарева, точно подметил одну из главных черт личности и деятельности последнего: «Г. Писарев никогда не лукавит с читателями; он договаривает свою мысль до конца. Благодаря этому драгоценному свойству роман Тургенева получил блистательнейшее подтверждение, какого только можно было ожидать. Г. Писарев, человек молодого поколения, свидетельствует о том, что Базаров есть действительный тип этого поколения и что он изображен совершенно верно» (Время, г962, № 4) [8, с. 73].

Сам Тургенев высоко оценил статью «Базаров»: «Статья Писарева в "Русском слове” мне показалась очень замечательная», - писал он П.В. Анненкову 8/20 июня І862 г. [І7, т. 5, с. 74]. «Разбор Писарева необыкновенно умен, - повторил Тургенев в І864 г. - Я должен сознаться, что он почти вполне понял, что я хотел сказать Базаровым» [7, т. 2 с. 67].

В марте г867 г. состоялось личное знакомство писателя и критика. Вопреки ожиданиям, Писарев произвел на Тургенева впечатление воспитанного юноши (в частности, писатель отметил его сдержанность во время спора с участием В.П. Боткина) [7, т. 2, с. 76]. Общались они прохладно, но откровенно, и Тургенев увидел в Писареве «человека честного и умного, которому не только можно, но и должно говорить правду» [І8, т. II, с. 33].

\section{2}

Вскоре после той встречи был опубликован еще один роман Тургенева - «Дым» (Русский вестник, І867, № 3), последний из вышедших при жизни Писарева. Новый роман вызвал еще больше нареканий - критики упрекали автора в недостатке патриотизма, отмечали бледность центрального персонажа Литвинова и малопонятную любовь к нему сразу двух молодых женщин - роковой Ирины и «тургеневской девушки» Татьяны. «В Дыме нет ни к чему почти любви и нет почти поэзии. Есть любовь только к прелюбодеянию легкому и игривому, и потому поэзия этой повести противна <...> я не могу трезво смотреть на автора, личность к<отор>ого не люблю, но, кажется, мое впечатление общее всем. Еще один кончил», - 
писал Л.Н. Толстой А.А. Фету 28 июня І867 г. [І5, т. 6I, с. І72]. Убеждение критиков, что «Дым» вышел слабее прежних романов Тургенева, в целом разделяли и позднейшие исследователи. Так, Л.В. Пумпянский увидел в «Дыме» роман «облегченного», «западнобуржуазного» типа, «первый у Тургенева пример беллетристики» [12, с. 48I].

Тургенев ждал отзыва Писарева. «Благодарю заранее за обещание сообщать толки; что-то скажет Писарев? Не смейтесь! Для меня это довольно важно - как симптом», - писал он П.В. Анненкову 24 апреля/6 мая I867 г. [І7, т. 7, с. І89]. И уже Іо/22 мая І867 г. Тургенев адресуется к Писареву лично, желая поскорее узнать его мнение о «Дыме».

Писатель ставит перед критиком вопрос, который его особенно занимал в данном случае: «...какое впечатление произвел “Дым” на Вас и на Ваш кружок - рассердились ли Вы по поводу сцен у “Губарева” и эти сцены заслонили ли для Вас смысл всей повести?» [I7, т. 7, с. 204]. Как известно, в сценах y Губарева памфлетно изображен заграничный кружок неких русских демократов, проводящих время в сплетнях и болтовне о судьбах России.

Свое мнение о «Дыме» Писарев изложил коротко, откровенно и вполне литературно в личном письме к Тургеневу от І8/30 мая I867 г., уточнив, что у него «нет кружка» и рядом нет даже единомышленников, за которых он бы мог поручиться: «Словом, я стою один и могу поделиться с Вами только моим личным мнением» [II, т. II, с. 279].

Слово «стою» употреблено здесь как будто не совсем по-русски и тем не менее сознательно - это автоциитата из статьи г862 г.: «Базаров один, сам по себе, стоит на холодной высоте трезвой мысли, и ему не тяжело это одиночество, он весь поглощен собою и работою...» («Базаров», VI) [II, т. 4, с. I84]. Это одно из подтверждений тому, что в статьях «Базаров» и «Реалисты» Писарев высказал много личного. «А Базаровым все-таки плохо жить на свете, хоть они припевают и посвистывают. Нет деятельности, нет любви, - стало быть, нет и наслаждения. Страдать они не умеют, ныть не станут, а подчас чувствуют только, что пусто, скучно, бесцветно и бессмысленно» («Базаров», ХІ) [ІІ, т. 4, с. 202]. И в І862, и в I867 г. Писарев страдал от неразделенной любви и разлада с окружающими, отождествляя себя с «бобылем» Базаровым.

Отсутствие у Писарева «кружка» удивило Тургенева, так что он даже посочувствовал ему в ответном письме - впрочем, назидательно заметив: 
«Писателю, особенно критику, не следует быть одиноким». Это почти библейское: «Нехорошо быть человеку одному» (Бытие 2: І8). И, что любопытно, библейские аллюзии возникают в их переписке не раз.

Неожиданным для Тургенева было и то, что его художественная провокация не вызвала у критика эмоциональной реакции, на которую он рассчитывал. «Сцены у Губарева меня нисколько не огорчают и не раздражают. Есть русская пословица: дураков в алтаре бьют», - отвечал Писарев [II, T. II, c. 280].

А еще Писарев заметил (и сделал это уже как профессиональный критик), что «сцены у Губарева составляют эпизод, пришитый к повести на живую нитку» - так, по его мнению, писатель хотел соблюсти баланс, дабы в своей критике правых (кружка генералов) не оказаться «в несвойственном ему обществе красных демократов» [II, т. II, с. 280]. Тем самым Писарев намекнул на шаткость либеральных воззрений Тургенева. В среде «красных демократов» (к которым принадлежал и Писарев) было обычаем свысока глядеть на либералов с их половинчатыми и переменчивыми убеждениями. Словом, ответ на поставленный автором вопрос Писарев дал острый и даже немного пристыдил Тургенева за «глубоко фальшивую и неожиданно сладкую руладу» в финале, где упоминалось «великое царское слово: “свобода” (гл. XXVII). Демократы не ощущали на себе этой свободы и при «царе-освободителе». «Современник» и «Русское слово»- органы русской демократии - были запрещены после покушения Каракозова (І866), ввиду «доказанного с давнего времени вредного их направления» [ІІ, т. І2, с. 502]; «нигилистов» арестовывали по малейшему подозрению и высылали из столиц без суда; цензурный режим второй половины І86о-х гг. был настолько суров, что Писарев стал терять интерес к литературной работе.

\section{3}

Свое мнение о романе в целом Писарев высказал, как всегда, без обиняков: «“Дым” меня решительно не удовлетворяет» [II, т. II, с. 280]. Главная претензия критика состояла в том, что в числе разнообразных персонажей «Дыма» он не нашел никого, кто напомнил бы ему Базарова, - и это при том, что в романе много говорится о России, а действие датировано I862 г. А это был всем памятный год, когда вышел в свет роман «Отцы и дети», когда в Петербурге разбрасывались революционные прокламации и горел 
Апраксин двор, когда молодежь ждала революции и когда был арестован (за революционную агитацию) сам Писарев.

Ответив на вопрос Тургенева, критик ставит перед ним свой вопрос, вроде библейского, который Тургенев оценил (воспроизвел в своем ответе): «Каин, где брат твой Авель? <...> Иван Сергеевич, куда Вы девали Базарова?» [II, т. II, с. 280]. Писаревская критика «Дыма» вообще образна: автор не заметил слона, и «не при первом, а при втором посещении кунсткамеры»; он выбрал в качестве ориентира «низкую и рыхлую муравьиную кочку», забыв о том, что у него есть «каланча», которую он же сам открыл и описал.

Упрек серьезный: через пять лет после опубликования «Отцов и детей» выяснилось, что создатель Базарова не понял ключевой роли разночинцев в общественном движении г86о-х гг., а значит, утратил и понимание общественных процессов, происходивших в России. По крайней мере такой вывод сделал Писарев: «Неужели же Вы думаете, что первый и последний Базаров действительно умер в I859 году от пореза пальца? Или неужели же он с г859 года успел переродиться в Биндасова?» [II, т. II, с. 280]. Напомним, Тит Биндасов - это тип русского хама, остросатирический персонаж с «гнусным затылком» и беспримерной наглостью, который занимает деньги без отдачи и находит бесславный конец в трактирной драке.

В связи с Базаровым стоит еще припомнить «вьюношу», занимающегося естественными науками, над которым Потугин (если верить его рассказу) одержал блистательную победу в словесном поединке, во время которого студент-нигилист «с истинно детским ожесточением» отрицал брак, а Потугин его побивал аргументами из области зоологии. Сначала студент подтвердил как аксиому нелепое утверждение Потугина, что человек - животное плотоядное и хищное, а затем чуть не расплакался, когда тот сразил его открытием, что все хищные животные «пребывают в единобрачии» (гл. XIV). Правда, в числе «единобрачных» хищников Потугин назвал львов (живущих прайдами), но этой ошибки не заметили ни студент-естественник, ни Потугин, ни сам автор. Любопытно, что Достоевский в материалах к «Дневнику писателя» за 1875-I877 гг. ассоциирует этого юношу-нигилиста с Писаревым, опираясь на рассказ Тургенева о встрече с ним у В.П. Боткина: «Потугин и заплакавший нигилист: ложь и незнание действительности. Не заплакал бы, если б и был сбит. Не сбили же вы Писарева, он просто молчал» $[6$, т. 24, с. 88]. Достоевский имел в виду вот эту фразу из воспоми- 
наний Тургенева: «Не знаю, что подумал Писарев, но он ничего не отвечал мне. Вероятно, он не согласился со мною» [І8, т. ІІ, с. 32-33]. Но Иван Сергеевич лукавил: во время той встречи в марте І867 г. Писарев не молчал, о чем ясно свидетельствует начало его письма к Тургеневу: «Я и тогда говорил с Вами совершенно откровенно...» [II, т. ІІ, с. 279].

«Дым» явно тяготел к сатире: Тургенев смеялся над всем и всеми, исключая Литвинова и двух его женщин. Литвинов же воплощает в романе некую золотую середину (которая была близка и самому писателю). Крайности ему чужды, и даже его короткий роман с замужней Ириной не имел серьезных последствий, если не считать отложенной женитьбы на Татьяне. «На Литвинове, как на полированном стекле, нет ни одного пятнышка, но от него, как от стекла, не дождешься ни одного человеческого звука. Это, в полном значении слова, благопристойное ничтожество, выведенное из своей рутинной сферы только на время любовью к Ирине», - писал Г.Е. Благосветлов [3, № I, с. 8]. Как точно заметил Страхов, в Литвинове «ничего нет, кроме благоразумия и честности», и даже сам автор не смог «порядочно заинтересоваться такою будничною, бесцветною личностью» [I4, с. 2II]. Писарев тоже не увидел в Литвинове героя времени - он разглядел в нем лишь еще одного друга Аркадия Николаевича, «которого Базаров безуспешно просил не говорить красиво» [II, т. II, с. 280].

4

В ответном письме к Писареву от 23 мая/4 июня г867 г. (из Баден-Бадена) Тургенев скороговоркой признал, что его Литвинов «дюжинный честный человек - и все тут» [I7, т. 7, с. 209]. Видимо, он сам к тому времени осознал, что Литвинов неинтересен (во всяком случае критики дружно убеждали его в этом), и ему явно не хотелось обсуждать с Писаревым этого неудавшегося героя. Однако упрек Писарева, что автор «Дыма» проглядел базаровский элемент в общественном движении шестидесятых годов и тем самым отнял у своего романа «всякое серьезное значение» [II, т. II, с. 28I], задел Тургенева за живое. «Вам “Дым” не нравится, так же как и почти всем русским читателям; ввиду такого единодушия я не могу не заподозрить достоинств своего детища...» [I7, т. 7, с. 208]. И он готов спорить с Писаревым: «Ваши аргументы мне кажутся не совсем верными» [І7, т. 7, с. 208]. В обтекаемых выражениях Тургенев дает понять Писареву, что его оцен- 
ка Базарова как значимого общественного типа кажется ему завышенной: «...а пока он себя не заявил, беседовать о нем или его устами - было бы совершенною прихотью, даже фальшью. “Каланча” эта, стало быть, не годится...» [I7, т. 7, с. 209].

Зато автор охотно беседует с читателем устами другого персонажа, Потугина, изрекающего желчные парадоксы о России и русских в своих беседах с Литвиновым. Критики сразу догадались, что Тургенев высказал от имени Потугина много собственных мыслей и чувств, не исключая и потугинского odi et amo: «...я и люблю и ненавижу свою Россию, свою странную, милую, скверную дорогую родину» [І8, т. 7, с. 276]. О том же свидетельствует (хотя и пристрастно) Достоевский, рассказавший в письме к А.Н. Майкову от І6/28 августа І867 г. о своей встрече с Тургеневым в Баден-Бадене: «Он сам говорил мне, что главная мысль, основная точка его книги состоит в фразе: “Если б провалилась Россия, то не было бы никакого ни убытка, ни волнения в человечестве” [6, т. 28, кн. 2, с. 2го]. И хотя это парафраз слов Потугина, показательно убеждение Достоевского, что от лица этого персонажа говорит сам автор.

Так же охотно Тургенев говорит о Потугине во втором послании к Писареву, вполне признавая резонерскую функцию этого персонажа: «Быть может, мне одному это лицо дорого; но я радуюсь тому, что оно появилось, что его наповал ругают в самое время этого всеславянского опьянения, которому предаются именно теперь, у нас» [I7, т. 7, с. 209]. Потугин «был нужен автору как маска его собственных назиданий», - писал Г.Е. Благосветлов [3, № I, с. 7].

\section{5}

С Потугиным связано курьезное недоразумение, возникшее в ходе этой переписки: Тургенев уверенно предположил, что Писарев, говоря о Литвинове, nерепутал его с Потугиным. И это при том, что критик не сказал о Потугине ни единого слова и ясно дал понять, что имеет в виду именно Литвинова: «Вы подводите итоги с его точки зрения, Вы его делаете центром и героем романа...» [II, т. II, с. 280]. Литвинов, при всей своей блеклости, действительно является центром повествования - он связывает все события романа, на него обращены взоры других персонажей, и его глазами писатель смотрит на всё происходящее, в том числе и на Потугина. Как 
писал Ю.В. Манн, «по системе связей с другими персонажами и характеру авторской интроспекции Литвинов выдвигается на центральное место» [9, с. I42].

Вообще Писарев не допускал столь грубых промахов, чтобы рассуждать об одном лице романа, имея в виду совсем другое. Вдобавок он тогда обдумывал статью о «Дыме» и наверняка помнил его действующих лиц (кроме Литвинова, он упоминает в письме Губарева, Ратмирова, Биндасова), следовательно, едва ли мог их перепутать, тем более что Литвинов и Потугин совершенно не схожи. И, говоря о подведении итогов с точки зрения Литвинова, Писарев, конечно же, имел в виду размышления героя из XXVI главы «Дыма», которые чаще всего ставили писателю в упрек: «“Дым, дым”, - повторил он несколько раз; и всё вдруг показалось ему дымом, всё, собственная жизнь, русская жизнь - всё людское, особенно всё русское. Всё дым и пар, думал он <...> и даже всё то, что проповедовал Потугин... дым, дым и больше ничего» [І8, т. 7, с. 397]. Наконец, взгляд на современность с высоты «рыхлой муравьиной кочки» - это, скорее, взгляд Литвинова, который, по собственному признанию, не имеет «никаких политических убеждений» (гл. IV), тогда как Потугин позиционирует себя как «западник», преданный европейским началам «до чрезвычайности» (гл. V).

Ошибку Тургенева (т. е. его ложную уверенность в ошибке Писарева) отчасти подтверждает он сам, опровергая сравнение Литвинова-Потугина с Аркадием Кирсановым: «... Аркадия нет никаких убеждений - а Потугин умрет закоренелым и заклятым западником, - и мои труды пропали даром, если не чувствуется в нем этот глухой и неугасимый огонь» [I7, с. 209]. Как видим, Литвинов и Аркадий характеризуются Тургеневым в одних и тех же выражениях. А сравнение Потугина с Аркадием прозвучало бы совсем уже странно из уст Писарева, знавшего «Отцов и детей» наизусть. Тем не менее Тургенев счел нужным наставительно заметить, что «критическое чувство» Писареву «изменило»: между Аркадием и Потугиным «ничего нет общего». Это чистая правда, с тем лишь уточнением, что Писарев говорил не о Потугине, а о Литвинове.

Однако и Литвинова автор не захотел отнести к числу скромных обывателей, идущих по стопам отцов: «А об Литвинове и говорить нечего: он тоже не Аркадий...». Полагаем всё же, что писаревское сравнение Литвинова с Аркадием метко обрисовывает его характер, потому что друг Арка- 
$\partial u \check{u}$ - это и есть «дюжинный честный человек», каким является, по словам самого автора, Литвинов (а Потугин отрекомендован читателю как человек «недюжинный»).

Некоторый повод для смешения этих персонажей дал, впрочем, сам Писарев, вспомнивший о том, что Базаров просил Аркадия не говорить красиво. Видимо, эта реминисценция и позволила Тургеневу заподозрить ошибку со стороны критика, поскольку даром красноречия в романе наделен Потугин, а Литвинов больше молчит и только однажды «красиво» размышляет - в том самом «итоговом» внутреннем монологе о «дыме» всего русского. Но это опять-таки тонкий намек Писарева на размытую позицию самого автора, который, подобно Протею, высказывается то от лица Потугина, то от лица Литвинова. В этом смысле для Писарева действительно не было большой разницы между тем и другим. Для критика-реалиста была важнее точка зрения самого Тургенева, а она обозначена достаточно ясно и подтверждена его письмами. И, что характерно, Тургенев целиком принял «низкую и рыхлую кочку» на свой счет, не без торжественности объявив Писареву, что кочку он выбрал «не такую низкую», как полагает его оппонент: «С высоты европейской цивилизации можно еще обозревать всю Россию» [I7, с. 209]. Современные тургеневеды (П. Уоддингтон, Н.П. Генералова, и др.) также считают, что черты автора есть и в Потугине, и в Литвинове [20, с. $142 ; 4$, с. 338].

Важно и то, что Тургенев, сам указавший на прототипы своих героев, в случае с Потугиным не назвал никого, заставляя исследователей делать предположения. В частности, Уоддингтон, приведя тургеневскую фразу из детального плана: «Не верит в Бога - но сокрушается втайне этим и никогда не кощунствует», - комментирует ее так: «Создается впечатление, что Тургенев говорит о себе» [20, с. I4I]. Конечно, это предположение не лишено оснований.

6

Из «Формулярного списка действующих лиц новой повести» (I863) видно, что Тургенев задумывал Потугина как «главное лицо всей повести», намереваясь изобразить в нем «философа русского в настоящем смысле слова, человека, глубоко <...> понявшего Россию и русских» [20, с. I09]. Впрочем, к написанию романа Тургенев приступил только в ноябре I865 г., 
а закончил его в январе I867 г., поэтому многое из задуманного претерпело изменения. И, сравнивая замысел с его воплощением, приходится констатировать, что Потугин не получил в романе «главной» роли. Этого персонажа слишком заслоняет любовная история, связывающая Литвинова, Ирину и Татьяну (описанная самым подробным образом). А роль Потугина в романе - эпизодическая и резонерская.

«Недюжинность» Потугина заявлена автором, но не очевидна для читателя. Как верно писал А.И. Батюто, «В жалком облике Потугина, в его почти приниженной фигуре, во всем его поведении не обнаруживается ни признаков “гениальной натуры” Рудина или красоты духовного мира Лаврецкого, ни железной целеустремленности Инсарова, ни силы и трагизма переживаний, присущих Базарову» - Тургенев «изображает в нем прежде всего умного неудачника» [2, с. 357, 365].

Отсюда понятно безразличие Писарева к этому персонажу: он всегда был на стороне «молодых», «свежих» и «новых» людей, а Потугин - человек во всех смыслах «отставной» и помятый жизнью, находящий утешение лишь в продолжительном отдыхе за границей и долгих разговорах. Неспособность Потугина наполнить слова живыми делами лапидарно изобличает финальная фраза романа: «Та девочка, которую поручили его попечениям, недавно умерла» (гл. XXVIII) [I8, т. 7, с. 407].

«Философом» можно назвать Потугина лишь с большой натяжкой, хотя уже первые критики находили в его речах влияние П.Я. Чаадаева (см. историю вопроса: [4, с. 326-327]). Это не философия, а, скорее, публицистика в непринужденной форме - квинтэссенция вульгарного западничества, а равно сатира на русскую самобытность и русский национальный характер.

Уже первые критики заметили, что сарказмы Потугина «иногда остроумны, но в целом удивительно мелки и поверхностны» [I4, с. 226] и что его амбивалентные чувства к родине («люблю и ненавижу») в меньшей степени питаются любовью. Острее других это почувствовали Толстой, Тютчев, «почвенники» (Достоевский, Страхов, Николай Соловьев), и даже старый западник Герцен увидел в Потугине надоедливого болтуна, сравнив его с фонтаном, который хочется заткнуть по совету Козьмы Пруткова («Отцы сделались дедами», І867) [5, т. І9, с. 26г]. «Это бесцельное, бессвязное и исполненное противоречий старческое ворчанье...» - сказал о речах Потугина демократ Благосветлов [3, № ı, с. 7]. А Тютчев, говоря о воззре- 
ниях Тургенева в связи с «Дымом», употребил в то время еще редкое слово «русофобия» (в письме к А.Ф. Аксаковой, 20 сентября I867 г.) [19, с. 269; об этом: 4, с. 479]. «У Тургенева-Потугина мы видим именно национальное самоуничижение», - писал позднее Д.Н. Овсянико-Куликовский [Іо, с. 2г].

При всей определенности характеристики Потугина в письмах Тургенева, образ его вышел таким же зыбким, как и весь роман. С одной стороны, «неугасимый огонь» его западнических убеждений как будто противопоставлен «дыму» пустых речей других персонажей; с другой стороны, речи Потугина кажутся Литвинову тем же «дымом». А для Писарева потугинские сарказмы и парадоксы были скорее дымовой завесой, скрывающей дезориентированную личность автора.

Главное (применительно к задачам нашего сюжета) - то, что Потугин не воплощает собой узнаваемого «русского» типа (хотя автор и желал представить его таковым). Как писал критик Николай Соловьев, «Потугин собственно не характер, а скорее тень или более или менее верное отражение личных мнений и чувствований автора» («Дым отечества. Критика романа И.С. Тургенева “Дым” , І867) [І3, ч. 3, с. І68]. И Писарев закономерно проигнорировал этого персонажа - он был критик-реалист, а значит, оценивал художественные фигуры лишь в соотнесении с типами, которых он встречал в реальной жизни. Потугиных он либо не встречал, либо не обращал на них внимания.

\section{7}

«Едва ли теперь для дельного и практического журналиста можно найти лучший девиз, чем: “Европейская цивилизация” - даже в потугинском вкусе», - написал Тургенев в конце второго послания к Писареву (23 мая/4 июня І867 г.) [І7, т. 7, с. 209-2Іо]. Хотел того писатель или нет, но девиз прозвучал как наставление. Почти теми же словами Потугин прощается с Литвиновым, который едет в Россию: «Позвольте же старому болтуну - ибо я, увы! болтун и больше ничего - дать вам напутственный совет. Всякий раз, когда вам придется приниматься за дело, спросите себя: служите ли вы цивилизации...» [18, т. 7, с. 395].

Тургенев забыл о том, что его адресата не требовалось убеждать в значении европейской цивилизации. Писарев неустанно пропагандировал ее достижения в своих статьях, одновременно сурово оценивая прошлое 
и настоящее своей страны. Когда-то он даже выразился в эпатажном чаадаевском стиле: «Мы не думаем, чтобы мыслящий гражданин России мог смотреть на прошедшее своей родины без горести и без отвращения; нам не на что оглядываться, нам в прошедшем гордиться нечем; мы молоды как народ...» («Бедная русская мысль», І862) [II, т. 4, с. 215].

Однако и фанатичным поклонником Запада «в потугинском вкусе» Писарев не был - он лишь разделял с западниками «их стремление к европейской жизни», сходясь в то же время со славянофилами «в их отвращении к цивилизаторам, насильно благодетельствующим человечеству» (имея в виду прежде всего Петра I, в приказном порядке вводившего западные обычаи и учреждения) [II, т. 4, с. 2І4-2I5]. Вообще же Писарев был против навешивания ярлыков: «Ничто не может быть бесцветнее и неопределеннее общих выражений: обскурант, прогрессист, либерал, консерватор, славянофил, западник; эти выражения нисколько не характеризуют того человека, к которому они прикладываются; они надевают непрошеный мундир на его умственную личность и вместо живого человека, мыслящего и чувствующего по-своему, показывают нам неподвижную вывеску замкнутого круга убеждений» («Русский Дон-Кихот», I862) [II, т. 4, с. 87].

При всем глубоком интересе к западной культуре Писарев не имел возможности познакомиться с ней изнутри - у него не было даже случая побывать в Европе туристом (Третье отделение не давало ему заграничный паспорт), а значит, не имел и особых причин фетишизировать «европейскую цивилизацию». Его письмо к Тургеневу говорит о том, что он скорее согласился бы с «почвенником» Страховым, который сказал, что «русская жизнь может показаться дымом только тому, кто этою жизнью не живет, кто не участвует ни в едином ее интересе» [I4, с. 226].

Если бы Писарев изложил свое мнение о «Дыме» в виде статьи (обстоятельства помешали ему сделать это), он вряд ли смог бы умолчать о Потугине и, скорее всего, охарактеризовал бы его как «фразера» (он любил это слово). По его определению, фразер - это тип человека, «совершенно чистосердечно увлекающегося потоком своего красноречия <...> для которого слово заменяет дело и который, живя одним воображением, прозябает в действительной жизни» («Писемский, Тургенев и Гончаров», I86I) [II, T. 3, c. 248]. 
Еще в начале г860-х гг. Писарев упоминал споры славянофилов и западников как неактуальные в реалиях пореформенной России. Отсюда понятно отсутствие у него интереса к фигуре Потугина с его экзальтированным западничеством времен Чаадаева и Белинского. Показательно, что и другие критики (П.В. Анненков, Н.Н. Страхов, Г.Е. Благосветлов, П.Л. Лавров) отмечали анахронистичность речей Потугина, его пристрастие к фразам и лозунгам при слабом понимании того, что такое циивилзация в научном значении слова.

Говоря же строго фактически, Писарев не приметил Потугина в романе «Дым», точно так же как Тургенев не приметил Базарова среди русских типов г86о-х гг. В письме к А.П. Философовой от ІІ/23 сентября I874 г. Тургенев прямо заявлял, что «в действительной жизни» Базаровых искать бесполезно: «Времена переменились; теперь Базаровы не нужны. Для предстоящей общественной деятельности не нужно ни особенных талантов, ни даже особенного ума - ничего крупного, выдающегося, слишком индивидуального; нужно трудолюбие, терпение...» [I7, т. І3, с. I8I]. И это было кредо Тургенева. «Я всегда был и до сих пор остался “постепеновцем”, либералом старого покроя в английском, династическом смысле, человеком, ожидающим реформ только свыше, - принципиальным противником революций...» - писал он М.М. Стасюлевичу 2 января І88о г. (из Парижа) [16, т. I5, с. I85]. И здесь взгляды писателя и критика расходились кардинально. Тургенев желал видеть героем эпохи либерала, русского европейца, героя малых дел, «постепеновца», а Писарев связывал будущее России с деклассированной и радикально настроенной интеллигенцией («мыслящим пролетариатом»), находя образцы для подражания в Базарове, «новых людях» Чернышевского, Молотове Помяловского, Рязанове Слепцова. И только таких людей он считал героями I860-х гг.

\section{8}

Диалог Тургенева и Писарева вылился в quiproquo. Каждый твердил о своем: Писарев о Базарове, а Тургенев о Потугине - о том, что меньше всего занимало собеседника во время спора. Естественно, каждый остался при своем мнении. Тургенев вежливо предложил Писареву встретиться в Баден-Бадене (даже не подозревая о том, что Писарев был невыездным), а тот не менее вежливо предложил обмениваться письмами и больше не пи- 
сал. Можно предположить, что Писарев утратил интерес к переписке после второго письма Тургенева, которое убедило его в том, что у них мало общего и продолжать запутанный спор бесполезно.

Они в самом деле плохо понимали друг друга, и их взаимный интерес был ограниченным. Писарев интересовал Тургенева в первую очередь как выразитель настроений «кружка» радикальной молодежи («как симптом»), а Писарев ценил в Тургеневе главным образом первооткрывателя базаровского типа. Как выяснилось, Писарев не был глашатаем кружковых мнений, а Тургенев не видел в Базарове героя І860-х гг. Сойдясь в понимании образа нигилиста Базарова, писатель и критик разошлись в понимании эпохи, последовавшей за смертью Базарова.

Писарев был ровесником Базарова и одним из наиболее известных шестидесятников. Он понимал это время не созерцательно, как Тургенев, а органически и деятельно. Тюремное заключение Писарева (I862-I866) было следствием его убеждений, и в этом смысле он был под стать Базарову. «Он честен, правдив и демократ до конца ногтей $<\ldots>$, и если он называется нигилистом, то надо читать: революционером», - писал Тургенев К.К. Случевскому І4/26 апреля І862 г., объясняя характер Базарова [I7, т. 5, c. 57-58]. Эти слова целиком приложимы и к Писареву. Сообщая автору «личное мнение» о его новом романе, Писарев, сам того не желая, выразил точку зрения широкого круга демократической интеллигенции, которая не узнала «себя и своих» в шаржированных фигурах «Дыма».

\section{Список литературы}

I Антонович М.А. Литературно-критические статьи. М.; Л.: Гослитиздат, І96I. 5I5 c.

2 Батюто А. И. Тургенев-романист. Л.: Наука, г972. 388 с.

3 Благосветлов Г.Е. <псевдоним «Н. Лунин»> Старые романисты и новые Чичиковы // Дело. г868. № I. С. I-I7 (отд. пагинация); № 3. С. I-20. (отд. пагинация).

4 Генералова Н.П. И.С. Тургенев: Россия и Европа: из истории русско-европейских литературных и общественных отношений. СПб.: Изд-во РХГИ, 2003. 583 с.

5 Гериен А.И. Собр. соч.: в 30 т. М.: Изд-во Академии наук СССР, І954-I966.

6 Достоевский Ф.М. Полн. собр. соч.: в 30 т. Л.: Наука, г972-г99о.

7 И.С. Тургенев в воспоминаниях современников: в 2 т. М.: Худож. лит., І983.

8 Критика 6о-х гг. ХІХ века / сост. Л.И. Соболев. М.: АСТ, 2003. 445 с.

9 Манн Ю.В. Диалектика художественного образа. М.: Сов. писатель, I987. 3I9 с. 
IO

Овсянико-Куликовский Д.Н. Этюды о творчестве И.С. Тургенева. Изд. 2-е. СПб.: Орион, І904. 266 с.

II

\section{References}

Antonovich M.A. Literaturno-kriticheskie stat'i [Literary criticism]. Moskow, Leningrad, Goslitizdat Publ., I96I. 515 p. (In Russ.)

Batiuto A. I. Turgenev-romanist [Turgenev the novelist]. Leningrad, Nauka Publ., I972. 388 p. (In Russ.)

3 Blagosvetlov G.E. < psevdonim "N. Lunin" > Starye romanisty i novye Chichikovy [Old novelists and new Chichikovs]. Delo, I868, no I, pp. I-I7 (separate pagination); no 3, pp. I-20 (sep. pag.). (In Russ.)

4 Generalova N.P. I.S. Turgenev: Rossiia i Evropa: iz istorii russko-evropeiskikh literaturnykh i obshchestvennykh otnoshenii [Ivan Turgenev: Russia and Europe: from the history of Russian-European literary and public relations]. St. Petersburg, Izdatel'stvo RKhGI Publ., 2003. 583 p. (In Russ.)

5 Gertsen A.I. Sobranie sochinenii: $v$ zo t. [Collected works: in 30 vols.]. Moscow, Izdatel'stvo Akademii nauk SSSR Publ., I954-I966 (In Russ.)

6 Dostoevskii F.M. Polnoe sobranie sochinenii: $v$ zo $t$. [Complete works: in 30 vols.]. Leningrad, Nauka Publ., I972-I990. (In Russ.)

$7 \quad$ I.S. Turgenev $v$ vospominaniiakh sovremennikov: $v 2 t$. [I.S. Turgenev in the memoirs of his contemporaries: in 2 vols.] Moscow, Khudozhestvennaia literatura Publ., I983. 
Kritika 6o-kh gg. XIX veka [Literary criticism of the I86os], comp. by L.I. Sobolev. Moscow, AST Publ., 2003. 445 p. (In Russ.)

9 Mann Iu.V. Dialektika khudozhestvennogo obraza [Dialectics of the fictional image]. Moscow, Sovetskii pisatel' Publ., I987.3I9 p. (In Russ.)

Io Ovsianiko-Kulikovskii D.N. Etiudy o tvorchestve I.S. Turgeneva [Studies on the work of I.S. Turgenev]. $2^{\text {nd }}$ ed. St. Petersburg, Orion Publ., I904. 266 p. (In Russ.)

II Pisarev D.I. Polnoe sobranie sochinenii: $v$ I2 $t$. [Complete Works: in I2 vols.]. Moscow, Nauka Publ., 2000-20I3. (In Russ.)

I2 Pumpianskii L.V. Klassicheskaia traditsiia: Sobranie trudov po istorii russkoi literatury [Classical tradition: collection of works on the history of Russian literature]. Moskow, Iazyki russkoi kul'tury Publ., 2000. 864 p. (In Russ.)

I3 Solov'ev N.I. Iskusstvo i zhizn': v 3 ch. [Art and life: in 3 parts]. Moscow, Izd. S.P. Annenkova Publ., I869 (In Russ.)

I4 Strakhov N.N. Literaturnaia kritika [Literary criticism]. Moscow, Sovremennik Publ., I984. 430 p. (In Russ.)

I5 Tolstoi L.N. Polnoe sobranie sochinenii: $v$ go t. [Complete works: in 90 vols.]. Moscow, GIKhL Publ., I935-I964. (In Russ.)

I6 Turgenev I.S. Polnoe sobranie sochinenii i pisem: $v 28 t$. [Complete works and letters: in 28 vols.]. Sochineniia [Works]. Moscow, Leningrad, Nauka Publ., I968. Vol. I5. 495 p. (In Russ.)

I7 Turgenev I.S. Polnoe sobranie sochinenii i pisem: $v$ zo $t$. [Complete works and letters: in 30 vols.]. $2^{\text {nd }}$ ed., Pis'ma: $v$ I8t. [Letters: in I8 vols.] Moscow, Nauka, I982(prodolzhaiushcheesia izd. [ongoing ed.]). (In Russ.)

I8 Turgenev I.S. Polnoe sobranie sochinenii i pisem: v 30 t. [Complete works and letters: in 30 vols.]. Sochineniia: $v$ I2 $t$. [Works: in 12 vols.]. Moscow, Nauka Publ., I978-1986. (In Russ.)

I9 Tiutchev F.I. Polnoe sobranie sochinenii i pis'ma: $v 6 t$. [Complete works and Letters: in 6 vols.]. Moscow, ITs Klassika Publ., 2004. Vol. 6. 590 p. (In Russ.) Uoddington P. [Waddington P]. Turgenev I.S. Drafts to the Novel The Smoke. Edited and afterword by P. Waddington. Russkaia literatura, 2000, no 3, pp. I06-I43. (In Russ., transl. from English) 
УДК 82I.I6I.I

ББК $83.3(2 \mathrm{Poc}=\mathrm{Pyc}) 52$
ТРАНСФОРМАЦИЯ

ПОСТРИТОРИЧЕСКОЙ МОДЕЛИ

«УСАДЕБНОГО ТЕКСТА»

В ПОЭЗИИ А.А. ФЕТА

(C) 2020 г. О.А. Гриневич

Гродненский государственный университет

им. Я. Купаль, Гродно, Беларусь

Дата поступления статьи: о2 ноября 2019 г.

Дата публикации: 25 июня 2020 г.

DOI: I0.22455/2500-4247-2020-5-2-220-233

Аннотация: Цель статьи - выявление этапов и основных тенденций функционирования «усадебного текста» в поэзии XIX в.: формирование инвариантной модели, отражающей особенности стадии эстетического креативизма (художественной модальности) на рубеже XVIII-XIX вв., и трансформация этой модели в творчестве А.А. Фета. В задачи статьи входит определение ключевых особенностей новой элегической модели на уровнях семантики, синтактики и прагматики и рассмотрение механизмов ее встраивания в индивидуально-авторский контекст поэзии Фета. Доказывается, что для усадебной поэзии Фета характерно устранение биографических, литературных, исторических контекстов функционирования «усадебного топоса», а также углубление его интериоризации, начало которой заложено в поэзии первой трети XIX в. Противоположная тенденция представлена в усадебной поэзии современников поэта, где «усадебный топос» аккумулирует культурную память, в частности, актуализирует жанровый канон руистической элегии начала XIX в., изображающей старинные полуразрушенные имения, запущенные сады (А.К. Толстой, А.Н. Майков). Основные особенности литературной ситуации второй половины XIX в., определившие развитие усадебной поэзии этого направления, следующие: прозаизация поэтических форм (реакцией на которую стали две стратегии: принятие прозаического влияния и дистанцирование от него); литературная полемика между «реалистами» и сторонниками «чистого искусства»; формирование феномена «уединенного сознания» и попытки его преодоления. Внелитературные предпосылки связаны с крестьянской реформой, вызвавшей или разорение дворянских гнезд, или смену социально-исторических условий их функционирования.

Ключевые слова: сверхтекст, «усадебный текст», семиосфера, семантика, синтактика, прагматика, А.А. Фет.

Информация об авторе: Ольга Артуровна Гриневич - аспирант филологического факультета, Гродненский государственный университет им. Я. Купалы, ул. Ожешко, д. 22, 230023 г. Гродно, Беларусь. ORCID ID: o0оo-о003-383I-805X

E-mail: olga.grinevich.I994@mail.ru

Для цитирования: Гриневич О.А. Трансформация постриторической модели «усадебного текста» в поэзии А.А. Фета // Studia Litterarum. 2020. Т. 5, № 2. C. 220-233. DOI: IO.22455/2500-4247-2020-5-2-220-233 


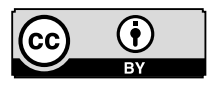

This is an open access article distributed under the Creative Commons Attribution 4.0 International (CC BY 4.0)

\section{POST-RHETORICAL MODEL OF THE "ESTATE TEXT" AND ITS TRANFORMATION IN FET'S POETRY}

\author{
(C) 2020. O.A. Grinevich \\ Yanka Kupala State University of Grodno, Belarus \\ Received: November 02, 2019 \\ Date of publication: June 25, 2020
}

Abstract: The aim of this article is to highlight the stages and the tendencies in the development of the so called "estate text" in the poetry of the $19^{\text {th }}$ century. Namely, it shows how a new invariant model developed at the turn of the $18^{\text {th }}$ and $19^{\text {th }}$ century and how it was transformed in the work of A.A. Fet. The article studies the key features of the new elegiac model at semantic, syntaxic, and pragmatic levels and examines how the model was integrated in Fet's poetry. I argue that Fet excludes biographical, literary, and historical contexts of the estate topos and continues its interiorization initiated by the poets of the early $19^{\text {th }}$ century. The opposite trend is to be found in the works of Fet's contemporaries, where the estate topos accumulates cultural memory and actualizes the genre of ruistic elegy that describes ancient dilapidated estates and neglected gardens and that was developed at the beginning of the $19^{\text {th }}$ century (A.K. Tolstoy, A.N. Maykov). In the second part of the $19^{\text {th }}$ century, a number of literary tendencies influenced on the estate poetry. They include prosaization of poetic forms (that resulted in either acceptance of prosaic influence or distancing from it); polemics between "realists" and supporters of "pure art"; the phenomenon of "solitary consciousness" and attempts to overcome it. Extra-literary prerequisites are associated with the peasant reform that caused the ruin of the so called "noble nests" or a change in the socio-historical conditions of their functioning.

Keywords: supertext, "estate text", semiosphere, semantics, syntactics, pragmatics, A.A. Fet.

Information about the author: Olga A. Grinevich, graduate student, Philological Department, Yanka Kupala State University of Grodno, Ozheshko St. 22, 230023 Grodno, Belarus. ORCID ID: 0000-0003-383I-805X

E-mail: olga.grinevich.1994@mail.ru

For citation: Grinevich O.A. Post-Rhetorical Model of the "Estate Text" and Its Transformation in Fet's Poetry. Studia Litterarum, 2020, vol. 5, no 2, pp. 220-233. (In Russ.) DOI: IO.22455/2500-4247-2020-5-2-220-233 
Формирование «усадебного текста» как одного из локальных сверхтекстов русской литературы происходит на стадии рефлективного традиционализма [I] (эйдетической поэтики [І2]). Инвариантные черты усадебной поэзии на этой стадии поэтики развиваются в русле риторической традиции и определяются риторической моделью. На рубеже XVIII-XIX вв. при переходе к стадии эстетического креативизма [I4] (поэтике художественной модальности [І2]) формируется новая, постриторическая, или элегическая, модель.

В основе семантики риторической модели лежит принцип бинарности, эксплицирующий в структуру текста оппозиции деревня - город, покой - суета, творчество - военная слава и др. Семантические особенности постриторической модели обусловлены жанровой памятью элегии, проблематизирующей пространственно-временную и психологическую границы, а центром схождения противопоставленных друг другу миров является фигура лирического героя.

Парадигмальная особенность новой стадии поэтики - формирование «уединенного сознания» [І4, с. Іо], автономной личности [І2, с. 222] повлияла на интроспективный статус топики «усадебного текста». Автономность лирического субъекта в постриторической модели позволяет преодолеть характерную для риторического этапа бинарность мышления. Пример нового статуса субъекта представлен в повести Н.М. Карамзина «Бедная Лиза». Как отмечает А. Шёнле, повествователь «выполняет функцию одного из посредников между исследуемыми в повести двумя моделями культуры. Традиционная провиденциалистская парадигма, воплощенная в представленной в качестве жертвы православной Москве, а также в 
образе покорной Божьей воле Лизиной матери, сталкивается с модерной, имперской, самоопределяющейся политической философией, олицетворяемой энергично торгующей Москвой и колонизаторством Эраста» [I7, c. 68]. Исследователь подчеркивает амбивалентную позицию повествователя по отношению к парадигме модерности, и эта пограничность субъекта повествования становится свойством, которое определяет не только прагматику, но и семантику элегической модели.

Семантика постриторического (элегического) инварианта связана с новым восприятием времени и пространства. «Усадебный текст» XVIII в. отображает циклический принцип восприятия времени, связанный с описанием ежедневных, ежесезонных, ежегодных занятий лирического героя, обеспечивающих воспеваемую им стабильность и спокойствие сельской жизни. Элегизация всех поэтических форм на рубеже XVIII-XIX вв. [Іо, с. 449] привносит в усадебную поэзию линейное время, когда лирический герой осознает его скоротечность и, возвращаясь в родные места, сопоставляет состояния «сейчас» и «прежде». Существуют и более сложные формы проживания и репрезентации времени: событие настоящего («миг») становится катализатором для воспоминания о единичном и неповторимом событии прошлого. Такой хронотоп, представляющий собой тесную пространственно-временную связь и предельное сужение и сгущение пространства и времени, зарождается в усадебной поэзии А.А. Фета, определившей векторы развития «усадебного текста» второй половины XIX - начала XX вв.

Между элементами семантических оппозиций и образами, соединенными в риторической модели прямой связью, в элегической модели появляется посредник, снимающий эксплицитную бинарность развития мысли. Образец субъектного посредничества задает Н.М. Карамзин в фигуре повествователя с амбивалентной позицией. Другой тип посредничества заключается в формировании интепретативной сетки понятийных категорий, представляющих собой художественный и интеллектуальный язык эпохи. Эти категории находятся между собой в сложных и разнонаправленных связях, которые смягчают бинарность сверхтекстовой семантики. Ключевые для «усадебного текста» категории образуют триаду «человек - природа - культура».

Металитературная проблема автономной личности способствует актуализации в образно-мотивной системе усадебной поэзии первой трети 
XIX в. первого элемента триады. В сочетании с семантическими константами «усадебного текста» эта проблематика образует ряд инвариантных элегических мотивов: мотивы воспоминания и забвения, воображения, творчества, медитативной прогулки. В усадебной поэзии этого периода формируется понятие мест памяти, маркирующих личные воспоминания. Культ личных воспоминаний характерен для дружеского послания поэтов пушкинской эпохи [5]. Индивидуальная маркировка усадебных локусов создает особые отношения между текстом и внетекстовой реальностью, домашнюю семантику, «которая не терпит “пояснительных" мест и развитых описаний» [13, с. I30].

В 40-50-е гг. XIX в. развитие субъектного начала достигает кульминации, в результате чего появляются варианты элегической модели, в которых заостряется романтическое противоречие между социальным окружением («толпой») и ментальным миром лирического героя (например, «Как часто пестрою толпою окружен...» (г840) М.Ю. Лермонтова). Это приводит к формированию новой бинарности, относящейся уже не к сфере морально-дидактических противопоставлений, а к сфере сознания, расщепленного внутренним конфликтом.

Преодолению этой бинарности способствует актуализация категории природы в усадебной поэзии Фета. Как отмечает Г.П. Козубовская, «в лирике Фета мир культуры постепенно уходит в подтекст, растворяется в тексте, реализующем концепцию природного человека и очеловеченной природы» [7, с. 9]; «отказ от четкой бинарности ведет у Фета к тому, что планы перерастают друг в друга незаметно, естественно, без фиксации точки зрения» [7, с. 2г]. Другими словами, переход «усадебного топоса» в интроспективный план у Фета представляет собой наложение друг на друга внутреннего мира человека и внешнего, природного мира, представленного усадебным микрокосмом.

Природоцентрично не только самовосприятие лирического героя, но и восприятие «другого», что приводит к трансформации мотива усадебной любви. Образ возлюбленной в риторической модели и ранних образцах элегической функционален и подчинен общей риторической задаче, будь то амплуа идеальной хозяйки и матери в похвалах сельской жизни или объекта эротического желания в «легкой поэзии» К.Н. Батюшкова. В поэзии Фета образ возлюбленной обретает статус полноценного субъекта и, что 
важно для семантической структуры «усадебного текста», характеризуется посредством природных образов.

В поэзии второй половины XIX в. выделяется тематическая разновидность элегического инварианта, в которой центральной концептуально-тематической составляющей, организующей структуру стихотворения, является культура. Элегическая тоска лирического героя сфокусирована на осознании уходящей в прошлое дворянской культуры, воплощенной в образе старой усадьбы (полуразрушенного дома, заброшенного сада). Внелитературные предпосылки для формирования такой модели - крестьянская реформа г86г г., изменившая условия функционирования усадебного хозяйства и способствовавшая кризису дворянских гнезд. Наиболее очевидна данная тенденция в поэзии А.К. Толстого («Ты помнишь ли, Мария...» (г840-е гг.), «Шумит на дворе непогода...» (І840-е гг.), «Пустой дом» (г840-е гг.), «Из “Крымских очерков”» (г856-г858) и др.).

Образ усадьбы в этой разновидности элегической модели метонимически представляет часть русской культуры, иногда культуры всего человечества, как в стихотворении А.Н. Майкова «Мраморный фавн». Лирический герой обращается к статуе фавна в заброшенном саду: «Ты некогда был бог, / Цинический кумир! <...> О, расскажи: / Что, жаль тебе тех дней? Как ты расстался с властью, / Развенчанный? Тогда - бывали ближе ль к счастью / Младые племена? Иль это умной лжи / Несбытный вымысел - их мир и наслажденья? / Иль век одни и те ж земные поколенья?» [8, с. 28-29]. Авторская рефлексия затрагивает семантический метаязык «усадебного текста», подвергая сомнению центральные оппозиции естественное - искусственное, прошлое - настоящее. Проблематика стихотворения при этом выходит за пределы усадебной темы, расширяя ее пространственно-временные границы.

Таким образом, на семантическом уровне динамика «усадебного текста» XIX в. регулируется чередованием процессов ослабления и усиления бинарной организации. Помещение этих стадий в синтагматические контексты (уровень синтактики) позволяет выявить, какие устойчивые и ситуативные связи вырабатываются в процессе семантических чередований.

Устойчивые связи очевиднее всего отражаются на уровне сюжета. В первой трети XIX в. наиболее частотное сюжетное воплощение элегической модели - ситуация медитативной прогулки. Как и сюжет рито- 
рической модели, он строится по принципу нанизывания семантических элементов - образов, мотивов, топосов, однако их взаимосвязь ориентирована уже не на прецедентный источник и не на логику риторической аргументации - в данном случае она имитирует свободное передвижение в пространстве и свободное течение мыслей, объединенных сознанием субъекта лирической медитации.

Композиция прогулки организуется перечнем «подвижных картин», которые в широком смысле являются своеобразной иллюстрацией изменчивости и скоротечности жизни. При этом, несмотря на обязательную привязку к топографии, а иногда и подробное перечисление конкретных «мест памяти», формируется жанровый канон, регулирующий отбор и репрезентацию визуальных элементов. Согласно этому канону, существуют перечень образов и топосов, останавливающих внимание героя, и способ их интерпретации. Так, появляются устойчивые образы реки или пруда, руин, «семьи» молодых деревьев, заросшей тропинки.

Постепенно на основании разных вариантов складывается двухфазная сюжетная схема жанра прогулки. Первую фазу составляет нанизывание визуальных «поводов» и сопутствующие им размышления, вторую - попытка выхода из осознаваемого лирическим героем неостановимого круга времени в план вечного и вневременного. Это оказывается возможным посредством контакта с умершими - с людьми, которые при жизни были связаны с описываемыми местами, но в момент лирического высказывания уже перешли в вечность. Здесь лирический герой вступает в контакт не только с утраченным прошлым, но и с самим собой, поскольку одним из инвариантов смыслового ядра элегической модели является проблематизация самотождественности героя.

Выбор сюжетной схемы и характер ее воплощения во многом зависит от контекста. Для полноценного восприятия усадебных элегий первой трети XIX в. важны биографические, ситуативные, топографические детали, ставшие поводами для их написания. Ключевым контекстом «Запустения» (г832) Е.А. Боратынского является биографический (образ отца поэта), а за репрезентацией топоса усадьбы Олениных в стихотворении Гнедича «Приютино» (I820) стоит атмосфера творчества, созданная знаменитыми гостями имения. Понимание «Славянки» В.А. Жуковского неполно 
без учета реалий, связанных с топографией Павловска и жизнью царской семьи, указания на которые содержатся в элегии.

Отношения между текстом и контекстом меняются во второй половине XIX в., и важный этап в этом процессе - поэзия Фета. Принципиальным новаторством Фета было уменьшение значимости контекстов в процессе смыслообразования. Это касается их роли не только в авторском восприятии топоса усадьбы, но и в конкретном текстовом воплощении инвариантной модели. Усадьба воспринимается Фетом как гармоничный природно-культурный синтез с преобладанием природного компонента. Культурные контексты рецепции «усадебного топоса», сконцентрированные в формуле И.М. Долгорукого «экстракт вселенной всей» [9, с. 2І2], для Фета нерелевантны. Конкретные воплощения авторских рецептивных установок манифестируют самоценность текста как такового.

Авторскую стратегию Фета, противоположную сформировавшейся в предшествующей традиции усадебной элегии, можно объяснить, обратившись к историко-литературной ситуации конца 40-х - начала 50-х гг. XIX в. Это время характеризуется исследователями как переломная эпоха, ознаменованная полемикой «Современника» и «Москвитянина» об «исторической» и «эстетической» критике, спором между сторонниками «реальной» поэзии и представителями «чистого» искусства [II]. Для последних усадьба и усадебная поэзия становятся реальным и метафорическим убежищем. Эту мысль Фет выражает в предисловии к сборнику «Вечерние огни» в ответ на критику «реалистов»: «Мы <...> постоянно искали в поэзии единственного убежища от всяческих житейских скорбей, в том числе и гражданских. Откуда же могли мы взять этой скорби там, куда мы старались от нее уйти? Не все ли это равно, что обратиться к человеку, вынырнувшему из глубины реки, куда он бросился, чтобы потушить загоревшееся на нем платье, с требованием: “Давай огня!” [І5, с. 24I].

Стремление дистанцироваться от «гражданских скорбей» претворяется в стратегию эстетического эскапизма, которая отражается на всех уровнях текста. Устранение биографических, историко-культурных, социальных контекстов особенно очевидно на фоне сохранения инвариантного семантического ядра элегической модели. Такая деконтекстуализация создает эффект «чистой» литературы, когда внимание сфокусировано на литературных приемах, изменении точки зрения и художественной оптики, 
требующих от реципиента эстетического вкуса, тонкости восприятия, а не обширных знаний, будь то «домашняя семантика» или культурные аллюзии. Рассмотрим разные формы процесса деконтекстуализации в усадебной поэзии Фета.

Наиболее очевидна тематическая деконтекстуализация, которая проявляется в очерчивании узкого круга поэтических тем и рецепции «усадебного топоса» как пространства творчества и любви. Свою задачу автор видит не в расширении тематического диапазона и точки зрения, а в смене ракурса освещения темы. При этом возрастает роль поэтических тропов как способов остранения: метафоры как переноса привычного значения и метонимии как проявления выборочного внимания, замены целого частью.

Другой способ деконтекстуализации относится к перцептивному плану. Фет осуществляет попытку вернуть первичное, неопосредованное литературной традицией восприятие природы и, в частности, «усадебного топоса». Для репрезентации этих перцептивных установок необходим новый подход к поэтическому языку, что объясняет языковую деконтекстуализацию в усадебной поэзии Фета. Это выражается в том, что устойчивые элементы семантической парадигмы усадебного художественного языка помещаются в новые контексты на уровне синтагмы и в новое семантическое окружение. Основное направление трансформации топосов, образов и мотивов - переход из предметно-материальной области в сферу сознания, психологизация предметного мира усадебной семантики.

На этапе формирования элегической модели интроспективный и экстраспективный планы существовали параллельно друг другу, по принципу сопоставления. Например, в стихотворении Н.М. Языкова «Тригорское» (1826) есть развернутое обоснование преимуществ сельской жизни с точки зрения их влияния на душевное состояние лирического героя: «Как сна отрадного виденья, / Как утро пышное весны, / Волшебны, свежи наслажденья / На верном лоне тишины, / Когда душе, не утомленной / Житейским бременем трудов, / Доступен жертвенник священной / Богинь кастальских берегов; / Когда родимая природа / Ее лелеет и хранит / И ей, роскошная, дарит / Все, чем возвышена свобода» [9, с. 344]. В «Запустении» (г832) Е.А. Боратынского дан психологический облик умершего отца лирического героя, примечательный своей близостью к природной среде: «Тот не был мыслию, тот не был сердцем хладен, / Кто, безыменной неги жаден, / 
Их своенравный бег тропам сим указал, / Кто, преклоняя слух к таинственному шуму / Сих кленов, сих дубов, в душе своей питал / Ему сочувственную думу» [2, с. II7]. Оба примера сходны тем, что природный и психологический планы разграничены: в первом случае синтаксической конструкцией с союзами как, когда, во втором - предикативными связями, отображающими диалогическое взаимодействие человека и природы. Эксплицированы оба компонента сопоставления (природа и ментальный мир) и связи между ними: воздействие природы на человеческую душу (Языков) и обратная связь - воздействие человека на природу (Боратынский).

В усадебной поэзии Фета эксплицитное сравнение преобразуется в метафорический перенос. Структура метафоры спроецирована на структуру всего стихотворения, в котором «мерцают» природные и психологические значения, но между ними нет четкой границы (отказ от фиксации точек зрения, который отмечает Г.П. Козубовская [7, с. 2г]). Особенно очевидно это в тех примерах, где отсутствует переход между описанием эмоционального состояния человека и природным миром: «Какая грусть! Конец аллеи / Опять с утра исчез в пыли» [16, с. I40]; «Ночь лазурная смотрит на скошенный луг. / Запах роз под балконом и сена вокруг; / Но зато ль, что отрады не жду впереди, - / Благодарности нет в истомленной груди» [16, с. 315]. Внезапный переход из природного плана в психологический сглаживает различия между ними, подчеркивает «естественность» человеческих состояний и антропоморфность природного начала.

Различия между этапом формирования постриторической модели и ее трансформацией в творчестве Фета проявляются в коммуникативной структуре «усадебного текста» (уровень прагматики). Здесь важно учитывать как внутреннюю коммуникацию (субъектная структура стихотворения), так и внешние связи произведения и контекстов его создания и восприятия. Кроме того, на коммуникативном уровне отражается взаимодействие между разными художественными языками (вербальным и визуальным, поэтическим и прозаическим), что затрагивает проблему межсемиотического перевода внутри «усадебного текста».

Русская литература второй половины XIX в. характеризуется расцветом прозы. Ее эталонное проявление - тургеневскую усадебную повесть - детально исследовал В.Г. Щукин [І8]. Как отмечает М.Л. Гаспаров, русская поэзия в І840-І88о гг. «развивается в новых для нее условиях - в 
обстановке господства прозы» [2, с. I6I]. Реакцией на прозаизацию поэзии второй половины XIX в. стали две авторские стратегии. Первая предполагает усвоение прозаического художественного языка. Для усадебной поэзии прецедентным текстом и источником заимствований стала тургеневская проза. С точки зрения межсемиотических взаимодействий внутри «усадебного текста» она занимает то же положение, что в первой трети XIX в. занимала «Бедная Лиза» Н.М. Карамзина. Влияние прозы, в частности усадебной прозы И.С. Тургенева, проявляется в актуализации различных идеологических, исторических и социальных контекстов функционирования топоса. Эта тенденция реализована в трактовках усадьбы как топоса памяти - культурной, родовой, семейной, а также как модели России. Например, в стихотворении В.Г. Бенедиктова «Плач остающегося в городе при виде переезжающих на дачу» (I857) традиция усадебной поэзии XVIII в. (прощание с другом, уезжающим в деревню) соединяется с открытиями «натуральной школы» (подробно описаны разные социальные категории людей, покидающих город, приведены их диалоги и т. д.). Стихотворение можно трактовать как репрезентацию жизни определенных социальных кругов в летнее время.

Другая авторская стратегия, проявившаяся, в частности, в творчестве Фета, связана с дистанцированием от влияния прозы. Фет делает выбор между «пользой» и «красотой» в пользу последней, при этом категория «пользы» относится к сфере прозаического языка (описание усадебной жизни в очерках «Жизнь Степановки, или Лирическое хозяйство», I862-I87I), а категория «красоты» выражается языком поэзии (усадебная жизнь в стихах).

Между усадебной поэзией Фета и усадебной прозой Тургенева есть точка пересечения - монологизм высказывания. Отмеченный В.Г. Щукиным как отличительная черта усадебной повести (см.: [І8, с. 320]), он сохраняется и у Фета, даже в тех случаях, когда лирический сюжет стихотворения представляет собой попытку преодоления «уединенного» сознания и пантеистического «растворения» в природе [I4, c. 20] как надличностной сущности.

Таким образом, специфика усадебной поэзии XIX в. определяется как внешними, внелитературными обстоятельствами, так и внутрилитературными процессами и выражается на уровнях семантики, синтактики и праг- 
матики. Уровень семантики «усадебного текста» в динамическом аспекте на разных этапах характеризуется усилением и ослаблением бинарности мышления. В поэзии начала XIX в. преодоление семантической бинарности происходит посредством нового статуса элегического субъекта, а в поэзии Фета - в ходе обновления художественного языка. Уровень синтактики отражает проблемы сюжетообразования и линейных связей между элементами семантической парадигмы. В поэзии первой трети XIX в. это сюжет элегической прогулки, в середине и второй половине XIX в. - сюжет усадебной любви (Фет) и сюжет «вглядывания в прошлое» (А.К. Толстой, А.Н. Майков). В поэзии Фета происходит деконтекстуализация и интериоризация «усадебного топоса», что является реакцией на влияние усадебной прозы Тургенева, в которой усадьба рассматривается в исторических, семейных и социальных контекстах. Позиции представителей «чистого искусства» противостоит тенденция к включению этих контекстов в усадебную поэзию, близкая «реалистам». Взаимодействие поэтического и прозаического художественного языка затрагивает уровень прагматики, связанный с коммуникативной структурой «усадебного текста».

\section{Список литературы}

I Аверинцев С.С. Историческая подвижность категории жанра: опыт периодизации // Историческая поэтика. Итоги и перспективы изучения. М.: Наука, I986. C. IO4-II6.

2 Баратынский Е.А. Стихотворения и поэмы. М.: Профиздат, 20II. 256 с.

3 Бухштаб Б.Я. А.А. Фет // Фет А.А. Стихотворения и поэмы. Л.: Сов. писатель, 1986. $752 \mathrm{c}$.

4 Гаспаров М.Л. Очерк истории русского стиха: Метрика, ритмика, рифма, строфика. М.: Наука, 1984. 319 с.

5 Жаплова T.M. Усадебная поэзия в русской литературе XIX века. Оренбург: Изд-во ОПГУ, 2004. $232 \mathrm{c.}$

6 Жемиужников А.М. Избранные произведения / вступит. ст., подгот. текста и примеч. Е. Покусаева. М.; Л.: Сов. писатель, І963. 416 c.

7 Козубовская Г.П. А. Фет и проблема мифологизма в русской поэзии XIX - начала ХХ веков: автореф. дис. ... д-ра филол. наук. СПб., г994. 46 с.

8 Майков А.Н. Избранное / вступит. ст., подгот. текста и примеч. Н. Гайденкова. Л.: Сов. писатель, 1952.324 с. 
Сельская усадьба в русской поэзии XVIII - начала XIX века / сост., вступит. ст., коммент. Е.П. Зыковой. М.: Наука, 2005. 432 с. ской культуры, 20I2. T. I: О русской поэзии XIX и XX веков. Об истории русской художественной культуры. 600 с. «Современник» против «Москвитянина». Литературно-критическая полемика первой половины І850-х годов / изд. подгот. А.В. Вдовин, К.Ю. Зубков, А.С. Федотов. СПб.: Нестор-История, 20I5. 872 с. Теория литературы: учеб. пособие для студ. филол. фак. высш учеб. заведений: в 2 т. / под ред. Н.Д. Тамарченко. М.: Издат. центр «Академия», 2004. Т. 2: С.Н. Бройтман. Историческая поэтика. 368 с. Тынянов Ю.Н. Пушкин и его современники. М.: Наука, І968. 424 с.

I4 Тюпа В.И. Литература и ментальность. М.: Юрайт, 20I8. 23I с.

I5 Фет А.А. Вечерние огни / под ред. Д.Д. Благого. М.: Наука, I979. 8I5 c.

I6 Фет А.А. Стихотворения и поэмы / вступит. ст., сост. и примеч. Б.Я. Бухштаба. Л.: Сов. писатель, г986. 752 с.

I7 Шенлё А. Архитектура забвения: руины и историческое сознание в России Нового времени. М.: Новое литературное обозрение, 2018. 360 с.

I8 Щукин В.Г. Российский гений просвещения. Исследования в области мифопоэтики и истории идей. М.: РОССПЭН, 2007. 608 с.

\section{References}

Averintsev S.S. Istoricheskaia podvizhnost' kategorii zhanra: opyt periodizatsii [Historical mobility of the category of the genre: the experience of periodization]. In: Istoricheskaia poetika. Itogi i perspektivy izucheniia [Historical poetics. Results and perspectives of the study]. Moscow, Nauka Publ., I986, pp. I04-II6. (In Russ.) Baratynskii E.A. Stikhotvoreniia i poemy [Poems and poems]. Moscow, Profizdat Publ., 20II. 256 p. (In Russ.)

3 Bukhshtab B.Ia. A.A. Fet [A.A. Fet]. In: Fet A.A. Stikhotvoreniia i poemy [Poems]. Leningrad, Sovetskii pisatel' Publ., I986. 752 p. (In Russ.)

4 Gasparov M.L. Ocherk istorii russkogo stikha: Metrika, ritmika, rifma, strofika [Essay on the history of Russian verse: Metric, rhythm, rhyme, stanza]. Moscow, Nauka Publ., I984. 3 I9 p. (In Russ.)

5 Zhaplova T.M. Usadebnaia poeziia v russkoi literature XIX veka [Estate poetry in Russian literature of the $19^{\text {th }}$ century]. Orenburg, Izd-vo OPGU Publ., 2004. 232 p. (In Russ.) Zhemchuzhnikov A. M. Izbrannye proizvedeniia [Selected works], ed. E. Pokusaev. Moscow, Leningrad, Sovetskii pisatel' Publ., I963. 4I6 p. (In Russ.) 

vekov [Fet and the problem of mythologism in Russian poetry of the $19^{\text {th }}-$ early $20^{\text {th }}$ centuries: PhD thesis, summary]. St. Petersburg, I994. 46 p. (In Russ.)

8 Maikov A.N. Izbrannoe [Chosen], ed. N. Gaidenkov. Leningrad, Sovetskii pisatel' Publ., I952. 324 p. (In Russ.)

9 Sel'skaia usad'ba v russkoi poezii XVIII - nachala XIX veka [Country estate in the Russian poetry of the $18^{\text {th }}-$ early $19^{\text {th }}$ centuries], comp., introd., comm. by E.P. Zykova. Moscow, Nauka Publ., 2005. 432 p. (In Russ.)

IO Senderovich S.Ia. Figura sokrytiia. Izbrannye raboty: $v 2 t$. [The figure of concealment. Selected works: in 2 vols.]. Moscow, Iazyki slavianskoi kul'tury Publ., 20I2. Vol. I: O russkoi poezii XIX i XX vekov. Ob istorii russkoi khudozhestvennoi kul'tury [On the history of Russian art culture]. 600 p. (In Russ.)

II "Sovremennik" protiv "Moskvitianina”. Literaturno-kriticheskaia polemika pervoi poloviny I850-kh godov ["Sovremennik" vs. "Moskvityanina”. Literary and critical debate in the first half of the I85os], ed. A.V. Vdovin, K.Iu. Zubkov, A.S. Fedotov. St. Petersburg, Nestor-Istoriia Publ., 20I5. 872 p. (In Russ.)

Teoriia literatury [Theory of literature]: ucheb. posobie dlia stud. filol. fak. vyssh ucheb. zavedenii: v 2 t., ed. by N.D. Tamarchenko. Moscow, Izdatel'skii tsentr "Akademiia" Publ., 2004. Vol. 2: S.N. Broitman. Istoricheskaia poetika [S.N. Breitman. Historical poetics]. 368 p. (In Russ.)

I3 Tynianov Iu.N. Pushkin i ego sovremenniki [Pushkin and his contemporaries]. Moscow, Nauka Publ., I968. 424 p. (In Russ.)

I Tiupa V.I. Literatura i mental'nost' [Literature and Mentality]. Moscow, Izdatel'stvo Iurait Publ., 20I8. 23I p. (In Russ.)

I5 Fet A.A. Vechernie ogni [Evening lights], ed. by D.D. Blagoy. Moscow, Nauka Publ., I979. 8I5 p. (In Russ.)

I6 Fet A.A. Stikhotvoreniia i poemy [Poems], comp., introd., comm. by B.Ia. Bukhshtab. Leningrad, Sovetskii pisatel' Publ., I986. 752 p. (In Russ.)

I7 Shenle A. Arkhitektura zabveniia: ruiny i istoricheskoe soznanie v Rossii Novogo vremeni [Architecture of oblivion: ruins and historical consciousness in modern Russia]. Moscow, Novoe literaturnoe obozrenie Publ., 20I8. 360 p. (In Russ.)

I8 Shchukin V.G. Rossiiskii genii prosveshcheniia. Issledovaniia v oblasti mifopoetiki i istorii $i d e i$ [Russian genius of enlightenment. Research in mythopoetics and the history of ideas]. Moscow, ROSSPEN Publ., 2007. 608 p. (In Russ.) 
УДК 82I.I6I.I + 79I.3 ББК $83.3(2 \mathrm{Poc}=$ Рyс $) 52+$ $85.373(0)$

\section{ПЬЕСА М. ГОРЬКОГО «НА ДНЕ» В МИРОВОМ КИНЕМАТОГРАФЕ}

(C) 2020 г. А.Г. Плотникова

Институт мировой литературы

им. А.М. Горького Российской академии наук, Москва, Россия

Дата поступления статьи: І2 августа 20I9 г. Дата публикации: 25 июня 2020 г.

DOI: I0.22455/2500-4247-2020-5-2-234-25I

Статья подготовлена при финансовой поддержке Российского фонда фундаментальных исследований (грант № 19-ог2-ооз25)

Аннотация: В статье производится обзор и анализ экранизаций пьесы М. Горького «На дне» в мировом кинематографе. Описывается история попыток самого писателя поставить пьесу в кино в г920-е гг., а также анализируются художественные особенности киносценария М. Горького «По пути на дно» и использование мотивов этого сценария в последующих опытах кинематографа. Рассматриваются экранные версии пьесы, созданные в России и Советском Союзе, в Германии, Франции, Венгрии, Японии и Китае от начала XX в. до 200о-х гг. В статье охарактеризованы фильмы А.О. Дранкова, П.И. Чардынина, А. Деэши, М. Мурата, Ж. Ренуара, Х. Цуолина, А. Куросава, Ю.Ю. Карасика, В.К. Котта. Обращение к разным по художественной задаче и эстетической реализации кинофильмам позволяет выделить универсальные компоненты пьесы, увидеть, как происходила трансформация сюжета, проблематики, мотивной структуры пьесы в интерпретации режиссеров разных стран и эпох. В статье прослеживается, каким образом авторская экранизация может способствовать расширению и углублению смыслов литературного произведения для читателей и зрителей других поколений и культур. В приложении приводится наиболее полная фильмография экранизаций пьесы М. Горького «На дне».

Ключевые слова: М. Горький, «На дне», «По пути на дно», драма, экранизация, А.О. Дранков, П.И. Чардынин, А. Деэши, М. Мурата, Ж. Ренуар, Х. Цуолин, А. Куросава, Ю.Ю. Карасик, В.К. Котт.

Информация об авторе: Анастасия Геннадьевна Плотникова - кандидат филологических наук, старший научный сотрудник, Институт мировой литературы им. А.М. Горького Российской академии наук, ул. Поварская, д. 25 а, I2I069 г. Москва, Россия. ORCID ID: 000о-0003-I866-0608

E-mail: filologinya@gmail.com

Для цитирования: Плотникова А.Г. Пьеса М. Горького «На дне» в мировом кинематографе // Studia Litterarum. 2020. Т. 5, № 2. С. 234-25I. DOI: $10.22455 / 2500-4247-2020-5-2-234-25 \mathrm{I}$ 


\section{GORKY'S DRAMA THE LOWER DEPTHS IN THE WORLD CINEMA}

This is an open access article distributed under the Creative Commons Attribution 4.0 International (CC BY 4.0)
(C) 2020. A.G. Plotnikova

A.M. Gorky Institute of World Literature of the Russian Academy of Sciences, Moscow, Russia Received: August 12, 2019

Date of publication: June 25, 2020

Acknowledgements: This article has been prepared with the financial support of the Russian Foundation for Basic Research (grant No. I9-0I2-00325).

Abstract: The article overviews and analyzes the adaptations of M. Gorky's drama The Lower Depths in the world cinema. It describes the history of the writer's attempts to adapt his drama for the cinema in the I920s, and also analyzes the artistic features of M. Gorky's cinema script On the Way to the Depths and the use of the motives of this scenario in subsequent cinema experiments. Screen versions of The Lower Depths appeared in Russia and in the Soviet Union, in Germany, France, Hungary, Japan, and China from the beginning of the twentieth century to the 2ooos. The article describes films by A.O. Drankov, P.I. Chardynin, A. Deeshi, M. Murata, J. Renoir, H. Zuolin,

A. Kurosawa, Y.Y. Karasik, and V.K. Cott. Appeal to films which are different in their artistic task and aesthetic implementation allows us to identify universal components of the drama, and to see how the transformation of the plot, problems, motive structure of the drama in the interpretation of directors from different countries and eras took place. The article traces how the author's film adaptation can help expand and deepen the meanings of a literary work for readers and spectators of other generations and cultures. The appendix contains the most complete filmography of the adaptations of M. Gorky's the drama The Lower Depths.

Keywords: M. Gorky, “The Lower Depths”, "On the way to the Depths”, drama, film adaptation, A.O. Drankov, M. Murata, A. Deésy, J. Renoir, H. Zuolin, A. Kurosawa, V.K. Kott.

Information about the author: Anastasia G. Plotnikova, $\mathrm{PhD}$ in Philology,

A.M. Gorky Institute of World Literature of the Russian Academy of Sciences, Povarskaya 25 a, I2I069 Moscow, Russia. ORCID ID: 0000-0003-I866-0608

E-mail: filologinya@gmail.com

For citation: Plotnikova A.G. M. Gorky's Drama The Lower Depths in the World Cinema. Studia Litterarum, 2020, vol. 5, no 2, pp. 234-25I. (In Russ.)

DOI: IO.22455/2500-4247-2020-5-2-234-25I 
Пьеса М. Горького «На дне» имеет обширную историю экранизаций. Всего известно более 20 фильмов как российского, так и зарубежного производства. Почему же эта пьеса привлекала внимание кинематографистов чаще других? Что именно в ней - проблематика, герои, мотивная структура, философское наполнение - интересовало режиссеров разных эпох? Попробуем осмыслить те ракурсы, те грани пьесы, которые каждый режиссер считает определяющими для своего варианта «На дне».

Пьеса М. Горького «На дне» появилась в І902 г. и сразу приобрела всемирную известность. Ее ставили не только в России, но и в Германии, Великобритании, Польше, Франции, Японии и в других странах. Практически сразу пьеса попала в поле зрения кинематографа.

Первые экранизации «На дне» не отличались художественностью, привлекая зрителей экзотичностью и эпатажностью материала. Сам Горький не принимал участия в работе над этими картинами и прямо запрещал использование своей пьесы, что, однако, не останавливало кинематографистов. В г908 г. один из первых русских кинофабрикантов А.О. Дранков анонсировал фильм «Бывшие люди - типы М. Горького» по пьесе «На дне». Ранее этот материал уже был показан как хроника «Московский Хитров рынок», однако успеха не имел, а имя Горького привлекло публику, и лента принесла Дранкову значительный доход. В июне І9г7 г. П.И. Чардынин, ведущий режиссер кинофабрики Д.И. Харитонова, представил зрителям фильм «Жизнь Барона» (другое название - «Васька Пепел и Барон») [І4]. В кинокартине рассказывалась история двух героев горьковской драмы «На дне», в том числе воспроизведена вся жизнь Барона (его молодость, неудачная женитьба на эгоистичной развратной женщине, доведшей его до «дна»). 
В эти же годы появилась и первая зарубежная экранизация «На дне». Венгерский режиссер Альфред Деэши в I9I7 г. снял фильм «Radmirov Katalin». Драматург Юзеф Пакотс написал сценарий, в котором показал предысторию горьковских героев, включив в сюжет совершенно новых роковую красавицу Каталину Радмилову, графа Миловского, толстовца Павлова и др. В полной страстей мелодраматической истории есть все: любовь, шпионаж, предательство, самоубийство, а в финале - тюрьма и ночлежка. Кинематографисты далеко отступили от горьковского сюжета, но имя писателя было обозначено на афишах.

Очевидно, после революции Горький все-таки дал согласие на экранизацию своей главной пьесы. В конце I9I8 г. газета «Правда» сообщала, что с разрешения писателя готовятся для экрана его произведения «Трое» и «На дне» [з3], но в Советской России фильм так и не вышел.

В начале г920-х гг., в период ярких художественных экспериментов в кинематографе, пьеса «На дне» была экранизирована и на Западе, и на Востоке. В І9І9 г. в Германии режиссер Р. Мейнерт снял фильм «Nachtasyl». Эта экранизация была близка к оригиналу, хоть и трактовалась не как социально-философское произведение, а как криминальный роман. Фильм был поставлен в эстетике немецкого экспрессионизма, предполагавшего активное использование контрастных светотеней, гротескное искажение пространства, энергичную, подчеркнуто выразительную, даже гиперболизированную игру актеров. В фильме играли Юлитта Брандт (Василиса), Мария Фореску (Наташа), Фридрих Кюне (Актер) и др.

$$
\text { *** }
$$

Фильм японского режиссера Минору Мурата «Rojô no reikion» («Призраки на дороге»), новаторский и в тематическом, и в формальном отношении, стал значительной вехой в истории кинематографа Японии. Сценарий, написанный Кехико Усихара, имел два литературных источника: драму Горького «На дне» и роман «Дорога-мать, конец молодости» немецкого писателя Вильгельма Августа Шмидтбона. Эти произведения указаны в самом начале фильма отдельным кадром, при этом имя Горького и название его произведения написаны по-русски. На следующем кадре из «На дне» - реплика Луки: «Жалеть людей надо! Христос всех жалел и нам так велел. Я тебе скажу, вовремя пожалеть человека - хорошо бывает». Она 
также написана по-русски, в дореформенной орфографии, и даже шрифт напоминает газеты начала XX в. Парадоксально, что в качестве идейной основы авторы японского фильма выбрали как раз позицию Луки, которую Горький опровергает в своей пьесе.

В остальном сюжет художественного фильма «Rojô no reikion» далек от драмы Горького, важнее рецепция мотивной структуры русской пьесы. В фильме рассказываются три истории, которые впоследствии связываются воедино. Первая посвящена неудачливому скрипачу Коичиро и его конфликту с отцом, который обижен на сына и отказывает ему в помощи. Вторая история связана с беглыми преступниками, которых встретил Коичиро на дороге. Воры хотят ограбить скрипача и его семью, но видят, что те еще беднее них, и неожиданно проявляют милосердие и разделяют с путниками нехитрую пищу. Видимо, в изображении этих персонажей более всего проявилось влияние пьесы Горького. Они страдают от своей нищенской жизни, от блужданий по ночлежкам, от одиночества и неустроенности. При этом они не лишены сострадания и готовы поделиться последним куском хлеба с теми, кому еще хуже. В рождественскую ночь в поисках пищи они пытаются проникнуть в дом богатой девушки Йоко, но сама хозяйка выходит и приглашает их присоединиться к богатому празднику. При этом показано, что бы произошло с нищими ворами без милосердия Йоко: тюрьма и смерть. Третья сюжетная линия связана с девушкой Йоко и ее любовью к бедному парню Таро. Социальные различия препятствуют их отношениям, но Йоко ценит честность, трудолюбие и способность к милосердию, и в конце фильма влюбленные воссоединяются. Конечно, в литературном отношении М. Мурата и драматург К. Усихара опирались не только на Горького. Однако острый социальный конфликт, обращение к изображению низов общества и философская проблематика фильма указывают на влияние русского писателя.

\section{***}

В середине 1920-х гг. Горький попытался самостоятельно адаптировать «На дне» для экрана. Писатель был убежден: в кинематографе заключены огромные просветительские и воспитательные возможности, а на начальном этапе своего существования молодое искусство представляло собой скорее развлекательное коммерческое предприятие, вызывая весьма критические оценки писателя (подробнее об этом см.: [І2, с. 7-3I]). Но благо- 
творное воздействие кино на общество возможно только в том случае, когда сценарий представляет собой отдельное оригинальное произведение, а не адаптацию романа или пьесы. Сценарий должен рассказывать новую историю. Так появилось произведение «По пути на дно», где освещалась предыстория героев знаменитой пьесы: криминальное прошлое Луки, юность мечтательного телеграфиста Сатина, молодость юнкера Барона, жизнь других будущих обитателей ночлежки. Этот ход уже привлекал кинематографистов: на этом основаны фильмы П.И. Чардынина и А. Деэши. Однако еще раньше на необходимость ретроспективного взгляда в прошлое героев обратил внимание А.П. Чехов, который писал Горькому 29 июля 1902 г. о пьесе: «Смерть актера ужасна; Вы точно в ухо даете зрителю, ни с того ни с сего, не подготовив его. Почему барон попал в ночлежку, почему он есть барон - это тоже недостаточно ясно» [I5, c. I2]. При первой публикации сценария в 1938 г. И.П. Ладыжников сообщил, что намерение написать сценарий «На дне» возникло у М. Горького после неоднократных обращений к нему за разрешением переделать для кино пьесу «На дне»: «В процессе работы над сценарием у Горького явилась мысль дописать новые сцены, в которых он задумал дать характеры типов - Луки, Сатина, Барона, Насти, Василисы, Костылева и других, - какими они могли быть в жизни до того, как оказались “на дне”, - кем они были, как жили, чьи интересы защищали. Эти новые сцены Алексей Максимович и назвал “По пути на дно”» [5, с. I9].

На протяжении нескольких лет М.И. Будберг пыталась организовать экранизацию этого сценария. Очевидно, в этом деле были некоторые успехи, потому что в июле г925 г. советская пресса сообщала: «Горький написал сценарий по своей пьесе "На дне”. Сценарий приобрела неизвестная американская кинофирма» [Іо, с. 49г]. 20 августа І925 г. Будберг писала Горькому: «...не осталось ли у Вас русского текста сценария “На дне”. Если найдете, пришлите очень срочно» [I, с. II4]. К концу І925 г. переговоры, казалось, пришли к какому-то промежуточному результату: «За “Дно” обещают заплатить 2.000 согласно контракту 3І декабря» [I, с. І25], - однако немой фильм «На дне» так и не был поставлен.

Сценарий «По пути на дно» решал некоторые кинематографические проблемы драмы. Например, неоднократная перемена места действия в сценарии «разбавляла» сценическую условность, статичность пьесы - Горький стремился воспользоваться теми возможностями, которые дает кинематограф 
по сравнению с театром. Здесь крайне мало реплик персонажей, зато детально прорисованы их жесты, позы, особенности пластики. Например: «Все трое смеются раздраженно. Четвертый смотрит на них, соображает, понял, бросается с кулаками. Его сбили с ног, ушли» [7, с. 306]. Сцена решается исключительно по законам немого кинематографа. Главная же проблема перевода театральной пьесы на язык немого кино заключалась собственно в языке. Реплики персонажей, их речевые особенности обусловливали их характеры, поступки и в конечном итоге развитие действия. Немое кино не давало такой возможности, поэтому Горький добавил историю персонажей, объясняющую логику их становления и поступков. Можно предположить, что сценарий «По пути на дно» мыслился как первая часть или даже первая серия фильма.

В сценарии Лука - деревенский староста, обманувший мужиков, завладевший лугами. Он соблазняет чужую жену, становится причиной самоубийства односельчанина, бежит из-под стражи. Актер и Костылев, который описан как «вороватый человечек», обманывают юного мечтательного телеграфиста Сатина и заставляют его проиграться и участвовать в ограблении пьяного прохожего. Благородный юноша Сатин пытается отдать украденные деньги своей квартирной хозяйке и ее больной дочери, но в этот момент его настигает полиция. На стене своей тюремной камеры он выводит осколком стекла слова: «Все - в человеке, все - для человека!» [7, с. 3І2] - эти слова ранее он прочитал в книге, и тогда он улыбался, как человек, «который нашел истину» [7, с. 309]. Теперь же Сатин нервно смеется над этой фразой.

Будущий Барон, а пока - высокомерный юнкер, становится свидетелем сцены, где Лука стоит над трупом односельчанина. Барон говорит своей даме с удивлением: «Оказывается, это - драма» [7, с. 307]. Он называет участвующих в этой истории «люди для неприличных трагикомедий», высокомерно замечает: «Идемте смотреть; мужики - это всегда смешно» [7, с. 305]. Однако и сам он через пьянство, безделье и мотовство спустя некоторое время становится таким же «бывшим человеком».

В сценарии появляется некий «тучный человек», который приводит к проституции милую горничную Настю, страдающую от неразделенной любви к молодому улану. Он объявляет Барону: «Я покупаю только женщин» [7, c. 3I6]. Образ тучного человека, вероятно, сутенера, дан исключительно через описание его жестов и действий (кроме упомянутой фразы): он облизывает и подкручивает усы, закуривая, начинает разговор с Настей, наблюдает за ней 
из-за колонны. Этого достаточно: в соответствии с канонами немого кино мы видим яркий, однозначный образ неприятного, отталкивающего человека.

Василиса, «красивая девушка с узелком» [7, с. 315], выходит из тюрьмы, у ворот которой ее дожидается Костылев - «вороватый мещанин лет сорока» [7, с. 3Іо]. Очевидно, брак с ним - единственная ее возможность для относительно нормальной жизни. Появляется и Наташа, девочка «лет семи-девяти», и полицейский Медведев, «молодой, с глупым лицом», и толстый скорняк Бубнов.

Почти все герои сценария - будущие персонажи пьесы «На дне» связаны невидимыми нитями судьбы, многие сталкиваются, не замечая и не запоминая друг друга (Сатин на принудительных работах сидит на земле, мимо него проходит Настя; Лука видит случайно заехавшего юнкера Барона и т. д.). Они уже - тени в загробном царстве, и только вопрос времени, когда они соберутся в одном месте. Этот мотив усиливает метафизическое звучание пьесы. Все люди связаны и пусть разными путями, но все попадают в одно место - в аналог загробного мира, в ночлежку, последнее пристанище.

Однако по целому ряду обстоятельств [12, с. 50-55] немой фильм «На дне» по сценарию Горького не удалось снять, а сценарий «По пути на дно» был поставлен в только г968 г. к гоо-летию писателя Горьковской телестудией (реж. М. Скворцов).

Однако Горькому все же удалось, хотя бы косвенно, поспособствовать экранизации своей пьесы. В г936 г. к нему обратился Е.И. Замятин, который уже несколько лет работал во французском кинематографе. В очерке, посвященном Горькому, Замятин вспоминал: «За месяц-полтора до его смерти одна кинематографическая фирма в Париже решила сделать по моему сценарию фильм из известной пьесы Горького “На дне”. Горький был извещен об этом, от него был получен ответ, что он удовлетворен моим участием в работе, что он хотел бы ознакомиться с адаптацией его пьесы, что он ждет манускрипта. Манускрипт для отсылки был уже приготовлен, но отправить его не пришлось: адресат выбыл - с земли» [8, с. 72]. Замятин был в целом доволен результатом своей работы. Он писал И.Е. Кузминой-Александер г5 декабря г936 г.: «...летом сделал сценарий из “На дне” Горького (нелегкая была задача!). На прошлой неделе прошла премьера, говорят - с успехом; пресса - очень хорошая» [II, с. 344].

Над фильмом «Les bas-fonds», премьера которого состоялась г декабря г936 г., работали режиссер Ж. Ренуар, сценаристы Ш. Спаак и Ж. Ком- 
панеец, продюсер А. Каменка. Создатели фильма внесли существенные изменения в сюжет пьесы Горького. Действие перенесено в современную им Францию, и, хотя герои сохранили русские имена и прозвища, большинство реалий - интерьеры, костюмы, бытовые детали - соответствуют французской действительности. Ренуар сделал это осознанно, стремясь, во-первых, избежать ошибок в изображении другой страны, а во-вторых, желая возвысить историю до универсальной. «Я считаю, - писал он, - что, отказавшись от псевдорусской специфики - самоваров, балалаек, цыган, - я смогу лучше передать мысль автора. Я не стремился сделать “русский фильм”, я хотел сделать общечеловеческую драму» [4, с. 8].

В сюжете также были сделаны изменения. Лука и Сатин стали второстепенными персонажами, а на первый план выведена любовная история Васьки Пепла (Жан Габен) и Наташи (Жюни Астор). Это было обусловлено требованиями зарубежного кино тех лет. Анализируя фильм, Л.И. Белова писала: «Сценарий мелодраматизирован, что приближает его к французской кинематографической традиции и заметно уводит от драматургии Горького» [2, с. 20].

Предыстория Барона и Васьки Пепла стала основой сюжета фильма. В начале повествования аристократ Барон совершает роковую ошибку, проигрывает в карты казенные деньги, и по суду его лишают всего имущества за долги. Он знакомится с Пеплом, когда тот пытается ограбить его дом, но в нем уже нечего красть. Эволюция героев разнонаправленная: Барон опускается «на дно», а Пепел, наоборот, стремится изменить свою жизнь к лучшему. Для Барона уход в ночлежку в известной степени - протест, бунт, восстание против несовершенств социальной системы. Эта коллизия, центральная в фильме Ренуара, отсутствует в драме М. Горького. Для Ренуара важно показать путь человека из глубин к свету, и он делает это на примере образа Васьки Пепла.

Финал картины Ренуара, в отличие от концовки пьесы Горького, оптимистичен: Пепел и Наташа вместе покидают ночлежку, вдохновленные надеждой на прекрасное будущее. Ренуар смещает акценты: важная для Горького тема соотношения реальности и вымысла («правды» и «сказки») у него ослаблена, а мрачный тон пьесы сознательно смягчен визуальным рядом. В фильме много открытого пространства, широких городских улиц, природы; возникает мотив детства, который подразумевает надежду на будущее. 
В стенах ночлежки происходит менее половины действия, именно сцены в мрачном подземелье организованы наиболее интересно с визуальной точки зрения. Драматическая игра света и тени, старые кирпичи, грубые деревянные балки, которые часто разделяют экран по вертикали или по диагонали, создают возможности для кинематографических акцентов [I6, p. I37].

Таким образом, Ренуар создал художественный фильм, который стал ярким феноменом французско-русских культурных связей. С одной стороны, фильм «На дне» напоминал зрителю о политических убеждениях его авторов, о связи с Советским Союзом и русской литературой, а с другой соответствовал зрительским требованиям, предполагавшим увлекательный сюжет, мелодраматизм и счастливый финал.

$* * *$

Идея переноса сюжета драмы М. Горького на совершенно иную историко-культурную почву была реализована еще не раз. Так, в 1947 г. пьеса «На дне» была адаптирована для экрана в Китае драматургом Ке Лингом и поставлена режиссером Хуан Цуолином. В фильме «Yѐ Diăn» («Ночлежка») сохранена общая канва сюжета, так же изображена гостиница для самых бедных людей. Так же приходит к ним Лука (здесь его зовут Куана Лаоту), умирает несчастная Анна (Лай Саози), а вор Пепел (Ян Ци) влюблен в Наташу (Меймей) и тяготится романом с Василисой (Саи Гуанинь). Однако, во-первых, здесь изображена жизнь китайского общества, а во-вторых, положительные и отрицательные черты героев значительно усилены, характеры резко поляризованы.

Так, Пепел превращен в симпатичного популярного героя, связанного с образами национальных китайских богатырей. Обитатели ночлежки уважают и любят Пепла. В самой первой сцене фильма, эпизоде, которого нет у Горького, люди на улице помогают ему скрыться от полиции. Наташа подчеркнуто чиста, прекрасна и хрупка, что также отсылает к героиням китайского эпоса. Судьба ее в фильме значительно более драматична: сестра страшно издевается над ней, а в конце связывает и хочет продать ее богатому старику. Фильм заканчивается самоубийством девушки (а не Актера, как в пьесе Горького), не вынесшей мучений. Василиса - злая, двуличная женщина, безусловно самая сложная и интригующая фигура в фильме. Она не только истязает Наташу, но и плетет сложную интригу, вовлекая в убийство мужа двух своих любовников. 
Анна - незначительная фигура в фильме, но важная для раскрытия качеств главных героев. Как и в пьесе Горького, Анна хочет знать, есть ли жизнь после смерти и рай. Добрый странник Лука, также второстепенный персонаж в фильме, утешает ее. Костылев, не получив от Анны платы за постой, выкидывает ее на улицу и становится непосредственным виновником ее смерти. В фильме обитатели ночлежки демонстрируют сострадание к умершей, собирая деньги на похороны. Пепел дает большую сумму, и делает он это из сочувствия, мотив пренебрежения, присутствующий в пьесе Горького, здесь совершенно исключен.

Образ Луки в фильме упрощен и совершенно не связан с конфликтом правды и лжи. Он остается среди героев до самого конца, именно он находит повесившуюся Наташу. В конце он обращается к зрителю: «Этот мир настолько холодный. Хорошие люди должны терпеть горечь и трудности, в то время как злые люди преуспевают. Где найти справедливость?»

Авторы фильма стремились максимально расширить аудиторию фильма, они не только адаптировали сюжет пьесы Горького к китайским реалиям, но и существенно усилили мелодраматичность, упростили характеры, резко разграничили положительных и отрицательных героев. Исследователи отмечают, что, «перейдя с российской сцены на китайскую сцену и в китайское кино, история была преобразована из натуралистического коллективного портрета городской бедноты в мелодраму в стиле Голливуда, которая характеризуется сильным столкновением между силами добра и зла» [I7, p. 30].

Японский фильм «Donzoko» (1957), наверное, является одной из самых известных зарубежных экранизаций творчества Горького. Режиссер Акира Куросава и драматург Хидэо Огуни продолжили характерную для Востока традицию адаптации иностранных литературных произведений для национального зрителя.

Действие фильма «На дне» происходит в Японии эпохи Эдо, в начале XIX в., и выбор этого исторического периода обусловлен художественной задачей режиссера. Куросава хотел обратиться к социальным потрясениям в Японии в середине г950-х гг., но по политическим причинам дистанцировал свое высказывание, переместив его в прошлое не только относительно своей современности, но и относительно времени написания пьесы Горького. Пере- 
неся действие во времени и пространстве, А. Куросава и Х. Огуни дали героям новые японские имена. Так, Васька Пепел стал Сутэкити, Лука - Кехэй, Наташа - Окае и т. д. Жизни героев оказались связанными с японской культурой: Барон (Тоносама) в фильме - бывший самурай, потерявший положение в обществе, а Квашня (Отаки) торгует сладкими палочками, национальным лакомством. Изменено множество бытовых деталей, упоминаемых в пьесе Горького: часы, которые Пепел продал Костылеву, превратились в шкатулку, а пельмени - в японские моти. Рассказывая о фильме, Л.И. Белова отмечала: «Обстановка, течение и ритм действия, манера людей двигаться, выражать эмоции - все сугубо национальное, японское» [2, с. 23].

Однако основная фабула, характеры персонажей, большая часть реплик остались горьковские, и «Donzoko» Куросавы - один из немногих зарубежных фильмов, который можно с уверенностью назвать экранизацией горьковской пьесы «На дне». Здесь несколько сокращены роли Наташи, Костылева, Луки, Сатина (например, отсутствует ключевой монолог «Человек! Это звучит... гордо!»), но роль Пепла, которого сыграл культовый японский актер Тосиро Мифуне, осталась практически без изменений. Основной сюжет строится вокруг любовного конфликта Пепла, Василисы и Наташи. Однако Куросава освещает главный горьковский конфликт - противоречие между жестокой правдой и сладкой ложью, хотя и реализует его через Пепла. Лука, который в японском фильме в блестящем исполнении Бокузена Хидари превращается в буддийского монаха, теряет свою уверенность и становится менее убедительным.

Главной особенностью трактовки японским режиссером пьесы «На дне» стал общий иронический тон, который сложно разглядеть в оригинальной пьесе Горького. Это проявляется и в манере игры актеров, иногда напоминающей о традиционном японском театре, и в финальной сцене фильма, которая превращается в настоящий музыкальный импровизационный номер, связанный с национальной традицией ритуального танца бакабайаши. Такой танец исполнялся на празднике, посвященном торжеству жизни, и зритель понимал, что даже здесь, на дне общества, люди все еще могут радоваться и сохранять человечность.

Куросава интересно обращается с художественным пространством фильма, в первых кадрах зритель видит, что ночлежка, где сосредоточено действие, находится на дне глубокого оврага. За оврагом на холме стоит храм, таким образом, пространство делится на три уровня: духовный, человеческий 
и мир смерти, где и обитают ночлежники. При этом практически все реплики, связанные с мотивом смерти, погребения, мира мертвых, сохранены, что, как и в горьковском тексте, ставит вопрос об умирании душ героев.

Фильм Куросава напоминает китайскую переработку «На дне» (1947), однако «Donzoko» «не имеет ни сентиментальных, ни мелодраматических качеств, которые характеризуют китайский фильм. Не прилагается никаких усилий, чтобы разделить персонажей на два противоречивых моральных лагеря добродетели и подлости» [I7, p. 3I]. В целом, Куросава следует мысли Горького, а перемещение сюжета на иную национальную почву прямо утверждает его универсальность.

\section{$* * *$}

В Советском Союзе экранизации пьесы «На дне» шли совершенно иным путем, далеким от зарубежных адаптаций. Для русского зрителя «На дне» оставалась прежде всего театральной пьесой и долго не появлялась на экране. В 1952 г. был снят фильм по спектаклю Московского художественного театра в классической версии К.С. Станиславского и В.И. Немировича-Данченко. В 1972 г. появилась телевизионная версия спектакля Г.Б. Волчек в московском театре «Современник».

Первая настоящая отечественная экранизация «На дне» вышла только в 1987 г.: режиссер Ю.Ю. Карасик представил свой фильм «Без солнца». Именно таким было одно из первых названий пьесы Горького. В фильме были заняты такие выдающиеся актеры, как М.А. Глузский, А.В. Петренко, И.М. Смоктуновский, В.В. Глаголева. Текст пьесы Горького сохранен полностью, но постановка выглядит необычно. В фильме происходит сочетание театральной и кинематографической эстетики. Пространство действия разомкнуто, герои уходят с площадки и оказываются в современных театральных помещениях, они курят, общаются с работниками сцены, им поправляют грим и костюм. Режиссер фильма словно полемизирует с К.С. Станиславским и классическими постановками, разрушая «четвертую стену». Персонажи пьесы одновременно являются и актерами, которые их играют. Это значительно усиливает мотив карнавальности, двойственности, ложности окружающего мира, который неоднократно звучит в тексте Горького. Ю.Ю. Карасик пользуется почти тем же приемом, что мы видели во французском, японском, китайском фильмах, - изменяет временную ос- 
нову горьковской пьесы, но идет дальше, напрямую соединяя горьковское время и современность.

$* * *$

Пьесу М. Горького «На дне» продолжают экранизировать и в XXI в. В 20I4 г. фильм «На дне» российского режиссера В.К. Котта, получил специальный приз «За актуальное прочтение классики» на XXII фестивале «Окно в Европу». Котт перенес действие в 2ооо-е гг., в современную нам эпоху. Кажется, после многих зарубежных экранизаций, использовавших такой прием, он должен был стать уже «общим местом», но в интерпретации современного кино пьеса М. Горького зазвучала совершенно неожиданно.

События в фильме В.К. Котта происходят не в темной ночлежке, а на городской свалке. Режиссер так объяснял свою идею: «Поскольку мы снимали на свалке твердых бытовых отходов, где находятся остатки деятельности человека: двери, окна, картины, игрушки, - то было ощущение соприкосновения с человеческой памятью. В каждой памяти присутствует элемент поэзии, ностальгии, печали» [9]. Действительно, такой сложный ландшафт, содержащий огромное количество больших и малых предметов, конструкций, дает возможности для создания причудливого пространства. Эпизоды фильма происходят на открытой местности, в огороженном «дворике», в тесноте сломанного автобуса, усложненное пространство создает дополнительные драматургические возможности.

Герои пьесы Горького узнаваемы и по внешнему облику, и по репликам, которые В.К. Котт кропотливо воспроизводит из текста пьесы, добавив в сценарий современные слова: «интернет», «постмодернизм», «менты» и др. М.О. Ефремов исполнил роль Актера, который становится в фильме центральным персонажем: именно он переживает наибольшие перемены в своей личности, его монологами обрамлен фильм. В образе Наташи (А.Е. Кузнецова) присутствуют черты двух героинь пьесы Горького: проститутки Насти и девушки Натальи. Она мечтает о другой жизни, но каждую ночь уходит к клиентам в сигналящих у дороги машинах. Ее сестра Василиса (Е.В. Добровольская) - жестокая, истеричная женщина, жена тупого властного Костылева (Б.Б. Каморзин), на которого работают обитатели свалки, разбирая мусор в попытке найти в нем чтото полезное. 
Наибольшей трансформации подвергся образ Луки (С.А. Трескунов). В фильме он не старец, а подросток. Режиссер в интервью так объяснял свое решение: «Человек с возрастом покрывается цинизмом, а ребенок своей чистотой срывает это налет цинизма <...>. К тому же для фильма мне нужен герой, который был бы из абсолютно другого мира» [9]. Лука в фильме появляется из того же мусора, которым наполнено пространство. Просто однажды поднимается слой картона, и под ним оказывается мальчик лет I2-I4. Он ведет беседы с каждым из жителей свалки, ухаживает за умирающей Анной, готов выслушать и пожалеть всех, всем поверить. В пьесе Горького Лука уходит, оставляя обитателей ночлежки еще более несчастными, чем они были раньше. В фильме Котта юноша становится жертвой случайного убийства, и с его телом остальные поступают так же, как со своей собственной жизнью, - закапывают в мусоре.

Герои фильма Котта отличаются от горьковских. Они абсолютно сломлены, сцены пьяных драк, истерик и скандалов сменяют друг друга, а в том безразличии, с которым бродяги закрывают тело юного Луки кусками картона, видится полная обреченность их существования. Критик писал: «У Владимира Котта “дно” - размером в страну. Помойка, на которой пытаются жить и выживать человеки. Те самые, что век назад звучали гордо. Сейчас им не до жиру» [3].

В.К. Котт совершил интересный эксперимент, внеся в классическую пьесу из школьной программы значительные изменения. Споры, возникшие о его неоднозначном, ярком фильме, свидетельствуют о том, насколько и сегодня остаются актуальными проблемы, которые ставил Горький.

На сегодняшний день история экранизаций пьесы Горького «На дне» составляет более века. Не многие литературные произведения имеют такую обширную фильмографию.

В первую очередь кинорежиссеров разных эпох и разных культур привлекала универсальность ее проблематики. В пьесе «На дне» есть и сложный философский конфликт, и плач о социальной несправедливости и человеческой жестокости, и сложный любовный многоугольник, и над всем этим - надежда, вера в возможность изменения, перерождения. Ведь только достигнув самого дна Ада, Данте мог начать восхождение к свету. Для усиления универ- 
сальности пьесы режиссеры часто перерабатывали ее пространственно-временной и культурный фон. Герои «На дне» в этом смысле - уникальный культурный феномен, они путешествовали в будущее (во Францию Ренуара и в Россию Котта), оказывались в далеком прошлом (в фильмах Цуолиня и Куросава), перемещались в пространстве. Но оказывается, что их истории звучат одинаково актуально и в средневековой Японии, и в предвоенной Франции, и в России XXI в. Художественная правда литературного произведения оказалась более значимой, чем та культурная почва, на которой оно было создано.

Парадоксально, но самые яркие экранизации «На дне» - именно те, что глубоко переосмысливают «дух» оригинала, а не точно следуют его «букве». Видимо, только такое личное художественное режиссерское высказывание на основе действительно гениального литературного произведения оказывается способным выразить художественные идеи эстетического направления, как экспрессионистский фильм Мейнарта, изменить национальный кинематограф, как это сделали фильмы Мурата или Цуолина, или просто явить миру такие шедевры, как сумел Куросава.

Экранизация - особый жанр кинематографа, она далека от иллюстрации литературы, это сложное единство, где переплавлены идея и образы писателя, художественный замысел режиссера, работа сценариста, оператора, художника, актеров и многих других участников. И чем более активно творческое переосмысление текста режиссером, тем более глубокие и актуальные смыслы литературного произведения становятся очевидны.

\section{Приложение}

\section{Фильмография пьесы М. Горького «На дне» (1908-2017)}

Российская империя I9I7, «Жизнь барона», «Васька Пепел и Барон», реж. П.И. Чардынин, к/Ф Д.И. Харитонова. Российская империя

3 I9I8, «Radmirov Katalin», реж. А. Деэши. Венгрия

4 I9I9, «Nachtasyl», реж. Р. Мейнерт. Германия

5 I92I, «Rojô no reikion», реж. М. Мурата. Япония

6 I936, «Les bas-fonds», реж. Ж. Ренуар. Франция

7 I952, «На дне», реж. А.В. Фролов, И.М. Раевский. СССР

8 I957, «Dondzoko», реж. А. Куросава. Япония

9 I958, «The Lower Depths» (телесериал «ВBC Sunday-Night Theatre»), реж. М. Эллиот. США

Iо I959, «Nachtasyl», реж. П. Верховен. ФРГ 


\section{Список литературы} № 9. C. III-II6. 1968. № 3. С. 8-9. I973. T. I9. 560 c. T. 3. C. 60-72. № I48. I8 авг. 2004. 698 c.

I968, «Les bas-fonds», реж. Ж.-П. Сэсси. Канада, Франция, Швейцария I97I, «Nachtasyl», реж. П. Купке. ГДР I972, «На дне» (фильм-спектакль), реж. Г.Б. Волчек, Л.А. Пчелкин. СССР I974, «Nachtasyl», реж. Ф. Борнеманн. ГДР 1976, «Рå bunnen», реж. Я. Варден. Норвегия I978, «На дне», реж. А.А. Панкратов. СССР I980, «Nachtasyl», реж. А. Хеттерле. ГДР I982, «Nachtasyl», реж. Ю. Гош. ФРГ 1987, «Без солнца», реж. Ю.Ю. Карасик. СССР I987, «На дне», реж. Ф.М. Мкртчан, П. Дноян. СССР 2005, «Nachtasyl», реж. Х. Штурм. Германия 20I4, «На дне», реж. В.К. Котт. Россия 20I7, «The Lower Depths», реж. М.Б. Эллис. Великобритания

А.М. Горький и М.И. Будберг: Переписка (1920-I936) // Архив А.М. Горького. М.: ИМЛИ РАН, 200г. Т. І6. 543 с.

Белова Л.И. Русское слово на зарубежном экране. М.: Знание, І980. 56 с.

Богомолов Ю. «Ностальгия вперед» уже не возможна // Искусство кино. 2014.

Глаголева Н. Из истории экранизаций Горького за рубежом // Искусство кино.

Горький М. По пути на дно // Год двадцать первый. Альманах тринадцатый. М.: Гослитиздат, 1938. С. 19-28.

Горький М. Полн. собр. соч. Письма: в 24 т. М.: Наука, 2006. Т. І2. 726 с. Горький М. Полн. собр. соч. Художественные произведения: в 25 т. М.: Наука,

Замятин Е. Горький // Замятин Е.И. Собр. соч.: в 5 т. М.: Русская книга, 2004.

Заозерская А. Владимир Котт: «Я не настолько экстремальный режиссер, чтобы из пьесы Горького создать фильм-жесть или чернуху» // Вечерняя Москва. 2014.

Летопись российского кино: I863-I929 / под ред. В.И. Фомина. М.: Материк,

I Неизвестные письма Евгения Замятина из американского архива / вступит. ст., публ. и коммент. Дж. Куртис // Евгений Замятин и культура XX века.

СПб.: РНБ, 2002. С. 30I-35I.

Плотникова А.Г. М. Горький и кинематограф. М.: ИМЛИ РАН, 2ОI8. 336 с. Правда. І9І8. № 279. 22 дек.

Проектор. І9І7. № II/І2. С. I2.

Чехов А.П. Полн. собр. соч.: в 30 т. М.: Наука, І982. Т. ІІ. 7І9 с

Durgnat R. Jean Renoir. London, Los-Angeles, I974. 442 p. 
I7 Pickowicz P.G. Sinifying and Popularizing Foreign Culture: From Maxim Gorky's «The Lower Depths» to Huang Zuolin’s «Ye dian» // Modern Chinese Literature. 1993. Vol. 7. No 2. P. 7-3I.

\section{References}

I A.M. Gor'kii i M.I. Budberg: Perepiska (I920-I936) [A.M. Gorky and M.I. Budberg: Correspondence (I920-I936)]. In: Arkhiv A.M. Gor'kogo [Archive A.M. Gorky]. Moscow, IWL RAS Publ., 200I. Vol. I6. 543 p. (In Russ.)

2 Belova L.I. Russkoe slovo na zarubezhnom ekrane [A Russian word on the foreign screen]. Moscow, Znanie Publ., I980. 56 p. (In Russ.)

3 Bogomolov Iu. "Nostal'giia vpered" uzhe ne vozmozhna ["Nostalgia Ahead" is no longer possible]. Iskusstvo kino, 20I4, no 9, pp. III-II6. (In Russ.)

4 Glagoleva N. Iz istorii ekranizatcii Gor'kogo za rubezhom [From the history of Gorky's adaptations abroad]. Iskusstvo kino, I968, no 3, pp. 8-9. (In Russ.)

5 Gor'kii M. Po puti na dno [On the way to the bottom]. In: God dvadtsat' pervyi. Al'manakh trinadcatyi [The Twenty-first Year. Almanac thirteenth]. Moscow, Goslitizdat Publ., I938, pp. I9-28. (In Russ.)

6 Gor'kii M. Polnoe sobranie sochinenii. Pis'ma: $v 24$ t. [Complete works: Letters: in 24 vols.]. Moscow, Nauka Publ., 2006. Vol. I2. 726 p. (In Russ.)

7 Gor'kii M. Polnoe sobranie sochinenii. Khudozhestvennye proizvedeniia: $v 25 t$. [Complete works: in 24 vols.]. Moscow, Nauka Publ., I973. Vol. I9. 560 p. (In Russ.)

8 Zamyatin E. Gor'kii [Gorky]. In: Zamyatin E.I. Sobranie sochinenii: $v 5 t$. [Collected works: in 5 vols.]. Moscow, Russkaia kniga Publ., 2004, vol. 3, pp. 60-72. (In Russ.)

9 Zaozerskaia A. Vladimir Kott: “Ia ne nastol'ko ekstremal'nyi rezhisser, chtoby iz p'esy Gor'kogo sozdat' fil'm-zhest' ili chernukhu” [Vladimir Kott: “I'm not such an extreme film director to make a film-gesture or a porn out of Gorky's play”]. Vecherniaia Moskva [Evening Moscow], 20I4, no I48, August I8. (In Russ.) Letopis' rossiiskogo kino: 1863-1929 [Chronicle of Russian cinema: I863-1929], ed. V.I. Fomin. Moscow, Materik Publ., 2004. 698 p. (In Russ.) Neizvestnye pis'ma Yevgeniia Zamyatina iz amerikanskogo arkhiva [Unknown letters of Yevgeni Zamyatin from the American archive], introd., publ., comm. by Dzh. Kurtis. In: Yevgeni Zamyatin i kul'tura XX veka [Yevgeni Zamyatin and the culture of the $20^{\text {th }}$ century]. St. Petersburg, RNB Publ., 2002, pp. 30I-35I. (In Russ.) Plotnikova A.G. M. Gor'kii i kinematograf [M. Gorky and cinema]. Moscow, IWL RAS Publ., 20I8. 336 p. (In Russ.)

I3 Pravda, I9I8, no 279, December 22. (In Russ.)

I4 Proektor, I9I7, no II/I2, p. I2. (In Russ.)

I5 Chekhov A.P. Polnoe sobranie sochinenii: $v$ zo t. [Complete works: in 30 vols.]. Moscow, Nauka Publ., I982. Vol. II. 79I p. (In Russ.)

I6 Durgnat R. Jean Renoir. London, Los-Angeles, I974. 442 p. (In English)

I7 Pickowicz P.G. Sinifying and Popularizing Foreign Culture: From Maxim Gorky's “The Lower Depths” to Huang Zuolin's “Ye dian”. Modern Chinese Literature, I993, vol. 7, no 2, pp. 7-3I. (In English) 


\section{"LA VITA DI KLIM SAMGIN" E IL ROMANZO DELL' "UOMO SENZA QUALITÀ"}

This is an open access article distributed under the Creative Commons Attribution 4.0 International (CC BY 4.0)
(C) 2020. P. Cioni

Istituto italiano di Cultura di San Pietroburgo, Russia Data di invio dell'articolo: Io Settembre 2019 Data di pubblicazione: 25 giugno 2020

Sommario: A partire dagli anni 30 del XX secolo, l'interpretazione dell'opera di M. Gor'kij è stata profondamente condizionata da un giudizio di tipo politico, che ha determinato, soprattutto in Occidente, una notevole diminuzione dell'interesse per la sua figura di scrittore. Inoltre, l'identificazione di M. Gor'kij con il realismo socialista ha spesso portato i critici a negare il suo talento. Le storie della letteratura russa dedicano, ormai, pochissimo spazio allo scrittore e le sue opere, con rare eccezioni, non vengono più tradotte. A questo punto vale la pena chiedersi se l'identificazione di Gor'kij con il realismo socialista, almeno dal punto di vista letterario, corrisponda al vero. Molti documenti pubblicati negli ultimi anni dimostrano che lo scrittore non partecipò alle riunioni che portarono alla definizioni della nuova corrente letteraria e che, una volta creata l'Unione degli scrittori non fosse assolutamente d'accordo sul modo in cui era stata organizzata. Inoltre, le ultime opere di M. Gor'kij a partire da "I racconti del 2224" fino a "La vita di Klim Samgin", come aveva già acutamente notato Mark Slonim nel I953, non hanno nulla in comune con il realismo socialista. Questo articolo mira a fornire una diversa interpretazione dell'ultimo romanzo di M. Gor'kij e lo reiserisce nell'ambito del modernismo europeo, basandosi sia sull'analisi tematica di "La vita di Klim Samgin”, che sulle dichiarazioni dello stesso scrittore. Rileggendo infatti le sue ultime opere risulta chiaro che negli anni Trenta, M. Gor'kij non ha mai scritto una sola riga nello spirito del realismo socialista.

Parole chiave: “La vita di Klim Samgin”, M. Gor’kij, Realismo socialista, uomo senza qualità, modernismo.

Informazioni sull'autrice: P. Cioni, dottore di ricerca in Storia della Russia, Direttore dell'Istituto italiano di Cultura di San Pietroburgo, Piazza del teatro Io, I90068 San Pietroburgo, Russia. ORCID ID: 000o-0002-6878-9357

E-mail: paolacioni@gmail.com

Per citazioni: Cioni P. "La vita di Klim Samgin” e il romanzo dell' "uomo senza qualità”. Studia Litterarum, 2020, vol. 5, no 2, pp. 252-269. (In Italian)

DOI: $10.22455 / 2500-4247-2020-5-2-252-269$ 


\section{LIFE OF KLIM SAMGIN AS A NOVEL ABOUT THE "MAN WITHOUT QUALITIES"}

This is an open access article distributed under the Creative Commons Attribution 4.0 International (CC BY 4.0)
(C) 2020. P. Cioni

Italian Institute of Culture in St. Petersburg, St. Petersburg, Russia

Received: September Io, 2019

Date of publication: June 25, 2020

Abstract: Starting from the I930s, the interpretation of Maxim Gorky's works has been deeply influenced by the judgements of political kind that determined, especially in the Western world, a considerable decrease in interest towards his works. Furthermore, the identification of Gorky with socialist realism often made critics completely deny his literary talent. Today's courses of Russian literature do not devote much space to Gorky and his literary works, with rare exceptions, are no longer translated. At this point, it is worth asking oneself if Gorky's association with socialist realism was true. Many documents published in the last few years show that the writer did not even take part in the meetings which defined new developments in literature and that after the Union of writers had been created, he did not agree with the way it was organized. Besides, the late works by Gorky, starting from Short Stories of the 1922-1924 and ending with Life of Klim Samgin, as it has been argued by Mark Slonim in 1953, have nothing in common with socialist realism. The goal of this article is to give a different interpretation of Gorky's last novel and to place it back into the context of European modernism, through both the thematic analysis of Life of Klim Samgin and the statements of the writer himself. In fact, while reading the writer's last works it becomes clear that Gorky never wrote a single line in the spirit of Socialist Realism.

Keywords: Life of Klim Samgin, M. Gorky, socialist realism, "man without qualities”, modernism.

Information about the author: Paola Cioni, PhD in Russian History, Director of Italian Institute of Culture in St. Petersburg, Theater Square I0, I90068, St. Petersburg, Russia. ORCID ID: 0000-0002-6878-9357

E-mail: paolacioni@gmail.com

For citation: Cioni P. Life of Klim Samgin as a Novel about the "A Man without Qualities". Studia Litterarum, 2020, vol. 5, no 2, pp. 252-269. (In Italian)

DOI: IO.22455/2500-4247-2020-5-2-252-269 
УДК 82I.I6I.I

ББК $83.3(2 \mathrm{Poc}=\mathrm{Pyc})$

\section{«ЖИЗНЬ КЛИМА САМГИНА» И СЮЖЕТ О «ЧЕЛОВЕКЕ БЕЗ СВОЙСТВ»}

\author{
(C) 2020 г. П. Чони \\ Итальянский институт культуры в Санкт- \\ Петербурге, Санкт-Петербург, Россия \\ Дата поступления статьи: го сентября 20І9 г. \\ Дата публикации: 25 июня 2020 г.
}

DOI: I0.22455/2500-4247-2020-5-2-252-269

Аннотация: Начиная с г930-х гг. интерпретация творчества М. Горького была обусловлена политической конъюктурой, которая привела, прежде всего, на Западе, к заметному снижению интереса к его творчеству. Кроме того, отождествление Горького с соцреализмом часто заставляло критиков полностью отрицать его литературный талант. Специалисты по русской литературе сейчас отводят писателю очень мало места, и его произведения, за редким исключением, больше не переводятся. Здесь стоит спросить, соответствует ли суждение о Горьком как соцреалисте реальному положению вещей. Многие документы, опубликованные в последние годы, показывают, что писатель практически не участвовал в собраниях, на которых осуждалось определение нового литературного метода, и что после создания Союза писателей не согласился с тем, каким образом он был организован. Кроме того, последние работы М. Горького, начиная с «Рассказов І922-24 годов» и до романа «Жизнь Клима Самгина», как проницательно отметил Марк Слоним в 1953 г., не имеют ничего общего с соцреализмом. Цель этой статьи - дать другое толкование последнего романа М. Горького и подтвердить его значимость в контексте европейского модернизма, опираясь как на тематический анализ «Жизнь Клима Самгина», так и на заявления автора. При рассмотрении последних произведений писателя, становится ясно, что М. Горький никогда не писал ни единой строчки в духе соцреализма.

Ключевые слова: «Жизнь Клима Самгина», М. Горький, «человек без свойств», социалистический реализм, модернизм.

Информация об авторе: Паола Чони - кандидат исторических наук, директор Итальянского института культуры в Санкт-Петербурге, Театральная площадь, д. IO, I90068 г. Санкт-Петербург, Россия. ORCID ID: о0оо-о0о2-6878-9357

E-mail: paolacioni@gmail.com

Для цитирования: Cioni P. «Жизнь Клима Самгина» и сюжет о «человеке без свойств» // Studia Litterarum. 2020. T. 5, № 2. С. 252-269. DOI: $10.22455 / 2500-4247-2020-5-2-252-269$ 
Il saggista Ippolito Pizzetti, nella sua bella introduzione alla traduzione italiana de "La Vita di Klim Samgin" definisce il romanzo come "un capolavoro" [22, p. VIII] difficile da inquadrare in quanto rappresenta una novità assoluta in ambito letterario. La novità del romanzo nel panorama europeo è ben sottolineata anche da Leone Ginzburg: "A chi domandasse, con fare sbrigativo, se questo è un romanzo ottocentistico o un romanzo novecentistico non si saprebbe rispondere in breve. La sapienza di certi scorci, la maliziosa semplicità di molte notazioni richiamano la grande tradizione narrativa del secolo scorso; ma la virtuosità con cui certe vaste rievocazioni della memoria s'incastrano nel corso del racconto, il coraggioso buongusto con cui anche i contadini son fatti parlare senza pedanteschi compiacimenti folcloristici dimostrano un perspicuo riconoscimento delle migliori conquiste della novissima letteratura". Secondo il critico "i motivi ricorrenti nei ricordi di Klim Samgin ci riportano al gusto letterario dell'ultimo decennio" [I9, p. 236]. Tale affermazione può apparire stravagante soprattutto per un romanzo da sempre considerato un esempio di realismo socialista. In realtà, come afferma L. Spiridonova, “сложное полифоническое единство, в котором судьба отдельной личности рассматривается на фоне сорока лет жизни России и развития общественного сознания интеллигенции, никак не назовешь типичным образцом соцреализма” [І6, p. 229]. Il punto di vista di Lidia Spiridonova è largamente condivisibile del resto basta partire dalla definizione di realismo socialista quale «правдивого, исторически-конкретного изображения действительности в её революционном развитии» [I7] per comprendere quanto le intenzioni di Gor'kij fossero lontane da tale tipo di rappresentazione, soprattutto se si tiene conto delle caratteristiche del personaggio principale Klim Samgin, il quale va a ingrossare la lista degli "uomini senza qualità" al centro di 
molti romanzi della letteratura europea da Musil a Kafka, da Svevo a Pirandello. Come scrive infatti A. Ovčarenko:

Клим Самгин - тип мирового значения и в том смысле, что он является художественным достижением, делающим честь не одной лишь русской литературе, и в том что мысли, чувства Клима Самгина при всей их национальной окрашенности присущи определенным слоям буржуазной интеллигенций (и не только интеллигенций) других стран [ı2, p. 2о2].

A. Ovčarenko è uno dei rarissimi critici sovietici che inserisce il romanzo nel più vasto quadro della letteratura europea, ma non è il solo ad avere un opinione di questo tipo. Di notevole rilievo è lo studio del critico francese Philippe Chardin, esperto di letteratura comparata, il quale analizza La vita di Klim Samgin nella serie di nove opere oggetto del suo saggio "Le roman de la conscience dangereuse" [18]. I nove romanzi hanno come punto in comune quello di narrare l'Europa del periodo che precede la prima guerra mondiale attraverso gli occhi degli intellettuali, e terminano nell'immediato dopo guerra. Al centro dell'analisi del critico francese vi è il rapporto tra i personaggi e lo spirito del tempo, analizzato partendo dalla definizione che Hegel da nella Fenomenologia dello spirito della "coscienza infelice”. Per Hegel la coscienza sarebbe infelice per l'impossibilità di raggiungere il trascendente, pur aspirandovi. Nell'incapacità di trovare una mediazione tra ciò che è caduco e ciò che è eterno, l'uomo si trova in un vicolo cieco. Da tale condizione nasce una forma di alienazione dell'uomo da se stesso. È tale alienzazione, o per usare le parole di Hegel tale infelicità, a rendere l'uomo del Novecento inadatto ad agire nel mondo, incapace di porsi in una relazione equilibrata con la realtà sociale, con i suoi simili. Per questo motivo l'uomo inutile, l'inetto o per usare la terminologia di Musil "L'uomo senza qualità" diviene protagonista di molti romanzi del tempo, ivi compreso "La vita di Klim Samgin".

Gli autori scelti da Chardin sono I. Svevo ("La coscienza di Zeno"), M. Proust ("A la recherche du temps perdu"), R. Musil ("Der Mann ohne Eigenschaften”), T. Mann ("Der Zauberberg”), R. Martin du Gard ("Les Thibaulds"), H. Broch ("Die Schlafwandler"), J. Roth ("Radetzkymarsch”), L. Aragon (“Les voyageurs de l'Imperial"). Intenzione di questi autori non è, a suo avviso, fare il ritratto di un'epoca ma raccontare lo spirito del tempo, in un periodo in cui l'intellettuale gioca un ruolo ambiguo non è più né padrone né schiavo, e fatica a deter- 
minare il proprio posto nella società. Del resto è lo stesso Gor'kij ad affermare in una lettera del Io settembre I925 a R. Rolland: “ я напишу не роман, а хронику духовной жизни России с 8о-х годов до 918-го” [7, p. 263]. Secondo Chardin la scelta tematica degli autori sarebbe dovuta alla influenza dell'idealismo, che resterebbe forte anche in scrittori materialisti come M. Gor'kij o L. Aragon [cfr. I8, p. II], tanto da portarli ad ammettere "implicitement le postulat de bas de la Geistesgeschichte allemande: à chaque époque correspond un esprit du temps dominant, et un seul, cette unité synthétisante important beaucoup plus que le detail de formes et de pensée etrêmement diverse qui peuvent par ailleurs coexister au sein d'une même époque" [I8, p. II]. L'influenza dell'idealismo tedesco, che si era diffusa attraverso la lettura di Hegel o di Spengler, sarebbe stata secondo il critico francese determinante su tutti gli scrittori da lui esaminati. Senza dubbio, infatti, la lettura di Spengler lascia una traccia molto forte sul pensiero di Gor'kij, come dimostrano gli studi in N. Primočkina, che a proposito nota:

Он читал книгу («Закат Европы») с карандашом в руках и оставил на ее страницах множество помет. Об особом интересе и внимании писателя к книге свидетельствует и тот факт, что обычно скупой на словесные пометы в книгах, в данном случае он оставил достаточно много развернутых замечаний и реплик на полях, которые демонстрировали не только согласие, но и живую полемику, горячий спор Горького с основными идеями немецкого философа $[\mathrm{I} 4, \mathrm{p} .55]$.

Ancora più significativo in tal senso è quanto scrive Gor'kij a Prišivin in una lettera del I925:

...«закат Европы» - на мой взгляд - факт неустранимый <...>. Устали здесь люди, живут - не серьезно, а так как-то - без главного. Особенно ясна эта усталость и отсутствие «главного» в литературе, в живописи, вообще - в искусстве [7, vol. I5, p. II9].

Non è inoltre da trascurare il fatto che Gor'kij inizia a riflettere sulla crisi della sua epoca, anche se soprattutto in relazione alla crisi dell'intelligencija, molti anni prima. Nel saggio "Разрушение личности”, pubblicato nel I9o9 nella raccolta “Очерки философии коллективизма” [9], lo scrittore da un giudizio 
decisamente negativo degli intellettuali a lui contemporanei, che in nome di un estremo individualismo sarebbero incapaci di fondersi nel collettivo e battersi per il bene comune. E a proposito dell'intellettuale del suo tempo scrive:

...мы видим горестную пустоту его души, и это должно заставить нас подумать о том, чем грозит нам будущее, посмотреть, чему поучает прошлое, открыть причины, ведущие личность к неизбежной гибели [9, p. 389].

E infatti come spiegherà lo stesso autore nel I93I in una riunione in cui gli viene posta una domanda sul significato de "La vita di Klim Samgin":

Эта книга затеяна мною давно, после первой революции 905-6 года, когда интеллигенция, считавшая себя революционной, - она и действительно принимала кое-какое участие в организации первой революции, - в 7 и 8 годах начала круто уходить направо. Тогда появился кадетский сборник «Вехи» и целый ряд других произведений, которые указывали и доказывали, что интеллигенции с рабочим классом и вообще с революцией - не по дороге. У меня явилось желание дать фигуру такого, по моему мнению, типичного интеллигента Заката Европы [3].

Lo scrittore, sempre nella stessa occasione, precisa che il protagonista del suo libro non è una figura esclusivamente russa e, riferendosi all'intellettuale che vuole descrivere, afferma:

Я его знал лично в довольно большом количестве, но, кроме того, я его знал исторически, литературно, знал его как тип не только нашей страны, но и Франции и Англии. Этот тип индивидуалиста, человека непременно средних интеллектуальных способностей, лишенного каких-либо ярких качеств, проходит в литературе на протяжении всего XIX века [3].

È interessante notare come il romanzo, progettato negli anni dieci del Novecento, inizi a prendere forma nel I925, quando Gor'kij, ormai in esilio a causa delle forti frizioni con il governo sovietico, dopo un lunghissimo periodo in cui si era occupato solo di attività pubblicista e editoriale, impiegando tutte le sue forze per salvare l'intelligencija in difficoltà, aveva finalmente ripreso a scrivere e, so- 
prattutto, a cercare nuovi modi di espressione. I "Racconti degli anni I922-I924" e "Note di diario. Ricordi”, nati proprio in quegli anni, rappresentano nella complessa produzione gor'kijana una fase completamente nuova. Il 25 marzo del 1928 scriveva a V. Zazubrin:

«Рассказы 22-24 гг.»- моя попытка обрить некоторую внутреннюю лохматость <...> и, в то же время, это - ряд поисков иной формы, иного тона для «Клима Самгина» <...>. Лично для меня поиски эти я считаю очень полезными, особенно если вспомнить что с осени І6-ого г. по зиму 22-ого я ведь не написал не строки [7, vol. I5, p. 269].

Non a caso N. Primočkina definisce la scrittura dei "Racconti degli anni I922-I924" e di "Le note di diario" come lavori "sperimentali”: In questi libri, afferma la studiosa, - Gor'kij cerca di allontanarsi dalla precedente maniera di scrivere, trovare nuove forme di espressione capaci di trasmettere la tragica complessità del mondo nella nuova epoca [cfr. I3, p. I8). Il risultato degli sforzi dello scrittore è evidente: la produzione letteraria degli anni che vanno dal '22 al '36 è sostanzialmente diversa sia da quella dei primi racconti che hanno come protagonista il bosjak, e in cui è forte l'influenza di Nietzsche, sia da quella degli anni I905-I9Io, soprattutto se si guarda a Mat' e a Ispoved', dove l'elemento ideologico è volutamente molto forte. I due romanzi sono scritti nel periodo in cui Gor'kij compie una scelta definitiva a favore dei bolscevichi e si impegna in prima persona in politica, partecipando alle polemiche all'interno della frazione e facendosi promotore della scuola per operai di Capri. Nelle sue lezioni di Storia della letteratura russa tenute per gli operai della scuola di Capri nel I909, il cui manoscritto fu dato alle stampe dopo la morte dello scrittore afferma: “Литература, роман, повесть и т. д. является наиболее распространенным и успешным приемом пропаганды тех или иных идей” [6, p. I], ma a partire dal I9Iо si allontana da questa visione. Dopo la delusione politica, seguita alla fine della scuola di Capri, che definisce la morte della sua illusione n.Ior [7, vol. 7, p. 229], Gor'kij torna alla letteratura, eliminando totalmente l'elemento ideologico dalle sue opere. Il suo impegno politico resta costante, ma la scrittura diviene un campo separato in cui cerca una rivincita personale.

La corrispondenza degli anni del secondo esilio vede Gor'kij immerso nel mondo letterario alla ricerca di personaggi per i suoi racconti, ma anche attento 
lettore di romanzi a lui contemporanei, di cui discute con amici scrittori. Con i "Racconti degli anni I922-I924" M. Gor'kij concentra la sua attenzione da una parte sulla forma, dall'altra sullo studio di tipi letterari, di cui approfondisce la psicologia: i protagonisti sono antieroi che lo hanno colpito per alcune caratteristiche nel comportamento. Come giustamente scrive M. Selezneva: "Внимание писателя прежде всего сосредоточено на внутреннем мире индивида, на неосознаваемых движениях его души, на мотивах поступков в отношениях с окружающим миром, социумом, на соотношении сознательного и подсознательного” [ 5 , p. 8]. Questo aspetto è particolarmente evidente in “Karamora", il cui protagonista, proprio per le caratteristiche di doppiezza, è forse tra i personaggi gor'kiani che più si avvicina a Klim Samgin. Mentre lavora sul racconto, Gor'kij confessa a R. Rolland:

Недавно в одних «Мемуарах» я прочитал о человеке, которого мне тоже пришлось видеть в прошлом. Это некто Михайлов, рабочий, социал-демократ, он дважды был в ссылке, в Сибири, организовал в 906 г. вооруженное восстание в Темернике. Кажется, с 9Іо года он служил в жандармской полиции, оставаясь членом партии, конечно. В I7 году его «разоблачили». На вопрос: почему он предавал? Михайлов ответил буквально так: - Вы знаете, что я способен на подвиги, ну, вот так же тянет делать подлость самому близкому человеку [7, vol. I4, p. 239].

Lo scrittore non è interessato al rapporto del protagonista con l'ambiente rivoluzionario, ma alla sua doppiezza che può manifestarsi in qualsiasi circostanza e chiarisce:

В русском языке подвиг и подлость фонетически похожи. Я очень боюсь, что подвиг и подлость имеют один и тот же корень в душе <...>. Герой моего рассказа, революционер, сделался провокатором для того, чтоб узнать: есть в нем сила, которая могла бы запретить ему сделать преступление? Такой силы в нем не нашлось [7, vol. I4, p. 239].

La mancanza di tale forza, l'incapacità di agire, l'indifferenza verso il mondo esterno sono caratteristiche che ritroviamo nel romanzo fiume di Gor'kij e in tanti altri protagonisti della letteratura del tempo. 
Quello che porta a Klim Samgin è quindi un percorso stilistico, ma anche tematico, fatto di tentativi per approdare a una forma diversa di scrittura e l'esempio a cui mira Gor'kij è senza dubbio quello della grande letteratura europea, che in quegli anni pone al centro del romanzo l'interiorità dell'individuo.

Come Karamora, Klim Samgin è un antieroe, doppiogiochista, anche se come scrive Erica Klein il "suo doppio gioco è esclusivamente con se stesso. Nessuno lo accusa, nessuno lo incalza, nessuna situazione esterna lo mette alle strette, egli è unicamente impegnato a discutere con se stesso per trovare argomenti sempre nuovi, sempre validi, sempre adeguati al mantenimento del proprio stato di quiete morale” [18, p. 6o]. Con Klim Samgin, Gor'kij vuole creare un tipo letterario universale non ha in mente una caratteristica peculiare dell'anima russa:

Я вижу людей, которые чувствуют что внутри их всё непрочно, всё горит, плавится, разрушает целостность чувства, и чувство улетучивается, как газ, в мыслях, словах - человек опустошается [7, vol. I4, p. 240].

A nostro avviso Chardin ha, quindi, ragione a definire "La vita di Klim Samgin" un romanzo della coscienza e a scrivere che: "est le sentiment du soi que l'on privilègie par rapport à la conscience de soi” [20, p. 32]. In "Karamora”, ma anche in "La vita di Klim Samgin", l'elemento saliente è la coscienza allo stato puro o per usare le parole di Chardin una sorta di animalità, a cui l'uomo non può sottrarsi. Ed è questo elemento a costituire il vero campo di indagine di Gor'kij negli ultimi anni della sua vita. Lo scrittore scegli quindi situazioni estreme per mettere a nudo i suoi eroi. In "Karamora” Gor'kij fa spiegare le ragioni dell'indifferenza alla vita e agli uomini dallo stesso protagonista:

Я выдал охране и отправил на каторгу одного из лучших партийных товарищей. <...>. Выдал я его и ждал, что теперь в душе моей что-то взвоет. Ничего не взвыло [ıо, vol. г6, p. I64].

Ma quando Karamora prova ad analizzare le motivazioni della propria meschinità, non trova risposta:

Никак не могу не связывать себя с кем-то или с чем-то, с людьми или событиями. Не могу, и - это очень похоже все-таки на попытку оправдать 
себя, попытку, скрываемую мною неискусно. А между тем я совершенно лишен желания оправдываться, это я и знаю, и чувствую. Это не из гордости, не из отчаяния человека, который изломал свою жизнь непоправимо. Не потому, что я хотел бы крикнуть: да, я преступник, вы - тоже, но у вас сила, убивайте! Мне кричать некуда, некому. Людей я не чувствую, они мне не нужны [ı, vol. I6, p. I64].

Quello di Karamora è lo stesso stato d'animo che troviamo nel protagonista de "La vita di Klim Samgin". In una delle scene chiave del romanzo, Klim, ancora bambino, passa con facilità dal podvig alla pošlost': offre prima il suo aiuto all'amico Boris che sta annegando, ma poi, senza alcuna ragione, molla la presa e lo lascia morire, con una indifferenza quasi disumana:

Борис поймал конец ремня, потянул его и легко подвинул Клима по льду ближе к воде, - Клим, взвизгнув, закрыл глаза и выпустил из руки ремень. А открыв глаза, он увидел, что темно-лиловая, тяжелая вода все чаще, сильнее хлопает по плечам Бориса, по его обнаженной голове и что маленькие, мокрые руки, красно́ поблескивая, подвигаются ближе, обламывая лед. Судорожным движением всего тела Клим отполз подальше от этих опасных рук, но, как только он отполз, руки и голова Бориса исчезли, на взволнованной воде качалась только черная каракулевая шапка, плавали свинцовые кусочки льда и вставали горбики воды, красноватые в лучах заката. Клим глубоко, облегченно вздохнул, все это страшное продолжалось мучительно долго. <...>

Клим смотрел, как вода, успокаиваясь, текла в одну сторону, играя шапкой Бориса, смотрел и бормотал:

- Она его утопила... Он кричал - пусти, ругал ее. Ремень он вырвал... [Io, vol. 20, p. 83].

Klim ha assistito alla scena indifferente, incapace di provare una qualsiasi emozione e di agire per salvare l'amico. A questo punto della narrazione accade qualcosa di inaspettato, un uomo che cerca di capire cosa accaduto chiede:

Да - был ли мальчик-то, может, мальчика-то и не было?

«Был!» - хотел крикнуть Клим и не мог [Іо, vol. 2о, p. 83]. 
Naturalmente Klim non trova la forza per reagire, né di confessare la sua colpa. Il был ли мальчик, che introduce un elemento di tipo espressionistico, in una narrazione fino a quel momento segnatamente realistica, servirà a Klim per lavarsi la coscienza [cfr 4, p. 15-4I].

Ужас, испытанный Климом в те минуты, когда красные, цепкие руки, высовываясь из воды, подвигались к нему, Клим прочно забыл; сцена гибели Бориса вспоминалась ему все более редко и лишь как неприятное сновидение. Но в словах скептического человека было что-то назойливое, как будто они хотели утвердиться забавной, подмигивающей поговоркой: «Может, мальчика-то и не было?» [Iо, vol. 20, p. 9I].

Il был ли мальчик diventa quasi un ritornello che Klim continua a ripetere nelle situazioni più disparate, il leitmotiv del romanzo, la sua autogiustificazione [cfr. 4, p. I5-4I]. A fare da padrone in tutto il romanzo è l'indifferenza e la capacità di Klim di razionalizzare ogni cosa, anche grazie alla sua cultura, che però non lo spinge verso azioni positive. Klim è come uno specchio che tutto riflette nella sua immobiltà, ma non impara a vincere l'apatia, sa inventare se stesso, adattarsi alle situazioni più disparate, ma non agire.

In Gor'kij sembra essere definitivamente crollata la fede nell'uomo, che agli inizi del secolo rappresentava il tratto più evidente della sua concezione del mondo. Se, infatti, nel 1899 Gorkij idolatrava l'essere umano e scriveva a Repin: “Я не знаю ничего лучше, сложнее, интереснее человека. Он - всё. <...> Я уверен, что человек способен бесконечно совершенствоваться” [7, vol. I, p. 377], dopo la rivoluzione questa concezione si ribalta. In "Karamora" troviamo un affermazione che trasforma il credo giovanile dello scrittore «Человек - это зверь, который сошел с ума» [Іо, vol. I6, p. I57]. Da queste riflessioni nasce antieroe gorkiano che riempie le pagine dei racconti e de "La vita di Klim Samgin”, popolate da uomini meschini, deboli, opportunisti, doppiogiochisti, estranei emotivamente sia alla realtà che agli altri uomini. Non a caso il primo titolo dato dallo scrittore al romanzo è «История пустой души».

Klim nelle sue riflessione e nel suo atteggiamento verso la vita non è diverso dall'Ulrich di Musil, nè da Zeno o dagli altri uomini inutili di Svevo, e come loro è immerso in una profonda apatia. 
"La vita Klim Samgin” è un romanzo ambientato nel passato quasi una contraddizione in un epoca in cui in Unione Sovietica andava affermandosi "il romanzo dell'avvenire" richiesto dai limitati precetti del realismo socialista, soprattutto perché a scriverlo è l'autore che secondo la critica del tempo meglio avrebbe dovuto rappresentare la nuova letteratura proletaria. Marc Slonim sottolinea quella che solo apparentemente può sembrare una stranezza. " It was odd and somewhat paradoxical, - scrive Slonim - that the man admired as the leader of Soviet literature and the dean of proletarian writers belonged, because of his subject matter, completely to the pre revolutionary period” [23, p. 5I]. Slonim è però uno dei rarissimi critici a notare tale paradosso.

In realtà, negli ultimi anni della sua vita, lo scrittore si immerge nella scrittura del suo romanzo testamento, che ritiene sarà la sua opera migliore: scrive, riscrive, corregge, lavorando fino a IO-I2 ore al giorno, in modo ossessivo, quasi a cercare la perfezione [2I] e quando arriveranno le prime critiche non si darà per vinto, non cambierà direzione, né tema. Con "La vita di Klim Samgin”, Gor’kij vuole affermare la libertà di essere scrittore e di scegliere un proprio campo di indagine, rendendo protagonisti delle sue opere personaggi lontanissimi dalla rivoluzione e da se stesso. La politica non trova più posto tra le sue pagine e il suo ultimo romanzo altro non rappresenta che la rivincita della letteratura. Se è vero infatti che Gor'kij accetta il ruolo di primo scrittore proletario, esempio di realismo socialista, è altrettanto vero che, negli anni Venti e Trenta, non ha scritto una sola riga nello spirito della nuova corrente letteraria, creata a tavolino da Stalin. La documentazione recentemente pubblicata sugli incontri preparatori del Primo Congresso degli scrittori socialisti dimostrano che Gor'kij non collaborò in nessun modo alla definizione del Realismo socialista. I. Gronskij, che ebbe il ruolo di segretario di tali incontri, ha lasciato una testimonianza molto accurata di come andarono i fatti [г]. “Я помню, - scrive Gronskij, - беседы с Алексеем Максимовичем в 28-м, 29-м, 3І-м годах. Он говорил, что было бы хорошо все писательские организации объединить, что это объединение дало бы возможность расширить влияние коммунистов и советских настроенных литераторов на всю писательскую массу. Но тогда это провести было нельзя - обстановка не созрела для такого решения” [2, p. 7-8].

La testimonianza di Gronskij è di estrema utilità anche per chiarire il complesso rapporto tra Gor'kij e Stalin: 
Сталин относился к Горькому, на мой взгляд, весьма прохладно. Не раз мне приходилось слышать такие рассуждения: Что такое Алексей Максимович? После поражения революции I905-I907 гг. «Каприйская школа»: Богданов, Базаров, Луначарский, Шулятиков и прочие - враги большевизма. Во время войны выступает за поддержку войны. Колеблется. Перед февральской революцией, когда уже ясно, что монархический строй трещит, он предлагает издать газету «Луч» - правее социал-демократов, левее кадетов. Что это за позиция? Конституционная монархия или буржуазная республика вроде французской. Между февралем и октябрем против большевиков. «Новая жизнь» - борьба против Ленина. Поехал за границу - выпускает там журнал «Беседа» - антисоветский журнал. Теперь связь с вождями оппозиционных группировок: Бухариным, Каменевым, Радеком» <...>. Тем не менее Сталин прекрасно понимал, что Горький <...> это «политический капитал» [I7, р. I5I].

Ancora più significativo dell'atteggiamento di Gor'kij nei confronti dell'Unione degli scrittori, che lui stesso dirigeva, è il contenuto della lettera scritta a V. Molotov il Io gennaio I936, dove lamentava la mancanza di qualsiasi discussione: “В Союзе за полтора года после съезда не было ни одного дискуссионного собрания литераторов, а ведь поговорить, поспорить есть о чем! Вот, например, по поводу статей Эренбурга о Маяковском, по вопросу о пределах свободы творчества? Союз устроил для них хоть один литературный вечер? Что это? Паралич? Саботаж?» [5, p. 44]. Riportando le dichiarazioni di Gronskij e la lettera a Molotov non intendiamo certo giustificare Gor'kij per alcune delle decisioni prese negli ultimi anni della sua vita, ma mostrare che la "parabola esistenziale" dello scrittore è molto più complessa di quanto fino ad oggi ricostruito e che il giudizio sulla sua opera non può essere limitato dai singoli, seppur significativi, momenti di appoggio alla politica staliniana. Fino ad oggi, infatti, la lettura di tutta l'opera di Gor'kij è stata pesantemente condizionata dal giudizio politico sullo scrittore che, soprattutto nel periodo della guerra fredda, ha portato molti critici a negarne il valore letterario. "La vita di Klim Samgin”, il suo ultimo romanzo, il più amato dallo scrittore, meriterebbe una profonda rilettura che gli restituisca il meritato posto tra i capolavori del Novecento. 


\section{Список литературы}

Ариас-Вихиль М.А. «Инженеры человеческих душ» и «социалистический реализм»: о встречах Сталина с писателями на квартире А.М. Горького в I932 году // Постижение Запада. Иностранная культура в советской литературе, искусстве и теории I9I7-I94I гг.: исследования и архивные материалы / отв. ред. Е.Д. Гальцова. М.: ИМЛИ РАН, 2015. С. 644-668. Ариас-Вихиль М.А. Об истории создания термина «социалистический реализм» и подготовке Первого съезда советских писателей (стенограмма беседы И.М. Гронского с сотрудниками Архива А.М. Горького) // Codex manuscriptus. Статьи и архивные публикации / отв. ред. Д.С. Московская. М.: ИМЛИ РАН, 20І9. Вып. І. С. 66-Iі4.

Беседа с писателями-ударниками. Стенограмма. // Литературная учеба. I93I. № I (по выправленной М. Горьким стенограмме беседы). URL: http://gorkiy-lit. $\mathrm{ru} /$ gorkiy/articles/article-46.htm (дата обращения: го.о9.20I9). Борисова Л.М. «Да был ли мальчик-то?». О смысле горьковского рефрена // Вопросы литературы. 2018. № 4. С. І5-4I.

5 Горький и его адресаты // М. Горький. Материалы и исследования. М.: ИМЛИ РАН, 20І6. Вып. ІІ. 488 с.

6 Горький М. История русской литературы // Архив А.М. Горького. М.: Гослитздат, I939. T. I. 340 c.

7 Горький М. Полн. собр. соч. Письма: в 24 т. М.: Наука, І997-(продолж. изд.)

8 Горький М. Полн. собр. соч. Художественные произведения: в 25 т. М.: Наука, I968-I982.

9 Горький М. Разрушение личности Очерки философии коллективизма. СПб.: Знание, г909. 4І2 с.

го Горький М. Собр. соч.: в 30 т. М.: Гослитиздат, І949-1955.

II $\quad$ Гронский И.М. Из прошлого. М.: Известия, I99I. 379 с.

I2 Овчаренко А.И. М. Горький и литературные искания ХХ столетия. М.: Худож. лит., І $982.5 \mathrm{I2}$ с.

I3 Примочкина Н.Н. Горький и писатели русского зарубежья. М.: ИМЛИ РАН, 2003. 36I c.

I4 Примочкина Н.Н. «Любовь и голод правят миром»: культурологическая концепция М. Горького І920-х гг. // Ученые записки Крымского федерального университета имени В.И. Вернадского. Филологические науки. 2ог8. Т. 4 (70), № 2. С. 53-62.

I5 Селезнева М.Н. Поэтика характеров в «Рассказах І922-I924 годов» М. Горького: автореф. дис. ... канд. филол. наук. Тамбов, 2006. 2I с.

I6 Спиридонова Л.А. Творчество Горького и возникновение социалистического реализма // Studia Litterarum. 20I8. T. 3, № I. С. 212-233. 
I7 Устав Союза писателей СССР // Первый Всесоюзный съезд советских писателей. 1934. Стенографический отчет. М.: Гослитиздат 1934. 7 I8 c.

I8 Chardin P. Le roman de la coscience malheureuse. Genève: Librairie Droz, I998. 342 p.

I9 Ginzburg L. Scrittori russi. Torino: Einaudi, I948. 278 p.

20 Klein E. L'epopea di "un uomo senza qualita”: Klim Samgin // Incontri di Studio Istituto. № 47 : Massimo Gor'kij. Milano: Istituto Lombardo-Accademia di Scienza e Lettere, 2006, pp. 59-72.

2 I Knigge A. Der Autor und sein Held: Maksim Gor’kijs Roman “Zizn’ Klima Samgina” im Kontext des modernen europäischen Romans // Zeitschrift für Slavische Philologie. Vol. 48. No. I (I988), pp. I40-I54.

22 Pizzetti I. Introduzione // Gor'kij M. La vita di Klim Samghin. Quarantanni. Torino: Einaudi, I955. T. I. 822 p.

23 Slonim M. Modern Russian Literature: From Chechkov to the present. New York: Oxford University Press, I953. 467 p. 


\section{References:}

Arias-Vikhil' M.A. "Inzhenery chelovecheskikh dush" i "sotsialisticheskii realizm": o vstrechakh Stalina s pisateliami na kvartire A.M. Gor'kogo v 1932 godu ["Engineers of the human soul" and "socialist realism": about the meetings between Stalin and writers at Gorky' house in I932]. Postizhenie Zapada. Inostrannaia kul'tura v sovetskoi literature, iskusstve i teorii I9I7-I94I gg.: issledovaniia i arkhivnye materialy [Comprehension of the West. Foreign culture in the Soviet Literature, Art and Theory I9I7-I94I]; ex. ed. E.D. Gal'tsova. Moscow, IWL RAS Publ., 20I5, pp. 644-668 (In Russ.) Arias-Vikhil' M.A. Ob istorii sozdaniia termina "sotsialisticheskii realizm" i podgotovke Pervogo s”ezda sovetskikh pisatelei (stenogramma besedy I.M. Gronskogo s sotrudnikami Arkhiva A.M. Gor'kogo j [About the origin of the term "socialist realism"]. In: Codex manuscriptus. Stat’i i arkhivnye publikatsii [Codex manuscriptus. Essays and Archive Publications], ex. ed. D.S. Moskovskaya.

Moscow, IWL RAS Publ., 20I9, issue I, pp. 66-II4. (In Russ.)

3 Beseda s pisateliami-udarnikami. Stenogramma [Meeting with writers-shock workers. Transcript]. Literaturnaia ucheba. I93I, no I (po vypravlennoi M. Gor'kim stenogramme besedy). Available at: http://gorkiy-lit.ru/gorkiy/articles/article-46.htm (Accessed ro September 2020) (In Russ.)

4 Borisova L.M. "Da byl li mal'chik-to?” O smysle gor'kovskogo refrena ["Was the boy something, maybe he was not a boy?” About the meaning of Gorky' refrain]. Voprosy literatury, 20I8, no 4, pp. I5-4I. (In Russ.) Gor'kii i ego adresaty [Gorky and his addressees]. In: M. Gor'kii. Materialy i issledovaniia [M. Gorky. Materials and research]. Moscow, IWL RAS Publ., 20I6. Issue II. 488 p. (In Russ.)

6 Gor'kii M. Istoriia russkoi literatury [The history of Russian literature]. In: Arkhiv A.M. Gor'kogo [Archive A.M. Gorky]. Moscow, Goslitzdat Publ., I939. Vol. I. 340 p. (In Russ.)

7 Gor'kii M. Polnoe sobranie sochinenii. Pis'ma: v 24 t. [Complete works. Letters: in 24 vols.] Moscow, Nauka Publ., 1997- (In Russ.)

8 Gor'kii M. Polnoe sobranie sochinenii. Khudozhestvennye proizvedeniia: $v 25$. [Complete works. Literature: in 25 vols.] Moscow, Nauka Publ., I968-I982. (In Russ.)

9 Gor'kii M. Razrushenie lichnosti. Ocherki filosofii kollektivizma [Destruction of the personality. Essays on the philosophy of collectivism]. St. Petersburg, Znanie Publ., I909. 4I2 p. (In Russ.) Gor'kii M. Sobranie sochinenii: $v$ o t. [Collected works: in 30 vols.] Moscow, Goslitizdat Publ., I949-I955. (In Russ.). Gronskii I.M. Iz proshlogo [From the past]. Moscow, Izvestiia Publ., I99I. 379 p. (In Russ.)

Ovcharenko A.I. M. Gor'kii i literaturnye iskaniia XX stoletiia [Gorky and the literary quest of the $2 \mathrm{O}^{\text {th }}$ century]. Moscow, Khudozhestvennaia literatura Publ., I982. 5 I2 p. (In Russ.) 
I3 Primochkina N.N. Gor'kii i pisateli russkogo zarubezh'ia [Gorky and Russian writers abroad]. Moscow, IWL RAS Publ., 2003. 36I p. (In Russ.)

I4 Primochkina N.N. "Liubov' i golod praviat mirom": kul'turologicheskaia kontseptsiia M. Gor'kogo I920-kh gg. [Love and hunger rule the world: cultural conception of M. Gorky in the I920s]. Uchenye zapiski Krymskogo federal'nogo universiteta imeni V.I. Vernadskogo. Filologicheskie nauki, 2018, vol. 4 (70), no 2, pp. 53-62. (In Russ.)

I5 Selezneva M.N. Poetika kharakterov v "Rasskazakh I922-I924 godov" M. Gor'kogo [The poetics of the characters in the Short stories of $1922-I 924$ by M. Gorky: PhD thesis, summary]. Tambov, 2006. 2I p. (In Russ.)

I6 Spiridonova L.A. Tvorchestvo Gor'kogo i vozniknovenie sotsialisticheskogo realizma [Creative Works of M. Gorky and the origin of Socialist realism]. Studia Litterarum, 20I8, vol. 3, no I, pp. 2I2-233. (In Russ.)

I7 Ustav Soiuza pisatelei SSSR. Pervyi Vsesoiuznyi s”ezd sovetskix pisatelei. [Statute of the Union of Writers. The first Congress of Soviet Writers 1934]. Stenograficheskii otchet. Moscow, Goslitizdat Publ. I934. 718 p. (In Russ.)

I8 Chardin P. Le roman de la coscience malheureuse. Genève, Librairie Droz, I998. 342 p. (In French)

I9 Ginzburg L. Scrittori russi. Torino, Einaudi, I948. 278 p. (In Italian)

20 Klein E. L'epopea di “un uomo senza qualità”: Klim Samgin. Incontri di Studio Istituto. № 47: Massimo Gor'kij. Milano, Istituto Lombardo-Accademia di Scienza e Lettere, 2006, pp. 59-72. (In Italian)

2I Knigge A. Der Autor und sein Held: Maksim Gor'kijs Roman “Zizn’ Klima Samgina” im Kontext des modernen europäischen Romans. Zeitschrift für Slavische Philologie.

Vol. 48. No. I (I988). S. I40-I54. (In German) Pizzetti I. Introduzione. Gor'kij M. La vita di Klim Samghin. Quarantanni. Torino, Einaudi, I955. T. I. 822 p. (In Italian)

23 Slonim M. Modern Russian Literature: From Chechkov to the present. New York, Oxford University Press, I953. 467 p. (In English) 
УДК $82.0+7.0$ I

ББК $83.3(2 \mathrm{Poc}=\mathrm{Pyc})$

\section{«КАРНАВАЛ» ШУМАНА В ПОЭЗИИ ДМИТРИЯ КЛЕНОВСКОГО}

(C) 2020 г. А.В. Марков

Российский государственный гуманитарный университет, Москва, Россия;

Владимирский государственный университет им. А.Г. и Н.Г. Столетовых, Владимир, Россия Дата поступления статьи: І3 января 2020 г. Дата публикации: 25 июня 2020 г.

DOI: IO.22455/2500-4247-2020-5-2-270-285

Аннотация: Балет-пантомима «Карнавал» Р. Шумана в постановке М.М. Фокина (I9Iо) способствовал реформе выразительного языка балета. Происходившая при этом семантизация одних элементов и автоматизация других нашла отражение в поэзии Дмитрия Кленовского. Поэт посвятил самому балету цикл из двух стихотворений, но на самом деле указания на художественные принципы этого балета содержатся во многих его стихах. В данной статье доказывается, что внимание Дмитрия Кленовского к сюжету балета «Карнавал» не сводится только к общему интересу этого поэта к постановкам Фокина и танцу Тамары Карсавиной, но важен для выстраивания им своего собственного образа как поэта. Кленовский создает концепцию одинокого поэта, опираясь на роль Пьеро в балете, при этом имеет в виду не только особенности постановки Фокина, но и полемический смысл самого произведения Шумана. Кленовский наследует не только трагической иронии Иннокентия Анненского, но и романтической иронии Шумана. Обращение к замыслу Шумана позволяет объяснить некоторые образы как посвященных балету стихотворений Кленовского, так и других стихотворений с перекликающимися образами. Раскрытие мотивировок некоторых темных образов Кленовского дополняется указанием на типологическое сходство его понимания сюжетной иронии с достижениями тогдашней гуманитарной науки.

Ключевые слова: русский балет, русские сезоны, Шуман, Михаил Фокин, Тамара Карсавина, Дмитрий Кленовский, карнавализация, лирический герой, романтическая ирония, трагизм.

Информация об авторе: Александр Викторович Марков - доктор филологических наук, профессор, Российский государственный гуманитарный университет, Миусская площадь, д. 6, І25993, ГСП-3, г. Москва, Россия; Владимирский государственный университет им. А.Г. и Н.Г. Столетовых, ул. Горького, д. 87, $60000 о$ г. Владимир, Россия. ORCID ID: оооо-ооог-6874-I073

E-mail: markovius@gmail.com

Для цитирования: Марков А.В. «Карнавал» Шумана в поэзии Дмитрия Кленовского // Studia Litterarum. 2020. T. 5, № 2. C. 270-285.

DOI: I0.22455/2500-4247-2020-5-2-270-285 


\section{SCHUMAN'S CARNIVAL IN THE POETRY OF DMITRY KLENOVSKY}

This is an open access article distributed under the Creative Commons Attribution 4.0 International (CC BY 4.0)
(C) 2020. A.V. Markov

Russian State University for the Humanities, Moscow, Russia; Stoletovs Vladimir State University, Vladimir, Russia

Received: January 13, 2020

Date of publication: June 25, 2020

Abstract: The ballet-pantomime Carnival by R. Schumann directed by M.M. Fokin (I9IO) contributed to the reform of the language of the ballet. Semantization of some elements and automation of others found reflection in the poetry of Dmitry Klenovsky. The poet devoted a cycle of two poems to the ballet, however, many of his poems contain allusions to the artistic principles of this performance. This article argues that Klenovsky's appeal to the plot of the ballet Carnival is not limited to the general interest of this poet in Fokin's ballets and Tamara Karsavina's dance but is necessary for him to construct his own image as a poet. Klenovsky invented the concept of a lonely poet relying on the role of Pierrot in the ballet, while taking into account not only the peculiarities of Fokin's production but also the polemical meaning of Schumann's work itself. Klenovsky inherits not only the tragic irony of Annensky but also the romantic irony of Schumann. Examining Schumann ideas allows me to explain the imagery of Klenovsky's poems dedicated to ballet and his other poems with transgressive images. Besides the study of the motivations behind obscure images in Klenovsky's poetry, the article draws typological similarities between his understanding of irony and the achievements of contemporary Russian humanities.

Keywords: Russian ballet, Russian seasons, Schumann, Mikhail Fokin, Tamara Karsavina, Dmitry Klenovsky, carnivalization, lyrical protagonist, romantic irony, tragedy.

Information about the author: Alexander V. Markov, DSc in Philology, Professor, Russian State University for the Humanities, Miusskaya square 6, I25993, GSP-3, Moscow, Russia; Stoletovs Vladimir State University, Gorky St. 87, 600000 Vladimir, Russia. ORCID ID: 0000-000I-6874-I073

E-mail:markovius@gmail.com

For citation: Markov A.V. Schumann's Carnival in the Poetry of Dmitry Klenovsky. Studia Litterarum, 2020, vol. 5, no 2, pp. 270-285. (In Russ.)

DOI: I0.22455/2500-4247-2020-5-2-270-285 
Балет М. Фокина «Карнавал» (І9Iо) на музыку фортепианного цикла P. Шумана (1834-І835) стал событием в истории русского балета: произошла трансформация пространства, времени, самой интриги, не говоря уже о введенных новых хореографических принципах, отчасти обязанных прежним камерным экспериментам [5, c. I60-I62]. Прежний сценический канон, подразумевавший эффектное зрелище на сцене, сменился новым каноном вовлеченности, когда появление на сцене и уход со сцены оказываются не менее выразительными, чем само действие, чем представление. Важно, с какой страстью и каким напором появляется на сцене новый персонаж и начинает определять не только перелом действия, но и само состояние сцены, саму ее как бы состоятельность, как будто он не смог сдержаться и потому оказался в центре самого действия.

Соответственно, было изменено и пространство, от создания иллюзии правдоподобия - к принципиальной условности (расписанный Львом Бакстом задник для Русских сезонов просто представлял небо, украшенное цветами и гирляндами, как бы праздник космоса). Переменилось и качество времени, смена сцен без какого-либо перерыва отчасти предвосхитила кинематографический принцип монтажа, и иной стала интрига, которую в конце концов создает не логика действия, но логика вмешательства в действия, логика действия «поэта» и поэтического вдохновения на сцене.

Вскоре после первой постановки «Карнавал» был принят в «Русские сезоны» как спектакль, предъявлявший публике основные узнаваемые образы нового творчества. Постановка впечатлила западных зрителей настолько, что даже появился мейсенский фарфор с героями «Карнавала» [ı2, с. 89], что стало возможно благодаря продуманной ди- 
зайнерской программе костюмов с использованием синего и золотого света. Коломбину танцевала Тамара Карсавина, которая и была идеалом для Кленовского, восхищавшегося не только ее артистизмом, но и явно «прецедентным именем» [6] ее как своеобразного синонима артистизма и глубоко личной драматургии вообще, и интересом к ее игре была во многом определена разработка этой темы. Эта роль Коломбины принесла ей мировую известность, повлияв даже на сюжеты массовой литературы [Із, c. 257], и отношения Коломбины и Пьеро и оказываются исходными для лирических размышлений Кленовского. Но любовной интригой всё не ограничивается.

Само произведение Шумана, с небывалой психологической проработкой характеров [2, с. 335], представляло собой вершину романтической иронии: предметом этого цикла служит победа давидсбюндлеров, членов выдуманного им «Союза Давида», над «филистимлянами» (филистерами, мещанами). При этом триумф творчества над косностью происходит только в финальной сцене «марша», но предшествующие сцены, принадлежащие карнавально-маскарадным обычаям, наследующие масленичным гуляниям и итальянской комедии дель арте, мотивированы публицистической деятельностью самого Шумана.

Два главных мужских персонажа опуса - Эвсебий и Флорестан псевдонимы самого Шумана как вождя давидсбюндлеров, но также общий сюжет взят из одного из фельетонов композиторов. Следует заметить, что по выводам О.М. Фрейденберг [9, с. 282] Эвсебий, также герой «Мага-чудодея» (г637, Фрейденберг переводит как «Чудесный кудесник») Кальдерона - это образ «святого разбойника», сам по себе ироничный и важный для образования сюжетов как одиночества, соблазнения и падения под влиянием собственного соблазна. Проведенный Фрейденберг образцовый сравнительный анализ «Демона» Лермонтова и пьесы Кальдерона, при всей ироничности формы ее доклада [9] (пародирующего лабораторный журнал), как раз очень важен для нас, учитывая, что весь доклад иронизирует как над принципами научного производства с обязательной отчетностью, так и над коллегами и учителями самой Фрейденберг, которых она чтила, но сам научный поиск того, как именно из амбивалентного мифологического образа возникают одновременно вполне трагические и вполне комические, даже карнавальные сюжеты. 
Шуман напечатал в недавно созданной «Новой музыкальной газете» якобы отчет о карнавале, который происходил в редакции на масленичной неделе, с целью познакомить критиков и ценителей с новой музыкой, но филистеры устроили протест во время показа, так что давидсбюндлерам пришлось их утихомиривать и пройти торжественным маршем. Обиженные филистеры, согласно отчету, организуют отрицательные рецензии на еще не знакомое читателям газеты произведение. Ирония оказывается двойной: музыкальный опус создается как иллюстрация к вымышленному газетному рассказу, а не репортаж объясняет, как воспринималось произведение, а отрицательная рецензия появляется раньше самого реального (не вымышленного) произведения: всё оказывается не просто наоборот, а наоборот в квадрате, с целью показать не только недалекость, но и суетливость филистерских вкусов.

M.М. Фокин создавал свой балет, конечно, как веселое произведение, хотя имея в виду не столько образ обывателя, сколько новый образ поэта как самого драматического субъекта, превосходящего драматизмом и трагизмом привычные амплуа актеров. Для Дмитрия Кленовского, поэта, наследовавшего акмеизму, считавшего себя продолжателем Гумилева и Анненского, впечатления балета (он старался не пропускать ни одного балета с участием Карсавиной) были очень важны: идеал одинокого поэта с развитой чувственностью, отказ от мотивации событий в пользу драматургии вдохновения, многочисленные условности и при этом общая трагическая атмосфера - всё это как нельзя лучше соответствовало миру Иннокентия Анненского. Но и соединение замкнутости и иронии, глубокая индивидуальность вкуса и при этом предвосхищение новых тенденций, по сути, отвечает романтической иронии Шумана и его газетному проекту, только уже не в газете, а в лирике, и не в виде торжества команды давидсбюндлеров, а в виде превращения вымышленной поэтической реальности в критерий настоящего вкуса и подлинности всего пережитого. Образы балета были важны для Кленовского не как образы сезонных метаморфоз, как у других эмигрантских поэтов акмеистической традиции [г, с. 7I], но как образы трагически переживаемой личной судьбы, часть поисков протосюжета этой судьбы. В исследованиях по Кленовскому его театральные и балетные темы обычно обходят стороной, сводя жесты поэта к движению из нынешнего бытия к инобытию, к неким елисейским полям забвения [7, с. 239], либо 
указывая на пересборку акмеистических образов [II], соединенную с общей для эмиграции интуицией распада культуры [Іо], не проясняя, как соединяются конструктивный и деструктивный моменты, так что старая жалоба рецензента [I5] на то, что собственный профиль Кленовского в исследованиях русской эмигрантской литературы не найден, вопреки его заслуженной репутации в русских литературных кругах, отчасти остается актуальной и сейчас.

Посвященный «Карнавалу» Фокина мини-цикл Кленовского (8 и 9, здесь и далее стихи цитируются по [3] с указанием номера стихотворения) носит общее название, имитирующее французское галантное наречие, «Les deux sonnets de l'amoureux de Colombine» - «Два сонета любовных дел Коломбины». Первое стихотворение цикла «После спуска занавеса» имеет в виду финальную сцену: пока давидсбюндлеры маршируют со своими подругами, занавес опускается, и неудачник Пьеро, ставший, по точному замечанию Д.Д. Кумуковой, «символом глобального обобщения» [4, с. Іо2], и стародум Панталоне оказываются за опущенным занавесом на стороне зрителя. Арлекин, удачливый в любви, связал двух холостяков рукавами самого Пьеро, и они, путаясь в рукавах, оказываются одинокими и после завершения спектакля. По сути, перед нами продолжение спектакля уже в действительности.

Шуман мыслил всю историю как двойную иронию: обиженный на веселую влюбленную молодежь Панталоне попадает в комические сцены, а Пьеро, как новый поэт, обиженный и на стародумов тоже, оказывается жертвой комической ситуации, и тем самым комичным становится любой дальнейший шаг филистеров, они обижают уже тогда не отдельные решения давидсбюндлеров, а само созерцательное искусство. Решение Фокина закрывать занавес меняет ситуацию, оказывается, что зрители невольно на стороне стародумов и трагических поэтов, и для того, чтобы не отождествиться с этими персонажами, они должны принять всю экспериментальную эстетику Фокина и вспоминать о ней как о чем-то самом замечательном и удивительном.

Первое четверостишие сонета описывает ряд сцен «Карнавала», такие как вторая (одинокий Пьеро), восьмая (реплика Пьеро, иначе говоря, его жалоба на одиночество) и, наконец, тринадцатая (танец Эстреллы): 
Незваным я пришел на этот карнавал.

Я не знаком ни с кем. И лишь одна Эстрела,

С улыбкою своей и долгой и несмелой,

Сказала мне слова... но я их не слыхал...

Строго говоря, Эстрелла ни в сюжете Шумана, ни в хореографическом решении Фокина ничего не говорит Пьеро, но Кленовский отождествляет позицию Пьеро с позицией зрителя балета или исполнителя музыки, для которого выступление Эстреллы и есть отдельный номер, а значит, сообщение. Далее идея «остаться за занавесом» трактуется метафизически, в духе Иннокентия Анненского: остаться в неопределенности, между ночью и днем, между явью и сном, разумом и безумием:

И я иду один. Едва светает... Бал

Уже окончился. Я помню, - скрипка пела...

И в памяти моей какой-то образ белый

Остался... - Эта ночь безумна... Я устал...

Конечно, в этом четверостишии сразу узнаются все знакомые образы Иннокентия Анненского, начиная от графики многочисленных многоточий и кончая звуками скрипок, белыми призраками, безумными ночами и другими надрывно-томительными изображениями, определяемыми любым читателем, который хотя бы открывал стихи этого поэта. Таким образом, одинокий Пьеро отождествляется с повествователем, как бы тенью или двойником самого Анненского, и далее идет интереснейший поворот в терцетах, от двойничества к ироничному признанию самого повествователя поэтом:

У длинного стола, где догорают свечи,

Пьеро! - ты, может быть, мечтал о той же встрече?

Но ты ушел; твой стул теперь стоит пустой...

Я сяду на него и черным силуэтом

На фоне скатерти и дали золотой -

Я буду ждать ее... Я буду час поэтом... 
Если Шуман создавал иронию газетную, с целью, чтобы давидсбюндлеры стали единственным субъектом и мысли, и речи о музыке, то Кленовский создает индивидуальную иронию, которая должна сделать его поэтом уже не на час, а поэтом навсегда.

Второй сонет цикла, Jalousie (фр. Ревность), с сюжетом Шумана-Фокина прямо не связан, только героями, представляя собой уже ревнивую речь Пьеро, где удивительным образом галантный сюжет соединяется с множеством мещанских модных словечек, вроде «шокирует» и «апломб»:

Меня безумно злит Ваш пестрый арлекин!

Вы любите его печальными глазами...

Скажите, отчего он так обласкан Вами?

Он недостоин Вас, царица коломбин!

Пусть вместе вы сошли со стершихся картин:

Ужимки и прыжки нельзя любить годами!

Сознайтесь, ведь уже он был несносен в раме!

Он так шокирует мой поэтичный сплин!

Он беззаботен, пусть, его апломб безмерен;

Вы не находите? - Он слишком в Вас уверен!

Я вызову его сегодня на дуэль!..

Мы будем драться там, у длинной балюстрады, В рассветном воздухе, туманном как пастель... И буду я убит... - И будете Вы рады.

Здесь среди общих мест любовной истории, разыгранной в масках галантно понятой комедии дель арте, несмотря на отсылки вроде бы к другим произведениям, вроде старинных картин, в духе мистификаций Михаила Кузмина как любителя галантного века, сквозит намек и на «Карнавал». А именно слова «Он слишком в Вас уверен» понятны только из эпизода I4 балета («Узнавание»), где Коломбина и Арлекин уединяются, но, слыша приближение шагов, Коломбина прячет Арлекина под своей пышной юбкой. Кленовский домысливает ситуацию: так как в следующем эпизоде Ко- 
ломбина будет водить за нос Панталоне, то это явно был не он. Значит, приближался Пьеро, который сразу заподозрил неладное и обратился к своему сопернику.

Теперь понятны становятся и «ужимки и прыжки», совершенно цирковой поступок Арлекина, и почему дуэльная ситуация возникла из совершенно обыденной для этого комического мира перебранки, причем патетичность последних строк говорит, что дуэлью пахнет серьезно. Таким образом, здесь романтическая ирония оказывается обернута вокруг более чем комического, по сути, анекдотического сюжета, и оборачивается как окончательным посвящением Пьеро в поэты, так и невозможностью для него настоящей любви, а не любви карнавально-игровой, без испытания настоящей дуэлью.

В «Песне русского Пьеро» (35) Кленовский представляет героя как тоже осуществившегося поэта, неудачливого соперника Арлекинов («тех, кто скучают с Коломбинами), но там вся ситуация решается идиллически: повествователь уходит от искусственных красот к совершенно наивным и простодушным природным красотам. При этом адресат его песни сохраняется прежний, он хочет ее шепнуть «вуали с золотыми мушками», и здесь ирония оказывается в простой недостижимости идеала, а не в необходимости проходить испытания ради этого идеала. Точнее, как подразумевал и Шуман, идеал достижим, но внутри сложной фигуральной речи, когда любое прямое высказывание выдает содержание души, и значит, двигать интригу можно только создав непрямое высказывание из материала совершенно прямых реплик. Дальше, в стихотворении «Последняя ночь Пьеро» (38) герой полностью перемещается в мир детских сказочных страхов, тогда как Арлекин и Коломбина «Поэмы о шести утятах заглохшего пруда» (39) относятся как к природному, так и к сказочному миру довольно цинично, как к материалу для своих культурных интересов, тем самым становясь филистерами. Таким образом, и в других стихах о героях дель-арте-Шумана-Фокина Кленовский тоже имеет в виду определенное развитие иронии, но уже окончательно разводящее поэта с обывателями.

В этих стихах $(35,38,39)$ воспроизводится галантный мир поэзии Анри де Ренье, которого Кленовский много переводил. Например, балюстрады (balustres, балясины), около которых и происходят галантные встречи, пришли из поэзии де Ренье (правда, Кленовский перевел des jardins de 
balustres et d'eaux как «сады с террасами и тихими прудами). Слово «злит», которое Кленовский в оригинальных стихах приписывает Пьеро, также соотносится с опытом перевода де Ренье «Погоня злит меня, сон - отдых не дает», и эта строка необычна для довольно точных переводов Кленовского тем, что меняет смысл оригинала на противоположный. В оригинале сатир говорит не о психологии, а о физиологии: La poursuite m'essouffle et la halte m'endort (погоня меня выматывает, но остановка меня вгоняет в сон) - в смысле - что бы ни делал, это будет только к худшему организму. Таким образом, для Кленовского было важно стилизовать даже самую что ни на есть галантную поэзию под его собственное авторское видение Пьеро, под переживание своей поэтической тайны, а не под галантное приключение.

В разобранных двух сонетах соблюдается строгая, совершенно классицистическая цезура в третьей стопе, что вполне отвечает общим метрическим поискам эмигрантской поэзии к некоторой классикализации ядра лирики [I4, p. 224], что получило потом объяснение в совершенно акмеистическом стихотворении (II7):

Пирог с грибами стынет на столе.

Меня зовут. Бегу огромным садом.

Вот этот полдень, в Царском ли Селе

Иль в Павловске, он здесь, со мною рядом.

Он был хорош не только тишиной, Не только беззаботностью и ленью, -

Он был взыскательный учитель мой

И научил высокому уменью:

Уменью жить цезурою стиха,

Как эти вот дворцы, аллеи, шлюзы,

Как тот кувшин в бессмертных черепках,

Откуда пили ласточки и музы.

Последнюю строчку процитирует архиепископ Иоанн (кн. Д.И. Шаховской) в письме к поэту [8, с. 284], считая, что статуя была отправлена похитившими ее немцами на переплавку в оружие. На самом деле, скульптуру 
во время войны прятали. Но сюжет Шаховского о похищении Молочницы как вдохновляющей даже муз находит свое основание в обращении к музе самого Кленовского (352) явно сближает эту музу с Коломбиной, которая

То боязлива, то нежна,

То радуясь, то плача,

Сегодня рвет сирень она

По царскосельским дачам.

Облик Коломбины, которая переменчивым настроением разыгрывала Панталоне по-настоящему, а Арлекина - для эротической игры, оказывается отчасти приписан музе. Только у Фокина Арлекин на себя брал любое действие, рвал письмо Панталоне и похищал Коломбину. Здесь муза действует сама, сама определяет то, как именно и где, в каком антураже будет развертываться галантная сцена. Тем самым Молочница и оказывается настоящей невестой Пьеро-поэта, а не Коломбина, уходящая с Арлекином.

Неожиданную цитату из балета Фокина мы находим в стихотворении Кленовского «Мы потому смотреть на небо любим...» (226):

И только на какой-нибудь планете,

Где светят три смарагдовых луны,

Иль по дороге к альфе или бете

Какой-то звездной золотой страны...

В этом четверостишии спрятано прямое указание на часть 12 балета «Карнавал», «Шопен», там, где звучит мелодия, напоминающая ноктюрны Шопена, на сцене появляется мечтательный юноша поэт, напоминающий призрак. Перед ним - три балерины, встав на цыпочки, медленно танцуют и потом исчезают со сцены. Само слово «ноктюрн» указывает на лунную ночь, и отождествление балерин с лунами тогда понятно, и даже фантастический пейзаж неба других планет дополняется образом «золотой» страны, сразу напоминающим о занавесе Л. Бакста. Другое указание на Шопена, совершенно в духе Анненского, в финале стихотворения «От многих лет, от повторенья...» (208): 
...Вот так шопеновский бемоль

Милей прозрачного хорала

- имеет в виду, конечно, самый известный и самый исполняемый ноктюрн Шопена в ми-бемоль мажоре (Op. 9, No. 2). Тем самым мир Шопена, мир ноктюрнов и мир «Карнавала» с его лунами и страдающим Пьеро оказываются еще раз отождествлены.

Проведенное исследование позволяет сделать следующие выводы. При всей продуманности образа Пьеро в эстетике символизма, для которой опыт комедии дель арте являлся одновременно примером демократизации театра и преодоления психологизма ради обобщений более высокого уровня, ради новой концепции характера и культуры, этот образ нашел довершение только в практике балета Фокина. Ослепительная слава балетов Фокина не позволяла раскрыть значение каждого отдельного образа, и тем более их влияние на литературную традицию. Дмитрий Кленовский, соединивший восходящую к символизму склонность к обобщению характеров с галантными стилизациями следующего поколения поэтов, смог благодаря обращению к пушкинскому мифу русской культуры дать в своих стихах продуктивную интерпретацию образов Фокина. Мы видим, как влияние музыки Шумана, его композиционного мышления и жизнестроительной романтической программы позволяло преодолевать наследие символизма в лирике.

В исследовании были раскрыты некоторые темные места поэтики Кленовского, с опорой на обстоятельства жизни и творчества Шумана, определившие литературную рецепцию западной романтической музыки вообще и обновление романтического музыкального мифа как своеобразного сюжета о спасении в период между двумя мировыми войнами. Так были реконструированы контексты, которые позволяют разомкнуть мир эмигрантской поэзии, с указанием на типологические параллели в западной культуре: от усвоения эротических программ Анри де Ренье до нового прочтения классической пластики в музыкально-танцевальном действе. Мы можем уточнить и определение «психологической лирики» для русской эмигрантской поэзии, но также, проводя параллели с поисками того же времени в области теории культуры, сравнительной мифологии и сюжетологии, уточнить влияние интермедиальных практик искусства на становление 
оригинальных сюжетов. Оказывается, что символистская идея «синтеза искусств» сменилась другой идеей искусства, в том числе перформативного, например, танцевального, как средства обобщения. Новая идея, возможно, была и менее впечатляющей, но более продуктивной для сюжетных поисков самой лирики.

\section{Список литературы}

I Арустамова А.А., Расторгуева М.Ю. Африка на поэтической карте А. Ладинского // Вестник Пермского университета. Российская и зарубежная филология. 20I5. № 3. С. 68-76.

2 Зенкевич С.И. «Карнавал» Р. Шумана в Санкт-Петербурге // Немцы в СанктПетербурге. Биографический аспект. СПб.: МАЭ РАН, 2оІІ. № 6. С. 333-350.

3 Кленовский Д.И. Полное собрание стихотворений / под ред. О.А. Коростелева. М.: Водолей, 20II. 704 с.

4 Кумукова Д.Д. Сценическая судьба персонажа-маски Пьеро // Вестник Академии Русского балета им. А.Я. Вагановой. 20I7. № I. С. Іоо-Іо7.

5 Лебедева Г.Д. Балет Серебряного века. Два пути и две судьбы: Фокин и Горский // Вестник РГГУ. Серия: История. Филология. Культурология. Востоковедение. 2007. № Iо. С. $154-$ I70.

6 Леонтьева А.Ю. Прецедентное имя «Тамара Карсавина» в поэзии Серебряного века // Евразийский союз ученых. 2018. № 3 (48). С. 73-76.

7 Пономарев Е.P. Человек разрушенного мира в поэзии второй эмиграции (Дмитрий Кленовский и Иван Елагин) // Russian Literature. 2оIо. T. 67. № 2. C. 23I-272. Странник [архиепископ Иоанн (кн. Д.И. Шаховской)]. Переписка с Кленовским. Париж: [Б.и.], І98г. 3І7 с.

9 Фрейденберг О.М. О неподвижных сюжетах и бродячих теоретиках: (из служебного дневника) / публ. и коммент. Н.В. Брагинской // Одиссей: человек в истории. І995. Представления о власти. М.: Наука, І995. С. 272-297. Хадынская А.А. Жанр фрагмента в сборнике Дмитрия Кленовского «Разрозненная тайна» // Уральский филологический вестник, 2018. № 3. С. 43-57. Хадынская А.А. Образ Петербурга в лирике Дмитрия Кленовского // Мировая литература глазами современной молодежи. Цифровая эпоха: сборник материалов IV междунар. молодежной научно-практической конференции, I8-2о сентября 2018 г. / науч. ред. С.В. Рудакова. Магнитогорск: Изд-во Магнитогорск. гос. техн. ун-та им. Г.И. Носова, 2018. С. 215-221. 
I2 Хмельницкая Е.С. Л. Бакст и воплощенные в фарфоре фигуры участников «Русских сезонов» С. Дягилева // Вестник Академии Русского балета им. А.Я. Вагановой. 20І6. № 5. С. 83-92.

I3 Шешунова С.В. Русский балет в творчестве Агаты Кристи // Вестник Нижегородского университета им. Н.И. Лобачевского. 20I7. № 5. С. $255^{-259}$.

I4 Smith G.S. The Metrical Repertoire of Russian Émigré Poetry, I94I-I970 // The Slavonic and East European Review. 1985. P. 210-227.

I5 Babenko-Woodbury V.A. [A review:] Glad, J. Russia Abroad: Writers, History, Politics // World Literature Today. 2000. Vol. 74, № I. P. I86-I87. 


\section{References}

Arustamova A.A., Rastorgueva M.Iu. Afrika na poeticheskoi karte A. Ladinskogo [Africa on the poetic map of A. Ladinsky]. Vestnik Permskogo universiteta. Rossiiskaia $i$ zarubezhnaia filologiia, 2015, no 3, pp. 68-76. (In Russ.)

Zenkevich S.I. “Karnaval” R. Shumana v Sankt-Peterburge [Shumann’s Carnival in St. Petersburg]. In: Nemtsy v Sankt-Peterburge. Biograficheskii aspekt [Germans in St. Petersburg. Biographical aspect]. St. Petersburg, MAE RAN Publ., 20II, no 6, pp. 333-350. (In Russ.)

Klenovskii D.I. Polnoe sobranie stikhotvorenii [Complete poems], ed. by O.A. Korostelev. Moscow, Vodolei Publ., 20II. 704 p. (In Russ.)

Kumukova D.D. Stsenicheskaia sud'ba personazha-maski P'ero [The fate of Pierrot as a character-masque]. Vestnik Akademii Russkogo baleta im. A.Ia. Vaganovoi, 20I7, no I, pp. IOO-IO7. (In Russ.)

Lebedeva G.D. Balet Serebrianogo veka. Dva puti i dve sud'by: Fokin i Gorskii [Ballet in the Silver Age. Two paths and two fates: Fokin and Gorsky]. Vestnik RGGU. Seriia: Istoriia. Filologiia. Kul'turologiia. Vostokovedenie, 2007, no Io, pp. I54-I70. (In Russ.) Leont'eva A.Iu. Pretsedentnoe imia “Tamara Karsavina” v poezii Serebrianogo veka [The name of "Tamara Karsavina" in the Silver Age poetry]. Evraziiskii soiuz uchenykh, 20I8, no 3 (48), pp. 73-76. (In Russ.)

Ponomarev E.R. Chelovek razrushennogo mira v poezii vtoroi emigratsii (Dmitrii Klenovskii i Ivan Elagin) [The man of the destroyed world in the second emigration poetry (Dmitry Klenovsky and Ivan Elagin)]. Russian Literature, 20Io, vol. 67, no 2, pp. 23I-272. (In Russ.)

Strannik [archbishop Ioann (prince D. I. Shakhovskoi)]. In: Perepiska s Klenovskim [Correspondence with Klenovsky]. Paris, I98I. 3I7 p. (In Russ.)

Freidenberg O.M. O nepodvizhnykh siuzhetakh i brodiachikh teoretikakh: (iz sluzhebnogo dnevnika) [On motionless plots and roving theorists: (from the official diary)], ed. N.V. Braginskaya. In: Odissei: chelovek v istorii. 1995. Predstavleniia o vlasti [Odyssey: a man in history. I995. Views of power]. Moscow, Nauka Publ., I995, pp. 272-297. (In Russ.)

Khadynskaia A.A. Zhanr fragmenta v sbornike Dmitriia Klenovskogo "Razroznennaia taina" [Genre of the fragment in the collection of poems by Dmitry Klenovsky Disparate Secret]. Ural'skii filologicheskii vestnik, 2018, no 3, pp. 43-57. (In Russ.) Khadynskaia A.A. Obraz Peterburga v lirike Dmitriia Klenovskogo [The image of St. Petersburg in the lyrics of Dmitry Klenovsky]. In: Mirovaia literatura glazami sovremennoi molodezhi. Tsifrovaia epokha: sbornik materialov IV mezhdunar. molodezhnoi nauchno-prakticheskoi konferentsii, I8-20 sentiabria $20 I 8 \mathrm{~g}$. [World literature viewed by the youth today. Digital era: collection of materials of the 4 th International Youth Scientific and Practical Conference, September I8-20, 20I8], ed. by S.V. Rudakova. Magnitogorsk, MTU Publ., 20I8, pp. 215-22I. (In Russ.) 
I2 Khmel'nitskaia E.S. L. Bakst i voploshchennye v farfore figury uchastnikov "Russkikh sezonov" S. Diagileva [L. Bakst and the figures of participants of the "Russian Seasons" by S. Diaghilev as embodied in porcelain]. Vestnik Akademii Russkogo baleta im. A.Ia. Vaganovoi, 2016, no 5, pp. 83-92. (In Russ.)

I3 Sheshunova S.V. Russkii balet v tvorchestve Agaty Kristi [Russian ballet in the works by Agatha Christie]. Vestnik Nizhegorodskogo universiteta im. N.I. Lobachevskogo, 20I7, no 5, pp. 255-259. (In Russ.)

I4 Smith G.S. The Metrical Repertoire of Russian Émigré Poetry, I94I-I970. The Slavonic and East European Review, I985, pp. 210-227. (In English)

I5 Babenko-Woodbury V.A. [A review:] Glad, J. Russia Abroad: Writers, History, Politics. World Literature Today, 2000, vol. 74, no I, pp. I86-I87. (In English) 
УДК 821.І6г.2

ББК 83.3(4Укр)
ЭТНОКУЛЬТУРНОЕ ПОГРАНИЧЬЕ: КОНЦЕПТУАЛЬНЫЙ, ТИПОЛОГИЧЕСКИЙ И СИТУАТИВНЫЙ АСПЕКТЫ (Чужое-Иное-Свое)

Статья вторая: Харьков. Донбасс - этно- и лингвокультурное пограничье

(C) 2020 г. Ю.Я. Барабаш

Институт мировой литературы

им. А.М. Горького Российской академии наук, Москва, Россия

Дата поступления статьи: о2 октября 2019 г. Дата публикации: 25 июня 2020 г.

DOI: I0.22455/2500-4247-2020-5-2-286-32I

Аннотация: В статье, продолжающей дискурс этнокультурного пограничья, внимание сосредоточено на фактах и проблематике, относящихся к украинско-русскому культурному пограничью востока Украины. Полиэтнический характер социума изначально, с середины XVII в., определил наличие в регионе двух культурообразующих компонентов, украинского и русского, динамику соотношений между ними в разные исторические периоды. Под этим углом зрения в статье проводится диахронический анализ основных этапов литературного процесса на Слободской Украине, преимущественно в ее центре, Харькове, роли основанного в І805 г. Харьковского университета, харьковских русско- и украиноязычных периодических изданий и сборников, деятельности Г. Сковороды, Г. Квитка-Основьяненко, П. Гулак-Артемовского, И. Срезневского, Н. Костомарова, А. Потебни и др., литературной жизни Харькова в эпоху национального культурного возрождения 20-х - начала 30-х гг. XX в. и в последующие периоды. «Донбасский сегмент» восточного этнокультурного пограничья рассматривается в синхроническом срезе, в компаративном сопоставлении разных писательских судеб и творческих феноменов.

Ключевые слова: пограничье, полиэтничность, идентичность, лингвокультурная ситуация, харьковская школа романтиков, «расстрелянное возрождение», «донбасский сегмент».

Информация об авторе: Юрий Яковлевич Барабаш - доктор филологических наук, профессор, главный научный сотрудник, Институт мировой литературы им. А.М. Горького Российской академии наук, ул. Поварская, д. 25 а, І2Іо69 г. Москва, Россия.

E-mail: barabash.yuri@gmail.com

Для цитирования: Барабаш Ю.Я. Этнокультурное пограничье: Концептуальный, типологический и ситуативный аспекты (чужое - иное - свое). Статья вторая: Харьков. Донбасс - этно- и лингвокультурное пограничье // Studia Litterarum. 2020. T. 5, № 2. C. 286-32I. DOI: IO.22455/2500-4247-2020-5-2-286-32I

* Статья первая «Этнокультурное пограничье: концептуальный, типологический и ситуативный аспекты. (Чужое-Иное -Свое)» опубликована в: Studia Litterarum. 20I9. T. 4, № 3. С. $290-329$. 


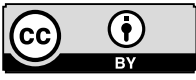

This is an open access article distributed under the Creative Commons Attribution 4.0 International (CC BY 4.0)
ETHNO-CULTURAL BORDERLINE: CONCEPTUAL, TYPOLOGICAL, AND CIRCUMSTANTIAL ASPECTS (Alien - Other - One's Own). Second article: Kharkov. Donbass - ethno-linguistic and cultural borderland

(C) 2020. Yu.Ya. Barabash A.M. Gorky Institute of World Literature of the Russian Academy of Sciences, Moscow, Russia Received: October 02, 2019

Date of publication: June 25, 2020

Abstract: This article continues discussing ethnocultural borderline as it focuses on the Ukrainian-Russian cultural borders in the Eastern part of Ukraine. Ever since midI $7^{\text {th }}$ century, two formative elements, Russian and Ukrainian, have accounted for the polyethnic character of the socium in the area. We can speak of dynamic correlation of these elements in different historical periods, of the mobility of transitive forms and ambivalent states that in their turn, had an impact on the regional literature. From this point of view, the essay diachronically analyzes the main stages of the literary process in Slobodskaya Ukraine with Kharkov as it center. The paper emphasizes the role of Kharkov University founded in I805 as well as of Kharkov periodical editions and collections in Russian and Ukrainian languages. It covers activity of such influential figures as G. Skovoroda, G. Kvitka-Osnovyanenko, P. Gulak-Artemovsky, I. Sreznevsky, N. Kostomarov, and A. Potebnya and reveals contradictions and dramatism of the literary life in Kharkov during the national cultural Renaissance of the I920-s through the beginning of the I930s (the so-called "Executed Renaissance") and in the subsequent periods. Finally, the essay examines the "Donbass segment" of the Eastern ethnocultural borderline that has a shorter history but is no less controversial than Kharkov segment. It offers a comparative analysis of the fates of different writes and texts of the region in synchronic perspective.

Keywords: polyethnic character, identity, linguocultural situation, bylinguism, Kharkov Romantic school, "Executed Renaissance”, "Donbass segment”.

Information about the author: Yuri Ya. Barabash, DSc in Philology, Professor, Director of Research, A.M. Gorky Institute of World Literature of the Russian Academy of Sciences, Povarskaya 25 a, I21069 Moscow, Russia.

E-mail: barabash.yuri@gmail.com

For citation: Barabash Yu.Ya. Ethno-cultural Boerderline: Conceptual, Typological, and Circumstantial Aspects (Alien - Other - One's own). Second article: Kharkov. Donbass - ethno-linguistic and cultural borderland. Studia Litterarum, 2020, vol. 5, no 2, pp. 286-32I. (In Russ.) DOI: IO.22455/2500-4247-2O2O-5-2-286-32I 


\section{Харьковский сегмент}

«Харків, Харків, де твоє обличчя?» («Харьков, Харьков, что в твоем обличье?»), - с этим вопросом Павло Тычина в г923 г. обращался к столице советской Украины. Стихотворение «Харьков» - по сути развернутая поэтическая метафора пограничья.

Пограничья психологического; перед нами случай перехода от первого, в некотором смысле стрессового, впечатления эмоционально настроенной личности, поэта-лирика, только-только прибывшего из тихого в то время Киева и сохраняющего живую память о провинциальном, но прекрасном Чернигове, к восприятию столицы-мегаполиса - с присущими ей резкими социальными и культурными контрастами, с фронтирными зонами между Университетской горкой и старыми «ремесленными» улицами Чоботарской, Коцарской, Кузнечной, между элитарным «нагорным районом» и криминальными окраинами, между русифицированной промышленной Петинкой и воспетыми когда-то Квиткой-Основьяненко патриархальными Гончаровкой и Основой, еще не совсем утратившими национальные черты. Между пролетарским духом и мещанским душком, как тогда говорили.

Концепт пограничья был укоренен в исторической судьбе Слободской Украины и ее центра - Харькова (см. об этом: [6]). В середине XVII в. значительная часть территории Дикого Поля, в районе Сиверского Донца, была заселена украинскими казаками и крестьянами, выходцами из Приднепровья. Слобожанщина с самого начала складывалась как полиэтнический пограничный регион с преимущественно украинским, частично русским (главным образом городским, торгово-ремесленным) населением; этнические русские составляли часть слобожанского дворянства, впрочем, 
дворянами становились, по воле монархини, и представители украинской старшины. Именно полиэтничность слобожанского социума стала главным фактором, определяющим характер и особенности развития этнокультурной ситуации в крае, прежде всего в Харькове, в котором стабильность доминирующей черты - наличия двух культурообразующих компонентов, украинского и русского (еврейский элемент присутствовал, но в ту пору еще не был таким компонентом, он обрел существенную функцию в общей этнокультурной системе Слобожанщины значительно позднее, главным образом в XX в.) - эта стабильность сочеталась с изменчивостью соотношений между ними на разных исторических этапах, с динамикой переходных форм и амбивалентных состояний.

Важнейшим фактором формирования слобожанского этнокультурного пространства была деятельность «украинского Сократа» - Григория Сковороды (г722-I794), в течение десяти лет, с перерывами, преподававшего в Харьковском коллегиуме поэтику, синтаксис, греческий язык и этику. Философское и литературное наследие Сковороды знаменовало завершение плодотворной для украинской литературы эпохи барокко и создание предпосылок для ее перехода к новому этапу развития. В старый мех было налито новое вино. Судьба, по выражению Ивана Франко, поставила Сковороду «на пересечении двух великих эпох» и, есть все основания добавить, на пересечении (пограничье) двух культур - украинской и русской, обогащенных библейской и античной традициями, идеями европейского гуманизма и космополитизма - в изначальном, лишенном позднейших конъюнктурных идеологических наслоений значении этого понятия.

Как пишет Л. Ушкалов, авторитетный исследователь проблемы, «слободскую традицию <...> просто невозможно представить “вне Европы” . Для воспитанников Харьковского коллегиума, для учеников Сковороды, молодых людей его круга был характерен активный интерес к французскому просветительству и особенно к немецкой романтической философии и мистике - по примеру учителя, который изучал немецкий язык и немецкую философию еще в Киево-Могилянской академии, затем во время своих европейских «мандров». Именно со Сковороды, продолжает Л. Ушкалов, начинается «немецкий след» на Слобожанщине, что видно, в частности, на примере национального состава преподавателей Харьковского университета, открывшегося в г8о5 г. [25, с. 4, 6]. Из 47 профессоров I8 (I9?) были нем- 
цами, среди них рекомендованные Гёте, по просьбе попечителя харьковского учебного округа графа Северина Потоцкого, И.-Б. Шад, заменивший И.Г. Фихте, чей приезд в Харьков не состоялся по стечению обстоятельств, Л. Шнауберт и М. Пильгер, также К.Д. Роммель, описавший впоследствии свое пребывание в Харькове в мемуарной книге [23], Л. Ванноти, Ф. Гизе, Й. Ланг, Б. Райт, К. Нельдехен и др. Улица, на которой жили немецкие профессора и их обслуга, называлась Немецкой (с I899 г. Пушкинская).

Хотя большинство иностранных преподавателей со временем осваивали русский язык, а Роммель даже украинский, лекции они читали в основном на латыни. В целом языком общения и обучения был русский. Первым ректором университета был выпусник Псковской духовной семинарии, русский писатель, филолог и философ Иван Рижский. Русскоязычными были основанные по инициативе преподавателей университета первые на Слобожанщине периодические издания - газета «Харьковский еженедельник», журналы «Украинский Вестник», «Украинский журнал», «Харьковский Демокрит».

Вырисовывается достаточно четкая картина превалирования русскоязычия в харьковском научно-культурном, в первую очередь университетском, пространстве первых десятилетий XIX в. Превалирования, но не абсолютного доминирования. Картина будет односторонней без учета по меньшей мере двух факторов. Во-первых, это украиноязычное окружение, украинский язык харьковского городского, тем более слобожанского сельского, населения. А из этих слоев (это во-вторых) рекрутировалась значительная часть харьковского студенчества, да и кое-кто из преподавательского состава, так что в коридорах университета звучала украинская речь, даже в некоторых лекциях слышались «малороссийские» лексика, обороты, интонация.

Именно в университетской (и околоуниверститетской) среде зарождались и все более активно заявляли о себе тенденции и течения, органически связанные с общенациональным контекстом становления новой украинской литературы, с процессом осознания национальной культурной и научной элитой своей идентичности и вместе с тем отражающие специфику слобожанского (прежде всего харьковского) межъязыкового, этнокультурного пограничья.

I Этот философ-фихтеанец отличался открыто выражаемыми свободомыслием и антиклерикализмом, за что в конце концов был выслан из России, а его книга «Institutiones juris naturae» («Установления естественного права») сожжена (см: [2]). 
Ключевыми фигурами Харькова послесковородинской эпохи были Григорий Квитка-Основьяненко (I778-I843) и Пётр Гулак-Артемовский (I790-I865).

Квитка - коренной слобожанин-харьковец, он родился в пригородной слободе (селе) Основа, принадлежавшей старшинско-дворянской семье, в которой господствовал культ украинского языка, истории, культуры. В доме бывал Сковорода, что оставило след в памяти писателя. Как многие выходцы из тогдашних дворянских семей, Григорий получил домашнее образование, он не учился в Харьковском университете, но был тесно связан с ним как член университетского Общества наук и один из самых активных участников общественной и культурной жизни Харькова. Квитка был основателем, затем директором профессионального театра в Харькове, инициатором и соиздателем (вместе с Р. Гонорским и Е. Филомафитским) журнала «Украинский Вестник», содействовал созданию альманаха «Молодикъ».

Первые свои завоевашие успех сочинения (самые ранние ученические опыты не принимаем во внимание) Квитка написал по-русски, это комедии «Приезжий из столицы, или Суматоха в уездном городе», ее считают предшественницей гоголевского «Ревизора», и «Шельменко-денщик», а также высоко оцененные С. Аксаковым и Н. Полевым, но не разрешенные к постановке «Дворянские выборы». В историю украинской литературы Квитка вошел как основатель новой прозы и комедии, создав целый корпус ставших хрестоматийными повестей бурлескно-смехового и сентиментально-реалистического характера («Салдацкий патрет», «Конотопская ведьма», «Маруся», «Сердечная Оксана», «Бой-баба»), комедию «Сватанье на Гончаровке». Практически параллельно Квитка писал русскоязычную прозу - роман «Пан Халявский», повести «Жизнь и похождения Петра Степанова сына Столбикова», «Ганнуся», «Панна Сотниковна», историко-этнографические и физиологические очерки. Это была характерная особенность этапа становления новой национальной литературы и характеристическая черта слобожанского этнокультурного пограничья, где русский язык имел достаточно широкое распространение, прежде всего в системе образования, в культурной жизни, литературном творчестве, при этом, однако, языком широких кругов населения оставался украинский.

Показательны с этой точки зрения примеры различных форм внутритекстовой языковой двойственности в русскоязычных произведениях 
Квитки. В комедии «Шельменко-денщик», например, такая двойственность несет структурную и социальную функцию: по-русски говорят персонажи, представляющие привилегированный, образованный класс, это не только русский офицер, дворянин, но и украинские помещики, их жены и дети, старающиеся, так сказать, «соответствовать», даже их горничные и лакеи, по-украински же - только денщик офицера, украинец, бывший солдат русской армии, или «москаль», как тогда говорили. В рамках каждой группы была своя дифференциация: украинский помещик Шпак, его жена Фенна (Парфена?) Степановна и дочь Присинька (Ефросинья?), соседи - Лопуцьковский и Опецковський - изъясняются на старательно выученном русском, но в их речь время от времени вклиниваются украинизмы²; Аграфену Семеновну, например, Фенна Степановна называет Горпинкой, Шельменко же, напротив, уснащает свой искаженный украинский русскими (точнее, кажущимися ему русскими), канцелярскими либо «москальскими» словечками и оборотами, приросшими к языку за годы солдатской службы.

B «Сватанье на Гончаровке» с самого начала также акцентируется разграничение между украинской стихией, доминирующей в языке абсолютного большинства персонажей - жителей пригородной слободы, и русскоязычными авторскими ремарками. Но вот пояляется Осип Скорик, отставной солдат, только это в данном случае не симпатичный Шельменко, а ловкий пройдоха и циник, изъясняющийся на дикой смеси двух изуродованных языков, русского и украинского: «Усі нашаво брата поважають! Нi хрестини, ні свадьба у знакомих не буваїть, штоб без меня та абашлось. Правда і то, што уж ніхто так парядка не дасть, как я <...>. Все закони знаю, аттаво і усе ка мне». Этот рожденный и выношенный в имперском лоне лингвистический уродец - предтеча будущего «харьковского суржика». Последний, как показывает Квитка в своих комедиях, в ту пору уже зарождался и набирал силу на городских окраинах, например, на близкой к Благовещенскому базару Панасовке, где селился чаще всего пришлый люд, весьма пестрый как в этническом, так и в социальном отношениях, что наложило отпечаток на языковую ситуацию в регионе, в том числе и на автох-

2 Фамилии Лопуцьковский и Опецковский основаны на комическом обыгрывании просторечных украинских слов: лопуцьок - это травянистый стебель, опецькуватый неуклюжий. 
тонный, украинский, ее сегмент. В статье «Украинцы» Квитка с грустной интонацией замечает, что те, кто изначально заселял слобожанские земли, «большею частью были украинцы и имели с малороссиянами один язык и одни обычаи», однако со временем они «значительно отклонились от них (т. е. от малороссиян. - Ю.Б.) до заметной разности...» $[\text { I7, с. 84] }]^{3}$.

В отличие от Квитки, его младший современник Пётр Гулак-Артемовский не был коренным харьковцем, он родился на Черкасщине, в тогдашней Киевской губернии, в семье священника - выходца из известного казацко-старшинского рода. Но его связи с Харьковским университетом были значительно более тесными и основательными, чем у Квитки. Поступив в университет в І8І7 г. вольнослушателем, он через короткое время стал магистром, адъюнктом, экстраординарным и ординарным профессором, затем деканом словесного факультета, а в I84I г. - ректором университета и оставался в этом качестве до г849 г. Основным направлением лекторской деятельности Гулака-Артемовского была русская история, он также читал лекции по русской словесности, эстетике, польскому языку, который знал с детства (мать происходила из польского шляхетского рода Артемовских), по сравнительному анализу славянских языков. Украинского компонента - отдельно взятого, специального - в круге педагогических и научных занятий Гулака-Артемовского, как видим, не было. Между тем в его литературном творчестве, в поэзии и переводах, украинский язык превалирует абсолютно, он ввел новый для украинской литературы жанр романтической баллады, в баснях и стихотворных притчах продолжил и развил заложенную И. Котляревским традицию творческого освоения приемов национального низового барокко, бурлеска и травестии. В русле этой традиции находится, в частности, ставшая хрестоматийной басня-сказка «Пан и Со-

3 Чтобы точнее понять смысл приводимых Квиткой понятий единства и «разности», надо учесть следующее. «Малороссией» в XVIII в. именовалась Гетманщина - казацко-гетманское государственное образование на Левобережной Украине, тамошнее население - это «малороссияне». Украиной неформально именовалась Слобожанщина с Харьковом. После ликвидации Гетманцины в I78I г. на ее землях были созданы три наместничества, объединенные в 1796 г. в Малороссийскую губернию (территории нынешних Полтавской и Черниговской областей, без Киева). В ХІХ в. Малороссией официально называли всю входившую в состав Российской империи территорию. Следует также иметь в виду, что утвердившиеся с конца XIX в. и широко применяющиеся в украинском историко-публицистическом дискурсе $\mathrm{XX}$ в. понятия «малороссийство», «малороссы» не связаны с административно-географическим делением, это термины социополитического плана. 
бака» - едва ли не самый острый для дошевченковского времени образец социальной, антикрепостнической сатиры.

Написанные по-русски литературно-художественные сочинения Гулака-Артемовского составляют небольшую сравнительно с украинскими и, главное, не сопоставимую с ними (и, кстати, с русскоязычными произведениями Квитки) по художественному уровню часть наследия писателя. Это относящееся к годам пребывания в Киевской духовной академии уничтоженное автором пародийное переложение поэмы Буало «Налой» («Le Lutrin»), возвышенно-патетические стихотворение «Мудрость» и послание «Её с-ву графине А.А. Г-вой», религиозно-морализаторское «Чаяние души христианской», в поздний период деятельности поэт, к тому времени уже действительный статский советник, пишет историософские рефлексии консервативной направленности «Упадок века», цикл официозно-патриотических стихотворений по случаю Крымской войны.

Осознавал ли Гулак-Артемовский несопоставимость русскоязычной части своего творчества с украиноязычной, несопоставимость в пользу части второй? Испытывал ли душевный дискомфорт от ощущения своей языковой - и не только языковой - раздвоенности? Похоже, что да. В письме І828 г. к поэту, библиографу и издателю В. Анастасевичу [І2, c. I3I-I33] он пишет о своей тревоге («хандре») по поводу судьбы «с каждым днем умирающего родного языка», о котором грезит «во сне и наяву». Современник Гулака-Артемовского, харьковский историк А. Шиманов, в I882 г. писал в «Киевской старине»: «Гулак-Артемовский, видимо, был одним человеком pro domo sua и другим pro foro, при том с летами этот “другой человек” видимо осилил первого и под конец, может быть, остался уже главным хозяином...» (цит. по: [8]). Языковой фактор, несомненно, выступал маркером такого раздвоения. Именно это имел в виду Шевченко, когда упрекал Гулака-Артемовского в том, что он свой родной язык, «хотя и слышал [в колыбели матери], так забыл, потому что в паны постригся» [28, с. 208].

Совершенно иной случай - творческое и научное наследие Измаила Срезневского. Русский по происхождению, он был в младенческом возрасте увезен родителями из Ярославля в Харьков, с которым связаны его детские, студенческие годы, ранний период научной и творческой деятельности. Срезневский прекрасно освоил украинский язык, как, впрочем, и ряд 
других славянских языков, высоко оценивал его богатство, поэтичность, самобытную природу. В г834 г. в письме к И. Снегирёву он подчеркивал, что сейчас уже нет необходимости доказывать, что украинский («или как угодно называть другим - малороссийский») язык «является языком, а не наречием русского или польского» [3, с. 39]. При этом свои труды харьковского периода об украинском языке, фольклоре, этнографии, истории, литературе Срезневский писал по-русски.

В Харьковском университете Срезневский учился на «эфико-политическом» отделении, главным предметом его занятий была юриспруденция, и молодой человек занимался ею с присущей ему основательностью. И все же главное его увлечение еще с гимназических лет - литература, украинская история, народные традиции, обычаи, устное творчество. Это его, как и его друзей-единомышленников, увлечение было созвучно характерной для Украины первой трети XIX в. романтической тенденции пробуждения национального сознания, интереса к идее народности, к этнографии и фольклору; резонировали также тенденции русского романтизма периода после войны І8І2 г. и восстания декабристов; впрочем, это была тенденция общеевропейская (иенские и гейдельбергские романтики, английская «озерная школа», славянские «будители», польская «украинская школа», галицкая «Руська троица»).

В университетские годы вокруг Срезневского образуется кружок молодых людей, как и он, «юристов по образованию, но не по призванию» (В. Срезневский), литераторов, которые связывали свое творчество с украинской народнопесенной и исторической традицией, - братья О. и Ф. Евецкие, И. Росковшенко, А. Шпигоцкий, О. Джунковский. В г8зо-е гг. заявляет о себе вторая харьковская романтическая волна - Л. Боровиковский, А. Метлинский, Н. Костомаров, М. Петренко, А. Корсун, С. Писаревский, В. Забила. При поощрительной поддержке Квитки-Основьяненко и Гулака-Артемовского складывается целостное явление - группа поэтов, вошедшая в историю украинской литературы под именем «Харьковской школы романтиков».

«Школа» была органической частью общеукраинского романтического историко-литературно-этнографического контекста, его «харьковским сегментом». В то же время научная и творческая деятельность представителей «Школы», сформировавшейся в конкретных исторических и 
социокультурных обстоятельствах слобожанского пограничья, отмечена специфическими чертами этого пограничья. Одна из них, и, пожалуй, главная, связана с языком.

В печатном органе «Школы», «Украинском альманахе», изданном в I83і г. И. Срезневским и его сотоварищем по «эфико-политическому» отделению И. Росковшенко (будущим главным московским цензором, тайным советником), три четверти публикаций были русскоязычными, в том числе стихи обоих издателей. Надо заметить, что такое соотношение языковых пластов было характерно для харьковских периодических изданий того времени, так или иначе позиционировавших себя как украинские. В «Украинском вестнике», первом на Украине литературно-художественном, научном и общественно-политическом ежемесячном журнале (I8I6-I8I9), публиковались украинские сочинения, но по объему эти публикации не сравнимы с корпусом русскоязычных статей и обзоров, в том числе по истории Украины (М. Марков, М. Грибовский, Г. Квитка-Основьяненко), этнографии (А. Лёвшин), краеведению (И. Вернет, О. Левицкий). То же относится к таким изданиям, как «Украинский журнал», «Харьковский Демокрит», «Южный русский сборник». В г840-е гг. в Харькове вышли два украинских альманаха, весьма недолговечных, - «Сніп» («Сноп») и «Молодик», в Петербурге, усилиями Е. Гребинки, - альманах-антология «Ластовка» (см.: [I; 4; 9; 20]).

Что касается «Украинского альманаха», то его украинская часть состояла из нескольких народных песен и дум, двух стихотворений, Л. Боровиковского и А. Шпигоцкого, и двух переводов последнего (один из них, отрывок из пушкинской «Полтавы», это первый перевод Пушкина на украинский язык). Еще два помещенных в альманахе перевода того же Шпигоцкого были русскоязычными, как и вся дальнейшая его переводческая деятельность, а также поэтические опыты в жанре романса. Последние два, «Малороссийская мелодия» и «Малороссийский романс», примечательны сочетанием русского языка и отсылкой в названиях к украинской подоснове - своеобразная микромодель межкультурного и межъязыкового пограничья.

Подобное наблюдаем и у Л. Боровиковского, в его «малороссийских балладах», написанных по-русски, однако на легко узнаваемом украинском историческом («Смерть Пушкаря») или песенном («Две доли», «Кузнец», «Лихо») материале. Иной вариант - пограничная модель с «обратным» 
узнаванием: «Маруся», переложение «Светланы» Жуковского (с переименованием героини на украинский манер), «Дві ворони» («Ворон к ворону летит»), где вместо пушкинских «богатыря» и «хозяйки молодой» упоминаются «козак» и «козачка молодая», «Подражаніє Горацію» с приметами чисто украинского сельского пейзажа.

Но главное, благодаря чему Боровиковский занял заметное место в украинской литературе, - это стихи и баллады, написанные на украинском языке и в духе национальной лирико-романтической, песенной или барочной традиций. Таковы баллады «Чаровница», в ее основу положена песня «Ой не ходи, Грицю, та й на вечорницю», автором которой считается легендарная Маруся Чурай, и «Ледащо» (рус. лентяй, бездельник) - фольклорный мотив продажи казаком души черту. Высоко оценивались современниками басни и «прибаютки» Боровиковского, часто варьирующие традиционые сюжеты, однако с использованием приемов национальной смеховой культуры.

Яркой фигурой на тогдашнем харьковском горизонте был Николай Костомаров, фигурой, соизмеримой со Срезневским по своему положению на этом культурном пограничье и по значимости. Но не по «языковой биографии», она у него иная. Хотя Острогожский уезд Воронежской губернии, родина Костомарова, исторически относился к Слобожанщине и значительную часть населения здесь составляли этнические украинцы, для него, приехавшего в I833 г. в Харьков и поступившего на историко-филологический факультет университета, украинский язык был, по его признанию, совершенно незнакомым. Ситуация, олнако, изменилась быстро и кардинальным образом: глубокому и органичному освоению Костомаровым украинского языка способствовало сближение с представителями Харьковской школы романтиков, увлеченность украинским фольклором, этнографией, глубокий интерес к истории казачества. Важнейшую роль в этом процессе сыграл как раз Срезневский. «Я стал часто посещать его [Срезневского], и дом его сделался любимым местом отдыха и обмена мыслей», - вспоминает Костомаров в автобиографии. Н. Сумцов, приводя эти слова, добавляет, в своем пересказе, еще одно признание ученого: «И[змаил] И[ванович] сильно способствовал развитию в нем стремления к изучению малорусской народности. При его помощи, Костомаров стал изучать малорусский язык, мало ему знакомый, и малорусские повести Квитки» [7, с. 93]. В этот период в Харько- 
ве рождается украинский писатель Иеремия Галка - под этим псевдонимом Костомаров пишет и издает на украинском языке сборники стихов «Украинские баллады» и «Ветка», исторические произведения - драму «Савва Чалый» и трагедию «Переяславская ночь». В конце І840-х гг. в Киевском университете, куда он был приглашен ректором М. Максимовичем в качестве профессора русской истории, Костомаров входит (вместе с В. Белозерским, Н. Гулаком, П. Кулишом, А. Марковичем и чуть позднее присоединившимся к ним Т. Шевченко) в состав тайного славяно- и украинофильского Кирилло-Мефодиевского братства, пишет на украинском языке программную для братства «Книгу бытия украинского народа», результатом чего был арест, затем Петропавловская крепость, ссылка в Саратов. В І86о-е гг., возглавляя кафедру русской истории в Петербургском университете, Костомаров продолжает участвовать в украинском национальном движении, вместе с П. Кулишом и В. Белозерским он создает петербургскую украинскую «Громаду», активно сотрудничает в журнале «Основа». В условиях принятия в I863 г. печально известного Валуевского циркуляра, практически запрещающего украинский язык, Костомаров выступает инициатором сбора средств «в пользу издания книг научного содержания на южнорусском языке». «Каждый малорос знает, - пишет он в запрещенной цензурой статье “Правы ли наши обвинители?”, имея в виду прежде всего М. Каткова, - что она [“малорусская речь”] была речь отцов, дедов, прадедов его, что он ее всосал с материным молоком, что она его святое достояние; и этого довольно. <..> Вам не нравится малорусское наречие, на здоровье вам. А нам оно нравится. Что же с этим делать? Предоставьте нам говорить на этом “гадком грубом жаргоне”, не мешайте нам любить его <...>, а вы себе оставайтесь с мнением о его “ничтожестве и испорченности” (цит. по: [5, с. I44]).

Будучи русским ученым, специалистом по русской истории, Костомаров активно включает в круг своих научных занятий темы по истории Украины, пишет капитальные труды о Богдане Хмельницком, о периоде так называемой Руины, наступившей после смерти гетмана, о Юрии Хмельницком, Павле Полуботке, Иване Мазепе. Иеремия Галка остался в прошлом вместе с харьковским романтическим Sturm und Drang, но в истории остается благородная фигура русского ученого и украинского писателя, фигура, знаковая для русско-украинского духовно-культурного пограничья середины XIX в. 
В чем заключались суть и значимость русско-украинского духовно-культурного пограничья середины XIX в. как момента в истории украинской литературы? В том, что в обстоятельствах тотального имперского господства оно стало реальным и реалистичным для данных обстоятельств фактором утверждения этой литературой своей национальной идентичности, становления ее как одной из самобытных и самостоятельных европейских литератур. Процесс развивался в противоречивых условиях коэкзистенциального переплетения тендений, разделения и интеграции, фронтирного противостояния и творческого взаимодействия национальных традиций, ментальных особенностей, в том числе застарелых стереотипов и предрассудков. Все это закреплялось в нетривиальных, «симбиозных» формах, в частности, языковых, складываясь в феномен, который можно, с известной долей условности, обозначить обобщающим понятием «этнокультурное пограничье».

Примеры обращения ряда украинских писателей XIX в. к русскому и другим языкам относятся не только непосредственно к западной (Галичина) либо восточной (Слобожанщина, Харьков) пограничным этнокультурным зонам. Полтавец Иван Котляревский, с чьей «Энеидой» связывают начало новой украинской литературы, известен как автор «Оды Сафо» и новогодней «Песни», посвященной князю А.Б. Куракину. Евгений Гребинка, также полтавец, свое первое стихотворение опубликовал на русском языке («Рогдаев пир») в харьковском «Украинском альманахе», затем прославился украинскими баснями и «малороссийскими» приказками; в годы петербургской службы Гребинка написал ряд русскоязычных романов и текст получившего всемирную известность романса «Очи черные, очи страстные». «Петербуржец» и «казахстанец» Шевченко, как известно, оставил несколько стихотворных произведений на русском языке и целый корпус русскоязычных повестей. Вспомним также Квитку-Основьяненко, Гулака-Артемовского, многих «харьковских романтиков», еще П. Кулиша, М. Максимовича, Н. Костомарова, О. Бодянского, А. Стороженко. В галицком пограничном сегменте находим польско- и немецкоязычные тексты у И. Франко, немецкоязычные - у Ольги Кобылянской и О.-Ю. Федьковича. Или вот впечатляющий пример иного рода: этническая русская Мария Вилинская, автор русских романов и повестей, ставшая, под именем Марко Вовчок, классиком украинской литературы. 
Эмский акт, подписанный Александром II в I876 г. в немецком городе Бад-Эмс, закрепил и дополнил основные положения Валуевского циркуляра, направленные на ограничение использования и преподавания в России «малороссийского наречия». Украинское литературное поле на слобожанском пограничье, и до того не слишком щедрое на урожаи, было зачищено, казалось, более чем тщательно. Так казалось, но оказалось иначе.

Каким-то чудом в I883 г. в Харькове увидел свет сборник украинских стихов «Ворскло». Его автором был Яков Щоголев, последний из харьковских романтиков, тихо доживавший свой век в небольшом деревянном доме на улице Коцарской. За несколько десятилетий до этого, в самом начале I840-х гг., гимназист Щоголев опубликовал в «Литературной газете» А. Краевского элегию «Раздумье» и в «Отечественных записках» балладу «Канари», посвященную герою войны за независимость Греции адмиралу К. Канарису, к этому же периоду относится еще ряд русскоязычных элегий. Позднее, будучи студентом университета, Щоголев выступает в нескольких выпусках альманаха «Молодик», близком к школе харьковских романтиков, благожелательно принявших молодого поэта в свою среду, с обширной подборкой стихотворений, причем - обратим внимание - в разных выпусках поочередно публикуются то русские, то ранние украинские стихи. После то ли двух-, то ли трехлетнего перерыва он передает для «Южного русского сборника» несколько украинских стихотворений, которые, однако, по неизвестным причинам увидели свет лишь в г86о г. и не в «Сборнике», а в петербургском альманахе П. Кулиша «Хата». В последующие десятилетия Щоголев много времени и сил отдает чиновничьей службе, затем, уже будучи в отставке, он, угнетаемый житейскими заботами и семейными горестями, утратой близких, ведет уединенный образ жизнн (см.: [27]); пишет он в эти годы немного, но теперь исключительно на украинском. Негромкая поэзия Щоголева - натурфилософская и при этом зримо-предметная пейзажная лирика, проникнутая народнопесенными мотивами и интонацией, религиозным настроением, метафизической печалью, стихи историософского склада и казакофильской тематики, не лишенные патриархально-консервативного оттенка, поэтические «образки» народного быта и обычаев.

Поэзия Щоголева была замечена и оценена знатоками, но по-настоящему осмыслена критикой после его ухода. Вторая - и последняя - книга стихов Щоголева, «Слобожанщина», увидела свет в I898 г., в день его по- 
хорон. Путь самого молодого и последнего из поэтов харьковского романтического круга завершился. «Только тогда, - писал о почти мистическом эпизоде его похорон Б. Лепкий, - когда черный караван с гробом Щоголева двинулся по улицам Харькова на кладбище, в окнах книжных магазинов появилась его новая, вторая книжка стихов в зеленой обложке, словно зеленая ветка, заготовленная им на свой гроб» [19, с. І8].

К метафоре «гроба» прибегает, только в ином контексте и с иным значением, также Н. Зеров в работе о Щоголеве. По словам критика, Щоголев «донес до конца столетия» настроения харьковских романтиков, он словно «живой памятник на гробе давно прошедшей эпохи» [I6, с. 66]. Это сказано слишком категорично. Завершение деятельности Харьковской школы романтиков не было ее кончиной. В последние десятилетия XIX в. в том же Харькове на базе того же университета, не без влияния идей и при прямой поддержке Срезневского и Костомарова, сложилась научная «реинкарнация» «Школы» - Харьковская лингвистическая школа.

Основатель и признанный глава «Школы-2» Александр Потебня был выходцем из Полтавской губернии, гимназию заканчивал в польском Радоме, но вся его научная деятельность связана с Харьковом и отмечена печатью харьковского культурного и языкового пограничья. Потебня вырос в условиях русско-украинского двуязычия и в своих исследованиях опирался на диалог этих двух языков; при этом, однако, в работе «Язык и народность» отрицательно высказывался о двуязычии, считая, что оно «раздвояет круг мысли», затрудняет «достижение цельности миросозерцания» [Іо, с. 263]. Он прекрасно знал украинский язык, высоко ценил его лингвистический и художественный потенциал (кстати, перевел на украинский «Одиссею» Гомера). В письме к чешскому филологу-слависту Адольфу Патере от II декабря І886 г. Потебня вспоминает свои «уроки малорусского», полученные в детстве на хуторе у бабушки, и подчеркивает роль украинского языка в своем формировании как ученого: «Обстоятельствами моей жизни условлено то, что при научных моих занятиях исходной точкой моей, иногда заметной, иногда незаметной для других, был малорусский язык и малорусская народная словесность. Если бы эта исходная точка и связанное с ней чувство не были мне даны и если бы я вырос вне связи с преданием, то, мне кажется, едва ли я стал бы заниматься наукой» [2I, с. 93]. Но все свои научные и философские труды он пишет по-русски, более того, парадокс: 
украинский язык называет «малорусским наречием», а понятием «русский язык» обозначает совокупность восточнославянских языков.

Что касается литературного процесса, то «непривеченный», по определению Зерова, Щоголев был не столько «памятником прошедшей эпохи», сколько переходной фигурой, знаком преемственности духовно-национальных интенций романтической «Школы». Младшие современники и земляки Щоголева по слобожанско-харьковскому региону - Иван Манжура, Павел Грабовский, Архип Тесленко - первые свои шаги в литературе делали, как и он, на культурном и языковом пограничье: русскоязычные стихи, публицистические и научные статьи, переписка, переводы русских классиков. Как и Щоголев, они довольно быстро переключаются на - почти исключительно, или во всяком случае с абсолютным преимуществом, украинский, причем с «вторжением» его в новые, прежде мало освоенные им сферы. Для Грабовского, народника-революционера, это политика, подпольная деятельность, для Тесленко - острые социальные проблемы и аспекты крестьянской жизни накануне и во время революции І905 г., для Манжуры, племянника и верного последователя Потебни, - «сковородинство», «мандры», собирание, научное описание и осмысление фольклорно-этнографических материалов.

Что же происходит дальше?

Дальше дискурс харьковского этнокультурного пограничья приобретает - во всяком случае на определенный отрезок времени - прерывистый и драматический характер.

В условиях военных и революционных пертурбаций первых двух десятилетий XX в. нормальное развитие отмеченных выше культурных тенденций нарушается, начинает доминировать стихия хаоса, на поверхность процесса всплывают случайные, маргинальные, скоропреходящие факты и явления, смазываются границы, а значит, и пограничья, переходные формы отступают перед скачкообразными. Особенно остро подобные процессы проявляются в регионах, находящихся в зонах повышенной социальной турбулентности, на стыке противоборствующих политических тенденций и военных сил. Харьков той поры - именно такой регион: узел все более обостряющейся борьбы между набирающим силу пролетариатом и торгово-купеческим и промышленным капиталом, жизненное пространство, через которое попеременно, а то и одновременно, с разных сторон накатывались 
волны разной окраски - «сине-желтые» с юго-запада, «белые» с юго-востока, «красные» с северо-востока. На этом пограничье, в этой безумной круговерти рождался, становился другой Харьков. «Был Харьков слобод, хуторов и ремесленников, - пишет Ю. Шевелёв, харьковский старожил и свидетель событий. - Был Харьков - провинциальный купеческий город неисходимой и безысходно-серой российской империи. Теперь Хвылевой провозглашает третий Харьков, символ украинского урбанизма. Вздыбленной и мятежной Украины». «Я безумно люблю город!» - восклицает Хвылевой. Он безумно любит этот город, «украинский по своей сути», подчеркивает Шевелёв: «Третий Харьков - Харьков Хвылевого и ВАПЛИТЕ, курбасовского “Березоля”, выставок АРМУ (Ассоциация революционного искусства Украины. - Ю.Б.) <...> непримиримо-пламенных диспутов в Доме литературы им. Блакитного на Каплуновской, курсов востоковедения, украинского студенчества <...> постепенно украинизирующихся заводов и учреждений...» [29, с. 479, 480]. Такой - новый, украинизированный Харьков становится центральным «персонажем» произведений Хвылевого, его друзей и коллег (П. Тычина, М. Йогансен, И. Днепровский, Т. Масенко, А. Копыленко), складывается особый «харьковский текст» украинской литературы (см.: [26]).

Но все было не так просто. Союзная власть не намерена была мириться с таким положением вещей, и за дело берется ГПУ. Начинаются репрессии, после самоубийства Хвылевого (гз мая I933 г.) получившие громадный размах. Национальное культурное возрождение вошло в историю как «расстрелянное».

Не просто было все и по другим, объективным, причинам. Шевелёв, говоря в I948 г. (время написания статьи «Четвертый Харьков») об «украинизирующихся» в г920-е гг. харьковских заводах, отдает дань иллюзиям, которые в то время питали его старшие коллеги-земляки. На самом деле заводы не спешили украинизоваться, рабочие, хотя большинство (впрочем, отнюдь не абсолютное) в их среде составляли этнические украинцы, были в немалой части русскоязычными или во всяком случае не проявляли большой национальной активности. То же относится к значительной доле городского населения, принадлежавшего к другим национальным группам - русским, евреям, армянам, полякам, грекам, либо - что в силу исторических причин было традиционным для Харькова - к русскоязычным 
(впрочем, чаще «суржикоязычным») украинцам. Эта языковая, по существу - этнокультурная, ситуация отражена в известной комедии Миколы Кулиша, центральный персонаж которой, харьковский обыватель Мина Мазайло, при поддержке «тети Моти из Курска», меняет свою не слишком, по его мнению, благозвучную украинскую фамилию на русскую - Мазенин. Шевелёв неправ, когда создание в Харькове русского театра и русскозычной газеты ставит в один ряд с репрессивными действиями властей по отношению к национальному культурному возрождению. Русский театр и газета сами по себе - естественные и необходимые атрибуты этнокультурного пограничья, каковым был Харьков; другое дело, какие идеологические цели преследовала власть, в этом смысле превращение украинского «Березоля» из театра европейского образца и уровня, каким он был под руководством Леся Курбаса, репрессированного и расстрелянного в г930-е гг., в провинциальное этнографическое зрелище было куда более серьезным ударом по украинской культуре, чем открытие русского театра.

В последующие десятилетия обстановка на пограничье стабилизируется, время от времени застойная тишь-да-гладь нарушается идеологическими встрясками и кадровыми чистками в культурной сфере, борьбой то с «провокационными националистическими» призывами «любить Украину», то с сионистско-космополитическими «вылазками», после чего все возвращается на круги своя. Харьковское этнокультурное пограничье деструктурируется, утрачивает свою специфику и смысл. Да, в городе, как мы помним, функционируют два театра (до какого-то момента был и третий, еврейский), выходят русскоязычные газета и альманах, также газета и журнал на украинском, издательство выпускает книги на обоих языках. Местная писательская организация состоит из украинских и русских авторов, творчество двух представителей тех и других (И. Муратов и В. Добровольский) симметрично отмечено государственными наградами. Все идеологические нормы соблюдены, «дружба народов - дружба культур» продемонстрирована. Но пограничья как духовного феномена и как креативного фактора культурного развития нет, это, собственно, уже не пограничье - живое, пульсирующее противоречиями и взаимовлияниями, а конгломерат параллельно существующих фактов, формальных признаков. Неформальное русско- и украиноязычное пограничье остается на «низовом» уровне городской жизни - как примета повседневной жизни, общения, бытовой практи- 
ки, как маркер культурных запросов и вкусов различных групп населения; однако «трендом» этой пограничной ситуации на данном историческом этапе следует признать господство русскоязычной стихии в сфере культурного потребления. Причем речь идет о господстве, которое лишь частично, не в первую очередь, складывалось стихийно, в сиду объективных социально-экономических причин, а в большей степени под воздействием целенаправленных мер партийных органов и органов советской власти. К этой харьковской ситуации в полной мере подходит предлагаемый украинским ученым А. Сухомлиновым применительно к восточным регионам Украины, прежде всего к Харькову и Донбассу, термин «культурный тигель» - как определение «особенного типа культурного пограничья» [24, с. I49]. Автор предисловия к монографии А. Сухомлинова, польский филолог Гелена Красовска считает такой подход «интересным и перспективным», замечая, впрочем, что он «требует более подробного научно-теоретического обоснования» [I8, с. 8].

Перемены намечаются в г950-е гг., с началом оттепели, в следующем десятилетии они становятся реальным фактом духовно-культурной жизни Украины, одним из определяющих признаков эпохи. Возникшее на рубеже десятилетий как культурническое движение (киевский Клуб творческой молодёжи, І959 г., львовская группа «Пролісок», І96г г.) «шестидесятничество» быстро переросло в значимый идеологический фактор, в оппозиционную силу, в диссидентство. Оно охватило все сферы культуры, но особый резонанс вызвало в литературной среде, ибо затронуло такую чувствительную сферу, как проблемы национального языка. Творчество и выступления В. Стуса, И. Светличного, И. Дзюбы, Е. Сверстюка, Лины Костенко, Д. Павлычко, Миколы Руденко, В. Симоненко, Миколы Винграновского, И. Драча, авторитетных литераторов старшего поколения Б. Антоненко-Давидовича и Г. Кочура стали знаком нового этапа национального культурного возрождения, преемственного по отношению к возрождению г920-х гг., расстрелянному, но не забытому. На этнокультурном пограничье наметился сдвиг в «украинскую сторону», при этом реальное количественное соотношение между двумя составляющими практически не изменилось, это были новые акценты, корректировка представлений о ценностях и приоритетах. К тому же, хотя процесс в целом был общеукраинским, в разных регионах он протекал с разной степенью охвата и 
интенсивности. В Харькове это течение было не слишком бурным; правда, набирал силу созданный в 1956 г. украинский литературный журнал «Прапор» («Знамя), публиковавший произведения «шестидесятников», статьи о литературе I920-х гг., украинский театр освобождался от этнографической рутины, искал и часто находил пути к творческому продолжению курбасовских традиций, но общая конфигурация культурного пограничья, соотношение его компонентов, прежде всего языковых, по существу оставались прежними (см.: [3о]).

Оставались такими они до І990-х гг. и начала двухтысячных, когда в новых общественно-политических условиях украинский вектор обрел новую энергию и, если говорить в общем плане, стал в украинской литературе доминирующим. Такая тенденция отличает и ситуацию на харьковском пограничье, она очевидна и естественна, потому нет надобности останавливаться на подробностях. Кроме, пожалуй, одного интересного и существенно важного момента, касающегося, как представляется, в целом украинской «пограничной» проблематики в современных условиях.

«Сегодня <...> пришла мода, потребность и вообще время вспоминать и замечать до недавнего времени братьев наших “меньших" - русскоязычных писателей, живущих в Украине...» 4 - пишет харьковский критик Игорь Бондар-Терещенко. Не очень, так скажем, уместную есенинскую реминисценцию касательно «братьев наших “меньших” спишем на счет присущей ИБТ (так его обычно называют коллеги) иронично-провокативной манеры; слишком хорошо известно, кто́, согласно официозной имперской иерархии, считался на протяжении столетий «старшим братом», а кого снисходительно именовали «младшим». Примечателен факт признания критиком, находящимся не вовне, а в самой гуще литературной жизни региона, причем критиком украиноязычным, - признания того, что в сегодняшней Украине, конкретно - в Харькове, место русскоязычного писателя в общенациональном литературном процессе (а не в мифическом «русском мире») определяется прежде всего - и только - эстетическим уровнем и содержательной значимостью его, данного писателя, творчества. В СМИ, в специальной литературной прессе отмечается рост в последние годы чис-

4 Бондар-Терещенко İ. Українська і російська проза сьогодення: дві моделі «імперськості». URL: https://tsn.ua/blogi/themes/books/ukrayinska-i-rosiyska-proza-sogodennya-dvi-modeliimperskogo-buttya-892438.html (дата обращения: 12.09.2019). 
ла выпускаемых харьковскими издательствами произведений на русском языке, авторы некоторых из них занимают первые позиции в проводимом журналом «Фокус» рейтинге самых успешных писателей страны, их сочинения отмечены международными, в том числе российскими, премиями («Русский Букер» недавнего харьковчанина Михаила Елизарова). Такого рода показатели важны, но еще важнее критерии иного плана.

Важно, что наиболее интересные произведения живущих (или до недавнего времени живших) в Украине русскоязычных авторов дают критике повод и, главное, основания для широких - как позитивного, так и критического плана - сопоставлений и анализа в контексте украинской литературы «южнорусского» крыла литературы русской и образцов модернизма, таковы, например, постмодернистский роман Дмитрия Савочкина «Марк Шейдер» и остросоциальный роман Владимира Рафеенко «Долгота дня». Важно, что возникает и реализуется потребность сближения разноязычных и «разнорегиональных» писателей, сближения не на словах, а в творческом процессе, например, в создании коллективного проекта - романа «ДНК», объединившего представителей Харькова, Донбасса, Галичины и Волыни [I4]. Важно, что издающийся в Харькове вот уже около двадцати лет журнал «союз Писателей» распространяется не только в пределах слобожанско-донбасского пограничья, но в Киеве и Львове, продается в книжных магазинах Москвы, его можно найти в Германии, Италии, Дании, США, Израиле, где живут русские писатели - бывшие харьковчане. Основатель и соредактор «союза Писателей» Андрей Краснящих был одним из авторов и инициатором публикации в Facebook заявления харьковских писателей (2I человек, среди них - лауреаты, шорт- и лонглистеры российских премий), которые отвергают утверждения об «ущемлении прав русских в Украине»: «Мы, русские писатели Харькова, хотим, чтобы были услышаны и наши голоса: мы свободно, на работе и вне ее, общаемся на русском языке, и с украинскими коллегами тоже...»5.

5 URL: https://www.facebook.com/permalink.php?story_fbid $=724563634243372 \& \mathrm{id}=$ IOOO 00692271875\&comment_id=74I9I42\&ref=notif\%ACif_t=comment_mention (дата обращения: I0.09.2019). 


\section{Донбасский сегмент}

Решусь затронуть и щекотливую тему украинско-русского пограничья, конкретно на Донетчине и в Луганске. Могу говорить только о литературном аспекте этого пограничья. Много ли мы знаем о продолжительной совместной жизни в этих краях украинского и русского литературного слова? Исследована ли материя этой совместной жизни, ее история и динамика? А за этим - и политические, государственные проблемы, и социопсихологические, и этнокультурные, и этические...

Иван Дзюба

(Літературна Україна, 09.ІІ.20I7).

Под упомянутым только что харьковским «Заявлением 2I-го» нет подписи Владимира Рафеенко, автора романа «Долгота дней», и это объяснимо чисто формальным обстоятельством - он не харьковский писатель, он писатель донбасский. Но, думается, подпись могла бы быть. И не потому, что написанный на русском языке роман издан - и вряд ли это случайно - именно в Харькове [ІІ], главное - оба текста, такие разные по внешним параметрам, созвучны по смыслу и нравственной заряженности.

Владимир Рафеенко - уроженец и коренной житель Донецка. Окончил Донецкий университет, где учился на факультете русской филологии и культурологии. За четверть века литературной работы выпустил три поэтических сборника и семь романов, два из которых, «Московский дивертисмент» и «Демон Декарта», отмечены (соответственно в 2оIо и 2012 гг.) «Русской премией». В мае 20I4 г. Рафеенко был в числе тех, кто бил в набат на колокольне Свято-Преображенского кафедрального собора в Донецке в рамках акции за мирный Донбасс, тогда еше оставалась надежда. А в июле, когда в город вошли вооруженные люди (Рафеенко называет их «бурятскими танкистами-отпускниками»), он с семьей уехал в Киев, как и некоторые его коллеги-земляки.

«Обострилось ощущение, - рассказывает писатель о первых месяцах в статусе “переселенца”, - что меня не стало, убили по дороге в Киев, но Господь почему-то решил дать мне еще пожить. Я умер, но почему-то 
живу. Меня нет, но я есть. Я хочу домой, но дома нет. Это длилось с полгода. А потом жизнь и книга, которую я начал писать, стали лечить» ${ }^{6}$.

Метафора смерти-возрождения - это автореминисценция на предфинальные эпизоды романа «Долгота дней». Три центральных персонажа - профессор-банщик Сократ Гредис, литовец, никогда не бывавший в Литве, еще гуляка праздный, поэт, сочинитель сказок со знаковой русской фамилией Вересаев и еще девушка Лиза-Элеонора, отдаленно похожая одновременно на гетевскую Маргариту и на Маргариту булгаковскую, - эти персонажи проходят через некий метафизический тоннель между смертью «от рук матрешек цвета хаки» и «переселенческой» жизнью. В каждого из трех персонажей вложена частица личности и судьбы автора.

«Долгота дней» - роман сложной структуры и гибкой, подвижной системы поэтики. В нем два разных текстовых пласта, отражающих два ракурса в подходе к изображаемому. Один пласт, социально-бытовой, реалистический, местами не лишенный натуралистических черт, составляют «сказки»-новеллы Вересаева - фрагменты увиденного и пережитого в городе Z, отброшенном в некое пугающее инобытие, насыщенные, даже перенасыщенные болью «натюрморты войны», собрание моральных уродств, вранья, человеческих заблуждений, трагикомических ситуаций. Другой пласт текста - метафорический, игровой, с переходами в фантасмагорию, через которую открываются смыслы и поэтика замкнутого пространства некой Бани под названием «Пятый Рим», своего рода микромодели деформированного войной пространства города. Здесь ощутимы отголоски мистических снов Сковороды и гоголевских петербургских видений, магического реализма Маркеса и мнимой достоверности Йокнапатофы Фолкнера, а еще сказочных мотивов (в их «взрослых» интерпретациях) любимого автором «старого доброго Андерсена». Синтез контрастирующих поэтических стихий и пересекающихся времяпространственных дискурсов - решающий фактор реализации авторского замысла романа как трагической донбасской мистерии в Украине XXI в.

Почти одновременно с «Долготой дней» увидел свет еще один столь же актуальный «донбасский» роман, на сей раз украинский, - «Интернат»

6 Цит. по: Кригель M. Роман с Донецком. Посмертные приключения звонаря. Как писатель P. уехал из города Z. в страну U., по дороге умер и написал роман. URL: https://focus.ua/ long/350379/ (дата обращения: 12.09.2019). 
Сергея Жадана, уроженца Луганщины и довольно давнего уже харьковца [I5]. Роман столь же актуальный, как «Долгота дней», но - другой. Эта инаковость по сути «анонсировалась» - непрямо, в подтексте - еще до его выхода, в отзыве Жадана на украинский перевод романа Рафеенко7.

Жадан называет роман коллеги «чрезвычайно важным» и «необходимым», однако и «противоречивым», и эта противоречивость обозначена уже в заголовке рецензии - «Мистика против реальности». «Символические и мистические события», «босховские картины», «перетекание реального в нереальное», «игра», «реальность преобразуется в метафоры» - отмечая эти особенности поэтики романа «Долгота дня», рецензент стремится оставаться в литературных рамках, но, как ни удивительно, ему данное обстоятельство «мешает», ибо, считает он, «до сих пор сложно воспринимать события на Востоке [Украины] как литературный материал», который «подходит для эстетизации». То есть для художественного освоения, в сущности - для искусства. Сейчас не будем обсуждать этот тезис, особенно странный потому, что его формулирует писатель, в данном случае он интересен как косвенная («от противного») декларация о поэтике собственного романа, который - мы это теперь знаем - в ту пору заканчивался или, скорее, уже был готов.

Что же можно под этим углом зрения сказать об «Интернате»?

Декларация в значительной мере реализована в тексте, приоритет поэтики «реального» над поэтикой «нереального» очевиден. Реальность охваченной войной донбасской территории: полуразрушенный дом, простреливаемая улица, подвал-убежище интерната - повседневность, пронизанная атмосферой страха и упадка. Предельная достоверность на грани натурализма, «изнанка войны, ее кишки и внутренности», земля и люди предстают такими, «какими они бывают сразу после того, как по ним проедет своими гусеницами условный танк». Это характеристики чуткого рецензента, который стремится почувствовать и передать читательское восприятие романа. Доминанта этого восприятия - шок. «Как это - дом без стены? Как это - мертвые собаки, напуганные голуби, немытые и голодные двухлетние дети? Как это - когда не можешь свободно перейти улицу сво-

7 Жадан C. Містика проти реальності. URL: https://starylev.com.ua/club/article/mistykaproty-realnosti (дата обращения: 12.09.2019). 
его города, бегаешь от дерева к дереву, прячешься, боишься?» ${ }^{8}$ Шок усиливают сдержанность авторского тона, подчеркнутая простота изложения, за которыми угадывается попытка избежать литературной «эстетизации» изображаемого, «мистики» и всяческой метафоризации, оставив все это «Долготе дней» Рафеенко.

К счастью, эта попытка Жадану не удалась, да и не могла удасться, потому что «Интернат» написан не рассуждающим рецензентом, а художником, чувствующим и знающим, что у войны, кроме эмпирического, реального измерения, есть измерение четвертое, скрытое, ирреальное и что одной эмпирикой, даже самой достоверной, тут не обойтись. Осознанно или стихийно, по велению художественного чутья и таланта, писатель входит в многомерное пространство нетривиальных средств постижения реальности, ее скрытой символики и метафорики, ускользающих от поверхностного взгляда черт, ракурсов, изломов. Тогда интернат, где живут больные дети, превращается в метафизическое замкнутое пространство, в котором раскрашенные лица прячущихся в подвале интернатских девочек предстают метафорой недетского лица войны. Тогда роуд-сюжет поездки героя в интернат за племянником по разбитой фронтовой дороге между двумя противостоящими военными силами - «укропами» и «колорадами», в разбитом «Опеле» с привязанном к крыше гробом, обретает символический смысл как Путь к истине и к самому себе через войну, Путь, успешное завершение которого в романе, впрочем, только намечается, скорее угадывается. Тогда мотив бездомных, голодных, обозленных городских собак, эпизод со щенком на руках у вооруженного битой подростка («Вырастет - всех порвет») воспринимаются как метафоры всеобщего одичания, деформации детских душ.

Эти компоненты поэтики «Интерната» коррелируют с особенностями поэтики «Долготы дней». Пограничье, обозначаемое двумя романами, расширяется, эволюционирует от языкового к образно-поэтическому, мотивационному, семантическому.

Показательна близость позиций обоих авторов в акцентуации проблемы социально-нравственного выбора личности, оказавшейся в кризисных условиях, и в нестандартной трактовке этой проблемы через мотив вины и ответственности. С теми, кто инициировал трагедию в своих клано-

8 Кухар Альона. 3 нами стався «Інтернат». URL: http://litakcent.com/20I7/09/o5/z-namistavsya-internat/ (дата обращения: го.09.2019). 
вых или личных интересах, с теми, кто им покровительствует и помогает, и с «бандерлогами» вроде приехавшего «спасать» этот край Ивана Ивановича из романа Рафеенко - с ними все ясно. Но проблема вины глубже. В романе Жадана директриса интерната говорит: «Не тешьте себя иллюзиями, отвечать будут все. И хуже всего будет тем, кто отвечать не привык». «Все» - то есть виновные, и невиновные. Дело в том, что таких, кто «совсем ни при чем», в сущности нет, есть степень вины каждого, и есть общая вина всех, вина «покорности и усталости», беспечного довольства своим благополучием, вина беспамятства, утраты идентичности (наполненные пеплом чемоданы и дорожные сумки беженцев из «города, которого нет», в романе Жадана и в его же стихотворении «- Откуда ты, черная валка, птичья стая?»). Вина непонимания, неумения и нежелания понимать, пребывания под гипнозом старых идеологических стереотипов или новейших телевизионных клише; таков и у Рафеенко некий Пашка, который все «различал мутновато, как через грязное стекло. Ну и, в конце концов, записался, на войну против Правого сектора и, соответственно, за Гоголя, Гагарина...».

И есть особая вина тех, кто не чувствует своей вины, потому что не привык за что-либо отвечать. Таков у Жадана Паша, центральный персонаж «Интерната», который, находясь в огненном кольце войны, пытается оставаться в замкнутой зоне своего покоя, разумеется, безуспешно.

Общность тем, смыслов, трактовок, оценок, близость - при сохранении различий - некоторых аспектов поэтических систем и конкретных образных решений вносят в понятие пограничья новые моменты, но не размывают его, тем более, не отменяют. Стабилизирующим фактором пограничья как понятия/концепта выступает наличие двух языковых составляющих, в случае романов Рафеенко и Жадана - русской и украинской. При всех условиях эти составляющие сохраняют свою изначальную природу, язык остается одним из важнейших критериев национальной идентичности. Что не исключает возможности возникновения - под влиянием меняющихся внешних обстоятельств или внутренних импульсов - реакций на такие обстоятельства, тенденций «встречного движения» двух языковых стихий, моментов их взаимодействия, подчас тесного, вплоть до попыток преодоления разделительных линий, пограничных зон и даже смены языковых векторов. Так, Рафеенко в одном из интервью рассказывает, что свой новый роман, «дистанцированный от войны», но связанный с жизнью 
«переселенца с Востока», он пишет по-украински, хотя, правда, не уверен «в его языковой адекватности», поскольку отдает себе отчет в том, что его

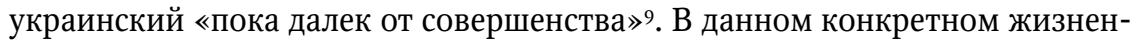
ном и творческом эпизоде отражаются вызванные войной сложнейшие, порой парадоксальные, нередко драматические процессы на донбасском этнокультурном, в частности - языковом, пограничье. С одной стороны, предельно обостряется, приобретает выраженно фронтирный, даже агрессивный характер, позиция представителей обеих сторон, объективно ведущая к превращению пограничья в зону отчуждения. С другой - противоположная тенденция, проявления толерантного, конструктивного подхода. Когда Жадан, комментируя радикальные выступления некоторых своих украиноязычных, как и он сам, коллег, говорит: «можно любить Украину на русском языке», за этим стоит знание и осознание неоднозначных реалий войны, ее слишком высокой цены, духовно-нравственных уроков и последствий: «[Я] лично знаю многих людей, которые являются добровольцами, волонтерами, общественными активистами, но они на четвертом году войны не отказались от своего русского», для этих людей украинский язык не чужой, они стараются на него переходить, «но не переходят полностью». Разве не лучше поддержать таких людей на этом переходе с перспективой дальнейшего движения, чем стараться вытеснить их за пределы пограничья, в чужую языковую зону?

Недавно увидело свет знаковое с точки зрения «пограничной» проблематики издание - антология «Порода», в нее вошли произведения украинских и русских писателей второй половины XX - начала XXI вв., чьи биографии и (или) творчество связаны с Донбассом [22]. Именно эта антология стала поводом для размышлений Ивана Дзюбы об украинско-русском литературном пограничье Донбасса, которые взяты в качестве эпиграфа к данному разделу статьи. Дзюба выступает автором предисловия к антологии, содержащего не только обзор и характеристику представленных текстов, но и суждения методологического характера, направленные на дальнейшее исследование темы, на «переоткрытие Донбасса» (название предисловия), на разработку различных аспектов проблемы украинско-русского пограничья

9 Этот роман, в постмодернистском ключе отражающий «переселенческую» судьбу автора, уже увидел свет: Рафеєнко В. Мондегрін. Пісні про смерть і любов. Черновцы: Meridian Czernowitz, 2019. $192 \mathrm{c}$. 
как важного структуро- и смыслообразующего фактора культуры Украины. Эти суждения Дзюбы важны и авторитетны как свидетельства литератора, знающего проблему не понаслышке - он родился на донбасской земле, закончил в свое время Сталинский педагогический институт (ныне Донецкий университет им. Василя Стуса, в 2014 г. эвакуированный в Винницу и продолжающий там функционировать) ${ }^{\mathrm{I}}$.

Название антологии не лишено провокативного оттенка, поскольку в речевом обиходе понятие «порода» связывается обычно с представлением о бесполезных отходах - либо в прагматическом аспекте, применительно к горнодобывающей сфере, либо в аспекте иносказательном, образном. Составители антологии вкладывают в ее название игру смыслов, «порода» здесь двуединая метафора: это скрытые в глубинных пластах общества и человеческой натуры, пока не познанные и не добытые ценные элементы и это сформированный особыми условиями человеческий тип высокого образца, «донбасский» характер, шахтерская косточка.

В антологию включены поэтические, прозаические и драматургические произведения - некоторые в отрывках - украинских и русских авторов старшего и среднего поколений, ушедших и здравствующих, среди них хрестоматийные классики - В. Сосюра, В. Стус, Эмма Андиевская, известные писатели - И. Светличный, Л. Лиман, Л. Талалай, И. Савич, В. Голобородько, А. Парщиков, также те, чье духовное и творческое становление пришлось уже на годы независимости, в частности, на последние Іо-І 5 лет; присутствие в антологии представителей этого литературного призыва И. Дзюба в своем предисловии отмечает как одну из существенных особенностей антологии, называя тут же две других («других» не по убывающей степени значимости, а, скорее, и даже несомненно, по нарастающей). Это

Iо Интересный, не лишенный парадоксальности, но по-своему знаменательный факт: помимо Ивана Дзюбы, автора нашумевшего в г96о-х гг. манифеста украинского национального движения «Интернационализм или русификация?», выходцами из Донбасса были другие видные представители украинского диссидентства - Василь Стус, Иван Светличный, Микола Руденко. Эти украинские писатели, замечает Дзюба, «появились не на пустом месте», украинская составляющая издавна присутствовала в литератуной жизни этого края, вспоминаются имена «харьковского романтика», уроженца донецкого Славянска Михайла Петренко, автора знаменитой песни «Дивлюсь я на небо..», Бориса Гринченко, создателя первого «Словаря украинского языка», в ХХ в. это тесно связанные с Донбассом биографиями и творчеством Микола Чернявский, Владимир Сосюра, Спиридон Черкасенко, Петро Панч, Павло Байдебура, Андрей Клоччя. 
«вызов представлению о Донецком крае (во всяком случае литературном) как о заповеднике советчины и “совковости”» и это акцент «на принципиально важном факте нормального (или соревновательного?) сосуществования <...> на Донетчине украинского и русского литературного Слова и $<$...> на возможной перспективе такого сосуществования в будущем, если оно, это общее будущее, все-таки будет...» [13, с. 6].

Как известно, количественные показатели немногое решают при оценке явлений и процессов художественного творчества, но все же стоит обратить внимание на тот - думается, примечательный - факт, что в антологии украинские и русские писатели представлены в равных, или почти равных, долях. Это может быть истолковано двояко - как, с одной стороны, свидетельство того, что украинское слово не растворилось в русскоязычной донбасской стихии, с другой - как подтверждение высказанного выше, применительно к современному Харькову, замечания о том, что характерная для последних десятилетий естественная интенсификация в общенациональном литературном потоке украинского «стержня» не сопровождается снижением творческого тонуса русской литературы, скорее напротив, есть основания отметить тенденцию его повышения. Собственно говоря, это два аспекта одного процесса - процесса гармонизации этнокультурного пограничья при сохранении его внутренней диалектики как стимулирующего, инновационного фактора.

С этим, безусловно благотворным, процессом связана еще одна весьма существенная особенность антологии. Объясним и закономерен тот факт, что в ее тематической, достаточно разнообразной, гамме, охватывающей проблематику второй половины прошлого века и начала нынешнего, что в этой гамме превалирующая роль принадлежит трагическим событиям последних лет на востоке Украины, мотивам, связанным с войной, страданиями и гибелью людей, беженством, извращением и подменой ценностей, расколом человеческих сообществ, распадом дружеских связей и даже семей, духовным и нравственным разложением. Примечательно, что в художественном отражении и постижении этого болезненного проблемно-тематического клубка находят свое место донбасские писатели обеих языковых групп. Выше это было показано на примере произведений С. Жадана и В. Рафеенко, оба представлены в антологии, первый - большой подборкой стихотворений, тематически, эмоционально и эстетически коррелирующих 
с «Интернатом», второй - отрывком из «Долготы дней». Без труда могут быть «выстроены», по принципу близости идейно-нравственных, гуманистических позиций и при очевидном, часто существенном, несходстве эстетики и поэтики, другие творческие «пары». Например, рассказ «Виклик» («Вызов») О. Завязкина, для манеры которого характерна причудливая смесь достоверности в описании будней прифронтовой скорой помощи с окрашенной иронией фантастикой, - и спокойно-раздумчивая, очень личностная русская проза Светланы Заготовой. Или знаковое для поэзии Любови Якимчук, переселенки из Луганска, трагико-экспрессионистическое стихотворение «розкладання» (рус. «разложение») - именно так, в экспериментальной манере, с маленькой буквы, с игрой звуков, разрывами слов и отсутствием знаков препинания («я больше не люба только ба»), - и философские поэтические этюды И. Козловского. Или гротескная фантастика прозаического фрагмента С. Федорчука «Столиця совків і Юрій» («Столица совков и Юрий») - и актуальные библейские аллюзии в поэтическом цикле Я. Минкина о «городе, которого вот-вот не станет».

Название издания сопровождено подзаголовком: «Антология украинских писателей Донбасса». То есть принадлежность всех представленных в антологии авторов к украинской литературе определена по географическому и тематическому признакам, независимо от того, на каком языке они пишут. Такой - простой, как дважды два, - подход не нов для литературно-критической практики в Украине, в последние десятилетия он не раз становился поводом для дискуссий, он кажется привлекательным и плодотворным тем, что якобы расширяет и обогащает пространство украинской литературы. Стоит, однако, обратить внимание на то, что И. Дзюба в своем предисловии к антологии формулирует суть проблемы принципиально иначе: «Украинское Слово и русское Слово в устах честных и ответственных сынов нашей страны звучат в унисон...» [13, с. I9]. Конечно, понятие «унисон» не универсально для этнокультурного пограничья как такового, есть много ситуативных вариантов, для характеристики которых уместны другие определения, например, «фронтир», «разграничение», «противостояние», «конфликт». Но применительно к конкретному случаю - современному донбасскому литературному пограничью - предложенное Дзюбой понятие «унисон» точно. 


\section{Список литературы}

I Багалей Д. Опыт истории Харьковского университета (по неизданным материалам). Харьков: Тип. и лит. М. Зильберберга и С-вья, I904. Т. 2 (I8I5-I835 гг.). II36 c.

2 Багалей Д. Удаление профессора И.Б. Шада из Харьковского университета. Харьков: Тип. Зильберберг, І899. 147 с.

3 Двести лет со дня рождения академика Измаила Ивановича Срезневского: сборник докладов Международной интернет-конференции, [I-3I марта, 2оI2 года] / под науч. ред. О.В. Лукина. Ярославль: ЯГПУ, 2оІ2. 2І8 с. Киселев В. Имперская словесность и славянский литературный регионализм: случай украинской журналистики начала ХІХ в. // Русин. 20I5. № 4 (42). С. 66-85. Костомаров Н. Правы ли наши обвинители? (до друку підготував Ю. Пінчук // Український історичний журнал. І990. № 7. С. I40-I46.

6 Кравченко В. Харьков/Харків: столица пограничья. Вильнюс: ЕГУ, 201о. 358 с.

7 Памяти Измаила Ивановича Срезневского. Книга І. Пг.: Тип. Императорской Акдемии Наук, г9г6. 42I с.

8 Полищук В. Из первых классиков. К 225-летию со дня рождения Петра Гулака-Артемовского // День. 30.0I.2015.

9 Полякова Ю. Русские литературно-художественные журналы Харькова XIX-XX веков (попытка перечисления) // ( Союз писателей. 2005. № I (6). C. 220-229. Рафеенко В. Долгота дней: городская баллада. Харьков: Фабула, 20I7. 304 с. Гулак-Артемовський П. Твори. Київ: Дніпро, г978. г59 с.

I3 Дзюба İ. Перевідкриття Донеччини // Порода. Антологія українських письменників Донбассу. Упоряд. Веніаміна Білявського та Микити Григорова. Передмова Івана Дзюби. [Київ]: Легенда, 20I7. С. 6-г9.

I4 Жадан С., Кідрук М., Фоззі, Карпа Ї., Винничук Ю., Кокотюха А., Рафєєнко В. ДНК. Харків: Клуб Сімейного Дозвілля, 2016. 240 с.

I5 Жадан C. Інтернат. Чернівці: Meridian Czernowitz, 20I7. 336 c.

I6 Зеров М. До джерел. Історико-літературні та критичні статті. Харків; Львів: Харківське видавицтво, г943. 272 с. Квітка-Основ’яненко Г. Зібрання творів: У 7 т. Київ: Наукова думка, г98г. T. $7.567 \mathrm{c}$.

I8 Красовська Г. Переднє слово // Сухомлинов О.М. Культурні пограниччя: новий погляд на стару проблему. Донецьк: Юго-Восток, 2008. С. 4-8.

I9 Лепкий Б. Яків Щоголів // Щоголів Я. Вибір творів. Берлін: Українське слово, I924. $74 \mathrm{c}$. Михайлин İ. Історія української журналістики XIX століття. Підручник. Київ: Центр навчальної літератури, 2003. 832 с. 
$2 \mathrm{I}$ Олександр Опанасович Потебня. Ювілейний збірник до г25-річчя з дня народження. Одеса: Вид-во Академії наук УРСР, І962. ІІ2 с.

22 Порода. Антологія українських письменників Донбассу. Упоряд. Веніаміна Білявського та Микити Григорова. Передмова Івана Дзюби. [Київ]: Легенда, 2017. $382 \mathrm{c.}$

23 Роммель Крістоф Дітріх, фон. Спогади про моє життя та мій час / пер. 3 нім. В. Маслійчук, Н. Оніщенко. Харків: Майдан, 20ог. 234, [г] с.

24 Сухомлинов О.М. Культурні пограниччя: новий погляд на стару проблему. Донецьк: Юго-Восток, 2008. 2 I2 c.

25 Ушкалов Л. Література галицька, слобідська та інші: принцип коекзистенції // Історії літератури: збірник статей. [Київ], Смолоскип, [Львів]: Літопис, 2010. $\mathrm{I} 84+\mathrm{I} 84 \mathrm{c}$.

26 Цимбал Я. «Харківський текст» І92о років: обірвана спроба // Літературознавчі обрії. Праці молодих учених. Київ, Інститут літератури НАНУ, 2ого. Вип. І8. C. 54-6I.

27 Шаховська-Брабант Є., кн. Біографія і спомини про батька // Діло (Львів). I5.06.I923.

28 Шевченко Т. Повне зібр. творів: у г2 томах. Київ: Наукова думка, 2003. Т. 5.492 с.

29 Шерех Ю. Пороги і запоріжжя. Література. Мистецтво. Ідеології. Харків: Фоліо, I998. T. I. 608 c.

30 Bertelsen O. Crossing Ethnic Barriers Enforced by the KGB: Kharkiv Writers' Lives in the I96os-70s // East/West: Journal of Ukrainian Studies. University of Alberta, Canadian Institute of Ukrainian Studiems. Canada. Tом 7 № I (2020). S. 7-54. 


\section{References $^{\text {II }}$}

I Bagalei D. Opyt istorii Khar'kovskogo universiteta (po neizdannym materialam) [History of the Kharkov university (based on unpublished materials)]. Kharkov, Tipografiia i litografiia M. Zil'berberga i Synov'ia Publ., I904. Vol. 2 (I8I5-I835 gg.). II36 p. (In Russ.)

2 Bagalei D. Udalenie professora I.B. Shada iz Khar'kovskogo universiteta [Removal of Professor I.B. Shada from the Kharkov University]. Kharkov, Tipografiia Zil'berberg Publ., I899. I47 p. (In Russ.)

3 Dvesti let so dnia rozhdeniia akademika Izmaila Ivanovicha Sreznevskogo: sbornik dokladov Mezhdunarodnoi internet-konferentsii, (I-3I marta, 20I2 goda) [Two hundred years since the birth of the Academician Izmail Ivanovich Sreznevsky: proceedings of the International Internet Conference, (March I-3I, 20I2)], sci. ed. by O.V. Lukin. Yaroslavl, Yaroslavl State Pedagogical University by K.D. Ushinsky Publ., 20I2. 2I8 p. (In Russ.)

4 Kiselev V. Imperskaia slovesnost' i slavianskii literaturnyi regionalizm: sluchai ukrainskoi zhurnalistiki nachala XIX v. [Imperial literature and Slavic literary regionalism: a case of Ukrainian journalism at the beginning of the $19^{\text {th }}$ century]. Rusin, 2015, no 4 (42), pp. 66-85. (In Russ.)

5 Kostomarov N. Pravy li nashi obviniteli? (published by Yu. Pinchuk) [Are our prosecutors right?]. Ukraïn'kii istorichnii zhurnal, I990, no 7, pp. I40-I46. (In Russ.)

6 Kravchenko V. Khar'kov/Kharkiv: stolitsa pogranich'ia [Kharkov / Kharkiv: the capital on the border]. Vil'nius, EGU Publ., 20Io. 358 p. (In Russ.)

7 Pamiati Izmaila Ivanovicha Sreznevskogo [In memory of Izmail Ivanovich Sreznevsky]. Petrograd, Tipografiia Imperatorskoi Akademii Nauk Publ., I9ı6. Book I. 42I p. (In Russ.)

8 Polishchuk V. Iz pervykh klassikov. K 225-letiiu so dnia rozhdeniia Petra GulakaArtemovskogo [Among the first classics. On the 225th anniversary of Peter GulakArtemovsky]. Den'. January 30, 2015. (In Russ.)

9 Poliakova Iu. Russkie literaturno-khudozhestvennye zhurnaly Khar'kova XIX-XX vekov (popytka perechisleniia) [Russian literary and art magazines in Kharkov of the $19^{\text {th }}-2 \mathrm{O}^{\text {th }}$ centuries (an attempt of a catalogue)]. Coiuz pisatelei, 2005, no I (6), pp. 220-229. (In Russ.) Potebny A. Estetika i poetika [Aesthetics and poetics]. Moscow, Iskusstvo Publ., I976. 6r3 p. (In Russ.) Rafeenko V. Dolgota dnei: gorodskaia ballada [Long days: a city ballad]. Kharkov, Fabula Publ., 20I7. 304 p. (In Russ.) Gulak-Artemovs'kii P. Tvori [Create!]. Kiev, Dnipro Publ., I978. I59 p. (In Ukrainian)

II Транслитерация осуществлена редакцией в соответствии с программой https://translit.

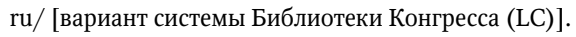


I3 Dziuba I. Perevidkrittia Donechchini [Rediscovery of Donetsk Region]. Poroda. Antologiia ukraïn'kikh pis'mennikiv Donbassu [Noble birth. Anthology of Ukrainian writers in Donbass], eds. Veniamin Bilyavsky and Mikiti Grigorov, introd. by Ivan Dziuba. Kiev, Legenda Publ., 20I7, pp. 6-I9. (In Ukrainian)

I4 Zhadan S., Kidruk M., Fozzi, Karpa I., Vinnichuk Iu., Kokotiukha A., Rafe€nko V. DNK [DNA]. Kharkov, Klub Simeinogo Dozvillia Publ., 20I6. 240 p. (In Ukrainian)

I5 Zhadan S. Internat [Boarding school]. Chernovtsy, Meridian Czernowitz Publ., 2017. 336 p. (In Ukrainian)

I6 Zerov M. Do dzherel. İstoriko-literaturni ta kritichni statti [On the sources. Historical, literary and critical articles]. Kharkov, Lviv, Kharkov Publishing House, I943. 272 p. (In Ukrainian)

I7 Kvitka-Osnovyanenko G. Zibrannia tvoriv: $u$ t $t$. [Col. of works: in 7 vols.] Kiev, Naukova dumka Publ., I98I. Vol. 7.567 p. (In Ukrainian)

I8 Krasovskaya G. Peredn€ slovo [Front word]. In: Suhomlinov O.M. Kul'turni pogranichchia: novii pogliad na staru problemu [Cultural borders: a new approach to the old problem]. Donetsk, Jugo-Vostok Publ., 2008, pp. 4-8. (In Ukrainian)

I9 Lepky B. Jakiv Shhogoliv [Yakov Shchogolov]. In: Shhogoliv Ja. Vybir tvoriv [Selection of works]. Berlin, Ukrai'ns'ke slovo Publ., I924. 74 p. (In Ukrainian)

20 Mikhailin I. Istoriia ukrai'ns'koi' zhurnalistyky XIX stolittia. Pidruchnyk [History of Ukrainian journalism of the $19^{\text {th }}$ century. Textbook]. Kiev, Centr navchal'noi' literatury Publ., 2003. 832 p. (In Ukrainian)

2I Oleksandr Opanasovych Potebnja. Juvileinyi zbirnyk do I25-richchia z dnia narodzhennia [Alexander Potebnya. Col. of works for the I25th anniversary]. Odessa, Izdatel'stvo Akademii nauk URSR Publ., I962. II2 p. (In Ukrainian)

22 Poroda. Antologiia ukraïn'kikh pis'mennikiv Donbassu [Noble birth. Anthology of Ukrainian writers in Donbass], eds. Veniamin Bilyavsky and Mikiti Grigorov, introd. by Ivan Dziuba. Kiev, Legenda Publ., 20I7. 382 p. (In Ukrainian)

23 Rommel' Kristof Ditrih, fon. Spogady pro moje zhyttja ta mij chas [Memories of my life and my time], transl. from German by V. Masliychuk, N. Onishhenko. Kharkov, Maidan Publ., 200I. 234, [I] p. (In Ukrainian)

24 Suhomlinov O.M. Kul'turni pogranichchia: novii pogliad na staru problemu [Cultural borders: a new approach to the old problem]. Donetsk, Jugo-Vostok Publ., 2008. 212 p. (In Ukrainian)

25 Ushkalov L. Literatura galyc'ka, slobids'ka ta inshi: pryncyp koekzystencii' [Literature of Galician, Slobidan, and others: the principle of coexistence]. In: Istorii' literatury: zbirnyk statei [Literary stories: a col. of articles]. Kiev, Smoloskip, Lviv, Litopys Publ., 20IO. I84+I84 p. (In Ukrainian)

26 Tsymbal Ya. "Harkivs'kij tekst” I920 rokiv: obirvana sproba [“Kharkov Text” I920s: An attempted trial]. In: Literaturoznavchi obrii’. Praci molodih uchenih [Literary 
Horizons. The works of young scientists]. Kiev, Institut literaturi NANU Publ., 20IO, issue I8, pp. 54-6I. (In Ukrainian)

27 Shahovs'ka-Brabant Je., kn. Biografija i spomyny pro bat'ka [Biography and memories of his father]. Dilo (Lviv). June I5, I923. (In Ukrainian)

28 Shevchenko T. Povne zibr. tvoriv: y 22 . [Complete works: in I2 vols.]. Kiev, Naukova dumka Publ., 2003. Vol. 5. 492 p. (In Ukrainian)

29 Shereh Ju. Porogy i zaporizhzhia. Literatura. Mystectvo. Ideologii' [Thresholds and Zaporozhye. Literature. Art. Ideologies]. Kharkov, Folio Publ., I998. Vol. I. 608 p. (In Ukrainian)

30 Bertelsen O. Crossing Ethnic Barriers Enforced by the KGB: Kharkiv Writers' Lives in the I960s-70s. East/West: Journal of Ukrainian Studies. University of Alberta, Canadian Institute of Ukrainian Studies. Canada. Toм 7 № I (2020). S.7-54. (In English) 
УДК 82I.5I2.I45

ББК $83.3(=632)$

\section{СТРУКТУРА И СЕМАНТИКА ПОЭТИЧЕСКИХ ЗАГЛАВИЙ ДЖ. КЕРМЕНЧИКЛИ}

(C) 2020 г. Т.Н. Киримов

НИИ крымскотатарской филологии, истории и культуры этносов Крыма, Государственное бюджетное учреждение высшего образования Республики Крым «Крымский инженерно-педагогический университет имени Ф. Якубова», Симферополь, Россия Дата поступления статьи: 3І января 2020 г. Дата публикащии: 25 июня 2020 г.

DOI: I0.22455/2500-4247-2020-5-2-322-335

Аннотация. В статье на примере литературного наследия поэта-публициста Джемиля Керменчикли и его современников Номана Челебиджихана, Бекира Чобанзаде, Мемета Нузета, Амди Гирайбая, Усеина Тохтаргазы, Мемета Ниязия, Абдуллы Лятифзаде рассматриваются семантические, композиционные, жанровые особенности поэтических заглавий, заголовочных комплексов в крымскотатарской поэзии начала XX в. Освещается преемственность тем, идей, а также литературных стратегий в творчестве упомянутых авторов. Целью настоящей работы является классификация, описание функций заголовка как ключа к пониманию сюжетного, идейного замысла художественного произведения. Автор статьи исследует важные черты творческого мышления Дж. Керменчикли, его стремление обсуждать проблемы классового неравенства, важности мусульманского просвещения, языкового сближения тюркских народов. Анализ диалогического, полилогического и монологического дискурсов заголовков произведений Дж. Керменчикли свидетельствуют об экспрессивности, коммуникативности и информативности его публицистических стихотворений, выявляет различные пути эмоциональнопсихологического воздействия на реципиента.

Ключевые слова: поэтика заглавий, заголовочный комплекс, авторская позиция, Керменчикли Джемиль, крымскотатарская литература.

Информация об авторе: Таир Нуридинович Киримов - кандидат филологических наук, ведущий научный сотрудник НИИ крымскотатарской филологии, истории и культуры этносов Крыма, Государственное бюджетное учреждение высшего образования Республики Крым «Крымский инженерно-педагогический университет им. Ф. Якубова», пер. Учебный-8, 295015 г. Симферополь, Россия. ORCID ID: 0000-0003-I282-0842

E-mail: tairkerimoff@gmail.com

Для цитирования: Киримов Т.Н. Структура и семантика поэтических заглавий Дж. Керменчикли // Studia Litterarum. 2020. Т. 5, № 2. С. 322-335. DOI: $10.22455 / 2500-4247-2020-5-2-322-335$ 


\section{THE STRUCTURE AND SEMANTICS OF POETIC TITLES BY D. KERMENCHIKLI}

This is an open access article distributed under the Creative Commons Attribution 4.0 International (CC BY 4.0)
(C) 2020. T.N. Kirimov

State Budget Educational Institution of Higher

Education of the Republic of Crimea Crimean

Engineering and Pedagogical University the Name of Fevzi Yakubov, Simferopol, Russia

Received: January 31, 2020

Date of publication: June 25, 2020

Abstract. The article examines semantic, compositional, and generic specificity of poetic titles in Crimean Tatar classical poetry at the beginning of the $20^{\text {th }}$ century, exemplified by the literary heritage of the poet and publicist Dzhemil Kermenchikli and his contemporaries Noman Chelebidzhikhan, Bekir Chobanzade, Mehmet Nuzhet, Mehmet Niyaziy, Hamdi Giraibay, Husein Tokhtargazy, and Abdullah Lyatifzade. The study highlights continuity of topics, ideas as well as literary strategies in the works of the mentioned the authors. The purpose of this work is to classify and describe the functions of the title as a key to understanding the plot and ideology of the literary work. The author of the article explores important traits of Dzh. Kermenchikli's work as well as his inclination to discuss such problems as class inequality, the importance of Muslim enlightenment, and linguistic vicinity of Turkic peoples. An analysis of the dialogical, polylogical, and monological discourses of the titles by Dzh. Kermenchikli testifies to the expressivity and conceptuality of his poems with a strong social content as well as it means to communicate with the reader and to influence her emotionally and its psychologically.

Keywords: title, the poetics of the title, author's position, Kermenchikli, Dzhemil, Crimean Tatar literature.

Information about authore: Tair N. Kirimov, PhD in Philology, Leading Researcher, State Budget Educational Institution of Higher Education of the Republic of Crimea Crimean Engineering and Pedagogical University the Name of Fevzi Yakubov, Uchebnyi lane 8, 2950I Simferopol, Russia. ORCID ID: 0000-0003-I282-0842

E-mail: tairkerimoff@gmail.com

For citation: Kirimov T.N. The Structure and Semantics of Poetic Titles by D. Kermencikli. Studia Litterarum, 2020, vol. 5, no 2, pp. 322-335. (In Russ.)

DOI: I0.22455/2500-4247-2020-5-2-322-335 
Присвоение произведению названия является трудоемкой задачей, над выполнением которой писателю приходится немало потрудиться. Ведь это первое, на чем концентрирует внимание реципиент, приступая к прочтению книги, сборника или отдельного текста. Его привлекают необычные, оригинальные заглавия, как в отдельности, так и в комплексе с подзаголовком, посвящением, эпиграфом, основным текстом, инициалами автора [I, с. 94]. В связи с этим писатель, обращаясь к психологии читательской аудитории, стремится построить максимально упрощенную, но в то же время совершенную конструкцию заглавия. Иногда не сразу удается достигнуть желаемого результата. Приходится вносить новые коррективы, так как длинные и замысловатые формулировки, по сравнению с краткими и простыми, ненадолго закрепляются в памяти реципиента [5, с. 205-216]. Обратимся к двум типам заглавий:

I. Длинные: «Къалай этип сырымны сагъа ачайым?» («Как же мне поведать свою тайну тебе?»), «Гениликнинъ бир дакъикъалыкъ зевкъы» («Сиюминутное блаженство молодости») [12, с. 33, 6о], «Къайдан чыкъкъан шу аслы?» («Откуда возникло это обыкновение?») [21, с. 67], «Кой хозяйствосы алетлери шай айта» («Сельскохозяйственные инструменты так говорят») [13, с. 29];

2. Короткие: «Антээткенмен!» («Поклялсяя!») [24, с. I48], «Татарым!» («Татарин я!») [15, с. 84], «Такъдирге» («Судьбе») [25, с. 39], «Налейи Къьрымм («Стоны Крыма») [23, с. І8], «Янбы саз» («Новый саз») [2о, с. 54], «Хиджрет» («Эмигращия») [ІІ, с. 86], «Тюркюли намаз» («Намаз под песнопения») [2I, c. I27].

Заглавия, приведенные во втором пункте, ассоциируются с поэтическим наследием таких крымскотатарских классиков, как Н. Челебиджихан, 
Дж. Керменчикли, Б. Чобанзаде, У. Тохтаргазы, А. Лятифзаде, А. Гирайбай, М. Нузет, и являются примечательными образцами их творчества. Впрочем, это вовсе не означает, что многосложные, более трех-четырех слов, названия из-за громоздкости уступают названиям с минимальным содержанием слов. Некоторые из них броскостью, аксиоматическим содержанием, своеобразностью стилистической окраски и даже провокационностью служат приманкой для читателя. Это явление в литературоведении обозначается английским термином «kicker» [9, с. I82]. Можно представить, какой эффект производило на крестьянина мистическое заглавие поэмы А. Чергеева «Эшит, мевта не севлеюр!» («Послушай, что говорит покойник!», 1909). В произведении просматривается социально-политический контекст трансформации национальной идентичности крымскотатарского народа. К киккеру можно отнести и небольшие заголовки. Например, стихотворение М. Нузета «Тюркюли намаз» («Намаз под песнопения»). В заголовке отражается ироническое отношение художника к необычной для мусульман форме совершения обряда поклонения Богу. Заинтригованный ирреальным эпизодом из жизни верующих, читатель с большим интересом принимается за прочтение стиха. Такой заголовок открыто предвещает сюжет произведения, в котором изобличается небрежное отношение проповедника и прихожан к религиозным предписаниям. Неординарностью поэтического названия поэт стремится привлечь реципиента к актуальной проблеме отдаления мусульманина от истинной веры.

Изучение поэтики заглавия берет начало в трудах известного советского писателя, театрального критика С.Д. Кржижановского. Изданная в I93I г., его монография «Поэтика заглавий» по сей день не утратила своей актуальности и остается востребованной исследователями. Основным материалом в книге является проза. Но исследовательница творческого наследия ученого А.А. Колганова утверждает, что контекст, на который была ориентирована теория Кржижановского, гораздо шире представленного в работе материала: сохранились архивные документы, в которых зафиксированы многолетние наблюдения ученого над природой названий книг, в частности драматургических произведений [5; 6].

В последнее время данная тема привлекает интерес исследователей различных гуманитарных дисциплин. Например, Т.В. Филат, А.А. Колганова, Н.А. Веселова, С.В. Иванова, Е.А. Соловьева рассматривают проблемы 
разработки методики исследования поэтики заглавия. В их работах сквозь призму литературного, лингвистического и психолингвистического анализа описываются эстетические, функциональные и структурные особенности авторских названий. В качестве материала используются как славяноязычные, так и англоязычные тексты разножанровых произведений [8; 6; 2; ; 7].

Вопросы поэтики художественного заглавия мало-помалу обретают популярность и в крымскотатарской науке. Можно отметить работы, в которых предпринимаются попытки освещения отдельных аспектов заголовочного комплекса. Например, «Опыт словаря псевдонимов крымскотатарских писателей» отражает многолетние искания И.А. Керимова в области довоенной и современной крымскотатарской печати. В процессе изучения заголовочного комплекса художественного текста словарь может оказать помощь при идентификации личности, определении специфики эволюции мышления национальных писателей [І4]. Ш.Э. Юнусов в монографии «Крымскотатарская поэзия I920-х годов XX века», обращаясь к творческому наследию Ш. Бекторе, указывает на взаимную подчиненность заглавий и текстов стихотворений поэта. Заголовок, утверждает исследователь, играет важную роль в раскрытии идейно-художественного замысла стихотворений, в обнаружении биографических сведений об авторе [Іо, с. 39-40].

Прежде, чем перейти к изучению творчества Дж. Керменчикли, в краткой форме осветим его творческую и жизненную судьбу. Поэт родился в г89г г. в дер. Керменчик Бахчисарайского уезда в семье учителя. Начальное образование получил в местной школе Абдуль-Алима. Продолжил учебу в бахчисарайском медресе «Зынджырлы». Затем усовершенствовал знания в стамбульском (1908-I909), оренбургском медресе (1909-I910). Вернувшись в Крым, полностью посвятил себя учительскому делу. Таким образом, на протяжении с г9го по I927 гг. Дж. Керменчикли работает в разных национальных школах Крыма. Публикуется в крымскотатарской прессе: «Терджиман» («Переводчик»), «Къырым оджагъы» («Крымский очаг»), «Миллет» («Народ»), «Енъи дюнья» («Новый свет»), «Къырым меджмуасы» («Крымский журнал»), «Ешиль ада» («Зеленый остров»). Здесь можно встретить его рецензии на крымскотатарские учебники, отзывы на выступления высокопоставленных политических деятелей, статьи, фельетоны, стихотворения, в которых обсуждаются проблемы истории, культуры, социально-экономической жизни Крыма. 
В I9I7 г. Дж. Керменчикли издал поэтический сборник «Кучюк достларыма» («Моим маленьким друзьям»). По данным газеты «Миллет», известно, что в I9I7 г. в печать готовились вторая и третья части упомянутого сборника, а также книга «Миллий хикяелер» («Народные рассказы»). Керменчикли черпает творческое вдохновение преимущественно в историческом прошлом простого народа. Различные стилистические приемы (экспрессивные лексические средства, насыщенная гиперболизация, филиппическая речь и пр.) в публицистических произведениях поэта были призваны служить воплощению эстетической категории порочного и идеального.

Дж. Керменчикли по обвинению в «национализме» был арестован 27 июля I937 г. Спустя год, I4 августа І938 г., приговорен к 8 годам лагерей. Погиб в 1942 г. Реабилитирован посмертно.

Чтобы ближе рассмотреть традиции озаглавливания в крымскотатарской литературе, обратимся к поэтическим текстам Дж. Керменчикли и его соратников М. Нузета, А. Кадризаде, М. Ниязия, Н. Челебиджихана и др. Наблюдения над творчеством Керменчикли выявляют различные по структуре и функциональной предназначенности заголовки. Примечательны заголовки-лозунги. С широким развитием печатного дела изначально размещающиеся на полотнах транспарантов, флагов, плакатов агитационные тексты получили высокую силу влияния на общественное сознание. Закрепившийся на столбцах многотиражных газет и журналов лозунг претерпевает значительные изменения. Мы находим его трансформации из сугубо политического в производственный, бытовой, рекламный и непосредственно в литературный лозунг. В поэтических текстах лозунг проявляется по-разному: в форме реминисценции, аллюзии на известные в определенных социальных кругах идеологические воззвания. В нем могут присутствовать элементы эллипсиса, то есть исключения отдельных частей предложения, фразы. Процесс эволюции печатного слова не затронул основное предназначение лозунга: отстаивать, требовать, констатировать и взывать.

Разберем заголовки революционных стихотворений Керменчикли: «Сен ольме догъ!» («Тыне умирай, возродисъ!»), «Ватанымдан чыкъ!» («Прочь из Родины моей!»), «Чалышмамакъ айып» («Стыдно не работать»), «Севин, эй, шанлы миллет!» («Ликуй, эй, славный народ!»), «Ватан хаинлерине къаргъышларым!» («Мои проклятия врагам отчизны!»). Автор выступает с уль- 
тимативным требованием к мурзам-изменникам Родины покинуть Крым, призывает народ к возрождению, констатирует негативное явление разложения морально-идеологических ценностей крестьян и рабочих. Посредством патетики, заключенной в рамках заголовочного текста, поэт задает читательской аудитории психологическую установку, которая способствует наиболее глубокому проникновению в идейный замысел произведения. Преемственность лозунговых традиций также наблюдается в творчестве Б. Чобанзаде: «Бир изин беринъиз!..» («Дайте право!..»), «Танъгъа догъру!..» («Вперед к рассвету!..»), «Келелер!.» («Идут!..») [25, с. І3, І5, 73]; А. Лятифзаде: «Къуртарынъыз ач олюмден!» («Спасите от голодной смерти!») [19]; А. Гирайбая: «Хош кельдинъиз» («Добро пожаловали»), «Уянынъыз, татарлар!» («Пробудитесь, татары!») [І2, с. 66, г3о]; У. Тохтаргазы: «Бизе пара керек!» («Нам нужны деньги!») [23, с. І6]. Апеллируя к общественному сознанию, писатели поднимают назревшие вопросы, касающиеся культурного возрождения, определения участи политических оппозиционеров, анализируют проблемы последствий голода в Крыму. Несмотря на общность социально-политических воззрений, их отличает манера обращения. В частности, Дж. Керменчикли, в отличие от единомышленников, более отчетливо обозначает адресата, к которому обращается персонально.

Анализ структурных особенностей заголовков, позволяет обнаружить их общую коммуникативную значимость для выражения авторских интенций. Можно выделить различные способы внутритекстового поэтического общения. В творчестве Керменчикли встречаются заголовки, определяющие:

- диалогическую: «Сен ольме, догъ!» («Ты не умирай, возродисъ!»), «Севин, эй, шанль миллет!» («Ликуй, эй, славный народ!), «Чалышмамакъ айып» («Стыдно не работать»), «Ватанымдан чыкъ!» («Прочь из Родинь моей!»);

- монологическую формы общения: «Татарым!» («Татарин я!») [15, с. 68, 78, 84], «Бен бир тюркюм» («Тюрок я») [18], «Сонъ созюм» («Мое окончательное слово») [16, с. 105-106];

- заголовки, включающие реципиента в круг собеседников: «Бизим багъча» («Наш сад»), «Озь тилимиз» («Наш язык»), «Учурымын башындайыз» («Мы на склоне обрыва») [15, с. 56, 70, 88]; 
- заголовки, предвещающие назидательный диалог непосредственно персонажей в поэтическом произведении: «Хакиминъ маслахаты» («Советы мудреия») [22, с. 85].

Названные формы вербального контакта поэта с реципиентом раскрывают сущность творческого мышления художника. Так, вопрошание, восклицание или повествование как элементы интонационных универсалий определяют смысл и значение фундаментальных операций мыследействия автора [9, с. І66-І69]. Интонационная организация заголовочного текстопостроения Дж. Керменчикли выражается, как показывает материал, предложением с восклицательным знаком. Эмоциональной насыщенности в названиях к стихотворениям автор достигает и с помощью смысловых акцентов. Тем не менее не все формы таких заголовков Керменчикли поддаются четкой интерпретации. Например, при первом прочтении таких заголовков, как «Сонъ сёз» («Последнее слово»), «Бен бир тюркюм» («Тюрок я»), читатель испытывает затруднения при их осмыслении, так как в значении этих словосочетаний нет той безоговорочности, что присутствует в заголовках с восклицательным знаком: «Сен ольме, догъ!» («Ты не умирай, возродись!»), «Севин, эй, шанлы миллет!» («Ликуй, эй, славный народ!), «Ватанымдан чыкъ!» («Прочь из Родины моей!»). Читатель может воспринимать их по-разному: положительно, отрицательно, с прискорбием, радостью или нейтрально.

Как упоминалось выше, авторскую позицию формирует цельный заголовочно-финальный комплекс, состоящий в основном из таких частей, как заголовок, подзаголовок, эпиграф, текст произведения, подпись писателя, дата. Немного остановимся на подписи автора. Сюда могут входить личные инициалы, псевдоним, криптонимы. В крымскотатарской литературе встречаются такие криптонимы, как М.Къ. (Мустафа Куртиев); УМБИ (Умер-Бекир Ипчи). Примечательно, что некоторые произнесенные вслух криптонимы обретают неожиданный смысл. Например, М.Къ. слышится как слово «мыкъ» и в переводе на русский язык означает «гвоздь». Впрочем, колкие, сатирические сюжеты произведений М. Куртиева целиком соответствуют его подписи.

Можно перечислить некоторые псевдонимы и развернутые конструкции инициалов современников Дж. Керменчикли. Это Муфтий Челебиджи- 
$х а н=$ Челебиджихан = Н. Челебиджихан; Солдат = Осман-Нури Акчокракль = О. Акчокраклы; Чатыртавлы = Темурджан = Темурджан Одабаш =X. Одабаш; Керчли М. = Керчли Мебсюсе = Махмут Недим; Тюйревич = Челеби-заде Мехмет Нузхэт = Мехмет Нузхэт = М. Нузхэт; Берке = Мустафа Курти = мустафа Куртиев; Эски Кырымлы = А.Р. Кадризаде = А. Рехми Кадризаде $=A$. Кадризаде. Они могут многое поведать о характере, деятельности их владельца. Как видно из примеров, для данных писателей присуще неоднократное переосмысление индивидуального имени. Это зависит от самооценки автора и специфики содержания произведения. Литературное имя также может отражать ценности, убеждения поэта. Например, псевдоним Керменчикли: «Къырымлы» («Крымещ»). Рассмотрим его связь с заголовком и текстом стихотворения:

\section{Бен бир тюркюм}

Эксериет тюрклюге атар джан,

Къардашлылар татар ве тюрк бирдир къан.

Бугунь онынъ аягъында ёкъ аркъан.

Бен бир тюркюм, тюрклюге къурбаным,

Меслегимден вазгечерсем, урьяным

Бен бир тюркюм, анълашылыр сёзюмден,

Тюрклюгин къаны фырлар юзюмден,

Хасрет яшы акъып турар козюмден,

Бен бир тюркюм, гъайып этмем лисаны,

Чатыртавлы, сыкъма бойле инсаны.

Керек дегиль дилимизи больмее,

«Тюрк», диерек халкъымызы кесмее.

O, хазырдыр бу макъсатта ольмее,

Бен бир тюркюм, пек северим бу дили,

Анълар буны Къырым, Кавказ, Рум или.

Къырымлы [18].

\section{(Тюрок я}

Страстью вожделеет к тюркизму народ,

Тюрок и татарин - братья по крови.

Легки от пут ноги их ныне.

Тюрок я, тюркизма ради жизни не жаль, 
Позор мне в случае измены убеждению.

Тюрок я, в свидетельство слог мой,

Пламенем рдеет тюркизма лик,

Слеза тоски глаза мои томит,

Тюрок я, наречием дорожу,

Чатыртавлы, за это не вини человека.

Не стоит разделять язык наш,

Делить народ укорами: «- Ты тюрок».

За это он готов погибнуть,

Тюрок я, люблю язык очень этот,

Со мной согласны Крым, Кавказ и земли Рума.

\section{крымеи) \\ [Перевод наш. - T.К.].}

Повторения словосочетаний и слов «Бен бир тюркюм» («Тюрок я»), «Тюрк» («Тюрок»), «Тюрклюк» («Тюркство») являются ключевыми в идеологии поборников тюркизма. Вдохновленный величием и родством тюркских языков, поэт посредством тавтологии повышает эффективность на первый взгляд мало информативного заголовка. В стихотворении автор стремится эмотивными средствами интерпретировать суть избранной миссии, проповедующей языковую коалицию тюркского мира [4, с. I36]. В связи с этим он обращается к идеологическому оппоненту Чатыртавлы (А. Одабашу) с просьбой не разобщать крымскотатарский народ. Дж. Керменчикли больше склоняется к идее сплочения всех тюркских народов.

Заголовки Керменчикли одновременно выполняют жанрово- и циклообразующую функции: «Мектеп шаркъысы» («Школьная песня»), «Экинджи мектеп» («Вторая школьная песня»), «Учюнджи мектеп шаркъысы» («Третья школьная песня) [22, с. 94-97]. В творчестве поэта встречаются оригинальные эпизоды, когда в текст заголовка вносится уточнение рода произведения: «Эсами джедвели ерине шиир» («Стих вместо поименного списка»). Стихотворение опубликовано в газете «Миллет» («Народ») за II сентября І9г7 г. Это время предвыборных агитаций в первый крымскотатарский Курултай. Таким способом поэт выражает личное отношение к бюрократизму предвыборной кампании. Он предлагает взглянуть на обратную сторону не сходящих с полос газеты длинных списков кандидатов 
в Курултай. Замещая сухой перечень имен строками стихотворения, автор погружается в собственные раздумья об утраченном чувстве патриотизма крымских татар. Возможно, это стихотворение вошло в один из его малоизученных сборников произведений. О них сообщается в газетных объявлениях под общим названием «Енъи китап» («Новая книга», I9I7). Речь идет о содержании вышедшей первой из трех частей книги «Кучюк достларыма» («Моим маленьким друзьям»). Какое-то время литературные обозреватели, судя по заглавию, ошибочно считали ее детской. Но из тех же газетных анонсов о содержании книги видно, что стихотворения поэта имеют философско-публицистическую направленность: «Сонъ сёз» («Последнее слово»), «Раст келе бир корюшюв» («Как-то раз встретившись»), «Хатибе» («Хатипу»), «Мукъаддес эмелимиз олуркен» («Когда осуществляется наша сокровенная мечта»), «Челебиджихана» («Челебиджихану»), «Бир фахише агъзындан» («Из уст путаны»), «Дженк мейданы» («Поле боя») и др. [4, c. 23-37]. Из воспоминаний сына Дж. Керменчикли известно, что в 1937 г. вышеупомянутым изданием основательно интересовались сотрудники НКВД. Тогда перевод книги с крымскотатарского языка на русский был поручен литературоведу А. Фетислямову [I7, с. 5I-53].

В заключение отметим, что поэт серьезно подходит к выбору названий для своих сочинений. Иногда он вносит поправки в заголовки. Отчасти это объясняется тем, что значение отдельных названий, из-за размытости интонационно-экспрессивных акцентов, мало поддается точной интерпретации. Так, название «Сонъ сёз» («Последнее слово») поэт заменяет более интонационно оформленным «Сонъ сёзюм» («Мое окончательное слово»).

Заголовки Керменчикли являются доминантами идейного мышления поэта, оказывают номинативно-коммуникативное воздействие на читателя. Перед исследователем возникают вопросы, связанные с всеобъемлющим изучением заголовков к прозаическим и публицистическим произведениям автора; разработкой специальной методики анализа истории развития, формирования, возникновения или исчезновения тех или иных традиций озаглавливания в крымскотатарской литературе. Творчество Керменчикли свидетельствует о необходимости исследования поэтики заглавий в контексте комплексного изучения макро- и микропоэтики художественных текстов. 


\section{Список литературы}

I Введение в литературоведение. Литературное произведение: основные понятия и термины / под. ред. Л.В. Чернеца. М.: Высшая школа, 2000. 556 с.

2 Веселова Н. А. Заглавие литературно-художественного текста: онтология и поэтика: автореф. дис. ... канд. филол. наук. Тверь, г998. 24 с.

3 Иванова С. Языковые особенности поэтического заголовка (на материале русского и английского яз.): автореф. дис. ... канд. филол. наук. Ульяновск, 2006. 24 с. Киримов Т. Творческое наследие Дж. Керменчикли. Симферополь: Оджакъ, 2007. I64 c.

Кржижановский С. Собр. соч.: в 5 т. СПб.: Симпозиум, 2006. Т. 4: Статьи. Заметки. Размышления о литературе и театре. 848 с. Кржижановский С.: доклад 1939 / вступит. ст. и коммент. А.А. Колгановой // Новое литературное обозрение. 200I. № 52. С. $205^{-216 .}$

Соловьева Е. Диалогические основы англоязычного поэтического текста в аспекте его категориальных свойств: автореф. дис. ... канд. филол. наук. Саранск, 2007. I9 c.

Филат Т. Поэтика заглавий прозы И. Шмелева (своеобразие семантики и структуры) // Вісник дніпропетропетровського університету економіки та права ім. Альфреда Нобеля: Серія «Філологічні науки». 20ІІ. С ІІ2-ІІ8.

Эстетика. Теория литературы: энциклопедический словарь терминов / сост. Ю. Борев. М.: Астрель, 2003. 575 с. Юнусов Ш. Крымскотатарская поэзия 2о-х годов ХХ века: традиционное мировоззрение и меняющийся мир. Симферополь: Доля, 2004. I68 с. Гирайбай А. Джигитке / терт. И. Керимов. Акъмесджит: Тарпан, 2009. II2 с. Гирайбай А. Шиирлер / аз. У. Эдемова. Акъмесджит: Таврия, I997. 143 с. Кендже Дж. Бала шиирлери. Акъмесджит: Къырым Меркезий Енъи Элифбе Комитеси нешри, I927. 33 с.

I4 Керимов И. Къырымтатарджа къыйын сёзлер. Тахаллюслер лугъаты. Акъмесджит: Таврия, 2006. I76 с.

I5 Керменчикли Дж. Ма-бих-иль ифтихарым - къырымлыкътыр меним гъурурым / аз. Т. Киримов. Симферополь: Крымучпедгиз, 2005. 136 с.

I6 Керменчикли Дж. Сонъ сёзюм // Къырым меджмуасы. І918. № 6. С. Iо5-Іо6.

I7 Керменчикли Э. Дешетли кечмишини хатырлап // Йылдыз. І996. № 4. С. 5I-53.

I8 Къырымлы. Бен бир тюркюм // Миллет. І9г8. г9 августа.

I9 Лятифзаде А. Къуртарынъыз ач олюмден! // Енъи дюнья. 1922. 27 января.

20 Лятифзаде А. Янъы саз. Акъмесджит: Къырым Меркезий Енъи Элифбе Комитеси нешри, I928. 54 с.

2I Нузет M. Къырымнынъ чёль аятындан / аз. Н. Сейтягья. Акъмесджит: Доля, 2003. $240 \mathrm{C}$. 


\section{References}

I Vvedenie v literaturovedenie. Literaturnoe proizvedenie: osnovnye poniatiia i terminy [Introduction to literary criticism. Key concepts and terms], ed. by L. Chernetsa. Moskow, Vysshaia shkola Publ., 2000. 556 p. (In Russ.) Veselova N.A. Zaglavie literaturno-khudozhestvennogo teksta: ontologiia i poetika: avtoref. dis. ... kand. filol. nauk [Title of the literary text: anthology and poetics: PhD thesis, summary]. Tver', I998. 24 p. (In Russ.)

3 Ivanova S. Iazykovye osobennosti poeticheskogo zagolovka (na materiale russkogo $i$ angliiskogo iaz.): avtoref. dis. ... kand. filol. nauk [Linguistic features of the poetic title (on the material of Russian and English languages): $\mathrm{PhD}$ thesis, summary], Ul'ianovsk, 2006. 24 p. (In Russ.)

4 Kirimov T. Tvorcheskoe nasledie Dzh. Kermenchikli [Creative legacy of Dzh. Kermenchikli]. Simferopol', Odzhak Publ., 2007. I64 p. (In Rus.)

$5 \quad$ Krzhizhanovskii S. Sobranie sochinenii: $v 5 t$. [Collected works: in 5 vols.]. St. Petersburg, Simpozium Publ., 2006. Vol. 4: Stat'i. Zametki. Razmyshleniia o literature i teatre [Articles. Notes. Reflections on literature and theater]. 848 p. (In Russ.)

6 Krzhizhanovskii S.: doklad I939 [Krzhizhanovskij S.D.: Report I939], introd. and comm. by A.A. Kolganova. Novoe literaturnoe obozrenie, 2001 , no 52, pp. $205^{-216 .}$ (In Russ.)

7 Solov'eva E. Dialogicheskie osnovy angloiazychnogo poeticheskogo teksta v aspekte ego kategorial>nykh svoistv: avtoref. dis. ... kand. filol. nauk [Dialogical foundations of the English poetic text in the perspective of its categorial properties: $\mathrm{PhD}$ thesis, summary]. Saransk, 2007. I9 p. (In Russ.)

Filat T. Poetika zaglavii prozy I. Shmeleva (svoeobrazie semantiki i struktury) [Poetics of the titles in I. Shmelev's prose (originality of semantics and structure)]. Visnik dnipropetropetrovs'kogo universitetu ekonomiki ta prava im. Al'freda Nobelia: Seriia "Filologichni nauki", 20II, pp. II2-II8. (In Russ.)

9 Estetika. Teoriia literatury: entsiklopedicheskii slovar' terminov [Literary theory: Encyclopedic dictionary of terms], comp. by Iu. Borev. Moskow, Astrel' Publ., 2003. 575 p. (In Russ.) 
Iunusov Sh. Krymskotatarskaia poeziia 2o-kh godov XX veka: traditsionnoe mirovozzrenie i meniaiushchiisia mir [Crimean Tatar poetry of the I920s: traditional worldview and changing world]. Simferopol', Dolia Publ., 2004. I68 p. (In Russ.)

Giraibai A. Dzhigitke [To hothead], ed. by I. Kerimov. Simferopol', Tarpan Publ., 2009. II2 p. (In Crimean Tatar)

Giraibai A. Shiirler [Verses], ed. by U. Edemova. Simferopol', Tavriia Publ., I997. I43 p. (In Crimean Tatar)

Kendzhe Dzh. Bala shiirleri [Verses for children]. Simferopol', Kyrym Merkezii Eni Elifbe Komitesi neshri Publ.,I927.33 p. (In Crimean Tatar)

Kerimov I. Kyrymtatardzha kyiyn sezler. Takhalliusler lugaty [Dictionary of difficult words of the Crimean Tatar language and pseudonyms]. Simferopol', Tavriia Publ., 2006. I76 p. (In Crimean Tatar)

Kermenchikli Dzh. Ma-bikh-il' iftikharym - kyrymlyktyr menim gururym [Belonging to Crimea is my pride], ed. by T.N. Kirimov. Simferopol', Krymuchpedgiz Publ., 2005. I36 p. (In Crimean Tatar)

Kermenchikli Dzh. Son sezium [My last word]. Kyrym medzhmuasy, I9I8, no 6, pp. I05-I06. (In Crimean Tatar)

Kermenchikli E. Deshetli kechmishini khatyrlap [Remembering the past]. Iyldyz [Star], I996, no 4, pp. 5I-53. (In Crimean Tatar)

Kyrymly. Ben bir tiurkium [I am a Turk]. Millet [Nation], I9I8, August I9. (In Crimean Tatar)

Liatifzade A. Kurtarynyz ach oliumden! [Save from starvation!] Eni diun’ia, I922, January 27. (In Crimean Tatar)

Liatifzade A. Iany saz [New swamp]. Simferopol', Kyrym Merkezii Eni Elifbe Komitesi neshri Publ., I928. 54 p. (In Crimean Tatar)

I Nuzet M. Kyrymnyn chel' aiatyndan [From the life in Crimean steppe], ed. by N. Seitiag’ia. Simferopol', Dolia Publ., 2003. 240 p. (In Crimean Tatar)

Saadet ichiun. U. Toktargazy ve dig. Shiirler, poemalar, p'esa [For the sake of happiness. U. Toktargazy and others. Verses, poems, play], ed. by A. Altanly ve dig. Tashkent, Edebiiat ve sanat neshr Publ., I976. I38 p. (In Crimean Tatar)

3 Tokhtargazy U. Naleii Kyrym [Moans of Crimea]. Karasubazar, Z.O. Rushannyn matbaasy Publ., I9IO. I8 p. (In Crimean Tatar)

4 Chelebidzhikhan N. Ant etkenmen [I took oath]. Kyrym medzhmuasy [Crimean Journal], I9I8, no 8, pp. I48. (In Crimean Tatar)

Chobanzade B. Bir sarai kuradzhakman [I will build a palace]. Simferopol', Sonat Publ., 200I. I92 p. (In Crimean Tatar) 
УДК 398

ББК 82.3

\section{БЛАГОВЕРНАЯ ЦАРИЦА ХИТРА БЫЛА МУДРА: ОБ ОДНОЙ СИНОНИМИЧЕСКОЙ ПАРЕ В РУССКОМ ФОЛЬКЛОРЕ}

\author{
(C) 2020 г. Т.А. Агапкина \\ Институт славяноведения \\ Российской академии наук, Москва, Россия \\ Дата поступления статьи: I7 февраля 2020 г. \\ Дата публикации: 25 июня 2020 г.
}

DOI: $10.22455 / 2500-4247-2020-5-2-336-389$

Аннотация: В настоящей статье предпринято исследование синонимических пар, таких как хитрый-мудрый, хитёр-мудёр, хитрость-мудрость и т. д., а также сложного слова хитромудрый в русском фольклоре. Проанализированы материалы тех жанров, в которых эти пары представлены наиболее широко: это заговоры, былины, причитания, свадебные и лирические песни, а также сказки. Рассматриваются фольклорные контексты, в которых синонимические пары типа хитрый-мудрый формируют круг регулярных значений; то, что́ и кого регулярно называют хитростями-мудростями и хитрым-мудрым в разных жанрах; в какие тематические поля попадают эти парные конструкции, их значения и особенности функционирования в отдельных жанрах и др. Устанавливается, что бо́льшая часть значений, которые обнаруживает эта синонимическая пара, имеет отношение к специальному знанию - будь то магия, оборотничество, военное дело, профессиональные навыки или искусное владение ремеслом. Предполагается, что именно на основе этого общего значения в заговорах, в соответствии с их установкой на «вежество», сформировалось специальное значение ‘быть связанным с тайным знанием, ведовством, магией', которое в итоге и становится доминирующим. Это значение находит поддержку в диалектной речи, обнаруживаясь у слов на хитр- и мудр- в разных регионах Европейской России, особенно широко на Русском Севере и примыкающих территориях северо-запада и северо-востока.

ключевые слова: русский фольклор, синонимические пары, заговоры, былины, вербальная магия, русские диалекты.

Информация об авторе: Татьяна Алексеевна Агапкина - доктор филологических наук, ведущий научный сотрудник, Институт славяноведения Российской академии наук, Ленинский пр., д. 32 а. ІІ999г г. Москва, Россия.

E-mail: agapi-t@yandex.ru

Для цитирования: Агапкина Т.А. Благоверная царица хитра была мудра: об одной синонимической паре в русском фольклоре // Studia Litterarum. 2020. T. 5, № 2. С. 336-389. DOI: I0.22455/2500-4247-2020-5-2-336-389 


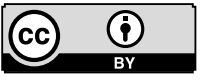

This is an open access article distributed under the Creative Commons Attribution 4.0 International (CC BY 4.0)
BLAGOVERNAIA TSARITSA KHITRA BYLA MUDRA: ON ONE SYNONYMOUS PAIR IN THE RUSSIAN FOLKLORE

\author{
(C) 2020. T.A. Agapkina \\ Institute of Slavic Studies \\ of the Russian Academy of Sciences, Moscow, Russia \\ Received: February 17, 2020 \\ Date of publication: June 25, 2020
}

Abstract: The article is devoted to the study of synonymous pairs that are deviations from the words khitr-/mudr- (sly/wise) such as khitryi-mudryi, khiter-muder, khitrost'-mudrost' etc., and a compound word khitromudryi in the Russian folklore. The essay analyzes those genres where these pairs are most widely represented: charms, folk epics, lamentations, wedding and lyrical songs as well as fairy tales. The author examines folklore contexts in which the synonymous pair khitryi-mudryi and the same-root pairs form a cycle of regular meanings; also, it focuses on what or who are regularly called khitrosti-mudrosti and khitryi-mudryi in different genres; which thematic fields these paired constructions are included in; their meanings and specificity of functioning within certain genres, etc. The article argues that most of the meanings implied by this synonymous pair relate to specific knowledge - whether it is wizardry, changelings, military affairs, professional skills, or skilful mastery of a craft. The authors suggests that this general meaning that generated specific meaning, e.g. "associated with secret knowledge, witchcraft, and wizardry" that has eventually become dominant. This meaning discloses itself in the dialect speech of different regions of the European Russia, especially widely represented in the Russian North and the adjacent territories of the North-West and North-East.

Keywords: Russian folklore, synonymous pairs, charms, epics, verbal magic, Russian dialects.

Information about the author: Tatyana A. Agapkina, DSc in Philology, Leading Research Fellow, Institute of Slavic Studies of the Russian Academy of Sciences, 32 a, Leninsky Ave., II999I Moscow, Russia.

E-mail: agapi-t@yandex.ru

For citation: Agapkina T.A. Blagovernaia Tsaritsa Khitra Byla Mudra: on One Synonymous Pair in the Russian Folklore. Studia Litterarum, 2020, vol. 5, no 2, pp. 336-389. (In Russ.) DOI: I0.22455/2500-4247-2020-5-2-336-389 
Синонимические пары, парные сочетания синонимов или, как их еще называют, парные синонимические конструкции (далее - ПСК) - тоска-кручина, ум-разум, путь-дорога, булат-железо, глупый-безумный, сильный-могучий, тихий-смирный, плакать-рыдать, кручиниться-печалиться, собираться-соезжаться, думать-гадать, нежданно-негаданно, безданно-беспошлинно и мн. др. - известны в восточнославянских языках (и некоторые из них являются общеязыковыми), однако особенно широкое распространение они получают в фольклоре, при том что степень неразложимости, внутренней устойчивости таких парных конструкций, их частотность и объем функциональности сильно разнятся. ПСК обычно состоят из двух слов одного лексико-грамматического класса, семантика которых совпадает полностью или частично. Укреплению связей между двумя сближаемыми словами иногда способствует рифма, имеющая в основном грамматический характер.

ПСК и близкие им формы (композиты, парные слова и т. д.) не раз становились предметом обсуждения этнолингвистов и лингвофольклористов, в том числе в самое последнее время. Напомним в этой связи о работах В.И. Собинниковой [87], С.Е. Никитиной [50], М.А. Бобуновой [II], И.А. Багликовой [4], Ф.Р. Минлоса [47], Э.В. Фомина [97], Е.Л. Березович и В.С. Кучко [9] и ряде других, где речь идет о том, как трактовать парные сочетания синонимов, чем ПСК отличаются от композитов, как различаются значения отдельных синонимов, входящих в пару, что нового привносит в них сосуществование в рамках одной конструкции, каковы формальные отношения компонентов пары, каково происхождение отдельных ПСК и т. д. С точки зрения изучения этого явления в фольклоре актуальность до сих пор сохраняет работа А.П. Евгеньевой ([3о], там же см. обзор предшествую- 
щей литературы вопроса), в которой целая глава посвящена интересующему нас явлению («Синонимические сочетания и их роль в устной поэзии»).

В настоящей статье мы предпримем исследование ПСК со словами на хитр-/мудр-, таких как хитрый-мудрый, хитёр-мудёр, хитрость-мудрость и т. д. (а также их морфологических вариаций), и сложного слова хитромудрый в восточнославянском, преимущественно русском фольклоре. ПСК всегда характеризует один субъект или объект. В рассматриваемых ПСК первым стоит слово на хитр-, вторым - слово на мудp-, поскольку подобные сочетания, как отмечалось исследователями, обладают свойством «непереставимости» [47, с. 99]. Эти парные сочетания и сложное слово мы рассмотрим как единый конце п т, получивший в фольклоре достаточно широкое распространение. Выяснилось, что ПСК хитрый-мудрый и под. чаще всего встречаются в заговорах и былинах, значительно реже в народной лирике, причитаниях, сказках, паремиях и совсем уж редко в других жанрах.

Мы будем рассматривать фольклорные контексты, в которых ПСК хитрый-мудрый и однокоренные ей встречаются относительно часто и формируют круг регулярных значений. Нас будут интересовать основные контексты, связанные с этими парными сочетаниями; то, что́ и кого регулярно называют хитростями-мудростями и хитрым-мудрым в разных жанрах; в какие тематические поля попадают эти парные конструкции, их значения и особенности функционирования в отдельных жанрах и др. Собственно лингвистические проблемы, касающиеся исследования ПСК и близких им форм, остаются за рамками настоящей работы.

Слова на хитр- и мудр-, составляющие в фольклоре эту синонимическую пару (хитрить (ся), хитрый, хитрец, хитрость, хитрушка, хитро и мудрить(ся)/мудрять, мудрый, мудрец, мудрость, мудрушка, мудро и мн. др.), в истории языка и в современных диалектах не являются в строгом смысле синонимами, однако очень близки друг другу по семантике ${ }^{\mathrm{I}}$.

I B современном русском языке слова из этой пары синонимами не являются и по своей семантике отстоят друг от друга значительно дальше, чем в диалектах и фольклоре, ср.: рус. хитрый 'т. изобретательный, проницательный, хитроумный; 2. искусный; 3. действующий непрямыми, обманными путями и т.д.' [83, т. 17, с. 150-153] и рус. мудрый ‘. Обладающий высшим знанием, большим умом, дальновидностью; 2. Содержащий в себе результат большого ума, знаний, опыта; 3. Простореч. Сложный, замысловатый; мудреный’ [83, т. 6, с. 1339-1340]. 
Как первое слово синонимической пары, хитрый привлекает к себе особое внимание. Этимологи считают праславянское *xytrъ(jь) производным от *xytati, *xytiti, ср. др.-рус., рус.-цслав. хытати, хытиmи 'хватать, кусать', 'хищничать', 'похищать' [гоо, т. 8, с. I62-I63; 94, т. 4, с. 340], т. е. хитрый 'хватающий, быстро схватывающий', а затем уже 'умный, сообразительный, хитрый'. В то же время через ст.-слав. хытръ 'искусный, умелый' и хытрость 'искусство, мастерство, умение', которое, в свою очередь, является калькой греч. $\tau \dot{\chi} \chi v \eta$ [90, с. 769], а также др.-рус. хытръ 'ловкий, сведущий, опытный (о враче)', рус. хитрый связано с кругом значений, имеющих отношение к искусству, мастерству, профессиональному опыту и т. п. Оба эти круга значений хитрого (как ‘быстро схватывающий’ и как ‘искусный, опытный’) нашли отражение в рус. хитрый-мудрый.

Для ст.-слав. мждрость Словарь старославянского языка называет два основных значения: ‘знание', а также 'наука, учение' [90, с. 342]. В Словаре Срезневского м४дрыи определяется как 'умный, разумный; мудрец' [89, т. 2, с. I87]. Что касается слова хытрыи, то объем этого лексического гнезда и значения отдельных слов гораздо шире: хытрити 'придумывать; соображать; обманывать' [89, т. 3, с. I427]; хытрища 'знающая, постигающая; мудрая’ [89, т. 3, с. І427]; хытро 'искусно' [89, т. 3, с. І428]; хытрокъ 'искусник' [89, т. 3, с. I428]; хытрость 'искусство; произведение искусства; ум, разум; умение; знание; наука; рассуждение; хитрость; ухищрение; лукавство, обман' [89, т. 3, с. І427-I429]; хытрыи 'искусный; искусно сделанный; творческий; художник; ученый; умный, разумный; хитрый, ловкий; замысловатый’ [89, т. 3, с. І430-I43I]; хытрьць ‘художник; творец, создатель; знаток; сведущий в чем; искусный в чем’ [89, т. 3, с. I43I-I432].

В Словаре XI-XVII вв. слова на мудр- получают более широкий круг значений: мудрец 'мудрец, философ; мудрый человек, тот, кто может дать мудрый совет; искусный в чем-л. человек, мастер своего дела' [8I, т. 9, c. 294]; мудрок 'мудрец’ [8I, т. 9, с. 296]; мудрость 'мудрость, ум, разум; благоразумие; совокупность знаний, ученость; хитрость, лукавство, плутовство; произведение искусства' [8I, т. 9, с. 297-298]; мудрый 'проявляющий ум, сметливость, хитрость в чем-л. (по Остромирову Евангелию І057 г.); умудренный опытом, знающий мудрый; исполненный мудрости, основанный на благоразумии; замысловатый, сложный, трудный. || Тонкий (об искусной 
работе)' [8I, т. 9, с. 299-300]. (К сожалению, том со словами на хитр- пока не опубликован.)

Если сравнивать значения слов на хитр- и мудр- по названным словарям, то выделяется по крайней мере три группы значений, характерных для обоих лексических гнезд. Во-первых, это значения, связанные с умом, его остротой и вообще с силой интеллекта²; во-вторых, значения, имеющие отношение к знаниям, науке и обучению, и, в-третьих, значения, касающиеся искусства, искусной работы и мастерства. Создается впечатление, что в истории языка имело место «встречное» сближение значений слов этих двух лексических гнезд.

В словаре Даля слову хитрость приписывается значение 'умственная ловкость, изворотливость, тонкость и острота соображений, уменье достигать своей цели, нередко обманом; лукавство, коварство', а хитрый, соответственно, описывается как 'искусный, мудреный, изобретательный, замысловатый, затейливый’ [26, s.v. Хuтрый]. С этим согласуется второе основное значение слова мудрость 'хитрость, искусство, уменье; замысловатость или трудность' [26, s.v. Мyдрый].

В русских диалектах слова на хитр- и мудр- также демонстрируют тенденцию к взаимному сближению, например:

- псков., твер., костром., перм. мудрять 'хитрить', перм. мудряться ‘прибегать к разнообразным уловкам’ [8о, т. І8, с. 331], рус. диал. мудрить, мудровать, перм. мудрять, мудреничать 'хитрить, придумывать необычайное, делать самонадеянно свое; умничать, дурачить кого-л.' [26, s.v. Мyдрый] и том. хитревать 'хитрить', свердлов. хитреваться 'обманывать', архангел. хитриться 'хитрить, ловчить' [8о, т. 50, с. I43];

- смолен. мудреный 'умный, разумный, сообразительный', псков., твер. мудристый 'хитрый, хитроумный’ [8о, т. I8, с. 330], и рус. диал. хиmрый 'I) умный, толковый (в т. ч. опытный, умелый); 2) замысловато, сложно изготовленный' [80, т. 50, с. I47-I48]; рязан. хитрый 'мудреный, странный' [84, с. 583];

- ярослав., новгород. мудру́шка 'хитрушка, обольщенье, обман или шутка' [26, s.v. Мyдрый] и ярослав. хитрушка 'хитроумие, умение обвести вокруг пальца, обмануть' [80, т. 50, с. I47] и т. д.

2 О семантике слов мудрость, мудрый в исторической динамике см.: [98]. 
Близость значений слов на хитр- и мудр- в русских диалектах подчеркивается целым рядом дополнительных моментов. Как уже отмечалось, в словарях в зоне толкования этих слов часто оказываются сами эти слова, т. е. они описываются друг через друга, а также через такие общие «знаменатели», как обманывать, ловчить, лукавить и под. В паремиях слова на хитр- и мудр- выступают как регулярные синонимы, подменяя друг друга в идентичных контекстах, см., например, рус. «Премудрость одна, а мудростей много (лукавства, хитростей)» [26, s.v. Премудрый]; «Хитрее (мудренее) теленка не будешь» (тот везде языком достанет) [26, s.v. Теля]. В легендах о царе Соломоне его называют то мудрым/премудрым, то хитрым. В итоге именно сходство семантики является ключом к объединению этих слов в ПСК, а также к образованию сложного слова хитромудрый.

ПСК со словами на хитр-/мyдр- известны по церковнославянскому переводу Библии, переводным и оригинальным памятникам древнерусской книжности. Парная конструкция «премудрость и хитрость» встречается в церковнославянском переводе Библии: «Сотворилъ веселеиль і єлиавъ, и всАкъ м४дрый оумомъ, єм४же дана єсть прем४дрость и хитрость раз8мъти творити всА дьлеса льпотна $<\ldots>$, гже стыни по всьм8, елико заповьда г ь»3 (Исх 36: І, цит. по тексту Острожской Библии I58I г.). В тексте Толкового Апостола (по рук. XIV в.) имеется выражение «премудръ и хытръ»: «Кто премудръ и хытръ въ васъ, да явит от добра житиа дъла своя въ кротость премудрости» [38, с. ІІо]. Аналогичные парные конструкции обнаруживаются в памятниках переводной книжности. В Житии Василия Нового (по рук. XVI в.): «Всегда въщавааше в притчяхь бесьдовааше, всъмь страшенъ сый и больша, в гаданиихъ зъло хитръ сый, и мудръ, и утверженъ» [37, c. 526]; в Повести о споре жизни и смерти (по рук. XVI в.): «О человече, не мудрее ты царя Соломона - царь Соломонъ хитр и мудр был, да и той со мною не смъл поговорити, и того яз <смерть> взяла» [6I, с. 96] и др. Кроме того, эти парные конструкции встречаются и в памятниках оригинальной древнерусской литературы. В Слове Даниила Заточника (по рук. XVII в.): «Всякъ бо человъкъ хитрить и мудрить о чюжей бъди, а о своей не можеть смыслити» [85, с. 272]; в Слово о житии... святого Стефана (по рук. XVI в.): «<Стефан Пермский в споре с кудесниками и волхвами> 
Всъм бо им уста загражаше и противу глаголющая обличаше, и въпреки глаголющим запрещаше дивный сей мужъ, чюдный дидаскалъ, исполнь мудрости и разума, иже бъ измлада научился всей внъшней философии и книжней мудрости и грамотичней хитрости, ктому же еще добраго ради исповЂданиа и чюднаго ради наказаниа его, изряднаго ради учениа его дасться ему даръ благодатный и слово разума и мудрости» [86, с. I70] и других памятниках.

Рассматриваемая парная конструкция нечасто встречается в современной диалектной речи, газетном и художественном дискурсе, демонстрируя при этом разнообразие частеречных вариаций: твер. Теперь люди схитривши, смудривши [69, т. 7, с. 127]; воронеж. В нем ни хитрости, ни мудрости, живет спроста, как самый небесхитростный человек [8о, т. 20, c. 3І7]; архангел. Така одна хитра, мудра дефка, дельня была [2, т. II, с. 19]; донск. Фсе мудрасти и хитрасти, такой мудряк [13, с. 290]; Сом такой хитрамудрай, вынисиш йиво метрах на питнацциать, а вон етими стопками, кулачками талкаищца и палозит у воду ([7о, с. г23], казаки-некрасовцы); прибайкал. Здоровья бог не даст, хитростями-мудростями ничо не возьмешь [78, т. I, с. 64]; Генерал шёл напролом и составил план, чтобы из его разбалованного шалопая, который требовал «лозы учительной», хитро-мудро и невеликим коштом образовать человека государственного, и именно «дипломата в русском духе» (Н. Лесков. «Сеничкин яд»). В этих обыденных и литературных контекстах рассматриваемые слова и выражения стилистически окрашены, им явно присущ фольклорный колорит.

Эту особенность узуса соответствующих слов и выражений фиксируют словари. В СРНГ композиты хитро-мудро, хитро-мудрый, хитрости-мудрости имеют помету «фольк.» [8о, т. I8, с. 33г]. В комментариях к рус. диал. хитромудрый со значением 'хитроумный’ фольклорные контексты явно преобладают над остальными: «Хитромудрый, ая, ое. г. Хитроумный. 2. Фольк. Искусный, опытный. 3. Фольк. Искусно сделанный (о сложном красивом рукоделии)» [80, т. 50, с. I46].

Основной сферой употребления ПСК на хитр-/мудр- являются заговоры (как устные, так и рукописные). Тексты заговоров демонстрируют целый спектр значений ПСК, контекстов, в которые они входят, а также их частеречных и морфологических вариаций. 
Подавляющее большинство ПСК со словами на хитр-/мyдр- в заговорах вписывается в те му «вр едоносная магия».

В рамках этой темы выделяется группа «вредоносные действия», представленная глагольными ПСК со значением 'причинять вред / колдовать', например: «Как сине море не обсыхает... так же бы никто не мог ни хитровать, ни мудровать над моими ловушками...» ([4I, с. I42], Вятская губ. $)^{4}$. К двум словам, составляющим ПСК, может присоединяться третье, имеющее близкое значение, например «...да как бы не подхитрить и не подмудрить и не спортить не на стрелу, не на гулу ни колдуну, ни колдуницы, не ученику, не ученицы...» - заговор на то, чтобы исправить испорченное ружье ([25, с. 46], Новгородская губ.); «Кто сможет океан-моря воду выпити... и тот может надо мной, рабом Божим, похитрить, помудрить и похимостить» ([59, с. 195], Пермская губ.), где похимостить 'поворожить, поколдовать' ([80, т. 30, с. 346], в т. ч. с пометой «перм.»).

Еще более обширную группу составляют ПСК, представленные преимущественно именами существительными хитрости и мудрости, которыми обозначаются сама вредоносная магия, порча, сглаз и иные подобные способы воздействия на человека, например: «Ино и во веки веком... никакому волху никоторыми хитростми и мудростми, и меня, раба Божия имярек, не испортит, ни мужеску полу, ни женску...» ([22, с. I84], рук. XVII в.), см. в заговоре, где испрашивается защита «и от всех языков, от царей и королей, и от князей, и от бояр, $и$ от хитрецов, и от волшебников, и от еретиков, $и$ ото всякой мудрости, и ото всякой хитрости...» ([Іо, с. I5], Воронежская губ.).

В подобных заговорах вредоносной магии (а именно хитростям-мудростям) часто противопоставляется добывание/пожелание здоровья (как магия целительная), поэтому типовым в них становится упоминание соответствующей ПСК в оппозиции к здоровью (чаще всего), например, заговор, читаемый, если корова потеряет удой: «Царь водяной, царь земляной.... благословите воды5 взять не ради хитрости, не ради мудрости, а ради Божьей рудонюшки, чтобы по старому доила, чтобы молочко по старым струйкам бежало» ([42, с. 2], Олонецкая губ.); «Хожу я, раба Божия

4 Здесь и далее курсив в цитатах наш. - Т.A.

5 Подобные заговоры часто читаются в процессе ритуализованного взятия воды, земли, лекарственных растений и других субстанций, используемых в лечебной магии: «Царь земной и небесной... дай водицы не для хитрости, не для мудрости, а окупать раба Божия» ([53, І885, № 75, с. 667], Олонецкая губ.). 
(имя), на зари, не с хитростям, не с мудростям, а с добрым здоровъем» ([95, c. 298], Новгородская обл.).

Хитрость-мудрость противопоставляется в заговорах высшей силе и даруемым ею благам - божьей милости: «С восточной стороны пойду я, раб Божий, не с хитростью, не с мудростью, а с Божиею милостию» ${ }^{6}$ ([49, № 216], Нижегородская обл.) и божьей помощи: «Пособите, помогите коровушке... от причты, от остуду, от доспеху... Кто и с хитростю, кто и с мудростью, а мы с Божьей помочью» ([44, с. 322], Санкт-Петербургская губ.). Кажется, не будет слишком опрометчивым предположить, что такое противопоставление связывает сами хитрости-мудрости с вредоносной магией и дьявольским началом.

Описываемые значения ('колдовство', 'вредоносная магия’), характерные для исследуемой ПСК в рамках фольклорного узуса, типичны также для отдельных слов с корнями хитр- и мудр- в диалектной лексике, хотя, кажется, что здесь они встречаются реже, чем в заговорной традиции. Если говорить о корне $x u m p-$, то, к примеру, в пермских говорах известны такие слова, как похитриться 'колдовать': «Колдуны над лошадьми похитряются: кони встанут и дальше не идут» [76, т. 2, с. І9г], см. также: «Коли ты спроста, и я спроста; коли ты с хитрости, и я с хитрости (говорит знахарь, разводя или снимая залом, закрутку хлеба)» [26, s.v. Спрастывать]. То же относится и к словам с корнем мудр-, см. смолен. мудровать “колдовать’: «Он мудруить и любжу делъить, штоб замыш узяли» [82, т. 6, с. II5], где синонимом к мудровать выступает выражение любжу делать 'присушивать, практиковать любовную магию’, а также пинеж. мудрёный глаз: «Мудрёный глаз у него, над скотиной проказит»; «Мудрёной глаз, знатливой у него, проказливой» [7I, с. 83, 7I], где синонимами к мудрёный являются прилагательные, прямо связанные с наведением порчи и тайным знанием: проказливой, знатливой.

Следующая группа представлена парными конструкциями со словами на хитр-/мyдp-, которые обозначают лиц, владеющих магическими знаниями и умениями. Очень редко в заговорах появляются соответствующие имена существительные, например: «Сохрани в путях, в дороженьке от хи-

6 Этот мотив перекочевывает в свадебные причитания почти без изменений. В Олонецкой губ. при подготовке к свадьбе невеста просила сестру: «Сестрица моя родимая, / Затопляй-ко парну баенку. / Ты без хитрости, без мудрости, / Со великой Божьей милости» $[7$, c. 3]. 
треща, от мудреца, от колдовща» ([34, с. 66], Юж. Урал), где третий синоним пристраивается к паре хитрец-мудрец, меняя свой морфологический облик (колдун $\rightarrow$ колдовец). Иногда в заговорах встречаются адъективные ПСК, с помощью которых описываются колдуны: «..всякие хитрые-мудрые люди» ([53, І884, № 90, с. 895], Вытегра), а также субстантивированные прилагательные: «Мои замки никто не отворит и ключи никто не найдёт, и меня, рабу божью (имярек), ни хитрой, ни мудрой не победит. Аминь» ([62, c. 206], Пермская обл.).

И в этом случае мы вновь замечаем поддержку ПСК со стороны диалектной лексики, в которой отдельные слова на хитр- и мудр- используются для обозначения лиц, занятых колдовством и владеющих эзотерическими знаниями. Подобные примеры на мудр- единичны в русском диалектном пространстве, см. нижегород. мудрёна ‘колдунья’ [28, т. 2, с. II8]7, а вот примеры таких наименований на хитр- довольно многочисленны и разнообразны. Среди них есть и имена существительные вроде архангел. хитряк ‘2. Чародей, знахарь': «В загадке: Рассыпалось золото По чёрному бархату. Никому его не собрати, Ни попам, ни дьякам, ни каким хитрякам (роса)» [80, т. 50, с. I48], и субстантивированные прилагательные: смолен. хитра 'чародейка' [82, т. II, с. 53]. Но в основном это атрибутивно-номинативные сочетания типа хитрые люди, хитрые бабы 'колдуны, ведьмы', см. в следующих контекстах: перм. «Какие-то хитрые люди есть. Мужик дурит, дурит с нами и посадил мне этих бесей» [79, т. І, с. 99]; перм. «Хитрые люди с человеком что хотят, то и сделают: болезнь нагонят, отправят куда-нибудь. Колдуны молитвы не признают, они словами владеют» [79, т. I, с. ІІ8] бел.-полес. «Хитрыя бабы мелом хату обводять перед Хрэшчэннем, штоб у хату нека гадосць не пришла и богатство не вышло»9; бел.-полес. «На Петриўского Ивана в двенацать чосоў ночи папороть цвэтэ. То есь таки люди хитрые. Трэбо тож цвит взять, цвит очень помогае. Видьмы и ведьмары» ${ }^{\text {го }}$.

7 Производные от мудр- в качестве наименования людей, занятых колдовством и обладающих специальными знаниями и умениями, известны прежде всего в западноукраинской и польской традициях.

8 Ср. севернорусское поверье, согласно которому сглазить может тот, у кого взгляд «с хитринкой»: «вот как отличить вот... С хитринкой есть. И... взгляд у других такой, что... вот... взглядом убьёт» [36, с. г3г].

9 Полесский архив Института славяноведения РАН (Москва). Зап. в с. Велута Лунинецкого р-на Брестской обл.

го Там же. Зап. в с. Заболотье Лунинецкого р-на Брестской обл. 
Помимо «вредоносной магии» ПСК со словами на хитр-/мудр- могут входить и в смежное тематическое поле «м а г и че с к и е умен и я и 3 н а н и я ». В рамках этой темы «хитрость-мудрость» ассоциируется уже не с вредоносной, а скорее с целительной магией, см. заговор, в котором слова на хитр-/мyдp- используются для называния людей, такими навыками владеющих: «Из этого каменя выходит красная девиия, u хитра и мy$\partial p a$, и выносит свой притугой отстрильцятой калиновой лук, и вкладываё калиновы стрелы, и стрилят, и отстриливат и все и думы, и прици, и призоры...» ([46, № 220], Олонецкая губ.). Хитрые-мудрые люди наделяются и иными навыками и умениями. При этом к хитрым-мудрым людям/масте$p a м$, в частности помогающим имярек в охотничьем промысле и целебной практике, могут причисляться даже православные святые: «Царь меня, раба Божия, не ослышается, и посылает св. Николу на пособ и на помощь ловить белых зверей горносталей чернохвостых, хитрых и мудрых слуг посылает ко мне, рабу Божиему имярек» ([3I, с. I85], Архангельская губ.); «...раб Божий имрек... пойду в далече в чистое поле... идет на стрету стар матер муж... за ним идет святой честной Козма и Дамьян, хитромудрые мастеры, на руках несут мису золотую; а на мисе золотое перо» ([58, ч. 4, с. 255], Олонецкая губ.).

Значительно реже ПСК со словами на хитр-/мудр- в качестве эпитетов характеризуют артефакты, используемые в промысле и обладающие особыми, «непростыми» качествами, см., например: «Идут и текут Божьи твари из-за темных лесов... из-за тридевять хитрых, мудрых ловушек...» ([4I, с. I39-I40], Вятская губ.). Как и в других случаях, эти контексты находят поддержку со стороны диалектной лексики, в которой слова на хитри мудр- (существительные, прилагательные, глаголы) обозначают вещи, свойства и действия, созданные и функционирующие на грани магии, высокого мастерства и тайного знания, ср. новгород., ярослав. мудрушка 'хитрая вещица, игрушка и пр.’ [26, s.v. Myдрый]; «Что за такой мудреный перстенек, дай я померяю. - Кольцо оввилось и воссияло» ([80, т. 22, с. 292], Волго-Камье); карел. хитрая удочка 'браконьерское орудие лова': «Еще есть такая снасть, хитрая удочка называется» [77, т. 6, с. 589].

В рамках темы «магические умения» выделяется еще одна группа адъективных ПСК с производными от хитр-/мyдp-, которые определяют само заговорное слово. Называя это слово хитрым-мудрым, заговор тем 
самым указывает на его магическую природу: «На мои на хитрые, на мудрые слова - ключ, замок положить. Ключ - в роте, замок - в море» ([67, № 635], Архангельская обл.). Характеристика хитрый-мудрый в этом примере выступает в одном ряду с другими: «Будьте, мои слова, крепки и лепки, переговорены и недоговорены, все будете истинны, хитры и мудры, старого мастера, кто меня учил» ([43, с. г3], Вост. Сибирь).

Наконец, совсем уж редко ПСК, в основе которых лежат слова на xump-/мyдp-, применяются в качестве названий болезней или видов порчи: «Как вода-матушка по реке проходит, так же проходи, нечистый дух, неприятна сила, болезни хитрость-мудрость-ноготь...» ([IоI, с. I58], Пермская губ.).

О с о б ен н ость ю фун кци о н и р о а н и я ПСК хитрый-мyдрый и под. в 3 а го в о рн ой т ради ц и и является повторение ее вариаций в рамках одного контекста, что усугубляет магический эффект и в целом отвечает инерционной поэтике заговора с его тяготением к многочисленным повторам (слов, частей слова, грамматических форм, звуков и т. д.). Иногда редупликация имеет место в рамках одной синтагмы, в которой оказываются соположены две или даже три частеречные вариации ПСК. Например, следующий фрагмент заговора объединяет существительное, прилагательное и прилагательное в сравнительной степени: «Будь, моя молитва, крепка и липка: хитряе хитрова хитрока, мудряя мудрова м удр о ка» ([23, вып. 2, № 95], Костромская губ.). Во втором примере редупликация происходит в рамках глагольного словосочетания: «Спасі, Госпадзі, памілуй, божы Мікіця, мудрасцю мудрыся, хітрасцю хітрыся» ([35, № ı236], Гомельская обл.). В других случаях частеречные вариации ПСК входят в разные фрагменты довольно пространного текста и благодаря этому становятся своего рода лейтмотивом заговора: «Пойду аз, раб божий... навстречу мне идут три хитрых хитреца и три мудрых мудреца, в руках несут три златых кубка, наполнены кубцы хитростями и мудростями; и аз, раб божий... у тех хитрых хитрецов и мудрых мудрецов отнимаю из рук три златых кубца и выпиваю из них все хитрости и мудрости. И придут те хиmрые хитрецы и мудрые мудрецы ко Господу Богу и расплачутся на меня... и рече им Господь Бог: раб мой имрк именем моим отнял у вас y mpeх xumpых хитрецов из рук три златых кубца и выпил из них все хитрости и мудрости, и буди над ним, рабом моим, благословение... во всяком деле от всякого зло- 
го зверя, от лихих людей и немилостивых судей, и от всех врагов и супостатов...» ([88, с. 234], по рук. XVIII в. $)^{\mathrm{II}}$.

$* * *$

Как уже говорилось в начале, взаимное сближение слов на хитр- и мyдp - (и однокоренных им) и образование соответствующих ПСК объясняется общей близостью семантики этих слов в русских диалектах. Вместе с тем активное употребление парных конструкций типа хитрый-мудрый именно в заговорах обусловлено скорее такими относительно редкими и специальными значениями слов с корнями хитр- и мудр-, как 'колдовать' и 'обладать особыми знаниями и умениями'. Заговоры, будучи основной формой вербальной магии (целительной и вредоносной), стали той благоприятной средой, в которой эти значения оказались особенно востребованы и где сформировалось целое поле однокоренных слов на хump- и мyдp-, что, в свою очередь, позволило этим специальным значениям развиться и распространиться. При этом иногда, как, например, на северо-востоке Европейской России (в Пермском крае прежде всего), популярность ПСК типа хитрый-мудрый в заговорах активно поддерживалось диалектом, в котором слова на хитр- и мудр- этими специальными значениями обладали. В других же регионах такой прямой зависимости между диалектной лексикой и рассматриваемой ПСК в местном фольклоре мы не обнаруживаем.

В былинах ПСК со словами на $х и m p-/ м y \partial p$ - также известны довольно широко, однако значения этих ПСК в заговорах и былинах заметно разнятся.

К тем значениям, которые характерны для ПСК в заговорах, более всего близки былинные контексты, где хитростью-мудростью называется

II Для заговорного универсума не характерна ярко выраженная биполярность. Поэтому несмотря на присутствие в нем целого ряда противопоставлений (белая и черная магия, лечить и вредить, наводить порчу и снимать порчу, благословение и проклятие), они если не нивелируются, то во всяком случае смягчаются и, скажем так, деидеологизируются. Выше мы уже приводили пример того, как хитрыми-мудрыми людьми (т. е. по сути колдунами, помогающими человека в его магических предприятиях) заговор называет святых. В этом примере мы усматриваем сходную ситуацию: имярек выпивает хитрости-мудрости (можно предположить, что имеются в виду магические знания и умения), но вместо проклятия получает божье благословение, в некотором смысле легитимизирующее использование этих навыков в магической практике имярека. 
с по собн ость ге роя к оборотничеству ${ }^{12}$, его приобщенность к «ве́дению» и тайным знаниям. Эти значения встречаем в нескольких сюжетах, но прежде всего в былине о Волхе Всеславьевиче.

Былины сообщают, что в семилетнем возрасте Волх обучается грамоте, а в десять лет - «премудрости»: оборачиваться зверем, птицей и т. д. Поэтому последующие подвиги героя, о которых рассказывает былина, осуществляются не с помощью богатырской силы, а с помощью той же колдовской «премудрости» - оборотничества: охота с дружиной (чудесный лов) и завоевание сказочного Индейского царства. В.Я. Пропп называл Волха великим охотником и колдуном, а также великим воином, который тем не менее как воин совершенно не похож на воинов позднейшего русского эпоса - на Илью, Добрыню, Алешу: он воюет так же, как охотится: путем волшебного умения, «хитрости-мудрости» [64, с. 72]: «Ише тут-то славной Волх да Светославьёвич / Он ведь пал-то на свети-то как всих хитрей, / Онто всех ведь пал-то хитре да изо всех мудрей, / Ише тот ли ведь Волх да Светославьёвич / Овернулсэ-то он перьво всё серым волком, / Во второй раз овернулсэ чорным вороном, / Он ише же овернулсэ ясным соколом, / Он ише же овернулсэ-то оленём златорогиим, / Он ише же обернулсэ горносталюшком, / Как ише Волх овернулсэ мурашом малым» ([8, с. 2І6], «Волх Светославьёвич»). Вместе с тем, рассказывая об оборотничестве Волха, былина далеко не всегда пользуется парной конструкцией типа хитрый-мудрый, часто употребляя вместо нее одиночные слова премудрость/мудрый (ср., например: [29, с. 33]). Говоря о Вольге (которого принято отождествлять с Волхом), былина так же описывает его навыки оборотничества: «А й задался он Вольга да во мудрости, / А й во мудрости Вольга да он в хитры хитрости, / Птицей он летать да под оболоку, / Рыбою ходить да в глубоки стана, / Зверями ходить да во темны леса...» [54, № 15]. Поэтому калики перехожие, поднявшие Илью после многолетнего сидения, дают ему завет не биться со старшими богатырями, в том числе с Вольгой: «...не ходи още на Вольгу Сеславьича: он не силою возьмет, так хитростью-мудростью» ([58, ч. г, № 51], «Святогор и Илья»).

I2 Прямой поддержки этому значению в диалектной речи мы не находим, однако в Архангельской и Вологодской губ. мудрушками порой называли ряженых, также изменяющих свою внешность, см.: «Вырядятся на Святках. У нас, в Сидорове, мудрушками наряжались: то в праздничное, а то висок на виске, как нищие» [74, с. 47]. 
К редким былинным сюжетам, в которых речь идет о колдовстве и превращениях, относится «Добрыня и Маринка». Добрыня встречает киевскую ведьму Маринку - чародейницу и отравительницу, которая извела многих богатырей, превратив их в животных: «Она больно Марина похваляется: / - Гой еси вы, княгини, боярыни! / Во стольном во городе во Киеве / А и нет меня хитрее, мудрее, / А и я-де обернула девять молодцов, / Сильных могучих богатырей гнедыми турами; / А и ныне я-де отпустила десятого молодца, / Добрыню Никитьевича, / Он всем атаман - золотые рога»³. Эта похвальба своими колдовскими способностями (в былине из сборника Кирши Данилова) встречает отповедь со стороны Анны Ивановны, крестной матери Добрыни, которая вступается за своего крестника. Спор Маринки и Анны Ивановны примечателен тем, что фактически две женщины меряются колдовской силой - степенью хитрости-мудрости каждой их них: «А и молода Анна Ивановна / Выпила чару зелена вина, / А Марину она по щеке ударила, / Сшибла она с резвых ног, / А и топчет ее по белым грудям, / Сама она Марину больно бранит: / - А и сука ты, ..., еретница ...! / Я-де тебя хитрее $u$ мудренее, / Сижу я на пиру, не хвастаю; / А и хошь ли, я тебя сукой оберну? / А станешь ты, сука, по городу ходить, / А станешь ты, Марина, много за собой псов водить!» ([29, с. 46], «Три года Добрынюшка стольничел») $)^{\text {I4. }}$

Названными сюжетами тема хитрости-мудрости как колдовства и оборотничества в былинах, пожалуй, и исчерпывается. Но за рамками этих контекстов остается еще много других, расширяющих спектр значений парных конструкций со словами на хитр-/мyдр-.

«Хитромудрие»как особое свойство ума при п и с ы в а е т с я многим персонажам русского эпоса, и едва ли не чаще других - же н щ и н а м. Характеристика хитрый-мудрый подразумевает быстроту суждений, проницательность, находчивость, знание этикета и целый ряд других качеств.

I3 Целью Маринки является вступление в брак с Добрыней, для чего она применяет приемы любовной магии, что фактически приводит к появлению в былине цитаты из заговора: «Как я режу-то Добрынины следочики, / Так бы резало Добрынино сердечушко / А по мне ли, по Мариночке Игнатьевной / <...> / Как горят эти Добрынины следочики, / Так горело бы Добрынино сердечушко» [54, № 227].

I4 Вар.: «В те часы атвичала родная тетушка. / - Насмиюсь та я насмешичку, / Ишшо хитрей та мудрей тибя, / Маришки шельмы ябидницы: / Уж я зделаю тибя сукаю папалзучаю...» ([40, с. 9I], терские казаки). 
Хитрой и мудрой оказывается Опраксея-королевична, которая приказывает проложить «ходы подземельние» и тайно кормить Илью Муромца во время его заключения в темнице князя Владимира ([I5, с. 318], «Исцеление Ильи Муромца»); мать Егория Храброго, спрятавшаяся вместе с сыном в пещерах: «...удоньской цярь, / Уж он Божьи-то церьквы на дым спустил, / Он из Божьих-то икон да взял мосты смостил. / Цяря Федора Смоленьского под гнет склонил, / Он под гнець-то склонил, взял голову срубил. / Благоверную цярицю изуродовать хотел, / Благоверная ияриия хитра была мудра, / Уходила в пешшоры горы каменныя, / Уносила своего да цяда милого, / Цяда милого Ёгорья света храбрыя» ([8, № 238], «Егорий Храбрый»); царица Елена, жена казанского царя Симеона, которая в отличие от мужа при взятии Казани правильно повела себя с Иваном Грозным, и тот оставил ее в живых, а Симеона казнил: «Загорели [в]си царьски-ти тут полатушки. / Ише царица Елена была хитра, мудра, / Да хитра была, мудра, всё она догадьлива; / Она слыхала про матушку про сьвятую Русь - / Ишше как на Руси-то да дело делают. / Да берёт она цариця да в руки белой хлеб, / Шьчо стрецят она князя света Москоського, / Ище Грозного царя Ивана Васильёвича, / Ище кланеитце всё ему низёшенько, / Принесла ему покорносьть всё з благодарносью» ([8, с. 24I], «Взятие Казани и смерть царя Симеона»). И даже жена Соловья-разбойника понимает, как надо вести себя с Ильей Муромцем, полонившим ее мужа, хотя ее сыновья и отказываются подчиниться матери: «Подхватил Илья Муромец Соловья на белы руки. / Привязал Соловья ко той ко луке ко седельныя. / Проехал он воровску заставу крепкую, / Подъезжает ко подворью дворянскому: / И завидела-де его молода жена, / Она хитрая была и мудрая, /... / Его, Соловьева, молодая жена, / И увидела доброго молодца Илью Муромца, / И бросалась с чердака во свои высокие терема, / И будила она девять сыновей своих: / - А встаньте, обудитесь, добры молодцы, / А девять сынов, ясны соколы! / Вы подите в подвалы глубокие, / ... / А берите вы мою золоту казну, / Выносите ее за широкой двор / И встречайте удала доброго молодца: / А наедет, молодцы, чужой мужик, / Отца-то вашего в тороках везет!» ([39, с. 2I-22], «Первая поездка Ильи Муромца»).

Герои-мужчины также не обделены этими качествами: х и т р ы й мудрый как характеристика главного героя подразумевает его находчивость и ловкость прежде всего, а также, конечно, ум. 
Для героя-любовника Чурилы Пленковича - это способность быстро ретироваться, чтобы не быть пойманным: «А Цюрилушко-то всё он был $x u$ трой-мудрой, / Он хитрой-от, мудрой все был догадьливой; / Он охвоць ходить за бабами был, за девками; / Он ведь скоро брал со спицьки пухову шляпу, - / Он услышал топот всё кониную; / Он выскакивал косисцятым всё окошоцьком, / Он бежал-то Цюрилушко всё ведь Пленковиць...» ([8, c. 66-67, № 7], «Чурила»). А в поздней былине о шведской войне «хитрость-мудрость» приписывается военачальнику Екатерины II, который демонстрирует скорость реакции и решительность. Когда шведский король решает взять Москву, о чем и сообщает Екатерине, «предводитель её хитрой приуму́дрилсэ, / Приуми́дрилсэ он да приухи́трилсэ: / Доставает скоро ножицёк булатной-от, / От отрезал королю-ту буйну голову; / Ешшо сам-то взял его да приоку́тал всё, / Он спусьтил-то эту голову в мешок, в муку, / Положил мешок-то королю да под оку́тоцьку» ([8, № 4I], «Шведская война при Екатерине Второй»).

Искомые качества приписываются и сильным мира сего, прежде всего князю Владимиру, хотя делается это обычно опосредованно. В былине о Михайле Потыке его жена Овдотья Лиходеевна - колдунья и оборотень, поэтому после смерти ее и Михайло Потыка князь Владимир велит обустроить могилу «по-хитрому-по-мудрому», т. е. похоронить их отдельно, в разные могилы, Потыка положить с его конем (который впоследствии и спасет героя из могилы), а у ее могилы поставить «караульщиков», которые будут стеречь колдунью и не дадут ей выйти: «Говорит-то князь Владимир таковы реци: /... / Уж поставлю я к могилы крепких караульшицьков. / Закрывали с могилы их решотоцькой железною; / Как ведь жолтым-то песоцьком не зарыли-то; / По роспореженьицю всё ведь было по-хорошому, / По-хорошому да всё по-хитрому, / Всё по-хитрому было, по-мудрому: / Тут поставил он крепких всё караульшицьков» ([8, с. 69], «Михайло Потык»). Решение князя Владимира является своего рода ответом на происки Авдотьи Лиховидьевны, т. е. и в этой былине, как и в других, мы видим следы эпического состязания в хитромудрости, хотя и заочного. Так, в былине из сборника Кирши Данилова об Авдотье Лиховидьевне говорится, что она мудрости искала над мужем своим [29, с. ІІ9], что вполне однозначно читается как то, что она хотела перехитрить и обмануть его: утянуть Потока за собой в могилу и погубить. Таким образом, в былине о Михайле Потыке 
хитромудрость князя Владимира в большей степени означает предусмотрительность, предосторожность и даже предвидение обмана, замысленного колдуньей.

Все эти качества - предус м о тр и те льность и предвидение, расчет и решительность, знание человече с к о г о п о в е д е н и я - присущи еще одному персонажу русского эпоса, а именно царю Соломану (явно ассоциирующемуся с премудрым царем Соломоном), причем тема хитрости-мудрости буквально пронизывает эту былинуㄷ․ На пиру у неженатого царя Василия Окуловича (вар.: Иван Микульевич и др.), правящего в Царьграде или другом месте, некто (Васька Торокашков и др.) сообщает ему, что в Иерусалиме живет царь Соломан, а у него жена-красавица царица Соломаниха. После некоторых колебаний царь соглашается на ее похищение, и Васька Торокашков снаряжает корабли с товарами и отправляется и Ерусалим, чтобы увезти Соломаниху. В отсутствие дома царя Соломана он тайком и хитростью увозит Соломаниху на корабле; хитрой-от, мудрой Соломан, вернувшись, переодевается странником и отправляется искать жену, до поры до времени пряча свою дружину и дав ей наказ строго следовать знакам, которые тот может подать им. В результате он находит жену, та узнает его и прячет в сундуке, на который садится сама, однако по возвращении домой нового мужа Соломаниха выдает ему царя Соломана. Приводимые ниже фрагменты относятся к последующему развитию сюжета ([16, с. 562], «Василий Окулович и Соломан»).

Здесь, отчасти как и в былине о Добрыне и Маринке, г е р о и с о перничают не в силе, а в ловкости, расчете и обмане, совокупно назыв а емых хи тростью-мудростью. Иван Микульевич, убежденный в том, что одолел хитромудрого Соломана, издевается над ним, недвусмысленно выражая сомнение в мудрости последнего: «Говорил же Иван царь ему Микульевич: / - Что сказали хитре-мудре

I5 Былина, по-видимому, является фольклорным переложением одного из сюжетов Повести о рождении и похождениях царя Соломона, получившей широкое распространение в русской рукописной традиции XVII-XVIII вв. (об этом см.: [9г]). В этой повести деяния премудрого царя Соломона десятки раз называются мудрыми, мудростями, а о его действиях говорится с использованием глагола умудрить и наречия мудро, однако парной конструкции хитрый-мудрый в них нет, если не считать единственного упоминания о том, что неверная жена Соломона Соломонида Володомовна была «мудра и хитра» [91, с. 228]. 
царя Соломана на свете нет, / А глупе тебя, царь Соломан, же на свети нет, / Ты бы хитрой-мудрой был, не сел бы бабы под гнузно ${ }^{16}$. Соломан игнорирует издевку и просит Ивана Микульевича приготовить для своего повешения «грядочки с тремя петельками», при этом Соломаниха дважды пытается предостеречь Ивана Микульевича, но тот ослеплен мнимой глупостью Соломана: «И говорил тут царю-ту царица Соломаниха: / - А ты прекрасной царь Иван же всё Микульевич, / А царь Соломан отойдет он своей хитросъю же мудростью. / Говорил же царь Иван же всё Микульевич: / - Уж ты ой еси, царица Соломаниха, / А какой же царь Соломан хитрой, мудрой? / Он бы хитрой, мудрой был, не сел бы тебе под гнузно, / А вот нету его некакой же хитрости». Когда Соломана приводят к виселице с тремя петельками, он просит позволения в последний раз вострубить в рог, проститься с белым светом, и Иван Микульевич позволяет, хотя Соломаниха в третий раз предупреждает его: «Отойдет же изарь Соломан своей хитросью же мудросъю!» ${ }^{17}$, а тот опять не соглашается с ней, приводя уже известный аргумент: «И глупе цзаря Соломана на свети нет!» ([I7, с. 367-368], «Про царицу Соломаниху» $)^{18}$. В итоге по знаку Соломана дружина приходит ему на помощь и хитрый-мудрый Соломан одолевает и жену, и Ивана Микульевича и в конце вешает на трех «петельках» всех троих - Соломаниху, Ивана Микульевича и Ваську Торокашкова.

Здесь уместно обратить внимание на то, что мотивы, связанные с оценкой хитромудрости того или иного персонажа, характерные для былин о царе Соломане, становятся до некоторой степени общим местом былевого эпоса, обнаруживаясь в разных былинах и разных сюжетных ситуациях. В частности, мотив «герой сомневается в мудрости соперника» встречаем в былине о Соловье Будимировиче, который прибывает в Киев, чтобы по-

I6 Т. е. не забрался бы в сундук, на который уселась Соломаниха.

I7 Вар.: «И говорила царица Саламания: / - Ты прекрасный царь, Василий Окульевич! / - Уйдет он от тебя с хитростью / - И с великою уйдет мудростью!» ([58, т. І, № 94], «Царь Саламан и Василий Окульевич»); «Говорит душка Маринка лебедь белая: / “Уж ты гой еси, Василий царь Викулович! / Не продолжай время и ты не мешкайся, / У Соломана много мудростей, / Много мудростей, много хитростей, / Не спроведать его всех хитростей”» [19, № 83].

I8 В других произведениях на этот сюжет в качестве синонима хитрости-мудрости Соломана может выступать хитрость, см.: «Она говорит... / У меня царь Соломон под ж... сломан, / Казни скурва, хитростями будет хитрый, / А топерь-то в наших руках» ([96, с.62], Заонежье). 
свататься к племяннице самого Владимира, Забаве Путятишне. Соловей отвергает все милости Владимира и просит только об одной: он хочет в саду Забавы Путятичны выстроить златоверхий терем. Забава восхищена красотой терема и в этом восхищении показывает себя не очень ловкой и умной. Например, в одной из мезенских записей, придя в терем, Забава садится на порог, а Соловей Будимирович слегка издевается над ее простоватостью: «Говорит-то тут Соловей Блудимирович: / - Да сказали, Забава-та хитра-мудра, / Нам сказали, Забава да очунь хоробра; / А заправо Забавы да глупей не нашол!» [16, с. 304].

И еще один мотив былины о царе Соломане - «герой обходит соперника хитростью-мудростью» (вар.: «обманывает кого-то хитростью») встречается в других сюжетах: «Они рыцари-ти были очунь бойкия, / ... / А они скоро-то они да догадалисе, / А своей хитросъю они, мудросъю дозналисе, / И они стречали тут салатана премладого царевиця / ... / Увешшали они его словами ласковыма, / А и обошли-то они своей хитросью же, мудросъю» ([I7, № II6], «Марута Богуслаевна»). Понятно, что выражение обойти хитростью-мудростью не сводимо к простому обману, а предполагает более сложный путь к достижению цели - через наблюдение, опыт, знания, размышления, выдумку и находчивость.

Тот же набор качеств востребован и в другой сюжетной ситуации, когда герой должен разгадать хи тромудрые загадки, и от этого его решения многое зависит. Эпизод с разгадыванием загадок является одним из ключевых в былине о Глебе Володьевиче и Маринке Кайдаловне. Князь Глеб Володьевич осаждает Корсунь, в котором засела еретица-безбожница Маринка Кайдаловна. Она требует от князя разрешения загадок в обмен на освобождение города, обещая, кроме того, выйти замуж за победителя: «Уж ты ой еси же, князь да Глеб же сын Володьевич, / Отгадай-ко ты у мня да три хитрых мудрых загадочек, / Отгадаешь же мои же ты загадочки, / Я отдам тебе же все да черны карабли заморские...» ${ }^{19}$ ([I7, с. 355-356], «Глеб да сын Володьевич»).

I9 Известно, что разгадывание загадок как условие освобождения - типовой мотив эпоса и сказок, но одновременно оно является также одним из этапов эпического или сказочного сватовства (см. «Садко»). Как заметил Б.Н. Путилов, в былине имеется явное противоречие: Глеб Володьевич, отгадывая загадки, идентифицируется как жених (суженый), но он против брака с Маринкой. В эпическом подтексте имеется в виду намерение Маринки женить на себе Глеба с целью погубить его [20, с. 528]. 
Последующая полемика героев предстает как настоящее эпическое состязание, в котором мы видим следы уже знакомого нам мотива «герой сомневается в мудрости соперника» и насмешки героя над соперницей:

- «А как перва та у мня загадка хитромудрая:

Еще что же в лете бело, да в зимы зелено?»

Говорит-то Глеб да таковы речи:

«Не хитра твоя мудра загадка хитромудрая,

А твоей глупе загадки на свете нет:

А как в лете-то бело Господь хлеб дает,

А в зимы-то зелено да тут ведь ель цветет».

- «А загану тебе втору загадку хитромудрую:

А да что без кореньица растет да без лыж катится?»

- «Без кореньица растут белы снеги,

А без лыж-то катятся быстры ручьи».

- «Загану тебе третью загадку хитромудрую:

А как есть у вас да в каменной Москвы,

В каменной Москвы да есть мясна гора,

А на той на мясной горы да кипарис растет,

А на той парисе-дереве сокол сидит».

- «Уж ты гой еси, Маринка дочь Кайдаловна!

Нехитра твоя загадка хитромудрая,

А твоей загадочки глупе на свете нет:

Как мясна та гора - да мой ведь доброй конь.

Кипарисо дерево - мое седёлышко,

А ка соловей сидит - то я, удалой доброй молодец»

([8, № 50], «Глеб Володьевич и Маринка Кайдаловна»)

Знания Глеба Володьевича сродни предусмотрительности князя Владимира, поставившего караульщиков у могилы Авдотьи Лиходеевны: в этом хитромудром знании присутствует эпический подтекст, нечто, оставшееся за рамками былинного сюжета, - это знания, данные героям предыдущим опытом, или просто сверхзнания, «положенные» эпическому герою².

20 Мы не пытаемся определить природу этого подтекста, но первое, что приходит на ум, это известные размышления Б.Н. Путилова о немотивированных мотивах в славянском эпо- 
Глухой намек на подобные эпические предзнания встречаем и в другом жанре, а именно в Стихе о Голубиной книге, где также встречается парная конструкция хи трый-мудрый как х а ракте ри сти к а к н я з е й и ц а р е й. Напомним, что большая часть вариантов этого Стиха начинается с того, что с небес на землю падает книга Голубиная, для прочтения которой собираются цари, короли и князья, и только некоторые из них - хитромудрые - способны прочесть ее:

... Што на ту на славушку да на великую

Собиралосе-соежжалосе

Веть сорок царей, сорок царевицэй,

И сорок королей, сорок королевицэй.

Во-первых выбиралса из их хитрой-мудрой изарь,

Хитрой-мудрой царь Вытусей-от изарь,

Витусей-от царь Витусеевичь;

И во-фторых выбиралса из их хитрой-мудрой ц̧арь,

Хитрой-мудрой изарь Волонтоман-ц̧арь...

([І, т. 3, ч. 4, с. I20, № 325], Мезень);

Выискався бо тамко хитрэй-мудрэй царь,

Хитрэй-мудрэй иарь Володзимер изарь,

Володзимер царь, Витовцеевич...

Ты на басенки усё на добрыи,

На отгадычки усё на мудрыи:

Прочитай нам книгу голубиную...

$$
\text { ([66, с. 288], Белоруссия) }
$$

Вместе с тем в русском эпосе присутствует и те м а 3 н а н и й к а к т а к о в ы х, не сопряженных со сверх- или предзнанием. Хитростями-мудростями в этих случаях называются знания и науки вообще, а эпитет $х и$ трый-мудрый приложим как к самим наукам, так и к ученикам, этими науками овладевающим, и к их учителям, обучающим этим наукам: 
Ишше стал у нас да Петр-от Перьвой-от,

Стал семи годов - да ёму от роду;

Как премудрой был ияревищь-от хитрой-мудрой;

Изучилсэ-то он скоро Божьей грамоте,

Ко всему он изучилсэ, цёму надобно.

([8, с. 244, № 6o], «Семейная жизнь Петра I»);

Задался Вольга сударь Буслаевич на семь год,

А прожил двенадцать лет;

Обучался хитростям, мудростям,

Всяким языкам разныим.

[58, ч. I, c. I, № $\mathrm{I}]$;

...Услыхали тут узнали учители прехитрые,

Прехитры они были очунь премудрые,

И они стречали тут салатана премладого царевиця...

«Уж ты ой еси, премладой ты царевиць же,

И-и мы желаем тебя взять да на ученьицо...

Э-и научись-ко-се ты нашой хитрой мудрости,

Научись-ко ты нашой рыцарськой же храбрости...

И пожелал-то он учитьсе к им на Милитрисьски славны острова,

А и ихной хитрой-то премудрой славной грамоты,

Э и как и рыиарьской же ихной всё же смелости,

И богатырьской то же всё да силь великою...

([I7, № II6], «Марута Богуслаевна»).

Последний пример показателен еще и тем, что обучение воинским наукам и знанию специальных военных приемов органично русским былинам по тематике: «Будет Василий семнадцати лет, / Обучился Василий всяких хитростей-мудростей, / Разных наук воинскиих и рыцарскиих...» [58, ч. 2, № I50]. Указание на такую «учебу» встречаем и в относительно поздней печорской былине «Лука, Змея и Настасья» (о ней см.: [3, с. I4I, I76, I77]). Во второй части былины Лука Данилович, который на тот момент служит турецкому царю, послан им в чужие земли обучиться профессиональной военной науке, которую, собственно, былина и называет хитростями-мудростями: 
Призывал бы царь его да нынь турецкий же,

Он и сказыват ему бы службу царскую -

Поезжать бы ему во земли дальние,

Там узнать бы все хитрости-мудрости:

«Сосходить бы тебе в землю дальнюю,

Разузнать бы тебе хитрости да мудрости!»

Он приехал во земли во дальные -

Показали ему все хитрости-мудрости:

Там накопаны копы да земли медныей,

Там отправлены мины нынче с порохом.

Не спускают к этим минам бы с порохом

И направляют эти мины да с порохом.

Это списал он все эти хитрости-мудрости...

Обратитьсе нынь теперича назад ему.

([I8, с. 340, № 28I], Печора)

И последнее, о чем целесообразно здесь сказать, - это т е м а п р о -

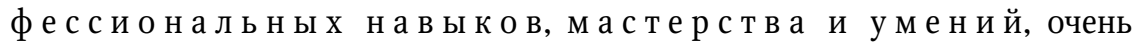
характерная для ПСК со словами на хитр-/мудр-. Профессионалы-специалисты (лекари, мельники, строители, музыканты и др.) в традиционном обществе считались если не колдунами, то во всяком случае людьми, имеющими контакты с нечистой силой ${ }^{21}$. Эти знания выделяли их на общем фоне и заставляли относиться к ним с известной осторожностью. Вместе с тем их навыки составляли важную часть общего знания, и к их услугам обращались по мере необходимости. Все это в целом объясняет, кажется, тот факт, что эти профессиональные навыки и их носители вписываются в концепт хитрости-мудрости, соединяющий идею высокого профессионального знания (ср. «Серебряного, сканного дела хитрецы» - [26, s.v. Хитрый]) и знания специального, особого, сверхзнания, который, как мы отмечали выше, получил особенно широкое распространение в заговорах.

Так, в былине-скоморошине «Терентий муж» хитрыми-мудрыми названы доктора, которых герой ищет для своей жены:

2 I См. на эту тему специально: [24]. 
Жил-был Терентий-муж.

у ёго была жона молода

Да Прасофья Ивановна.

Она с утра больна и трудна,

Она под вецер недужна вся.

«Уж ты ой еси, Терентий-муж!

Да ты поди-тко по Нову-городу

Да кричи-тко во всю гору,

Наживай хитрых мудрых дохтуров;

“Да не знают ли моей жены пособить

Да Прасофьи Ивановны?”»

([I, т. I, ч. 2, с. I90, № 4I], «Терентий муж», Пинега)

В былине «Поездки Ильи Муромца» Илья встречает на своем пути судьбоносную надпись, повелевающую ему поставит церковь и закончить там свои дни:

Как выкатил казну да Илья Муромец,

Нанял хитро-мудрыих плотников,

Построил он церкву соборную

Святителю Николы Можайскому,

Во славном во городи во Киеви,

Сам заехал во пещеры во глубокие,

Тут-то Илья уже преставился.

Поныне теперь мощи нетленные.

$$
\text { [56, № 266] }
$$

Помимо людей, владеющих тайнами того или иного мастерства, эпитет хитрый-мудрый присваивается искусному рукоделью: шитью, вышиванию, плетению и другим видам ручной работы. Особенно часто такое употребление рассматриваемой ПСК встречаем в былине о Соловье Будимировиче:

Он кнегины Опраксеи подарки дарыт,

Педдесят аршын хрущатой камки. 
Ишша княсь камоцьку розвёртывал,

Ишша княсь узоры высматрывал:

А-й хитры-мудры узоры заморские...

([I, т. I, ч. 2, с. 389], Пинега, «Соловей Будимирович»)

Этот эпитет применяется к сложному и замысловатому рукоделию и, как мы показали вначале, соответствует значению 'искусный' (характерному для слов с корнем хитр- и во вторую очередь - с корнем мудр-). Как мы увидим в дальнейшем, эпитет хитрый-мудрый в этом значении встречается не только в былинах, но также и в других жанрах русского фольклора. Вместе с тем для отдельных слов, составляющих исследуемую ПСК, это и близкие значения отмечаются и в диалектах, см.: смолен. мудренка 'узор на холсте в виде мелких, кружочков, вышитых по контуру красной бумажной нитью' [8о, т. I8, c. 330]; вологод. примудрушка 'украшение, причудливая деталь в одежде' и т. д.

$* * *$

Таков в общем и целом круг тем, с которым связана ПСК со словами на хuтр-/мyдp- в русских былинах. В значительной своей части они согласуются с теми, что обнаруживаются в заговорах. Прежде всего это колдовство и вредоносная магия (в былинах трансформировавшиеся в оборотничество), а также сверхзнание - магическое, профессиональное или просто заданное эпическим подтекстом былины. Все эти темы, хотя проявляют себя в обоих жанрах, но делают это по-разному. Относительно высокая частотность ПСК со словами на хитр-/мудр- в былинах приводит к тому, что парная конструкция выступает в роли своего рода маркера, указывающего на тему особых знаний, умений и сверхспособностей, которыми владеет герой эпоса (прежде всего Волх). В эпосе хитрость-мудрость как определенный комплекс интеллектуальных качеств и магических способностей героев играет заметную роль в развитии некоторых сюжетов, прежде всего связанных с эпическим соперничеством.

В народной лирике темы, сюжеты и мотивы, в которых чаще всего употребляется ПСК со словами на хитр-/мyдр-, частично повторяют былинные контексты, хотя в лирике эта конструкция встречается значительно реже, чем в былинах. 
Первый лирический сюжет «Молодец по улицам гуляет, ищет хитромудрого человека»; известная лирическая песня, популярная на Урале, в Сибири, а также в казачьей среде. В ней мы вновь возвращается к теме колдовства, знахарства и особых навыков и умений, которыми должен обладать тот, кого ищет молодец:

...Ой да сокрушала доброва молодца славушка худая.

Ой да не ясен сокол да по воздуху, братцы, летает,

Ой да молодой сержан по лагерам, братцы, розъезжает,

Ой да человека он ишшет, братцы, да не простого,

Ну как не простого, братцы, только, братцы, хитра, мудра.

Исшо хто бу из добра коня вывел такой норов,

Молодецкой доброй сабле' ржавчину повывел,

С моего бу ретива сердца вывел, братцы, кручину?

$$
\text { ([12, с. 285], Колыма })^{22}
$$

Второй, также знакомый нам контекст исследуемой ПСК, - это загадывание хитромудрых загадок, подразумевающее чаще всего некое тайное знание, позволяющее герою разгадать эту загадку, называемую не только хитрой-мудрой, но также и неотгадчивой (неотгадливой), см.:

...Не взять мне души красной девицы!

Загадаю девице загадочку,

Хитру, мудру, не отгадчиву:

Ах, что у нас, девица, без огня горит,

Без огня у нас горит и без крыл летит,

Без крыл у нас летит и без ног бежит?»

Да что взговорит душа красна девица:

«Уж как эта ли загадка не хитра, не мудра,

Не хитра, не мудра, лишь отгадлива.

Без огня у нас горит солнце красное,

А без крыл у нас летит туча грозная,

А без ног у нас бежит мать быстра река...»

([2I, т. I, № 325], «По крутому, по красному по бережочку»)

22 Вар.: «...Добрый молодец по улицам гуляет; / Он изыскивает хитра-мудрого человека» [2I, т. 3, № 2Іо], где ПСК хитрый-мудрый фактически переходит в сложное слово. 
В лирике возможно включение этого эпизода и в совершенно иной трагический контекст, где разгадка диктуется не тайным знанием, а обыденностью ситуации: девушка убивает милого и «потчует» им его сестер:

Позову ли я гостей,

Всё твоих сестер,

Всё твоих подруг,

Загадаю ль им загадочку,

Не хитру и не мудру,

Не отгадчивую:

«Я на миленьком сижу,

Милым подчиваю...

Как одна тут из сестриц

Догадалася,

Домой скоро собиралася:

«Говорила брату я

И наказывала:

Не ходи ты, молодец,

К красной девице душе:

Ведь она тебя не любит,

Буйну голову погубит...»

([57, вып. 2, ч. I, № І42г], «Ты не шей не шей, девица...»; вар.: [99, вып. І, с. 196; 21, т. 7, № 737])

И, наконец, третий контекст подразумевает употребление ПСК $x u$ трый-мудрый или соответствующего сложного слова для описания искусного рукоделия, тонкой ручной работы:

Уж я шила, вышивала

Да все хитрые узорцики,

Хитро-мудрые узориики, шириноцьки

Свет Алексею Захарьевицю

Под пуховую под шляпоцьку.

[57, вып. І, с. 22] 
Такое же значение встречаем в свадебных ${ }^{23}$ причитаниях и песнях, близких по тематике и стилистике к народной лирике. В них хитрыми-мудрыми (или хитромудрыми) называют:

- узоры и рукоделие: «И по-прежнему она, да по-досюльному, / И за девочьим сидит да рукодельицем, / И вышиват, пущай, узоры хитромудрыи...» ([5, т. 2, с. 297], Олонецкая губ.);

- швей, создающих одежду для новобрачной: «И у меня, да у печальной головушки, / И нет возрощено ведь белыих лебедушек, / И у мня зимних на бесёдушке прядиюшек, / И дорогих нету угловых у мня ткиюшек, / И нету вешных хитромудрых у мня швиюшек / И ушивать да тонку белую сорочечку!» ([5, т. 2, с. 330], Олонецкая губ.);

- свадебные блюда («стряпни»): «Уж как нонче да нонечи /.../ Наложи-ко ты, крестная, / Да на блюдце, на золотце / Стряпни хитрыё-мудрыё!» ([32, с. 336], Вологодская обл.); «Я отдам эту красоту / Я родимоей матушке. / У матушки работа тяжелая, / И стряпни хитромудрые, - / Это тоже моей красоте / Тут не место, не местечко!.» ([45, № 474], Вологодская обл., причет при отдании невестой своей «красоты»);

- писарей, к которым невеста должна обратиться за тем, чтобы те написали письмо родителям жениха, а они, в свою очередь, откажутся от сватовства и оставят ее на воле: «Ты послушай-ка сестрица моя родная, / ... / Уж мы съездим-ка в Шунгский столбовой погост, / Мы закупим лист гербовоей бумаженьки, / Мы наймем там писарей да хитромудрыих, / Мы пошлем да скорописчатую грамотку / Что во эту во столицу Петербургскую, / Пригласим своих желанныих родителей, / Не откажут ли остудника чужа сына, / Не оставят-ли во вольной тебя волюшке» ([55, с. І2], Олонецкая губ.).

Таким образом, основной темой ПСК со словами на хитр-/мудр- в свадебных причитаниях являются профессиональные знания и навыки:

23 В кругу индоевропейских образований, родственных праслав. mо̨агъ, выделяются слова с такими значениями, как 'мудрый', 'живой, бодрый’, 'иметь намерение, цель', на основании чего этимологи допускают, что и.-е. *mendh- (к которому возводится *mǫdrъ) изначально служило обозначением ментального возбуждения [10о, т. 20, с. 133]. В.Н. Топоров в связи с этим сравнивал сексуальный аспект *mǫdrъ c *mǫdę 'тестикулы’ и писал о соотнесении головы и testicula (как носителей мудрости) в мифопоэтической традиции [93, с. 253]. Ср. в связи с этим в русской свадебной песне: «Что хитёр-мудёр первобрачный князь, / Что хитря-мудря его не было. / Да пройдет эта ноченька / В хитростях да во мудростях» [50, с. 304]. 
людей, ими владеющих, а также продукты их труда причитания последовательно называют хитрыми/мудрыми и хитромудрыми. К этой традиции примыкают севернорусские похоронные и рекрутские причитания. В собрании Е.В. Барсова мы насчитали более 20 упоминаний слова хитромудрый, относящегося почти исключительно к писарям: их просят написать бумагу, которая бы освободила от службы рекрута, «списать на бумагу» лицо умершего родственника и т.д.: «Ты послушай же, родитель моя дяденька! / Лучше возьмем золотой казны по надобью, / Мы закупим-ко гербовой лист бумаженьки, / Писарёчков наймем да хитромудрыих; / Уж мы спишем-ко персонь да лицо белое, / На патрет да его ясны эты очушки, / Колесисты эты черны его бровушки, / Молодецкии завивныи кудёрышки...» ([5, т. I, c. I64], Олонецкая губ.). Других вариантов употребления этого слова в похоронных и рекрутских причитаниях практически нет, как нет и собственно ПСК со словами на хитр-/мудр-.

В свадебных причитаниях и свадебной лирике хитрый-мудрый приобретает также оценочное значение и выступает как позитивная характеристика лица, обычно невесты или жениха. В следующем причитании невеста жалуется на то, что сват расхваливает ее и ее семью перед семьей жениха: «Съидет домой да злодий большой сват, / Против семьи разспохваляется, / На меня да роспеняется: / Коль хитра да мудра девица, / Коль проворны милы братьица» ([99, вып. 2, с. 5II], Пинега). Аналогичным образом описывается и жених в шуточной свадебной припевке, с помощью которой девочек припевали к мальчикам-«женихам»: «Хитёр-мудёр Иван-молодец, / Хитрей-мудрей да его не было, / ... / Уж он плёл колыбель да из семи шелков, / Из семи шелков да из семи сортов. / Повесил колыбелюшку на улицу / ... / Говорил-то Иван таковы словеса: /- Качайте колыбелюшку повыше всех, / Чтобы мне увидеть получше всех, / Чтобы мне увидеть свою суженую, / Богосужену Овдотью Семеновну» ([52, № 702], Терский берег Белого моря). Вообще, подобная характеристика в свадебном фольклоре чаще всего относится именно к жениху, см. контекст, в котором синонимом к хитрому-мудрому выступает эпитет хоробёр: «Нам сказали-то - молод князь-то не хитёр. / Да он хитёр, мудёр, сам хоробёр $p^{24}$ / ... / Да со крылечка да в нову

24 Такое соединение эпитетов, видимо, неслучайно, ср.: «Кон же его бысть борз и горазд играти, а юноша храбр бысть и хитр на нем сидети» [27, с. 74], а также мудрохрабрый 'соединяющий в себе храбрость с мудростью' ([8I, т. 9, с. 298], XVII в.). 
горницу зашел. / Да ко душе ко красной девушке, / Да ко невесты да зарученоей. / Он и брал-то ей руку за руку...» ([45, № I52], Мезень). Оценочные коннотации парной конструкции хитрый-мудрый мы уже встречали в былинах при характеристике женских и мужских персонажей.

Мы не будем подробно рассматривать «хитрость-мудрость» в русских сказках - и прежде всего потому, что парная конструкция xumpocms-мyдрость (или однокоренные с ней) представлена в них достаточно слабо. Вероятно, это связано с тем, что в сказках важную роль играет близкий к этой ПСК концепт «хитрость» (иногда «мудрость») 25 , который довольно разнообразен в своих значениях. Под «хитростью» здесь понимается превращение и оборотничество, а также просто ловкость и находчивость, причем особенностью сказки является то, что эти аспекты сказочной «хитрости» порой трудно различимы (вспомним многочисленных премудрых дев и хитрых персонажей сказок).

Тем не менее попробуем бегло обозначить основные контексты, в которых рассматриваемая парная конструкция все же встречается. К заговорам и особенно к былинам ближе всего сказочные контексты, в которых хитрость-мудрость связывается со способностью сказочной героини к оборотничеству и превращениям. Так, в сказке «Настасья-королева» (вариант сюжета СУС 450 «Братец и сестрица»), когда брат с сестрой убегают от погони, сестра бросает позади себя предметы, тем самым создавая преграды на пути преследователей; последние, видя эти преграды, говорят о сестре: «- Вот хитронья, вот мудронья, не ухитрится, не умудрится, будет у меня. Сверлили они и бурили (преграду. - Т.А.). Высверлили, выбурили, а они ужо далеко» ([73, № 64], Рус. Север). Очевидно, что именно способность сестры превратить чудесные предметы в нечто иное и провоцирует называние «хитроньей-мудроньей», т. е. указывает на ее принадлежность к категории людей, владеющих магическими навыками. Продолжением же этих слов становится угроза, что сестре не хватит «хитрости-мудрости» уйти от преследования и она будет схвачена: «не ухитрится, не умудрится, будет у меня».

«Хитрости-мудрости» появляются и в контекстах, связанных с традиционным для сказки концептом чудесного. В сказке «Каровушка-Бя- 
лонюшка» (вариант сюжета СУС 5II «Чудесная корова»), записанной на псковско-смоленском пограничье, между мачехой и падчерицей разворачивается заочный спор, своего рода «меряние» хитростью-мудростью (см. выше в былинах). Падчерица обещает родить царю чудесных детей: «А я, гаварит, цичм хитра, циим мудра: ражу, гарит, три раза па три мальцика: руки в злате, ноши в сребре, на макушке драбные звезды, в патылицы ясен ме[сяц], паходка у паходку и гаворка у гаворку и ростом как адин», и рожает их. Мачеха же оспаривает «хитрость-мудрость» падчерицы, приводя в качестве примера настоящей «хитрости-мудрости» другие чудеса: «Што ты! это ня хитрость, это ня мудрость. Вот есь на десятом царстве в десятом гасударстве этый ваперь: луцём (рылом) ареть (пашет), хвастом скародеть (боронит), за им белая пшаница родится, сытница пякется и на торг нясется. Вот eто хитрость, вот ето мудрость» или «Ай, зятек мой милый, эта ня хиmрость, эта ня мудрость. В [три ]десятом царстве, в (...)десятом гасударстве сасна стаить, дятел сядить, на адин бок кинеть - злато, на другей - сребро. Bom ето хитрость, вот ето мудрость» ([5I, с. 252-253], Рус. северо-запад).

Однако чаще всего упоминания о хитрости-мудрости встречаются в тех сказочных сюжетах, где грань между чудесным и волшебным, с одной стороны, и ловкостью и находчивостью - с другой, едва различима. В сказке «Хитрая наука» (вариант сюжета СУС 325) учитель, которому мальчик был отдан в ученье, требует, чтобы старик-отец выбрал своего сына из 30 совершенно одинаковых на вид учеников: «И сделал он из тридцати учеников своих тридцать молодцев: молодец к молодцу! А сын успел шепнуть отцу: “На моем-де лице мушка сядет, я ее платком смахну”. Так и сделал; по той примете старик угадал сына. "Ну, не ты мудёр-хитёр, - сказал ему учитель, - мудёр-хитёр твой сын! Угадывай сызнова” ([48, т. 2, № 252], Нижегородская губ.); заметим, что приведенный фрагмент - редчайший пример перестановки частей ПСК. Как и в эпосе, в сказке мы вновь встречаем сюжетные ситуации, в которых герои стремятся одолеть друг друга при помощи хитрости-мудрости: «Случись на то время быть там учителю. Пристал к купцу: “Продай да и продай лошадь!” - “Изволь, давай триста рублев”. - “Дам, продай с уздечкою”. Купец призадумался. “Продай - надбавлю!” Соблазнился старик и продал. Учитель сел на коня да и был таков! Взмылил он коня вспенил ему бока; а сам бьет да приговаривает: “Я ж тебя перехитрю, я ж тебя перемудрю!” $[48$, т. 2, № 252]. 
ПСК со словами на хитр-/мyдp- встречаются также в паремиях, хотя и достаточно редко. Никаких специальных значений здесь мы не обнаруживаем. В пословицах эти ПСК могут обозначать что-нибудь особенное, например искусно сделанное, затейливое и т. п., что соответствует некоторым значениям хитрый, например укр. «Хочеться так, щоб хитро-мудро та невеликим коштом» [63, с. 388]. Как уже отмечалось выше, многие паремии допускают варьирование за счет чередования слов хитрый и мудрый вроде «Нужда хитрее (или мудрее) мудреца» [26, s.v. Мудрый], что, впрочем, напрямую к концепту хитрый-мудрый не относится.

***

Подведем итоги. ПСК со словами на хитр-/мyдp-, а также соответствующие сложные слова широко известны в целом ряде жанров русского фольклора, а частеречные и морфологические вариации этой парной конструкции довольно разнообразны. С ее помощью в фольклоре могут обозначаться

- лица: хитреи-мудрец, хитрок-мудрок, хитронья-мудронья, хитрой-мудрой;

- события/состояния/объекты: хитрость-мудрость, хитрости-мудрости (с предлогами ради, для, $c$, от, без и в составе оборотов: дознаться хитростью-мудростью, обойти хитростью-мудростью, обучаться хитростям-мудростям, распознать/понимать хитрости-мудрости, взять хитростью-мудростью и др.);

- атрибуты: хитрый-мудрый, прехитрый-премудрый, хитёр-мудёр, хитрее-мудрее (редко - хитрее-мудрёнее), хитромудрый;

- действия: хитровать-мудровать, похитрить-помудрить, перехитрить-перемудрить, подхитрить-подмудрить, мудриться-хитриться, приумудриться-приххитриться;

- способ действия: по-хитрому-по-мудрому, хитро-мудро, хитрому$\partial p o^{26}$.

Рассматриваемые ПСК демонстрируют разные формы синтаксической реализации и, соответственно, разную степень слитности отдельных

26 К примеру: «Сидят пташечки весёлыё, весёлыё, весёлыё, весёлыё. / Ой, они песни поют заунывны, заунывны, свет заунывны, / Словеса говорят хитромудро, ой, хитромудро, свет, хитромудро» [6, с. 165]. 
частей. Как отмечала А.П. Евгеньева, «синонимические пары, несмотря на свою слитность... тем не менее не являются неразрывными... [3о, с. 268]. ПСК может функционировать как парное слово типа хитрый-мудрый, как перечисление (хитрый, мудрый), в том числе перечисление с предлогами и с отрицанием, а может разделяться союзами $(u, \partial a)$, частицами $(ж е)$ и даже самостоятельными словами: премудра сарачина прехитрая ([8о, т. 36, с. І39], Мезень); если хитра ваша слуга да мудра [72, № І6] и т. д. Слитность ПСК обеспечивается не только тем, что оба слова в целом характеризуют один объект, но и тем, что в большом количестве контекстов, даже будучи разделенными другими словами, они имеют одно определяемое слово: $с и$ дят две мудрые, две хитрые девищы ([67, № 2269], Архангельская обл.).

Почти всегда ПСК сохраняет порядок частей относительно друг друга, а исключения из этого правила единичны (мудёр-хитёр; премудрый, прехитрый). Иногда парная конструкция может трансформироваться, например, в атрибутивно-номинативные словосочетания типа «И тут же зачали его учители прехитрыя / И обучать-то его стали хитрой мудрости» [I7, № II6].

Семантическая близость слов на хитр-/мудр- обусловливает и тот факт, что при появлении в фольклорном тексте одного из слов рассматриваемой пары с высокой степенью вероятности может ожидать и второго: они будто притягиваются друг к другу. Вместе с тем два этих слова не всегда составляют парную конструкцию, поскольку могут относиться к разным объектам: «...лягу, раб Божий, в материну утробу, никто бы меня не нашел, к Царю Давыду пойду в смелость и кротость, к Александру Македонскому пойду по х и т р о с т в, ак Царю Соломону по п р е м у д р о с $m$ ь ...» ${ }^{27}$; «На панську мудрість мужищька хитрість» [63, с. 329] и т. д. Вообще, в паремиях два слова на $x u m p-$ и мудр- часто входят в один контекст, но при этом не образуют единого целого: брянск. «Голь хитра, голь мудра, голь на выдумки пошла» [92, с. І8о]; «Нет такого мудреца, как Ивана хитреща. Сел на конь, поехал в огонь» ([33, с. 43], с разгадкой «горшок») и др.

В некоторых случаях можно даже наблюдать противопоставление понятий, определяемых словами хитрый и мудрый. Так, в былине о Василии Буслаевиче рассказывается о том, как по мере взросления мать отдает его

27 Ордин Н. Заговоры, собранные в Сольвычегодском уезде // Архив Рус. геогр. о-ва.

Оп. І. Разр. 7. Д. 44. Л. 2о. Вологодская губ., заговор перед судом и начальством. 
сначала в одно учение - мудрое, т. е. учиться грамоте, а затем и в другое xumpoe, т. е. учиться магии и превращениям:

Чесна вдова Омельфа Тимофеевна.

Родила она младого отрока,

Да младого Василия Буслаевиця.

Да стал-то Василий лет пяти-шести,

Отдавала его мать учителю,

Учиться ученье всяко мудроё:

Писать да читать скоро азбуке...

Отдавала его да мать-то ведь учителю,

Учиться ученье всё-ко хитроё:

По поднебесью летать да ясным соколом,

По чисту полю рыскать да нонь серым волком,

Да в землю уходить горносталюшком,

Да в воду ходить да ноньце рыбою,

По воды-то плавать ярым гоголем.

([г6, с. 494-495], Мезень, «Василий Буслаевич»; вар.: [I9, № I4])

Это яркий пример того, как сильно различаются между собой эти слова и понятия - мудрость, связанная прежде всего с книжной культурой, и хитрость, имеющая прямое отношение к колдовству, вежеству и в конечном счете языческому знанию.

Несколько слов о синонимии в связи с парными конструкциями. В целом в отношении ПСК и соответствующих сложных слов можно говорить о двух типах синонимии: о синонимах, во-первых, дополняющих парную конструкцию, и, во-вторых, заменяющих ее.

Дополняющая синонимия к ПСК с корнями хump-/мyдp- развита довольно слабо, что отчасти объяснимо синонимией слов хитрый и мудрый внутри самой ПСК. Тем не менее отметим появление третьего синонима, встающего в ряд со словами на хump-/мyдp-, в заговорах, см.: хuтреи, мудреи, колдовеи; не подхитрить и не подмудрить и не спортить; похитрить, помудрить и похимостить, хитрость-мудрость-ноготь и т. д., что, вероятнее всего, объясняется характерной для этого жанра тенден- 
цией к выстраиванию разного рода перечислительных рядов. В былинах и народной лирике синонимами к парной конструкции хитрый-мудрый, если речь идет о лице, чаще выступает прилагательное догадливый: царииа Елена была хитра, мудра, да хитра была, мудра, всё она догадьлива [8, c. 24I] и непростой: человека он ишшет, братцы, да не простого, ну как не простого, братиьь, только, братиьы, хитра, мудра [І2, с. 285], а также храбрый (хоробрый): Забава-та хитра-мудра, нам сказали, Забава да оиунь хоробра [16, с. 304]; если речь идет о загадке, то она может определяться также как неотгадливая ('трудная’): загадаю девице загадочку, хитру, мудpy, не отгадчиву [2I, т. I, № 325].

Теперь о синонимах, заменяющих ПСК. Нам известно всего два сложных слова, которые можно счесть полными синонимами слова хитромудрый. В севернорусских диалектах фиксируется хитродумный [75, с. 540], в олонецких причитаниях - хитроумный (единично):

И пораздумаюсь победным умом-разумом:

Нынь не скроешь-то сердечного ведь дитятка:

Времена теперь пошли да все бедовыи,

Хитроумны стали власти страховитыи.

[5, т. 2, с. 49], Олонецкая губ.)

В заговорах замена ПСК на отдельное слово представлена слабо, что, на наш взгляд, свидетельствует об органичности парных конструкций поэтике и семантике текстов этого жанра. Что касается других жанров, то в них в качестве синонимов к парным конструкциям со словами на хитр-/ мудр- используются отдельные слова из пары (или однокоренные им), и такие замены имеют регулярный характер (мы указывали на подобные случаи по ходу статьи). Приведем лишь два примера. Выше мы упоминали, что в похоронных и рекрутских причитаниях одним из наиболее частых выражений является хитромудрый писарь, которое может заменяться мудреным писарем: «Ты возьми, кормилец батюшко, / Лист бумаженки гербовыя, / Возьми писаря мудреного; / Напиши-тко ты прошеньице / Ко Царю, ко благоверному... ([І4, с. II2], Олонецкая губ.). А характерное для многих жанров выражение хитромудрые узоры (шитье, рукоделие и т. д.) может чередоваться с хитрыми узорами: Шел-шел, шел-шел, увидал 
медное царство; во дворце сидят тридцать три девицы-колпицы, вышивают полотенца хитрыми узорами - городками с пригородками» ([48, т. I, № І 30$]$, «Три царства»).

Антонимы к рассматриваемой парной конструкции также единичны, но крайне любопытны. Антоним глупый (Не хитра твоя мудра загадка хитромудрая, а твоей глупе загадки на свете нет и другие подобные примеры) противопоставляет хитрого-мудрого глупому по наличию/отсутствию ума, что кажется вполне логичным. Вместе с тем в фольклоре известна и другая пара антонимов, в которой хитрость-мудрость, напротив, противопоставляется уму/смысловатости. В песне-сказке, записанной в Поволжье П.И. Мельниковым-Печерским, девушка Сашайка обещает взять Казань: «Я бы, Сашайка, своим девичьим умом в три часа взяла, / Взяла бы не хитростью, не мудростью, а своим умом девичьим» [56, с. 592]: здесь «хитрость-мудрость» понимается либо как уловки и обман ${ }^{28}$, либо как колдовство и магия и тем самым противопоставляется уму. Сказка «Незнайко», описывая своего героя - третьего брата Ивана, сообщает, что «Ванюшка не хитёр, не мудёр, а куды смысловат!» ([48, т. 2, № 296], Архангельская губ.). Ср. аналогичное противопоставление хитрости-мудрости и ума в пинежском свадебном причитании: «Родитель мой батюшко! / Чего я у тебя поспрошаю, / Я не с хитрости и не с мудрости, - / С девъя глупого ума-разyмa...» ([99, вып. 2, с. 393], Пинега), где также допустимо разное прочтение ПСК хитрость-мудрость.

Можно с уверенностью говорить о том, что функционирование в фольклорном тексте двух слов со сходной семантикой вместо одного, а также их объединение/слияние в устойчивую пару и даже одно сложное слово, существенно усиливает тот общий смысл, который их объединяет, акцентирует на нем внимание слушателя, о чем упоминала А.П. Евгеньева («оба слова взаимно ограничивают друг друга, уточняя, усиливая, выделяя только одно, общее им обоим значение...», [30, с. 264]). Как нам кажется, этому немало способствуют и случаи своего рода «удвоения» ПСК в границах одного текста вроде «меня учители учили хитрые хитрецы, мудрые мудрецы» ([4I, с. I4I], Вятская губ.) - явление, описанное нами выше прежде всего на материале заговоров.

28 Ср.: «...за град Псков битися с литвою до смерти безо всякия хитрости», т. е. биться без обмана [6о, с. 548]. 
Общий круг значений синонимических пар со словами на хитр-/ мудр- в русском фольклоре выглядит следующим образом:

- умный, проницательный, предусмотрительный, находчивый, ловкий;

- связанный с обманом, уловками, обходными способами решения проблемы и т. д.;

- имеющий отношение к тайным знанием и магическим навыкам;

- касающийся знаний, наук, учения;

- владеющий профессиональными навыками и умениями;

- искусный; мастерски сделанный.

Обращает на себя внимание, что бо́льшая часть этих значений имеет отношение к специальному знанию - будь то магия, оборотничество, военное дело, профессиональные навыки или искусное владение ремеслом. Поэтому хитрый-мудрый - это человек умеющий и знающий то, что другим недоступно. Тема хитрости-мудрости как владения специальными знаниями присутствует во всех жанрах, о которых выше шла речь, - и в заговорах, и в былинах, и в сказках, и в лирике. Допустимо предположить, что именно на основе этого общего значения в заговорах, в соответствии с их установкой на «вежество» и тайное знание, сформировалось специальное значение ‘быть связанным с тайным знанием, ведовством, магией', которое в итоге и стало доминирующим. Это значение хотя и находит поддержку в диалектной речи, но эта поддержка слишком ограниченна (в том числе локально), чтобы ею можно было объяснить многочисленные примеры реализации этого значения в мотивах заговоров и былин на обширных пространствах Русского Севера и примыкающих к нему территориях севера-востока и северо-запада - Олонецкая и Архангельская губернии прежде всего, а также Вологодская, Новгородская, Санкт-Петербургская, Вятская, Костромская, Нижегородская и Пермская губ. Как мы заметили в начале статьи, парные сочетания синонимов со словами на хитр-/мyдp- были также известны в древнерусской книжности, как переводной, так и оригинальной, и потому нельзя исключать книжного влияния на формирование ПСК хитрый-мудрый в русском фольклоре, особенно на Русском Севере, в том числе через посредство рукописной заговорной традиции. 


\section{Список литературы}

Архангельские былины и исторические песни, собранные А.Д. Григорьевым в I899-I90 гг. с напевами, записанными посредством фонографа: в 3 т. СПб.: Тропа Троянова; Кулой, 2002-2003. Т. г (ч. І-2); Т. 2 (ч. 3); Т. 3 (ч. 4). Архангельский областной словарь / под ред. О.Г. Гецовой. М.: МГУ, г980-. Вып. I-. Астахова А.М. Русский былинный эпос на Севере. Петрозаводск: Гос. изд-во Карело-Фин. ССР, І948. 396 с.

Багликова И.А. Хитрости-мудрости // Лингвофольклористика. Курск: Изд-во Курск. гос. ун-та, 2003. С. 88-92.

Барсов Е.В. Причитания Северного края / изд. подгот. Б.Е. Чистова, К.В. Чистов. СПб.: Наука, І997. Т. І-2.

Бахматов А.А., Подюков И.А., Хоробрых С.В., Черных А.В. Юрлинский край. Традиционная культура русских Юрлинского района в XIX-XX в. Материалы и исследования. Пермь: Пермское книж. изд-во, 2003. 240 с.

Б-в И. Свадебные обычаи в Немжинском приходе Лодейнопольского уезда // Олонецкие губ. вед. Ч. неофиц. І897. № 19. С. 2-3.

Беломорские старины и духовные стихи: Собрание А.В. Маркова / отв. ред. Т.Г. Иванова; подгот. изд-я С.Н. Азбелева, Ю.И. Марченко. СПб.: Дмитрий Буланин, 2002. Iо8о с.

Березович Е.Л., Кучко В.С. Менять шило на мыло: диалектологический комментарий к фразеологизму // Вестник Пермского ун-та. Российская и зарубежная филология. 20I7. Т. 9, вып. 3. С. 5-14.

Блохин С.А. Заговоры // Труды Орловской архивной комиссии. Орел: Тип. губ. управления, І889. Вып. 5. С. І2-20.

Бобунова М.А. Единицы фольклорной лексикографии (в словаре языка былин). Курск: Изд-во Курского гос. пед. ун-та, 200I. І5I с.

Богораз В.Г. Областной словарь колымского русского наречия // Сборник Отделения русского языка и словесности. СПб.: Изд-во Имп. Академии наук, І90I.

T. 68. С. I-346.

3 Большой толковый словарь донского казачества / отв. ред. В.И. Дегтярев. М.: Русские словари; Атрель; АСТ, 2003. 608 с.

$4 \quad 5$ - $p$-ов E. Пудожские свадебные причитанья // Олонецкие губ. вед. Ч. неофиц. I867. № 7. С. IIO-II3.

5 Былины Мезени: Север Европейской России / отв. ред. А.А. Горелов. СПб.: Наука; М.: Классика, 2003. 53І с. (Былины: в 25 т. Т. 3.)

I6 Былины Мезени: Север Европейской России / отв. ред. А.А. Горелов. СПб.: Наука; М.: Классика, 2004. 7І6 с. (Былины: в 25 т. Т. 4.)

Былины Печоры и Зимнего берега. Новые записи / изд. подгот. А.М. Астахова. М.; Л.: Изд-во АН СССР, Ленинградское отд-ние, г96г. 608 с. 
I8 Былины Печоры: Север Европейской России / отв. ред. А.А. Горелов. СПб.: Наука; М.: Классика, 200I. 784 с. (Былины: В 25 т. Т. 2.)

I9 Былины Севера / записи, вступит. ст. и коммент. А.М. Астаховой. М.; Л.: Изд-во АН СССР, г938. Т. г: Мезень и Печора. 656 с. Былины: Сборник / вступит. ст., сост., подгот. текстов и примеч. Б.Н. Путилова. Л.: Сов. писатель, І986. 552 с.

2I Великорусские народные песни: в 7 т. / изд. проф. А.И. Соболевским. СПб.: [Б.и.], І895-1907.

22 Великоустюжский сборник XVII в. (Предисловие и публикация А.А. Турилова, А.В. Чернецова) // Отреченное чтение в России XVII-XVIII веков / отв. ред. А.Л. Топорков, А.А. Турилов. М.: Индрик, 2002. С. 177-224.

23 Виноградов Н. Заговоры, обереги, спасительные молитвы и проч. (по старинным рукописям и современным записям): в 3 вып. СПб.: Тип. М-ва путей сообщения, I907-1909.

24 Виноградова Л.Н. Непростые люди в сельском сообществе: о людях, наделенных сверхъестественными способностями. Часть 2. Мастера-профессионалы, магические специалисты, полудемонические существа // Славянский альманах 2018. Вып. I-2. С. 215-233.

25 Воскресенский В.А. Из быта и поэзии крестьян Новгородской губ. / публ. Д.К. Зеленина // Живая старина. І905. №-2. С. I-56.

26 Даль В.И. Толковый словарь живого великорусского языка. 2-е изд. СПб.; М.: Изд-е книгопродавца-типографа М.О. Вольфа, І88о-І882 (1955). T. I-IV.

27 Девгениево деяние / подгот. текста, пер. и коммент. О.В. Творогова // Библиотека литературы Древней Руси / под ред. Д.С. Лихачева, Л.А. Дмитриева, А.А. Алексеева, Н.В. Понырко. СПб.: Наука, І999. Т. 3: ХІ-ХІІ века. С. 58-9I.

28 Диалектный словарь Нижегородской области / редкол.: Л.А. Климкова и др. Нижний Новгород: Изд-во Нижегородского госуниверситета им. Н.И. Лобачевского, 20І3-. Вып. І-.

29 Древние российские стихотворения, собранные Киршею Даниловым / подгот. А.П. Евгеньева, Б.Н. Путилов. 2-е изд., доп. М.: Наука, І977. 488 с.

30 Евгеньева А.П. Очерки по языку русской устной поэзии в записях XVII-XX вв. М.: Л.: Изд-во АН СССР, І963. 346 с.

3I Ефименко П.С. Материалы по этнографии русского населения Архангельской губернии. М.: Типо-литогр. С.П. Архипова и К을 І878. Ч. 2: Народная словесность. C. 139-222.

32 Ефименкова Б.Б. Севернорусская причеть: Междуречье Сухоны и Юга и верховья Кокшенги (Вологодская область). М.: Сов. композитор, г980. 392 с.

33 Загадки русского народа / сост. Д. Садовников. СПб.: Тип. Н.А. Лебедева, г876. $333 \mathrm{c.}$ 
34 Замкну замки замками: Заговорно-заклинательная поэзия Шадринского края / сост. В.Н. Бекетова, М.А. Колмогорцев. Шадринск: Исеть, 200I. II9 с. Замовы / уклад., сістэмат. тэкстаў, камент. Г.А. Барташэвіч. Мінск: Навука і тэхніка, 1992.597 с.

36 Знатки, колдуны и чернокнижники: колдовство и бытовая магия на Русском Севере / под общ. ред. А.Б. Мороза. М.: Форум, Неолит, 2013. 592 с.

Из «Жития Василия Нового». Хождение Феодоры по воздушным мытарствам // подгот. текста Ю.А. Грибова и А.В. Пигина, пер. М.Б. Михайловой и В.В. Семакова, коммент. А.В. Пигина // Библиотека литературы Древней Руси / под ред. Д.С. Лихачева, Л.А. Дмитриева, А.А. Алексеева, Н.В. Понырко. СПб.: Наука, 2003. T. 8: XIV - первая половина XVI века. С. 494-527.

38 Из Толкового Апостола / подгот. текста, пер. и коммент. О.П. Лихачевой // Библиотека литературы Древней Руси / под ред. Д.С. Лихачева, Л.А. Дмитриева, А.А. Алексеева, Н.В. Понырко. СПб.: Наука, І999. Т. 2: ХІ-ХІІ века. С. 82-І25. Илья Муромец / подгот. текстов, ст. и коммент. А.М. Астаховой; отв. ред. Д.С. Лихачев. М.; Л.: Изд-во АН СССР, І958. 559 с.

40 Карпинский М. Старинные песни гребенских казаков // Сборник материалов для описания местностей и племен Кавказа. Тифлис: Тип. главноначальствующего гражданскою частию на Кавказе, І898. Т. 24. С. 85-ІІ8. Комаровских А. Знахарство в Орловском уезде // Календарь и памятная книжка Вятской губ. на І898 год. Вятка: Губ. тип., І898. С. І36-І47. Кофырин Н. Суеверия крестьян села Песчаного, Пудожского у. // Олонецкие губ. вед. Ч. неофиц. г90о. 26 окт., № І26. С. 2. Красноженова М. Материалы по народной медицине Енисейской губернии // Изв. Вост.-Сиб. отдела имп. Рус. географ. общества. Иркутск: Тип. Н.Н. Синицына, г9го. Т. 39. С. го-23.

44 Лиль-Адам Вильер де. Деревня Княжая Гора и ее окрестности // Зап. имп. Рус. географ. о-ва по Отд-нию этнографии. СПб.: Тип. М-ва внутр. дел, І87І. Т. 4. С. $235-366$.

45 Лирика русской свадьбы / изд. подгот. Н.П. Колпакова. Л.: Наука, I973. 324 с. 46 Мансикка В.Й. Заговоры Пудожского у. Олонецкой губ. // Sborník filologický. Vydává III Třída Česke Akademie věd a umění. Sv. 8. Č. I. Praha: česká academia věd a umění, I926. S. I85-233.

47 Минлос Ф.Р. Рифмованные сочетания в русском фольклоре. Редупликация и парные слова // Русский язык в науч. освещении. 2005. № I. С. 96-II5.

48 Народные русские сказки А.Н. Афанасьева: в 3 т. / подгот. Л.Г. Бараг, Н.В. Новиков; отв. ред. Э.В. Померанцева, К.В. Чистов. М.: Наука, І984-1985.

49 Нижегородские заговоры (В записях XIX-XX веков) / сост. А.В. Коровашко, К.Е. Корепова. Нижний Новгород: [Б.и.], І997. 128 с.

50 Никитина C.E. Об уме и разуме (на материале русских народно-поэтических тек- 
стов) // Славянские этюды. Сборник к юбилею С.М. Толстой. М.: Индрик, г999. С. $298-307$.

Николаев О.Р. Сказки верхнего течения Западной Двины // Русский фольклор. I996. T. 29. C. 24I-277.

52 Обрядовая поэзия / сост., предисл., примеч., подгот. текстов В.И. Жекулиной, А.Н. Розова. М.: Современник, г989. 735 с.

53 Олонецкие губернские ведомости. Часть неофициальная.

54 Онежские былины, записанные А.Ф. Гильфердингом летом I87I года. СПб.: [Б.и.], І873. І336 с.

55 П., учитель. Древние остатки народной поэзии в нашей Олонии // Олонецкая неделя. І9г3. № I8. С. І2-13.

56 П.И. Мельников-Печерский / публ. П.Д. Ухова // Песни, собранные писателями. Новые материалы из архива П.В. Киреевского. М.: Наука, І968. С. 589-598.

57 Песни, собранные П.В. Киреевским. Новая серия / под ред. акад. В.Ф. Миллера и проф. М.Н. Сперанского. М.: О-во любителей росс. словесности при Моск. ун-те, І9Іі. Вып. І: Песни обрядовые; г9г7. Вып. ІІ, ч. І.

58 Песни, собранные П.Н. Рыбниковым. СПб.: Тип. А. Семена, І86І-І867. Ч. І-4.

59 Петухов Д. Горный город Дедюхин и окольные местности. СПб.: Тип. В. Безобразова и $\mathrm{K}^{\circ}$, I864. $2 \mathrm{I} 7 \mathrm{c.}$

60 Повесть о прихождении Стефана Батория на град Псков / подгот. текста, пер. и коммент. В.И. Охотниковой // Библиотека литературы Древней Руси / под ред. Д.С. Лихачева, Л.А. Дмитриева, А.А. Алексеева, Н.В. Понырко. СПб.: Наука, 2005. Т. г3: XVI век. С. 534-607.

6I Повесть о споре жизни и смерти / подгот. текста и коммент. Р.П. Дмитриевой, пер. Л.А. Дмитриева // Библиотека литературы Древней Руси / под ред. Д.С. Лихачева, Л.А. Дмитриева, А.А. Алексеева, Н.В. Понырко. СПб.: Наука, 2ооо. Т. Іо: XVI век. С. 94-99.

62 Подюков И.А., Белявин А.М., Крыласова Н.Б., Хоробрых С.В., Антипов Д.А. Усольские древности. Традиционная культура русских конца XIX-XX в. Усолье: Пермское книжн. изд-во, 2004. 240 с.

63 Прислів’я та приказки: Людина. Родинне життя. Риси характеру / Упор. М.М. Пазяк. Київ: Наукова думка, І990. 528 с.

64 Пропп В.Я. Русский героический эпос. 2-е изд., испр. М.: Гос. изд-во худож. лит., I958. $603 \mathrm{c}$.

65 Путилов Б.Н. Русский и южнославянский героический эпос: Сравнительно-типологическое исследование. М.: Наука, І97І. 315 с.

66 Романов Е.Р. Белорусский сборник. Витебск: Типо-лит. Г. А. Малкина, І89г. Вып. 5.450 с.

67 Русские заговоры и заклинания. Материалы фольклорных экспедиций І953-г993 гг. / под ред. В.П. Аникина. М.: МГУ, І998. 480 с. 
68 Савицкая Л.В. Хитрость как свойство сказочных персонажей в русской волшебной сказке // Вісник Харківського Національного Університету ім. В.Н. Каразіна. № 787. Серія Філологія. Вип. 52. Харків, 2007. С. І25-г29.

69 Селигер: материалы по русской диалектологии: словарь / рук. А.С. Герд. СПб.: Изд-во СПбГУ, 2003-20I7. Вып. І-7.

70 Сердюкова О.К. Словарь говора казаков-некрасовцев / науч. ред. В.И. Дегтярев. Ростов н/Д.: Изд-во Ростов. ун-та, 2005. 320 с.

7I Симина Г.Я. Пинежский говор: материалы по русской диалектологии. Калининград: Калининград. ун-т, І976. І72 с.

72 Сказки и легенды пушкинских мест: Записи на местах, наблюдения и исслед. В.И. Чернышева. М.; Л.: Изд-во АН СССР, г950. 342 с.

73 Сказки и предания Северного края / запись, статья и коммент. И.В. Карнауховой. Л.: Academia, I93I. 446 c.

74 Словарь вологодского режского говора (по материалам диалектологических экспедиций в Сямженский район Вологодской области) / науч. ред. Л.Ю. Зорина. Вологда: Вологодский гос. ун-т, 2017. 604 с.

75 Словарь областного вологодского наречия. По рукописи П.А. Дилакторского I902 г. / изд. подгот. А.Н. Левичкин, С.А. Мызников. СПб.: Наука, 2006. 677 с.

76 Словарь пермских говоров: в 2 т. Пермь: Книжный мир, 2000-2002. Т. I-2.

77 Словарь русских говоров Карелии и сопредельных областей: в 6 вып. / гл. ред. А.С. Герд. СПб.: изд-во СПбГУ, г994-2005.

78 Словарь русских говоров Прибайкалья / сост. М.Л. Арутюнян и др.: в 4 вып. Иркутск: Изд-во Иркутского ун-та, І986-г989.

79 Словарь русских говоров севера Пермского края / гл. ред. И.И. Русинова. Пермь: Изд-во Пермского ун-та, 2оІі-. Вып. І-.

80 Словарь русских народных говоров / под ред. Ф.П. Филина, Ф.П. Сороколетова, С.А. Мызникова. М.; Л. (СПб.): Наука, г965-. Вып. І-.

8I Словарь русского языка XI-XVII вв. / отв. ред. С.Г. Бархударов. М.: Наука, I975Вып. I-.

82 Словарь смоленских говоров / под ред. А.И. Ивановой. Смоленск: СГПУ, 19742005. Вып. І-ІІ.

83 Словарь современного русского литературного языка / редколл.: В.И. Чернышев (гл. ред.) и др. М.; Л.: Наука, І950-І965. Т. І-І7.

84 Словарь современного русского народного говора (д. Деулино Рязанского района Рязанской области) / под ред. И.А. Оссовецкого. М.: Наука, І969. 6I2 с.

85 Слово Даниила Заточника / подгот. текста, пер. и коммент. Л.В. Соколовой // Библиотека литературы Древней Руси / под ред. Д.С. Лихачева, Л.А. Дмитриева, А.А. Алексеева, Н.В. Понырко. СПб.: Наука, І997. Т. 4: ХІІ век. С. 268-283.

86 Слово о житии... святого Стефана, бывшего епископом в Перми... / подгот. текста Ю.А. Грибова, пер. Е.Г. Водолазкина, Н.Ф. Дробленковой, Л.С. Шепелевой, коммент. Т.Р. Руди // Библиотека литературы Древней Руси / под ред. Д.С. Лихачева, Л.А. Дмитриева, А.А. Алексеева, Н.В. Понырко. СПб.: Наука, 2003. Т. г2: XVI век. C. I44-23I. 
87 Собинникова В.И. Конструкции с однородными членами, лексическим тождеством и параллелизмом в народных говорах. Воронеж: Изд-во Воронежского гос. ун-та, І969. 103 с.

88 Соколов А. Заговоры // Известия Общества археологии, истории и этнографии при Казанском ун-те. г892. Т. го, вып. 2. С. 232-234.

89 Срезневский И.И. Материалы для Словаря древнерусского языка по письменным памятникам. СПб.: Тип. Имп. Академии наук, І893-I903. Т. I-3.

90 Старославянский словарь (по рукописям X-XI вв.) / под ред. Р.М. Цейтлин, Р. Вечерки и Э. Благовой. М.: Рус. язык, г999. 842 с.

9I Tuтова Л.В. Фольклорные обработки XVIII в. Повести о рождении и похождениях царя Соломона // Источники по истории русского общественного сознания периода феодализма / редколл.: Е.К. Ромодановская, Л.В. Титова. Новосибирск: Наука, І986. С. 209-25I.

92 Тиханов П. Брянский говор. Заметки из области русской этнологии // Сборник Отделения русского языка и словесности. СПб.: Изд-во Имп. Академии наук, I904. T. 76, № 4. C. I-263.

93 Топоров В.Н. Пространство и текст // Текст: семантика и структура / отв. ред. Т.В. Цивьян. М.: Наука, І983. С. 227-284.

94 Фасмер М. Этимологический словарь русского языка / пер. с нем. и доп. О.Н. Трубачева. М.: Наука, І964-I973. Т. І-4.

95 Фольклор Новгородской области: История и современность. По материалам фольклорного архива Новгородского университета за зо лет / сост. О.С. Бердяева. М.: Стратегия, 2005. 352 с.

96 Фольклорные записи А.А. Шахматова в Заонежье / подгот. текстов, статьи и примеч. А. Астаховой и С. Шахматовой-Коплан, предисл. М. Азадовского. Петрозаводск: Гос. изд-во Карело-Финской ССР, г948. 92 с.

97 Фомин Э.В. О сущностных параметрах парных слов русского языка // И.А. Бодуэн де Куртенэ и мировая лингвистика: Труды и материалы Международной конференции / под общ. ред. К.Р. Галиуллина и др. Казань: Казанский (Приволжский) федеральный ун-т, 20I7. С. 278-280.

98 Фролова О. Русская мудрость в жанре пословицы // Мудрость - праведность святость в славянской и еврейской культурной традиции. Сб. статей / отв. ред. О.В. Белова. М.: Сэфер, 201г. С. 213-224.

99 Шейн П.В. Великорусс в своих песнях, обрядах, обычаях, верованиях, сказках, легендах и т.п. СПб.: Тип. Имп. Академии наук, І898. Т. І, вып. І; І90о. Т. І, вып. 2.

Iоо Этимологический словарь славянских языков. Праславянский лексический фонд / под ред. О.Н. Трубачева. М.: Наука, І974-. Вып. I- . Янович В.М. Пермяки // Живая старина. І903. № I/2. С. 52-I7I. 


\section{References}

I Arkhangel'skie byliny i istoricheskie pesni, sobrannye A.D. Grigor'evym v I899-I9oI gg. s napevami, zapisannymi posredstvom fonografa: $v 3 t$. [Arkhangelsk folk epics and historical songs collected by A.D. Grigor'ev in I899-I90I with tunes recorded using a phonograph: in 3 vols.]. St. Petersburg, Tropa Troianova Publ., Kuloi Publ., 2002-2003. Vol. I (part I-2); Vol. 2 (part 3); Vol. 3 (part 4). (In Russ.) Arkhangel'skii oblastnoi slovar' [Arkhangelsk regional dictionary], ed. by O.G. Getsova. Moscow, MGU Publ., I980-. Vol. I-. (In Russ.)

3 Astakhova A.M. Russkii bylinnyi epos na Severe [Russian folk epos in the North]. Petrozavodsk, Gos. izd. Karelo-Fin. SSR Publ., I948. 396 p. (In Russ.)

4 Baglikova I.A. Khitrosti-mudrosti [Slyness/wisdom]. In: Lingvofol'kloristika [Linguistic folklore studies]. Kursk, Kursk. gos. un-t Publ., 2003, pp. 88-92. (In Russ.)

5 Barsov E.V. Prichitaniia Severnogo kraia [Lamentations of the Northern region], ed. by B.E. Chistova, K.V. Chistov. St. Petersburg, Nauka Publ., I997. Vols. I-2. (In Russ.)

6 Bakhmatov A.A., Podiukov I.A., Khorobrykh S.V., Chernykh A.V. Iurlinskii krai. Traditsionnaia kul'tura russkikh Iurlinskogo raiona $v$ XIX-XX v. Materialy i issledovaniia [Yurlinsky region. Traditional culture of the Russians of Yurlinsky district in the $19^{\text {th }}-2 \mathrm{O}^{\text {th }}$ centuries. Materials and studies]. Perm, Permskoe knizh. izd-vo Publ., 2003. 240 p. (In Russ.)

7 B-v I. Svadebnye obychai v Nemzhinskom prikhode Lodeinopol'skogo uezda [Wedding customs in Nemzhinskii parish of Lodeinopol'skii governorate]. Olonetskie gub. ved. Ch. neofits. [The Olonets governorate sheets, non-official part], I897, no I9, pp. 2-3. (In Russ.)

8 Belomorskie stariny i dukhovnye stikhi: Sobranie A.V. Markova [The White Sea antiquities and spiritual verses: A.V. Markov's collection], ed. by T.G. Ivanova; prepared by S.N. Azbeleva, Iu.I. Marchenko. Saint Petersburg, Dmitrii Bulanin Publ., 2002. I080 p. (In Russ.)

9 Berezovich E.L., Kuchko V.S. Meniat' shilo na mylo: dialektologicheskii kommentarii $\mathrm{k}$ frazeologizmu [Meniat' shilo na mylo: dialectological commentary on the idiom]. Vestnik Permskogo universiteta. Rossiiskaia i zarubezhnaia filologiia, 2017, vol. 9, issue 3, pp. 5-I4. (In Russ.)

Blokhin S.A. Zagovory [Charms]. Trudy Orlovskoi arkhivnoi komissii [Proceedings of the Oryol archive commission]. Orel, Tip. gub. upravleniia Publ., I889, vol. 5, pp. I2-20. (In Russ.)

Bobunova M.A. Edinitsy fol'klornoi leksikografii (v slovare iazyka bylin) [Units of folklore lexicography (in the dictionary of the epics language)]. Kursk, Izd-vo Kurskogo gos. ped. un-ta Publ., 200I. I5I p. (In Russ.) Bogoraz V.G. Oblastnoi slovar' kolymskogo russkogo narechiia [Regional dictionary of Kolyma Russian dialect]. Sbornik Otdeleniia russkogo iazyka i slovesnosti [Collection 
of Russian language and literature department]. St. Petersburg, Izd-vo Imp. Akademii nauk Publ., I90I, vol. 68, pp. I-346. (In Russ.)

I3 Bol'shoi tolkovyi slovar' donskogo kazachestva [Large explanatory dictionary of the Don Cossacks], ed. by V.I. Degtiarev. Moscow, Russkie slovari Publ.; Atrel' Publ.; AST Publ., 2003. 608 p. (In Russ.)

I4 B-r-ov E. Pudozhskie svadebnye prichitan'ia [Pudoga wedding lamentations].

Olonetskie gub. ved. Ch. neofits. [The Olonets governorate sheets, Non-official part], I867, no 7, pp. IIO-II3. (In Russ.)

I5 Byliny Mezeni: Sever Evropeiskoi Rossii [Mezen’ Epics: European Russia North], in 25 vols. Vol. 3, ed. by A.A. Gorelov. St. Petersburg, Nauka Publ.; Moscow, Klassika Publ., 2003. 53I p. (In Russ.)

Byliny Mezeni: Sever Evropeiskoi Rossii: $v 25$ t. [Mezen' Epics: European Russia North: in 25 vols.] St. Petersburg, Nauka Publ.; Moscow, Klassika Publ., 2004. Vol. 4, ed. by A.A. Gorelov. 7I6 p. (In Russ.)

Byliny Pechory i Zimnego berega. Novye zapisi [Epics of Pechora and Zimnii Coast], ed. by A.M. Astakhova. Moscow, Leningrad, Izd-vo AN SSSR Publ., Leningrad department, I96r. 608 p. (In Russ.) North: in 25 vols.] St. Petersburg, Nauka Publ.; Moscow, Klassika Publ., 200I. Vol. 2, ed. by A.A. Gorelov. 784 p. (In Russ.)

I9 Byliny Severa [Epics of the North], records, introductory article and comm. by A.M. Astakhova. Moscow, Leningrad, Izd-vo AN SSSR Publ., I938. Vol. I: Mezen' i Pechora [Mezen' i Pechora]. 656 p. (In Russ.) B.N. Putilova. Leningrad, Sovetskii pisatel' Publ., I986. 552 p. (In Russ.) Velikorusskie narodnye pesni: $v 7$. [Russian folk songs: in 7 vols.], ed. by prof. A.I. Sobolevskii. St. Petersburg: [s.n.], I895-1907. (In Russ.) Velikoustiuzhskii sbornik XVII v. (Predislovie i publikatsiia A.A. Turilova, A.V. Chernetsova) [Veliki Ustyug Collection of $\mathrm{I} 7^{\text {th }}$ century (introduction and edition by A.A. Turilov, A.V. Chernetsov)]. Otrechennoe chtenie $v$ Rossii XVII-XVIII vekov [Otrechennye books in Russia of $\mathrm{I} 7^{\text {th }}-\mathrm{I} 8^{\text {th }}$ centuries], ed. by A.L. Toporkov, A.A. Turilov. Moscow, Indrik Publ., 2002, pp. I77-224. (In Russ.)

23 Vinogradov N. Zagovory, oberegi, spasitel'nye molitvy i proch. (po starinnym rukopisiam $i$ sovremennym zapisiam): $v 3 t$. [Charms, oberegs, saving prayers, and so on (from old manuscripts and modern records): in 3 vols.] St. Petersburg, Tip. M-va putei soobshcheniia Publ., I907-I909. (In Russ.)

24 Vinogradova L.N. Neprostye liudi v sel'skom soobshchestve: o liudiakh, nadelennykh sverkh" estestvennymi sposobnostiami. Chast' 2. Mastera-professionaly, magicheskie spetsialisty, poludemonicheskie sushchestva [Complicated people in a rural community: about people with supernatural powers. Part 2. Masters-professionals, 
magic specialists, semi-demonic beings]. Slavianskii al'manakh, 20I8, no I-2, pp. 215-233. (In Russ.)

25 Voskresenskii V.A. Iz byta i poezii krest'ian Novgorodskoi gub., publ. D.K. Zelenina [On everyday life and poetry of Novgorod province peasants, ed. by D.K. Zelenin]. Zhivaia starina, I905, no I-2, pp. I-56. (In Russ.) living and great Russian language], $2^{\text {nd }}$ ed. St. Petersburg, Moscow, M.O. Volf Publ., I880-I882 (I955). Vol. I-4. (In Russ.)

27 Devgenievo deianie [Devgenievo deianie], prep., transl. and comm. by O.V. Tvorogov. In: Biblioteka literatury Drevnei Rusi [Library of literature of Ancient Russia], ed. by D.S. Likhachev, L.A. Dmitriev, A.A. Alekseev, N.V. Ponyrko. St. Petersburg, Nauka Publ., I999. Vol. 3: $\mathrm{II}^{\text {th }}-\mathrm{I2}^{\text {th }}$ centuries, pp. 58-9I. (In Russ.)

28 Dialektnyi slovar' Nizhegorodskoi oblasti [Dialect dictionary of Nizhni Novgorod Region], ed. by L.A. Klimkova et al. Nizhni Novgorod, Izd-vo Nizhegorodskogo gos. un-ta im. N.I. Lobachevskogo, 2013-. Vols. I-. (In Russ.)

29 Drevnie rossiiskie stikhotvoreniia, sobrannye Kirsheiu Danilovym [Ancient Russian poems collected by Kirsha Danilov], prep. by A.P. Evgen'eva, B.N. Putilov. $2^{\text {nd }}$ ed. Moscow, Nauka, I977. 488 p. (In Russ.)

30 Evgen'eva A.P. Ocherki po iazyku russkoi ustnoi poezii v zapisiakh XVII-XX vv. [Essays on the language of Russian oral poetry in the records of the $17^{\text {th }}-2 \mathrm{O}^{\text {th }}$ centuries]. Moscow, Leningrad, AN SSSR Publ., I963. 346 p. (In Russ.)

3I Efimenko P.S. Materialy po etnografii russkogo naseleniia Arkhangel'skoi gubernii [Materials on ethnography of the Russian population of the Arkhangelsk province]. Moscow, I878. Part 2: Narodnaia slovesnost' [Folk literature]. Moscow, Tipo-litogr. S.P. Arkhipova i K Publ., pp. I39-222. (In Russ.)

32 Efimenkova B.B. Severnorusskaia prichet': Mezhdurech'e Sukhony i Iuga i verkhov'ia Kokshengi (Vologodskaia oblast') [North Russian lamentations: Sukhona and Yug interfluve and the upper reaches of Kokshen'ga (Vologda Region)]. Moscow, Sovetskii kompozitor Publ., 1980. 392 p. (In Russ.)

33 Zagadki russkogo naroda [Riddles of the Russian people], comp. by D. Sadovnikov. St. Petersburg, Tipografiia N.A. Lebedeva Publ., I876. 333 p. (In Russ.)

34 Zamknu zamki zamkami: Zagovorno-zaklinatel'naia poeziia Shadrinskogo kraia [Locked with locks: charms and spells poetry of the Shadrinsky region], comp. by V.N. Beketova, M.A. Kolmogortsev. Shadrinsk, Iset’ Publ., 200I. II9 p. (In Russ.)

35 Zamovy [Charms], comp. and comm. by G.A. Bartashevich. Minsk, Navuka i tekhnika Publ., I992. 597 p. (In Belarusian)

36 Znatki, kolduny i chernoknizhniki: koldovstvo i bytovaia magiia na Russkom Severe [Enchanters, wizards, warlocks: witchcraft and household magic in the Russian North], ed. by A.B. Moroz. Moscow, Forum Publ., Neolit Publ., 2013. 592 p. (In Russ.) Iz "Zhitiia Vasiliia Novogo". Khozhdenie Feodory po vozdushnym mytarstvam [From 
The Life of Basil The New. Theodora's road through the air hardships], prep. by Iu.A. Gribov and A.V. Pigin, transl. by M.B. Mikhailova and V.V. Semakov, comm. by A.V. Pigin. In: Biblioteka literatury Drevnei Rusi [Library of literature of Ancient Russia], ed. by D.S. Likhachev, L.A. Dmitriev, A.A. Alekseev, N.V. Ponyrko. Saint Petersburg, Nauka Publ., 2003. Vol. 8: $\mathrm{I} 4^{\text {th }}-\mathrm{I}^{\text {st }}$ half of $\mathrm{I}^{\text {th }}$ century, pp. 494-527. (In Russ.)

38 Iz Tolkovogo Apostola [From Tolkovy Apostol], prep., transl. and comm. by O.P. Likhacheva. In: Biblioteka literatury Drevnei Rusi [Library of literature of Ancient Russia], ed. by D.S. Likhachev, L.A. Dmitriev, A.A. Alekseev, N.V. Ponyrko. Saint Petersburg, Nauka Publ., I999. Vol. 2: $\mathrm{II}^{\text {th }}-\mathrm{I2}^{\text {th }}$ centuries, pp. 82-I25. (In Russ.)

39 Il'ia Muromets [Il'ia Muromets], prep. and comm. by A.M. Astakhova, ed. by D.S. Likhach. Moscow; Leningrad, AN SSSR Publ., I958. 559 p. (In Russ.)

$40 \quad$ Karpinskii M. Starinnye pesni grebenskikh kazakov. Sbornik materialov dlia opisaniia mestnostei i plemen Kavkaza [Old songs of the Grebensky Cossacks. Collection of materials for describing localities and tribes of the Caucasus]. Tiflis, Tip. glavnonachal'stvuiushchego grazhdanskoiu chastiiu na Kavkaze Publ., I898, vol. 24, pp. 85-II8. (In Russ.)

4I Komarovskikh A. Znakharstvo v Orlovskom uezde [Sorcery in Orlovsky Uezd]. In: Kalendar' i pamiatnaia knizhka Viatskoi gub. na I898 god [Calendar and memorable book of the Vyatka province for I898]. Viatka, Gub. tipografiia Publ., I898, pp. I36-I47. (In Russ.)

42 Kofyrin N. Sueveriia krest'ian sela Peschanogo, Pudozhskogo u. [Superstitions of the peasants of Peschany village]. Olonetskie gub. ved. Ch. neofits. [The Olonets governorate sheets, Non-official part], I900, 26 Oct., no I26, p. 2. (In Russ.)

43 Krasnozhenova M. Materialy po narodnoi meditsine Eniseiskoi gubernii [Materials on folk medicine of the Yenisei province]. Izv. Vost.-Sib. otdela imp. Rus. geograf. obshchestva [Proceedings of the East Siberian Department of the Emperor Russian Geographical Society]. Irkutsk, N.N. Sinitsyn Publ., I9Io, vol. 39, pp. Io-23. (In Russ.)

44 Lil'-Adam Vil'er de. Derevnia Kniazhaia Gora i ee okrestnosti [Kniazhaya Gora village and its surroundings]. Zap. imp. Rus. geograf. o-va po Otd-niiu etnografii [Proceedings of the Emperor Russian Geographical Society within Ethnography Department]. St. Petersburg, M-vo vnutr. del Publ., I87I, vol. 4, pp. 235-366. (In Russ.)

45 Lirika russkoi svad'by [Russian wedding lyrics], prep. by N.P. Kolpakova. Leningrad, Nauka Publ., I973. 324 p. (In Russ.)

46 Mansikka V.I. Zagovory Pudozhskogo u. Olonetskoi gub. [Charms of Pudozhsky uezd of Olonetskaya governorate]. Sbornik filologický. Vydává III Tř́da Česke Akademie věd a umění. Sv. 8. Č. I. Praha: Česká academia věd a umění, I926, pp. I85-233. (In Russ.)

47 Minlos F.R. Rifmovannye sochetaniia v russkom fol'klore. Reduplikatsiia i parnye slova [Rhyming combinations in the Russian folklore. Reduplication and paired words]. Russkii iazyk v nauch. osveshchenii [Russian language in scientific perspective], 2005, 
no I, pp. 96-II5. (In Russ.)

48 Narodnye russkie skazki A.N. Afanas'eva: $v 3 t$. [A.N. Afanasyev's Folk Russian fairytales: in 3 vols.], prep. by L.G. Barag, N.V. Novikov; ed. by E.V. Pomerantseva, K.V. Chistov. Moscow, Nauka Publ., I984-I985. (In Russ.)

49 Nizhegorodskie zagovory (V zapisiakh XIX-XX vekov) [Nizhni Novgorod charms (in the records of $19^{\text {th }}-2 \mathrm{O}^{\text {th }}$ centuries], comp. by A.V. Korovashko, K.E. Korepova. Nizhni Novgorod, [s.n.], I997. I28 p. (In Russ.)

$50 \quad$ Nikitina S.E. Ob ume i razume (na materiale russkikh narodno-poeticheskikh tekstov) [About mind and reason (based on Russian folk poetry texts)]. In: Slavianskie etiudy. Sbornik k iubileiu S.M. Tolstoi [Slavic studies. Collection for the anniversary of S.M. Tolstaya]. Moscow, Indrik Publ., I999, pp. 298-307. (In Russ.)

5I Nikolaev O.R. Skazki verkhnego techeniia Zapadnoi Dviny [Tales of the upper reaches of the Western Dvina river]. Russkii fol'klor, I996, vol. 29, pp. 24I-277.

52 Obriadovaia poeziia [Rites poetry], comp., intoduct., comm., texts prep. by V.I. Zhekulina, A.N. Rozova. Moscow, Sovremennik Publ., I989. 735 p. (In Russ.)

53 Onezhskie byliny [Onega epics], epics selection and scientific editing by Iu.M. Sokolov, preparing texts for printing, notes and dictionary by V.I. Chicherov. Moscow, Izdanie gos. lit. muzeia Publ., I948. 938 p. (In Russ.)

54 Onezhskie byliny, zapisannye A. F. Gil'ferdingom letom I87I goda [Onega epics recorded by A.F. Gil'ferding in Summer I87I]. St. Petersburg, [s.n.], I873. I336 p. (In Russ.)

55 P., teacher. Drevnie ostatki narodnoi poezii v nashei Olonii [Ancient remains of folk poetry in our Olonetsky region]. Olonetskaia nedelia [Olonetskaya week], I9I3, no I8, pp. I2-I3. (In Russ.)

56 P.I. Mel'nikov-Pecherskii. Pesni, sobrannye pisateliami. Novye materialy iz arkhiva P.V. Kireevskogo [Songs collected by writers. New materials from the archive of P.V. Kireevsky], publ. by P.D. Ukhov. Moscow, Nauka Publ., I968, pp. 589-598.

57 Pesni, sobrannye P.V. Kireevskim. Novaia seriia [Songs collected by P.V. Kireevsky. New series], ed. by acad. V.F. Miller \& prof. M.N. Speransky. Moscow, O-vo liubitelei ross. slovesnosti pri Mosk. un-te Publ., I9II. Vol. I: Pesni obriadovye [Rites songs], I9I7. Vol. 2, part I. (In Russ.)

58 Pesni, sobrannye P.N. Rybnikovym [Songs collected by P.N. Rybnikov]. St. Petersburg, Tip. A. Semena Publ., I86I-I867, part I-4. (In Russ.)

59 Petukhov D. Gornyi gorod Dediukhin i okol'nye mestnosti [Mountain town of Dedyukhin and roundabout areas]. St. Petersburg, Tip. V. Bezobrazova i K Publ., I864. 2I7 p. (In Russ.)

60 Povest' o prikhozhdenii Stefana Batoriia na grad Pskov [Novel about the arrival of Stefan Batory in the city of Pskov], prep., transl. and comm. by V.I. Okhotnikova. In: Biblioteka literatury Drevnei Rusi [Library of literature of Ancient Russia], ed. by D.S. Likhachev, L.A. Dmitriev, A.A. Alekseev, N.V. Ponyrko. Saint Petersburg, Nauka 
Publ., 2005. Vol. 13: $16^{\text {th }}$ century, pp. 534-607. (In Russ.)

Povest' o spore zhizni i smerti [Novel about a life and death dispute], prep. and comm. by R.P. Dmitrieva, transl. by L.A. Dmitrieva. In: Biblioteka literatury Drevnei Rusi [Library of literature of Ancient Russia], ed. by D.S. Likhachev, L.A. Dmitriev, A.A. Alekseev, N.V. Ponyrko. St. Petersburg, Nauka Publ., 2000. Vol. IO: I6 ${ }^{\text {th }}$ century, pp. 94-99. (In Russ.)

62 Podiukov I.A., Beliavin A.M., Krylasova N. B., Khorobrykh S.V., Antipov D.A. Usol'skie drevnosti. Traditsionnaia kul'tura russkikh kontsa XIX - XX v. [Usolsky antiquities. Traditional culture of Russians of the late $\mathrm{I}^{\text {th }}-2 \mathrm{O}^{\text {th }}$ centuries]. Usol'e, Permskoe knizhnoe izd-vo Publ., 2004. 240 p. (In Russ.)

63 Prisliv'ia ta prikazki: Liudina. Rodinne zhyttia. Rysy kharakteru [Proverbs and sayings: Man. Family life. Character trait], ed. by M.M. Paziak. Kiev, Naukova dumka Publ., I990. 528 p. (In Ukrainian)

64 Propp V.Ia. Russkii geroicheskii epos [Russian heroic epos], $2^{\text {nd }}$ ed. Moscow, Gos. izd-vo khudozh. lit. Publ., I958. 603 p. (In Russ.)

65 Putilov B.N. Russkii i iuzhnoslavianskii geroicheskii epos: Sravnitel'no-tipologicheskoe issledovanie [Russian and South Slavic heroic epos: a Comparative typological study]. Moscow, Nauka Publ., I97I. 315 p. (In Russ.)

66 Romanov E.R. Belorusskii sbornik [Belarusian collection]. Vitebsk, Tipo-lit. G.A. Malkina Publ., I89ı, Vol. 5. 450 p. (In Russ.)

67 Russkie zagovory i zaklinaniia. Materialy fol'klornykh ekspeditsii 1953-I993 gg. [Russian charms and spells. Materials of folklore expeditions of 1953-I993], ed. by V.P. Anikin. Moscow, MGU Publ., I998. 480 p. (In Russ.)

68 Savitskaia L.V. Khitrost' kak svoistvo skazochnykh personazhei v russkoi volshebnoi skazke [Cunning as a property of fairy-tale characters in a Russian fairy tale]. Visnik Kharkivs'kogo Natsional'nogo Universitetu im. V.N. Karazina [Proceedings of the Kharkov National University named after V.M. Karazin], no 787, Philology serial, issue 52. Kharkov, 2007, pp. I25-I29. (In Russ.)

69 Seliger: materialy po russkoi dialektologii: slovar' [Seliger: materials on Russian dialectology. Dictionary], ed. by A.S. Gerd. Saint Petersburg, SPbGU Publ., 200320I7. Vols. I-7. (In Russ.)

70 Serdiukova O.K. Slovar' govora kazakov-nekrasovtsev [Dictionary of the dialect of the Cossacks-nekrasovtsy], ed. by V.I. Degtiarev. Rostov-on-Don, Rostov. un-t Publ., 2005. 320 p. (In Russ.)

7I Simina G. Ia. Pinezhskii govor: materialy po russkoi dialektologii [Pinega dialect: materials on Russian dialectology]. Kaliningrad, Kaliningrad. un-t Publ., I976. I72 p. (In Russ.)

72 Skazki i legendy pushkinskikh mest: Zapisi na mestakh, nabliudeniia $i$ issled. V.I. Chernysheva [Tales and legends of Pushkin places: field records, observations, and studies by V.I. Chernyshev]. Moscow, Leningrad, AN SSSR Publ., I950. 342 p. 
(In Russ.)

73 Skazki i predaniia Severnogo kraia [Tales and legends of the Northern region], records, article and comm. by I.V. Karnaukhova. Leningrad, Academia Publ., I93I. 446 p. (In Russ.)

74 Slovar' vologodskogo rezhskogo govora (po materialam dialektologicheskikh ekspeditsii v Siamzhenskii raion Vologodskoi oblasti) [Dictionary of the Vologda Rezh dialect (based on the materials of dialectological expeditions to the Syamzhensky district of the Vologda region)], ed. by L.Iu. Zorina. Vologda, Vologodskii gos. un-t Publ., 2017. 604 p. (In Russ.)

75 Slovar' oblastnogo vologodskogo narechiia. Po rukopisi P.A. Dilaktorskogo 1902 $g$. [Dictionary of the Vologda regional dialect. According to the manuscript of P.A. Dilaktorsky of I902], prep. by A.N. Levichkin, S.A. Myznikov. St. Petersburg, Nauka Publ., 2006. 677 p. (In Russ.)

76 Slovar' permskikh govorov: $v 2 t$. [Perm dialect dictionary: in 2 vols.] Perm', Knizhnyi mir Publ., 2000-2002. Vols. I-2. (In Russ.)

77 Slovar' russkikh govorov Karelii i sopredel'nykh oblastei: $v 6 t$. [Dictionary of Russian dialects of Karelia and neighboring regions: in 6 vols.], ed. by A.S. Gerd. St. Petersburg, SPbGU Publ., I994-2005. (In Russ.)

78 Slovar' russkikh govorov Pribaikal'ia: $v 4 t$. [Dictionary of Russian dialects of the Baikal region: in 4 vols.], comp. by M.L. Arutiunian et al. Irkutsk, Izd-vo Irkutskogo universiteta Publ., I986-I989. (In Russ.)

79 Slovar' russkikh govorov severa Permskogo kraia [Dictionary of Russian dialects of the North of the Perm region], ed. by I.I. Rusinova. Perm', Perm. un-t Publ., 20II. Vol. I: A-V. 364 p. (In Russ.)

80 Slovar' russkikh narodnykh govorov [Dictionary of Russian folk dialects], ed. by F.P. Filin, F.P. Sorokoletov, S.A. Myznikov. Leningrad, Nauka Publ., I965-. Vols. I-. (In Russ.)

8I Slovar' russkogo iazyka XI-XVII $v$. [Dictionary of the Russian language of $\mathrm{II}^{\text {th }}-\mathrm{I}^{\text {th }}$ centuries], ed. by S.G. Barkhudarov. Moscow, Nauka Publ., I975-. Vols. I-. (In Russ.)

82 Slovar' smolenskikh govorov [Dictionary of Smolensk dialects], ed. by A.I. Ivanova. Smolensk, SGPU Publ., I974-2005. Vols. I-II. (In Russ.)

83 Slovar' sovremennogo russkogo literaturnogo iazyka [Dictionary of modern Russian literary language], ed. by V.I. Chernyshev et al. Moscow, Leningrad, Nauka Publ., I950-I965. Vols. I-I7. (In Russ.)

84 Slovar' sovremennogo russkogo narodnogo govora (d. Deulino Riazanskogo raiona Riazanskoi oblasti) [Dictionary of modern Russian folk dialect (Deulino, Ryazan district, Ryazan Region)], ed. by I.A. Ossovetsky. Moscow, Nauka Publ., I969. 6I2 p. (In Russ.) 
85 Slovo Daniila Zatochnika [Supplication of Daniel the Exile], prep., transl. and comm. by L.V. Sokolova. In: Biblioteka literatury Drevnei Rusi [Library of literature of Ancient Russia], ed. by D.S. Likhachev, L.A. Dmitriev, A.A. Alekseev, N.V. Ponyrko. Saint Petersburg, Nauka Publ., I997. Vol. 4: $2^{\text {th }}$ century, pp. 268-283. (In Russ.)

86 Slovo o zhitii... sviatogo Stefana, byvshego episkopom v Permi... [Novel about life... of Saint Stephen, who was a Bishop in Perm], prep. by Iu.A. Gribov, transl. by E.G. Vodolazkin, N.F. Droblenkova, L.S. Shepeleva, comm. by T.R. Rudi. In: Biblioteka literatury Drevnei Rusi [Library of literature of Ancient Russia], ed. by D.S. Likhachev, L.A. Dmitriev, A.A. Alekseev, N.V. Ponyrko. Saint Petersburg, Nauka Publ., 2003. Vol. I2: $16^{\text {th }}$ century, pp. I44-23I. (In Russ.)

87 Sobinnikova V.I. Konstruktsii sodnorodnymi chlenami, leksicheskim tozhdestvom i parallelizmom $v$ narodnykh govorakh [Constructions with homogeneous terms, lexical identity, and parallelism in folk dialects]. Voronezh, Voronezh gos. un-t Publ., I969. IO3 p. (In Russ.)

88 Sokolov A. Zagovory [Charms]. Izvestiia Obshchestva arkheologii, istorii i etnografii pri Kazanskom un-te [Proceedings of Archaeology, History and Ethnography Society in Kazan University], I892, vol. Io, issue 2, pp. 232-234. (In Russ.)

89 Sreznevskii I.I. Materialy dlia Slovaria drevnerusskogo iazyka po pis'mennym pamiatnikam [Materials for the dictionary of the Old Russian language on written monuments]. St. Petersburg, Tip. Imp. Akademii nauk Publ., I893-1903. Vols. I-3. (In Russ.)

90 Staroslavianskii slovar' (po rukopisiam X-XI vv.) [Old Slavonic language dictionary (by manuscripts of $\mathrm{IO}^{\text {th }}-\mathrm{II}^{\text {th }}$ centuries], ed. by R.M. Tseitlin, R. Vecherki \& E. Blagova. Moscow, Rus. iazyk Publ., I999. 842 p. (In Russ.)

9I Tikhanov P. Brianskii govor. Zametki iz oblasti russkoi etnologii [Bryansk dialect. Russian Ethnology notes]. Sbornik Otdeleniia russkogo iazyka i slovesnosti [Collection of the Department of Russian language and literature]. St. Petersburg, Imp. Akademiia nauk Publ., I904, vol. 76, no 4, pp. I-263. (In Russ.)

92 Titova L.V. Fol'klornye obrabotki XVIII v. Povesti o rozhdenii i pokhozhdeniiakh tsaria Solomona [ $18^{\text {th }}$ century folklore processings of The Tale of King Solomon's Birth and Adventures]. In: Istochniki po istorii russkogo obshchestvennogo soznaniia perioda feodalizma [Sources on the history of Russian social consciousness during the feudal period], ed. by E.K. Romodanovskaia, L.V. Titova. Novosibirsk, Nauka Publ., I986, pp. 209-25I. (In Russ.)

93 Toporov V.N. Prostranstvo i tekst [Space and text]. In: Tekst: semantika i struktura [Text: semantics and structure], ed. by T.V. Tsivian. Moscow, Nauka Publ., I983, pp. 227-284. (In Russ.)

94 Fasmer M. Etimologicheskii slovar' russkogo iazyka [Etymological dictionary of the Russian language], transl. from German and add. by O.N. Trubachev. Moscow, Nauka Publ., I964-1973. Vols. I-4. (In Russ.) 
95 Fol'klor Novgorodskoi oblasti: Istoriia i sovremennost'. Po materialam fol'klornogo arkhiva Novgorodskogo universiteta za zo let [Folklore of the Novgorod region: History and modernity. Based on the materials of the folklore archive of the Novgorod University for 30 years], comp. by O.S. Berdiaeva. Moscow, Strategiia Publ., 2005. 352 p. (In Russ.)

96 Fol'klornye zapisi A.A. Shakhmatova $v$ Zaonezh'e [Folklore records of A.A. Shakhmatov in Zaonezhye], prep. of texts, articles and notes by A. Astakhova and S. ShakhmatovaKoplan, introduction by M. Azadovsky. Petrozavodsk, Gos. izdatel'stvo Karelo-Finskoi SSR Publ., I948. 92 p. (In Russ.)

97 Fomin E.V. O sushchnostnykh parametrakh parnykh slov russkogo iazyka [On the essential parameters of paired words of the Russian language]. In: I.A. Boduen de Kurtene i mirovaia lingvistika: Trudy i materialy Mezhdunarodnoi konferentsii [I.A. Baudouin de Courtenay and world linguistics. Proceedings and materials of the International conference], ed. by K.R. Galiullin et al. Kazan, Kazanskii (Privolzhskii) federal'nyi un-t Publ., 20I7, pp. 278-280. (In Russ.)

98 Frolova O. Russkaia mudrost' v zhanre poslovitsy [Russian wisdom in the proverb genre]. In: Mudrost' - pravednost' - sviatost' v slavianskoi i evreiskoi kul'turnoi traditsii. Sb. statei [Wisdom - righteousness - holiness in the Slavic and Jewish cultural tradition. Collection of articles], ed. by O.V. Belova. Moscow, Sefer Publ., 2OII, pp. 213-224. (In Russ.)

99 Shein P.V. Velikoruss $v$ svoikh pesniakh, obriadakh, obychaiakh, verovaniiakh, skazkakh, legendakh i t.p. [The Russian in his songs, rituals, customs, beliefs, tales, legends, etc.]. St. Petersburg, Tip. Imp. Akademii nauk Publ., I898, vol. I, issue I; I900, vol. I, issue 2. (In Russ.)

Ioo Etimologicheskii slovar' slavianskikh iazykov. Praslavianskii leksicheskii fond [Etymological dictionary of Slavic languages. The Proto-Slavic lexical fund], ed. by O.N. Trubachev. Moscow, Nauka Publ., I974-. Vols. I-. (In Russ.)

IOI Ianovich V.M. Permiaki [Perm residents]. Zhivaia starina, I903, no I/2, pp. 52-I7I. (In Russ.) 
УДК $398+82$ I.52I+82I.I6I.I ББК 82.3 (5Япо) + $83.3(2 \mathrm{Poc}=\mathrm{Pyc})$
«КОДЗИКИ» И ФОЛЬКЛОРИСТИЧЕСКИЕ РАЗЫСКАНИЯ А.А. ВАНОВСКОГО ПРИ ИЗУЧЕНИИ ГЕНЕЗИСА МИФОЛОГИЧЕСКИХ СУЩНОСТЕЙ В АРХАИЧЕСКИХ МИФАХ ТВОРЕНИЯ ДРЕВНЕЙ ЯПОНИИ

\author{
(C) 2020 г. А.Л. Налепин \\ Институт мировой литературы \\ им. А.М. Горького Российской академии наук, \\ Москва, Россия \\ Дата поступления статьи: I3 апреля 2019 г. \\ Дата публикации: 25 июня 2020 г. \\ DOI: I0.22455/2500-4247-2020-5-2-390-4II
}

Аннотация: Настоящая публикация продолжает исследование фольклористических штудий Александра Вановского в области изучения фольклорной культуры Древней Японии, начатое в 2018 г. в статье «Японский фольклор в работах А.А. Вановского и их значение для русско-японского культурного трансфера», опубликованной в журнале «Studia Literarum» [7, с. 276-297], вводит в научный и культурный оборот работы оригинального философа XX столетия Александра Вановского, профессионального русского революционера, ставшего в японской эмиграции под влиянием произведений Шекспира самобытным религиозным мыслителем и интересным литературоведом, уделившим много внимания развитию русско-японской компаративистики. Публикация обогащает японскую, европейскую и русскую фольклористику, предлагая новые смыслы «прочтения» памятников эпоса древней Японии. Изучение творческого наследия Александра Вановского поможет найти и определить гармонический синтез философии и фольклора, что, несомненно, обогатит как философскую мысль (в частности, философскую теорию познания), так и отечественную фольклористику.

Ключевые слова: А.А. Вановский, Россия и Япония, русская эмиграция, Кодзики, русская и японская фольклорная культура, вулканы.

Информация об авторе: Алексей Леонидович Налепин - доктор филологических наук, ведущий научный сотрудник, Институт мировой литературы им. А.М. Горького Российской академии наук, ул. Поварская, д. 25 а, І2Іо69 г. Москва, Россия.

E-mail:a_nalepin@mail.ru

Для цитирования: Налепин А.Л. «Кодзики» и фольклористические разыскания А.А. Вановского при изучении генезиса мифологических сущностей в архаических мифах творения Древней Японии // Studia Litterarum. 2020. T. 5 , № 2. C. 390-4II. DOI: IO.22455/2500-4247-2020-5-2-390-4II 


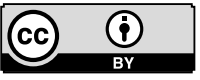

This is an open access article distributed under the Creative Commons Attribution 4.0 International (CC BY 4.0)

\section{"KOJIKI" AND A.A. VANOVSKY ON THE GENESIS OF MYTHOLOGICAL ENTITIES IN THE ARCHAIC MYTHS OF THE OF ANCIENT JAPAN}

(C) 2020. A.L. Nalepin

A.M. Gorky Institute of World Literature

of the Russian Academy of Sciences, Moscow, Russia

Received: April I3, 2019

Date of publication: June 25, 2020

Abstract: This article bears on the previous research of folkloristic works by Alexander Vanovsky in the field of Japan folklore studies. The research was initiated in 2018 by the article "Japanese Folklore in the Works of A.A. Vanovsky and Their Importance for the Russian-Japanese Cultural Transfer" (Studia Litterarum [7, p. 276-297]). It introduces works by an outstanding $2 \mathrm{O}^{\text {th }}$ century philosopher Alexander Vanovsky, a professional Russian revolutionary who became an original religious thinker and an interesting literary critic in Japanese emigration. Vanovsky paid much attention to the development of Russian-Japanese comparative studies. This article enriches Japanese, European, and Russian folklore studies, by offering new interpretation of the ancient Japan epic. The study of Vanovsky's heritage allows us to establish a harmonious synthesis of folklore studies and philosophy that is beneficial for both philosophical thought (especially the cognition theory) and the study of folklore in Russia.

Keywords: Vanovsky, Russia and Japan, Russian emigration, Kojiki, Russian and Japanese folk culture, volcanoes.

Information about the author: Alexey L. Nalepin, DSc in Philology, Leading Research Fellow, A.M. Gorky Institute of World Literature of the Russian Academy of Sciences. Povarskaya 25 a, I21069 Moscow, Russia.

E-mail:a_nalepin@mail.ru

For citation: Nalepin A.L. "Kojiki" and A.A. Vanovsky on the Genesis of Mythological Entities in the Archaic Myths of the Ancient Japan. Studia Litterarum, 2020, vol. 5, no 2, pp. 390-4II. (In Russ.) DOI: IO.22455/2500-4247-2020-5-2-390-4II 
Настоящая публикация продолжает исследование фольклористических разысканий А.А. Вановского в области изучения фольклорной культуры Древней Японии, начатое в 2018 г. в статье «Японский фольклор в работах А.А. Вановского и их значение для русско-японского культурного трансфера», опубликованной в журнале «Studia Litterarum» [7, с. 276-297].

Следует особо оговорить, что весьма специфические взгляды Александра Вановского, волею судеб оказавшегося в Японии (экзотической для него стране), не знавшего ни языка этой страны, ни ее культуры, ни ее истории, представляли собой наивную попытку пытливого русского эмигранта хотя бы каким-то образом попытаться понять и вписаться в японскую культуру, понять ментальность людей, живущих в Японии, в той стране, где ему, Александру Алексеевичу Вановскому, предстояло жить и умереть. Поэтому не имеют никакого практического смысла попытки соотнесения взглядов Вановского с постулатами японистики как серьезной эволюционирующей науки. Японистика Вановского была наукой особого рода. Она, конечно же, не имела никакого представления ни о знаменитой поливановской системе русской фонетической транскрипции японских слов, разработанной и предложенной в I9I7 г. выдающимся отечественным лингвистом и востоковедом Евгением Дмитриевичем Поливановым (I89I-I938), ни о классических переводах на русский язык «Кодзики», опубликованных в 2000 г. Е.М. Пинус, Д.М. Ермаковой и А.Н. Мещеряковым, ни о классических трудах по японской мифологии академика Н.И. Конрада и многих других.

Объективно говоря, «Японистика по Вановскому» носила утилитарный, во многих отношениях даже «доморощенный» характер, отразила его наивные представления о Японии столетней давности. Для человека, не 
обладавшего ни исторической, ни филологической подготовкой, заставившего себя не спасовать перед громадой древней японской истории, культуры и японского языка, именно такой «дилетантский» метод погружения в незнакомый экзотический материал представлялся единственно возможным. Именно по этой причине в настоящем исследовании особо не оговаривается, что в приводимых цитатах сохраняется оригинальное написание, характерное для начала XX столетия, т. е. времени, когда Вановский стал заниматься своими «японскими» исследованиями. Так, например, приводимое Вановским имя героя УРАШИМА сегодня, согласно общепринятой транскрипции Е.Д. Поливанова, должно звучать как УРАСИМА.

До недавнего времени имя Александра Алексеевича Вановского (I874 Тула - І967 Токио), этого оригинального русского ученого-эмигранта, тонкого и своеобразного философа, литературоведа и общественного деятеля, было известно лишь узкому кругу специалистов, главным образом, историков, занимающихся историей революционного движения в России.

Между тем Вановский является самобытным ученым, многого достигшим на поприще разных гуманитарных дисциплин - фольклористики, этнологии, философии и литературоведения. Большой интерес вызывают судьба и деятельность этого человека - не только своеобразного философа $\mathrm{XX}$ столетия, но и одного из основателей РСДРП, делегатом I съезда которого он являлся, профессионального революционера-боевика, ставшего в японской эмиграции под влиянием произведений Шекспира оригинальным религиозным мыслителем, продолжателя традиций философии Серебряного века и, наконец, интересного литературоведа, уделившего много внимания становлению и развитию русско-японской компаративистики.

Пройдя сложный, мучительный путь духовного Возрождения, путь от революционера-боевика до самобытного мыслителя мирового масштаба, Вановский после революции г905 г. вышел из РСДРП и принял христианство или, как он сам выразился в частном письме, «через Шекспира перешел от Маркса к Христу». В г19 г. он заболел нервным расстройством и переехал на лечение в Японию, где прожил почти 50 лет до своей кончины в 1967 г. Он преподавал русскую литературу в Токио в Университете Васэда, изучал японские фольклорные памятники с точки зрения вулканологии, публиковал материалы о своей революционной биографии, размышляя о том, почему гуманные идеи революционеров всегда приводят к трагедии. Ванов- 
ский считал, что возрождение России возможно только через обновленное христианство [9; го].

Своеобразным оказалось изучение Вановским феномена японской фольклорной культуры через призму японской мифологической системы «Кодзики». Вановский был первым ученым, кто текстуально сравнил языческие тексты японской «Кодзики» («Записи о деяниях древности») с каноническим текстом христианской Библии. Исследование фольклорной составляющей его философского наследия доказывает, что фольклорная культура России и Японии, будучи живой традицией, во многом определяла пути развития и японской, и русской цивилизации, а также смыслы их национальной ментальности. Важную роль в этом играл фольклор и, конечно же, фольклористика, как филологическая, так и философская, изучающая мировоззренческие доминанты и концепты народно-поэтического творчества. Творческое наследие Александра Вановского являет собой гармонический синтез философии и фольклора, что в значительной мере обогащает как философскую мысль, в частности, философскую теорию познания, так и фольклористику.

Важным этапом в изучении творческого наследия Александра Вановского стала опубликованная в 1995 г. в бюллетене университета Хоккайдо «Acta Slavica Iaponica» [4, c. I49-I66] работа известного исследователя японской культуры, литературоведа и искусствоведа Ирины Петровны Кожевниковой о жизни и трудах Вановского. В этой работе представлены стенографические записи бесед исследовательницы с Вановским, что представляет особый интерес [4, с. I49-I66].

Переехав в Японию и чувствуя определенный социально-культурный дискомфорт, вызванный полным незнанием японского языка, японской истории и культуры, не понимая поэтому вообще японского менталитета, русский эмигрант Александр Алексеевич Вановский приступает к изучению и осмыслению японской мифологии. В г92г г. в Харбине выходит его работа «В стране богов. Мысли об Урашиме - герое древне-японской легенды». Пересказывая эту легенду, Вановский дает свое философское толкование этого памятника японской фольклорной культуры: человек, совершивший паломничество в «страну бессмертия», вернувшись в прежнюю жизнь, не может оставаться обычным человеком. «Своими переживаниями в стране богов, - пересказывала автора И.П. Кожевникова, - Урашима создал себе 
свое будущее, предопределил свой земной путь. Он бессознательно сплел сети своей кармы и сам поймал себя в них» [4, с. I53].

В определенной степени Вановский соотносил эту древнюю японскую легенду с фактами собственной биографии, со своей собственной судьбой, связанной с поиском «сетей своей кармы», в частности, с тем его мистическим видением-прозрением, которое во многом и предопределило его японский исход, его японскую судьбу. И.П. Кожевникова пересказала для нас эту волшебную японскую сказку, которая так взволновала и пленила Александра Вановского:

Ему приснился вещий сон, по его словам - «замечательное сновидение», которое он назвал «космическим». Будто он находится в большом городе, а вверху блистает грандиозный фейерверк небесных огней, похожих на извержение вулкана. По небу двигаются сияющие планеты, оставляя сверкающие следы. С высоты небес медленно спускается бесконечная вереница людей в пламенных одеждах, их черные волосы и желтоватые лица придают им восточный вид. Вокруг одной из планет вьются огненные вихри, и на одно из мгновений она показалась Вановскому раскрытой книгой, листы которой треплет ветер. На черном, как уголь, небе остаются сверкающие следы от движущихся светил, которые, переплетаясь, складываются в сложный узор, похожий на огненные письмена. Склонный к предчувствиям и предзнаменованиям, Вановский расшифровал этот сон так: ему суждено будет попасть в страну с действующими вулканами и большими городами, где живут люди с желтой кожей, т. е. в Японию. Огненные письмена он понял как указание на таинственную книгу, которую ему суждено будет расшифровать, а в планете, похожей на книгу с трепещущими листами, - намек на «Апокалипсис», которым он в то время начал интересоваться [4, с. 150-I5I].

Видимо, И.П. Кожевникова записала поздний вариант этого пророческого видения, которое Вановский рассказывал уже на склоне лет. Друзья Александра Вановского вспоминали, что слышали от него и иной рассказ, в котором говорилось, что он увидел во сне некий похожий на лотос прекрасный цветок, который, распустившись, явил ему прекрасную женщину-птицу, обернувшуюся красавицей-японкой, которая взмахами крыльев-рук и позвала его к себе. Так Александр Вановский мистически объяснял себе са- 
мому и окружающим причину того, как он оказался в Японии. Впрочем, не следует забывать и того, что причиной переезда А.А. Вановского в Японию была необходимость экстренного лечения тяжелого психического недуга.

Александр Вановский вообще любил всякого рода мистификации, чему немало способствовали его многолетний опыт революционной конспиративной работы и богатое воображение, усугубленное душевным заболеванием. Александра Вановского с полным основанием можно считать «королем мистификации». Его мистификации в буквальном смысле «спасали» его от американских оккупационных чиновников, которых вокруг него всегда было более чем достаточно. Их интерес к Вановскому был вызван его революционным прошлым в России (в частности, тем, что он был делегатом Первого съезда РСДРП), а также его близким знакомством с В.И. Лениным и другими деятелями революционного движения и громадным опытом профессионального революционера-боевика (не только как практика, но и крупного теоретика революционного террора). Как правило, мистификации Вановского «крутились» вокруг его якобы постоянных контактов с «зелеными человечками». Рассказывают, что на встречу с ними он постоянно приглашал своих американских кураторов, но, когда последние приходили к Александру Алексеевичу, тот с сожалением разводил руками и говорил: «Только что, перед вашим приходом, они улетели». В эту наивную игру-мистификацию он продолжал играть до конца своих дней и даже опубликовал в Нью-Йорке І3 апреля 1952 г. в газете «Новое русское слово» статью под названием «Марсиане в квадрате».

Вановский рассматривал фольклорный памятник об урашиме в первую очередь как исторический источник, почти наощупь, как может поступать только пытливый иностранец, что называется «Devisu», совершая поездку по фольклорно-историческим следам героя этой легенды. Он побывал на могиле Урашимы с памятником в виде черепахи, которую поймал герой легенды. Посетил древний храм, воздвигнутый в честь Урашимы, где хранились священные реликвии: ларец морской царевны, волшебная удочка, которой герой легенды поймал черепаху, и палец героя. Он был русским эмигрантом, и «открытие» этого текста на вербальном уровне случилось много позже. Для Александра Вановского, не владевшего японским языком, смысл этого фольклорного памятника раскрывался не в словах, а в многочисленных сохранившихся деталях исчезнувшей фольклорной эпохи. Такое 
«тактильное», почти на осязательном уровне осмысление фольклорного произведения удивительным образом совпало с «пророческим видением», которое во многом предопределило необыкновенную японскую судьбу этого русского человека. Это и другие подобные историко-фольклорные путешествия стали «фирменным стилем» неофита Вановского, открывая ему дверь к познанию Японии.

Аналогичные методы исследования памятников фольклора, включая археологические методы, предлагала использовать, например, молодая американская фольклористика. В ряду других исследователей, кто активно использовал фольклор в качестве исторических источников, следует назвать известного американского антрополога, писателя и археолога Джесси Уолтера Фьюкеса (I850-I930), который в начале XX столетия ратовал именно за такое комплексное изучение фольклора США, отстаивая тезис, что именно фольклор в состоянии разъяснить как историю, так и археологию. Исследуя руины, сохранившиеся вокруг некоторых индейских деревень, Фьюкес одновременно собирал и произведения фольклора, полагая, что «легенды и мифы индейцев являлись важным руководством для воссоздания истории племен. Другими словами, фольклорная традиция содержала в себе исторический факт» [13, с. 32]. Наиболее важной для становления американской фольклористики была теоретическая установка Фьюкеса на то, что любое изучение археологических памятников неизбежно влечет за собой изучение современного фольклора (главным образом легенд и мифов об этих археологических памятниках). Только таким образом, утверждал американский археолог, возможно понять «нравы и обычаи тех людей, которые некогда обитали в них (т. е. в том, что сейчас является руинами. - А.Н.)» [12, с. 578].

Мировоззрение и морально-эстетические вкусы Александра Вановского - будущего исследователя мифологии «Кодзики» (древних японских мифов творения) - формировались под влиянием в первую очередь семьи. Сестра Зина «знакомила меня с начатками религии. Она рассказывала мне о Боге, о прекрасных ангелах, живущих в райских садах на небе, а также передавала своими словами разные трогательные эпизоды из жизни Спасителя. В общем, она напирала на светлую сторону религии, тогда как няня, наоборот, больше говорила о чертях, ведьмах, адских муках и Страшном суде. Солнечная и мрачная стороны религии сливались в моей душе в одно морально- 
эстетическое мироощущение, сообразно которому добро представлялось мне красивым, а зло - безобразным. Впоследствии, став социал-демократом, я отошел от религии, но эстетический критерий в вопросах морали, привитый ею мне в детстве, остался у меня на всю жизнь» [I, с. 446-447].

С другой стороны, на мировоззрение Вановского огромное влияние оказало радикальное окружение с его рабочими кружками и их серьезной образовательной программой, включающей обязательное изучение первоисточников. Вановский, спустя многие десятилетия, вспоминал: «В результате, была принята программа, состоявшая из следующих пунктов: I) Происхождение мира по Канту и Лапласу, 2) происхождение человека по Дарвину, 3) история первобытной культуры по Тэйлору, 4) происхождение семьи и государства по Энгельсу. И, в заключение - материалистическое понимание истории по Марксу» [г, с. 450].

С третьей стороны, огромное, возможно, даже решающее влияние оказывали старший брат и книги, которые тоже формировали мировоззрение, эстетический вкус и характер: «Я брал книги по его (брата Виктоpa. - A.Н.) совету, но далеко не всё было мне доступно. Так Златовратского и Глеба Успенского я бросил с первых страниц, но Писарев привел меня в восторг. Особенно мне нравился его критический выпад против Пушкина, в котором он разгромил всё великолепное здание его творчества. Это критическое варварство, к сожалению, надолго отвлекло меня от великого поэта. Читал я и Чернышевского “Что делать?”. Но социалистические фаланстеры, что снились героине его романа, меня не пленили. Я любил родных, и жизнь в семье казалась мне гораздо интересней и приятней жизни среди чужих людей, хотя бы и в хрустальном дворце. К Рахметову, являвшему собой тип революционера-аскета и подвижника, я относился с большим уважением, но Инсаров Тургенева, боровшийся за свою Родину, был мне и ближе, и понятней. В эпоху стачечной революции г905 года все революционеры походили на Рахметова, хотя и не спали на гвоздях, как герой Чернышевского, старавшийся закалить себя на случай пытки. Психологический парадокс заключался в том, что жертвенный идеализм, составлявший основу их мироощущения, резко противоречил материалистической философии, какую они исповедовали. Но тогда никто не придавал значения подобному противоречию, таившему в себе, к слову сказать, зерно религиозного социализма» [I, с. 45I-452]. 
Фольклор и мифология каждого народа - это сложное историко-мировоззренческое образование, и задача фольклориста-этнографа в XIX в. заключалась в выделении исторических пластов и их анализе. Недаром фольклористику и этнологию часто при этом прямолинейно сравнивали с геологией. Но если геология способна рассказать об истории формирования земной поверхности, то этнология раскрывает историю «умственного развития человечества». Вся история человечества - это цепь бесконечных этнических перемещений и взаимовлияний. Одни этносы завоевывали другие, вступали в тесные контакты, что сказывалось на их образе жизни, на их мышлении, на системе религиозных представлений. Иногда такое влияние значительно (например, Египта на Грецию), а иногда и огромно (например, Греции на Рим).

Древнейший памятник древне-японской литературы «Ко́дзики» («Записи о деяниях древности») был одним из первых письменных памятников Японии и являлся главной священной книгой синтоистского Троекнижия. Этот сложный в жанровом отношении литературный памятник представлял собой Свод древних легенд, мифов, исторических песен и хроник. В Предисловии к «Кодзики» утверждалось, что сказитель Хиэда-но Арэ спел эти священные тексты, а ученый придворный, которого звали O-но Ясумаро, записал и истолковал весь огромный мифологический массив, а также сохранившийся героический эпос японского народа. Через все тексты «Кодзики» проходила главная идея этого памятника: утвердить божественное происхождение императорского дома и его незыблемое постоянство. Учитывать все эти обстоятельства, в том числе и обстоятельства явно политического свойства, русскому эмигранту было жизненно необходимо.

Вановский считал, что любая наука, в том числе и общественная, не может строиться лишь на догадках; ей нужен строгий научный аппарат, своего рода универсальный метод, который раскрывал бы и объяснял «белые пятна» в истории развития человечества. Именно такой универсальный метод и пытался создать Вановский, анализируя японские «мифы мироздания» (в настоящее время подобные мифы называют «архаическими мифами творения» [5, с. 194]).

В первом из трех свитков «Кодзики» содержались сами архаические мифы творения - от космогонических мифов о сотворении Вселенной до мифов о богах-прародителях, о сотворении Земли, о героических подвигах 
божественных предков и героев и, наконец, о появлении на Свет Отца легендарного вождя страны Ямато Иварэ-хико, который и стал первым императором Японии. С тех легендарных времен императорский род никогда не прерывался, и этот императорский род будет править Японией вечно.

«Кодзики» был весь пронизан синтоистской идеей божественного происхождения японского императора, и этот постулат разделяло все японское общество. Никоим образом не допускались никакие сомнения и тем более намеки на иное толкование этой идеи. Желание Вановского обрести, наконец, идеологическую свободу в очередной раз окончилось неудачей. Уже не в Советской России, а в императорской Японии он столкнулся с жесткими идеологическими тисками, обусловленными не примитивными классовыми интересами, а синтоистской религией и мощным пластом древнего мифологического мышления японского народа.

Мифологическая картина мира, предложенная «Кодзики», до определенного момента напоминала Вановскому традиционную общеевропейскую мифологическую схему, знакомую ему еще по гимназическому курсу. Типологическое сходство между, например, древнегреческой мифологической системой и древнеяпонской было очевидно - скажем, схожая схема мифологического мироздания. Она представлена в мифах о том, как из левого глаза Бога-прародителя Идзанаги появилась богиня Аматэрасу, олицетворявшая собой Солнце; как из правого глаза появился бог Цукиюми, олицетворявший собой Луну; как из носа появился бог Сусаноо, олицетворявший собой бури и штормы, а сам бог Сусаноо стал повелителем Моря. Впоследствии Бог-прародитель Идзанаги разделил Мир между своими детьми: Аматэрасу становится главным божеством японского мифологического Пантеона, получает во владение Высокое Небо и становится покровительницей земледелия.

Важную роль в японских архаических мифах творения играла богиня Идзанами (Богиня, влекущая к себе) - сестра и она же жена бога Идзанаги (Бог, влекущий к себе). Брат и сестра Идзанаги и Идзанами находились в кровосмесительной связи. Это были «первые люди и первые синтоистские боги. Брат и сестра, муж и жена. Породили все живое и существующее. Аматэрасу, Сусаноо и Цукиюми - дети, порожденные из головы бога Идзанаги после ухода богини Идзанами в Страну Мрака» [II, C. 42I]. 
Традиционная исследовательская схема, предложенная А.А. Вановским и М.П. Григорьевым - на тот момент лучшим знатоком японского языка среди русских, проживавших тогда в Японии, - полностью устраивала и Вановского. Однако эта схема никак не могла объяснить миф о богине Идзанами и боге Сусаноо. И.П. Кожевникова приводит слова самого Вановского, который утверждал, что «наибольшую трудность для толкования мифа представляет собой история злосчастной богини Идзанами. Богиня-прародительница, спустившаяся с небес вместе с богом Идзанаги и сочетавшаяся с ним браком, родила восемь Великих японских островов, множество мелких, реки, горы и всё растущее на них, и богов, ведающих всем этим. Последним она родила бога огня, ставшего причиной ее смерти. Неутешный вдовец бог Идзанаги решил отправиться за возлюбленной супругой в страну теней, чтобы уговорить ее вернуться. Но, увидев, что тело богини уже кишело червями и истекало гноем, он пустился наутек и закрыл выход из страны теней огромной скалой. И разгороженные ею боги-супруги расторгают свой брачный союз, становясь непримиримыми врагами» [4, с. I56].

Решение загадки этого «странного» японского мифа Вановскому подсказало то давнее сибирское «космическое видение», которое не только привело его в Японию, но и вручило ему, как оказалось, ключ к разгадке тайны японской мифологии. Ключом к пониманию «Кодзики» является именно вулканическая природа Японии. Вановский считал, что «стоит только поставить вопрос, как сам собой напрашивается ответ: вулканы, рождающие из своего чрева целые острова, извергающие пламя и затем переходящие в состояние покоя, иначе говоря, превращающиеся в мертвые вулканы, есть та космическая почва, на которой возник миф о богине Идзанами. Богиня Идзанами - богиня земли, но не только в смысле богини плодородия, но и в смысле богини вулканической стихии, породившей японские острова. Эта вулканическая природа богини Идзанами является самой главной чертой ее характера и она-то и мешает уложить японский миф о творении в схему греческого и вавилонского мифов» [4, с. 157].

Еще один «темный», по мнению Вановского, эпизод «Кодзики» тоже был связан с темой вулканической деятельности. Изучая историю японских вулканов, Вановский явил собой новый тип исследователя, объединившего в себе талант фольклориста-этнолога и талант естествоиспытателя, что явилось уникальным событием в мировой науке, как естественной, так и 
гуманитарной. Именно это уникальное сочетание двух, казалось бы, несовместимых исследовательских векторов позволило Вановскому прийти к выводу, что извержение вулкана имеет не только пагубные, но и добрые, положительные последствия. Например, вулканическая грязь оказывается плодородной почвой для различных культурных растений, скажем, для винограда. Поэтому и богу вулканов Сусаноо приписываются разные добрые дела. Сусаноо как вулканический бог вообще предстает одним из самых ярких и любимых японских богов.

Вановский приходит к выводу, что плач и бунт Сусаноо олицетворяют собой картину грандиозного извержения огромного вулкана. Кроме того, он полагает, что геология могла бы помочь в определении времени возникновения мифа, учитывая данные об извержении того или иного вулкана в древности. Вановский считает: первоначально древний человек видел в богах Идзанами и Сусаноо богов вулканической стихии, что было в последующие века забыто. Вулканические боги из-за своего буйного и неуравновешенного характера были не способны творить и поддерживать порядок на Земле. Богиня Аматэрасу послала на Землю своих потомков, понимая, что только небесные боги могут принести с собой порядок и устроить государство. Сам Вановский выразил эту синтоистскую идею еще красочнее, совсем в духе классической японской поэзии: «Богиня Аматэрасу создает государство, посылая на землю свою душу, заключенную в зеркало» [2, с. 42].

«Это прекрасная страна, - передает Кожевникова слова Вановского, - страна его “космического сновидения” поистине была отмечена перстом судьбы. Она стояла на зыбкой, постоянно колеблющейся земле и так близко соприкасалась с раскаленной магмой, что в ней постоянно ощущалось пульсирование чрева планеты. С первых дней приезда в Японию, продолжает Кожевникова, - Ванновский постоянно ощущал его в землетрясениях, которые вызывали в нем двойственное чувство: “немного жутко, но интересно”. Он начинает интересоваться происхождением японских островов, катаклизмами, которыми так богата японская природа. Вулканы с их грозной силой захватили Вановского» [4, с. 154].

Он пешком совершает подъем на вершину потухшего вулкана Фудзи, самой высокой и почитаемой горы Японии. Пишет поэтическое эссе «Японский богатырь», в котором сравнивает Фудзи-сан с воином, стоящим на страже «счастья и покоя японского народа». 
В 2о0г г. в майском выпуске журнала «Восточная коллекция» Т.В. Померанская и автор настоящего исследования опубликовали статью «Путь и судьба Александра Вановского», где среди прочих уникальных материалов была опубликована фотография Вановского верхом на коне в белом тропическом шлеме во время его очередной «фольклорно-вулканологической экспедиции». Вановский выступал во время нее в двойной ипостаси - естествоиспытатель, изучающий вулканическую деятельность как уникальное явление японской Природы, и фольклорист-этнолог, изучающий «вулканологические мифы» древней Японии». Под фотографией есть приписка самого Вановского: «1959 год. Это меня сняли во время подъема на вулкан Михара-Яма, который находится на острове Ошима» [6, с. І29].

Вулканы, а говоря более определенно, «вулканология» и даже «геология», наряду с изучением японской мифологии, становятся важными частями его исследовательской деятельности. Кожевникова отмечает, что «вулканы, которые, по мнению многих авторитетов, во многом определили быт японцев и выковали их характер, стали для Вановского той точкой отсчета, от которой начались его основные гипотезы, легшие в основу его работ» [4, с. I54].

Решающее значение для Вановского имели сотрудничество и дружба с Михаилом Петровичем Григорьевым. Овладение уникальной японской культурой Вановский начал с изучения такого специфического жанра японской литературы, как «кайдан» - рассказы о привидениях. Особенно его интересовала тема загробной мести, встречающаяся как в русской, так и в европейской литературе. Выполненные переводы текстов не устраивали Вановского, и именно тогда он обратился к лучшему на тот период времени переводчику с японского языка, Михаилу Петровичу Григорьеву (І899-І943), бывшему офицеру войск атамана Г.М. Семенова, служившему в годы Гражданской войны переводчиком в штабе японских оккупационных войск в России.

Не только исследования Вановского стали итогом их совместной деятельности над текстами «Кодзики», но и труд самого Григорьева «Древнейший памятник японской литературы Кодзики», опубликованный в первом выпуске издававшегося в Токио под редакцией самого М.П. Григорьева сборника «На Востоке». Некоторое представление об уникальности этого издания может дать приводимый ниже краткий обзор опубликованных в нем материалов. Среди участников первого выпуска были указаны следу- 
ющие авторы: Александр Вановский, писатель, автор книг о японской мифологии; Георгий Иванович Чертков (г893-1983), член Сибирского правительства во главе с А.В. Сазоновым, писатель, который жил в Японии, Китае, США; Николай Матвеев (I866-I94I), писавший под псевдонимом Амурский, прозаик и поэт, живший в эмиграции в Японии; Павел Петрович Петров (1882-1967), генерал-лейтенант, начальник отдела РОВС в Мукдене, председатель Общества русских эмигрантов в Японии.

Сборник «На Востоке» давно стал библиографической редкостью. В настоящее время известно лишь о четырех экземплярах сборника, хранящихся в крупнейших библиотеках мира: один - в Баварии (Германия), один - в библиотеке Гарвардского университета (США), один - в библиотеке Токийского университета (Япония) и один - в библиотеке Гавайского университета (США).

Являясь редактором сборника «На Востоке», Григорьев публиковал собственные материалы под скромным псевдонимом «М.Г.». По этой причине многие его работы, среди которых оказалось и исследование «Древнейший памятник японской литературы Кодзики», затерялись среди маститых и громких имен других исследователей, как русских, так и японских. Содержание первого выпуска сборника действительно производило сильное впечатление. Вановский опубликовал новеллу «Японский богатырь» и статью «Зеркало судьбы (Сон Татьяны)». Григорьев (под псевдонимом «М.Г.») - статьи «Древнейший памятник японской литературы Кодзики» [3], «Несколько слов о старой и новой поэзии Японии», «Новые поэты Японии», «Лик Японии», «Танизаки Дзюнъичиро (краткая характеристика писателя)», «Акутагава Рюносукэ (краткая характеристика писателя)». Кроме работ русских авторов, в сборнике были напечатаны переводы произведений Акутагавы Рюносукэ, Исигава Такубоку и других японских писателей.

Кожевникова подробно рассказывает о начале совместной работы Вановского и Григорьева над текстами «Кодзики»: «Вановский познакомился с Григорьевым в конце 2о-х годов. Зная о его загруженности, он не очень надеялся склонить его заниматься изысканиями в древней литературе. Но к удивлению Александра Алексеевича тот охотно согласился. Когда Вановский заикнулся о вознаграждении за эту работу, он замахал руками и отказался: Меня интересует сам предмет, а не деньги, да и откуда они у вас! Оказалось, что в это время Григорьев сам мечтал, кроме практических пере- 
водов, необходимых для заработка, начать заниматься японской литературой, мечтая в будущем написать историю Японии, иллюстрировав каждый ее этап художественными произведениями той эпохи. Вскоре они перешли к началу начал японской литературы - к “Кодзики”» [4, с. I55].

О ходе совместной работы Вановский рассказывал следующее: «Сидим за “Кодзики”. Он переводит с листа, поясняя текст комментариями профессора Цугита. Со свойственной ему деловитостью он запасся необходимыми пособиями и, прежде всего, двумя увесистыми томами примечаний и пояснений к мифологическому периоду японской истории этого профессоpa. <..> Я обращаю его внимание на эпизоды, что могут понадобиться мне для статьи, и он дает мне их точный перевод». Наверное, только специалист может оценить познания и эрудицию тогда еще совсем молодого Григорьева - ему было около тридцати или тридцать с небольшим. К тому же он не был специалистом по древней литературе, не имел ни университетского образования, ни филологической подготовки. В чем же была главная трудность? Вановский объясняет ее так: «Мы ищем в “Кодзики” объединяющего начала, которое позволило бы нам понять японский миф как одно художественное целое. Нам нужна теория, исходя из которой можно было бы объяснить все темные и загадочные места мифа. А их так же много, как и в Гамлете. В поисках ключа обращаемся к обширной литературе о “Кодзики”. Но она нас не удовлетворяет, ибо в ней, как и в литературе о Гамлете, имеется несколько глубоких и оригинальных воззрений, а всё остальное сплошь вариации к ним. И мы ходим к специалистам по “Кодзики”, которые любезно принимают нас и дают указания, которые все-таки не выводят нас из лабиринта мифа». Дело заключалось в том, что Вановский и Григорьев рассматривали сюжет «Кодзики» как борьбу двух начал - начала светлого, организующего и темного, хаотического. Но в эту схему никак не укладывались богиня Идзанами и бог Сусаноо. В конце концов, пришлось признать подобную попытку неудавшейся. Но хоть загадка мифа и не была решена, совместный многолетний труд принес плоды. Оба досконально изучили «Кодзики» [4, с. I55-I56].

Однако проблема неразгаданного мифа о «странном» поведении некоторых японских богов продолжала оставаться центральной темой кропотливых исследований Вановского. Он внезапно, как иностранец, обратил внимание на то, что для японцев вулканическая активность является «обыч- 
ным делом», и в силу этого им просто не приходило в голову исследовать японские эпические памятники с точки зрения геологии и вулканологии.

Выводы Вановского и Григорьева о вулканической природе древних японских мифов творения были представлены японской научной общественности достойно: с русским размахом и японской деликатностью одновременно: «Весьма вероятно, - писал Вановский, - что древний человек видел в богах Идзанами и Сусаноо богов вулканической стихии. Но прошли века и первоначальный подлинный характер названных богов был забыт» [4, с. I58-I59]. Вановский, в развитие своей теории, приходил к выводу, «что в силу буйного и беспорядочного характера вулканических богов они не могут творить и не могут создать на земле порядок» [4, с. I59]. Именно поэтому «богиня Аматэрасу послала на землю своих потомков, потому что только они, небесные боги, могут принести с собой порядок и устроить государство» [4, с. I59], полемизируя тем самым с японскими учеными, которые считали, что «Кодзики» является всего лишь бессистемным собранием разных легенд, лишенным внутренней связи, лишенным единой повествовательной линии. Причину этого Вановский объяснял тем, что со временем была забыта «вулканическая подкладка» мифа, которая придавала внутреннюю связь излагаемым в мифе событиям.

В г960 г. в Токио на японском языке выходит его книга «Вулканы и Солнце: Новая концепция мифологии “Кодзики”». В заключительной главе, озаглавленной «Миф о творении в “Кодзики” и Библии» и являвшейся переработанным вариантом его знаменитой статьи, опубликованной в I934 г. в парижском журнале «Путь», Вановский сравнивает сакральные тексты обоих памятников и выделяет общее и особенное в этих памятниках. Он отмечает совпадение методов творения в обоих сакральных памятниках.

Если в тексте Библии Бог творит посредством Слова, то в тексте «Кодзики» Бог Амэ-но-Минака-нуси, что значит Властитель Небесного Царства творит Мир посредством своей творческой энергии через других богов (сущностей), чьи имена указывают на порядок и предмет творения. «Выходит, - считает автор, - что японские боги - это те же библейские слова, с помощью которых творился миф, только персонифицированные и обожествленные. Такое сходство наталкивает на мысль, что оба мифа вышли из какого-то одного источника, которым Вановский вслед за некоторыми японскими учеными считает мифы древней Месопотамии» [4, с. I59]. 
Гипотеза о том, что предки японского народа вышли из Месопотамии, была достаточно популярна в зо-е гг. XX столетия. Например, один из авторов сборника «На Востоке», где активно печатались и Григорьев, и Вановский, писатель Оябэ Дзэнитиро даже выдвинул смелое «предположение, что «предками японского народа были евреи, пришедшие из Малой Азии. Исследователь “Кодзики” Исикава Сансиро тоже считал, что предки японцев вышли из Месопотамии, но он считает ими древнее племя, жившее в верховьях реки Евфрат, которые по пути смешались с другими народами - семитами, малайцами и полинезийцами. Вановский приводит утверждение Исикава, что Страна пышного тростника, в которой небесные боги наводят порядок, находится именно в Месопотамии, а не в Японии, где нет обширных болот, поросших тростником. Исикава также считал, что название страны богов Такамагахара идет от названия города Харон, родины иудейского патриарха Авраама» [4, с. I59]. Как мы видим, вокруг проблемы этногенеза японского народа в зо-е гг. XX столетия кипели нешуточные фольклористические и этнологические страсти.

Исследования японских ученых, по мнению Вановского, подтверждали его выводы о сходстве архаических мифов творения в двух великих памятниках мировой культуры - в Библии и в «Кодзики». «Но, - задает он вопрос, - если предки японского народа принесли с собой с азиатского материка миф о происхождении земли, то, спрашивается, зачем им понадобилось создавать еще дополнительный миф о рождении японских островов?» [4, с. I59]. Он выдвинул оригинальную гипотезу, суть которой заключалась в следующем: «Предки японцев, двигающиеся с азиатского материка на Восток, должны были прежде всего попасть на богатый вулканами остров Кюсю. Там, кроме находящегося на побережье вулкана Сакурадзима, имеется еще гигантский вулкан Асо, “настоящее царство вулканов” [4, с. I59]. Он отправляется в научную экспедицию, которую сегодня можно назвать «комплексной», чтобы понять то грандиозное действо, которое неоднократно происходило в геологической истории Японии. Он пытался уловить настроение возникновения мифа, писал о поисках этого мифологического настроения, о поэзии рождения японского вулканического мифа буквально следующее: «Помимо самого Асо, обладающего пятью огромными кратерами, имеется еще обширное кратерное поле, а также целый ряд отдельных вулканов, вытянувшихся в струнку, подобно солдатам, построенным 
в одну шеренгу. Трудно себе даже представить, что произойдет, если такая вулканическая махина “заплачет” и “забунтует” всеми своими кратерами!» [4, с. I6o].

Вановский считал, что древние переселенцы явились свидетелями такого сильного извержения. «В каком бы направлении пришельцы ни передвигались по острову, они непременно должны были натолкнуться на Асо, ибо он находится в самом его центре, близ современного города Кумамото. Вспомним еще, что на азиатском материке, откуда они пришли, за исключением отдаленной Камчатки, нет действующих вулканов. Перевоплотимся в душу древнего человека, впервые узревшего грандиозные проявления вулканической деятельности, и мы поймем, что он должен был пережить сильнейшую потребность уяснить себе их значение. И вот тут на помощь ему приходит дар мифотворчества, ибо назначение мифа в том и заключается, чтобы путем одушевления природы служить осознанию ее явлений. Так и возник миф о богине Идзанами, рождающей острова, подобно тому, как вулканы извергают из своего чрева новые образования земли». Знакомство с деятельностью вулкана Асо подтвердили предположения Вановского о буйном боге вулканов Сусаноо. В окрестностях вулкана есть небольшое озеро, которое временами совершенно высыхает, точно его «выплакал» $C y$ саноо. Огромные массы пепла издали похожи на проливной дождь, от которого могло пойти представление о «слезах вулкана», а зрелище извержения, когда небо застилается тучами черного дыма, закрывающего солнце, - о борьбе вулканического бога с солнцем. Так постепенно мог сложиться миф о плаче и бунте Сусаноо [4, с. І6о].

Вановский делает свой вывод о сути вулканической основы архаических мифов творения Древней Японии: «Вулканические впечатления, вот фактор, сыгравший огромную роль в развитии мифотворчества. Вулкан Асо, можно сказать, - колыбель мифологии “Кодзики” - этого родного детища японской земли» [4, с. I60].

Работа Вановского «Вулканы и Солнце», где были сформулированы основные положения его «вулканической теории» происхождения архаических мифов творения Древней Японии, не стала предметом обсуждения японских мифологов. Началась война, и «автор, как и многие другие иностранцы, был интернирован в горное место Каруидзава, а потом послевоенная разруха <...> не способствовали ее публикации» [4, с. I6о]. 
Следует согласиться с И.П. Кожевниковой, когда она с горечью говорит о забвении в современной Японии «мифолого-вулканологических» трудов нашего гениального соотечественника. Однако если вспомнить, как и когда в головах двух русских эмигрантов, Александра Вановского и Михаила Григорьева, в муках и сомнениях возникла совершенно фантастическая теория «вулканического происхождения архаических мифов творения Древней Японии», то становится совершенно очевидно, что исторический контекст, вместивший в себя и Первый съезд РСДРП, и две русские революции, и две мировых войны, и Гражданскую войну с ее белым и красным террором, и горький хлеб эмиграции с ее унижениями и борьбой за «место под солнцем», и многое другое, - именно этот исторический контекст и сформировал для японской фольклористики русскую концепцию. Отрадно, что многие в Японии понимают и ценят этот научный факт, чему свидетельством может послужить следующая благодарственная цитата: «По свидетельству влиятельной синтоистской газеты “Священный путь” от г апреля І96г года “С первой страницы до последней книга А.А. Вановского полна серьезным научным материалом, но, благодаря мастерскому изложению писателя, она легко читается. "Вулканы и Солнце” содержит совершенно новый взгляд на “Кодзики”. До сих пор я ни в одной книге не читал и не слышал такого толкования. По прочтении “Вулканы и Солнце” передо мной впервые открылся мир наших мифов. И особенно замечательно, что эта ясная картина дана иностранным ученым, а не японским” $[8$, с. 23].

Полностью исчерпав для себя исследовательскую тему, связанную с архаическими мифами творения Древней Японии, Вановский сосредоточил свое внимание на «шекспировской теме», в чем добился ощутимых результатов, создав книгу «Путь Иисуса от иудаизма к христианству (обнаружение скрытого иудейского сюжета в трагедии “Гамлет”)», в которой за образом Гамлета Вановскому видится образ Христа. Таким образом, великая трагедия Шекспира обретает для него свой истинный потаенный смысл. 


\section{Список литературы}

I Вановский А.A. «Бурные годы» Александра Вановского // Российский Архив. М.: Российский фонд культуры, 20I7. Вып. 23: История Отечества в свидетельствах и документах XVIII-XX вв. С. 440-468.

2 Вановский А.А. Миф о творении в Кодзики и Библии. Отрывки из книги «Вулканы и Солнце» // Яковенко М.М. Мечтатель. Повесть о А.А. Вановском. М.: [Б.и.], г999. С. 37-47.

3 Григорьев М.П. Древнейший памятник японской литературы «Кодзики» // На Востоке. Токио: Изд-во книжного магазина Тайсиудоо, г935. Вып. І. 228 с.

4 Кожевникова И.П. Вановский и Япония // Acta Slavica Iaponica. I995. Vol. I3. С. I49-I66.

5 Мелетинский Е.М. Поэтика мифа. М.: Наука, 1976. 407 с.

6 Налепин А.Л., Померанская Т.В. Путь и судьба Александра Вановского // Восточная коллекция. 200I. № 2. С. І29-І33.

7 Налепин А.Л. Японский фольклор в работах А.А. Вановского и их значение для русско-японского культурного трансфера // Studia Litterarum. 20I8. T. 3, № 4 . С. 276-297.

8 Палиевский П.В. Пушкинское эхо из Японии // Родная Кубань. 1999. С. 77-80.

9 Яковенко М.М. Мечтатель. Повесть о А.А. Вановском. М. [Б.и.], І999. С. І-47.

го Яковенко M.M. «Куда ушла моя жизнь?..» Повествование в письмах, дневниковых записях, воспоминаниях и официальных документах о жизни и трудах Александра Алексеевича Вановского. М.: Звенья, 2009. 296 с.

II Японская мифология. Энциклопедия. М.: Эксмо, 2007. 464 c.

I2 Fewkes J.W. Tussayan Migration Traditions // Nineteenth Annual Report of the Bureau of American Ethnology. Washington, I900. Part 2. P. 573-633.

I3 McNeil W.K. History in American Folklore: An Historical Perspective // Western Folklore. 1982. Vol. XLI, № I. P. 30-35. 


\section{References}

I Vanovsky A.A. "Burnye gody" Aleksandra Vanovskogo ["Stormy Years” by Alexander Vanovsky]. In: Rossiiskii Arkhiv [Russian archive]. Moscow, Rossiiskii fond kul'tury Publ., 20I7, issue 23: Istoriia Otechestva v svidetel'stvakh i dokumentakh XVIII-XX vv. [History of the Fatherland in the testimonies and documents of the $18^{\text {th }}-2 \mathrm{O}^{\text {th }}$ centuries], pp. 440-468. (In Russ.)

2 Vanovsky A.A. Mif o tvorenii v Kodziki i Biblii. Otryvki iz knigi "Vulkany i Solnce” [The creation myth in the Kojiki and the Bible. Excerpts from the book Volcanoes and the Sun]. In: Yakovenko M.M. Mechtatel'. Povest'o A.A. Vanovskom [A Dreamer. The story of Alexander A. Vanovsky]. Moscow, I999, pp. 37-47. (In Russ.)

3 Grigor'ev M.P. Drevneishii pamiatnik iaponskoi literatury "Kodziki” [The oldest work in Japanese literature, “Kojiki”]. In: Na Vostoke. Vypusk pervyi [In the East]. Tokio, Izdatel'stvo knizhnogo magazina Taisiudoo Publ., I935. Issue I. 228 p. (In Russ.) Kozhevnikova I.P. Vanovskii i Iaponiia [Vanovsky and Japan]. Acta Slavica Iaponica, I995, vol. I3, pp. I49-I66. (In Russ.)

Meletinskii E.M. Poetika mifa [The poetics of the myth]. Moscow, Nauka Publ., I976. 407 p. (In Russ.)

Nalepin A.L., Pomeranskaia T.V. Put' i sud'ba Aleksandra Vanovskogo [Life and career of Alexander Vanovsky]. Vostochnaia kollektsiia, 200I, no 2, pp. I29-I33. (In Russ.) Nalepin A.L. Iaponskii fol'klor v rabotakh A.A. Vanovskogo i ikh znachenie dlia russkoiaponskogo kul'turnogo transfera [Japanese folklore in the works of A.A. Vanovsky and their significance for the Russian-Japanese cultural transfer]. Studia Litterarum, 20I8, vol. 3, no 4, pp. 276-297. (In Russ.)

Palievskii P.V. Pushkinskoe ekho iz Iaponii [Pushkin's echo from Japan]. In: Rodnaia Kuban' [Native Kuban'], I999, pp. 77-80. (In Russ.) Iakovenko M.M. Mechtatel'. Povest'o A.A. Vanovskom [Dreamer. Tale of A.A. Vanovsky]. Moscow, I999, pp. I-47. (In Russ.) Iakovenko M.M. “Kuda ushla moia zhizn'?..” Povestvovanie v pis'makh, dnevnikovykh zapisiakh, vospominaniiakh i ofitsial'nykh dokumentakh o zhizni i trudakh Aleksandra Alekseevicha Vanovskogo [“Where has my life gone?..” Letters, diaries, memoirs, and official documents on the life and works of Alexander Alekseevich Vanovsky]. Moscow, Zven'ia Publ., 2009. 296 p. (In Russ.) Iaponskaia mifologiia. Entsiklopediia [Japanese mythology. Encyclopedia]. Moscow, Eksmo Publ., 2007. 464 p. (In Russ.) Fewkes J.W. Tussayan Migration Traditions. Nineteenth Annual Report of the Bureau of American Ethnology. Washington, I900, part 2, pp. 573-633. (In English) McNeil W.K. History in American Folklore: An Historical Perspective. Western Folklore, I982, vol. XLI, no I, pp. 30-35. (In English) 
УдК 398

ББК 82.3
РЕЛИГИОЗНО-МИФОЛОГИЧЕСКИЕ ОБРАЗЫ И МОТИВЫ В НАРТСКОМ ЭПОСЕ БАЛКАРЦЕВ И КАРАЧАЕВЦЕВ

\author{
(C) 2020 г. Т.М. Хаджиева \\ Институт мировой литературы \\ им. А.М. Горького Российской академии наук, \\ Москва, Россия \\ Дата поступления статьи: 23 октября 2оІ9 г. \\ Дата публикации: 25 июня 2020 г.
}

DOI: I0.22455/2500-4247-2020-5-2-4I2-423

\begin{abstract}
Статья подготовлена в рамках проекта РФФИ №ㄱ8-ог2-оо266 «Нартский эпос народов Кавказа в кругу мировых эпических памятников: Опыт сравнительного исследования»
\end{abstract}

Аннотация: За свою многовековую историю балкарцы и карачаевцы создали чрезвычайно богатый фольклор. Центральное место в их устных поэтических произведениях занимает героический нартский эпос, являющийся одной из национальных версий общекавказской Нартиады. У балкарцев и карачаевцев, как и у других носителей Нартиады, сказания составляют ряд больших и малых циклов. Каждый цикл - это группа небольших по объему сказаний и песен о появлении на земле нартского племени; о различных этапах и событиях эпической жизни героев (рождение, богатырское детство, первый подвиг, женитьба, борьба с мифическими чудовищами, с кровником и т. д.). В эпосе балкарцев и карачаевцев есть оригинальные, самобытные песни и сказания, не имеющие параллелей ни в одной другой национальной версии Нартиады. Они относятся в основном к архаическому слою эпики, так как в них превалируют мотивы, связанные с тотемистическими, анимистическими, магическими и религиозными представлениями этих народов, у которых вплоть до XIX в. наряду с исламом бытовали некоторые пережитки первобытных форм религии и христианства. То, что балкарцы и карачаевцы продолжительное время поклонялись небу, огню, воде, небесным светилам, животным, деревьям и т. п. и что по их представлениям каждое явление, предмет имели своего Тейри (Тенгри), нашло отражение и в их нартском эпосе.

Ключевые слова: карачаевцы, балкарцы, нартский эпос, мифологические образы, мотив, культ, Тейри-Тенгри.

Информация об авторе: Танзиля Мусаевна Хаджиева - кандидат филологических наук, ведущий научный сотрудник, Институт мировой литературы им. А.М. Горького Российской академии наук, ул. Поварская, д. 25 а, г2го69 г. Москва, Россия.

E-mail: tanzila_@mail.ru

Для цитирования: Хаджиева Т.М. Религиозно-мифологические образы и мотивы в нартском эпосе балкарцев и карачаевцев // Studia Litterarum. 2020. T. 5, № 2. C. 4I2-423. DOI: IO.22455/250O-4247-202O-5-2-4I2-423 


\title{
RELIGIOUS AND MYTHOLOGICAL CHARACTERS AND MOTIFS IN THE NART EPIC BALKARS AND KARACHAI
}

This is an open access article

distributed under the Creative Commons Attribution 4.0 International (CC BY 4.0)

\author{
(C) 2020. T.M. Khadzhieva \\ A.M. Gorky Institute of World Literature \\ of the Russian Academy of Sciences, \\ Moscow, Russia \\ Received: October 23, 2019 \\ Date of publication: June 25, 2020
}

Acknowledgements: The article was supported by the Russian Foundation for Basic Research; project no I8-0I2-00266 "The Nart Epic of the Peoples of the Caucasus in the Circle of World Epic Monuments: The Experience of Comparative Research".

Abstract: During their many centuries of history, the Balkars and Karachays have created an extremely rich folklore. The heroic Nart epos occupies the central place in their oral poetic works; it is one of the national versions of the general Caucasus Nartiad. Among the Balkars and Karachays, as well as among other bearers of the Nartiad, the legends consist of a series of large and small cycles. Each cycle is a group of small (in bulk) legends and songs about the appearance of the Nart tribe on earth; about the various stages and events of the epic life of the heroes (birth, heroic childhood, the first exploit, marriage, and the struggle with mythical monsters, with a blood enemy, etc.). In the epos of the Balkars and Karachays, there are original individual songs and legends without parallels in any other national version of the Nartiad. They date basically from the archaic layer of the epic, since there is a predominance of motifs connected to the totemistic, animist, magic, and religious ideas of these peoples who, right up to the $19^{\text {th }}$ century, had some survivals of primitive forms of religion and Christianity, alongside Islam. The Nart epos also reflects the fact that the Balkars and Karachays used to worshiping the sky, fire, water, heavenly lights, animals, trees, stones, etc., and that according to their ideas, each phenomenon and thing had its own Teyri (Tengri).

Keywords: Karachays and Balkars, the Nart epic, mythological characters, mythological motifs.

Information about the author: Tanzily M. Khadzhieva, PhD in Philology, Leading Research Fellow, A.M. Gorky Institute of World Literature of the Russian Academy of Sciences, Povarskaya 25 a, I21069 Moscow, Russia.

E-mail: tanzila_@mail.ru

For citation: Khadzhieva T.M. Religious and Mythological Characters and Motifs in the Nart Epic Balkars and Karachai. Studia Litterarum, 2020, vol. 5, no 2, pp. 4I2-423.

(In English) DOI: I0.22455/2500-4247-2020-5-2-4I2-423 
One of the first researchers of Balkaro-Karachay mythology, L.I. Lavrov, pointed to the parallel existence in their religious beliefs of "ancient-Turkish, Alan and Caucasus strata”. In this connection he showed convincingly, on the basis of much folkloric and ethnographic material, that the Turkish layer was dominant in them.

Thus, in the religious beliefs of the Balkars and Karachays the supreme position is occupied by Teyri (Tengri) - the supreme god of all the Turko-Mongolian world (see $[2 ; 5 ;$ IO; II; 13; 23; 28] and others).

At the beginning of the $19^{\text {th }}$ century, G.Yu. Klaproth wrote that "the Balkars and Karachays honour a god named, not Allah but Tengri, in the capacity of the bearer of every kind of good thing” [I, p. 245]. Even at the beginning of the twentieth century the Karachays considered that "Teyri's will alone determined the life and death of a man" [12, p. 53]. Probably that is why in their algyshes (good wishes) and kargyshes (curses), which date from the most ancient genres of Turkish poetry, they always appeal to his name [12, pp. 380-409].

In the legends, Teyri steps out as "the creator and bearer of good things and blessings". When the Narts appeared, "Teyri of the Sky, Teyri of the Sun, Teyri of the Earth and Teyri of the Water took counsel and decided: Teyri of the Water will give water to the human race for them to drink; Teyri of the Earth took it on himself to grow the harvest and to feed man; Teyri of the Sun to shine with light; Teyri of the Sky to send rain" [I7, p. 302].

Teyri protects and helps the epic heroes in everything. In one of the Nart songs, an emegen (epic monsters) says to Sosuruk:

We would lay waste the land of the Narts,

We would extinguish their hearths. 
But the Teyris prevent us:

They help the land of the Narts [I7, p. I62].

The ancestors of the Balkars and Karachays, like many Turko-Mongolian peoples, used to organise special supplications and sacrifices to Teyri. Hymned prayers - psalms in honour of Teyri - were the chief component part of these mysteries. The epic text, "The supplication of the Narts to Teyri" [I7, p. 582], is probably a fragment of one such cult song. In it, the Narts not only swear by the name of Teyri, but they also appeal to him for help and they extol him, they even stress that Teyri's blood flows in their veins and that the Narts are a part of his flesh. With this, they call themselves "servants of Teyri", and display deep respect to him and worship before him. In this text, evidently, the propitiating imagery is linked to the insertion of such pagan hymns into the epos at the later stages of its development, when the consciousness of the people had already denied the imperative relations with the deity.

One of the specific traits of the Balkaro-Karachay epos is the absence of theomachist motifs (except for the Nart songs and legends about the struggle of Yoryuzmek with Fuk/Puk). We explain this by the fact that Christianity, and later Islam, were formally accepted by the ancestors of the Balkars and Karachays. They did not allow "the dogmatism of Islam into the depths of their soul. The religion remained as an outwardly social form, while its religious essence was filled up with survivals from the distant past, with a harmonious system of a whole range of ancient adats and with free fantasies in the field of artistic images, of distinctive rites and beliefs" [22, p. 63]. And since "the old mythological traditions are more firmly held in a place where the influence of the world religions is minimal or absent" [I9, p. I85], among the Balkars and Karachays the diverse ancient Turkish beliefs were conserved, and Teyri remained in their religious ideas "the god of gods" not only of the Turkish, but also of their Alan and underlying (Caucasus) deities.

After the complete establishment of Islam in Balkaria and Karachaya, the name of Teyri became for them one of the 99 epithets of Allah [28, p. I6r].

In the epos of the Balkars and Karachays, survivals are also preserved that are linked to reverence towards another deity of the ancient Turks - Umay [2I]. It seems to us that the Nart song "Umay-biyche" represents a fragment of one of the ritual songs in praise of this deity. It is possible that formerly it was performed 
during hunting rites, but with time, it became a part of a legend (song) of the hunting life of the Narts.

The epos of the Balkars and Karachays also reflects the cult of Suu Anasy, the Mother of Water, also well familia to some other Turkish peoples [I4, vol. 2, p. 47I]. In the epos, Suu Anasy appears as the actual foster mother of the little Satanay, and the godmother and foster mother of Debet [I7, pp. 302, 306].

Judging by the functions of the gods Teyri of the Water and Teyri of the Earth in the mythology of the Balkars and Karachays, there probably took place a splitting of the ancient-Turkish deity Yer-Su who, like Tengri, had a wide currency among all of the ethnic groups of the ancient-Turkish community [2I; II].

In the legends Teyri of the Earth helps and works with the Narts in everything ("Teyri and the Narts" [I7, p. 302], "Three Narts and three emegens" [I7, p. 486]). In the Debet cycle Teyri of the Earth personifies the feminine principle, she is the mother of the Nart blacksmith. Teyri of the Water (of the Sea) also protects the Narts. In the legend about the young Satanay he is portrayed as an all-powerful terrible creature, who is feared even by Teyri of the Sun and Teyri of the Moon [I7, p. 306].

In the epos of the Balkars and Karachays there are also preserved clear survivals of worship of the sun, who appears not only as Satanay's loving father, but also as the all-powerful protector of all the Teyris, one of the creators of the earth and the cosmos [I7, p. 302].

In the studied Nart epos, alongside the Turko-Mongolian deities there are also the subordinate deities of the Caucasus peoples: Apsaty and Elia.

In the past, one of the chief means of existence among the Balkars and Karachays was hunting. Evidently that wasa reason why, in their beliefs rites and folklore, Apsaty, the god of hunting and the patron of the mountains, forests and noble animals (deer, turs and so on) was allotted an important place. As with other Caucasus peoples, this image was significantly transformed over the centuries. Probably in the beginning Apsaty was a totem animal (a white deer). Later he takes on the appearance of the mistress of the deer (this is shown by the image of Apsaty's daughter Fatimat/Baydymat), and after that he appears in the form of a handsome grey-bearded venerable old man.

The ancient Balkars and Karachays, as other Caucasus peoples, deeply respected also the cult of Elia. Academic G.Yu. Klaproth wrote, "The Balkar people 
claim that he is often on the summit of the highest mountain; with singing and dancing they bring him as sacrifices: lambs, milk, cheese and beer" [I, p. 245].

In the Nart song, "Elia" this deity appears as a protector of the Narts in all their affairs (in hunting for bison, in campaigns and so on) and as a terrible all-shattering patron of the Nart warriors, who with one light blow can reduce the Narts' enemies to ashes.

In the mythological system of the Balkars and Karachays, as also among many peoples of the world, a special place is occupied by the sacred trees, which indicate the sacral centre of a rite $[26 ; 4 ; 27 ; 8$ and others]. Judging by the fact that these cult trees (Raubazy in Balkaria; Zhangyz terek - solitary tree, in Karachaya) are addressed with various requests, universal functions can be attributed to them. As also among the ancient Turks, the trees are dedicated to Teyri [I4, vol. 2, p. 537] and seem to be mediators between him and the people [I2, pp. 4I-42].

In the Nart epos of the Balkars and Karachays, survivals associated with the cult of the tree meet in the song "The magic staff of the Narts" [I7, p. 584]. In the song, it says that the Narts had a stuff that cured the Narts of all illnesses, and sowed wholesale death among the emegens. "One day the Narts went out to fight with the emegens and wiped them out with this staff" [I7, p. 584].

The old age of the motif underlying this song is shown by its hymn of praise character and that its basis is composed of traditional incantations and wishes, typical of the cult algyshes and kargyshes that are widely represented in the folklore of the Balkars and Karachays.

In this epos, the chains ("How Yoryuzmek fought in the sky with Fuk" [I7, p. 3II]) and ropes ("How the Narts and Satanay resettled in the sky" [I7, p. 3II]) coming down from the heavens are semantically equivalent to the world tree. In the epos, they are one of the means of communication between the Narts and the upper world.

The cult of mountains and stones also is reflected in the Nart songs - they are animated and even possess the gift of speech ("The birth of the Nart blacksmith Debet" [I7, p. 302], "How evil entered the Nart race” [I7, p. 404]).

In one of the variants of the legend about the birth of Sosuruk, Satanay addresses the mountains, as if addressing live almighty creatures, and asks them to protect her son ("The birth of Sosuruk" [I7, p. 365]).

The cult of a stone has something in common with the cosmogonic ideas of the ancient Balkars and Karachays, who believed in the heavenly origin of stones, 
gold and silver; and believing that iron, stones and the stars are related ("Yoryuzmek and the emegens" [I7, p. 339]; "Debet, the heavenly blacksmith” [I7, p. 596]; "Teyri and the Narts" [I7, p. 302]).

As is well-known, the wolf was one of the totems of the Turko-Mongolian peoples. We find survivals of the worship of the wolf also in the epos of the Balkars and Karachays, whose ancestors deeply honoured the wolf: Yoryuzmek, according to some variants, was nourished by a she-wolf; one of his permanent attributes is the wolf-skin coat (see [I7, p. 38; 24, p. 260] and others).

Yoryuzmek's fur coat is probably not merely a symbol of his power and strength, and a mark distinguishing him from the other Narts as their leader, and the patriarch of the tribe. Here, it seems to us, is a reflection and a survival of a cult of the wolf.

The wolf-skin coat, which Yoryuzmek always wore thrown over his shoulders, was also a symbol of his connection with the wolves. After all, in the legend "The birth of Yoryuzmek", this is indicated directly: "...After sucking the milk of the she-wolf, he (Yoryuzmek) has become related to the wolves", says a Nart shepherd to Debet [I7, p. 308].

The ancients believed that when a man is arrayed in the skin of a totem animal, as if he were transformed into it. This is clearly shown by the Nart songs and legends about Yoryuzmek's meeting with the shaytans. The ancestors of the Balkars and Karachays thought that the shaytans, by wishing, could be invisible for all living creatures on the earth, except wolves, and that the latter always lie in wait for and eat newly-born shaytans ("Where the almostus came from" [I7, p. 580]). Therefore, among the Balkars and Karachays any essential parts from the body of a wolf (the chief enemy of the shaytans) are the most effective protection against the unclean powers. That is why, at Yoryuzmek's meeting with the shaytans, his fur-coat induced in them an indescribable terror. Their terror was so great that even the words "wolf-skin coat" could not be mentioned, and they called the fur-coat "zhelpegey" ("what is thrown over the shoulders"), and, by insisting that Yoryuzmek should take it off, they were trying to get the Nart once more to attain his human reality, and consequently also his vulnerability.

In this version, besides the cult of the wolf, one can also observe traces of worship of the raven ("Elia” [I7, p. 582]), who was one of the ornithological totems of the ancient Turks and Mongols. 
The specific character of the studied version is that its main epic theme is the struggle of the Narts with the mythological emegen-monsters. "Between the Narts and the emegens a continual struggle was carried on, in which thanks to their intellectual superiority the Narts always were left the winners... The Narts nourished a perpetual hatred towards them because the emegens used to eat human flesh" [25, p. III]. The emegens were not only the permanent epic enemies of the Narts, but they were the source of evil and chaos on the earth.

In the tales, which are well-known also to other bearers of the Nartiad, the giant is presented in the mainstream of general Nart traditions, for example in the variants about the blinding by Yoryuzmek (Sosuruk) of the giant Cyclops. However, in the legends that are significantly different from the other versions, or were recorded only in the given epos, there exists a striking similarity, and sometimes even an absolute coincidence, of the image and function of the Balkaro-Karachay emegens with the fabulous and epic monsters of the Turkish and Mongolian peoples - the Yakut abaasy, the Mongol mangus, the Buryat mangadhay, the Kalmyts mus and mangus, and so on (see [20, pp. 43-52; I8, pp. III-I24] and others).

In this epic work of the Balkars and Karachays, as in other national versions $[15 ; 16 ; 9 ; 3 ; 6 ; 7]$, besides the religious-mythological outlook of the creators of the epos there are reflected also their communal institutions (the tyore, kunaks and so on), the rituals, some cultural elements of the material culture, elements of household activities and so on. 


\section{Список литературы}

Адыги, балкарцы и карачаевцы в известиях европейских авторов. Нальчик: Эльбрус, г974. 635 с.

Азаматов К.Г. Пережитки язычества в верованиях балкарцев // Из истории феодальной Кабардино-Балкарии. Нальчик: КБНИИ, І98І. С. I43-г6I. Алиева А.И. Адыгский нартский эпос. М.; Нальчик: Эльбрус, г969. І68 с. Вейденбаум Е.Г. Священные рощи и деревья у кавказских народов // Известия кавказского отдела Императорского русского географического общества. СПб., І878. № 3. С. I53-I79.

Гумилев Л.Н. Древние тюрки. М.: Наука, 1967. 247 с.

Далгат У.Б. Героический эпос чеченцев и ингушей. М.: Наука, г972. 467 с. Джапуа 3.Д. Абхазский нартский эпос: Текстология. Семантика. Поэтика. М.: Наука, Восточная лит., 20I6. 38г с.

Зеленин Д. Тотемы-деревья в сказаниях и обрядах европейских народов. М.; Л.: Изд-во Акад. наук СССР, І937. 77 с.

Ингушский нартский эпос / сост. И.А. Дахкильгов. Нальчик: Тетраграф, 2012. 594 с. История авган Мойсея Каганкатваци, писателя Х в. СПб.: Тип. Академии наук, I86I. 376 c.

Кляшторный С.Г. Мифологические сюжеты в древнетюркских памятниках // Тюркологический сборник і977. М.: Наука, І98г. С. ІІ7-І38.

Карачаево-балкарский фольклор: Хрестоматия / сост., авт. предисл.

Т.М. Хаджиева. Нальчик: Издат. центр «Эль-Фа», І996. 592 с.

Малкондуев Х.Х. Отголоски тенгрианства в карачаево-балкарском фольклоре // Тезисы Всесоюзной сессии по итогам полевых этнографических исследований І980-І98г гг. Ташкент: [Б.и.], І986. С. І53-І54.

Мифы народов мира: энциклопедия: в 2 т. М.: Сов. энциклопедия, I980-I982. Нарты. Адыгский героический эпос / сост. А.И. Алиева, А.М. Гадагатль, 3.П. Кардангушев. М.: Наука, І974. 420 с.

Нарты. Осетинский героический эпос / сост. Т.А. Хамицаев, А.Х. Бязыров, научный консультант В.И. Абаев. М.: Наука, І989-І990. Кн. I-3.

Нарты. Героический эпос балкарцев и карачаевцев / сост.: Р.А.-К. Ортабаева, Т.М. Хаджиева, А.З. Холаев; вступит. ст., коммент. и глоссарий Т.М. Хаджиевой, отв. ред. А.И. Алиева. М.: Наука, г994. 654 с.

Неклюдов С. Ю. Героический эпос монгольских народов. М.: Наука, I984. 509 с. Неклюдов С.Ю. Мифология тюркских и монгольских народов // Тюркологический сборник. I977. М.: Наука, І98г. С. 183-202.

Поппе Н.Н. Халха-монгольский героический эпос. М.; Л.: Изд-во Академии наук CССР, І937. $128 \mathrm{c.}$

Потапов Л.П. Умай - божество древних тюрков // Тюркологический сборник. I972. М.: Наука, І973. С. 265-286. 
Рогаль-Левицкий Дм. Песенное творчество карачаевцев // Советское искусство. 1928. № 3. С. 58-65.

23 Стеблева И.В. К реконструкции древнетюркской религиозно-мифологической системы // Тюркологический сборник. І972. М.: Наука, І973. С. 213-226.

24 Тульчинский Н.П. Поэмы, легенды, песни, сказки и пословицы горских татар Нальчикского округа Терской области // Терский сборник на І904. Владикавказ: [Б.и.], г903. Вып. 6. С. 249-334.

25 Урусбиев С.-А. Сказания о нартских богатырях у татар-горцев Пятигорского округа Терской области // Сборник материалов для описания местностей и племен Кавказа. г88г. Вып. г, отд. 2. С. г-УІІг; г-42.

26 Фрэзер Д. Золотая ветвь. М.: Политиздат, І980. 832 с.

27 Чурсин Г. Почитание деревьев на Кавказе // Кавказ. Ил. прилож. 1903. № 5.

28 Шаманов И.М. Древнетюркское верховное божество Тенгри (Тейри) в Карачае и Балкарии // Проблемы археологии и этнографии Карачаево-Черкесии. Черкесск: Карачаево-Черкес. НИИ истории, филологии и экономики, I982. С. I55-I70.

\section{References}

I Adygi, balkartsy i karachaevtsy v izvestiiakh evropeiskikh avtorov [European authors on Adygs, Balkars, and Karachais]. Nal'chik, El'brus Publ., I974. 635 p. (In Russ.)

2 Azamatov K.G. Perezhitki iazychestva v verovaniiakh balkartsev [Remnants of paganism in the beliefs of the Balkars]. In: Iz istorii feodal'noi Kabardino-Balkarii [From the history of the feudal Kabardino-Balkaria]. Nal'chik, KBNII Publ., I98I, pp. I43-I6I. (In Russ.)

3 Alieva A.I. Adygskii nartskii epos [Adyghe Nart epic]. Moscow, Nal'chik, El'brus Publ., I969. I68 p. (In Russ.)

4 Veidenbaum E.G. Sviashchennye roshchi i derev'ia u kavkazskikh narodov [Sacred groves and trees among the Caucasian peoples]. In: Izvestiia kavkazskogo otdela Imperatorskogo russkogo geograficheskogo obshchestva. St. Petersburg, I878, no 3, pp. I53-I79. (In Russ.)

5 Gumilev L.N. Drevnie tiurki [Ancient Turks]. Moscow, Nauka Publ., I967. 247 p. (In Russ.)

6 Dalgat U.B. Geroicheskii epos chechentsev $i$ ingushei [Heroic epic of Chechens and Ingush]. Moscow, Nauka Publ., I972. 467 p. (In Russ.)

7 Dzhapua Z.D. Abkhazskii nartskii epos: Tekstologiia. Semantika. Poetika [Abkhazian Nart Epic: Textology. Semantics. Poetics]. Moscow, Nauka, Vostochnaia lit. Publ., 2016. 38I p. (In Russ.)

8 Zelenin D. Totemy-derev'ia v skazaniiakh i obriadakh evropeiskikh narodov [Tree totems in the tales and rites of European nations]. Moscow, Leningrad, Izdatel'stvo Akademii nauk SSSR Publ., I937. 77 p. (In Russ.) 
Ingushskii nartskii epos [Ingush Nart epic], comp by I.A. Dakhkil'gov. Nal'chik, Tetragraf Publ., 20I2. 594 p. (In Russ.)

Istoriia avgan Moiseia Kagankatvatsi, pisatelia Xv. [The story of Agan Moysey Kagankatvatsi, a Io ${ }^{\text {th }}$ century author]. St. Petersburg, Tipografiia Akademii nauk Publ., I86I. 376 p. (In Russ.)

Klyashtorny S.G. Mifologicheskie syuzhety v drevnetyurkskikh pamyatnikakh [Mythological subjects in ancient Turkic monuments]. In: Tyurkologichesky sbornik, 1977. Moscow, Nauka Publ., I98I, pp. II7-I38. (In Russ.)

Karachaevo-balkarskii fol'klor. Khrestomatiia [Karachay-Balkarian folklore. Anthology], comp., introd. by T.M. Khadzhieva. Nal'chik, Izdatel'skii tsentr “El'-Fa” Publ., I996. 592 p. (In Karachay-Balkar)

Malkonduev X.X. Otgoloski tengrianstva v karachaevo-balkarskom fol'klore. [Echoes of Tengrianism in Karachay-Balkarian folklore]. In: Tezisy Vsesoiuznoi sessii po itogam polevykh etnograficheskikh issledovanii I980-I98I gg. Tashkent, I986, pp. I53-I54. (In Russ.)

Mify narodov mira: entsiklopediia: $v 2 t$. [Myths of the peoples of the world: encyclopedia: in 2 vols.] Moscow, Sovetskaia entsiklopediia Publ., I980-I982. (In Russ.)

Narty. Adygskii geroicheskii epos [Adyghe heroic epic], comp. by A.I. Alieva, A.M. Gadagatl', 3.P. Kardangushev. Moscow, Nauka Publ., I974. 420 p. (In Russ.)

Narty. Osetinskii geroicheskii epos [The Narts. Ossetian heroic epic], comp. by T.A. Khamitsaev, A.X. Biazyrov, scientific consultant by V.I. Abaev. Moscow, Nauka Publ., I989-1990. Book I-3. (In Russ.)

Narty. Geroicheskii epos balkartsev $i$ karachaevtsev [The Narts. The heroic epic of the Balkars and Karachays], comp. by R.A.-K. Ortabaeva, T.M. Khadzhieva, A.Z. Kholaev; introd., comm. and glossary by T.M. Khadzhieva, ex. ed. by A.I. Alieva. Moscow, Nauka Publ., I994. 654 p. (In Russ.)

Nekliudov S.Iu. Geroicheskii epos mongol'skikh narodov [Heroic epic of the Mongolian peoples]. Moscow, Nauka Publ., I984. 509 p. (In Russ.)

Nekliudov S.Iu. Mifologiia tiurkskikh i mongol'skikh narodov [Mythology of Turkic and Mongolian peoples]. In: Tiurkologicheskii sbornik. I977 [Turkic collection. I977]. Moscow, Nauka Publ., I98I, pp. 183-202. (In Russ.)

Poppe N.N. Khalkha-mongol'skii geroicheskii epos [Khalkha Mongolian Heroic Epic]. Moscow, Leningrad, Izdatel'stvo Akademii nauk SSSR Publ., I937. I28 p. (In Russ.)

I Potapov L.P. Umai - bozhestvo drevnikh tiurkov [Umai - the deity of the ancient Türks]. In: Tiurkologicheskii sbornik. I972 [Turkic collection. I972]. Moscow, Nauka Publ., 1973, pp. 265-286. (In Russ.)

2 Rogal'-Levitskii Dm. Pesennoe tvorchestvo karachaevtsev [Songwriting of Karachais]. Sovetskoe iskusstvo, 1928, no 3, pp. 58-65. (In Russ.)

Stebleva I.V. K rekonstruktsii drevnetiurkskoi religiozno-mifologicheskoi Sistemy [On the reconstruction of the ancient Turkic religious and mythological system]. In: 
Tiurkologicheskii sbornik. 9972 [Turkic collection. I972]. Moscow, I973, pp. 213-226. (In Russ.)

24 Tul'chinskii N.P. Poemy, legendy, pesni, skazki i poslovitsy gorskikh tatar Nal'chikskogo okruga Terskoi oblasti [Poems, legends, songs, and tales of the proverbs mountain Tatars of the Nal'chikskovo district of the Terek region]. In: Terskii sbornik na 1904 [Terek collection for I904]. Vladikavkaz, I903, issue 6, pp. 249-334. (In Russ.)

25 Urusbiev S.-A. Skazaniia o nartskikh bogatyriakh u tatar-gortsev Piatigorskogo okruga Terskoi oblasti [Tales of the Nart heroes among the Tatars-Highlanders Pyatigorsk district of Terek region]. In: Sbornik materialov dlia opisaniia mestnostei i plemen Kavka$z a$ [A collection of materials for describing localities and tribes of the Caucasus], I88I, issue I, depart. 2, pp. I-Uiı; I-42. (In Russ.)

26 Frezer D. Zolotaia vetv' [The golden bough]. Moscow, Politizdat Publ., I980. 832 p. (In Russ.)

27 Chursin G. Pochitanie derev'ev na Kavkaze [The veneration of trees in the Caucasus]. Kavkaz. Il. prilozh., I903, no 5. (In Russ.)

28 Shamanov I.M. Drevnetiurkskoe verkhovnoe bozhestvo Tengri (Teiri) v Karachae i Balkarii [The ancient Turkic supreme deity Tengri (Theories) in Karachai and Balkaria]. In: Problemy arkheologii i etnografii Karachaevo-Cherkesii [Problems of archeology and ethnography of Karachay-Cherkessia]. Cherkessk, Karachay-Cherkess. Research Institute of History, Philology and Economics, I982, pp. I55-I70. (In Russ.) 
УДК $398+398.2$ I

ББК $82.3(=64)$

\section{СЮЖЕТНО-КОМПОЗИЦИОННОЕ СВОЕОБРАЗИЕ БУРЯТСКИХ СКАЗОК (полевые материалы 2018 г.)}

(C) 2020 г. Б.-Х. Б. Цыбикова

Федеральное государственное бюджетное учреждение науки Институт монголоведения, буддологии и тибетологии Сибирского отделения Российской академии наук, Улан-Удэ, Россия

Дата поступления статьи: о2 января 2020 г. Дата публикации: 25 июня 2020 г.

DOI: I0.22455/2500-4247-2020-5-2-424-437

Статья подготовлена в рамках государственного задания (проект XII.I92.I.4. Миф и история в фольклоре и литературе бурят и русских сибиряков: универсалии и специфика, номер госрегистрации № AAAA-AI7-II7021310268-2)

Аннотация: Статья написана по результатам экспедиционных исследований 2ог8 г. и посвящена характеристике записей устной прозы китайских бурят, наиболее внушительный объем которых составили тексты сказок в исполнении местного краеведа, энтузиаста по сбору устного творчества бурят Сэбээнэй Нордобой Эрдэни. Зафиксированные от него двадцать девять полноценных сказок с развитой сюжетной фабулой, развернутыми структурными элементами систематизированы и сгруппированы по условным блокам. Рассмотренный в статье сюжетно-тематический фонд сказок, записанных от талантливого шэнэхэнского исполнителя, отличается разнообразием, полнотой текстов, художественными достоинствами. Проведенный анализ позволил сделать вывод: зафиксированная в полевом сезоне 2018 г. устная проза бурят Внутренней Монголии КНР, основная часть которой представлена сказками, восходит к традиционному фольклору бурятского этноса. Исконная форма исполнения сказок, основная их сюжетная основа не подверглись существенной трансформации. Этому способствовало несколько объективных факторов, один из которых заключается в том, что китайские буряты, оказавшиеся изолированными от материнского этноса, сознательно, возможно, неосознанно, выбрали замкнутый круг традиционного уклада жизни.

Ключевые слова: сказки, сюжеты, разновидности, систематизация, функции основного персонажа, буряты Китая, традиционный фольклор.

Информация об авторе: Бадма-Ханда Бадмадоржиевна Цыбикова - кандидат филологических наук, доцент, ведущий научный сотрудник, Федеральное государственное бюджетное учреждение науки Институт монголоведения, буддологии и тибетологии Сибирского отделения Российской академии наук (ИМБТ СО РАН), ул. Сахьяновой, д. 6, 670047 г. Улан-Удэ, Россия.

E-mail: bch58@yandex.ru

Для цитирования: Цыбикова Б.-Х.Б. Сюжетно-композиционное своеобразие бурятских сказок (полевые материалы 2018 г.) // Studia Litterarum. 2020. T. 5, № 2. C. 424-437. DOI: IO.22455/2500-4247-2020-5-2-424-437 


\section{THE SPECIFICITY OF THE PLOT AND STRUCTURE OF THE BURYAT FAIRY TALES (2018 field materials)}

This is an open access article distributed under the Creative Commons Attribution 4.0 International (CC BY 4.0)
(C) 2020. B.-Kh.B. Tsybikova

The Institute for Mongolian, Buddhist and Tibetan

Studies of the Siberian Branch of the Russian Academy of Sciences,

Ulan-Ude, Russia

Received: January 02, 2020

Date of publication: June 25, 2020

Acknowledgements: The research was supported by the state fund FASO Russia (project XII.I92.I.4. "Myth and History in Folklore and Literature of Buryat and Russian Siberians: universalia and specific features”, № AAAA-AI7-II702I3IO268-2).

Abstract: The article is based on the results of the expedition research in 20I8. It examines oral prose records of Chinese Buryats. The most impressive volume of these records includes the texts of fairy tales performed by Sebeenei Nordoboy Erdeni who is a local historian, an enthusiast for collecting oral creative art of Buryats. Twenty-nine fullfledged fairy tales have been recorded from him. The essay systematizes and groups into tentative blocks tales with a developed plot and detailed structural elements. The main principle of the fairy tales classification is the function of main character. Based on this principle, I classify the available material as the following six categories: heroic fairy tales, magic-fiction fairy tales, short stories, domestic fairy tales, cumulative fairy tales, and fairy tales containing mythological elements. Recorded from a talented shenekhen performer, this story-themed fund of fairy tales has variety and contains complete texts with artistic merits. The analysis made it possible to draw a conclusion: recorded in 20I8, the oral prose of the Buryats of Inner Mongolia of the PRC, mainly represented by fairy tales, goes back to the traditional folklore of the Buryat ethnic group. The original performance of fairy tales and their main plot basis have not undergone any significant transformation. This instance was facilitated by several objective factors. One of them is that the Chinese Buryats, who found themselves isolated from the mother ethnic group, consciously, or perhaps unconsciously, chose to keep a traditional way of life in a closed ethnic circle.

Keywords: fairy tales, plots, varieties, systematization, functions of the main character, Buryats of China, traditional folklore.

Information about author: Badma-Khanda $\mathrm{B}$. Tsybikova, $\mathrm{PhD}$ in Philology, Docent, Leading Research Fellow, The Institute for Mongolian, Buddhist and Tibetan Studies of the Siberian Branch of the Russian Academy of Sciences (IMBTS SB RAS), Sakhyanova St.,6, 670047 Ulan-Ude, Russia.

E-mail: bch58@yandex.ru

For citation: Tsybikova B.-Kh.B. The Specificity of the Plot and Structure of the Buryat Fairy Tales (2OI8 field materials). Studia Litterarum, 2020, vol. 5, no 2, pp. 424-437. (In Russ.) DOI: IO.22455/2500-4247-2020-5-2-424-437 


\section{Введение}

В ходе экспедиционных исследований 2018 г. в Эвенкийском хошуне Автономного района Внутренняя Монголия Китайской Народной Республики, где в Хулун-Буирском аймаке компактно проживают буряты, предки которых являются выходцами в основном из приононских бурятских поселений Читинской области (ныне - Забайкальского края), собран достаточно большой фольклорный материал. Произведенные полевые записи представлены в целом устной прозой бурят, как то сказки, устные рассказы, в том числе оригинальные рассказы с мифологической основой. Данная статья посвящена характеристике одного из больших блоков собранного материала - текстов сказок из обширного репертуара местного краеведа, энтузиаста по сбору устного творчества бурят Сэбээнэй Нордобой Эрдэни. От него было записано двадцать девять наименований полноценных сказок с развитой сюжетной фабулой, развернутыми структурными элементами.

При научном определении специфики жанра немаловажное значение имеет то, как сам народ именует свои повествования. Так, шэнэхэнские буряты, как еще называют представителей бурятской диаспоры по наименованию местности их проживания в Китае, обозначают сказки как истории (түүхэ), короткие ходячие сказания (ябаган үльгэр - букв. короткий ходячий улигер). Таким образом, устоявшееся в среде российских бурят определение сказки как 'онтохон' им неведомо. Это не удивительно, так как хори-буряты, к которым по родовой принадлежности относятся буряты Внутренней Монголии, при определении жанра сказки не используют, во всяком случае в пору активного бытования устного народного творчества в раннее время не употребляли этот термин. Обозначение жанра бурятской 
сказки восточными/китайскими бурятами хоть и разнится с общепринятой в настоящий момент терминологией, в своей основе весь сюжетный корпус сказок шэнэхэнских бурят восходит к общебурятским традиционным сказочным сюжетам и мотивам.

Систематизация сказок, исполненных С.Н. Эрдэни, осуществлена по разрядам, согласно В.Я. Проппу: «Наряду с распределением сказок по разрядам, имеется деление по сюжетам. Если неблагополучно обстоит дело с делением на разряды, то с делением на сюжеты начинается уже полный хаос... Забегая вперед, мы скажем, что деление волшебных сказок по сюжетам по существу вообе невозможно. Оно также должно быть поставлено на новые рельсы, как деление по разрядам» [5, с. 9]. Бесспорно, в связи с трудностью определения, какой из признаков главный в сказке, одна и та же сказка может быть отнесена к нескольким рубрикам по ряду признаков. В данном же случае мы исходили от функции основного действующего лица сказки. Следуя позиции Д.А. Носова, «Под функцией понимается поступок персонажа с точки зрения его значимости для развития сюжета» [4, с. 5], при систематизации материала доминирующим признаком для нас послужили «функции действующих лиц и образные формы их воплощения» [4, c. 6]. Это позволило сгруппировать тексты сказок, записанных в полевом сезоне 2018 г., условно по следующим блокам:

I. Сказки, содержащие мифологические черты (2 текста);

2. Богатырские сказки (3 текста);

3. Волшебно-фантастические сказки (го текстов);

4. Новеллистические сказки (6 текстов);

5. Кумулятивные сказки (г текст);

6. Бытовые сказки (7 текстов).

Сказки с мифологическими элементами в репертуаре С.Н. Эрдэни представлены двумя текстами. Присутствие мотива о мифологическом происхождении главного героя из хвоста козы [«һүүл хүбүүн» («Парень-хвост») ${ }^{\mathrm{I}}$ дало основание отнести сказку к произведению с мифологической основой. Общность человека с отдельными животными имеется в фольклоре и других народов: «..примитивный род легенд, где вообще не проводится строгая грань между человеком и животным и где предпола- 
гается, что низшие думают, говорят и действуют как люди. И живут друг с другом в полном смысле этого слова, как равные с равными» [7, с. І2г].

Наличие элементов мифа определяет характер и другой сказки под названием «Абай Хабай хоёр» («Абай и Хабай») ${ }^{2}$. Так, наряду с развитием сюжета в стиле традиционного волшебно-фантастического сказочного жанра ее своеобразие составляет, во-первых, то, что один из главных действующих персонажей - это представитель Верхнего мира, гений-хранитель (сахюусан). Он обладает мифическими возможностями перевоплощаться. Чтобы проверить сострадательность главного героя, он принимает облик нищего просителя и, когда убеждается в доброте и милосердии героя, спасшему его парню дает волшебный камень в виде коня. В этом случае также наблюдается момент мифологизированной интерпретации роли коня как предсказателя. Как предупреждает сахюусан, если глаза этого каменного коня вспыхнут красным огоньком, это будет сигналом о надвигающейся опасности, и парень должен предпринять меры по спасению себя и близких. В-третьих, в отличие от устоявшихся в бурятской сказке мотивов, когда ханскую дочь похищают мангадхаи, громадные змеи, в этом же тексте ее уносит сильным ветром-вихрем в виде воронки. В момент, когда парень, освобождая девушку, простреливает своей стрелой вихрь, с него, как с живого существа, капает кровь. Здесь очевидно присутствие мистического страха древних людей перед природными явлениями, наделение ветра определенной силой, приравнивание его к себе подобному живому существу.

Таким образом, распространенные в мифологических повествованиях элементы зооморфного появления человека (от медведя, коровы), в данном случае от хвоста животного (козы); кроме того, обнаруженные некоторые мотивы, характерные для мифологических устных рассказов, позволили эти два текста сказок рассматривать отдельно и обозначить как сказки, содержащие мифологические черты. «Рудиментарно черты мифического по своей сути сознания продолжают жить и воспроизводиться неконтролируемо и стихийно в массовых верованиях, предрассудках, обычаях, сказках, что полностью отражает присущее первичной мифологии свойство: миф скорее образ жизни» [3, с. II]. 
Богатырские сказки в исполнении С.Н. Эрдэни представлены тремя текстами: «Эрхии Мэргэн» (Эрхи Мэргэн)³, «Сог Мэргэн, Дүүдэй Мэргэн, Басагаадай» (Сог Мэргэн, Дудэй Мэргэн, Басагадай)4, «Хүдэр тугалшан хүбүүн» (Крепкий парень, пасущий телят) ${ }^{5}$, воспевающие подвиги главных персонажей в борьбе за освобождение от неволи, спасение близких. Вслед за авторитетными исследователями бурятского фольклора (Ц.Ж. Жамцарано, А.И. Уланов, Е.В. Баранникова и др.) констатируем, что сказки на сюжеты о деяниях сказочных мэргэнов, баторов, силачей из народа, направленных на преодоление трудностей, подавление врагов, спасение беззащитных, являются трансформированными отголосками героических сказаний бурят - улигеров. Подтверждением является наш материал в записях 2018 г. Так, подобную модификацию эпических произведений бурят, вероятно, демонстрируют вышеупомянутые три сказки. Они в сжатой форме (в сжатой - имеется в виду в отличие от развернутых эпических полотен бурятских улигерных произведений) повествуют о борьбе основного персонажа с пятнадцатиголовым мангадом, посягнувшим на его жену; с мангадом, захватившим в плен его сестру; об участии в состязаниях, устроенных ханом. Примечательно, что их содержание имеет сюжетные соответствия и параллели с общебурятскими вариантами: действие и разработка основной идеи сконцентрированы на подвигах главного персонажа (борьба с чудовищами - мангадом, змеей для освобождения похищенной невесты, сестры, дочери хана; подавление вылезшего из утробы матери сына мангада; победа в навязанных герою различных испытаниях).

\section{Волшебно-фантастические сказки}

Из всего комплекса анализируемого материала наиболее многочисленны волшебные сказки, основанные на чистом вымысле и народной фантазии. Их количество равняется десяти, что свидетельствует о популярности в народной среде именно этой разновидности сказочных повествований. В репертуаре нашего исполнителя Эрдэни содержатся увлекательные приключения главного персонажа сказки - выполнение трудных заданий с помощью чудесных помощников, необычных средств; освобождение близ-

3 Полевые материалы экспедиции 2018 г.

4 Полевые материалы экспедиции 2018 г.

5 Полевые материалы экспедиции 2018 г. 
ких, беззащитных от враждебных сил; раскрытие злодеяния; избавление от напастей нечистых сил, чудовищ, благоприятный финал - счастливая женитьба, воссоединение родственников, получение материального достатка: имущества, скота. В этот тип сказок вошли тексты следующего характера:

I. Коварная жена Нагадар Мэргэна, решив избавиться от его сестры, подбросила кольцо в рот девушки, отчего она поперхнулась. Нашедшие гроб с девушкой старики оживили ее, она стала женой их сына. Узнавание братом сестры в результате подслушанной колыбельной песни («Нагадар Мэргэн» $)^{6}$.

2. Спасенные из колодца орел, мышь, змея помогают герою взять в жены дочь хана и получить высокий чин («Парень Тоди, Тус, орел, мышь, змея») 7 .

3. Приключения парня Боро по спасению дочери хана от громадного змея, женитьба на ней («Парень-сирота Боро») ${ }^{8}$.

4. По принуждению хана парень Яшал отправляется добыть перо мифической птицы гаруди. Уничтожив гигантского змея, который поглощал детей, в благодарность получает искомое перо птицы. Приведя по велению хана страшного верблюда, задавившего хана и его чиновников, он завладел его добром («Единственный сын матери [по имени] Яшал») 9

5. Жена отправляет мужа на охоту. Раздевшись, он полез за лисой в нору, остался голый. Оказавшись в щекотливой ситуации, случайно подсмотрел, где находится кольцо жены богача, и выдал себя за знахаря. Подслушав разговор жены богача и сивого быка/шолмоса, поведал об их тайном сговоре извести богача, тем самым спас его от смерти. Эта сказка имеет соответствия с монгольской, калмыцкой сказочной традицией, в которой наблюдается заметное влияние древнеиндийских письменных источников, главным образом близость к сюжетам из «Волшебного мертвеца». Сошлемся на цитату Б.Б. Горяевой: «Отмечая схожесть индийских “обрамленных повестей” с родственными им образцами монгольской словесности, Ц. Дамдинсурэн и С.Д. Серебряный пишут: “Нечто противоположное произошло с другим индийским «обрамленным сборником» - «Двадцатью пятью

\footnotetext{
6 Полевые материалы экспедиции 2018 г.

7 Полевые материалы экспедиции 2ог8 г.

8 Полевые материалы экспедиции 2018 г.

9 Полевые материалы экспедиции 2018 г.
} 
рассказами Веталы», который у монгольских народов превратился также в «обрамленный сборник», известный под названием «Волшебный мертвец». Если «Панчатантра» дошла до монголов без обрамления, лишь в виде отдельных сюжетов, то от «Двадцати пяти рассказов Веталы» монголы взяли, напротив, лишь общую структуру обрамления, переосмыслив ее и наполнив другими сюжетами” [Дамдинсурэн, Серебряный 198I, с. I37]» [2, с. 60]. Таким образом, не подлежат сомнению древнеиндийские корни сказки в исполнении Эрдэни под названием «Гахай үзэлшэн Галбаа» (Знахарь [по имени] Гахай Галба) ${ }^{\mathrm{Io}}$, имеющей соответствующие варианты в монгольской и калмыцкой сказке о человеке - мнимом «знахаре», находящем различные предметы.

6. За уничтожение непобедимого противника змей одаривает парня-охотника способностью понимать язык зверей, животных. Парень нарушает запрет: не должен проговориться, что ездил на змее. Чтобы избежать наказания змеи, парень сказал, что проговорился не он, а «черный парень», т. е. водка («Семеро парней-охотников») ${ }^{\text {II }}$.

7. Волшебная говорящая птица рассказывает несколько поучительных историй: І. Хозяин опрометчиво убил свою собаку, которая честно охраняла имущество чужого человека; 2. Женщина умертвила кошку, ошибочно решив, что она покусала ухо ее ребенку; 3. Человек до смерти поколотил ворону, не поняв, что она намеревалась предотвратить от вкушения им змеиного яда. Вопреки уговору, тот, кто слушает эти рассказы, каждый раз выражает свои эмоции восклицанием, после чего каждый раз птица исчезает («Умная птица») $)^{12}$. Эта сказка отличается от других подобных сюжетов, восходящих к древнеиндийским и древнемонгольским письменным источникам, сохранением единой рамочной композиции, соответствующей общей структуре индийского обрамляющего сюжета: «некто посылает царя (царевича) за Веталой, и Ветала раз за разом рассказывает царю (царевичу) сказки» [2, с. 65].

8. Невинно гонимый младший брат разбогател, приютив и вскормив утку. Злая жена брата выпросила утку, желая тоже разбогатеть. Не дождавшись яиц, умертвила утку. Съев кусок высохшего мяса утки, младший брат

Iо Полевые материалы экспедиции 2018 г.

II Полевые материалы экспедиции 2018 г.

I2 Полевые материалы экспедиции 2018 г. 
стал испускать благовонные запахи, разбогател. Подмена младшего брата старшим, наказание обманщиков («Похождения младшего брата») ${ }^{\mathrm{r}}$.

9. За спасение сына водяного царства парень получает в качестве вознаграждения собаку, впоследствии превратившейся в красавицу-жену и одарившей его дворцом, скотом («Му Хара») $)^{\text {I4 }}$.

Iо. Ветер развеял с трудом добытую стариком муку. На претензии старика ветер-вихрь поочередно дает скатерть-самобранку; овцу, дающую золото-серебро; музыкальный предмет в виде раковины 'буреэ'. Женщину, забирающую предметы, подаренные старику, настигает справедливое наказание («Ветер-вихрь») $)^{15}$.

Итак, сюжетную основу перечисленных десяти сказок, объединенных по функции основного персонажа, составляют следующие звенья: отправление для выполнения трудных заданий, пространственное перемещение и связанные с этим события; поиск, спасение от вредителей; состязания и победа. Художественное единство текстов этих сказок составляет присутствие нерешенной задачи для главного героя, положительное разрешение ее в результате нахождения, борьбы, в некоторых случаях с участием чудесных помощников, и вознаграждение (женитьба на дочери статусного человека, получение богатства/достатка).

\section{Новеллистические сказки}

В репертуаре сказок С.Н. Эрдэни представлены сюжеты авантюрно-новеллистического характера о ловких проделках героев, направленных на торжество справедливости, наказание представителей враждебной стороны. Имея много общего с другими разновидностями волшебных сказок по характеру раскрытия функциональных возможностей основного персонажа (реализация трудных поручений, поиск и добыча определенных предметов и т. д.), вместе с тем в основу сказок данной группы положены, прежде всего, обман, хитрость, плутовство, свойственные действиям главного действующего лица, цепь авантюрных его похождений и поступков. Это подтверждают отдельные названия сказок в исполнении нашего ин- 
форматора: «Нэгэ хүбүүнэй ябадал» («Похождения одного парня») $)^{16}$, «Гурбан аха, дүүнэрэй бага дүүгэй ябадал» («Похождения младшего брата из трех

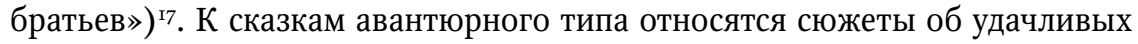
плутах-ворах («Парень [по имени] Шодон») ${ }^{18}$ («Парень-вор») ${ }^{19}$. О хитроумном старике, обманом променявшем лису на коня, лук со стрелами; ловко надувающем глупых сыновей богача, поверивших, что шило может избавить человека от тяжелой болезни; якобы, за мертвое тело можно обменять на верблюда («Мудрый старик») ${ }^{20}$. К ним примыкает сказка о находчивом человеке, умеющем находить выход из затруднительных ситуаций, и его антиподе с ограниченными умственными способностями, но отличающемся физической силой («Сметливый и Сильный») ${ }^{21}$.

\section{Кумулятивные сказки}

К данному разряду сказок можно причислить повествования, в которых функции действующих лиц построены по принципу удвоения, утроения и многократного повторения. Таковой оказалась одна сказка в исполнительском запасе С.Н. Эрдэни под названием «Старик Боролдой» ${ }^{22}$. Она начинается с описания исходного посыла - ворона (в данном тексте она выступает в роли связного/посыльного Хурмасты) выклевала глаз ягненка старика, затем происходит ряд повторов - каждый раз возобновляющиеся действия Хурмасты для наказания старика. Так, он поочередно отправляет к Боролдою волка, чтобы тот задрал коня старика; затем чертей, осу, чтобы они уничтожили его самого. Старик ловко справляется с засланными Хурмастой субъектами, а когда спускается к нему сам небожитель, он дает логичный ответ, почему он жестоко справился с ними, который удовлетворил Хурмасту. Особенность композиции рассмотренной сказки заключена в повторяющихся действиях одного персонажа для наказания/уничтожения другого персонажа, при этом предпринятые человеком защитные меры оказываются эффективнее методов верховного вершителя судеб людей.

I6 Полевые материалы экспедиции 2018 г.

I7 Полевые материалы экспедиции 20I8 г.

I8 Полевые материалы экспедиции 2018 г.

I9 Полевые материалы экспедиции 2018 г.

20 Полевые материалы экспедиции 2018 г.

2 I Полевые материалы экспедиции 2018 г.

22 Полевые материалы экспедиции 2018 г. 


\section{Бытовые сказки}

Из зафиксированных в период экспедиции 2018 г. семи сказок бытового характера две относятся к сюжету о мудрой девушке: «Алтан Хайша» («Золотые Ножницы») $)^{23}$ и «Сэсэн басган» («Умная девушка»)24. Функция главной героини в них, как и в других аналогичных вариантах, широко бытующих у всех этнических групп бурят, заключается в решении трудных заданий, остроумном разрешении сложных обстоятельств и ситуаций.

Сюжеты двух других сказок («Балан Сэнгэ» 25 , «Убить муху» ${ }^{26}$ ) также имеют прямые совпадения и однозначное сходство с произведениями на эту тему, популярными и у российских бурят. Кроме того, названия текстов Эрдэни идентичны тем, что опубликованы в сборниках бурятских народных сказок: «Аляаһанай ноён» («Мушиный начальник») [9, с. 2Іо-2ІІ], «Балан Сэнгэ» [I, c. I42-I43]. Общая черта, присущая этим произведениям: «Функции героев в них неизменны - проявить умение в разгадывании тайного, отгадывании различных загадок, способности говорить иносказательно, понимать завуалированную речь, метком парировании» [9, с. 7I].

Вместе с тем три текста бытовых сказок, записанных от С.Н. Эрдэни, являются оригинальными, хотя функциональные особенности персонажей характеризуются теми же вышеуказанными признаками. Сказки под названиями «Харамша, Үглигэшэ» («Скупой и Дарующий») $)^{27}$, «Сэсэн мэргэшүүлэй тоосоон» («Спор мудрых и метких») 28 , «Ноён, боол, түшэмэл» («Ноен/сановник, слуга, чиновник» $)^{29}$ представляют повествования с локальной тематикой о мудрецах и составляют так называемую «зональную группу». Суть их возникновения, по нашему мнению, заключается в осмыслении реальных эпизодов в быту, обобщении фактов наиболее яркого проявления остроты ума, человеческого достоинства, затем переработке таких случаев в устойчивый сюжет устного народной прозы. «Рождение сказки, особенно авторской (впрочем, народные сказки тоже имели авторов) может быть следствием экспликации личных комплексов, когда рассказчик фантазиру-

23 Полевые материалы экспедиции 2018 г.

24 Полевые материалы экспедиции 2ог8 г.

25 Полевые материалы экспедиции 2018 г.

26 Полевые материалы экспедиции 2ог8 г.

27 Полевые материалы экспедиции 2ог8 г.

28 Полевые материалы экспедиции 2ог8 г.

29 Полевые материалы экспедиции 2ог8 г. 
ет от того, чего лишен в реальной жизни и что может обрести только в трансцендентной реальности» [6, с. 78].

Итак, проанализированный материал ярко показывает традиционную жанровую направленность и сюжетное разнообразие сказок в исполнении талантливого собирателя устного творчества бурят, хранителя традиции народа Сэбээнэй Нордобой Эрдэни.

\section{Выводы}

В период естественного, необратимого процесса угасания классического фольклора, наблюдающегося повсеместно, обнаружение подлинного клада в лице Сэбээнэй Нордобой Эрдэни, запомнившего услышанные в детстве фольклорные произведения, восстановившего подзабытое в зрелом возрасте в своих записях и бережно хранящего культурное наследие своих предков, является несомненной находкой и редкой удачей участников экспедиции во Внутреннюю Монголию КНР. Сюжетно-тематический фонд сказок, записанных от талантливого исполнителя, отличается разнообразием, полнотой текстов, художественными достоинствами. В активе сказочного репертуара шэнэхэнского знатока фольклора имеются все ее виды это сказки богатырские, волшебно-фантастические, новеллистические, бытовые, кумулятивные, сказки, содержащие мифологические элементы.

Необходимо подчеркнуть собственно повествовательную традицию бурят, проживающих в Китае, - развернутость сюжетных рядов, детальное описание эпизодических для развития события моментов, насыщенная выразительность поэтических формул, изобразительных средств, наличие в большом объеме исконно бурятской лексики, вышедшей из активного багажа и употребления бурятами, проживающими в России.

В заключение отмечаем, что обширный репертуар С.Н. Эрдэни, большую часть которого составили сказки, восходит к традиционному фольклору бурятского этноса. Исконная форма исполнения сказок, основная их сюжетная основа не подверглись существенной трансформации. Более того, традиционная культура, этническое самосознание сохранились у бурят Внутренней Монголии в значительной степени без изменений, в исторических условиях изолированной от материнского этноса жизни китайским бурятам удалось сберечь духовное наследие своих предков, и им есть, что передать последующим поколениям. 


\section{Список литературы}

Бурятские народные сказки. Бытовые. Улан-Удэ: Бурятское книжн. изд-во, І98г. 448 c.

2 Горяева Б.Б. Калмыцкая волшебная сказка: сюжетный состав и поэтико-стилевая система. Элиста: НПП Джангар, 20II. І28 с.

3 Дашкова Е.В., Ивушкина Е.Б. Миф и сказка как основа русского фольклора // Сборник конференций ННЦ социосфера. 2015. № 37. С. 7-14.

4 Носов Д.А. Структура повествования монгольской народной сказки: автореф. дис. ... канд. филол. наук. СПб., 2огі. 24 с.

5 Пропn В.Я. Морфология волшебной сказки. М.: Лабиринт, 200I. I92 c.

6 Тен В.В. Миф и сказка: генезис и дифференциация // Международный журнал исследований культуры. 20I4. № 2 (I5). С. 72-78.

7 Фрэзер Д. Фольклор в Ветхом завете. М.: Соцэкгиз, І93г. 438 с.

8 Ц Цыбикова Б-Х.Б. Бытовые сказки. Сюжетный состав. Поэтика. Улан-Удэ: Изд-во БНЦ СО РАН, І993. II4 с.

9 Шадаев А.И. Алтан үндэгэн (Золотое яичко). Улан-Удэ: Бурятское книжн. Изд-во, I967. 279 c. 


\section{References}

I Buriatskie narodnye skazki. Bytovye [Buryat folk tales. Domestic tales].

Ulan-Ude, Buriatskoe knizhnoe izdatel'stvo Publ., I98I. 448 p. (In Buryat, Russ.).

2 Goriaeva B.B. Kalmytskaia volshebnaia skazka: siuzhetnyi sostav i poetiko-stilevaia sistema [Kalmyk magic fairy tale: plot structure, poetics, and style]. Elista, NPP Dzhangar Publ., 20II. I28 p. (In Russ.).

3 Dashkova E.V., Ivushkina E.B. Mif i skazka kak osnova russkogo fol'klora [Myth and fairy tale as the basis of Russian folklore]. In: Sbornik konferentsii NNTs sotsiosphera [Conference proceedings of the NNTs sociosphere], 20I5, no 37, pp. 7-I4. (In Russ.).

4 Nosov D.A. Struktura povestvovaniia mongol'skoi narodnoi skazki: avtoref. dis. ... kand. filol. nauk [Structure of the Mongolian folk tale narrative: $\mathrm{PhD}$ thesis, summary]. St. Peterburg, 20Ir. 24 p. (In Russ.).

5 Propp V.Ya. Morfologiia volshebnoi skazki [Morphology of a magic fairy tale]. Moscow, Labirint Publ., 200I. I92 p. (In Russ.).

6 Ten V.V. Mif i skazka: genezis i differentsiatsiia [Myth and fairy tale: genesis and differentiation]. Mezhdunarodnyi zhurnal issledovanii kul'tury, 20I4, no 2 (I5), pp. 72-78. (In Russ.).

$7 \quad$ Frehzer D. Fol'klor $v$ Vetkhom zavete [Folklore in the Old Testament]. Moscow, Sotsehkgiz Publ., I93I. 438 p. (In Russ.).

8 Tsybikova B-Kh.B. Bytovye skazki. Siuzhetnyi sostav. Poetika [Domestic tales. The plot composition. Poetics]. Ulan-Ude, Izdatel'stvo BNTs SO RAN Publ., I993. II4 p. (In Russ.).

9 Shadaev A.I. Altan undehgehn (Zolotoe yaichko) [Gold egg]. Ulan-Ude, Buriatskoe knizhnoe izdatel'stvo Publ., I967. 279 p. (In Buryat). 
УДК 82.09

ББК $83.3(2 \mathrm{Poc}=\mathrm{Pyc})$
АВТОРСКИЕ ЗНАКИ ПУНКТУАЦИИ КАК СПОСОБ СОЗДАНИЯ РЕДАКЦИИ ТЕКСТА. НА ПРИМЕРЕ ПОЭМЫ В. МАЯКОВСКОГО «150 $000000 »$

\author{
(C) 2020 г. Т.А. Купченко \\ Институт мировой литературы \\ им. А.М. Горького Российской академии наук, \\ Москва, Россия \\ Дата поступления статьи: I5 мая 2019 г. \\ Дата публикации: 25 июня 2020 г.
}

DOI: I0.22455/2500-4247-2020-5-2-438-469

Статья подготовлена при финансовой поддержке РФФИ.

Проект № 20-ог2-оо-477-А «Поэтика и текстология записных книжек

В. Маяковского» $($ I9I7-1930)

Аннотация: Первое анонимное издание поэмы В. Маяковского «I50 ооо ооО» (I92I) отличается «неклассической» пунктуацией. В контексте футуристической эстетики оно обретает смысл манифеста нового революционного искусства. Пунктуация рассматривается как проблема идиостиля автора и с точки зрения использования им авторских знаков препинания. Авторскими знаками в первом издании поэмы признаются нулевой знак в позиции конца строки, сочетание точки/нулевого знака и большой буквы в начале строки, вопросительные знаки и тире в позиции конца строки, а также конца сроки и конца строфы одновременно, а также сочетания тире и точки, тире и восклицательного знака в указанной последовательности. Сопоставление с рукописью лесенкой (I924) позволяет прояснить значение нулевых авторских знаков, проследить изменение сознания автора поэмы и движения ее смысла от футуристичности к большей эпичности. В тексте последнего прижизненного издания (I929) авторские знаки отсутствуют. Образ автора меняется с «указывающего пальцем в небо» выскочки и грубияна на соответствующего эпической вненаходимости поэмы автора. Изучение семантики авторских знаков и их роли в тексте позволяет проследить творческую эволюцию текста и его автора, а также выделить несколько редакций лексически не менявшегося произведения.

Ключевые слова: Маяковский, I50 ооо ооо, авангард, революция I9I7 г., революция Духа, текстология, семантика пунктуации, вариант, редакция, образ автора, футуризм, авторские знаки.

Информация об авторе: Татьяна Александровна Купченко - кандидат филологических наук, старший научный сотрудник, Институт мировой литературы им. А.М. Горького Российской академии наук, ул. Поварская, д. 25 а, І2Iо69 г. Москва, Россия.

E-mail: tkupchenko@gmail.com

Для цитирования: Купченко Т.А. Авторские знаки пунктуации как способ создания редакции текста. На примере поэмы В. Маяковского «І50 ооО ооО» // Studia Litterarum. 2020. T. 5, № 2. C. 438-469. DOI: I0.22455/2500-4247-2020-5-2-438-469 


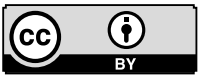

This is an open access article distributed under the Creative Commons Attribution 4.0 International (CC BY 4.0)

\section{AUTHORIAL PUNCTUATION SIGNS AS THE MARKERS OF THE MEANING. ON THE EXAMPLE OF MAYAKOVSKY'S 150000000}

\author{
(C) 2020. T.A. Kupchenko \\ A.M. Gorky Institute of World Literature \\ of the Russian Academy of Sciences, Moscow, Russia \\ Received: May I5, 2019 \\ Date of publication: June 25, 2020
}

Acknowledgements: The research was supported by the Russian Foundation for Basic Research. Project no 20-0I2-00-477-A "Poetics and Textology of Vladimir Mayakovsky's" Notebooks (I9I7-I930).

Abstract: The first anonymous edition of Vladimir Mayakovsky's poem I50,000,000 (I92I) is distinguished by its "non-classical" punctuation. In the context of the futuristic aesthetics, it becomes a manifesto of the new revolutionary art. The article examines Mayakovsky's punctuation as a problem of the author's idiostyle focusing on his use of authorial punctuation marks. Such marks in the first edition of the poem are: zero sign at the end of the line, combination of the period / zero sign and the capital letter at the beginning of the line, question marks and dashes at the end of the line, at the end of the term and at the end of the stanza simultaneously, a combination of the dash and the period, dashes, and exclamation points in the mentioned order. A comparison with a ladder-designed manuscript (1924) allows me to clarify the meaning of the zero signs intentionally used by the author and to trace the change in the poet's mindset as the meaning of the poem becomes less futuristic and more epic. Thus, in the last lifetime edition of the poem (I929), there are no authorial marks. Their absence signals the shift of the poem's style from avant-garde to epic. The poetic persona is no longer an impudent and rude guy "pointing with a finger at the sky" but the omnipresent and unplaceable author of the epic poem. Studying the semantics of the authorial punctuation and its role allows us to trace the evolution of the text and its author as well as distinguish between the editions of the same text.

Keywords: Mayakovsky, I50,000,000, avant-garde, October revolution, revolution of the spirit, textology, punctuation, semantics, variant, editorial, author's image, futurism, authorial punctuation.

Information about the author: Tatiana A. Kupchenko, PhD in Philology, Senior Researcher, A.M. Gorky Institute of World Literature of the Russian Academy of Sciences, Povarskaya St. 25 a, I2I069 Moscow, Russia.

E-mail: tkupchenko@gmail.com

For citation: Kupchenko T.A. Authorial Punctuation Signs of Punctuation as the Markers of the Meaning. On the Example of Mayakovsky's 150 ooo ooo. Studia Litterarum, 2020, vol. 5, no 2, pp. 438-469. (In Russ.) DOI: I0.22455/2500-4247-2020-5-2-438-469 
Статья отражает опыт подготовки 5 тома Полного собрания произведений B.В. Маяковского в 20 т. На примере истории текста поэмы «I50 ооо ооо» показана важность учитывания особенностей пунктуации первых прижизненных изданий, рассмотрение которых позволило найти новые редакции текста.

«І50 о0о о0о» выросла из замысла эпической революционной поэмы, который появился у Маяковского в г9г9 г. Финальные строки поэмы: «Это тебе // революций кровавая Илиада! // Голодных годов Одиссея тебе!» - прямо называют жанр поэмы - авангардный эпос о революции. На обложке первого издания не значилось имя автора, что по замыслу Маяковского работало на эту идею, намекая на древние образцы жанра. При этом поэма являла собой образец нового революционного искусства [27]. В договорах на издание она шла в ряду целой программы произведений комфутов («коммунистических футуристов»), включавших не только художественные произведения, но и теоретические тексты. Как только книга была издана (І92I), Маяковский отправил ее Владимиру Ленину, с «комфутским приветом». Все это заставляет нас уделить первому изданию поэмы пристальное внимание.

При жизни Маяковского поэма издавалась еще несколько раз. Это перепечатки текста в сборниках поэта «Із лет работы» (в 2 т. МАФ, І922), «255 страниц Маяковского» (М.; Пг.: ГИЗ, І923), «Избранный Маяковский» (Берлин, І923). Текст поэмы в этих изданиях по существу повторяет первое.

Все же Маяковский хотел вдохнуть новую жизнь в текст поэмы, снова издав ее отдельной книгой. Сохранился список лесенкой, сделанный ру- 
кой Лили Брик с редакционными пометами Госиздательства, датируемый октябрем 1924 г. Однако издание в этой созданной Маяковским в І92I г. новой строфике [г2] не было осуществлено.

Наконец, в І929 г. «І50 о0о ооо» входит в состав прижизненного Собрания сочинений [i9], которое можно считать еще одной редакцией поэмы (третьей после лесенки).

Важно, что за все эти годы лексически поэма не менялась, за исключением замены некоторых слов на однокоренные и написания отдельных слов. Новые редакции поэмы создаются только за счет изменения пунктуации и смены графического формата текста.

Вопросы важности графического образа текста поднимались футуристами с момента появления их на художественной сцене. Уже в первом манифесте «Пощечина общественному вкусу» (I9I2) читаем о «Новой Грядущей Красоте Самоценного (самовитого) Слова» [24, с. 4I]. Такое слово - это не только слово заново созданное, но по-особенному написанное. Предисловие ко II сборнику «Садок Судей» констатирует: «Мы расшатали синтаксис... Во имя свободы личного случая мы отрицаем правописание... а) считая частью неотделимой произведения его помарки и виньетки творческого ожидания b) в почерке полагая составляющую поэтического импульса с) в Москве поэтому нами выпущены книги (автографов) “самописьма” 6. Нами уничтожены знаки препинания, - в чем роль словесной массы - выдвинута впервые и осознана» [24, с. 42].

А. Крученых в «Новых путях слова» раскрывает «психическое» и мировоззренческое значение графики: «...сочетание слов по их внутренним законам <...>, а не по правилам логики и грамматики, как это делалось до нас... неправильное построение предложений... дает движение и новое восприятие мира и обратно - движение и изменение психики рождает странные “бессмысленные” сочетания слов и букв» [24, с. 52]. Он выделяет неправильность (равную неожиданности) грамматическую в несовпадении падежей, чисел, времен, родов, опущение частей предложения, местоимений и пр., а также «необычность размера, рифмы, начертания, цвета и положения слов» [24, с. 53]. Именно всяческие такого рода неожиданности, неправильности, ошибки и являются важным инструментом нового футуристического искусства. Через него осуществляется вход в иное измерение: «иррациональное (заумное) нам также непосредственно дано, как и умное» [24, с. 53]. 
К образцам нового футуристического письма можно причислить литографированные издания, созданные писателями-футуристами в союзе с новыми художниками: «Игра в аду» Н. Гончаровой и В. Хлебникова, «Я» (I9I3) В. Маяковского с его собственной обложкой и рукописным текстом, а также иллюстрациями Л. Шехтеля и В. Чекрыгина; трагедию «В. Маяковский» (I9I4), изданную с применением разных шрифтов, иллюстрированную В. и Д. Бурлюками, его рукописную миниатюрную книжку «Облако в штанах (1915)» с красными буквами [15, с. 74], рукописную книжку «Флейта-позвоночник» (І919), сборник Маяковского, Хлебникова, Д. Бурлюка «Требник троих» (1913), сборник «Мирсконца» (I9I2) А. Крученых и В. Хлебникова с рисунками и рукописным текстом М. Ларионова, Н. Гончаровой, Н. Роговина, В. Татлина и др ${ }^{\text {. }}$

Д. Бурлюк обращает особое внимание на облик творческого, освобожденного, в том числе и от оков грамматики, слова, так как такое слово воздействует на сознание всеми своими средствами: «Предпосылкой нашего отношения к слову, как к живому организму, является положение, что поэтическое слово чувственно <...> ...слово лишь настолько имеет значение для передачи предмета, насколько представляет хотя бы часть его качеств <...>, нужно различать авторский почерк, почерк переписчика и печатные шрифты. Иные слова нельзя печатать, так как для них нужен почерк автора <...>, напр<имер> стали фамилию автора передавать в его почерке $2 . .$. Громадное значение имеет расположение написанного на печатном поле» [24, с. 56].

В качестве примера реализации этих теоретических положений, помимо книг, приведем прошедшую еще в 1909 г. в Петербурге выставку импрессионистов «Треугольник» (организованную Н. Кульбиным), составной частью которой, помимо картин, были рисунки и автографы русских писателей, так как «некоторые из участников выставки интересуются ими как продолжением слова» [І4, с. 24-25].

I Многочисленны рукописные книги самого А. Крученых («Пустынники и пустынница», І913, «Полуживой», І9І3, «Помада», І913; «Голубые яйца», «Ковкази», «Туншап» - все I9I7, целиком построены на рукописных цветных шрифтах). Также можно вспомнить книги И. Зданевича («Янко, Круль Албанский», І9І8, «Остраф Пасхи», І919), которые выполнены различными типографскими шрифтами с необычной записью слов, для чего использовались, например, математические знаки, что позволяло образовывать словам разные формы [г]. 2 Заметим, что для авторизации своей поэмы в авторском сборнике «Із лет работы» (в 2 т. МАФ, 1922), до этого напечатанной анонимно, Маяковский использует фото со своей подписью красной ручкой на листе правленых гранок. 
Д. Бурлюк также говорит о математических знаках, разнице в значении больших и маленьких букв, о значении цвета, цветового пятна как знака в иероглифах. Он высказывает тезис, что «часто только варварство может спасти искусство» [24, с. 57]. Мы можем понять его слова как возвращение к синкретизму, множественному нерасчлененному воздействию. «Истинная поэзия не имеет никакого отношения к правописанию и хорошему слогу, этому украшению письмовников <.... >. Искусство ошибки также оттеняет созидаемое, как и академической язык» [24, с. 58].

В подобных представлениях о роли слова в новое время русские футуристы совпадают с итальянскими. Основатель футуризма Т. Маринетти в статье «Воображение без слов и слова на свободе» говорит о разрушении синтаксиса, который будет взорван прорвавшимися эмоциями - «клапаны пунктуации и прилагательные, которые обыкновенно расставляются наподобие болтов. У вас будут целые пригоршни существенных слов без всякого условного порядка, так как единственной заботой будет... передача всех вибраций своего “я” [26, с. 96-97]. Для передачи скоростного мышления нового времени через синтаксис предполагается использование математических и музыкальных знаков. «Типографский переворот» - «3 или 4 краски на странице или 20 различных шрифтов», «новое живописно-типографское представление на странице» [26, с. І03] - довершит создание эмоциональной партитуры текста, представляющей собой подсказку для читателя. Есть у него и нечто, близкое русской зауми, достигаемое через «свободное выразительное правописание» [26, с. Іо3], свободу ударения, укорачивание гласных при свободном синтаксисе. «Эта инстинктивная деформация слов соответствует нашей естественной склонности к междометию». А это то самое возвращение к «варварству, которое спасет искусство», о котором говорил Д. Бурлюк, так как человеческий язык развился из подобных эмоциональных выкриков. «Что за беда, если деформирование станет двусмысленным. Оно станет лучше сливаться с аккордами междометий или синтезами шумов и позволит нам скоро прийти к звукоподражательному психическому аккорду, звуковому и в то же время абстрактному выражению эмоции или чистой мысли» [26, с. І04].

В книге «Театр и его двойник» (1936) А. Арто описывает ту традиционную «грамматику», которой переполнен современный театр, «театр глупца, безумца, извращенца, грамматиста», опирающийся на логику лите- 
ратуры и слова, которой недостаточно для прояснения подлинной природы человеческих отношений, в то время как важно прийти к языку собственно театральному, «когда приходится наталкиваться на препятствия самой постановки и самой сцены», чтобы «поведать о человеческих мыслях персонажа, выявить ясные и четкие состояния сознания» - языку «активному» и «анархическому», «где были бы преодолены обычные ограничения чувств и слов» [5, с. I76].

Итак, в мировом авангардном искусстве в целом ощущается потребность выйти за рамки обыденного понимания искусства и средств его выражения, найти и выявить с помощью нестандартных формальных приемов, в том числе через графику, его сущность.

Работая в своей первой революционной поэме с графикой и пунктуацией, Маяковский следует футуристической линии творчества. Для него важно передать смысл не только с помощью самих стихов, их звучания, но и через визуальный канал воздействия. Он создает синтетическое произведение. Еще не читая авангардный текст, только по написанию названия, расположению букв имени автора и положению текста на странице, шрифтам или рукописным буквам, цвету, иллюстрациям, бумаге уже видно, к какому направлению он принадлежит, уже ожидается определенное содержание - погружение в авангардную картину мира. В этом контексте отказ от каких-то знаков пунктуации или возвращение к ним свидетельствуют о важных смысловых изменениях в тексте.

Безымянность поэмы также футуристична, так как разлитая в воздухе и стране Революция Духа выражает себя через революционный народ, который и дает новое искусство в виде этой поэмы. Идею безымянности, когда каждое имя подходит, каждый «Иван», гражданин революционного государства, является ее автором, можно сравнить с «феноменом наволочки», набитой стихами, которую носил с собой В. Хлебников. При чтении он не оканчивал стихи, говоря «и так далее», зовя слушателей в соавторы: каждый должен создать продолжение текста на основе выявленного поэтом принципа. Этот авангардный конструктор, когда каждый кусочек может быть и концом, и началом (принцип «мирсконца»), распространяется и на имя автора, и на саму идею авторства. 
Говоря о графике и пунктуации, необходимо учитывать не только художественное направление творчества, но и индивидуальную авторскую манеру и авторский стиль, что применительно к графике отражается в таком понятии как авторские знаки препинания.

В современном языкознании под «авторской пунктуацией» могут пониматься все знаки препинания, проставленные в авторской рукописи [8; 25]; знаки, которые не соответствуют кодифицированным правилам [7; 8; 13; 25]; а также знаки, являющиеся доминантными в произведении [7; I3; 22; 23; 3]. Представляется продуктивным под авторскими знаками иметь в виду знаки, поставленные не по правилам грамматики, обращать внимание также на пунктуацию, превалирующую в авторском тексте.

В глубинном смысле авторская пунктуация представляет собой «эстетически значимые единицы авторского мышления, с помощью которых создается неповторимая картина художественного образа мира и передаются эмоции творческой личности» [25, с. 22]. Иногда сама творческая личность, использующая авторскую пунктуацию, рассматривается в подчиненной функции, как часть творческого процесса, в которой она играет определенную роль. В этом смысле авторская пунктуация - не столько проявление индивидуальности пишущего, сколько «всецело принадлежность художественного текста, одно из мощных изобразительно-выразительных средств наряду с лексикой и грамматикой» [13, c. I4], поэтому под пунктуацией в целом ряд ученых понимают все знаки текста, за исключением букв и цифр [9; 29]. Пунктуация выражает на письме смысловые отношения, которые нельзя выразить лексическими или синтаксическими средствами [28]. Она является полноценной частью авторского замысла, с помощью которой передаются не передаваемые иначе смыслы («мимика и жесты» [7, с. I3I]), ритмическая структура высказывания, эмоционально-оценочные нюансы авторской интонации. Пунктуация играет особую роль в создании и интерпретации текста [7; 8; 13; 21; 22; 23; 25].

«Нарушения», «ошибки», любые прегрешения против грамматики служат расширению и углублению роли знаков препинания в художественном тексте [28, с. 6о]. Такое «неправильное» употребление позволяет реализовать их скрытые возможности, о чем и писали в своих теоретических текстах футуристы. Это так называемые «экспрессивные пунктуационные приемы» - «использование языковых средств, привлекающее внимание 
само по себе и которое воспринимается как необычное, лишенное автоматизма» [II, с. 50]. В целом пунктуация является экспрессивным средством выражения [2; II; 23; 30].

И в то же время пунктуация - это еще один, графический, способ выражения картины мира, выстраивающий «пунктуационную архитектонику текста, которая организует текст не только по горизонтали, но и по вертикали...» [І6, с. 23]. Это может быть гармонично, разумно устроенный мир и хаотичный, разорванный (что характерно для авангарда).

Пунктуация тесно связана с эмоциональностью и оценочностью авторского высказывания, т. е. она предельно субъективирует текст, что было важно для авангардного искусства, которое стремилось к предельно авторскому взгляду на мир, а не созданию объективной надличностной картины действительности. В случае анонимных «I50 о0о ооо» - это субъективность строителей нового мира, новых людей. Но также мы здесь увидим и личность Маяковского, например, в отличие от И. Зданевича и А. Крученых, он не использует математических знаков.

Анонимное издание поэмы «І50 о0о о0о» І921 г. в полном смысле слова является авторским, концептуальным изданием. Цифра «I50 ооо ооо» на обложке - это и название, и жанр, и имя автора.

Начало каждой главы печатается на отдельном листе тем же шрифтом, что и основной текст поэмы. Афиша в первой главе дается в рамке на отдельной странице разными шрифтами: слова «ВСЕМ! ВСЕМ! ВСЕМ!» набраны заглавными буквами жирным шрифтом, «текст» объявления и подписи на нем - разными шрифтами без выделения жирным, «подписи» и «три подписи», заключенные в круглые скобки, набраны с выравниванием по левому краю.

Однородные члены предложения, причастные и деепричастные обороты, сравнительные обороты, части сложных предложений вместо запя$m b x$, как это определено правилами, маркируются нулевыми знаками в позиции конца строки. Например, однородные члены предложения и части сложного предложения в строках I74-I9I (это I8 строк): 


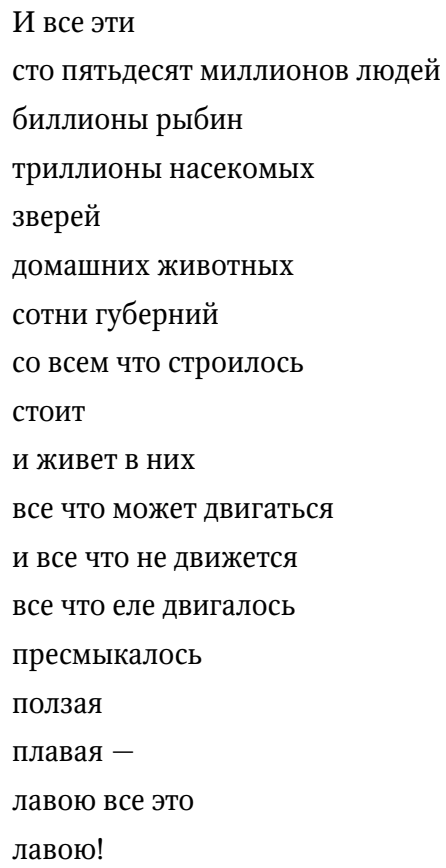

Нулевой знак вместо запятой проставлен в строках между частями сложного предложения в позиции конца строки:

И гудело над местом

где стояла когда-то Россия.

Нулевой знак в конце строки заменяет не только запятую, но и тире. В этом ощущается экономия средств и желание использования семантики стиховой формы - выявления смысловых возможностей стихотворной строки:

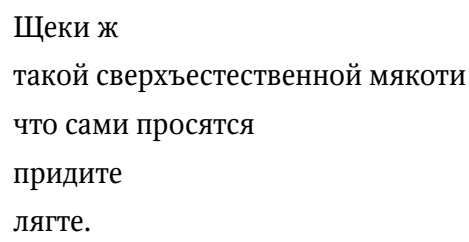


Нормативно нужна запятая после «мякоти» и тире после «просятся».

Точки в издании поэмы «І50 ооо ооо» І92I г. проставлены везде, где они требуются. Там, где они все-таки, видимо по ошибке, не стоят, следующее предложение начинается с большой буквы. Таким образом, заглавная буква также получает дополнительный пунктуационный смысл, как и позиция конца строки (при том, что в текстах Маяковского каждая строка никогда не пишется с большой буквы, как это принято в традиционном поэтическом тексте).

Насколько тщательно ставятся точки, видно на примере строк:

\author{
Были рабы. \\ Нет раба. \\ Баарбей. \\ Баарбань. \\ Баарабан.
}

На пять строк ни одного пропуска.

Такого рода позиции постановки нулевого знака в стихотворных произведениях отмечались учеными. Часть из них, приходящихся на конец строки, воспринимается как использование возможностей стихотворной строки, своего рода экономия средств и внимательное отношение к потенциалу стиха. «В стихотворной речи функцию знаков препинания способна взять на себя стихотворная строка, которая может стать единицей синтаксического членения. В таком случае максимально используются графические возможности вертикального контекста. Более того, такая манера письма, сознательно избранная, объясняется подчас усилением значимости слова в строке, освобождением его от всяческих оков» [8, с. 250]. Примечательно, что исследовательница Н.С. Валгина для этого случая использует цитату одного из футуристических манифестов, так как под «оковами» имеется в виду пунктуация.

Понять отсутствие знака или знаков в определенных позициях как постановку альтернативного знака, т. е. «нулевой знак», помогает обращение к такому явлению, как вариативность, или пунктуационная синонимия. «Знаки вариантного употребления <...> отражают скорее контекстуальную ситуацию, чем авторскую манеру письма. Авторскими они являются лишь 
постольку, поскольку при возможной вариантности указывают на нужный автору смысл. Хотя очевидно, что при необходимости передать тот же смысл, другой автор изберет тот же вариант», - отмечает Ф.С. Андросова [8, с. I86]. Таким образом, пунктуационная вариативность служит показателем авторского пристрастия к способу выражения определенного смысла.

Ф.С. Андросова отмечает еще одну важную черту авторского проявления в позициях выбора знака - выражающуюся таким образом экспрессивность: «...пунктуационная синонимия связана с заменой нейтрального или нулевого знака более сильным синонимичным ему знаком (в том числе и нулевым), который несет экспрессивную нагрузку в тексте. Представляется, что пунктуационная синонимия заключается в осуществлении автором выбора пунктуационного знака в зависимости от тактических намерений в отдельных случаях» [3, с. 53].

К особенностям пунктуации Маяковского, его любви к нулевым знакам можно подойти и со стороны изучения его черновиков. Рассматривая записные книжки Маяковского, В.А. Арутчева отмечала: «Маяковскому, когда он пишет стихи, совершенно не нужны ни знаки препинания, ни ступенька. Для него они лишь средство передать читателю ритм стихотворения, интонацию, паузы, необходимые при чтении» [6, с. 49-50]. Однако истинное значение отсутствия знаков препинания в черновиках, или, вернее, постановка нулевых знаков, становится видно в сопоставлении с имеющимися там знаками. И это как раз те знаки, которые присутствуют в издании поэмы «І50 ооо ооо» I92I г. «Точки являются исключением. Изредка их заменяет заглавная буква следующего слова, указывающая на начало фразы. Единственные знаки, которые Маяковский иногда употребляет в черновиках, - вопросительный, восклицательный и тире, то есть эмоционально окрашенные интонационные знаки» [6, с. 355-356].

При этом для Н. Валгиной нулевые знаки - «текст без знаков препинания <...>, это текст, сознательно претендующий на оригинальность. Если подобная форма письма принципиально важна для автора, если она предварительно запланирована и являет собой литературный прием <...>, то форма эта <...> и должна рассматриваться как деталь индивидуального стиля автора» [8, с. 250]. Схожий вывод делает и В.А. Арутчева, осмысляя его применительно к проблемам текстологии: «При почти полном отсутствии пунктуации в черновиках вообще, наличие ее драгоценно уже потому, 
что она, несомненно, выражает волю автора» [6, с. 356]. Как автор Маяковский использует определенные знаки препинания в определенных позициях, что отражает его авторское индивидуальное мышление и его мышление как авангардиста, передаваемое с помощью знаков препинания, в том числе и в черновиках. Идиостиль здесь неотделим от его эстетического мироощущения. Мы можем понять его нулевой знак в позициях конца строки как его излюбленный авторский знак, причислить к таким выделенным авторским знакам точки (или большую букву в начале строки своего рода метонимическую замену точки), восклицательный, вопросительные знаки и тире.

Важным знаком в издании г92I г. становится тире. Его значение в поэме - соединение разных частей текста, выражение эмоций. Часто тире стоит в сочетании с другими знаками - точками и запятыми. Например, сочетание «-.» в конце предложения и одновременном конце строфы. Так показано соединение со следующим предложением после пробела, подчеркивается непрерывность событий или описания. Например, тире в конце строфы:

Отсюда начинается то, что нам нужно -

- «Королевская улица» - .

по-ихнему

- «Рояль-стрит» -

Что за улица?

Что на ней стоит?

Или предложения соединяются тире по принципу противопоставления и одновременно соединения двух частей описания:

По ступенькам - (две)

приподымемся

взглянем

ахнем - ! 
То не солнце днем -

цилиндрище на нем

возвышается башнею Сухаревой.

Таким образом, тире в позиции конца строки, а также конца строки и конца строфы одновременно, а также сочетания тире и точки, тире и восклицательного знака именно в указанной последовательности в издании I92I г. это авторский знак. При этом тире еще и указывает на паузу, акцентирует дыхание. Отметим также чисто графический разделительный эффект, который имеет данный знак. «Как правило, ритмико-мелодическую организацию текста (в основном стихотворного) проявляет знак тире, ибо обладает наибольшей разделительной функцией, которая усиливается и зрительным эффектом, сопровождающим этот знак», - замечает Валгина [8, с. I94].

Лексически выделяются неологизмы «Скорейскорей!», «Идемидем!», составленные из удвоенных наречий сравнительной степени и глаголов в повелительном наклонении, записанных в одно слово. За счет этого приема они стали обладать дополнительным свойством звукоподражаний при передаче прямой речи зверей и дорог.

\author{
Скоре-е-е-е-е-е-е-е! \\ скорейскорей! \\ Эй \\ губернии \\ снимайтесь с якорей! \\ Идем! \\ Идемидем! \\ Не идем а летим! \\ Не летим а молньимся \\ души зефирами вымыв
}

Можно отметить и звукоподражания в «речи» зверей и дорог, созданные просто за счет протяжности звуков. Это «скоре-е-е-е-е-е-е-е!», «и-и-и-и-и-и-и-и-и-и-и-и-и-и-и!», «О о-гу!». 
В рукописи рукой Лили Брик (ОР ИМЛИ) новаторская пунктуация сохраняется, но к ней добавляется запись лесенкой, которая придает поэме эпичность. При этом при такой записи стиха позиция конца строк становится еще более семантически насыщенной. Можно выделить два ее типа: внутри большой строки и конце строки. При записи лесенкой они различаются и интонационно и зрительно. Читателю становится легче следовать логике Маяковского. Из знаков препинания в этом издании, как и в отдельном издании І92I г., используются точки, тире или двоеточия и нулевые знаки в конце строки. Любопытно отметить в этой связи, что при сравнении списка Лили Брик с изданием І92I г. видно, как исправляются ошибки, допущенные в издании І92I г. относительно авторской пунктуации.

Например, случаи, когда знаки, присутствующие в издании І92I г., в списке Лили Брик заменяются нулевыми:

$\begin{array}{ll}\begin{array}{l}\text { Ветрилась } \\ \text { паровозов борода седая }\end{array} & \text { Ветрилась паров } \\ \text { бьются } & \text { бьются } \\ \text { голод сдал } & \text { голод сдал } \\ \text { и по нем (без зн) } & \text { и по нем, } \\ \text { остатки съедая (без зн) } & \text { остатки съедая, }\end{array}$

(Заменены нулевым знаком запятые, которые обозначены началом новой строки, интонационной паузой, которая приходится на это место в таком случае, то есть исправлена «ошибка» первого издания).

$\begin{array}{cl}\text { Ядом бактерий (без 3н) } & \text { Ядом бактерий. } \\ \text { лапами вшей } & \text { лапами вшей }\end{array}$

(Точка заменена нулевым знаком. Из двух предложений таким образом получилось одно, хотя запятая не поставлена, но значимое ее отсутствие приходится на позицию начала строки - интонационную паузу).

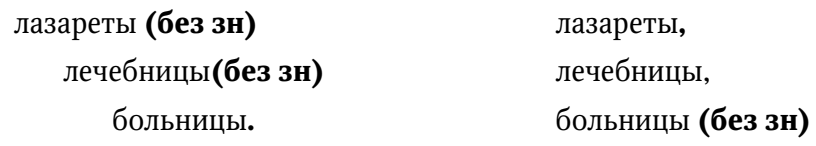

(Нулевой знак в положении конца строки создает равноценную замену запятых - паузу, возникающую при чтении). То же видим при сравнении строк I562-I564: нулевой знак вместо запятой после «разгромили». 
В некоторых случаях запятые, проставленные в издании г92I г. заменены нулевым знаком, так как его позволяет использовать лесенка:

$$
\text { и лысые (без зн) }
$$

как колено

и мохнатые (без зн)

как звери

с евангелиями вер (без зн) и лысые, как колено, и мохнатые, как звери, с евангелиями вер, с заговорами суеверий,

с заговорами суеверий,

То же в строках I586-I587.

Некоторые отдельные предложения объединены в одно сложное.

Дышит завод -

разруха слышит

Пустыни

смыты

у мира с хари;

деревья

за стволом расфеерили ствол.
Дышит завод.

Разруха слышит.

Пустыни смыты у мира с хари (без зн) деревья за стволом расфеерили ствол.

$\begin{array}{ll}\text { они грянули - } & \text { они } \\ \text { начинаем: } & \text { грянули- } \\ <. .> & \text { начинаем. }\end{array}$

Кое-где есть необходимые знаки препинания, в основном уточняющие, проясняющие - двоеточия, тире.

Например:

Список Лили Брик:

I50.000.000 - мастера этой поэмы - имя.

Издание г92г г.

I50.000.000 мастера этой поэмы имя.

(Тире служит для смыслового выделения.)

выстраивается цепь -

нечеловеческие дружины. и выстраивается цепь (без зн)

нечеловеческие дружины.

(В этом случае ставится тире для пояснения.) 


$$
\begin{array}{cl}
\text { Вышли - } & \text { Вышли. } \\
\text { песни бунта и молодости } & \text { Песни бунта и молодости }
\end{array}
$$

(Здесь тире нужно для соединения двух действий, обозначения их последовательности.)

Взвил

плечом

шитье эполетово:

«чтобы я -

о, господи -

этого самого? <...>

$\begin{array}{ll}\text { В ответ } & \text { В ответ } \\ \text { миллионный } & \text { миллионный } \\ \text { голос: } & \text { голос } \\ \text { «готово!» } & \text { «готово!» } \\ \text { «есть!» } & \text { «есть!» }\end{array}$

(В обоих случаях двоеточие обозначает начало прямой речи, как это и нужно по правилам.)

Ведется работа над лексикой в сторону улучшения и прояснения.

Мы

тебя доканаем

мир-романтик!
Взвил плечом шитье эполетово (без зн.) «чтобы я -

о господи -

этого самого? <...> миллионный

гОЛОс

«есть!»
Мы

тебя доко́наем

мир-романтик!

(Снято ударение, разговорное слово заменено на литературное.)

Анализ указывает на продуманность этих изменений и еще раз подтверждает использование авторских нулевых знаков, а не случайность отсутствия «необходимых» знаков препинания в первом издании.

В прижизненном Собрании сочинений (М., І929) [І9] (Соч. III) как издании академического типа текст поэмы дается в соответствии с кодифицированными правилами и нормами русского литературного языка. Собрание сочинений рассматривается как тип массового издания и должно подчиняться требованию понятности. Со времени написания поэмы прошло 
восемь лет, послереволюционная литература уже существовала, и понимание того, что же такое революционное искусство в сложившихся условиях у Маяковского сформировалось. Он прошел большой путь за этот период: работал с «литературой факта», создавал «газетные» стихи по следам реальных политических и бытовых событий «на злобу дня». Само время, столь важное для поэта понятие, с его изменившимися историческими реалиями, заставляет Маяковского печатать поэму в ином, нефутуристическом ключе. На то, что переход к большей повествовательности является волей Маяковского, указывает сопоставление с неопубликованным вариантом г924 г. (списком рукой Лили Брик), сделанным лесенкой, которая даже графически (очень длинные строки) дает более широкую спокойную интонацию по сравнению со столбиком книги І921 г. В издании I929 г. тенденция «объективизации» доведена до конца.

В Собрании сочинений главным отличием текста по сравнению с изданием г92I г. является отказ от использования авторских нулевых знаков, что ведет к смене типа выразительности.

Благодаря появившимся знакам в Собрании сочинений происходит важное изменение - исчезает образ героя-истерика, агрессора, грозящего всем вокруг, неуравновешенного апаша. Мы здесь наблюдаем феномен связи авторской пунктуации с субъективностью, с тем, что авторская пунктуация несет в себе авторский тип мышления и служит «навигационной картой», по которой читатель проникает в сознание автора. Изменение пунктуации указывает на изменение образа автора и мира.

Это ясно видно на примере замены тире в издании г92I г. запятыми в издании г928 г. Тире является авторским знаком в первом издании не только из-за способа постановки (часто имеет соединительные функции), но и потому, что семантически он отвечает за выделение и подчеркивание авторских эмоций, что позволяет считать его знаком присутствия автора, во многом создающим его образ. Можно сказать, что эмоциональные составляющие определений в этой интерпретации текста отнесены к образу автора. Он в этой версии важный и живой герой.

Так, в строках 546-547 два тире в издании г92і г. выделяют чудеса, и это эмоционально-смысловое выделение. В Соч. III две запятые и тире, которые сопоставляют другие слова: «не пустили», и именно по этой причине возникает необходимость чудес. Эмоциональная резкость, присущая 
авторскому видению мира, заменяется спокойной интонацией, присущей причинно-следственным, «объективным» связям.

Соч. III

Может, пустят и вас,

не пустили пока,

начиняйтесь же и вы чудесами, -

в скороходах-стихах,

в стихах-сапогах

исходите Америку сами!
I92I

Может пустят и вас

не пустили пока -

начиняйтесь же и вы чудесами -

в скороходах-стихах

в стихах-сапогах

исходите Америку сами!

«Образ автора» и тире связаны часто не только с выделением эмоциональности, но и с подчеркиванием необычных, нестандартных метафор, что также работает на образ автора.

Строки 53I-534. В первом издании тире выделяют «тысчесильную» машину, подчеркивается гиперболический смысл метафоры и ее отдельность. Она стоит в тексте особняком. В Соч. III стоит запятая, что соединяет «тысячесильность» с «тишью мышиною». Звуковая и эмоциональная составляющие выравниваются.

Соч. III

В Чикаго

такой свирепеем грохот, что грузовоз

с тысячесильной машиною казался, что ветрится тихая кроха, что ОН прошелестывал тишью мышиною.
I92I

В Чикаго

такой свирепеем грохотчто грузовоз

с тысячесильной машиноюказался

что ветрится тихая кроха чTO OH

Строки I337-I339. Тире в издании I92I г. выделяет развернутую метафору, подчеркивает необычность образа. В Соч. III стоят тире и запятая, которые отмечают начало и конец метафоры, что делает этот образ более ясным для читателя. 
Соч. III

Бросив насиженный фундамент, за небоскребом пошел небоскреб, как тигр в зверинце мясо

фунтами, пастью ворот особнячишки сгреб.
I92I

Бросив насиженный фундамент за небоскребом пошел небоскреб, как тигр в зверинце мясо фунтами пастью ворот особнячишки сгреб.

Строки г394-г396. Два тире в первом издании выделяют слова «вдруг крупно», что создает «движение камеры», стремительность смены «картинки». Именно сравнение с кинематографической сценой лежит в основе описания этого отрывка. В собрании сочинений эти строки интерпретированы как единое сравнение «в кинематографе бывает крупно», даже некая констатация факта, и от этого метафоричность, образность последующих строк теряется: «спекуляцию добивает встав на задние лапы Совнархоз». Это просто еще одно описание.

Coч. III

Как в кинематографе

бывает

вдруг

крупно, -

видят

сквозь хаос

ползущую спекуляцию добивает, встав на задние лапы,

Совнархоз.
I92I

Как в кинематографе

бывает -

вдруг

крупно -

видят

сквозь хаос

ползущую спекуляцию добивает

встав на задние лапы

Совнархоз.

Строки г368-г369. В первом издании после «колье» стоит тире, что подчеркивает движение, внезапный бросок колье - это и интонационная эмоциональность, связанная с образом автора, и создание зрительного образа. В Соч. III тире снимается и эти дополнительные смыслы уходят. Остается описание. 
Соч. III

И вот,

притворявшиеся добрыми,

колье

на Вильсоних

бросились кобрами.
I92I

И вот

притворявшиеся добрыми

колье -

на Вильсоних

бросились кобрами

Строка 785 - «рожи». Два тире в издании І92I г. отвечают за противопоставление и эмоциональный контраст, запятая на этом месте в Соч. III заменяет все эмоции простым перечислением.

Соч. III

Небольшое примечание:

художники

Вильсонов,

Ллойд-Джорджев,

Клемансо

рисуют -

усатые,

безусые рожи,

и напрасно:

все

это

одно и то же.

\section{I92I}

Небольшое примечание:

художники

Вильсонов

Ллойд-Джорджев

Клемансо

рисуют -

усатые

безусые рожи -

и напрасно:

все

это

одно и то же.

Строки I247-I248. В издании I92I г. подчеркнутая эмоциональность, даже театральность присуща речи Вильсона, мы видим два восклицательных знака и сочетание восклицательного знака с вопросительным, которые убираются в Соч. III, остается только сочетание восклицательного с вопросительным. При этом вся эмоциональная выразительность сохраняется.

Соч. III

$\ll<\ldots>$ Чтобы я

не смог

вот этого?!»
I92I

«<..> чтобы я?

не смог?

вот этого?!» 
Замена точек издания І92I г. на восклицательные или вопросительные знаки в Соч. III очень часто дает «обратный» эмоциональный эффект. Например, строка 353.

Соч. III

Стар - убивать!

На пепельницы черепа!
I92I г.

Стар - убивать.

На пепельницы черепа!

В первом случае перед нами - констатация, во втором - призыв. Формально более эмоционален второй вариант, но на деле это стандартные, ожидаемые при шокирующем смысле строки эмоции, и они притушевывают пугающий смысл.

В строках 753, 757: «теорий потоп.» «великолепнейшее экольдебазар.». В І92І г. стоят точки. В І939 - вопросительные знаки, которые кажутся логичными и необходимыми. Но в первом случае перед нами - ироничная авторская речь, тем более что далее по контрасту следуют эмоциональные отрицания с восклицательными знаками, создающими контраст. Во втором варианте перед нами - стандартный риторический вопрос, эмоциональная и в то же время ничем личным не наполненная взвинченность снижает последующее отрицание. «Вытравливание» эмоциональности ведет к утрачиванию индивидуального содержания, затушевыванию образа автора.

Соч. III

Конечно,

ученых

сюда

привел

теорий потоп?

Художников

какое-нибудь

великолепнейшее

экольдебазар?
I92I

Конечно

ученых

сюда

привел

теорий потоп.

Художников

какое-нибудь

великолепнейшее

экольдебазар.

То же самое происходит в строках 807-809. 
В строке 932 эмоциональное напряжение в варианте І92I г. передано с помощью восьми точек, в Соч. III - пятью.

$\begin{array}{ll}\text { И..... } & \text { И......... } \\ \text { очертанья идущего } & \text { очертанья идущего } \\ \text { нащупали, } & \text { нащупали } \\ \text { заметили, } & \text { заметили } \\ \text { увидели } & \text { увидели } \\ \text { маяки глазастые. } & \text { маяки глазастые. }\end{array}$

Многоточие в этом случае передает паузу, цезуру, когда это касается чтения вслух. В графике - это визуально созданная граница между прошлым и будущим, о чем и идет речь в отрывке, практически иллюстрация. Многоточие также создает возможность потянуть гласный звук при внешнем и внутреннем чтении. Когда точек целых восемь, получается очень эмоциональное пропевание. Эта эмоциональность связана с голосом автора, тем более что период заканчивается упоминанием «маяков». В редакции Собрания соч. остается скорее пауза. Эксклюзивность события принижается.

Введение «нормативных» знаков несколько упрощает образную структуру поэмы. Некоторые строфы в Собрании сочинений за счет изменений получают другую интерпретацию. Это касается и расстановки знаков, и изменений в лексике.

Сначала коснемся пунктуации. В издании г929 г. исчезают некоторые внутренние диалоги. Звучание поэмы характеризуется большей монологичностью.

Строки 338-342

I92I г.

Бей барабан!

Барабан барабань!

Были рабы.

Нет раба.

Баарбей.

Баарбань. 
Баарабань.

Эй стальногрудые!

Крепкие эй!

Бей барабан!

Барабан бей!

Или или.

Пропал или пан.

Будем бить

Бьем.

Били.

В барабан!

В барабан!

В барабан!

Для этого отрывка очень важно понять смысл возникающего подражания. Для поэтики поэмы использование звукоподражания-зауми характерно в случае изображения героев-зверей, неживой природы, вещей. Именно они действуют в этом отрывке. Строфа описывает превращение России в единого Ивана, который одновременно человек и нечеловек, олицетворение страны в ее ином природно-временном континууме. Перед барабанами идут слова «Идемидем!» По-видимому, слова, следующие после обращения к барабанам и заканчивающиеся восклицательными знаками, можно считать обращением к барабанам. Единый Иван обладает качествами слитности и одновременно многосоставности (потом он распадается на армию, как троянский конь), поэтому его части - люди, звери и вещи могут разговаривать друг с другом. В данном случае люди обращаются к барабанам, а барабаны отвечают. Требующееся по правилам выделение обращения отсутствует, что создает звуковую нерасчлененность. Говорят отдельные голоса из хора людей, зверей, дорог, ландшафтов, предметов, затем на их призыв отвечают барабаны. Они говорят похожие на их «языке» человеческие слова: «Были рабы / Нет раба», а затем переходят на свой «язык», обладающий свойствами звукоподражания и зауми: «Баарбей. / Баарбань. / Баарабань.» И дальше опять следует речь людей. Точки внутри «заумной» речи барабанов подчеркивают, что это именно их речь, а не звукоподражательные выкрики людей. 
В варианте прижизненного собрания сочинений этот внутренний монолог утрачен. Футуристическое представление о том, что революция имеет сложный, не только человеческий характер, что это некая стихийная сила природы и истории и даже закономерность бытия, Революция Духа, притушевывается. В этом варианте поэмы она - дело рук человеческих. Акценты расставлены только за счет появления восклицательных знаков по всех строках, где речь идет о барабанах. Таким образом, все эти строки оказываются призывами людей, их песней, которую они поют вместе с барабанами.

Соч. III

Бей, барабан!

Барабан, барабань!

Были рабы.

Нет раба.

Баарбей!

Баарбань!

Баарабань!

Эй, стальногрудые!

Крепкие, эй!

Бей, барабан!

Барабан, бей!

Или - или,

пропал или пан!

Будем бить!

Бьем!

Били!

В барабан!

В барабан!

В барабан!

В строке г637 за счет разных знаков даны разные смыслы. В издании I92I г. стоит тире, благодаря чему слова «начинаем» имеют значение начала праздника, а после них идут слова реквиема в кавычках, как дословная песня. В собрании сочинений перед «начинаем!» стоит двоеточие, и тогда 
перед нами такая же прямая речь, как и последующий реквием, они уравнены в смысле.

$\begin{array}{ll}\text { Соч. III } & \text { І92І } \\ \text { Прежде чем выстроится сумев, } & \text { Прежде чем выстроится сумев } \\ \text { они } & \text { они } \\ \text { грянули: } & \text { грянули - } \\ \text { Начинаем. } & \text { начинаем. } \\ & \\ \text { Соч. III } & \text { г92г } \\ \text { Голодный, } & \text { Голодный } \\ \text { с теплом в единственный градус } & \text { с теплом в единственный градус } \\ \text { жизни, } & \text { жизни } \\ \text { как милости даренной, } & \text { как милости даренной } \\ \text { радуюсь, } & \text { радуюсь } \\ \text { ход твой следя легендарный. } & \text { ход твой следя легендарный. }\end{array}$

В первом издании в этом отрывке используются авторские нулевые знаки. В прижизненном собрании сочинений проставленные запятые дают новую интерпретацию строк 947-948, связывая тепло с жизнью, в то время как без запятых этот отрывок мог читаться и по-другому, как будто характеристика «с теплом в единственный градус» относится к состоянию рассказчика, а не к жизни. Интересно, что и в этом случае в этом издании предпочтение отдается более объективному звучанию, характеристика образа автора становится менее подробной, менее важной.

Неологизмы Маяковского со слитным написанием «Скорейскорей!», «Идемидем!» в Собрании сочинений также подвергаются норматизации. Вместо одного слова в тексте стоит два, разделенных запятыми: «Скорей, скорей!», «Идем, идем!». Звериные слова «О о-гу!» '2І г. с цезурой посередине меняется на звукоподражение «О-о-гу!» Длина «крика» дорог «И-и-ии-и-и-и-и-и!» с девяти букв сокращена до семи в варианте г929 г.

Сравнение вариантов І92I и І929 гг. позволяет сказать, что перед нами - полноценные редакции поэмы. Ранний - футуристический - толь- 
ко подступающийся к стилю пореволюционной литературы и второй - советский. При этом вариативность почти полностью осуществлена на счет смены концепции пунктуации с авторской на нормативную. Благодаря проделанному анализу мы видим, как, подтверждая современные представления о смыслах и значении авторской пунктуации, знаки препинания меняют изображаемый образ мира в поэме с футуристического, авангардного, мира, подлежащего разбору и сборке на новых основаниях, и одновременно субъективного, так как выражается точка зрения переустроителей этого мира, на более эпический и «объективный», монологический лад. Мы видим, как нулевые знаки и авторские сочетания точек и тире, значения больших букв делают поэму более слитной, соединяют части, подчеркивают ритм, выделяют интонации авторского голоса, как они во многом «ответственны» за создание образа автора. В раннем варианте это традиционный для Маяковского, «указывающий пальцем в небо» молодой человек, выскочка и грубиян, во втором - более соответствующий эпической вненаходимости поэмы автор. Мы видим, как авторские знаки создают «препятствия» и «высекают» новые смыслы в сознании читателя, активизируют его рецептивную активность, подразумевают ее наличие и включают ее в творческий потенциал текста. Пунктуация действует как раз на наиболее сложно передаваемых уровнях авторской позиции и картины мира, поскольку она действительно является одним из полноценных инструментов в поэтике произведения. Таким образом, изучение семантики авторских знаков и их роли в тексте позволяет нам проследить творческую эволюцию текста и его автора, выделить несколько редакций лексически не менявшегося произведения. 


\section{Список литературы}

I I50 000 о०о. М.: ГИЗ, І92І. 70 с.

2 Александрова О.В. Проблемы экспрессивного синтаксиса. М.: Высшая школа, I984. 2 II C.

3 Андросова Ф.С. Авторские пунктуационные знаки в художественном тексте: функциональный аспект: дис. ... канд. филол. наук. Якутск, 20I4. 220 с.

4 Антология авангардистских приказов и декретов: приказ как литературный жанр: от футуристов до ничевоков 1917-1924 / сост. и науч. ред. А.А. Россомахин. СПб.: Изд-во Европ. ун-та в С.-Петербурге, 2019. І92 с. Арто А. Театр и его двойник. М.: ABCdesigne, 2019. 406 c.

6 Арутчева В.А. Записные книжки Маяковского // Литературное наследство. М.: Изд-во АН СССР, І958. Т. 65: Новое о Маяковском. С. 325-296.

7 Береговская Э.М. Очерки по экспрессивному синтаксису. М.: Рохос, 2004. 208 с.

8 Валгина Н.С. Актуальные проблемы современной русской пунктуации.

М.: Высшая школа, 2004. 259 с.

Веденина Л.Г. Пунктуация французского языка. М.: Высшая школа, І975. I68 с.

Iо Взорваль. Футуристическая книга в собраниях московских коллекционеров М. Либермана и И. Розанова. Альбом-каталог. М.: Контакт-Культура, 201о. 256 с. Дзякович E.B. Стилистический аспект современной пунктуации. Экспрессивные пунктуационные приемы: дис. ... канд. филол. наук. М., І995. 193 с. Зименков А.П. Маяковский. От столбика к лесенке // В. Маяковский в мировом культурном пространстве. Материалы международной научной конференции, посвященной І25-летию со дня рождения поэта. ИМЛИ им. А.М. Горького РАН І8-2о сентября 2018 г. М.: ИМЛИ РАН, 2ОІ8. С. 56-62.

I3 Канафьева А.В. Функции авторской пунктуации в художественном тексте: дис. ... канд. филол. наук. М., 200о. І2І с.

I4 Каталог выставки импрессионистов «Треугольник». [СПб., І909.] С. 24-25.

I5 Ковтун Е.В. Русская футуристическая книга. М.: РИП-Холдинг, 20I4. 232 с.

I6 Кольциова Л.М. Художественный текст через призму авторской пунктуации: автореф. дис. ... д-ра филол. наук. Воронеж, 2007. 48 с.

I7 Лотман Ю.М. Об искусстве. Структура художественного текста. Семиотика кино и проблемы киноэстетики. Статьи. Заметки. Выступления. СПб.: Искусство-СПБ, I998. 289 c.

I8 Лотман Ю.М. Тезисы к проблеме «Искусство в ряду моделирующих систем» // Лотман Ю.М. Статьи по семиотике культуры и искусства. СПб.: Академический проект, 2002. С. 274-293.

I9 Маяковский В.В. Собр. соч.: в го т. М.; Л.: ГИЗ, І929. Т. 3. С. 219-285.

20 Маяковский В.В. Полное собрание произведений: в 20 т. М.: Наука, 2013. Т. І. 635 с.

$2 \mathrm{I}$ Мельничук О.А. Повествование от первого лица. Интерпретация текста. М.: МГУ, 2002. 208 c. 
22 Мельничук О.А. Авторская пунктуация и явление пунктуационной синонимии в произведениях современных франкоязычных авторов // Романские языки в прошлом и настоящем: сб. ст. к 8о-летию Т.А. Репиной. СПб.: Филологический факультет СПбГУ, 2007. С. І78-г88.

23 Пронченко E.H. Авторское использование знаков препинания (на материале художественных произведений испаноязычных авторов) // Научный вестник Воронежского государственного архитектурно-строительного университета. Серия «Современные лингвистические и методико-дидактические исследования». 2010. № I3. C. II7-I24.

24 Русский футуризм. М.: Наследие, 2000. 480 с.

25 Сафронова И.П. Эстетическая функция пунктуации в поэзии М. Цветаевой: дис. ... канд. филол. наук. Ижевск, 2004. 247 с.

26 Тастевен Г. Футуризм на пути к новому символизму. М.: Изд-е книжного магазина «Циолковский», 20I7. І20 с.

27 Тренин В. К истории поэмы «І50 ооо ооо» // Тренин В. В мастерской стиха Маяковского. М.: Сов. писатель, г99г. С. г93-239.

28 Шапиро А.Б. Основы русской пунктуации. М.: Изд-во АН СССР, 1955.396 с.

29 Щерба Л.В. Теория русского письма. Л.: Наука, І983. І34 с.

30 Яхнович Н.И. Пунктуация как средство ритмико-стилистической организации текста: дис. ... канд. филол. наук. М., І991. І83 с. 


\section{References}

I I50 000 000. Moscow, GIZ Publ., I92I. 70 p. (In Russ.)

2 Aleksandrova O.V. Problemy ekspressivnogo sintaksisa [Problems of expressive syntax]. Moscow, Vysshaia shkola Publ., I984. 21I p. (In Russ.)

3 Androsova F.S. Avtorskie punktuatsionnye znaki v khudozhestvennom tekste: funktsional'nyi aspekt [Authorial punctuation marks in a literary text: functional aspect: PhD dissertation]. Iakutsk, 20I4. 220 p. (In Russ.)

4 Antologiia avangardistskikh prikazov i dekretov: prikaz kak literaturnyi zhanr: ot futuristov do nichevokov I9I7-I924 [Anthology of avant-garde orders and decrees: prikaz as a literary genre: from futurists to nitschevok I9I7-I924], comp. and ed.

A.A. Rossomakhin. St. Petersburg, Izdatel'stvo Evropeiskogo universiteta v St. Peterburge Publ., 2019. I92 p. (In Russ.)

5 Arto A. Teatr i ego dvoinik [Theater and its double]. Moscow, ABC designe Publ., 20I9. 406 p. (In Russ.)

6 Arutcheva V.A. Zapisnye knizhki Maiakovskogo [Mayakovsky's notebooks]. Literaturnoe nasledstvo [Literary heritage]. Moscow, AN SSSR Publ., I958. Vol. 65: Novoe o Maiakovskom [New research on Mayakovsky], pp. 325-296. (In Russ.) Beregovskaia E.M. Ocherki po ekspressivnomu sintaksisu [Essays on expressive syntax]. Moscow, Rokhos Publ., 2004. 208 p. (In Russ.)

8 Valgina N.S. Aktual'nye problemy sovremennoi russkoi punktuatsii [Actual problems of modern Russian punctuation]. Moscow, Vysshaia shkola Publ., 2004. 259 p. (In Russ.) Vedenina L.G. Punktuatsiia frantsuzskogo iazyka [Punctuation of the French language]. Moscow, Vysshaia shkola Publ., I975. I68 p. (In Russ.) Vzorval'. Futuristicheskaia kniga v sobraniiakh moskovskikh kollektsionerov M. Libermana i I. Rozanova. Al'bom-katalog [Vzorval'. Futuristic books in collections of Moscow collectors M. Liberman and I. Rozanov. Album catalog]. Moscow, Kontakt-Kul'tura Publ., 20Io. 256 p. (In Russ.)

Dziakovich E.V. Stilisticheskii aspekt sovremennoi punktuatsii. Ekspressivnye punktuatsionnye priemy [Stylistic aspect of modern punctuation. Expressive punctuation techniques: PhD dissertation]. Moscow, I995. I93 p. (In Russ.) Zimenkov A.P. Maiakovskii. Ot stolbika k lesenke [Mayakovsky. From the column to the ladder]. In: V. Maiakovskii v mirovom kul'turnom prostranstve. Materialy mezhdunarodnoi nauchnoi konferentsii, posviashchennoi I25-letiiu so dnia rozhdeniia poeta. IMLI im. A.M. Gor'kogo RAN I8-20 sentiabria $20 I 8$ g. [V. Mayakovsky in the global cultural space. Materials of the international conference dedicated to the I25th anniversary of the poet. IWL RAS September I8-20, 20I8]. Moscow, IWL RAS Publ., 20I8, pp. 56-62. (In Russ.)

I3 Kanaf'eva A.V. Funktsii avtorskoi punktuatsii v khudozhestvennom tekste [Functions of authorial punctuation in the literary text: PhD dissertation]. Moscow, 2000. I2I p. (In Russ.) 
I4 Katalog vystavki impressionistov "Treugol'nik" [Impressionist exhibition catalogue “Triangle”]. [St. Petersburg, 1909.] Pp. 24-25. (In Russ.)

I5 Kovtun E.V. Russkaia futuristicheskaia kniga [Russian futuristic book]. Moscow, RIP-Kholding Publ., 20I4. 232 p. (In Russ.)

I6 Kol'tsova L.M. Khudozhestvennyi tekst cherez prizmu avtorskoi punktuatsii [Literary text through the prism of authorial punctuation: DSc thesis, summary]. Voronezh, 2007. 48 p. (In Russ.)

I7 Lotman Iu.M. Ob iskusstve. Struktura khudozhestvennogo teksta. Semiotika kino i problemy kinoestetiki. Stat'i. Zametki. Vystupleniia [About art. The structure of the literary text. Semiotics of the cinema and problems of cinematographic aesthetics. Articles. Comments. Papers.]. St. Petersburg, Iskusstvo Publ., I998. 289 p. (In Russ.) Lotman Iu.M. Tezisy k probleme "Iskusstvo v riadu modeliruiushchikh sistem" [Abstracts on "Art in the series of modeling systems"]. In: Lotman M.Iu. Stat'i po semiotike kul'tury $i$ iskusstva [Articles on the semiotics of culture and art]. St. Petersburg, Akademicheskii proekt Publ., 2002, pp. 274-293. (In Russ.) Maiakovskii V.V. Sobranie sochinenii: in Io t. [Collected works: in Io vols.] Moscow, Leningrad, GIZ Publ., I929, vol. 3, pp. 219-285. (In Russ.) Maiakovskii V.V. Polnoe sobranie proizvedenii: $v 20 t$. [Complete works: in 20 vols.] Moscow, Nauka Publ., 20I3. Vol. I. 635 p. (In Russ.) Mel'nichuk O.A. Povestvovanie ot pervogo litsa. Interpretatsiia teksta [First-person narration. Interpretation of the text]. Moscow, MGU Publ., 2002. 208 p. (In Russ.) Mel'nichuk O.A. Avtorskaia punktuatsiia i iavlenie punktuatsionnoi sinonimii v proizvedeniiakh sovremennykh frankoiazychnykh avtorov [Authorial punctuation and the phenomenon of punctuation synonymy in the works of modern French-speaking authors]. In: Romanskie iazyki v proshlom i nastoiashchem: sb. st. $k$ 8o-letiiu T.A. Repinoi [Romance languages in the past and present: Sat. Art. to the 8oth anniversary of T.A. Repina]. St. Petersburg, Filologicheskii fakul'tet SPbGU, 2007, pp. I78-I88. (In Russ.)

23 Pronchenko E.N. Avtorskoe ispol'zovanie znakov prepinaniia (na materiale khudozhestvennykh proizvedenii ispanoiazychnykh avtorov) [Author's use of punctuation marks (based on the works by Hispanic authors)]. Nauchnyi vestnik Voronezhskogo gosudarstvennogo arkhitekturno-stroitel'nogo universiteta. Seriia "Sovremennye lingvisticheskie i metodiko-didakticheskie issledovaniia”, 2010, no I3, pp. II7-I24. (In Russ.)

24 Russkii futurizm [Russian futurism]. Moscow, Nasledie Publ., 2000. 480 p. (In Russ.)

25 Safronova I.P. Esteticheskaia funktsiia punktuatsii v poezii M. Tsvetaevoi [The aesthetic function of punctuation in the poetry of $\mathrm{M}$. Tsvetaeva: PhD dissertation]. Izhevsk, 2004. 247 p. (In Russ.) 
26 Tasteven G. Futurizm na puti k novomu simvolizmu [Futurism on the way to new symbolism]. Moscow, Izd-e knizhnogo magazina “Tsiolkovskii” Publ., 20I7. I20 p. (In Russ.)

27 Trenin. V. K istorii poemy “I50 ooo ooo" [On the history of the poem I50,000,00o]. In: Trenin V. V masterskoi stikha Maiakovskogo [In the workshop of Mayakovsky's poem]. Moscow, Sovetskii pisatel' Publ., I991, pp. 193-239. (In Russ.)

28 Shapiro A.B. Osnovy russkoi punktuatsii [The basics of Russian punctuation]. Moscow, AN SSSR Publ., I955. 396 p. (In Russ.)

29 Shcherba L.V. Teoriia russkogo pis'ma [Theory of Russian writing]. Leningrad, Nauka Publ., I983. I34 p. (In Russ.)

30 Iakhnovich N.I. Punktuatsiia kak sredstvo ritmiko-stilisticheskoi organizatsii teksta [Punctuation as a means of rhythmic and stylistic organization of the text: PhD dissertation]. Moscow, I99I. I83 p. (In Russ.) 
I K рассмотрению и опубликованию принимаются статьи, оформленные в соответствии с правилами, принятыми в журнале. Объем статьи вместе с примечаниями не более г п.л. - 40 ооо знаков вместе с пробелами (для аспирантов - не более о,5 п.л. - 20 ооо знаков вместе с пробелами), включая примечания.

2 Автор представляет все материалы (текст статьи, дополнительные шрифты, если таковые использовались в тексте, договор ${ }^{\mathrm{I}}$ ) по электронной почте: stud-lit@mail.ru или отправляет статью через услугу на сайте журнала www.studlit.ru

3 Текст должен быть напечатан в текстовом редакторе Microsoft Word, формат A4, поля - 2 см со всех сторон, шрифт - Times New Roman, кегль I4, межстрочный интервал - I,5, абзацный отступ (красная строка) - I,25, ориентация - книжная, без переносов.

4 Первая страница должна содержать следующую информацию:

- название рубрики, кегль - г4;

- УдК (см., например, teacode.com/online/udc или udk-codes.net), кегль - І4;

- ББК (см., например, http://roslavl.library67.ru/files/382/bbk.pdf), кегль - I4.

I B соответствии с частью четвертой Гражданского кодекса Российской Федерации (раздел VII «Права на результаты интеллектуальной деятельности и средства индивидуализации») представляемые в журнал статьи должны сопровождаться лицензионным договором о передаче Учредителю журнала неисключительных авторских прав. 
- Название статьи - по центру, без отступа, полужирным шрифтом, прописными буквами, кегль - I4.

- Под названием статьи по центру указывается знак авторского права, год, инициалы и фамилия автора/ов, кегль - I2.

- Далее по центру указывается полное название организации, город, страна, кегль - I2.

- По правому краю размещается информация о дате отправки статьи.

- Далее приводятся сведения о финансовой поддержке работы (грант и др.), кегль - I2, выравнивание по ширине.

- Размещаются аннотация (200-250 слов; она должна представлять собой реферат-резюме статьи с соблюдением последовательности изложения) и ключевые слова на русском языке, кегль - І2, выравнивание по ширине.

- Информация об авторе: имя, отчество, фамилия, ученая степень (если есть), звание (если есть), должность, полное название организации, адрес организации вместе с индексом, город, страна, E-mail, кегль - I2.

- После этого размещается та же самая информация на английском языке:

- Название статьи на английском языке - по центру, без отступа, полужирным шрифтом, прописными буквами, кегль - I4.

- Под названием статьи по центру указываются фамилия, имя, отчество автора/ов, кегль - I2.

- Далее по центру указывается полное название организации, город, страна, кегль - I2.

- По правому краю размещается информация о дате отправки статьи.

- Далее приводятся сведения о финансовой поддержке работы (грант и др.) (Acknowledgements), аннотация и ключевые слова (Abstract, Keywords), информация об авторе (Information about the author), кегль - I2, выравнивание по ширине.

- Далее - текст статьи - выравнивание по ширине, без переносов.

5 В конце статьи приводится СПИСОК ЛИТЕРАТУРЫ в алфавитном порядке (сначала русские источники, затем иностранные) в соответствии с ГОСТом 7.0.5.-2008 в виде нумерованного списка. Фамилия и инициалы авторов пишутся раздельно. В тексте статьи ссылки оформляются следующим образом: [1], [2, с. 5], [3, с. 34; 5, с. 2], [7, стб. 23], [го, л. 6]. 
6 Примечания оформляются в виде постраничных автоматических сносок. Цифра сноски в конце предложения ставится перед точкой. Шрифт сносок: Times New Roman, кегль г2.

7 Ссылки на архивные материалы даются в виде постраничных автоматических сносок.

8 После Списка литературы приводится REFERENCES:

- Транслитерируются только источники, написанные кириллицей; французские, немецкие, итальянские, польские и пр. источники не транслитерируются и не переводятся.

- Для выполнения транслитерации необходимо использовать специальную программу.

- Войти в программy http://translit.net/ и выбрать вариант системы Библиотеки Конгресса (LC).

- Вставить в специальное поле весь текст библиографии на русском языке и нажать кнопку «в транслит».

- Затем копировать транслитерированный текст в готовящийся список References.

- Далее необходимо отредактировать полученное и добавить переводы на английский язык:

- перевести на английский язык название книги, источника и др. и вставить его в квадратных скобках [ ] после соответствующих названий;

- заменить // на точку;

- заменить / на запятую;

- перевести на английский язык место издания (например, было М. - после редактирования: Moscow);

- заменить двоеточие после названия места издания на запятую;

- после транслитерации издательства добавить Publ.;

- исправить обозначение страниц: вместо 235 s. - 235 p., вместо S. $45-47-$ pp. 45-47;

- курсивом выделить название источника;

- в конце библиографической ссылки необходимо добавить указание на оригинальный язык статьи (In Russ.).

9 Сокращения. При первом упоминании лица обязательно указываются И.О., И.О. отделяются пробелом от фамилии. Годы при указании опре- 
деленного периода указываются только в цифрах: 30-е гг., а не тридцатые годы. Конкретная дата дается с сокращением г. или гг.: I920 г., I920-I922 гг. Не век или века, а в. или вв. (римскими цифрами): IX в. Писать только полностью: так как, так называемые. Из сокращений допускаются: т. д., т. п., др., т. е., cм.

Iо Кавычки - только «», если закавыченное слово начинает цитату или примыкает к концу цитаты, употребляются кавычки в кавычках: «“раз”, два, три, “четыре”».

II Архивные материалы должны сопровождаться вступительной статьей, оформленной в соответствии с вышеизложенными правилами. 


\section{ПОРЯДОК РЕЦЕНЗИРОВАНИЯ}

I Рукописи, поступившие в редколлегию журнала «Studia

Litterarum», проходят обязательное рецензирование с целью их экспертной оценки.

2

На первом этапе редакцией проводится экспертиза рукописей на предмет их соответствия формальным требованиям.

3 Рукописи, не соответствующие требованиям к оформлению и не отвечающие содержательно-тематическому профилю журнала, не рассматриваются и не рецензируются. Решение об отклонении статьи от рассмотрения и публикации в этом случае принимается редколлегией.

4 Рукописи, соответствующие содержательно-тематическому профилю журнала и удовлетворяющие формальным требованиям, передаются на рецензирование двум независимым экспертам, имеющим наиболее близкую к теме статьи специализацию.

5 Экспертная оценка рукописи проводится по принципу внешнего двойного «слепого» рецензирования, когда ни рецензент не знает имени автора, ни автор не знает имени рецензента.

6 Для проведения экспертной оценки рукописи могут привлекаться как члены редколлегии, так и высококвалифицированные специалисты из ИМЛИ РАН и других организаций. Рецензенты обязаны следовать принятой в журнале Публикационной этике.

7 Рецензии пишутся в свободной форме или по разработанной редколлегией схеме.

8 Текст рецензии предоставляется автору по его запросу без указания 
Ф.И.О., должности и места работы рецензента. В случае наличия в рецензии рекомендации доработать и/или переработать текст статьи автору направляется сокращенный текст рецензии с конструктивными замечаниями без указания Ф.И.О., должности и места работы рецензента. В случае отклонения статьи от публикации автору направляется мотивированный отказ.

9 Статья, направленная автору на доработку, должна быть возращена в сроки, указанные в письме.

Iо Статья, не рекомендованная рецензентами к публикации, к повторному рассмотрению не принимается и не рассматривается на заседании редколлегии. 
Сроки рецензирования в каждом отдельном случае определяются с учетом возможности максимально оперативной публикации статьи. Максимальный срок рецензирования статьи - 3 месяца.

I2 Статьи, успешно прошедшие процедуру рецензирования, рассматриваются на заседании редколлегии. После принятия редколлегией решения о допуске статьи автор получает письмо с краткой информацией о результатах рецензирования и примерных сроках публикации рукописи. I3 Оригиналы рецензий хранятся в архиве журнала «Studia Litterarum» в течение 5 лет.

I4 Статьи членов редакции, редколлегии и международного редакционного совета, имеющих право на приоритетную публикацию в журнале I (одной) статьи в год, подвергаются рецензированию и обсуждаются на заседании редколлегии в общем порядке. 


\section{PEER-REVIEW PROCESS}

I It is mandatory that all manuscripts submitted to the journal Studia Litterarum are peer reviewed by experts in the field.

2 At the first stage of the reviewing process, the Editorial Department reviews manuscripts on the subject of their compliance with the journal's formal requirements.

3 Manuscripts that do not meet the formal requirements or the subject scope of the journal will not be considered or peer reviewed. The Editorial Board decides whether the essay shall not be considered or accepted for publication.

4 Manuscripts that meet the formal requirements or the subject scope of the journal are sent to two independent reviewers in the specific field of the submitted manuscript.

5 The essay undergoes a double "blind" review process, e.g. when any of the reviewers knows the author's name nor the author knows the names of the reviewers.

6 The invited reviewers may be members of the Editorial Board or any other highly qualified experts from IWL RAS and other institutions. Reviewers must follow the principles of Publishing Ethics accepted by the journal.

$7 \quad$ Reviews are written in a free form or according to the scheme developed by the Editorial Board.

8 The review is sent to the author on his or her request without indicating the reviewer's name, job title, and place of work. If the reviewer recommends that the author revises/makes minor revisions and resubmits the manuscript, he or she will be sent a partial text of the review with suggestions without indicating the 
reviewer's name, job title, and place of work. In case of rejection, the author will receive a motivated refusal.

9 The essay sent to the author for revision shall be returned by the time specified in the letter.

Io The essay rejected by reviewers shall not be resubmitted or considered at the Editorial Board meeting.

II The time period of the review is determined in each particular case considering the most rapid possible publication of the essay. It takes the maximum of three months to have the manuscript reviewed.

I2 The manuscripts that have successfully undergone the peer review process will be considered at the Editorial Board meeting. After making a decision about the essay's acceptance, the author will receive a letter briefly informing him or her about the results of the review and the possible date of publication.

I3 The original copies of reviews are kept in the archive of the journal Studia Litterarum for 5 years.

I4 Members of the Editorial Board, international Editorial Board, and the Editorial Department have the right for the priority publication of one (I) article per year; these articles are reviewed and accepted for publication on a common basis. 


\section{ПОДПИСКА}

Уважаемые коллеги!

Оформить подписку на журнал «Studia Litterarum» можно во всех отделениях Почты России по каталогу ОАО Агентства «Роспечать» «Газеты. Журналы».

Подписной индекс - 80538.

Рассылка экземпляров журналов производится только по подписке.

По поводу приобретения отдельных номеров журнала необходимо обращаться в редколлегию: І2Іо69 г. Москва, ул. Поварская, д. 25 а. 


\section{STUDIA LITTERARUM}

Литературные исследования

Literary Studies

Научный журнал

Academic journal

Том 5, № 2

Vol. 5, no 2

Дизайн обложки и макет журнала В.А. Музыченко

Верстка А.З. Бернштейн

Корректор Е.Н. Сченснович

I6+

Подписано в печать 26.05.2020

Формат 60×90 I/16

Усл.-печ. л. 30,0

Тираж 500 экз. Заказ №

Отпечатано в ФГУП «Издательство “Наука”

(Типография “Наука”)»

І2Іо99, Москва, Шубинский пер., д. 6

Институт мировой литературы им. А. М. Горького

Российской академии наук

І2І069, Москва, ул. Поварская, д. 25 а

тел. (495) 69I-23-0I, 690-05-6I 
